Recht in Ostasien

Anna Katharina Suzuki-Klasen

\title{
A Comparative Study of the Formation of Contracts in Japanese, English, and German Law
}


Recht in Ostasien

Volume 18

\section{Editorial Board}

Prof. Dr. Yuanshi Bu | Prof. Dr. Alexander Bruns | Prof. Dr. Jan von Hein | Prof. Dr. Sonja Meier | Prof. Dr. Hanno Merkt | Prof. Dr. Dr. h.c. mult. Michael Pawlik| Prof. Dr. Dr. Eiji Takahashi | Prof. Dr. Silja Vöneky 
Anna Katharina Suzuki-Klasen

A Comparative Study of the Formation of Contracts in Japanese, English, and German Law

\section{Nomos}


The Deutsche Nationalbibliothek lists this publication in the Deutsche Nationalbibliografie; detailed bibliographic data are available on the Internet at http://dnb.d-nb.de

a.t.: Hamburg, Univ., Diss., 2020

ISBN 978-3-8487-7128-8 (Print)

978-3-7489-1177-7 (ePDF)

British Library Cataloguing-in-Publication Data

A catalogue record for this book is available from the British Library.

ISBN

978-3-8487-7128-8 (Print)

978-3-7489-1177-7 (ePDF)

\section{Library of Congress Cataloging-in-Publication Data}

Suzuki-Klasen, Anna Katharina

A Comparative Study of the Formation of Contracts in Japanese, English, and German Law

Anna Katharina Suzuki-Klasen

$632 \mathrm{pp}$.

Includes bibliographic references and index.

ISBN

$$
\begin{aligned}
& \text { 978-3-8487-7128-8 (Print) } \\
& \text { 978-3-7489-1177-7 (ePDF) }
\end{aligned}
$$

1st Edition 2022

(c) Anna Katharina Suzuki-Klasen

Published by

Nomos Verlagsgesellschaft $\mathrm{mbH} \& \mathrm{Co}$. KG

Waldseestraße 3-5 | 76530 Baden-Baden

www.nomos.de

Production of the printed version:

Nomos Verlagsgesellschaft $\mathrm{mbH} \& \mathrm{Co}$. KG

Waldseestraße 3-5 | 76530 Baden-Baden

ISBN 978-3-8487-7128-8 (Print)

ISBN 978-3-7489-1177-7 (ePDF)

DOI https://doi.org/10.5771/9783748911777

\section{(9) (1) $\Theta \Theta$}

This work is licensed under a Creative Commons Attribution

- Non Commercial - No Derivations 4.0 International License. 


\section{Foreword}

This book was submitted as a $\mathrm{PhD}$ dissertation to the University of Hamburg in December 2019. It was defended by me in the Summer of the following year. The manuscript takes account of the law as of December 2019 , so that the discussion is based on the law previous to the coming into force of the reform of the Japanese civil code (Minpō) on 1 April 2020. Nevertheless, the new Japanese rules pertinent to the formation of contracts are included in the analysis.

This comparative study was elaborated during my time as a Research Associate in the Japan Unit of the Max Planck Institute for Comparative and International Private Law in Hamburg, Germany. I am deeply grateful to Professor Dr Harald Baum, who supervised my PhD dissertation patiently and offered his kind guidance and numerous helpful suggestions during this time. I also thank my former colleagues for their support and constructive criticism and the whole staff of the Max Planck Institute for their support in a multitude of matters. Furthermore, I am obliged to Professor Dr Peter Mankowski, who acted as second examiner of my PhD dissertation.

The pertinent part of my research on Japanese law was conducted in 2015/2016 during my one-year research stay at the University of Kyōto in Japan. This would not have been possible without the generous funding of the Japan Society for the Promotion of Science through the JSPS Postdoctoral Fellowship (short term) for North American and European Researchers (FY 2015, PE 15768). In a similar manner, the publication of my $\mathrm{PhD}$ dissertation could not have been realised without the kind support of the Studienstiftung ius vivum. The author is immensely grateful for this funding.

My search for answers was greatly enriched through many discussions. In particular, I would like to express my gratitude to my host, Professor Dr Keizō Yamamoto, for his kind support, as well as for allowing me to participate in his classes and to contribute to his project to translate the modified provisions of the Minpō into German (see Keizo Yamamoto, Hiroyuki Kansaku, Gabriele Koziol et al, Übersetzung des novellierten Zivilgesetzes 2020 [Translation of the Reformed Civil Code 2020] 45 (2018) Zeitschrift für Japanisches Recht / Journal of Japanese Law 183-305; Keizo Yamamoto and Gabriele Koziol (eds), Das Reformierte japanische Schuldrecht [The 
Reformed Japanese Law of Obligations] (Mohr Siebeck 2021) 177-363). These and other group discussions were simply enlightening.

All the individual interviews that I have conducted were similarly stimulating. I am indebted to all the people who kindly gave me some of their time, in particular: Professor Yamamoto; Professor Kunihiro Nakata (Ryūkoku University); Professor emeritus Dr Shōji Kawakami (University of Tōkyō); Professor Mika Yokoyama (University of Kyōto); and $\mathrm{Mr}$ Ryōsuke Naka (Attorney at law, Kitahama Hōritsu Jimu-sho). It is through these exchanges, in which much light was shed on the workings of Japanese law, that my dissertation has been greatly enriched. My gratitude goes to all the other people who cannot be named here but whose invaluable help is not forgotten.

My special thanks also go to my dear friends, who greatly encouraged me along the way. Last - but not least - I am deeply grateful to my husband and my parents for the vital support they have provided during this process. I dedicate this work to you.

Bielefeld, January 2022 Dr. Anna Katharina Suzuki-Klasen 


\section{Table of Contents}

A. Introduction

I. Motivation, Subject, and Objectives of the Analysis 34

II. Defining and Delimiting the Topic 37

III. A Note on the Method 39

B. Comparative Background

I. Classification of the Legal Traditions of English and German Law and the Sources of their Contract Laws

1. Classification of the Legal Traditions of English and German Law

2. Sources of English and German (Contract) Law

a. Sources of English (Contract) Law

i. The Inter-relationship of the Sources in English

(Contract) Law

ii. English Legislation: Statutes and Statutory Instruments

iii. English Case Law

iv. EU Law: Legislation and Cases 51

v. International Law 54

b. Sources of German (Contract) Law 55

i. The Inter-relationship of the Sources in German (Contract) Law

ii. German Legislation: Gesetze and Verordnungen, German Statutes and Regulations

iii. German Case Law: Rechtsprechung, German Court Decisions

iv. EU Law: Legislation and Cases

v. International Law: The CISG 
II. Contracts in English Law 65

1. 'Contract' Defined 66

2. The Historical Development of the English Law of Contract

a. Contracts in the Kingdom of England in Tudor and Stuart Times: The Transition from Medieval to Modern Law Through the Action of Assumpsit and the Emergence of the Doctrine of Consideration $\left(16^{\text {th }} \sim 17^{\text {th }}\right.$ Century)

i. Political and Social Background 71

ii. The General Structure of Law 73

iii. The Law of Contracts $\quad 75$

aa) Definition and Types of Contract 75

bb) The Law of Contracts: Forms of Actions for Contractual Claims

cc) The Formation of Contract and the Further Requirement of Giving Consideration $\quad 82$

dd) Contract Forms

b. Contracts in the Kingdom of Great Britain and the United Kingdom in Hanoverian and Georgian Times: The Requirement of the Intention to Create Legal Relations and the Doctrine of Offer and Acceptance $\left(18^{\text {th }} \sim 19^{\text {th }}\right.$ Century)

i. Political and Social Background 88

ii. The General Structure of Law 90

iii. The Law of Contracts $\quad 91$

aa) Definition of Contract 92

bb) The Conclusion of Contracts: Emergence of the Doctrine of Offer and Acceptance and the Postal Rule

cc) The Further Requirement of an Intention to Create Legal Relations

c. The Subsequent Development of English Contract Law in Windsor Times (20 th Century-) 98

i. Overview of Political and Social Developments $\quad 98$

ii. Overview of (Contractual) Legal Developments $\quad 100$

3. Contracts in Current English Law and Legal Practice 101

a. The Current Legal Background 103

i. Basic Principles: Agreement Through Offer and Acceptance 
ii. Offer 107

aa) 'Offer' Defined 107

bb) Offers and Invitations to Treat 108

cc) Certainty of Offer, Terms 115

dd) Communication of Offers 118

ee) Coming into Effect of Offers: The Mailbox Rule 118

ff) Loss of Effect of Offers 121

iii. Acceptance 124

aa) 'Acceptance' Defined 124

bb) Communication and Method of Acceptance 126

cc) Coming into Effect of Acceptance: The Mailbox and Postal Rules 128

dd) Loss of Effect of Acceptance 134

iv. The Further Requirement of an Intention to Create a Binding Legal Relationship 135

v. The Requirement of Consideration 139

aa) 'Consideration' Defined 142

bb) Rule 1: Sufficient Consideration, not Adequate 145

cc) Nominal Consideration 148

dd) Insufficient Consideration 150

ee) Rule 2: No Past Consideration 151

ff) Rule 3: Consideration of the Promisee 153

b. Form Requirements in English Law 153

i. Excursus: The Classification of Things in English

Law

ii. Written Forms: Standard Written Form and Evidence in Writing

aa) The Requirements of Writing and of Evidence in Writing

bb) Instances of the Written and the Written Evidence Forms

iii. Special Instrument: Deed

aa) Requirements of Deeds $\quad 164$

bb) Instances of Deeds 166

iv. Signing and Sealing 167

aa) 'Signing' and 'Sealing' Defined 168

bb) Instances of Signing and Sealing 170

v. Electronic Communication: Writing and Signatures 172

aa) Electronic Documents: Writing 173

bb) Electronic Signatures: English and EU Law 173 
c. Other Requirements under English Law 176

i. Registration of Title to Land 177

ii. Stamp Tax on Land Transactions 178

d. Current Legal Practice in England $\quad 180$

4. Summary of Results 181

III. Contracts in German Law 182

1. 'Vertrag'(Contract) Defined 182

2. The Historical Development of the German Law of Contract

a. Contracts in the Alte Reich $\left(16^{\text {th }} \sim 19^{\text {th }}\right.$ Century):

Emergence of the First Great Private Law Codifications 188

i. Political and Social Background 189

ii. The General Structure of Law 191

iii. The Law of Contracts: Gemeines Recht

(Common Law) and the Allgemeines Landrecht für die Preußischen Staaten (General State Laws of the Prussian States)

aa) Definition and Types of Contract 195

bb) Contract Conclusion: Offer and Acceptance 196

cc) The Coming into Effect of Declarations of Intentions 198

dd) Contract Forms 200

ee) The Further Requirement of Giving Arrha or Draufgabe (Earnest)

b. Contracts in the Time from the Deutsche Bund to the Deutsche Reich: The Drafting of the BGB and of the HGB (19 $9^{\text {th }}$ Century)

i. Political and Social Background

ii. Structural Changes in the Law: Creation of an Imperial Supreme Court and the Codification of the BGB and the HGB

iii. Contract Law in the Draft Legislation 208

c. The Subsequent Development of German (Contract) Law (20 $0^{\text {th }}$ Century $)$

i. Overview of Political Developments

ii. Overview of (Contractual) Legal Developments 
3. Contracts in Current German Law and Legal Practice

a. The Current Legal Background

i. Basic Principles: Contracts as Rechtsgeschäfte

(Legal Transactions) and Willenserklärungen

(Declarations of Intention)

aa) 'Willenserklärungen' Defined

bb) Types of Willenserklärungen and Methods of Declaration

cc) Interpretation of Willenserklärungen

dd) Rechtsgeschäfte (Legal Transactions)

ii. Antrag or Angebot (Offer)

aa) 'Antrag'or 'Angebot' Defined

bb) Angebot and Invitatio ad Offerendum (Invitation to Make an Offer)

cc) Certainty of Angebote

dd) Coming into Effect of Angebote: Empfangstheorie (Receipt Theory)

ee) Bindingness and Loss of Effect of Angebote

iii. Annabme (Acceptance)

aa) 'Annahme' Defined

bb) Method of Annabme

cc) Certainty of Annahme

dd) Coming Into Effect and Loss of Effect of Annabme

iv. The Further Requirement of a Rechtsbindungswille (Intention of Legal Commitment)

b. Form Requirements in German Law

i. Excursus: The Classification of Things in German Law

ii. Written Forms: Schriftform and Textform

aa) The Requirements of the Urkunde

bb) The Requirement of the lesbare Erklärung auf

cc) Instances of Written or Text Form

iii. Special Forms Involving Public Authorities:

Öffentliche Beglaubigung (Official Certification) and Notarielle Beurkundung (Notarial Authentication)

aa) Excursus: Seals of Public Authorities

bb) Unterschrifts- and Handzeichensbeglaubigung

(Certification of Signatures and Marks) 
cc) Notarielle and Öffentliche Beurkundung (Notarial and Official Authentication)

dd) Instances of Beglaubigungen and of Beurkundungen

iv. Unterschreiben(Signing) and Siegeln (Sealing)

aa) 'Unterschrift'Defined

bb) Characteristics of an Unterschrift

cc) The Method of Unterschreiben

v. Electronic Communication: Data, Documents and Signatures

aa) 'Electronic Contract' and 'Electronic Declarations of Intention' Defined

bb) Electronic Form and Electronic Signatures

vi. Legal Consequences of Non-Fulfilment and Healing Methods

aa) General Consequence of Non-Fulfilment: Voidness

bb) Exceptional Instances of Other Consequences

cc) Extent of Operation of Form Requirements and their Consequences

dd) Healing and Other Ways of Avoiding the Consequences of Non-fulfilment

c. Other Requirements under German Law

i. Delivery and Registration of Property

303

ii. Draufgabe(Earnest)

304

d. Current Legal Practice in Germany 306

4. Summary of Results

C. Contracts in Japanese Law

I. Classification of the Legal Tradition of Japanese Law and the Sources of its Contract Law

1. Classification of the Legal Tradition of Japanese Law

2. Sources of Japanese (Contract) Law

a. The Inter-relationship of the Sources of Japanese (Contract) Law

b. Japanese Legislation: Hōrei (法令), Japanese Laws and Regulations

c. Japanese Case Law: Hanrei (判例), Japanese Court Decisions

d. International Law: The CISG 
II. 'Keiyaku'(契約, Contract) Defined

III. The Historical Development of the Japanese Law of Contract

1. Contracts in Japan's Early Modern Period, the Tokugawa Era (1 $7^{\text {th }} \sim 19^{\text {th }}$ Century): Legal Fragmentation in Peaceful Times of Growing Commerce, the Sowing Ground for Contract Law

a. Political and Social Background 324

b. The General Structure of Law 327

c. The Law of Contracts 328

i. Definition and Types of Contracts 328

ii. Contract Law 329

iii. Contract Forms 330

iv. The Further Requirement of Giving Tetsuke (Earnest)

2. Political and Legal Change during the Meiji Era:

The Creation of the First Great Japanese Private Law

Codifications (Turn of the $19^{\text {th }}$ Century)

a. Political and Social Background

b. Initial Reform Projects in Japanese Private and Commercial Law

c. First Codification Attempts and the Codification Dispute

i. First Codification Attempt of a Civil Code

ii. First Codification Attempt of a Commercial Code

iii. The Codification Dispute

d. The Creation of the Minpo (Civil Code) and of the Shōhō (Commercial Code)

3. The Subsequent Development of Japanese Contract Law during the Taishō, Shōwa, and Heisei Eras (20 ${ }^{\text {th }}$ Century $)$

a. Overview of Political and Social Developments

b. Overview of (Contractual) Legal Developments

IV. Contracts in Current Japanese Law and Legal Practice 348

1. The Current Legal Background

a. Basic Principles: Contracts as Matching Ishi Hyōji (意思 表示, Declarations of Intention)

i. Contracts as Ishi Hyoji

ii. Mōshikomi (申込み, Offer)

aa) 'Möshikomi'Defined 
bb) Mōshikomi and Mōshikomi no Yüin(申込みの誘 引, Invitation to Make an Offer)

cc) Coming into Effect of Mōshikomi: Tötatsu Shugi (到達主義, Arrival Rule)

dd) Loss of Effect of Möshikomi: The Distinction Between Taiwa-sha-kan (対話者間, Between Present Persons) and Kakuchi-sha-kan (隔地者 間, Between Persons at Distance) iii. Shōdaku (承諾, Acceptance)

aa) 'Shōdaku' Defined

bb) Method of Shödaku

cc) Coming into Effect of Shödaku: Hasshin Shugi (発信主義, Dispatch Rule) and Tötatsu Shugi (到達主義, Arrival Rule)

dd) Loss of Effect of Shōdaku

b. Form Requirements in Japanese Law

i. Excursus: The Classification of Mono (物, Things) in Japanese Law

ii. Written Form: Writing and Shomen (書面, Document)

aa) 'Writing' and 'Document' Defined 380

bb) Instances of the Written Form

iii. Shomei suru(署名する, Signing) and O'in suru (押印 する, Sealing)

aa) 'Signing' and 'Sealing' Defined

bb) Instances of a Requirement to Sign and Seal

cc) Excursus: The Different Types of Seals in Japan for Individuals

iv. Contracts and Köshō-nin (公証人, Japanese Notaries)

aa) Drafting of Contract Documents by Japanese Notaries (Notarial Authentication)

bb) Notarial Certification of Private Documents

c. Other Requirements under Japanese law

i. Registration of Property

ii. Inshi-zei(印紙税, Stamp Tax)

iii. Tetsuke(手付, Earnest Money)

aa) 'Tetsuke'Defined

bb) Method of Effecting Tetsuke

cc) Types and Functions of Tetsuke 
2. Legal Thinking and Current Legal Practice in Japan

a. Japanese Legal Thinking Generally

b. Contracts in Japanese Legal Thinking

c. Contractual Formality in Japanese Legal Thinking

d. Current Legal Practice in Japan

V. The Modernisation of the Saiken-hō (債権法, Japanese Law of Obligations)

1. Reasons Underlying the Reform Project of the Law of Obligations

2. The Reform Process: Initiation, Intermediate Results, Coming into Effect of the Amendments

3. Content of the Reform Project

a. Concerning the Coming into Effect of Declarations of Intention

i. Article 97 Minpō

422

ii. Article 526 Minpō; Article 508 Shōhō

426

iii. Article 4 Denshi keiyaku-hō

427

b. Concerning the Time of the Formation of a Contract

c. Concerning the Effectiveness of Declarations of Intention: Validity and Revocability

i. Former Article 521, new Article 523 Minpō

ii. Former Articles 522-523, new Article 524 Minpō; Article 508 Shōhō

iii. Former Article 524, new Article 525 Minpō; Article 507 Shōhō

d. Concerning Formalities of Contracts

i. New Article 522 Minpō

ii. New Article 587-2 Minpō

iii. Article 557 Minpō; Article 39 Paragraph 2 Takuchigyō-hō

D. Comparative Analysis of the Rules on the Formation of Contracts in Japanese, English, and German Law

I. The Concept and Types of Contract 
II. The Three Pillars of the Formation of Contracts and Indicia of Seriousness

1. Offer

a. Differentiation Between Offers and other Statements or Acts

i. Statements and Acts Deemed as Offers

ii. Statements and Acts Deemed as Invitations to Make an Offer

b. Requirements for Offers: Certainty and Communication

c. The Effectiveness of Offers

2. Acceptance

a. Acceptance and other Acts or Statements; Method of Acceptance

b. Requirements for Acceptance: Unconditionality, Congruence, and Communication

c. The Effectiveness of Acceptance

i. Coming into Effect of Acceptance

ii. Loss of Effect of Acceptance

3. Intention to be Legally Bound

4. Indicia of Seriousness

III. The Form Requirements

1. Written Forms and (Notarial) Deeds

a. Simple Written Forms: Evidence in Writing and the Textform

b. The Standard Written Form

c. Special Instruments: (Notarial) Deeds

i. Requirements of (Notarial) Deeds

ii. Instances of (Notarial) Deeds

2. Seals, Signatures, and Other Forms of Signing

a. Signatures

b. Seals

i. The Use of Seals in England, Germany, and Japan until Modern Times (19 $9^{\text {th }}$ Century)

aa) Types and Functions of Seals 474

bb) Sealing in Contracting

cc) The Accessibility of Seals

dd) The Development of the Sealing Practice 
ii. Today's Use of Seals in England, Germany, and Japan

aa) Seals in England and Germany

bb) Seals in Japan

c. Excursus: Other Forms of Authenticating Documents

IV. Contracts in the Digital Economy: Online Transactions and Beyond

1. Declarations of Intention and Formation of Contracts in Online Transactions

a. The Classification of Statements made Electronically as Legally (Ir)relevant

b. Coming into Effect of Electronic Declarations of Intention

2. Contractual Form and Methods of Authentication in Online Transactions

a. Electronic Contract Forms

b. Electronic Forms of Authentication: Electronic Signatures and Seals

3. Excursus: The Future of Contracting in Online

Transactions through Legal Tech and Smart Contracts

V. The Formation of a Sales Contract Concerning Real Estate

1. The Classification of Real Estate in Terms of Property

2. The Course of a Real Estate Transaction in Practice

3. The Legal Requirements for a Contract Concerning Real Estate

4. The Professional Parties Involved in a Real Estate

Transaction

a. The Role of Solicitors, Rechtsanwälte, and Bengo-shi (弁 護士)

b. The Role of Notaries Public, Notare, and Köshö-nin (公 証人)

c. The Role of Real Estate Agents, Immobilienmakler, and Fudō-san-ya (不動産屋)

d. The Role of Shihō shoshi (司法書士, Judicial Scriveners) 
E. Results of the Comparative Analysis Contrasted and Final Conclusions

I. Results of the Comparative Analysis Juxtaposed with the International Perspective: The CISG

1. The Sphere of Application of the CISG: International Sale of Goods

2. The Formation of Contract under the CISG: Offer and Acceptance, no Form

a. Offers

i. 'Offer' Defined and Distinction from Invitations to Make an Offer

ii. Requirements of Offers: Certainty of Terms and Intention

b. Acceptance

i. 'Acceptance' Defined; Distinction from Other Acts and Statements

ii. Method of Acceptance

iii. Congruence Between Offer and Acceptance

c. The Effectiveness of Declarations of Intention

i. Coming into Effect of Declarations of Intention

aa) Coming into Effect of Offers to the Public

bb) Coming into Effect of Acceptance: Must be Made Within a Set or Reasonable Period; Late Acceptance

cc) 'Reaching' Defined

ii. Loss of Effect of Declarations of Intention

d. No Form Requirements

3. Summary of Results

II. Results of the Comparative Analysis Juxtaposed with the European Legal-political Perspective: The DCFR, the CESL, and the PECL

1. The Sphere of Application of the CESL, the DCFR, and the PECL

2. The Formation of Contracts under the CESL, the DCFR, and the PECL

a. 'Contract' Defined 550

b. Offers 551

c. Acceptance 
d. Effectiveness of Declarations of Intention 554

i. Coming into Effect of Declarations of Intention $\quad 555$

ii. Loss of Effect of Declarations of Intention $\quad 558$

e. The Sufficiency of the Agreement: Certainty or Determinability 559

f. The Requirement of an Intention to be Legally Bound 560

g. Form Requirements 561

i. The Standard Written Form and the Textual Form $\quad 562$

ii. Instances of Form Requirements 565

3. Summary of Results 566

III. Synthesis of the Comparative Analysis and Final Conclusions $\quad 568$

Bibliography $\quad 575$

Literature in Print 575

Online Resources: Blog Entries and Websites 602

Personal Interviews, Lectures, and Seminars $\quad 610$

Table of Legislation $\quad 612$

International Conventions $\quad 612$

European Union $\quad 612$

England 613

Germany $\quad 614$

Japan 616

Table of Cases 619

European Union (Court of Justice of the European Union; in chronological order)

England (alphabetical order) 619

Germany (by court in chronological order) 622

Federal Consitutional Court (Bundesverfassungsgericht, 1951-) 622

Federal Court of Justice (Bundesgerichtshof, 1950-) 622

Federal Labour Court (Bundesarbeitsgericht, 1954-) 624

Higher Regional Courts (Oberlandesgerichte) 624

Regional Courts (Landgerichte) 624

Local Courts (Amtsgerichte) 624

Imperial Court (Reichsgericht, 1879-1945) 624 
Other German Courts $\quad 625$

Japan (by court in chronological order) 625

Great Court of Judicature (Dai-shin'i, 大審院, 1875-1947) 625

Japanese Supreme Court (Saikō Saiban-sho, 最高裁判所, 1947-) 625

Japanese District Court (Chibō Saiban-sho, 地方裁判所) 625

Other Courts 626

$\begin{array}{ll}\text { Index } & 627\end{array}$ 


\section{Abbreviations}

AC

$\mathrm{AcP}$

ADHGB

AG

AGB

ALR

$\operatorname{art}(s)$

B2B contracts

B2C contracts

BAG

BAGE

BauVertrRefG

BEA 1882

BeurkG

BGB

BGBl

BGH

BMJV

BNotO
Appeal Cases

Archiv für die civilistische Praxis [Archive of Civilian Practice]

Allgemeines Deutsches Handelsgesetzbuch [Common German Commercial Code]

Amtsgericht [local court]

Allgemeine Geschäftsbedingungen [standard terms]

Allgemeines Landrecht für die Preußischen Staaten [Gen-

eral State Laws of the Prussian States] (1794)

article(s)

business to business contracts

business to consumer contracts

Bundesarbeitsgericht [Federal Labour Court]

Entscheidungen des Bundesarbeitsgerichts [Decisions of the Bundesarbeitsgericht]

Gesetz zur Reform des Bauvertragsrechts [...], [Law to

Reform the Law on Construction Contracts [...]] (2017)

Bills of Exchange Act 1882

Beurkundungsgesetz [Notarial Authentication Law] (1969)

Bürgerliches Gesetzbuch [German Civil Code] (1896; 2002)

Bundesgesetzblatt [German Federal Law Gazette]

Bundesgerichtshof [Federal Court of Justice]

Bundesministerium der Justiz und für Verbraucherschutz [German Federal Ministry of Justice and Consumer Protection]

Bundesnotarordnung [Federal Ordinance on Notaries] (1937) 
BVerfG

BVerfGE

BVerfGG

C2C contracts

$\mathrm{CA}$

cf

CESL

$\mathrm{Ch}$

Chūkan shi'an

CISG

CJ

CJEU

CLC

CLJ

CoA 2006

Consumer Distance Selling Regulation 2000

CPR 1998

CRA 2015

CUP

DCFR
Bundesverfassungsgericht [Federal Constitutional Court ]

Entscheidungen des Bundesverfassungsgerichts [Decisions of the Federal Constitutional Court]

Gesetz über das Bundesverfassungsgericht [Act on the Federal Constitutional Court] (1993)

consumer to consumer contracts

Court of Appeal

confer (compare)

Common European Sales Law

Chancery

Minpō (saiken kankei) no kaisei ni kansuru chükan shi an [Interim Tentative Plan for the Reform of the Civil Code (Law of Obligations)] (2013)

United Nations Convention on Contracts for the International Sale of Goods (1980)

Chief Justice

Court of Justice of the European Union (previously: ECJ)

Commercial Law Cases

Cambridge Law Journal

Companies Act 2006

Consumer Protection (Distance Selling) Regulations 2000

Civil Procedure Rules 1998

Consumer Rights Act 2015

Cambridge University Press

Draft Common Frame of Reference for European Contract Law

Denshi keiyaku-hō Denshi shōhi-sha keiyaku oyobi denshi shōdaku tsūchi ni kansuru minpō no tokurei ni kansuru höritsu [Act on Special Provisions to the Civil Code Concerning Electronic Consumer Contracts and Electronic Acceptance Notice] (2001) 
Denshi shomei-hō Denshi shomei oyobi ninshō gyōmu ni kansuru hōritsu [Act on Electronic Signatures and Certification Business] (2000)

DNotZ

Draft Proposal

Outline

EC Act 1972

ECHR

ECJ

E-Commerce Regulations 2002

ECR

ed $(s)$

EDI

edn

EGBGB

eIDAS Regulation 2014

ER

EU

EU Distance Selling Directive 1997

EU Withdrawal Act 2018

ex $\mathrm{p}$

FA 2003

$\mathrm{fn}(\mathrm{s})$
Deutsche Notar-Zeitschrift [German Notary Journal]

Minpō (saiken kankei) no kaisei ni kansuru yōkö-an no tatakidai [Draft Proposal for the Motion Outline in Relation to the Reform of the Civil Code (Law of Obligations)]

European Communities Act 1972

European Convention on Human Rights (1953)

European Court of Justice (now: CJEU)

Electronic Commerce (EC Directive) Regulations 2002

European Court Reports

editor(s)

electronic data interchange

edition

Einführungsgesetz zum Bürgerlichen Gesetzbuche [Introductory Act to the Civil Code] $(1994 ; 1997)$

Regulation (EU) 910/2014 of the European Parliament and of the Council of 23 July 2014 on electronic identification and trust services for electronic transactions in the internal market and repealing Directive 1999/93/EC

\section{English Reports}

European Union

Council Directive 97/7/EC on the protection of consumers in respect of distance contracts European Union (Withdrawal) Act 2018

ex parte (on behalf of)

Finance Act 2003

footnote(s) 
FormAnpG

FormAnpG Draft Law

GBO

GbR

GG

GVG

HC

HGB

$\mathrm{HoL}$

ibid

ICJ

ICJ Statute

$\mathrm{J}$

JuS

JZ

$\mathrm{KB}$

Kaisei-kai

Kaisei kankei-hō
Gesetz zur Anpassung der Formvorschriften des Privatrechts und anderer Vorschriften an den modernen Rechtsgeschäfsverkebr [Act on the Amendment of Provisions of Form in Private Law and Other Provisions in Accordance with Modern Legal Transaction Methods] (2001)

Gesetzentwurf der Bundesregierung: Entwurf eines Gesetzes zur Anpassung der Formvorschriften des Privatrechts und anderer Vorschriften an den modernen Rechtsgeschäftsverkehr [Draft Law of the Government: Draft of a Law to Adapt the Form Requirements in Private Law and other Provisions to Modern Legal Transactions] (2000)

Grundbuchordnung [Land Registration Law] (1994)

Gesellschaft bürgerlichen Rechts [civil law partnership]

Grundgesetz [Basic Law for the Federal Republic of Germany] (1949)

Gerichtsverfassungsgesetz [Court Constitution Act] (1975)

High Court

Handelsgesetzbuch [German Commercial Code] (1897)

House of Lords

ibidem

International Court of Justice

Statute of the International Court of Justice

Judge

Juristische Schulung [Legal Education]

Juristenzeitschrift [Legal Journal]

King's Bench

Hōsei Shingi-kai Minpō (Saiken Kankei) Bukai

[Japanese Civil Code (Law of Obligations) Reform Commission]

Minpō ichibu wo kaisei suru höritsu no shikō ni tomonau kankei höritsu no seibi-tō ni kansuru höritsu [Law to Maintain Laws Affected by the Enforcement of the Law to Amend one Part of the Civil Code] (2015) 
Kaisei hō'an

Kenpō

Kyū-shōhō

LG

$\mathrm{LJ}(\mathrm{SC})$

(L)MR

LOI

LPA 1925

LPMPA 1989

LQR

LR

LRA 2002

METI

Minpō

Minso

MMR

NJW

no(s)

OJ

OJLS

OLG

OLGR

OUP

P\&CR

$\operatorname{para}(\mathrm{s})$

PC

PECL

PICC
Minpō ichibu wo kaisei suru höritsu [Law to Amend one Part of the Civil Code] (2017)

Nihon-koku Kenpō [Japanese Constitution] (1946)

[Former Japanese Commercial Code] (1890)

Landgericht [Regional Court]

Lord Justice (Supreme Court)

(Lord) Master of the Rolls

Letter(s) of Intent

Law of Property Act 1925

Law of Property (Miscellaneous Provisions) Act 1989

Law Quarterly Review

Law Reports

Land Registration Act 2002

Ministry of Economy, Trade and Industry, Keizai

Sangyō-shō

Minpō [Japanese Civil Code] (1896)

Minji soshō-hō [Japanese Code of Civil Procedures]

(1996)

MultiMedia und Recht [Multi-media and Law]

Neue juristische Wochenschrift [New Legal Weekly Journal]

number(s)

Official Journal of the European Communities

Oxford Journal of Legal Studies

Oberlandesgericht [Higher Regional Court]

OLG-Report

Oxford University Press

Property(, Planning) \& Compensation Reports

$\operatorname{paragraph}(\mathrm{s})$

Privy Council

Principles of European Contract Law

UNIDROIT Principles of International Commercial

Contracts 


\begin{tabular}{|c|c|}
\hline $\mathrm{pt}(\mathrm{s})$ & $\operatorname{part}(s)$ \\
\hline QB & Queen's Bench \\
\hline QC & Queen's Counsel \\
\hline$r(s)$ & $\operatorname{rule}(s)$ \\
\hline RabelsZ & $\begin{array}{l}\text { Rabels Zeitschrift für ausländisches und internationales } \\
\text { Privatrecht / The Rabel Journal of Comparative and } \\
\text { International Private Law }\end{array}$ \\
\hline Reg & (EC/EU) Regulation \\
\hline $\operatorname{reg}(s)$ & regulation(s) \\
\hline $\begin{array}{l}\text { Repeal Bill White } \\
\text { Paper }\end{array}$ & $\begin{array}{l}\text { Legislating for the United Kingdom's withdrawal } \\
\text { from the European Union (White Paper) }\end{array}$ \\
\hline repr & reprint \\
\hline RG & Reichsgericht [Imperial Court] \\
\hline RGZ & $\begin{array}{l}\text { Entscheidungen des Reichsgerichts in Zivilsachen [Deci- } \\
\text { sions of the Imperial Court in Civil Matters] }\end{array}$ \\
\hline$s(s)$ & $\operatorname{section}(s)$ \\
\hline SA 1891 & Stamp Act 1891 \\
\hline $\operatorname{sch}(s)$ & schedule(s) \\
\hline SGA 1979 & Sale of Goods Act 1979 \\
\hline SGSA 1982 & Supply of Goods and Services Act 1982 \\
\hline Shita'uke-hō & $\begin{array}{l}\text { Shita'uke daikin shiharai chi'en tō böshi-hō [Act against } \\
\text { Delay in Payment of Subcontract Proceeds, etc to } \\
\text { Subcontractors] (1956) }\end{array}$ \\
\hline Shōhō & Shōhō [Japanese Commercial Code] (1899) \\
\hline SI & Statutory Instrument \\
\hline SOF 1677 & Statute of Frauds 1677 \\
\hline $\operatorname{subs}(s)$ & $\operatorname{subsection}(s)$ \\
\hline $\operatorname{subpara}(s)$ & subparagraph(s) \\
\hline Takuchi-gyō-hō & $\begin{array}{l}\text { Takuchi tatemono toribiki-gyō-hō [Building Lots and } \\
\text { Buildings Transaction Business Act] (1952) }\end{array}$ \\
\hline TFEU 2012 & $\begin{array}{l}\text { Consolidated Version of the Treaty on the Function- } \\
\text { ing of the European Union }\end{array}$ \\
\hline TMG & Telemediengesetz [Tele-media Law] (2007) \\
\hline
\end{tabular}


Tokutei shō-torihi- Tokutei shō-torihiki ni kansuru hōritsu [Act on Specified ki-hō Commercial Transactions] (1976)

$\operatorname{tr}(s) \quad$ translator(s)

UK United Kingdom

UKSC United Kingdom Supreme Court

ULFC UNIDROIT Convention relating to a Uniform Law on the Formation of Contracts for the International Sale of Goods (1964)

UN United Nations

UNTS United Nations Treaty Series

UTP (The) University of Tōkyō Press

$\operatorname{vol}(s) \quad \operatorname{volume}(s)$

WLR Weekly Law Report

WM Wertpapier-Mitteilungen [Investment News]

ZEuP Zeitschrift für europäisches Privatrecht [Journal of European Private Law]

ZJapanR / JJapanL Zeitschrift für Japanisches Recht / Journal of Japanese Law

ZPO Zivilprozessordnung [German Code of Civil Procedure] (2005; 2006) 


\section{A Note on Style, Transcriptions, and Translations}

Style

Both the writing and the citation style adopted in this dissertation generally follows the 'New Hart's Rules: The Oxford Style Guide' and the 'Oxford University Standard for the Citation of Legal Authorities (OSCOLA)'. ${ }^{1}$ OSCOLA will be used for all bibliographical material (monographies, journal articles, websites, etc), English case law and legislation, and for EU cases and legislation. German and Japanese legislation and cases will be cited according to the conventions of each country. ${ }^{2}$ Accordingly, a German case will be referenced by naming the court, the decision date, the case reference number, and, where applicable, one or two case records. Similarly, Japanese cases will be identified by the court name, the date of the decision, and the case record. Deviations from the two standards mentioned above will be consciously adopted in the following cases:

First, where the title of a source is in a language other than English, the original title will be given first, followed by a translation into English in square brackets. Secondly, in order to avoid doubts, reference to page numbers will be given as a page range with the numbers in full, ie, 150164 instead of 150-64. Thirdly, for ease of readability, links to webpages will not be put between angled brackets $(<>)$, nor will the last date of access be included. Finally, for easy readability, titles of references will be written in italics and without inverted commas, irrespective of the language of the reference or its type (monography, journal article, etc).

1 Robert M Ritter, New Hart's Rules: The Oxford Guide to Style (OUP 2005); Oxford University Standard for the Citation of Legal Authorities (4 ${ }^{\text {th }}$ edn, 2012), hereinafter 'OSCOLA 2012'. The rules for citing international law are contained in OSCOLA 2006: Citing International Law Sources Section (excerpt from the 2006-edn), hereinafter 'OSCOLA 2006'.

2 Although there seems to be no uniform citation style in Germany, the following is a useful general guide: B Sharon Byrd and Matthias Lehmann, Zitierfibel für Juristen [Citationguide for Lawyers] ( $2^{\text {nd }}$ edn $\mathrm{CH}$ Beck/Nomos/Manz/Vahlen 2016). A useful guide on the form of citation and translation of titles of judicial, statutory, or other materials from Japanese into English, see, eg, Hideo Tanaka and Malcolm DH Smith (eds), The Japanese Legal System: Introductory Cases and Materials $\left(10^{\text {th }}\right.$ edn, UTP 2000) 30-35. 


\section{Translations and Transcriptions of Foreign Language Terms}

Any terms from languages other than English, ie, German or Japanese, and occasionally Latin, will be given in two forms: Either the English translation will be followed by the original term in brackets; or, where this seems more practical, the order will be reversed. Japanese words will be transcribed into the Roman alphabet ('romanised'), but the original kanji ${ }^{3}$ will be stated also in order to minimise misunderstandings. The romanisation of Japanese terms will be made in accordance with the transcription and segmentation system adopted by Bernd J Götze. ${ }^{4}$ Unless otherwise stated, transcriptions of Japanese characters, especially of legal provisions, will have been prepared by this author with reference to this segmentation system.

English translations of German and Japanese statutory provisions, and, in case of Japanese legislation, kanji, will be taken from the translations of the law in question as provided by the German Federal Ministry of Justice and Consumer Protection (Bundesministerium der Justiz und für Verbraucherschutz, hereinafter 'BMJV') ${ }^{5}$ and the Japanese Ministry of Justice (Homu-sho , 法務省 $)^{6}$ in so far as these are available. ${ }^{7}$ Titles of Japanese

3 According to the entry in the Oxford English Dictionary Online at www.oed.com, 'kanji' means: '(a) The corpus of borrowed and adapted Chinese ideographs which forms the principal part of the Japanese writing system. Cf. kana n. (b) Any one of these ideographs. Used esp. attributive.'

4 Bernd J Götze and Harald Baum, Merkblatt für eine einheitliche Transkription, Übersetzungen und Zitierweise für Veröffentlichungen in der Zeitschrift für Japanisches Recht [Explanatory Notes for a Uniform Approach Regarding Transcriptions, Translations and Citations in Publications for the Journal of Japanese Law] (1998) 5 ZJapanR / JJapanL 207-216. For more detailed rules on the word segmentation of transcribed Japanese terms, see Bernd J Götze, Wortsegmentierungsregeln (nicht nur) für japanische Rechtsbegriffe [Word Segmentation Rules (Not Just) for Japanese Legal Terms] (2005) 19 ZJapanR / JJapanL 207-213.

5 See www.gesetze-im-internet.de/Teilliste_translations.html.

6 See www.japaneselawtranslation.go.jp/. For further information regarding the development of the governmental project surrounding the English translation of Japanese laws, as well as explanations of the translation methods used, see Noboru Kashiwagi, Translation of Japanese Statutes into English (2007) 12 ZJapanR / JJapanL 221-226 and ibid, Translation of Japanese Statutes (2014) 11 University of Tōkyō Journal of Law and Politics 1-7; see further Carol Lawson, Found in Translation: The "Transparency of Japanese Law Project" in Context (2007) 12 ZJapanR / JJapanL 187-199.

7 Thus, unless otherwise stated, translations of provisions will have been taken from these (official) translations. Direct links to the translations of specific laws will be indicated when the enactment in question is referred to for the first time. 
and German pieces of statutory legislation (höritsu, 法律, and Gesetze respectively) will be translated as 'law', not 'act' in order to avoid confusion with English statutes, unless an official translation uses the latter term. ${ }^{8}$ Japanese legal terms that are not included in statutory provisions will normally be taken from the Standard Legal Terms Dictionary published by the Japanese Law Translation Council. ${ }^{9}$ Otherwise, reference in relation to translations and transcriptions will also often be made to Bernd J Götze's Japanisch-Deutsches Rechtswörterbuch [Japanese-German Legal Dictionary], ${ }^{10}$ and, in relation to the meaning of kanji, to Wolfgang Hadamitzky and others (eds), Langenscheidt Großwörterbuch Japanisch-Deutsch Zeichenwörterbuch [Langenscheidt's Japanese-German Character Dictionary]. ${ }^{11}$ Translations of other cited texts, such as quotes from articles or monographies in a foreign language, will be the work of this author. Exceptionally, where an English translation of a work exists, this will be shown by adding the phrase 'English title' or similar in the reference.

8 Confusion with the wide meaning of the term 'law' should not arise, as the context of the discussion will indicate instances of the wider meaning.

9 Japanese Law Translation Council, Hōrei yōgo nichi'ei byöjun taiyaku jisho [English title: Standard Legal Terms Dictionary] (Version 14, 2019), available at www.japaneselawtranslation.go.jp/dict/download? $\mathrm{re}=02$. This dictionary will hereinafter be referred to as the 'Dictionary of Standard Japanese Legal Terms'. For further information regarding the Dictionary, see Kashiwagi, '2014' (fn 6).

$102^{\text {nd }}$ edn, Seibun-dō 2012.

11 Langenscheidt KG 1997. 


\section{A. Introduction}

Contracts form the basis of numerous aspects of our daily lives, both in private matters and in relation to our work. Not only may we have rented, leased, or even purchased the house we live in, we will probably have purchased the clothes we wear, and almost certainly the food we consume; similarly, our work relationship will usually be based on an employment contract; whenever we use public transport, watch a movie, go to a concert, see a doctor, or hire a tax adviser, we rely on service contracts. These are only a few examples of all the different contracts that govern our lives. As a consequence, the coming into existence of these contracts is a vital question when considering any kind of legal (trans)action.

Despite the advance in globalisation and the internationalisation of trade, as well as the appearance of international treaties like the United Nations Convention on Contracts for the International Sale of Goods (adopted 11 April 1980; hereinafter 'CISG') ${ }^{12}$ and projects to harmonise contract law ${ }^{13}$, such as the Principles of European Contract Law ${ }^{14}$ (of 2002, commonly abbreviated as 'PECL'), domestic laws are still of relevance in several respects. ${ }^{15}$ This is not only true for matters that are not regulated

121489 UNTS 58. On the status of the Convention, including a list of signatory states, see https://treaties.un.org/Pages/ViewDetails.aspx?src=IND\&mtdsg_no=X-1 0\&chapter $=10 \&$ clang=_en.

13 For the purposes of this dissertation, contract law is understood as those rules which govern a contract. The differentiation of whether this subject is a standalone category of private law, as in English law, or rather seen as a sub-category of a law of obligations, as in German and Japanese law, will thus not be discussed here. See on this briefly Martin Schmidt-Kessel and Shane McNamee, Methodological Issues in Selected Branches: European Contract Law, in: Karl Riesenhuber (ed), European Legal Methodology (Intersentia 2017) 405, 408-409.

14 Ole Lando (ed), Principles of European Contract Law (Kluwer Law International) Parts 1-2 (rev edn, 2000), Part 3 (2003).

15 Something along this line is suggested by Konrad Zweigert and Hein Kötz, Einführung in die Rechtsvergleichung [Introduction to Comparative Law] ( $3^{\text {rd }}$ edn, Mohr 1996) V (preface). See also Thomas Kadner Graziano, Comparative Contract Law: Cases, Materials and Exercises (Eleanor Grant tr, Palgrave Macmillan 2009) 3 , who states that provisions of national law 'play an important role [...], particularly in purely domestic scenarios', but that these are 'not the only rules' applicable to contracts, in particular to transnational ones. The author goes on to note that national law and international treaties 'coexist'. One given example 
on a transnational scale, such as the form of contracts, but is due to the fact that contracting parties seem to tend to choose national laws to govern their relationship. ${ }^{16}$ In this respect, it also ought to be borne in mind that modern contract laws foresee a range of norms that are sometimes prescriptive (mandatory), but more often dispositive (optional) in nature, so that the latter act as default rules to the contractual provisions made by the parties. ${ }^{17}$ In this way, domestic laws support the self-determination of the parties. For all of these reasons, knowledge of the national rules is crucial when considering the issues surrounding the conclusion of a contract. This is true not only for one's own domestic law, but also for foreign laws that may govern the formation process. ${ }^{18}$

is the CISG, which contains stipulations on the formation of contracts (arts 1424). These provisions will be discussed in detail in Section E.I. and II. below. A detailed introduction to and discussion of the Convention can be found in, eg, Larry A DiMatteo (ed), International Sales Law: a Global Challenge (CUP 2014).

16 The question of choice of law is one of private international law and will not be considered in this dissertation. Interested readers are referred to the following materials: Lawrence Collins (gen ed) and others, Dicey, Morris and Collins on the Conflict of Laws (15 ${ }^{\text {th }}$ edn, Sweet \& Maxwell 2012) Vol 2, 1797-1817; Gisela Rühl, Rechtswahl [English title: Choice of Law by the Parties], in: Jürgen Basedow and Klaus J Hopt and Reinhard Zimmermann (eds), Handwörterbuch des europäischen Privatrechts [English title: The Max Planck Encyclopedia of European Private Law] (Mohr Siebeck 2009) Vol II 1270-1274 (the German version of the Encyclopedia is available online at http://hwb-eup2009.mpipriv.de/index.php/Handw\%C3\%B6rterbuch_des_Europ\%C3\%A4ischen_Privatrechts); Yūko Nishitani, $\mathbb{} 26$ Internationales Privat- und Zivilverfahrensrecht [Chapter 26 Private International and International Procedural Law], in: Harald Baum and Moriz Bälz (eds), Handbuch Japanisches Handels- und Wirtschaftsrecht [Handbook Japanese Commercial- and Business Law] (Heymann 2011) 1211, 1235-1237 paras 64-66.

17 Compare Hein Kötz, Europäisches Vertragsrecht [European Contract Law] (Mohr Siebeck 2015) 10, who puts the largely dispositive nature of contractual rules down to the principle of freedom of contract. A similar argument is advanced by Schmidt-Kessel and McNamee (fn 13) 415, who even rank the declarations by and the consensus of the parties first before dispositive and mandatory contract law rules. According to these authors, the function of the mandatory rules is the 'set[ting of] certain limits', see Schmidt-Kessel and McNamee, ibid 416.

18 This may be due to the regulation in the conflict of law rules. Again, this topic will not be considered in this dissertation, as its breadth would demand a consideration on its own. Readers are therefore referred to works on private international law, in particular: Collins (fn 16); Rühl (fn 16), and Jürgen Basedow, Internationales Privatrecht [English title: Private International Law], in: Basedow and Hopt and Zimmermann (fn 16) Vol I 902-906; Nishitani (fn 16). 


\section{A. Introduction}

\section{Motivation, Subject, and Objectives of the Analysis}

When considering the conclusion of a binding contract from a legal perspective, there are numerous aspects that need to be borne in mind. In this dissertation, the requirements foreseen for the formation of a contract in Japanese law will be contrasted with those found in English and German law. This constitutes an endeavour to indicate the variations within the legal formation of contracts in relation to English, German, and Japanese law, which, although sometimes deceptively small, and while certainly interesting from a comparative law perspective, may have great importance for contracting in practice. Coming with a little practical experience herself, the author is aware that some aspects of importance in applied (contract) law can be easily overlooked when confronted with purely theoretical treaties on a particular subject. In this sense, some legal academics have commented that the purpose of contracts lies in economic benefits. ${ }^{19}$ As a consequence, it has been argued that contracts will necessarily appear to be the same in their final form, with little or no local differences. ${ }^{20}$ While this may be true, it cannot be denied that the basic requirements for contracts vary across different legal regimes. ${ }^{21}$

By looking at these three legal orders, a rough understanding may be gained of the situation in three different legal families: the civilian system, represented by Germany; the common law system, represented by England; and that of a hybrid or mixed system that has been influenced by both of these systems, represented by Japan. While this selection cannot give a definite picture of the situation in each of the three legal families, it suffices to give an inkling of the general differences that exist in contract-

19 Compare Hein Kötz and Axel Flessner, European Contract Law Vol 1 Formation, Validity, and Content of Contracts; Contract and Third Parties (Clarendon Press 1997) 6.

20 Indeed, a functional comparative analysis will often lead to the result that what appear to be differences in legal stipulations are resolved when viewed in terms of their function, see Colm P McGrath and Helmut Koziol, Is Style of Reasoning a Fundamental Difference Between the Common Law and the Civil Law? (2014) 78 RabelsZ 709, 710, who refer to the comparative approach created by Konrad Zweigert and Hein Kötz in their work 'An Introduction to Comparative Law' (Tony Weir tr, $3^{\text {rd }}$ edn 1998).

21 This is true even for the notion of a contract. See on this Arthur T von Mehren, Chapter 1: Introduction, in: René David and others (eds), International Encyclopedia of Comparative Law (Mohr Siebeck/Nijhoff 2008) Vol VII/1 3, 5-6. 
ing across the world. ${ }^{22}$ As will be seen, these differences begin with both of the required declarations of intention, ie, the offer and the acceptance; however, they do not end there. Although the fundamental principle of consensual contracts is present in all three of the jurisdictions considered in this dissertation, a range of other requirements exists. Aptly termed 'indicia of seriousness', ${ }^{23}$ the legal orders considered in this dissertation prescribe that something beyond a mere consensual and usually mutual arrangement must exist before deeming an agreement to be an enforceable contract. This may be a factual question concerning the willingness to be legally bound, a particular form, or that something be handed over at contracting as a token of one's earnestness. ${ }^{24}$ It is these further requirements that bring out the differences between the legal systems best, especially with regard to formalities. This is the case even within Europe, as the juxtaposition of the legal frameworks in England and Germany in Section B. will show. Notable differences are equally visible in comparison with Japanese law (on which see Section C. below), as will become clear from the comparison of the three legal orders in Section D.

To this author's best knowledge, no one piece of academic work has focused on a comparison of the contract formation rules in this constellation, ie, of these three legal systems, while also considering the context of its background and operating framework. ${ }^{25}$ Even when looking at each

22 Indeed, it has been argued that a comparison between two systems of the same legal family gives a wider scope to the analysis: compare, eg, Guido Alpa, Conceptions and Definitions of Contract: Some Thoughts on the Differences in English and German Law (2019) 2 Zeitschrift für Internationales Wirtschaftsrecht (IWRZ) 51, 52. While this may have merit, the aim of this dissertation is to highlight the similarities and differences between European and Asian countries.

23 The expression was coined by Konrad Zweigert and Hein Kötz in their joint work cited in fn 15 above. For a brief discussion of the term, see Hein Kötz, Seriositätsindizien [Indicia of Seriousness; in English version 'Tests of Earnestness'], in: Basedow and Hopt and Zimmermann (fn 16) Vol II 1397-1400; for a deeper analysis, see Zweigert and Kötz (fn 15) 382 et seq; or Kötz, 'Europäisches Vertragsrecht' (fn 17) 68 et seq.

24 Kötz, 'Seriositätsindizien' (fn 23) 1398.

25 Of course, comparative analyses exist, such as the classical work by Rudolf B Schlesinger (ed), Formation of Contracts: A Study of the Common Core of Legal Systems (Oceana 1968); or the more recent work by Jessica Schmidt, Der Vertragsschluss: ein Vergleich zwischen dem deutschen, französischen, englischen Recht und dem CESL [The Formation of Contracts: A Comparison of German, French, English Law and the CESL] (Mohr Siebeck 2013). There are also works in which contract law from across the world is considered, in which, however, no in-depth comparison is made. See, eg, David and others (fn 21) Vols VII/1 and 2. 


\section{A. Introduction}

legal system individually, the fact that the basic rules have changed little in the past century, while the practical circumstances have, makes a fresh evaluation worthwhile. The comparative approach adopted in this analysis allows for the variations to be brought into focus more clearly. At the same time, the juxtaposition brings to light issues that are not usually discussed — or at least not at length - in one or the other legal system, although these might be practically relevant.

This dissertation cannot and in fact does not aspire to become a handbook for practitioners in transnational contract law. Instead, the aim is to present a work that goes beyond a mere theoretical exposition and to include facets which are often treated too superficially, if at all, in present literature. This is especially true for form requirements and the mark verifying a person's intention in a written document: the signature or seal impression. The aim is to raise awareness of these matters by discussing them in the context of their operating framework, including the legal thinking prevalent in each system, as explained in the following section.

In order to avoid confusion, it should be noted at the outset that any reference to 'English law' in this dissertation means the law as applicable in England and, generally, Wales. ${ }^{26}$ The fact that England forms part of the United Kingdom ${ }^{27}$ (hereinafter 'UK') notwithstanding, the law in Scotland and Northern Ireland differ from that of England. ${ }^{28}$ Focus will be on the latter, as this is what is sometimes referred to as the 'mother of all common laws'. ${ }^{29}$ More on English law and its sources will be said in Section B. Before proceeding with the analysis, a further delimitation of the topic will be made in Section II. This is followed by a note on the method of the analysis in Section III.

26 Authors have noted that the legal system of Wales is the same as that of England, see, eg, Collins (fn 16) Vol 1, 31 para 1-067. See further the geographical definition of England as including Wales, ibid 32 para 1-073. cf the legal definition of England and Wales in sch 1 Interpretation Act 1978 and ss 1 and 20 Local Government Act 1972. cf also David H Griffith and Joel Harrison, United Kingdom, in: Dennis Campbell (ed), E-commerce and the Law of Digital Signatures (Oceana Publishing 2005) 637, 639, who note that the law in Wales may deviate in some situations.

27 For a geographical definition, see Collins (fn 16) Vol 1, 33 paras 1-075 (United Kingdom), 1-074 (Great Britain), and 32 para 1-073 (England).

28 Compare Penny Darbyshire, Darbyshire on the English Legal System $\left(11^{\text {th }}\right.$ edn, Sweet \& Maxwell 2014) 9 para 1-008; Griffith and Harrison (fn 26) 639.

29 Darbyshire (fn 28) 11 para 1-013. 


\section{Defining and Delimiting the Topic}

The formation of a contract can be a complex process which can hardly be set out adequately in a doctoral dissertation, even if only one legal system were analysed. As this dissertation will investigate three jurisdictions, ${ }^{30}$ aspects must be selected in order to allow for deeper discussion. It may be said generally that the exposition will analyse contracts in three constellations: between businessmen (B2B contracts), between businessmen and consumers (B2C contracts), and between consumers only (C2C contracts). The latter seems to be of growing importance recently, due to the rise of a number of internet platforms that allow private individuals to contract directly with each other, whether this be for the purposes of selling, swapping, lending (eg, tools) or renting something (eg, a car or a house), or even just to give someone a helping hand. ${ }^{31}$ This phenomenon has been labelled the 'share economy'. 32

While relevant aspects of specific fields such as consumer, labour, or land law will be touched upon during the subsequent discussion, details must be left to works dedicated wholly to the subject in question. In contrast, agreements or arrangements arising in relation to family affairs, such as marriage and divorce contracts, adoptions, etc will not be discussed and will be equally left to specialists in the area of family law. Similarly, the area of law surrounding quasi-contracts will not be covered in this dissertation, as these kinds of obligations are not contracts in the strict

30 The scope is in fact even larger, as applicable rules on the formation of contract found in European and international law will also be considered. More on this subsequently.

31 Next to global companies such as eBay, Uber, and Airbnb, a plethora of regional platforms exist, eg, www.any-times.com (Japan, for skills), www.libraryofthings.co.uk (UK, for tools and skills), www.nebenan.de (Germany, for goods and skills).

32 See generally, eg, Jenny Kassan and Janelle Orsi, The Legal Landscape of the Sharing Economy (2012) 27 No 1 Journal of Environmental Law \& Litigation 1, 313; Devyani Prabhat, "BorrowMyDoggy.Com": Rethinking Peer-to-peer Exchange for Genuine Sharing (2018) 45 No 1 Journal of Law and Society 84, 87, 90. Perhaps due to the rising success of these platforms, commercialisation has slowly crept in, so that the parties may not be private persons only, but involve merchants or entrepreneurs. On the problems of this phenomenon, see, eg, Prabhat, ibid 87-90; on the legal challenges, see Kassan and Orsi, ibid 13 et seq. 


\section{A. Introduction}

sense due to the fact that they arise from law rather than from the parties' agreement. $^{33}$

In terms of the formation process, it may be stated at the outset that the legal frameworks in Europe and in other parts of the world are cast in a similar fashion. Thus, for there to be an agreement that is deemed legally binding, a contract must arise from declarations of intention that are flawless (ie, the person must possess the required mental and legal capacity to act, the declaration must be free from errors or undue influence, etc), the declarations must also be mutual and correspond in terms of their content. A range of these issues will not be covered. This includes the matter of a person's mental and legal capacity, as well as mistake, duress, and fraud. The reason is that the interest of this author lies in the contract itself and its formation process. And while it may be true that the abovenamed issues have a bearing on this process, they are subjects eliciting diverse discussions in all three jurisdictions examined in this dissertation, making them worthy of individual examination, and would thus surpass the limits set for this dissertation. ${ }^{34}$ For the same reasons, aspects like the interpretation of a contract's terms and control of its content through public morals or standard term regulation will be largely omitted and only referred to, as required, to illustrate a point. Similarly, other aspects such as promissory estoppel, culpa in contrahendo, and good faith will only be mentioned where directly relevant to the discussion in this dissertation, ie, the formation of a contract.

Apart from the three individual jurisdictions named above, regulation from selected other sources will be considered, namely, pertinent supraand international law from the European Union (hereinafter simply 'EU law' $)^{35}$ and the CISG. Moreover, transnational efforts in relation to the

33 See Halsbury's Laws of England (4 ${ }^{\text {th }}$ edn, LexisNexis 1974) Vol 9 paras 201, 212, 634. cf Atiyah, An Introduction to the Law of Contract ( $5^{\text {th }}$ edn, Clarendon Press 1995 ) 45-46, who states that this is now treated as a separate branch of law from contract, namely, under the law of restitution.

34 Beside general comparative works such as Kötz, 'Europäisches Vertragsrecht' (fn 17), see more specifically: Ernst A Kramer and Thomas Probst, Defects in the Contracting Process, in: David and others (fn 21) Vol VII/2 3 et seq; Michael $\mathrm{H}$ Whincup, Contract Law and Practice: The English System, with Scottish, Commonwealth, and Continental Comparisons ( $5^{\text {th }}$ edn, Kluwer Law International 2006) 107-123, 287-335; Raymond Youngs, English, French \& German Comparative Law ( $3^{\text {rd }}$ edn, Routledge 2014) 580-584, 608-630.

35 The importance of EU law has been noted by many; see, eg, Stefan Grundmann, Series Preface, in: Riesenhuber (fn 13) v-vii. cf Christian Twigg-Flesner, Lessons for Consumer Law Reform from the UK's Consumer Rights Act 2015 (Lecture, Ryūkoku 
harmonisation of contract law, in particular the PECL, the Draft Common Frame of Reference for European Contract Law ${ }^{36}$ (commonly abbreviated as 'DCFR'), and the Common European Sales $\mathrm{Law}^{37}$ (commonly abbreviated as 'CESL') will be considered briefly in Section E.II. ${ }^{38}$ The UNIDROIT Principles of International Commercial Contracts (commonly abbreviated as 'PICC') will not be examined, as its content - in particular in relation to the formation of contracts - is an almost identical wording to the provisions of the CISG. ${ }^{39}$

\section{A Note on the Method}

The dissertation follows a particular order in its exposition. First, the legal framework is set out in a theoretical manner to provide for a solid basis. Having said this, reiterations at length of discussions on technical or semantical points will be avoided wherever possible to maintain a certain level of easy readability. Instead, an overview of the key points of any

University, Kyōto, Japan, 8 November 2015), who notes that EU law does not regulate the formation of contracts.

36 Christian von Bar and Eric Clive and Hans Schulte-Nölke (eds), Principles, Definitions and Model Rules of European Private Law: Draft Common Frame of Reference (DCFR) (full edn, Sellier European Law Publishers 2009) 6 Vols. The text is available online at http://storme.be/european-private-law_en.pdf. Page numbers refer to the online version.

37 European Commission, Proposal for a Regulation of the European Parliament and of the Council on a Common European Sales Law COM (2011) 635 final. The Proposal contains the CESL in Annex I to the regulation. Hereinafter, references to the regulation will be as 'art [no] CESL Reg', while references to the actual CESL will simply be 'art [no] CESL'. Note that this project has been abandoned, see Jan M Smits, Contract Law: A Comparative Introduction (2 ${ }^{\text {nd }}$ edn, Edward Elgar Publishing 2017) 31.

38 An excellent overview over these and other European projects is given by Nils Jansen and Reinhard Zimmermann, General Introduction: European Contract Laws, in: ibid, Commentaries on European Contract Laws (OUP 2018) 1-13.

39 See, International Institute for the Unification of Private Law (UNIDROIT), UNIDROIT Principles of International Commercial Contracts (2016) xxix (introduction to the 1994 edition), where it is stated that some rules have 'been taken over more or less literally from the world wide accepted United Nations Convention on Contracts for the International Sale of Goods', and that inter alia arts 1.9 (now 1.10, Notice) and 2.2 (now 2.1.2, Definition of offer) 'follow the solutions found in that Convention'. 


\section{A. Introduction}

discussions will be given and reference material for further in-depth investigation offered to those interested in the topic.

In relation to this first aim, the theory will be set out in its context, so that contract law can be seen as 'a law in action'. ${ }^{40}$ The setting will be composed of the historical development on the one hand, to aid in uncovering the rationale behind a particular rule and improve understanding of the way in which the norms came to be. ${ }^{41}$ On the other hand, simultaneously acting as a second step, points that are relevant to legal practice will be highlighted. Moreover, in order to foster greater comprehension of the legal practices in question, significant aspects of the legal mentality cultivated in the three legal systems will be set out. ${ }^{42}$

Put in technical terms, this dissertation therefore combines a functional comparison with an analysis of the legal origin and its current practice. The author aims to balance the level of theory and information with readability in order to keep the end product digestible. Stemming from this objective, the legal theory and practice of English, German, and Japanese contract law will be set out with its context (history, legal mentality) for each jurisdiction separately, before a direct comparison is made on specific points of interest.

The following exposition is written as seen through the eyes of the English legal system, as this jurisdiction forms the foundation of the author's legal education. ${ }^{43}$ This perspective has also affected the choice of vocabulary and particular stylistic elements (on which see Section 2. below).

40 Compare Stefan Grundmann and Jan Thiessen, Vorwort [Preface], in: ibid (eds), Recht und Sozialtheorie im Rechtsvergleich / Law in the Context of Disciplines: Interdisziplinaeres Denken in Rechtswissenschaft und -praxis / Interdisciplinary Approaches in Legal Academia and Practice (Mohr Siebeck 2015) V, stating this to be the approach of a functional legal comparison.

41 In the words of Youngs (fn 34) xvi: '[A] proper understanding of a legal system can be obtained only by looking into the past.' This approach gains importance if one considers what Schmidt-Kessel and McNamee (fn 13) have pointed out at 423 , namely, that 'the basis for enactment of a certain norm often is not actually a conscious political decision of the legislature, but rather simply tradition' (emphasis added).

42 As was said by one German legal academic, law cannot be understood without regard to the understanding of a particular circle of persons as it is a 'spiritual reality' ('geistliche Wirklichkeit'). Compare Ernst-Wolfgang Böckenförde, Der Rechtsbegriff in seiner geschichtlichen Entwicklung: Aufriß eines Problems [The Concept of Law seen in its Historical Development: Outline of the Matter] (1968) 12 Archiv für Begriffsgeschichte 145, 146.

43 To quote the very fitting words of Youngs (fn 34) xvii once again: 'I have to admit that I have seen the other legal systems through English eyes.' 
Perhaps more importantly, it has prompted the exposition to be weighted: the section on English law has been written concisely on purpose; rather, more focus is given to the section on German law, and, even more to the one on Japanese law. 


\section{B. Comparative Background}

As stated, the basis for the comparison of Japanese contract law will be English and German contract law as representatives of the common law and the civil law tradition respectively (see below). Both of these systems are relevant when analysing Japanese contract law, since Japanese law has been influenced by each of these laws (among others), particularly during the modernisation of the Japanese legal system starting in 1868. This process will be explained in detail in Section C.III.2. below. In what follows, the classification of English and German law will be explored in Section I. The emergence and development of contract law in England will be explored in Section II., followed by a similar discourse of German contract law in Section III.

\section{Classification of the Legal Traditions of English and German Law and the Sources of their Contract Laws}

In analysing and contrasting the laws of different countries, it is important to bear in mind that differences in legal regulation stem - at least partially - from the tradition underlying the legal system in question. For this reason, the sketching of the comparative background will begin with a classification of the English and the German legal systems (see Section 1. below) and an identification of the sources forming these two legal orders (Section 2.). Another aspect affecting the development of regulations is the historical context. This will be considered separately for each of the countries in Sections II.2. and III.2. below.

\section{Classification of the Legal Traditions of English and German Law}

The classification of legal systems into groups or families has been attempted by applying various criteria, eg, by concentrating on the legal ideology of a country, or by focusing on the sources or the content of a legal 
system. ${ }^{44}$ Irrespective of which classification standard is applied, it remains true that the English system, which is usually subsumed under the AngloAmerican or Common Law legal tradition, and the German system, which is normally contained in the (Roman-) Germanic (civil) legal family, are treated as distinct traditions. ${ }^{45}$ In contrast, Japanese law is generally not contained in lists of the different legal traditions, as it is not so much a source for a legal family, but rather the recipient of several foreign inspirations. The nature and classification of the Japanese legal system as 'mixed' will be analysed in C.I. below.

\section{Sources of English and German (Contract) Law}

Owing to the differences in their legal traditions, the sources of English and German law vary; or, rather, the weight given to each source differs in the two legal systems. ${ }^{46}$ This becomes clear in the exposition of the inter-relationship of the different sources of English and German law. It can be stated at this point that one exception is the co-existence of law and equity in the English legal system (see Section a. below). ${ }^{47}$ Conversely, one point in common is that the first source for both English and German contract law, adhering to the principle of freedom of contract, is the

44 For a discussion of these criteria and references to authors adopting different categorisations, see Zweigert and Kötz (fn 15) 62-64, 66. They present a modification of the discussed classification methods, namely, by grouping according to 'legal styles' ('Rechtsstile'), see ibid 67-73. They refer to, inter alia, common historical roots and legal thought as two aspects for distinguishing between these styles. Similar: Smits (fn 37) 25.

45 This categorisation is adopted by, eg, Zweigert and Kötz (fn 15) 177-178 and 130-131 respectively. Smits (fn 37) gives a brief overview of the features of the civil and common legal systems at 25-26 and 28-29 respectively. Zweigert and Kötz, ibid 64 caution that such classifications are made by academics from the field of private law, so that the groupings are best described as being true for private law only; the results may deviate where other areas, eg, constitutional law, are contrasted. In this author's opinion, the classification of English, German, and Japanese law as belonging to the traditions of the Common, Civil, and a hybrid legal system respectively holds true for contract law and is thus adopted in this dissertation.

46 Compare Smits (fn 37) 16.

47 While it is true that there is no organised system like equity to be found in German law, there is the notion of Treu und Glauben (good faith), which seems to underpin German legal reasoning in a similar way to equity. This will be considered cursorily in Section b. below. 


\section{B. Comparative Background}

agreement between the parties itself. ${ }^{48}$ Subsidiarily, ${ }^{49}$ the sources of the legal system, ie, of England (see Section a.) or of Germany (see Section b.) come into play. Within these sources, the two systems have - for the time being $^{50}$ - two sources in common from the European Union (hereinafter 'EU'): ${ }^{51}$ legislation adopted by the European Parliament, the Council of the European Union, and the European Commission (hereinafter 'EU legislation'); 52 and decisions made by the Court of Justice of the European Union (CJEU; hereinafter 'EU case law'). ${ }^{53}$ There is further international law, such as the European Convention on Human Rights ${ }^{54}$ (hereinafter 'ECHR'), which is applicable in the two countries. These sources will be

48 Compare generally Smits (fn 37) 16-17; Schmidt-Kessel and McNamee (fn 13) 415 , borrowing the former phrasing of the French civil code 'the contract is the law of the parties' (former art 1134 para 1). For English law, see, eg, Ewan McKendrick, Contract Law: Text, Cases and Materials (5 ${ }^{\text {th }}$ edn, OUP 2012) 1 and Roy Goode (founder) and Ewan McKendrick, Goode on Commercial Law ( $5^{\text {th }}$ edn, Penguin Books 2016) 910 para 32.09. For German law see, eg, Manfred Wolf and Jörg Neuner, Allgemeiner Teil des Bürgerlichen Rechts [General Part of the Civil Code] (Karl Larenz founder, 10 $0^{\text {th }}$ edn, Beck 2012) 97 para 23.

49 Where national laws set out mandatory rules, these obviously have priority over anything the parties have stipulated that is contrary to these norms. Otherwise, national contract law will often be made up of default rules, which only take effect if the parties have not made a stipulation on the matter in question. See generally on this Smits (fn 37) 18. Contrast Schmidt-Kessel and McNamee (fn 13) 426, who question dispositive rules and case law acting as a source of law.

50 Presumably, this statement will cease to be true once the UK has ceased to be a member of the European Union. This scenario will be considered briefly in Section a.iv. below.

51 On the influence of the EU on European laws, see generally Kötz, 'Europäisches Vertragsrecht' (fn 17) 11-13.

52 For more details on the law-making process in the EU, see https://europa.eu/european-union/about-eu/institutions-bodies_en\#law-making. See also Paul Craig and Gráinne de Búrca, EU Law (6 $6^{\text {th }}$ edn, OUP 2015) 31-46, $50-57$ (EU institutions involved in legislating), 124-146 (EU law-making process).

53 Further information on the court can be found at https://europa.eu/european-union/about-eu/institutions-bodies/court-justice_en. The court was formerly known as the European Court of Justice, so that the abbreviation ECJ is also sometimes used in literature, see Catherine Elliott and Frances Quinn, English Legal System (15 ${ }^{\text {th }}$ edn, Pearson 2014) 98. See further Craig and de Búrca (fn 52) 57-66 on the CJEU and the EU's court system.

54 Convention for the Protection of Human Rights and Fundamental Freedoms, opened for signature in Rome on 4 November 1950, came generally into force in 1953, see www.echr.coe.int/pages/home.aspx?p=basictexts. For a detailed discussion of this Convention and its application in the UK and Germany, see, eg, Youngs (fn 34) 115-363. 
borne in mind during the subsequent discussion of the two legal systems, whereby international law will only be considered selectively as explained in Sections a.v. and b.v. below.

\section{a. Sources of English (Contract) Law}

In England, legal sources are broadly divided into primary and secondary sources. ${ }^{55}$ Within each of these categories, further demarcations are made, whereby an order of preference can be observed. ${ }^{56}$ The weight given to these sources will be explored first in Section i., before the sources themselves are addressed briefly in Sections ii.-v.

\section{i. The Inter-relationship of the Sources in English (Contract) Law}

While the differentiation between primary and secondary sources already connotes some preference, further distinctions are made within these two categories. Thus, primary sources of the English legal system include (in order of importance): EU legislation, English legislation, EU case law, English case law, the ECHR and the decisions of the European Court of Human Rights, as well as other international law. ${ }^{57}$ Of these, the ECHR

55 Deviating classifications have been made, see, eg, Whincup (fn 34) 1 para 0.2, who speaks of 'three main sources or elements' of modern English law.

56 For a brief overview of the classification, see the Quick Reference Guide in OSCOLA 2012 (fn 1) 55 (back cover).

57 Compare Darbyshire (fn 28) 21 para 2-001, who lists the sources in a slightly different order. As will be seen in the subsequent discussion, the arrangement by this author corresponds to the theoretical order of application. For information on the treaties entered into by the UK, see www.gov.uk/guidance/uk-treaties. There are, furthermore, other rules beside treaties, including international custom or general principles (see art 38 para 1(b)-(c) Statute of the International Court of Justice, signed on 26 June 1945 at San Fransico; hereinafter 'ICJ Statute'; published, inter alia, in International Court of Justice, Acts and Documents Concerning the Organization of the Court No 6 (February 2007) 59-87, available online at www.icj-cij.org/en/publications). The International Court of Justice (hereinafter 'ICJ') is the 'judicial organ' of the United Nations (hereinafter 'UN'), see art 1 ICJ Statute. See Darbyshire (fn 28) 47 para 4-044 for further discussion, in particular of international custom. 
will not be considered further, as its provisions, while certainly significant, have little bearing on the formation process of contracts..$^{58}$

Secondary sources include (in no particular order): books of authority, ${ }^{59}$ custom (and usage), and equity. ${ }^{60}$ These sources are all significant - to different degrees - for contracts, in keeping with the statement that English contract law 'is a well-blended mix of common law, equity, and statute'. ${ }^{61}$ While this is true, customs ${ }^{62}$ and equity ${ }^{63}$ play no substantial part in the

58 This is because issues in relation to the ECHR rarely arise at the contracting stage. One counter-example of this is a very recent case over an application for judicial review, in which the ECHR (art 8, Right to respect for private and family life) and the issue of whether an application for accreditation under an incentive scheme was a legally binding contract were considered and dismissed, Re Doran's Application for Judicial Review $v$ re Decision of the Department for the Economy and the Minister for the Economy in Connection with the Renewable Heat Incentive Scheme (No. 2) [2017] Northern Ireland QB (NIQB) 24, 2017 WL 00956529 (official transcript) at [18], [28]-[30], [37], [39]-[40] (Deeny J). Those interested in the ECHR are referred to other works, eg, Darbyshire (fn 28) 81-110, or Elliott and Quinn (fn 53) 304-328, and to the website of the Council of Europe on the ECHR, www.coe.int/en/web/human-rights-convention/home.

59 Darbyshire (fn 28) 21 para 2-001; cf Elliott and Quinn (fn 53) 7, who does not mention this category at all. Only a limited number of books written by persons such as Blackstone or Glanvill are considered to be authoritative. For a list of the accepted works, see Darbyshire (fn 28) 46-47.

60 Elliott and Quinn (fn 53) 6.

61 Robert Chambers, The Importance of Specific Performance, in: Simone Degeling and James Edelman (eds), Equity in Commercial Law (Lawbook 2005) 431.

62 Custom has been defined as 'a reasonable act iterated, multiplied, and continued by the people from time out of mind' (Tanistry Case (1607) Davis 28; 80 ER 516, as cited in Halsbury's Laws of England (5 ${ }^{\text {th }}$ edn, LexisNexis 2012) Vol 32 para $1 \mathrm{fn} \mathrm{1)}$ and is such a usage as has obtained the force of law and is in truth a binding law as regards the particular place, persons, and things which it concerns'. See Halsbury's Laws Vol 32, ibid. See also the entry for 'custom' in Elizabeth A Martin (ed), A Dictionary of Law ( $5^{\text {th }}$ edn, OUP 2002; hereinafter 'Oxford Dictionary of Law') 132, and the entry for 'usage' in ibid 520.

63 It is both a source of law and a separate jurisdiction in its own right, although it has also been referred to as a separate system of law (Darbyshire (fn 28) 9 para 1-007), or as a branch of law (Harold G Hanbury (Founder) and Jill E Martin, Modern Equity (18 ${ }^{\text {th }}$ edn, Sweet \& Maxwell 2009) 3 para 1-001 and 4 para 1-002). Its development was a practical necessity born from the fact that the medieval English legal system was riddled with defects. Some of these shortcomings were alleviated through the work of the Chancery, which - not being fettered by the procedural chains binding the royal courts - could see to it that justice was done where the court proceedings could not. See John Hamilton Baker, An Introduction to English Legal History ( $3^{\text {rd }}$ edn, Butterworth 1990) 117-121. On the historical origins, including the role of the Chancellor, see, eg, Hanbury and 
formation of contracts; rather, customs are referred to in relation to the terms of a contract (interpretation), ${ }^{64}$ while equity is a recourse for parties in distress. ${ }^{65}$ Therefore, these two sources will not be considered further. ${ }^{66}$ The following exposition will therefore treat primary sources only, beginning with English legislation and case law (Sections ii. and iii.), followed

Martin, ibid 5-18. A distinct court with its own jurisdiction gradually evolved, which acted according to conscience and led to equity being born as a system of legal rules and principles distinct to the common law. See Baker, ibid, and 122-128. See also the entry for 'equity' in Oxford Dictionary of Law (fn 62) 178179. Although the courts of equity were abolished in the nineteenth century, the substantive rules of equity were maintained and applied in parallel to law in the (common law) courts. See Hanbury and Martin, ibid 15-16 and 22-29; see also Baker, ibid 131-132. Equity still prevails today if the common law is incompatible. See Hanbury and Martin, ibid 22 para 1-020; see further Darbyshire (fn 28) 164 para 8-015.

64 See Goode and McKendrick (fn 48) 13 para 1.21; see further ibid 94 para 3.57.

65 Certain remedies are available - at the court's discretion - in equity only, such as specific performance of a party's obligation, or rectification of the contractual document or deed to reflect the parties' intentions, if certain conditions are fulfilled. On the requirements of the former, see Gunter $\mathrm{H}$ Treitel (founder) and Edwin Peel, The Law of Contract (15 ${ }^{\text {th }}$ edn, Sweet \& Maxwell 2020) 21-018 et seq. See also Hanbury and Martin (fn 63) 751-792. Specific performance is not usually available in sales of goods, as the application of equity in commerce is deemed generally 'undesirable', see Whincup (fn 34) 296-297 para 10.22; cf PJ Millet, Equity's Place in the Law of Commerce (1998) 114 LQR 214, according to whom '[e]quity's place in the law of commerce, long resisted $[, \ldots$,..] can no longer be denied.' On the other remedy, rectification, see Elliott and Quinn (fn 53) 126; Darbyshire (fn 28) 163 para 8-012 speaks of a deed. Note that this remedy is only available if a mistake has been made in the recording of the intended agreement but not as to the content, ie, if it turns out to be a bad bargain, that is not rectifiable. Something similar was held by James Vice Chancellor in Mackenzie $v$ Coulson (1869) LR 8 Eq 368 (Ch), 375: 'Courts of Equity do not rectify contracts; they may and do rectify instruments [... where a] contract is inaccurately represented in the instrument' (emphasis added). While the court found that there was a contract in the form of a signed policy, the mistake had been made by the plaintiffs themselves in carelessness so that they could not 'escape the obligation of the contract' (375-376). See on this Treitel/Peel, ibid paras 8-063 et seq. For details on the conditions for rectification, see Hanbury and Martin, ibid 34 para 1-037 (common law remedies must be inadequate), 30 para 1-027 (equitable maxim of 'he who seeks equity must do equity'), and 30-31 para 1-028 (equitable maxim of 'he who comes to equity must come with clean hands'). On the equitable maxims, see also Elliott and Quinn, ibid 125-126.

66 Readers interested in customs are referred to Halsbury's Laws Vol 32 (fn 62), especially paras 1-6, 50-56; further to Darbyshire (fn 28) 46 para 2-042; and Elliott and Quinn (fn 53) 118-120. 


\section{B. Comparative Background}

by EU and international law (Sections iv. and v.). It should be borne in mind, however, that the foremost source of an English (-style) contract will be the terms of the agreement itself, unless some mandatory statutory provisions exist. ${ }^{67}$

\section{ii. English Legislation: Statutes and Statutory Instruments}

English (contract) law is mostly contained in court decisions. ${ }^{68}$ This is true despite the constitutional principle of parliamentary sovereignty, according to which statutory law, ie, law enacted by the English Parliament, is officially the first source of English law. ${ }^{69}$ Apart from the historical development of the common law, there are two other reasons for this relationship. First, at least as regards contract law, much is made of the lack of a comprehensive piece of legislation. ${ }^{70}$ Instead, one finds a range of specific codifications. ${ }^{71}$ These may take the form of primary legislation, ie, statutes enacted by Parliament; or secondary, delegated, legislation, ${ }^{72}$ which encompasses statutory instruments, byelaws, and orders. ${ }^{73}$ Due to this absence of a general statutory framework, the system must therefore draw on judicial decisions to fill any voids. Secondly, even where legislation exists, it is often not only interpreted by case law, ${ }^{74}$ but even supple-

67 Compare the sources listed in fn 48 above.

68 See Smits (fn 37) 24, who refers to case law as the 'dominant source' of contract law. More generally, Elliott and Quinn (fn 53) 7 call it the 'base of our law today'.

69 See Elliott and Quinn (fn 53) 3. On the origin of this principle, see, eg, the succinct exposition in Darbyshire ( $\mathrm{fn} 28$ ) 22. cf John H Baker, Why the History of English Law has not Been Finished (2000) 59 No 1 CLJ 62, 67, who notes that law reports are treated 'as the primary source of common-law authority'.

70 Compare, eg, Smits (fn 37) 24. See further Neil Andrews, Contract Law ( $2^{\text {nd }}$ edn, CUP 2015) 5, who points out that legislation on 'the general part of contract law' are few in number.

71 These seem to 'cluster' in certain areas, namely, those of the common law (ie, case law) which are thought in need for reform. Compare Smits (fn 37) 24. For a list of statutes, see, eg, Andrews (fn 70) 5.

72 Darbyshire (fn 28) 25-26 para 2-011 points out the difference between the two forms as being that secondary legislation can be quashed by the courts if these are ultra vires (made outside the delegated-legislator's power).

73 Elliott and Quinn (fn 53) 80.

74 See Darbyshire (fn 28) 26. For further details on the interpretation rules used in this process, see ibid 27-36, and Elliott and Quinn (fn 53) 53-76. cf Andrew Burrows, The Relationship Between Common Law and Statute in the Law of Obligations 
mented by it ${ }^{75}$ underlining the common law focus on judicial decisions further. ${ }^{76}$

The most important pieces of legislation in relation to the formation of contracts are as follows: In relation to trade, there is Part II of the Sale of Goods Act 1979 (hereinafter 'SGA 1979') and the Supply of Goods and Services Act 1982 (hereinafter 'SGSA 1982') 77 . As a consequence of the Consumer Rights Act 2015 (hereinafter 'CRA 2015'), a comprehensive regulation of legal consumer issues, ie, of $\mathrm{B} 2 \mathrm{C}$ contractual relationships, that has unified and repealed several individual pieces of consumer legislation, both the SGA and the SGSA are now largely applicable to B2B and $\mathrm{C} 2 \mathrm{C}$ transactions only; ${ }^{78}$ however, since the CRA is not an all-encompassing piece of legislation, parts of these statutes, in particular the provisions of the SGA 1979 concerning the conclusion of contracts, are still applicable to $\mathrm{B} 2 \mathrm{C}$ transactions as well. ${ }^{79}$ Concerning formalities, the Law of

(2012) 128 LQR 232, 235, who calls case law that has developed in relation to statutes 'statute-based common law', as opposed to 'pure common law'.

75 See Burrows (fn 74) 234, who states that statutes are almost never 'entirely self-contained' and that they thus rely on the existence of the meanings and institutions developed and contained in the common law.

76 Interestingly, and perhaps surprisingly, textbooks on contract law usually begin with a list of English cases, followed by a list of English statutes and a table of European and international legislation. See, eg, Treitel/Peel (fn 65) ccliii-cclxix; or Andrews (fn 70) x-lii. Other areas, such as Commercial law, may deviate from this pattern, see, eg, Goode and McKendrick (fn 48) xxxi-cxliii. This practice reflects the reality of case law effectively being the most important source of English contract law, as just discussed. Compare Andrews, ibid 4. An explanation might be that it was the most important source historically, as the law was developed from it, see Youngs (fn 34) 61. See also Burrows (fn 74) 233, who then goes on to argue 'that common law and statute are more fully integrated than has traditionally been thought.' Cf Darbyshire (fn 28) 10 and 37, who states that case law 'is at least as important to us as' and 'can be just as important as' legislated law.

77 Note that the statute is concerned with 'supply' and not 'sale' of goods, see s 1 subss 1 (contract concerning the transfer of property in goods) and 2 (sale of goods contracts are excepted) SGSA 1982.

78 See Department of Business, Innovation and Skills, Consumer Rights Act 2015: Explanatory Notes (2015; hereinafter 'CRA 2015 Explanatory Notes') para 24, which shows a table with the English legislation related to consumers that is affected by the CRA 2015, including the SGA 1979 and the SGSA 1982. The Notes are available online at www.legislation.gov.uk/ukpga/2015/15/notes/contents.

79 Another example from the SGA 1979 is the stipulations on the passage of property (s 4 CRA 2015, ss 16-20B SGA 1979). For a summary of the provisions of and changes under the CRA 2015, see, eg, Treitel/Peel (fn 65; $14^{\text {th }}$ edn 2015) paras 23-001-23-002. 
Property (Miscellaneous Provisions) Act 1989 (hereinafter 'LPMPA 1989') is of importance in sales of land. Furthermore, the Electronic Commerce (EC Directive) Regulations $2002^{80}$ and Consumer Protection (Distance Selling) Regulations $2000^{81}$ deserve mentioning.

\section{iii. English Case Law}

For the two reasons just mentioned, case law is an important source for English contract law. ${ }^{82}$ In this respect, it is necessary to bear in mind the hierarchical structure of the courts. The highest instance is principally the Supreme Court (hereinafter 'UKSC'), known as the House of Lords (hereinafter 'HoL') until 2009; however, sometimes it may be the CJEU (on which see Section iv. below), whose decisions are binding on the English courts. ${ }^{83}$ Lower English courts in civil matters are, in descending order: the Court of Appeal (hereinafter 'CA'), the High Court (hereinafter 'HC') and the county courts, all of which are bound by decisions of the UKSC or the HoL. ${ }^{84}$ And while the CA is bound by its own decisions, ${ }^{85}$ the other courts are not. ${ }^{86}$ This general binding nature flows from the doctrine of (judicial) precedent, which in turn is governed by the principle

80 SI 2002/2013 (hereinafter 'E-Commerce Regulations').

81 SI 2000/2334 (hereinafter 'Consumer Distance Selling Regulation').

82 Due to this heavy reliance, an overabundance of cases has amassed over time. Only the most important of these, what are known as 'leading cases', will be discussed in this dissertation. For further references, readers are referred to textbooks on contract law such as Treitel/Peel (fn 65).

83 See Elliott and Quinn (fn 53) 15.

84 See Darbyshire (fn 28) 39 para 2-032. For brief descriptions of each instance, see Elliott and Quinn (fn 53) 20-21, who show a flow chart of the hierarchy in civil matters at 23 figure 1.2 .

85 The CA bound itself in the case of Young v Bristol Aeroplane Co, Ltd [1944] KB 718 , although it laid down three exceptions. These regard conflicting opinions in CA cases, or with a HoL decision, as well as an in curiam (ie, in error) decision. For further information, see Darbyshire (fn 28) 41 at 2-033.

86 Until 1966, the HoL was bound by its own rulings, when its members resolved in a Practice Statement that they would 'treat[...] former decisions of this House as normally binding, [but would] depart from a previous decision when it appear[ed] right to do so', see HoL, Practice Statement (Judicial Precedent) [1966] 1 WLR 1234 (Gardiner LC; emphasis added). While the HoL is seemingly 'reluctant' to do so, it has departed from its own decisions in a number of cases, see Elliott and Quinn (fn 53) 16. For information on the HC and the county courts, see Darbyshire (fn 28) 41 para 2-034 and 42 para 2-035 respectively. 
of stare decisis ('let the decision stand'). ${ }^{87}$ Decisions made by the Judicial Committee of the Privy Council (hereinafter 'PC'), the final instance of appeal for Commonwealth jurisdictions and whose members are mostly Justices of the UKSC, are persuasive only to other English courts. ${ }^{88}$ This structure must be borne in mind when considering (conflicting) decisions made by different courts on a subject.

\section{iv. EU Law: Legislation and Cases}

Although EU law was listed in Section i. above as having priority over English law, the situation is not straightforward. This is largely due to the dualistic approach in the UK to both EU and other international law. ${ }^{89}$ Accordingly, EU law has been categorised by the courts in the past as not being a source of English law in the traditional sense. In the words of Lord Mance, 'European law is part of United Kingdom law only to the extent that Parliament has legislated that it should be', ${ }^{90}$ so that the English Parliament's sovereignty was affirmed..${ }^{91}$ On the other hand, the HoL later accepted that the European Communities Act 1972 (hereinafter 'EC Act 1972') ' $^{92}$ 'constitutes EU law as an entirely new, independent and overriding source of domestic law, and the Court of Justice as a source of binding judicial decisions about its meaning. ${ }^{93}$

87 Elliott and Quinn (fn 53) 14, 10. According to this principle, a court has to decide a case that is similar in its facts to an earlier case in line with the ratio decedendi ('reason for deciding') of that previous decision, unless the case in question can be sufficiently distinguished on its facts. In contrast, the obiter dicta ('things said by the way') do not bind the courts but may nevertheless be persuasive. See on this ibid 14.

88 See Darbyshire (fn 28) 11 para 1-013. One influential case of this court relating to formation of contracts is Pao Onv Lau Yiu Long [1980] AC 614 (PC). As the main issue relates to consideration, the case will be discussed in Section II.3.v. below.

89 See Craig and de Búrca (fn 52) 296.

90 Pham $v$ Secretary of State for the Home Department [2015] UKSC 19 [76] (Mance L).

91 It was called 'the ultimate legislative authority', see Pham (fn 90) [80] (Mance L).

92 As amended, particularly by the European Union (Amendment) Act 2008.

$93 R$ (on the application of Miller) (Respondents) $v$ Secretary of State for Exiting the European Union (Appellant) [2017] UKSC 5 [80] (Neuberger L, Lady Hale, Mance L, Kerr L, Clarke L, Wilson L, Sumption L, Hodge L). The latter statement is in line with the supremacy principle of EU law that the ECJ once stated in Case C-6/64 Costa $v$ ENEL [1964] ECR 585, 593. A citation of the pertinent part of the decision as well as a discussion of the case can be found in Craig and de Búrca (fn 52) 267-268. Indeed, the HoL later used a similar phrase in Reg $v$ Secretary of 


\section{B. Comparative Background}

The situation has been complicated further by the UK having applied to and consequently left the EU as a Member State. ${ }^{94}$ As a consequence, the influence of EU law will diminish over time, if not cease altogether. While the Government has - at the time of writing - given no concrete plan as to the legal changes ahead, legal academics expect that EU law will not simply cease to be effective at the time that membership in the EU ends; rather, it is being predicted that EU law will be phased out, so that an interim, transitional phase will arise. ${ }^{95}$ Indeed, the government has stated in its Repeal Bill White Paper that English legislation would be drafted to transpose all EU law into English law so that no 'holes [would appear] in our statute book'. ${ }^{96}$ This measure will allow the government to review, amend, and repeal law as necessary on a step by step basis. ${ }^{97}$

State for Transport, Ex p Factortame Ltd (No 2) [1990] 3 WLR 818 (HoL), [1991] 1 AC 603, 658-659 (Bridge L). For details on this case, see Craig and de Búrca, ibid 297-298. They further discuss the supremacy principle at ibid 266-279 (ECJ's stance), 296-304 (UK's stance).

94 The people of the UK cast their vote in a referendum on 24 June 2016 to leave the EU, whereby almost $52 \%$ voted leave and approximately $48 \%$ voted remain, see the results published by, eg, the BBC on www.bbc.com/news/politics/eu_referendum/results. Article 50 Treaty of Lisbon [2007] OJ C 306/01 (hereinafter 'Lisbon Treaty') was invoked on 29 March 2017, so that the negotiation process between the UK and the EU should end by April 2019, as art 50 para 3 Lisbon Treaty stipulates a maximum time frame of two years for the negotiations. See also Department for Exiting the European Union, Legislating for the United Kingdom's withdrawal from the European Union (White Paper, Cm 9446; hereinafter 'Repeal Bill White Paper') chapter 1; the Paper is available online at www.gov.uk/government/publications/the-repeal-bill-white-paper. This period has been extended several times. Section 1 European Union (Withdrawal) Act 2018 (hereinafter 'EU Withdrawal Act 2018') merely refers to 'exit day' for the repeal of the EC Act 1972; according to s 20 of that Act, that day is ' 31 January 2020 at 11.00 p.m.' A transition period is in effect until 31 December 2020. On this, see Tom Edgington, Brexit: What is the transition period?, BBC (1 July 2020), https://www.bbc.com/ news/uk-politics-50838994.

95 See, eg, Andrew Dickinson, Back to the Future - The UK's EU Exit and the Conflict of Laws (2016) Oxford Legal Studies Research Paper No 35 (draft as of 31 May 2016) 2. The paper is available online at https://ssrn.com/abstract=2786888.

96 Repeal Bill White Paper (fn 94) 10 at 1.11-1.13. This is reiterated in Department for Exiting the European Union, European Union (Withdrawal) Act 2018 Explanatory Notes (c 16-EN, 2018), inter alia, 10-11, 14. The Notes are available at the source indicated in fn 94 and will hereinafter be referred to as 'EU Withdrawal Act Explanatory Notes'.

97 Repeal Bill White Paper (fn 94) 10 at 1.12. The same idea is contained in ss 2-3 European Union (Withdrawal) Act 2018. 
It remains unclear at this point to what extent legislation will be modified. Having said this, as one of the Law Lords of the Supreme Court, Lord Reed, has stated: The influence of EU law did not begin and will not end with the UK's membership in the EU. ${ }^{98}$ Thus, while some changes in law are imminent, this may not have a great effect due to the current stance in legal practice. ${ }^{99}$ On the other hand, authors have noted that the influence of EU law has not been equally strong in all areas of English law to begin with. Thus, by way of example, while it has shaped consumer law, it has not greatly impacted commercial law. ${ }^{100}$ For all these reasons, this dissertation proceeds on the basis of the current status quo, ie, without making speculations as to possible future changes.

While EU law is therefore applicable in England, a differentiation has to be made between legislation that is directly applicable and that which is not. By virtue of s 2 subs 1 EC Act 1972, rights and obligations created by EU Treaties and made directly applicable by the same are recognised as such. Similarly, EU regulations are also directly applicable. ${ }^{101}$ Conversely, this means that any EU law that is not directly applicable, like a directive, ${ }^{102}$ has to be implemented by English legislation. ${ }^{103}$ In situations of conflict between English and directly effective EU law, the courts must 'override any rule of national law'. ${ }^{104}$ With regard to judgments by the

98 Lord Reed, Comparative Law in the UK Supreme Court (Lecture, Max Planck Institute for Comparative and International Private Law, Hamburg, Germany, 10 July 2017).

99 This could be the case for, say, choice of law clauses that are currently uniformly regulated within the EU by virtue of the Regulation (EC) No 593/2008 of the European Parliament and of the Council of 17 June 2008 on the Law Applicable to Contractual Obligations (Rome I), see Malcolm Clarke and others, Commercial Law: Text, Cases, and Materials ( $5^{\text {th }}$ edn, OUP 2017) 52.

100 See Clarke and others (fn 99) 52; see also McKendrick (fn 48) 2-3.

101 See s 228 Consolidated Version of the Treaty on the Functioning of the European Union [2012] OJ C326/01 (hereinafter 'TFEU 2012').

102 While initially no direct effect was foreseen (compare art 228 TFEU 2012), directives can now be directly effective under certain circumstances. This was established in case C-9/70 Grad v Finanzamt Traunstein [1970] ECR-I 826 and confirmed in case C-41/74 van Duyn v Home Office [1974] ECR-I 1338. In summary, a directive can be directly applicable if its provisions are clear, precise, and unconditional. See Darbyshire (fn 28) 66 para 3-029; Elliott and Quinn (fn 53) 106.

103 See Darbyshire (fn 28) 51.

104 Factortame No 2 (fn 93) 659 (Bridge L). 
CJEU, these must be borne in mind by the English courts, so that EU case law is also a source of EU law. ${ }^{105}$

\section{v. International Law}

As with EU law, international treaties signed by the UK will not be automatically applicable in England due to the principle of sovereignty of the UK Parliament; the government usually first has to enact legislation transposing the treaty into English law. ${ }^{106}$ Having said this, provisions of treaties which the UK has signed have priority over the English common law and will thus prevail over conflicting common law. ${ }^{107}$ This will be explored separately for each of the sources discussed below.

It has been stated that most legal instruments aiming at harmonising the law of contracts deal only with international but not domestic transactions. ${ }^{108}$ One example of an international treaty ratified by the UK is the UNIDROIT Convention relating to a Uniform Law on the Formation of Contracts for the International Sale of Goods, adopted 1 July 1964 (hereinafter 'ULFC'). The Convention was not successful and became the 'forlorn predecessor' of the CISG. ${ }^{109}$ It is perhaps a little ironic that while the UK ratified the ULFC, it has not signed the CISG, and seems unlikely

105 Darbyshire (fn 28) 51. This was laid down in s 3 subss 1-2 EC Act 1972.

106 See Section iv. above. See further Darbyshire (fn 28) 6 para 1-001, 47 para 2-044; Elliott and Quinn (fn 53) 131-132.

107 It was held in the case of Sidhu and Others $v$ British Airways Plc [1997] AC 430 (HoL), 437-438, 444, 446-447, 453 (Hope L) that where an international convention provided exclusive provisions in a matter, national law providing otherwise was not applicable. The convention in question was the Convention for the Unification of Certain Rules Relating to International Carriage by Air Signed at Warsaw on 12 October 1929 as amended by the Protocol Modifying the said Convention Signed at the Hague on 28 September 1955.

108 Roy Goode, Reflections on the Harmonisation of Commercial Law (1991) 19 No 1 Uniform Law Review 54, 63. One reason given is that the latter are usually seen as being better regulated in domestic legislation, see ibid 63, 73 .

109 Thus described by Goode (fn 108) 74. In light of the fact that the convention only has two (!) remaining signatory states, namely, the UK and Gambia, this seems an apt description. On the status of the convention, see www.unidroit.org/status-ulfc-1964. On the ULFC's demise, see Ulrich Hubner, Der UNCITRAL-Entwurf eines Übereinkommens über internationale Warenkaufverträge [The UNCITRAL-Draft of a Convention on International Sale Contracts] (1979) 43 RabelsZ 413, 414-415. 
to do so in the future. ${ }^{110}$ Furthermore, while the English courts could theoretically apply the CISG under English conflict of law provisions, they seem not to have done so. ${ }^{111}$ Both of these conventions may therefore be deemed irrelevant as sources of provisions on the formation of contracts in English law, so that the ULFC will not be discussed further; however, seeing as the CISG is relevant in relation to Germany and Japan, its provisions will be discussed in Section E.II. below.

\section{b. Sources of German (Contract) Law}

In the German legal system, we find the same kind of sources as in English law: German and European legislation (Sections ii. and iv. respectively), German case decisions (Section iii.), customary law (Gewohnheitsrecht), and international law (Section v.). This is because all of these sources are general and contain 'norms, which determine the legal assessment of life circumstances'. ${ }^{112}$ Accordingly, charters or articles of incorporation (autonome Satzungen) or collective bargaining law (Tarifrecht) can also be sources of law, whereas academic text(book)s cannot. ${ }^{113}$ Slight differences with England are therefore already visible at this level. Furthermore, as was intimated above, the inter-relationship between the sources is different in the German legal system as compared to that of England. This relationship will be analysed first before each of the sources are examined further.

110 Speculation on the reasons for this position have been made by, inter alia, Goode and McKendrick (fn 48) 972. A succinct account of the political reasons is given by Sally Moss, Why the United Kingdom has not Ratified the CISG (2005) 25 Journal of Law and Commerce 483-485: the low political priority was due to the reserved response by the English business community to several enquiries.

111 Goode and McKendrick (fn 48) 973 in fn 11. Or at least, not often: One example is perhaps Kingspan Environmental Ltd and Others $v$ Borealis AS, Borealis UK Ltd [2012] EWHC 1147 (Comm), WL 1469127 (official transcript), in which Clarke $\mathrm{J}$ found the law applicable to the contract in question to be Danish law, which in turn incorporated the CISG. The court thus applied it. See paras 557 (applicability of Danish law), 617 et seq, and 993 et seq (application of the CISG) of the decision. In this way, the 'UK courts may sometimes be obliged to apply' the Convention, see Djakhongir Saidov and Sarah Green, Software as Goods (2007) Journal of Business Law (JBL) 161, 163.

112 Definition given by Arthur Kaufmann, Rechtsbegriff und Rechtsdenken [The Concept of Law and Legal Thought] (1994) 37 Archiv für Begriffsgeschichte 21, 52: '[...] Normen, die für die rechtliche Entscheidung von Lebenssachverhalten bestimmend sind [...]'.

113 Kaufmann (fn 112) 53, 52. 


\section{B. Comparative Background}

\section{i. The Inter-relationship of the Sources in German (Contract) Law}

There seems to be no classification of sources into primary and secondary sources in German law. Having said this, there is of course an order of application, so that the sources of German law are (in order of importance): the ECHR ${ }^{114}$ and international law, EU law (legislation), German legislation, and customary law. ${ }^{115}$ Furthermore, there are German and EU case decisions and academic literature, the latter of which plays a role in court decisions; ${ }^{116}$ however, none of these three are sources of law in the strict sense. ${ }^{117}$ Out of these, the ECHR, ${ }^{118}$ customary law, ${ }^{119}$ and academic

114 It was incorporated into German law by virtue of the Gesetz über die Konvention zum Schutze der Menschenrechte und Grundfreibeiten [Law on the Convention of the Protection of Human Rights and Fundamental Freedoms] of 7 August 1952, Bundesgesetzblatt [German Federal Law Gazette; hereinafter 'BGBl'] 1952 II 685; and came into force on 3 September 1953, see Bekanntmachung über das Inkrafttreten der Konvention zum Schutze der Menschenrechte und Grundfreibeiten [Announcement of the Coming into Force of the Convention of the Protection of Human Rights and Fundamental Freedoms] of 15 December 1953, BGBl 1954 II 14. On the relationship between the ECHR and the fundamental rights contained in German law, see Bundersverfassungsgericht (German Federal Constitutional Court, hereinafter 'BVerfG') decision of 4 May 2011, 2 BvR 2365/09, BVerfGE 128, 326-409; an English translation is available online at www.bundesverfassungsgericht.de/SharedDocs/Entscheidungen/EN/2011/05/rs20110504_2bvr236509en.html. See further BVerfG order of 5 April 2005, 1 BVR 1664/04, paras 14-15; an English translation is available online at www.bundesverfassungsgericht.de/SharedDocs/Entscheidungen/EN/2005/04/rk20050405_1bvr166404en.html. The BGBl can be accessed at www.bgbl.de.

115 See Wolf and Neuner (fn 48) 44, 59 para 40, 52.

116 It has been termed a 'persuasive authority' due to this fact by Youngs (fn 34) 84.

117 See Wolf and Neuner (fn 48) 25 para 17, 27 para 25.

118 The reason given in relation to English law in Section a. above applies.

119 Gewohnheitsrecht (customary law), is 'the law of the whole legal community', ie, rules which can be seen as law, see Peter Krebs and Maximilian Becker, Entstehung und Abänderbarkeit von Gewohnheitsrecht [Creation and Modifiability of Customary Law] (2013) JuS 97, 98. It has to be certain and must be applied constantly or at least regularly, ie, be recognised by the community as customary law in order to exist, see ibid 98-99; see also Kaufmann (fn 112) 52. It is not a certain practice but a legal understanding that can become customary law, see Krebs and Becker, ibid 98. See also Kaufmann, ibid 52. For further details on the necessary conditions, ie, of the general recognition of the legal validity (in Latin: opinio iuris sive necessitatis) of a custom and the element of time in terms of its observation (Latin: longa consuetudo), see Krebs and Becker, ibid 98-101 or Wolf and Neuner (fn 48) 21-22 paras 5-8; Karl Larenz, Methodenlehre der 
literature will not be considered below. ${ }^{120}$ Another concept of influence in German law, which will also not be considered further, is Treu und Glauben (good faith). While it is sometimes applied in relation to contract law, inter alia, when interpreting contracts, it is not relevant for their formation and thus falls outside the scope of this dissertation. ${ }^{121}$

It should be noted that Germany is a federal republic (art 20 para 1 Grundgesetz, Basic Law for the Federal Republic of Germany of 1949, hereinafter ' $G G{ }^{122}$ ), comprised of 16 Bundesländer (federal states) with legislative, executive, and judicial competences (regulated in arts 70 et seq, 83 et seq, and 92 et seq GG respectively), meaning Germany has institutions for these purposes on both the central and federal level. ${ }^{123}$ This feature will be borne in mind in the subsequent discussion, which will begin with German legislation (Section ii.) and case law (iii.), followed by EU and international law (iv. and v. respectively).

Rechtswissenschaft [Methodology of Jurisprudence] ( $6^{\text {th }}$ edn, Springer 1993$) 433$. In general, its role today is seemingly negligible (see Wolf and Neuner ( $\mathrm{fn} 48$ ) 22 para 5), namely, of amending existing law (legislation), rather than filling lacunae. While it could, in theory, still be used in cases of non-regulation, eg, in relation to new technologies, it has been suggested that the emergence of a customary law would be hindered particularly by the nature of such technological advances (short-lived) due to the requirement of the time element. See on this Krebs and Becker, ibid 98. Due to this minor role and a general absence of a practical application, customary law will not be considered further.

120 Readers interested in German academic literature are directed to the references provided by Youngs (fn 34) 84-85.

121 It has been likened to equity in its effects, see Youngs (fn 34) 82. Indeed, similar ethical notions seem to underpin the two standards, as becomes clear when looking at the wide application of $\$ 242$ BGB (Leistung nach Treu und Glauben, Performance in good faith) to generally curb 'dishonest use of a right'. See on this Wolf and Neuner (fn 48) 230 para 75 and 232-238.

122 BGBl III, Gliederungsnummer 100-1. An English translation is available at www.gesetze-im-internet.de/englisch_gg/index.html.

123 For further information on the interplay of the central and the federal states, see, eg, Bernd Grzeszick, Artikel 20 GG, in: Theodor Maunz and others (eds), Grundgesetz Kommentar [Basic Law Commentary] (CH Beck, 2017 issue) at II. Die Verfassungsentscheidung für die Demokratie [II. The Constitutional Decision for a Democracy] paras 253 et seq; see also the entry for 'Bundesländer' in Uwe Andersen and Wichard Woyke (eds), Handwörterbuch des politischen Systems der Bundesrepublik Deutschland [Handbook on the Political System of the Federal Republic of Germany] ( $7^{\text {th }}$ edn, Springer VS 2013), available online at www.bpb.de/nachschlagen/lexika/handwoerterbuch-politisches-system/. 


\section{B. Comparative Background}

ii. German Legislation: Gesetze and Verordnungen, German Statutes and Regulations

Before turning to the pieces of legislation that are relevant in German contract law, it is important to make a note of vocabulary. As has been pointed out by some authors, the German term Gesetz has a wide meaning, encompassing both primary as well as secondary legislation. ${ }^{124}$ In this sense, and despite perhaps not being quite adequate, whenever this broad meaning of legislated norms is to be conveyed, the simple term 'legislation' will be used. Whenever a more specific meaning is intended, several terms will be used, depending on the type of enactment in question. Within the categories of primary and secondary legislation, further distinctions must be made: On the one hand there are Gesetzbücher, hereinafter referred to as 'codes of law', which set out a broad area of law; on the other hand, there are pieces of legislation of narrower scope, Gesetze in its strict sense, which will be called 'laws'. ${ }^{125}$ German secondary legislation includes (Rechts-) Verordnungen (regulations), laid down by the government ${ }^{126}$ and public authorities, and öffentlich-rechtliche Satzungen (bye-laws), laid down by public institutions such as universities. ${ }^{127}$

Note that, due to Germany's dual political structure, legislation may be Bundesrecht (federal law) or Landesrecht (regional state law). Legislative competences are split, whereby these may be ausschließlich (exclusive) or, shared (konkurrierend, meaning 'competing', art 70 para 2 GG). Under art 70 para 1 and art 72 para 1 GG, the Länder (regional states) are granted residual legislative competence, which means that, unless the Bund (central state) has been given authority to legislate and this right is exercised, the Länder may do so. ${ }^{128}$ In case of conflict, Bundesrecht will take precedence

124 See, eg, Youngs (fn 34) 64; cf Wolf and Neuner (fn 48) 21, who also include customs; cf, again, Kaufmann (fn 112) 52, who sees custom as gesetztes Recht (set(tled) law) but differentiates it from Gesetze. The following systematisation, as well as the English terms have been largely adopted from Youngs (fn 34) $63,64,65,67$. For an overview of the development of the notion of Gesetz throughout history, see Kaufmann, ibid 22-37.

125 These terms are also used by, eg, Smits (fn 37) 23-24. As already explained in Section A.III.3. above, by using this word, confusion with English legislation (Acts) is avoided.

126 That is, by the Executive, see Wolf and Neuner (fn 48) 21 para 3.

127 Ibid 21 para 4.

128 The Bund may authorise the Länder in areas of its exclusive competence (art 71 GG). See on this Arnd Uhle, Artikel 70 GG, in: Maunz and others (fn 123) at 2-3. This applies to primary, but not to secondary legislation, see ibid at 34 . 
over Landesrecht (art 31 GG). Having said this, federal institutions have to take regional law into consideration, eg, in the area of administrative law. ${ }^{129}$ Private law (bürgerliches Recht) and commercial law (Recht der Wirtschaft, business law) are two of the competences that are shared by Bund and Länder (art 74 para 1 nos 1 and $11 \mathrm{GG}$ ).

Although it is true to say that primary legislation in the form of codes provides for comprehensive and systematic regulation, it is not all-encompassing, so that supplementation is necessary, either through laws or secondary legislation. As a consequence, German private law, in particular the law on contracts, is fragmented. ${ }^{130}$ The two most important codes in this area are undoubtedly the Bürgerliches Gesetzbuch (German Civil Code, hereinafter 'BGB') ${ }^{131}$ and the Handelsgesetzbuch (German Commercial Code, hereinafter ' $\mathrm{HGB}$ ') ${ }^{132}$. Of particular relevance to the discussion in this dissertation are the first three books of the BGB, namely, Allgemeiner Teil (General Part), Recht der Schuldverhältnisse (Law of Obligations) and Sachenrecht (Law of Property), ${ }^{133}$ as well as the first and fourth books of the HGB, namely, Handelsstand (Commercial Entities) and Handelsgeschäfte (Commercial Transactions). It is important to note that while the BGB can be described as the basic legislation in the area of private law, the HGB is a Sonderprivatgesetz (special private law) whose rules must be applied prior to those contained in the BGB; conversely, rules from such special frameworks can be applied to general private relationships where the BGB makes no provision and the special rules are not exceptional regulations

129 See Grzeszick (fn 123) at IV. Die Verfassungsentscheidung für den Bundesstaat [IV. The Constitutional Decision for a Federal State] paras 154 et seq.

130 Compare Youngs (fn 34) 64-65, who notes that there is piecemeal legislation to be found in Germany as well, not just in the UK.

131 Originally from 1896, the BGB was published in revised form in 2002 BGBl 2002 I 42, 2909; BGBl 2003 I 738) and last amended by Law of 20 July 2017 (BGBl 2017 I 2787), see www.gesetze-im-internet.de/bgb/BJNR001950896.html. An English translation of the BGB can be found at www.gesetze-im-internet.de/englisch_bgb/index.html. Note that this translation is based on the BGB as of 2013, so that subsequent amendments may have altered the text.

132 Originally from 1897, the HGB was last amended by Law of 18 July 2017 (BGBl 2017 I 2745), see www.gesetze-im-internet.de/hgb/index.html. A partial English translation is available online at www.gesetze-im-internet.de/englisch_hgb/index.html. A complete English translation can be found in, eg, Thomas Rittler (trans), HGB - German Commercial Code: Deutsch-englische Text-Synopse / German-English Synopsis ( $3^{\text {rd }}$ revised edn, Plattform-compliance 2015).

133 These English terms are used in the BMJV's translation of the BGB, see fn 131. 


\section{B. Comparative Background}

but are of general application. ${ }^{134}$ Another special area of relevance to this dissertation is that relating to consumers. ${ }^{135}$ Other relevant pieces of legislation include the Zivilprozessordnung (German Code of Civil Procedure, hereinafter 'ZPO'), ${ }^{136}$ and the Einführungsgesetz zum Bürgerlichen Gesetzbuche (Introductory Act to the Civil Code, hereinafter 'EGBGB'), 137 the latter of which contains, inter alia, commencement provisions for legislation or amendments.

\section{iii. German Case Law: Rechtsprechung, German Court Decisions}

German court decisions (Rechtsprechung) are not a source of law like Geset$z e$; they have even been called an informal source. ${ }^{138}$ This may be due to the fact that judges in Germany fulfil the function of applying and interpreting legislation, rather than creating law, as is the case in England. ${ }^{139}$ Indeed, richterliche Rechtsfortbildung (judge-made law) has been categorised

134 Compare Wolf and Neuner ( $\mathrm{fn}$ 48) 67 paras 11-13. One example given is $\$ 350 \mathrm{HGB}$, which foresees a deviation from the general rule for the form of declarations of suretyships (Bürgschaften) found in $\$ 766$ BGB. This deviation is discussed further in Section III.3.b.ii. below.

135 See Christoph Reymann, Das Sonderprivatrecht der Handels- und Verbraucherverträge: Einheit, Freiheit und Gleichheit im Privatrecht [Special Private Laws for Commercial and Consumer Contracts: Union, Freedom, and Equality in Private Law] (Mohr Siebeck 2009) 1. The author analyses the tri-partition of German private contract law on a general level in his book but is critical of this division, see, eg, ibid 3 or 6. Also slightly sceptical: Wolf and Neuner (fn 48) 64 para 4.

136 BGBl 2005 I 3202 and 2006 I 431 and 2007 I 1781. An English translation is available online at www.gesetze-im-internet.de/englisch_zpo/index.html.

137 BGBl 1994 I 2494 and 1997 I 1061. A partial translation (based on the law as amended in November 2015) into English is available online at www.gesetzeim-internet.de/englisch_bgbeg/index.html.

138 Compare Youngs (fn 34) 75, 79. cf Larenz (fn 119) 432-436, discussing different interpretations of the term 'source of law' and the effect of case law, but he is ultimately sceptical of judge-made law being a true source of law in Germany.

139 Compare Krebs and Becker (fn 119) 97, who state that German case law cannot become binding like legislation. Johanna Schmidt-Räntsch, $\mathbb{2 3}$. Germany, in: Riesenhuber (fn 13) 591, 593-594 aptly states that 'the courts must so to speak translate - judgment for judgment - the abstract rules of law into concrete rules'. For a common law perspective, see Whincup (fn 34) 39 para 1.51. On case law in England, see Section a.iii. above. 
as a 'continuation of [legal] interpretation'. ${ }^{140}$ Having said this, it could be argued that when judges fill lacunae of statutory regulation, and especially when they develop a rule further, they do, in this sense, create law. ${ }^{141}$ While it goes beyond the scope of this dissertation to go into details, two examples of judge-made law are the doctrine of culpa in contrabendo (since 2002 contained in $\$ 311$ para 2 BGB) and the protection of third party interests. ${ }^{142}$ Furthermore, the decisions of the Bundesverfassungsgericht (Federal Constitutional Court, hereinafter 'BVerfG') can — albeit in a limited set of circumstances - have Gesetzeskraft (force of law; see $\ 31$ para 2 Gesetz über das Bundesverfassungsgericht, Act on the Federal Constitutional Court, hereinafter 'BVerfGG'143).

140 Larenz (fn 119) 366. cf Dirk Olzen, Einleitung zum Schuldrecht [Introduction to the Law of Obligations], in: Julius von Staudinger and others, Kommentar zum Bürgerlichen Gesetzbuch mit Einführungsgesetz und Nebengesetzen [Commentary on the Civil Code with Introductory Act and Ancillary Laws] (rev online edn, Sellier de Gruyter 2015) paras 1, 208, who states that judicial law making and interpretation are both forms of applying law. For a detailed discussion of the judges' role in German law, see Heinrich Honsell, Einleitung zum Bürgerlichen Gesetzbuch [Introduction to the Civil Code], in: Staudinger and others, ibid (2018) paras 1, 200-232.

141 Compare and contrast Larenz (fn 119) 366-367, who differentiates between filling lacunae as acting within, and developing a legal rule further as going beyond statutory law. Arguably, the former would be a form of interpretation or application of law, whereas the latter might be seen as creating law in some sense. Indeed, Larenz speaks of such further developments as acts 'modifying' statutory law, see ibid 366. He goes on to state that judges ought to do this only when 'very serious cause' is given. For an in-depth discussion, see ibid 370-404 (filling lacunae), 413-429 (further development). For a discussion of possible conflicts between the courts filling lacunae and statutory law, see Olzen, 'Einleitung' (fn 140) paras 210-211. Contrast Karl Kroeschell, Deutsche Rechtsgeschichte Band 3: Seit 1650 [German Legal History Vol 3: From 1650] (4 $^{\text {th }}$ edn, Böhlau Verlag 2005) 189-191, arguing that positive law cannot be created through judicial decisions, not even in the form of customary law.

142 See on this Olzen, 'Einleitung' (fn 140) paras 213-214 (culpa in contrahendo), 216-221 (third parties). On the importance of the judiciary generally, see Larenz (fn 119) 234 et seq. cf Kroeschell (fn 141) 190, arguing that the notion of culpa in contrahendo had been developed by Jhering from Roman law, and that the court decision said to have laid down this concept 'only referred to earlier decisions; and no longer to academic or legislative reasons' ('berief sich allerdings nur noch auf frührere Entscheidungen, nicht mehr auf wissenschaftliche oder gesetzgeberische Erwägungen').

143 BGBl 1993 I 1473; English translation available online at www.gesetze-im-internet.de/englisch_bverfgg/englisch_bverfgg.html. 


\section{B. Comparative Background}

Moreover, while there is no formal rule in Germany which binds courts to their own or higher court decisions, ${ }^{144}$ in practice, a rule of precedence (Präjudizien) exists, so that decisions on cases which concern similar facts are deemed to be model rulings. ${ }^{145}$ In particular, the highest courts will not readily depart from their own decisions. ${ }^{146}$ As a consequence, practitioners will take case law into account when assessing situations, thus effectively making court decisions applicable law (geltendes Recht). ${ }^{147}$ Given that the courts ought to judge the case in question and not blindly apply another judge's interpretation or rule development, case law is perhaps better termed persuasive authority or at least a plausible indication on the legally desirable result. ${ }^{148}$

Turning to the court structure, the highest instance in civil (and criminal) matters ${ }^{149}$ in Germany is the Bundesgerichtshof (Federal Court of Justice, hereinafter 'BGH'). ${ }^{150}$ The lower courts are, in descending order:

144 Youngs (fn 34) 79. Having said this, decisions of the BVerfG (arts 93-94 GG) are binding on '[a]ll other government institutions', inter alia, other German courts, see www.bundesgerichtshof.de/DE/DasGericht/Aufgaben/aufgaben_node.html; see also $\$ 32$ para 1 BVerfGG.

145 See Larenz (fn 119) 429. See also www.bundesgerichtshof.de/DE/DasGericht/Aufgaben/aufgaben_node.html on the binding effect, in practice, of decisions by the Bundesgerichtshof (Federal Court of Justice). A concise account in English is given by Schmidt-Räntsch (fn 139) 594-595.

146 Larenz (fn 119) 429. Schmidt-Räntsch (fn 139) 595 explains that this is due to the procedure necessary for making such a departure.

147 Compare Schmidt-Räntsch (fn 139) 594; Larenz (fn 119) 430.

148 Compare Larenz (fn 119) 430, 431. Indeed, Schmidt-Räntsch (fn 139) 595 notes that decisions of 'landmark decisions' by the federal supreme courts 'are designed to provide guidance to the courts of first and second instance'. cf $₫ 31$ para 2 BVerfGG, according to which decisions made by the BVerfG will have force of law in certain circumstances.

149 Note that under art 95 para 1 GG, four other supreme courts exist in Germany: the Bundesarbeitsgericht (Federal Labour Court, hereinafter 'BAG'), the Bundesfinanzhof (Federal Finance Court), the Bundessozialgericht (Federal Social Court), and the Bundesverwaltungsgericht (Federal Administrative Court). There is also the already-mentioned BVerfG. For further information and links to the other courts, see www.bundesgerichtshof.de/DE/DasGericht/StellungGerichtssystem/stellungGerichtssystem_node.html. Another specialised court in Germany is the Patentgericht (patent court), dealing with matters relating to patents and other intellectual property such as trademarks. On this court, see www.bundespatentgericht.de/cms/index.php?lang=en; see further Monika Jachmann, Artikel 96 GG, in: Maunz and others (fn 123) paras 10-16.

150 See www.bundesgerichtshof.de/EN/Home/home_node.html for further information on this court, its organisation, and tasks. 
Oberlandesgerichte (higher regional courts, hereinafter 'OLG'); Landgerichte (regional courts, hereinafter 'LG'); Amtsgerichte (local courts, hereinafter 'AG'). ${ }^{151}$

\section{iv. EU Law: Legislation and Cases}

EU law, in the form of primary and secondary legislation, but not legal opinions or recommendations by the European Commission and other EU institutions, ${ }^{152}$ is a source of German law that has priority over national law. ${ }^{153}$ This was stated by the ECJ in the Costa case ${ }^{154}$ and is said to flow from art 23 para 1 GG. ${ }^{155}$ Having said this, the BVerfG has laid down limits to this supremacy in a range of cases in relation to fundamental rights, constitutional identity, and competence. ${ }^{156}$ In general, however, EU primary legislation (treaties) as well as EU regulations are directly applicable and have priority; whereas directives first need to be transposed into German law by German legislation. ${ }^{157}$

For important pieces of EU legislation in relation to contract law, see the enumeration in Section a.iv. above. As with England, the strongest area in which German contract law has been influenced by EU law is in relation to consumers. ${ }^{158}$

151 See $\mathbb{S} 12$ Gerichtsverfassungsgesetz (Court Constitution Act, BGBl 1975 I 1077; hereinafter 'GVG'; English translation available online at www.gesetze-im-internet.de/englisch_gvg/index.html); see further Bundesgerichtshof, Der Bundesgerichtshof [The Federal Court of Justice] (brochure, 2014) 7 (hereinafter 'BGH Brochure'), available online at www.bundesgerichtshof.de/SharedDocs/Downloads/EN/BGH/brochure.pdf?_blob=publicationFile. For further information in English on the German court system, see, eg, Youngs (fn 34) 97-114 and the provisions on each court instance contained in $\$ \$ 22$ et seq GVG.

152 These do not have binding force, see art 288 para 5 TFEU 2012; see also Wolf and Neuner (fn 48) 27 para 26, who notes it can be relevant as soft law.

153 Honsell (fn 140) paras 112.

154 See fn 93 above.

155 See Craig and de Búrca (fn 52) 280.

156 For further discussion of the supremacy issue, see Craig and de Búrca (fn 52) 266-279 (ECJ's stance), 279-290 (Germany's stance). See also Wolf and Neuner (fn 48) 52 para 26.

157 See Wolf and Neuner (fn 48) 52-54, 55-56. See further the discussion in Section a.iv. above.

158 Compare Jan Busche, Vorbemerkung (Vor $\$ 145$ ) [Foreword (to S 145)], in: Franz J Säcker and others, Münchener Kommentar zum BGB [Munich Commentary on the Civil Code] Vol 1 ( $7^{\text {th }}$ online edn, CH Beck 2015) paras 1, 4. 


\section{B. Comparative Background}

\section{v. International Law: The CISG}

Apart from the sources just discussed, German law includes another external source beside those from the EU. In particular, there are international treaties, which require what is called a Zustimmungsgesetz (Law of Consent), ie, a federal law under which the international law in question is incorporated into German law. ${ }^{159}$ One of these is the CISG, which was ratified by Germany and transposed in 1990.160 The BGH has held it to be a special law on international sales which has priority over the rules of German sales law (Kaufrecht). ${ }^{161}$ The CISG will thus be applicable automatically in cases of international sales of goods, ${ }^{162}$ unless the parties have excluded its application (art 6 CISG). In particular, the Convention will be a priori applicable in contractual relations between parties from Germany and Japan, since both countries are Contracting States. ${ }^{163}$ Its rules on the formation of contracts will be discussed in Section E.I.2. below.

Furthermore, by virtue of art 25 GG, general rules of international law are treated as part of German law, but at the same time override it. These 'general rules' include the list of sources found in art 38 para 1(b)-(c) ICJ Statute, namely, general principles of law and international customs. ${ }^{164}$

159 See Wolf and Neuner (fn 48) 59 para 43 with further references. cf Kaufmann (fn 112) 53, who rejects international treaties (Staatsverträge) constituting sources of German law.

160 See Gesetz zu dem Übereinkommen der Vereinten Nationen vom 11 April 1980 über Verträge über den internationalen Warenkauf [...] [Law on the United Nations Convention on Contracts for the International Sale of Goods of 11 April 1980 (...)] of 5 July 1989, BGBl 1989 II 586, BGBl 1990 II 1699.

161 BGH decision of 25 November 1998, VIII ZR 259/97, NJW 1999, 1259-1261, para 13.

162 The application of the CISG will be discussed in detail in E.II.1. below. Let it be noted at this point that it applies to those transactions in which the two countries involved are Contracting States to the CISG, or where their private international law rules lead to the CISG's application (see art 1 CISG). For further details on the CISG's application, see arts 2-5 CISG, as well as United Nations Commission on International Trade Law (UNCITRAL) Secretariat, Explanatory Note on the United Nations Convention on Contracts for the International Sale of Goods (UN Publication, November 2010) 34-36. This document, which will hereinafter be referred to as 'CISG Explanatory Note', is available online at www.uncitral.org/pdf/english/texts/sales/cisg/V1056997-CISG-e-book.pdf. On the application and excluded issues, see further the contributions in Franco Ferrari and Clayton P Gillette (eds), International Sales Law Vol 1 (Edward Elgar Publishing, 2017) 113-415.

163 See fns 162 and 15 above.

164 Wolf and Neuner (fn 48) 59 paras 40, 42. 
The BVerfG has held that this does not include international treaties, but that these general international rules are complemented by national principles. ${ }^{165}$

\section{Contracts in English Law}

England traditionally being a nation of commerce, ${ }^{166}$ it has had notions of contracts for a long time. ${ }^{167}$ Initially, however, these existed as customs, and would only later develop into what we understand as 'law'. ${ }^{168}$ Initially, this was a 'law of contracts', ie, a law of a plurality of special contracts, which would turn into one general 'law of contract' in the nineteenth century. ${ }^{169}$ Similarly, the denomination of the concept of contract has evolved over time. This concept will be defined first in Section 1., before

165 BVerfG order of 8 May 2007, 2 BvM 1/03, BVerfGE 118, 124-167, para 31. One such principle is good faith, see Wolf and Neuner (fn 48) 59 para 42 with further references.

166 See, eg, McKendrick ( $f$ n 48) 2. The origins of this tradition seem to go back to prehistoric times, since Frere notes that some kind of commercial connection already existed between Britain and continental Europe from that time onwards, see Sheppard S Frere, Britannia: A History of Roman Britain ( $3^{\text {rd }}$ edn, Routledge \& Kegan Paul 1987) 275; however, it is more probable that it lies in the Bronze Age, where Western Saxons (Wessex) already carried out commerce extensively - not only within, but even beyond the British Islands, see Encyclopaedia Britannica, United Kingdom (Online Academic Edition 2019), http:// academic.eb.com/EBchecked/topic/615557/United-Kingdom at 'History: Bronze Age'. In contrast, the first British chamber of commerce as a form of trading organisation was only established in the Channel Islands in the eighteenth century, see Encyclopaedia Britannica, Trade Association (Online Academic Edition 2015), http://academic.eb.com/EBchecked/topic/601677/trade-association. The commercial aspect continues to be of importance today. Thus, English contract law is directed at facilitating rather than hindering commercial transactions, see Whincup (fn 34) 17 para 1.1. As will be seen below, many legal rules place importance on legal certainty for reasons of commerce even today, see, eg, the explanation for the objective approach or the use of legal presumptions under Sections II.3.a., and II.3.a.ii.bb) respectively.

167 At least commercial contracts existed and gained legal recognition during the time of the writ system, ie, between the eleventh and sixteenth centuries. See on this development briefly H Patrick Glenn, Legal Traditions of the World: Sustainable Diversity in Law (5 ${ }^{\text {th }}$ edn, OUP 2014) 244, 245, 253-254.

168 Compare the general statement made by Baker, 'English Legal History' (fn 63) $1-4$.

169 See Andrews (fn 70) 3 para 1.01, listing further references. 


\section{B. Comparative Background}

its historical development as well as the current legal and practical situations are addressed in Sections 2. and 3. respectively.

\section{1. 'Contract' Defined}

As English law belongs to the common law tradition, the law of contract is not found in a code nor in one single piece of legislation; instead, one has to look into case law to discover what the principles of English contract law are. ${ }^{170}$ This explains the lack of a formal, ie, statutory, definition of a contract as understood in English law; however, 'indicative or illustrative' as opposed to 'definitive or comprehensive' statements on the meaning of contracts can be found in academic writing. ${ }^{171}$

A basic description of a contract has been given by Sir Treitel:

[It] is an agreement giving rise to obligations which are enforced or recognised by law[, whereby the contractual] obligations [...] are based on the agreement of the contracting parties. ${ }^{172}$

Professor Atiyah has not only described a typical common law contract, but has summarised the formation of contracts and the philosophy underlying English contract law at the same time:

[F]irst, [there is] a bilateral executory agreement. It consists of an exchange of promises; the exchange is deliberately carried through, by the process of offer and acceptance, with the intention of creating a binding deal. When the offer is accepted, the agreement is consummated, and a contract comes into existence before anything is actually done by the parties. [...]. The contract is binding because the parties intend to be bound; it is their will, or intention, which creates the liability. [... T] he law has this technical requirement known as the doctrine of consideration, but, except in rare and special cases, mutual promises are consideration for each other [...].173

170 In the words of Andrews (fn 70) 4 para 1.06: 'English contract law is predominantly a case law subject'.

171 McKendrick (fn 48) 3.

172 Treitel/Peel (fn 65) para 1-001. Compare the simpler definition in Halsbury's Laws of England Vol 22 ( $5^{\text {th }}$ edn, LexisNexis 2012) para 220: 'a promise or set of promises which the law will enforce'.

173 Patrick S Atiyah, Essays on Contract (repr, Clarendon Press 1990) 12 (emphasis added). cf the elements listed in Halsbury's Laws 22 (fn 172) para 203, and the 
Similarly, in a recent commercial case, the HC stated that a contract was generally subject to the following four requirements, namely, that:

(i) the parties have reached an agreement, which (ii) is intended to be legally binding, (iii) is supported by consideration, and (iv) is sufficiently certain and complete to be enforceable. ${ }^{174}$

Each of the elements of the formation of a contract found in this summary, except for completeness, will be analysed subsequently. The aspect of certainty will be considered in relation to each constituent of a contract, as it relates to these individual elements of a contract and their validity, thus impacting the existence of the agreement reached. Conversely, (in)completeness of a contract will not be discussed in detail, as this issue often relates to the question of the interpretation of contracts, ${ }^{175}$ an aspect that goes beyond the scope of this dissertation due to its extent. Before turning attention to the historical development and the requirements of contracts,

description in paras 204-205. Note that executory arrangements are those 'made with a view to future performance', Atiyah, ibid 13, 17. Executory agreements have thus not yet been fully performed, whereas they become executed once done, see Halsbury's Laws, ibid para 205. This distinction is of importance in some areas of contract, like in sales or land law. Consequently, the Sale of Goods Act 1979 (SGA 1979) differentiates between sales as executed contracts and agreements to sell as executory contracts, see s 2 subss 4 (sale) and 5 (agreement to sell) SGA 1979. For further discussion of this distinction, see Goode and McKendrick (fn 48) 219-222 paras 7.25 et seq. As for land, executed transactions are governed by ss 51-55 Law of Property Act 1925 (hereinafter 'LPA 1925') while executory transactions fall within s 2 LPMPA 1989. This was clarified recently in the case of Rollerteam Ltd v Riley [2016] EWCA Civ 1291, [2017] Ch 109 [29] (Henderson L). The case concerned the question whether two declarations of trusts over two pieces of land were effective. The court found that they were, and that they became so upon the two deeds being signed by the party declaring the trust (one of the defendants), see in particular [44][45] (Henderson LJ).

174 Blue v Ashley [2017] EWHC 1928 (Comm), 2017 WL 03129053 (official transcript) [49] (Leggatt J). The case concerned an alleged oral agreement made in a pub for remuneration (bonus) payment by the defendant to the claimant and whether such an agreement had arisen. It was held that the contract would have been 'inherently absurd', lacking commercial sense, and for several reasons (examined in Section 3.a.iv. below), the court found that the alleged offer was not seriously made, so that no contract could have arisen. See ibid [80] et seq (ibid).

175 See on this, eg, Treitel/Peel (fn 65) paras 2-085 et seq; McKendrick (fn 48) 126145. 


\section{B. Comparative Background}

a quick note needs to be made of the different ways in which contracts are classified.

Aside from the differentiation between executory and executed contracts, ${ }^{176}$ one key point in English contract law is the distinction between unilateral and bilateral ${ }^{177}$ contracts. The difference here lies in whether only one or all of the parties promise something. ${ }^{178}$ Sales are common examples of bilateral contracts, whereas a promise of a reward is a typical example of a unilateral contract. ${ }^{179}$ In the latter situation, the promisor indicates that they will give something to the other party if something is done or omitted, although the recipient makes no promise in return. Despite this, a contract arises. ${ }^{180}$ A more illustrative example of a unilateral agreement is the promise of money in return for the performance of a particular act, eg, going to a specific place. ${ }^{181}$ Particularly unilateral contracts must be contrasted with gifts, which, although constituting a mechanism by which one person may transfer property rights to another, are not contracts; ${ }^{182}$ they 'can be concealed in the form of one,

176 See fn 173 above.

177 This category is also known as 'synallagmatic' contracts, meaning a contract 'imposing reciprocal obligations', Halsbury's Laws Vol 22 (fn 172) para 204.

178 See the entry for 'unilateral contracts' in the Oxford Dictionary of Law (fn 62) 517. See also Halsbury's Laws 22 (fn 172) para 204. Its concept and the requirements will be discussed in Section 3.a. below. A recent case in which the existence of a unilateral contract was examined is Blue $v$ Ashley (fn 174). In the event, the court held that the alleged contract had not arisen.

179 See, eg, Andrews (fn 70) 8 para 1.11.

180 See Treitel/Peel (fn 65) para 2-052, who goes on to note at para 2-053 that acceptance is made at the time of complete performance. See also Andrews (fn 70) 64 para 3.42 .

181 Example given by, eg, Treitel/Peel (fn 65) para 2-052. Note that this kind of situation is not a donation on the part of the promisor. It is not gratuitous, since the promisee gives something in return: consideration. See on this John Cartwright, Formation and Variation of Contracts: The Agreement, Formalities, Consideration and Promissory Estoppel (Sweet \& Maxwell 2014) 136 in fn 124. This point will be discussed in further detail in Section 3.a.v. below.

182 See Halsbury's Laws Vol 22 (fn 172) para 208, who states that gifts 'have their legal consequences determined exclusively by other branches of the law'. The distinction is due to the consideration requirement, which will be discussed in Section 3.a.v. below. Atiyah, 'Introduction' (fn 33) 150-151 states that not gifts themselves but promises of gifts are made difficult by the doctrine of consideration. See on gifts generally Michael Bridge, Personal Property Law $\left(4^{\text {th }}\right.$ edn, OUP 2015) 171-175. The gift, or rather, the promise of a gift, is executed by the donor having the necessary intention and effecting the gift through delivery or otherwise, see Bridge, ibid. 
however, if nominal consideration is given in return for the promise. ${ }^{183}$ Despite not being contracts per se, they do constitute legal transactions when executed. 184

Another differentiation among contracts may be made according to their subject matter, eg, sale contracts and lease contracts, ${ }^{185}$ or their formation (mode), ie, as contracts made under seal and simple contracts, ${ }^{186}$ whereby the former are contracts made as deeds (by speciality) and the latter are in any other form. ${ }^{187}$ The following section will trace the historical evolution of the notion of contract. Section 3. will then give an overview of the current or modern law of contract in England, which will later serve as part of the comparative background.

\section{The Historical Development of the English Law of Contract}

The development of English contract law has followed a meandering course rather than a straight line, ${ }^{188}$ as this area of law was created through several legal predecessors. This in turn is due to the fact that historically, the origin of the common law lies in court procedures: English substantive law, including the law of contract, was developed from procedural law, namely, from procedural forms called writs, and forms of actions. ${ }^{189}$ Furthermore, despite the fact that the maxim that promises should be kept was of great importance during the Middle Ages, the common law did

183 Bridge, 'Property' (fn 182) 171. On the problems arising with gratuitous promises, see Atiyah, 'Introduction' (fn 33) 152.

184 See Bridge, 'Property' (fn 182) 171.

185 Halsbury's Laws Vol 22 (fn 172) para 219.

186 cf Halsbury's Laws Vol 9 (fn 33) para 209 and Halsbury's Laws Vol 22 (fn 172) para 215 (the latter no longer referring to seals, but to deeds only). This differentiation is made in statutory provisions as well, eg, in relation to limitation periods, see ss 5-7 (actions founded on simple contract), 8 (actions on a speciality) Limitation Act 1980.

187 Halsbury's Laws 22 (fn 172) paras 216, 218. The different formation requirements will be discussed in Section 3.b. below. There is a third class of contracts, 'of record', which will not be considered in this dissertation as it does not relate to private agreements but rather to public records, see on this ibid para 215. Note that von Mehren, 'Introduction' (fn 21) 7 speaks of unilateral contracts as 'unilateral acts under seal' or 'promise[s] under seal'.

188 See Baker, 'English Legal History' (fn 63) 360.

189 See ibid 63. This has been succinctly summarised in one sentence by David J Ibbetson, A Historical Introduction to the Law of Obligations (OUP, repr 2006) 11: 'The medieval Common law was a law of actions and procedure.' 


\section{B. Comparative Background}

not provide for a uniform (and thus reliable) way of enforcing them. ${ }^{190}$ Instead, there were several different actions, whose significance fluctuated over time. Due to this root in procedure, there was initially no legal theory of contracts in English law, a fact that remained true for the seventeenth century. ${ }^{191}$ It was only in the eighteenth and nineteenth centuries that a theoretically-founded law of contracts emerged: a notion of agreement that was separated from the procedural forms of action. ${ }^{192}$

It becomes evident from this that an examination of the evolution of the law of contract must therefore begin by looking at procedural actions, in particular at the action of assumpsit. The writ system had inherent deficiencies but was nevertheless of marked importance and, despite its faults, the writ formula continued to exist one way or another throughout the twentieth century. ${ }^{193}$ Thus, the development of the law, including the law of contract in the form of simple contracts, 'is essentially a tale of circumventing, of overcoming the special limitations of the medieval forms of action [...]'. ${ }^{194}$ Writs no longer exist today, but have been replaced by what are known as 'claim forms' ${ }^{195}$ Other remnants of this old system are still perceptible even today, like the sometimes indistinct lines drawn between different areas of law, and in the substantive law that was created from this system. ${ }^{196}$

Four aspects of modern English contract law will be explored in further depth with regard to its historical development: the first two are the action of assumpsit and the doctrine of consideration, both of which developed during Tudor and Stuart times (see Section a. below); the second two are the contractual doctrine of offer and acceptance and the requirement that the parties intend to be legally bound, both of which only emerged after the birth of the Kingdom of Great Britain in the nineteenth century (Section b.). The overview of the historical developments closes by consid-

190 See Morris S Arnold, Fourteenth-Century Promises (1976) 35 No 2 CLJ 321.

191 Compare Ibbetson, 'Historical Introduction' (fn 189) 215.

192 See ibid, also at 153-154.

193 See Baker, 'English Legal History' (fn 63) 80-81.

194 Samuel J Stoljar, A History of Contract at Common Law (Australian National University Press 1975) 3.

195 Hanbury and Martin (fn 63) 6; compare the entry for 'claim form' in Oxford Dictionary of Law (fn 62) 83. More information on the claim form can be found in parts 7 and 16 Civil Procedure Rules 1998, SI 1998/3132 (hereinafter 'CPR 1998').

196 See Baker, 'English Legal History' (fn 63) 81, 61. 
ering legal developments in the area of contract law that occurred after the twentieth century (Section c.).

a. Contracts in the Kingdom of England in Tudor and Stuart Times: The Transition from Medieval to Modern Law Through the Action of Assumpsit and the Emergence of the Doctrine of Consideration $\left(16^{\text {th }} \sim 17^{\text {th }}\right.$ Century)

The period between the sixteenth and the eighteenth centuries was the formative time for English contract law. At the beginning of this development phase, English law was in a 'transitional stage between the medieval $[\ldots]$ and the modern law'. ${ }^{197}$ This development may have been due to the economic and social upheavals that characterised this period (see Section i. below). The change from the medieval to the modern law is reflected in the general structure of law, in which the stiffness of the old procedural system is gradually broken up (Section ii.). The law of contract emerged from this process and would take on its current, modern form in the eighteenth and nineteenth centuries. This was due, in particular, to the emerging action of assumpsit (Section iii.bb)) and was aided further by the doctrine of consideration (Section iii.cc)).

\section{i. Political and Social Background}

It has been stated that the transition from Medieval to Modern times had already begun in England in the fourteenth century, at least in relation to the development of its economy and society. ${ }^{198}$ In this period, the people became 'a racial and cultural unit', namely, the 'English'. ${ }^{199}$ A sense of nationality began to emerge: people no longer felt bound only to their particular locality, which, in turn, led to a change in the social structure: expanding commerce led to an increase in the merchant and manufacturer classes, while the disappearance of the feudal manor farm led to the

197 Ibbetson, 'Historical Introduction' (fn 189) 96.

198 George M Trevelyan, Illustrated English Social History 1: Chaucer's England and the Early Tudors (repr, Penguin Books Ltd 1973) 20.

199 See Trevelyan (fn 198) 16. 


\section{B. Comparative Background}

appearance of free farmers and other farm labourers (yeomen). ${ }^{200}$ Later, in the seventeenth century, the upper strata transformed, not only in terms of the people making up the peerage and gentry, but also in terms of the sources of these nobles' wealth. ${ }^{201}$ The transformations continued, despite the political and, occassionally, also economical turbulences in the sixteenth and seventeenth centuries. ${ }^{202}$ Not only the towns ${ }^{203}$ but even the villages transformed: they became centres of agriculture, craft, and commerce, a change that continued until the nineteenth century. ${ }^{204}$ Nevertheless, the majority of the English lived in rural rather than urban areas, with around 800 towns, several provincial cities, and London facilitating inland trade. ${ }^{205}$

This change in size and composition of settlements had other consequences. In the villages and the countryside, the established life patterns changed. ${ }^{206}$ Furthermore, the crowds of people in the towns led to congestion of streets, confusion, noise and clamour, as well as poor sanitation. ${ }^{207}$ A more positive consequence of the flourishing of the economy and the expanding middle class was an increased consumption of goods: the lower classes strove to emulate the higher classes by acquiring similar merchandise, whereby the demand for more affordable goods led to increased production and fostered inventions. ${ }^{208}$ Indeed, 'shopping became an important cultural activity'. 209 This strive for emulation might be explained

200 See ibid 19, 20, 67, 22-23, 21, 32. For further details on the latter development, see ibid 24-32.

201 On this, see Encyclopaedia Britannica, 'United Kingdom' (fn 166) at 'A New Society'.

202 A comprehensive account of the events can be found in ibid at 'Elizabethan Society' et seq.

203 On average, these had a population of 2,000 to 3,000 inhabitants, see Trevelyan (fn 198) 74. cf 'provincial cities', such as Norwich or Bristol, with around 15,000 inhabitants; and London, with 250,000 people at the beginning of the seventeenth century. See on this Encyclopaedia Britannica, 'United Kingdom' (fn 166) at 'England in 1603 '.

204 Compare Trevelyan (fn 198) 68, 40.

205 See Encyclopaedia Britannica, 'United Kingdom' (fn 166) at 'England in 1603'.

206 William R Cornish and Geoffrey de N Clark, Law and Society in England: 1750/1950 (Sweet \& Maxwell 1989) 4.

207 A succinct account of the conditions is given by Matthew White, The Rise of Cities in the $18^{\text {th }}$ Century (British Library, 14 October 2009), www.bl.uk/georgian-britain/articles/the-rise-of-cities-in-the-18th-century.

208 See Cornish and Clark (fn 206) 5.

209 Matthew White, The Rise of Consumerism (British Library, 14 October 2009), www.bl.uk/georgian-britain/articles/the-rise-of-consumerism. 
on the ground that while English society of the seventeenth century was strictly divided into classes, there was no obstacle, albeit money, to the rise or fall from one class to another. ${ }^{210}$

Another positive development during the sixteenth and seventeenth centuries was the rise in literacy: more people were able to read and write; and, by the mid-seventeenth century, this seems to have been true for the majority. ${ }^{211}$ Furthermore, perhaps as a corollary to this development came the establishment of 'The King's Posts', a postal service exclusive for the Court but which would later be opened to the public and became known as the 'Royal Mail'.212

These changes also affected the political sphere, increasing the sway of the lower house of Parliament, the House of Commons, and allowing the interests of the lower and middle classes to be protected, eg, in the area of labour. ${ }^{213}$ On the other hand, the dire situation of the towns necessitated the law to intervene in matters of the general public, ${ }^{214}$ while the turmoils under the Glorious Revolution of the later seventeenth century brought about several pieces of political legislation. ${ }^{215}$ As for the Royal Mail, the facilitation of sending letters would lead to an important legal development, the 'postal rule', discussed in Section b.iii.bb) below.

\section{ii. The General Structure of Law}

The positive developments occurring on the social, economic, and political level were not paralleled in the legal sphere. The stiffness that had previously governed English society initially persisted in the structure of law

210 For further details on the composition and movement of classes, see Encyclopaedia Britannica, 'United Kingdom' (fn 166) at 'England in 1603'.

211 See ibid at 'Elizabethan Society'.

212 See www.bbc.com/timelines/zxnbr82\#z39q2hv and www.royalmailgroup.com/en/about-us/our-story/.

213 See Trevelyan (fn 198) 22, 33-34. For examples, see www.parliament.uk/about/ living-heritage/transformingsociety/tradeindustry/industrycommunity/keydates/ and further www.parliament.uk/about/living-heritage/transformingsociety/livinglearning/19thcentury/keydates/.

214 The relevant Acts of Parliament are listed at www.parliament.uk/about/ living-heritage/transformingsociety/towncountry/towns/keydates/. See also www.parliament.uk/about/living-heritage/transformingsociety/towncountry/towns/overview/georgianimprovement/.

215 On this, see Encyclopaedia Britannica, 'United Kingdom' (fn 166) at 'The Revolution Settlement'. 


\section{B. Comparative Background}

(see below) as well as in the legal procedure itself (Section iii.bb)). As will be seen, a transformation did nevertheless occur.

Although the common law was born in the twelfth century, several factors initially impeded a permeation of a uniform law, of the 'law and custom of the realm'216 as laid down by the king's courts. In essence, these impediments came down to a multitude of laws, local customs ('folkright'), and courts existing in parallel in the Kingdom of England during this period. ${ }^{217}$ Adding to the insecurity of court decisions was the fact that the notions of precedent and stare decisis were only properly developed in the nineteenth century. ${ }^{218}$ A reason for this could lie in the fact that the English 'legal culture was largely oral' and that reports of cases in print form only became widespread in the seventeenth century. ${ }^{219}$ This fact may also explain why there were no law journals or law books during this period. 220

This situation was not aided by the inflexible system of the writ, a system of formulas which defined the court procedure to be followed. ${ }^{221}$

216 Baker, 'English Legal History' (fn 63) 14, 16.

217 See ibid 3-4, 9, 15-16, who notes the existence of three sets of laws that stood alongside a variety of local customs, as well as the competition for jurisdiction between the local 'administration' (of the shires, hundreds, boroughs, etc) on the one hand and the central 'government' (the king's court) on the other. cf Elliott and Quinn (fn 53) 10, who state that the three laws were 'largely based on local custom'.

218 See Baker, 'English Legal History' (fn 63) 225-230.

219 Ibbetson, 'Historical Introduction' (fn 189) 11, 12.

220 See Baker, 'History not Finished'(fn 69) 69. In fact, two treatises from the twelfth and thirteenth centuries by Glanvill and Bracton on the writs and forms of actions existed; however, the first systematic and comprehensive treatise on contract law only appeared at the turn of the nineteenth century. On the former, see Baker, 'English Legal History' (fn 63) 200-202. On the latter, see Ibbetson, 'Historical Introduction' (fn 189) 220, giving a list of the contract law treatises starting with John J Powell, Essay upon the Law of Contracts and Agreements $\left(1^{\text {st }}\right.$ edn 1790; P Byrne et al 1796), over Joseph Chitty Jr, A Practical Treatise on the Law of Contracts not Under Seal; and Upon the Usual Defences to Actions Thereon ( $1^{\text {st }}$ edn 1826; $2^{\text {nd }}$ edn, S Sweet 1834) 3, and up to William R Anson, Principles of the English Law of Contract and of Agency in its Relation to Contract ( $1^{\text {st }}$ edn 1879; $3^{\text {rd }}$ edn, Clarendon Press 1884). On the development of legal literature generally, see Baker, ibid 200-221; see further Michael Lobban, Part Two: Contract, in: William Cornish and others (eds), The Oxford History of the Laws of England Vol XII: 1820-1914 Private Law (OUP 2010) 295, 300 et seq.

221 According to Glenn (fn 167) 215, 242, a 'writ' was essentially an instruction given by the Crown to a sheriff or other royal officer, stating how the officer was to act in a case in order for it to proceed: to summon a party for questioning, to 
Moreover, it has been noted that these writs were 'often evaded or defied' and that the 'arm of the law' was 'weak', so that there was no uniformity in legal enforcement, ${ }^{222}$ and no guarantee of equal treatment or outcome. Irrespective of its effectiveness, this system gave rise to actions that are important for the development of contract law. Before going into details on these in Section iii.bb), it is worth making a note of the concept of contract during this period.

\section{iii. The Law of Contracts}

The law of contract in the English Early Modern period cannot be compared to today's framework. In the first place, the notion and types of contract were very different at that time (see Section aa) below). The same goes for the way in which contract claims were seen (Section bb)). Moreover, the type of agreement affected how the contract was concluded (Section cc)), the process of which often involved some contract form (Section dd)).

\section{aa) Definition and Types of Contract}

The notion of contract in this period differed from today's meaning. Initially, the definition from the medieval age persisted. In this respect, 'contract' must be contrasted with 'covenant'. A medieval common law lawyer would have understood 'contract' to mean 'transaction' in terms of transferring property or generating debt, rather than 'exchange of promises'. ${ }^{223}$ It was a bargain, a bilateral and reciprocal agreement (actus contra actum) requiring the giving and receiving of quid pro quo (consideration), ${ }^{224}$ exe-

form a jury, etc. It therefore determined - and limited - the actions of both the sheriff and of the judge(s): it conferred jurisdiction to the court, but only within the procedural boundaries of the writ. See on this Baker, 'English Legal History' (fn 63) 65. For an overview of the different kinds and examples of the formulations used in writs, see the table provided in Baker, ibid 83 and 613 et seq.

222 Trevelyan (fn 198) 44, 40-42.

223 Baker, 'English Legal History' (fn 63) 360.

224 Ibbetson, 'Historical Introduction' (fn 189) 140, 135, 141. 


\section{B. Comparative Background}

cuted rather than executory in nature, ${ }^{225}$ but not consensual. ${ }^{226}$ Contracts were usually concluded between present parties, face to face, rather than across a distance through some means of communication, with perhaps the exception of messengers. ${ }^{227}$

Instead of 'contract', it was the term 'covenant' that was understood to be 'no more nor less than an agreement between parties' in the fourteenth century. ${ }^{228}$ It was seen as a reciprocal (synallagmatic) act of exchange from which mutual obligations arose to do something in future. ${ }^{229}$ Initially, however, and even as late as the sixteenth century, the notion of an agreement was unilateral: there was a promise ${ }^{230}$ by one side, which was broken, and for which the other party had an action if something (consideration) had been given in return. ${ }^{231}$ This notion subsequently changed to a bilateral one, as will be seen below.

As covenants were used to stipulate a specific future conduct, the term initially did not refer to a document, but to an act; this perception would eventually change as sealing became an indispensable requirement to

225 John H Baker, New Light on Slade's Case (1971) 29 No 1 CLJ 51, 60.

226 Baker, 'English Legal History' (fn 63) 360.

227 Compare Ibbetson, 'Historical Introduction' (fn 189) 139, who discusses a case in which a servant passed on the promise of the defendant to their master (the claimant): Milles $v$ Rainton (from 1600). Interestingly, the court held that an implicit acceptance of the promise was not sufficient; where a promise is not made to a person directly, the promisee must accept expressly for the promise to be effective, see Ibbetson, ibid.

228 Arnold (fn 190) 321, citing Herle J from 1320. This seems to be in line with the understanding (although perhaps emerging at a later time) of a covenant as the promises contained in a deed, see Halsbury's Laws Vol 22 (fn 172) para 216. Arnold, ibid 322-323 also states that anything ranging from sales of land, business deals, to personal relationships might, among other things, be the object of a covenant.

229 Stoljar (fn 194) 6.

230 It ought to be noted that the meaning of 'promise' was not the same as today. Although it was linked to trust and the existence of an agreement, the notion was much weaker. See on this Warren Swain, Contract as Promise: The Role of Promising in the Law of Contract. An Historical Account (2013) 17 No 1 Edinburgh Law Review 1, 10.

231 See AW Brian Simpson, Innovation in Nineteenth Century Contract Law (1975) 91 LQR 247, 257. An example is the statement made in Golding's Case (1586) 2 Leonard 71, 74 ER 367 (KB) for a lease that '[i]n every action upon the case upon a promise, there are three things considerable, consideration, promise and breach of promise' (emphasis added). On the origin of consideration, see Section cc) below. 
mean 'agreement under seal'. ${ }^{232}$ Covenant did not concern the immediate transfer of rights; this was instead achieved through a grant. ${ }^{233}$ An example of the latter would be a consensual transaction (contract) like a sale of goods, ${ }^{234}$ or a gratuitous gift of a thing delivered. ${ }^{235}$ It was thus said that covenants were executory in nature, ${ }^{236}$ whereas contracts (grants) were executed actions. As with the example of a sale, 'contract' thus often denoted an informal agreement, although it could also be used for formal ones. ${ }^{237}$

In conclusion, 'contract' and 'covenant' were both sub-categories of 'agreements', which sometimes overlapped. ${ }^{238}$ Conversely, there was as yet no overarching notion of contract, which, as will be seen subsequently, was reflected in the law. It was only later that the term contract evolved into the 'classical' model when the essential elements of the modern doctrine of contract, ie, the doctrine of consideration and that of offer and acceptance, had evolved in the sixteenth and nineteenth century respectively. ${ }^{239}$ Nevertheless, it can be stated here that the notion of contract(ual liability) in the seventeenth century already foresaw that an agreement and thus, a voluntary act of the parties - and some reciprocity in the form of consideration (see Section cc) below) was necessary. ${ }^{240}$ Furthermore, the

232 Compare AW Brian Simpson, A History of the Common Law of Contract: The Rise of the Action of Assumpsit (repr, Clarendon Press 1996) 16, 19. On the seal becoming a necessary requirement, see Ibbetson, 'Historical Introduction' (fn 189) 126. For further details on formalities, see Section dd) below.

233 Simpson, 'History' (fn 232) 19; Stoljar (fn 194) 6.

234 See Simpson, 'History' (fn 232) 22.

235 See Stoljar (fn 194) 6. Ibbetson, 'Historical Introduction' (fn 189) 3 notes that gifts were the standard mechanism for transferring property in the Middle Ages. Furthermore, quite unlike today's notion, gifts were not perceived as unilateral acts, but as something reciprocal. This was because the receipt of a gift 'created a tension between the parties' to make a counter-gift, thus in effect creating an 'obligation of reciprocity'. See Ibbetson, ibid 3-4. Something similar is noted by Swain (fn 230) 3-4. This perception of gifts can perhaps be likened to the Japanese notion of giri, discussed in Section C.I.2. below.

236 Simpson, 'History' (fn 232) 19; compare the definition Atiyah gives for 'executory arrangements' as explained in Section 1. above.

237 Simpson, 'History' (fn 232) 53.

238 Ibid 189.

239 See ibid 5. On the latter, see Section b.iii.bb) below.

240 See Ibbetson, 'Historical Introduction' (fn 189) 203, 208. In this respect, see the account by, eg, Powell (fn 220) 9 et seq on assent (consent) by the parties to a contract. 
principle of sanctity of contract was recognised, so that a contract, once entered into, bound the parties. ${ }^{241}$

\section{bb) The Law of Contracts: Forms of Actions for Contractual Claims}

As intimated above, English contract law developed from several actions in court procedures. Three are of interest for this analysis: ${ }^{242}$ covenant, debt, and assumpsit. Covenant and debt arose in the twelfth century and continued to develop until they lost importance after the seventeenth century. ${ }^{243}$ The third action of assumpsit ('he undertook') 244 emerged in the fourteenth century and went on to become a crucial element in the development of the modern law of contract in the sixteenth and seven-

241 Compare Ibbetson, 'Historical Introduction' (fn 189) 213, speaking of contractual liability being 'absolute'.

242 There was a fourth action, detinue, which will not be considered further. For reasons of completion, let it be noted that it largely covered cases of what is known as bailment, but that the wide sense of 'detinue' was an action of debt for a chattel. See Simpson, 'History' (fn 232) 7, 55. It was related closely with debt, see Stoljar (fn 194) 13-15. Furthermore, there seemed to have existed an action of annuity and one of account, although these were supposedly rarely used in practice, see Baker and others, 'Oxford Legal History Vol XII' (fn 220) 314 in fn 88.

243 On this development, in particular for covenant, see Baker, 'English Legal History' (fn 63) 361-365; cf Simpson, 'History' (fn 232) 46-47, who states that covenant underwent a 'revival' in the seventeenth century. One reason given for the demise of the action of covenant was the requirement of a deed, see Swain (fn 230) 9. Another factor was an increased tendency of parties using a formula from the action of debt (bonds) to make contracts, see Baker, ibid 364; but see Simpson, ibid 43,117, and 44, who suggests that covenant was rarely applied to enforce agreements to begin with, as bonds were preferred, but that covenants were still used in connection with land. On debt, see Simpson, ibid 53-68. One reason for debt to fall into disuse was that several limitations of applicability created lacunae that the action of assumpsit went on to fill. See on this Simpson, ibid 65-68. Another cause might simply be that plaintiffs went from addressing the common law courts to the Chancery, which applied equity and not the common law forms of action. Compare Baker, ibid 372. It ought to be noted, however, that debt was still used for obligations (bonds) until the nineteenth century, see Baker, ibid 368.

244 Baker, 'English Legal History' (fn 63) 361; Philip Cooke and David W Oughton, The Common Law of Obligations ( $3^{\text {rd }}$ edn, Butterworth 2000) 8; but see Arnold (fn 190) 330, who uses the term 'agree' as a translation of assumpsit. 
teenth centuries. ${ }^{245}$ In fact, assumpsit largely displaced the other actions on contracts and covenants by the end of the sixteenth century. ${ }^{246}$

While covenant covered actions where an agreement to do something (except to pay a debt) was wrongfully broken, it was only available for 'formal agreements', ie, agreements that were made under seal. ${ }^{247}$ Informal agreements, such as 'transactions' like sales of goods, were regarded as 'contracts' and covered by the action of debt, the action for the specific recovery of a sum of money or of a chattel due. ${ }^{248}$ Having said this, debt also covered 'formal transactions' where money or a thing was due, ${ }^{249}$ and the debt was contained in a bond (see below). ${ }^{250}$ This seeming confusion did not pose a problem for medieval English lawyers, because an action of covenant was seen as an action for a wrongful breach of promise, while an action of debt was considered to be related more to property in that it was based on entitlement: the action of debt could only be brought if the claimant had performed their part of the agreement. ${ }^{251}$ There was an overlap between covenant and debt in practice only where one party had promised an amount of money or a thing. ${ }^{252}$ Having said this, it

245 See Simpson, 'History' (fn 232) 3. On the origin of assumpsit - the writ of trespass (on the case) - see Baker, 'English Legal History' (fn 63) 374-375, 7175. Interestingly enough, the decline of the action of covenant began in the fourteenth century, see Stoljar (fn 194) 5; however, he goes on to note at 7 that 'covenant $[\ldots]$ survived the rise of assumpsit', and instead points to the success of the penal bond ('obligation') under debt at 6 .

246 See Baker, 'English Legal History' (fn 63) 361. cf Ibbetson, 'Historical Introduction' (fn 189) 95 and 126, stating only that assumpsit had displaced the action of debt in relation to informal contracts.

247 Simpson, 'History' (fn 232) 6. This was not always true. It seems this change came about in the fourteenth century. See on this, eg, Swain (fn 230) 8-9 with further references. The form of contracts will be discussed in Section dd) below.

248 See Simpson, 'History' (fn 232) 56. Baker, 'English Legal History' (fn 63) 365 uses the term fungibles and gives the example of barley. It ought to be noted that the objects need not have been specific; where they were specific, ie, identified and attributable to an owner, the action of detinue was appropriate, since this action concerned personal property (chattels), see Baker, ibid, 365. On the differentiation between specific and non-specific objects and debt and detinue, see further Simpson, ibid 57-58.

249 See Simpson, 'History' (fn 232) 53.

250 See Baker and others, 'Oxford Legal History Vol XII' (fn 220) 314.

251 See ibid 67-68, where the author states that debt was a 'recupatory' action for something that the creditor owned; see also ibid at 75 and Stoljar (fn 194) 1011. On the basis of debt being an entitlement, see Swain (fn 230) 8.

252 Baker, 'English Legal History' (fn 63) 365-366. Note that the promise to pay a sum had to be to the other party of the agreement for an action of debt to 


\section{B. Comparative Background}

seems that covenant could be for future things, as it encompassed future conduct, whereas debt necessitated that the object be in existence at the time of entering into the agreement. ${ }^{253}$ Assumpsit was also available for breaches of (informal) promises, ${ }^{254}$ and was aimed at compensating for the breach. ${ }^{255}$ The application of these actions underwent a number of changes over time. For reasons of brevity, the focus in what follows will be on the action of assumpsit. ${ }^{256}$

Similar to an action of covenant, the plaintiff in an action of assumpsit complained about a wrongful act ('misfeasance'), which had not been stipulated by the parties, ${ }^{257}$ committed by the defendant while executing what he had undertaken to do, leading to the plaintiff suffering physical damage. ${ }^{258}$ In this respect, the phrase 'fideliter promisit' (faithfully promised) was normally used in conjunction with assumpsit. It was a statement of fact that the defendant had undertaken to act, ${ }^{259}$ had done so voluntarily, ${ }^{260}$ and assumed the risk of the undertaking. ${ }^{261}$ The phrase was therefore not used for the connotation of the defendant having promised to do something; the focus was on the breach of that promise. This only changed in the sixteenth century, where the phrase was modified as 'assumpsit et fideliter promisit' (assumed and faithfully promised). ${ }^{262}$ Indeed, it was

arise. Thus, where a party promised another party to pay a sum of money to a third party, this was a covenant, since no money was due to the other party, see Simpson, 'History' (fn 232) 71.

253 On covenant, see Stoljar (fn 194) 6; on debt, see Baker, 'English Legal History' (fn 63) 371.

254 Baker, 'English Legal History' (fn 63) 374; Cooke and Oughton (fn 244) 8.

255 See Simpson, 'History' (fn 232) 68, 80.

256 Readers interested in the other three actions are referred to Baker, 'English Legal History' (fn 63) 360-373, and Stoljar (fn 194) 3-15.

257 Cooke and Oughton (fn 244) 8.

258 Baker, 'English Legal History' (fn 63) 374-375. This may explain why the remedy available under the action of assumpsit was damages for breach of the contract, and not, say, specific performance of the promised action, see Ibbetson, 'Historical Introduction' (fn 189) 132.

259 Baker 'English Legal History' (fn 63) 375. On the theory of this phrase stemming from the action of fidei laesio of the ecclesiastical courts and its meaning, see Ibbetson, 'Historical Introduction' (fn 189) 136.

260 Cooke and Oughton (fn 244) 8.

261 Arnold ( $\mathrm{fn}$ 190) 331. The meaning of promise in assumpsit is explored by Ibbetson, 'Historical Introduction' (fn 189) 136-138.

262 On this, see Ibbetson, 'Historical Introduction' (fn 189) 130-131. The turning point (or end, compare ibid 138) was a case known simply as Slade's case (1595) 4 Coke 91a, 76 ER $1072(\mathrm{~KB})$. The dispute arose over a sale of crops (not yet harvested), upon the conclusion of which the defendant had 'faithfully promised' 
initially not possible to bring cases of non-performance ('nonfeasance') of an undertaking under the action of assumpsit, because an undertaking that had not been performed had a different connotation: in cases of nonfeasance, the undertaking was thought to be a promise, a covenant, thus making that action appropriate. ${ }^{263}$ The non-performance of a covenant was therefore a breach of such and not a wrong in trespass, ${ }^{264}$ unless the plaintiff suffered some damage. ${ }^{265}$ Although an action of assumpsit was first allowed for nonfeasance in a case of deceit in $1422,{ }^{266}$ it was only at the turn of the sixteenth century that nonfeasance was allowed as an action of assumpsit, ${ }^{267}$ even where there was in fact no deceit in the non-performance. ${ }^{268}$

By allowing assumpsit to be used for non-performance in the form of indebitatus assumpsit (trespass on the case for an obligation assumed), the notion of 'contractual obligation' was established in the sixteenth century: ${ }^{269}$

to pay, but did not do so after the agreed time had passed, despite the claimant requesting him to do so. The court found a contract but that no promise had been made by the defendant. A succinct account of the legal-political background of the case and the arguments advanced, as well as a transcription of the case from non-published manuscripts can be found in Baker, 'Slade's case transcripts' (fn 225) 51-67, and John H Baker, New Light on Slade's Case (1971) 29 No 2 CLJ 213-236 (hereinafter 'Slade's case background').

263 See Baker, 'English Legal History' (fn 63) 380. See also ibid, 'Slade's case background' (fn 225) 220: 'A failure to perform an obligation was not ipso facto fraudulent.'

264 Baker 'English Legal History' (fn 63) 380.

265 See David Ibbetson, Assumpsit and Debt in the Early Sixteenth Century: The Origins of the Indebitatus Count (1982) 43 No 3 CLJ 142, 145, 153, who states that the damage is the 'ground of liability'.

266 Shipton v Dogge (1442) B\&M 391, cited by Baker, 'English Legal History' (fn 63) 383. The case concerned a sale of land, whereby the seller had conveyed the land in question to a third party in order to not have to perform the agreement; the plaintiff claimed deceit and succeeded, because the defendant had made it impossible to perform the covenant due to their own 'deceit'.

267 See Baker, 'English Legal History' (fn 63) 380, who states that the barrier remained until the end of the fifteenth century, while Cooke and Oughton (fn 244) 9 state the year 1533 as the point at which nonfeasance was included under the action of assumpsit.

268 Baker, 'English Legal History' (fn 63) 384. See also Ibbetson, 'Historical Introduction' (fn 189) 129, who gives an outline of the first cases in the fifteenth century, including Shipton $v$ Dogge (fn 266), at 127-129.

269 Compare Glenn (fn 167) 222. A succinct explanation of the difference between debt and indebitatus assumpsit can be found in Ibbetson, 'Historical Introduction' (fn 189) 132-133. 


\section{B. Comparative Background}

someone who received something in exchange for a promise should have to keep that promise. ${ }^{270}$ This notion is explored in Section cc) below. The basis of assumpsit shifted at this time from a broken promise to a mutual agreement between the parties, understood as a meeting of the minds. ${ }^{271}$ Moreover, the move away from formalities as constitutive requirements for contracts (see Section dd) below) led to consensual contracts being acknowledged. ${ }^{272}$

The action of assumpsit eventually replaced the actions of covenant and debt in the seventeenth century, so that the traditional notion of contract developed into 'agreement'. ${ }^{273}$ This unification greatly simplified the enforcement process and marked a change in the definition of a contract: While being understood as a 'transaction' during the Middle Ages, ${ }^{274}$ its meaning developed into 'agreement' ('agreamentum') or 'undertaking' ('assumpsit'; Latin: 'assumptio') around the turn of the sixteenth and the seventeenth century. ${ }^{275}$ 'Contract' thus became 'an agreement between two or more [parties] concerning something to be done [...]', the notion of which was, however, strongly connected to sale transactions. ${ }^{276}$

cc) The Formation of Contract and the Further Requirement of Giving Consideration

Apart from the need to overcome the inflexible forms of action found in the writ system as discussed above, the development of English contract

270 Ibbetson, 'Assumpsit and Debt' (fn 265) 153. Cf Glenn (fn 167) 217-218, who seems to reject the base of contract on promises in favour of an agreement on an action.

271 Compare Ibbetson, 'Historical Introduction' (fn 189) 145-146. A contemporary description of assumpsit can be found in Baker, 'Slade's case transcripts' (fn 262) 55.

272 See Ibbetson, 'Historical Introduction' (fn 189) 146-147.

273 Baker, 'English Legal History' (fn 63) 361; see also Ibbetson, 'Historical Introduction' (fn 189) 147.

274 Compare also the discussion on the 'classical model' of English contracts in Section 1. above.

275 See Baker, 'English Legal History' (fn 63) 360-361; see also Simpson, 'History' (fn 232) 3. On agreement, cf Ibbetson, 'Historical Introduction' (fn 189) 146, stating that it means meeting of the minds. The term assumpsit is sometimes also understood to mean 'to assume', as in indebitatus assumpsit (assumed obligation), see Glenn (fn 167) 254.

276 Baker, 'English Legal History' (fn 63) 361, citing Serjeant Sheppard. 
law had to grapple with another theoretical hurdle: the non-bindingness of naked promises. It appears that a mere promise as to some future act was not recognised as being binding in the Middle Ages. ${ }^{277}$ Instead, there were three ways in which a person could bind themself to their promise: by swearing an oath; by handing something over to the other person; or by creating personal ties through some customary manner, such as shaking hands or drinking wine together. ${ }^{278}$ The second method involved something of real or mere symbolic value, like an amount of money (earnest money) or a stick respectively, being given by the promissor (debtor) to the promisee (creditor) and this had the effect of giving the promisee a right to vengeance if the promise was broken, whereby at least earnest money acted as a formality to 'make [the contract] perfect'. ${ }^{279}$ This idea seems to have been carried over into the forms of action, in particular debt and assumpsit.

Where an action of debt was for contract, ie, for informal agreements for which no deed existed as proof, the claimant (creditor) had to show that there was a reason for the debt. This reason was termed as causa debendi from the Latin language, or more commonly as quid pro quo. ${ }^{280}$ Some form of reciprocity was thus required. A contract was created if the debtor was to receive something (a thing or benefit) through the act of the creditor. This situation has to be contrasted with cases of an exchange of promises between the parties, leading to an action of covenant. ${ }^{281}$

A similar principle developed in the action of indebitatus assumpsit in the sixteenth century: someone was bound by a promise only if they had received something in return. This principle of consideration echoed the quid pro quo found in debt, since consideration was understood to mean the cause, reason, or motive for making a promise at the beginning of the

277 cf Swain (fn 230) 6, who notes that generally, 'some promises pacta nuda were certainly binding' (italics as in original), including commercial contracts.

278 See on this Ibbetson, 'Historical Introduction' (fn 189) 4-6. On oaths, see also Swain (fn 230) 4.

279 For further details on the workings of this mechanism and the analogy to an oath, see ibid 5. On earnest money, see ibid 147.

280 Baker, 'English Legal History' (fn 63) 366.

281 Ibid 371. 


\section{B. Comparative Background}

seventeenth century. ${ }^{282}$ Its essence was reciprocity, an exchange of some kind (of words or acts) between the parties. ${ }^{283}$

Consequently, assumpsit was only allowed where the defendant had promised something because they had received something (nominal) from the plaintiff, even if this receipt was sometimes fictional, ${ }^{284}$ an agreement on its own was no longer sufficient. ${ }^{285}$ Thus, the idea of some form of consideration (sometimes called recompense) was applied to contractual promises to make 'naked promise[s]' enforceable by adding something to them. ${ }^{286}$ The notion of reciprocity between the parties contained in the doctrine of consideration would later, in the nineteenth century, become an important factor for a contract to be deemed as a 'reciprocal bargain' between the parties. ${ }^{287}$ It is interesting to note that the act of giving consideration - and quid pro quo before it — was seen as constituting (part-) performance of a contract and as such was evidence of the agreement's existence. ${ }^{288}$ The payment of small amounts of money was asserted regularly by claimants in actions of assumpsit initially, but seems to have lessened when the action was recognised readily by the courts. ${ }^{289}$

Beside this application, the courts made use of consideration in a different way: with the rise of the action of assumpsit, the doors to the courts were opened to a wider set of agreements; consideration was then invoked by the courts as a mechanism to limit the ever-increasing number of binding contracts, ${ }^{290}$ and, consequently, their enforceability. ${ }^{291}$ In other words, it was a way to stem the tide of claims raised in the courts. On the other hand, the formality of giving consideration was seen as a safeguard against hasty decisions by encouraging greater deliberation before entering into an

282 Compare Ibbetson, 'Historical Introduction' (fn 189) 144, 142, who goes on to note that the notion underlying consideration and debt was the same, namely, reciprocity.

283 See Swain (fn 212) 11.

284 Ibbetson, 'Assumpsit and Debt' (fn 265) 153-154. See also Cornish and Clark (fn 206) 203.

285 See Swain (fn 212) 11.

286 See Ibbetson, 'Assumpsit and Debt' (fn 265) 154. Compare also Simpson, 'Innovation' (fn 231) 258; Baker, 'English Legal History' (fn 63) 386 uses the Roman term nudum pactum ('naked pacts').

287 Cornish and Clark (fn 206) 207.

288 See Ernst Rabel, The Statute of Frauds and Comparative Legal History (1947) 63 LQR 174, 181.

289 Compare Ibbetson, 'Historical Introduction' (fn 189) 147.

290 See Smits (fn 37) 78-79.

291 Kötz, 'Europäisches Vertragsrecht' (fn 17) 71. 
oral contract: It was a mechanism through which the common law sought to protect people from reckless undertakings, something that had been latent in case law in the sixteenth century and was only acknowledged by the courts at the beginning of the nineteenth century. In relation to this, the courts also restated that consideration was not necessary when deeds were involved, as these instruments were thought to exert a sufficient cautionary restraint on the promisor. ${ }^{292}$ Consideration was therefore not an issue with formal contracts (on which see below).

Although the idea underlying consideration existed for a long time, ${ }^{293}$ it only became a settled requirement by the mid-sixteenth century. ${ }^{294}$ This development is perhaps not coincidental, as it was from the same century on that contract theory generally gained importance. ${ }^{295}$ Consideration would remain the primary basis of liability with informal contracts in the nineteenth century, ${ }^{296}$ and is still seen as a vital requirement for contracts even today. Therefore, the requirements of consideration will be analysed in Section 3.a.v. below. Attention will now be given briefly to contract forms in Tudor and Stuart times.

292 In the sixteenth century, this was stated in Sharington $v$ Strotton (1564) 1 Plowden 298, 75 ER 454 (KB) 469 (Plowden J): 'And because words are oftentimes spoken by men unadvisedly and without great deliberation, the law has provided that a contract by words shall not bind without consideration'. The case will be discussed further in Section 3.a.v. below. On the nineteenth century position, see Morley $v$ Boothby (1825) 3 Bingham 107 (Court of Common Pleas), [1825] 130 ER 455, 456 (Best CJ). The case concerned a bill of exchange issued by the defendant to the plaintiff. The promise to pay contained in the document was found invalid for want of consideration. See ibid 456-457 (Best CJ).

293 John Hamilton Baker, Origins of the "Doctrine" of Consideration, 1535-1585, in: Morris S Arnold and others (eds), On the Laws and Customs of England: Essays in Honor of Samuel E Thorne (University of North Carolina Press 1981) 337. Various theories on the origin of consideration exist. Some legal historians, such as Ibbetson, 'Assumpsit and Debt' (fn 265) 153, see an equivalent in the quid pro quo from the action of debt, others find it in the notion of causa from canon law. It has also been said to be a combination of both of these concepts, see Baker, 'Consideration', ibid 340-341, 352-356; Baker, 'English Legal History' (fn 63) 386-388.

294 Ibbetson, 'Assumpsit and Debt' (fn 265) 152. According to Baker, 'Consideration' (fn 293) 337, it was established before 1585. cf Stoljar (fn 194) 7, stating that it was an essential requirement for simple contracts.

295 Atiyah, 'Introduction' (fn 33) 2. cf Ibbetson, 'Historical Introduction' (fn 189) 153 , stating the eighteenth and nineteenth centuries to be the period in which English contract theory was established.

296 On this, see Cornish and Clark (fn 206) 222. 


\section{B. Comparative Background}

\section{dd) Contract Forms}

As noted above, contracts of the sixteenth century in England could be 'informal' or 'formal', also known as 'simple contracts' and those 'under seal'. ${ }^{297}$ The former could be contracts made orally or in 'simple' writing, whereas the latter had to be made in the form of a special instrument called a deed that bore a seal impression. ${ }^{298}$ Of course, form requirements were known before this time. Already in the Middle Ages, both unilateral or gratuitous 'contracts' (arrangements) had to be made 'under seal' in order to be enforceable at law. ${ }^{299}$ Beside covenants in the fourteenth century, other kinds of agreement were eventually made the subject of form requirements: During the seventeenth century, the in(famous) Statute of Frauds of 1677 (hereinafter 'SOF 1677') established form requirements for a range of circumstances, including guarantees (suretyships), sale of goods over a value of $£ 10$ (approx. $€ 12$ ), certain contracts relating to land, and wills. ${ }^{300}$ Accordingly, a guarantee had to be in the form of 'some Memorandum or Note thereof [...] in Writing and signed by the [guarantor]' (s 4 SOF 1677). As this requirement remains in force today, its meaning will be discussed in Section 3.b.ii. below. Suffice it to state here that a deed was not necessary. ${ }^{301}$

The stringency of the form requirements varied: sometimes, a form was imperative for the effectiveness of an agreement; sometimes it was optional. As an example of the former situation, a 'sealed instrument (a "speciality")'302 was a necessary requirement for the action of covenant

297 The latter term is used by Halsbury's Laws Vol 9 (fn 33) para 209.

298 On the difference, compare ibid paras 210, 212. As deeds are still a form requirement under current law, its requirements will be set out in Section 3.b.iii. below. Anticipating the exposition below, let it be noted at this point that a deed is a written document that fulfils a set of specific requirements and which is thus awarded special legal status.

299 Ibbetson, 'Historical Introduction' (fn 189) 135.

300 For an overview of the background to the enactment of this Act and a critical assessment, see Rabel (fn 288) 174-187. Ibbetson, 'Historical Introduction' (fn 189) 203 summarises these as the 'concern (based on experience) that juries might too easily infer contractual agreements from equivocal evidence'. On the application of the SOF 1677, see also Cornish and Clark (fn 206) 203 in fn 33.

301 See on this Rabel (fn 288) 182-183.

302 Simpson, 'History' (fn 232) 10. The term 'speciality' arose because the rights conferred or obligations imposed under these documents deviated from the common law stipulations, thus creating special law, see ibid 12 . There were exceptions to this requirement, namely, with 'petty cases', ie, agreements regard- 
by the fourteenth century. ${ }^{303}$ While not imperative, a debt agreement was normally contained in a deed and referred to as a bond or an obligation. ${ }^{304}$ In essence, it was a declaration by the debtor that they owed a sum of money to the creditor. ${ }^{305}$ In contrast, the (non-) existence of a deed was of no consequence with actions of assumpsit: As the issue was not the contract, but the wrongful act, it was irrelevant whether the contract was in the form of a deed or not; the existence of a document would not have proven the wrongful act. ${ }^{306}$ The nature of the cases brought under this action was another argument against requiring a deed: these were often daily matters of little consequence like ferry crossings or negligent medical treatment and did not warrant a speciality to be drawn up every time. ${ }^{307}$ While written agreements were therefore used in practice, deeds were not mandatory for some claims of action.

b. Contracts in the Kingdom of Great Britain and the United Kingdom in Hanoverian and Georgian Times: The Requirement of the Intention to Create Legal Relations and the Doctrine of Offer and Acceptance $\left(18^{\text {th }} 19^{\text {th }}\right.$ Century $)$

The time between the eighteenth and the twentieth centuries was one of consolidation, both in the social-political (see Section i. below) and

ing daily matters of little consequence, see ibid 223-224. The use of seals in England will be explored further in Sections 3.b.iv. and D.III.2.b. below.

303 See Stoljar (fn 194) 5-6, who notes that action of covenant was available to formal and informal agreements, ie, whether sealed or not in the thirteenth century; the restriction to sealed agreements only arose during the fourteenth century. See also Ibbetson, 'Historical Introduction' (fn 189) 126.

304 See Baker, 'English Legal History' (fn 63) 368; see also Simpson, 'History' (fn 232) 53. It ought to be noted that the document did not have a mere evidential function; it constituted the debt. Thus, if the document was lost or became invalid, there was no debt at law. See on this Simpson, ibid 95. As a result, pleadings before the court would often focus on the existence of the deed: whether there were reasons for which the deed should not be enforced, like forgery, or duress. See Baker, ibid 369; Simpson, ibid 98-99.

305 Compare the example formula given by Baker, 'English Legal History' (fn 63) 368: 'Know all men that I, AB, am firmly bound to CD in $£$ n to be paid at...'.

306 See Baker, 'English Legal History' (fn 63) 374.

307 See ibid 376, citing Cavendish CJ from the case of Stratton v Swanlond (1374) B\&M 360, 362. The case concerned a surgeon, who had not healed but maimed a patient's hand. For other cases, see ibid 375-376; see further Cooke and Oughton (fn 244) 8; Simpson, 'History' (fn 232) 223. 


\section{B. Comparative Background}

the legal sphere (Section ii.). In particular, the foundations for a unified theoretical framework of contract law were first laid and subsequently developed to become a stable structure. ${ }^{308}$

\section{i. Political and Social Background}

The United Kingdom of Great Britain arose in 1707 with the unification of England and Scotland. Less than a century later, in 1801, Ireland was added, so that the words 'and Ireland' were appended to its name. ${ }^{309}$ It was during this time of unification that the term 'British' began to be used to globally refer to the people living in this kingdom. ${ }^{310}$ Unification of the country was not complete, however; Scotland, Ireland, and Wales retained their cultures and people from these parts often could not even speak English, all of which would translate into political turmoils. ${ }^{311}$ The uniform demomyn 'British' notwithstanding, English society remained stratified in the eighteenth century. Like in the preceding century, it had a vertical hierarchical structure in which the observance of rank and social norms was of major importance, with the top being made up of a land-owning elite class. ${ }^{312}$ In the following century, a change of perception effectively made horizontal connection links more important than vertical ones, with rivalries ensuing between them. ${ }^{313}$

The general upwards trend in industry and commerce of the seventeenth century also continued, making Great Britain a formidable economic power. ${ }^{314}$ Furthermore, trade was conducted not only within the

308 See Ibbetson, 'Historical Introduction' (fn 189) 153 and 202, where it is noted that a 'skeletal structure' of contract law had already been created in the sixteenth century. See also ibid 220.

309 See Encyclopaedia Britannica, 'United Kingdom' (fn 166) at 'Introduction'; Ibid, 'Act of Union' (Online Academic Edition 2017), http://academic.eb.com/levels/collegiate/article/Act-of-Union/74264.

310 See ibid at 'Introduction'.

311 On this, see ibid at 'The State of Britain in 1714'.

312 For further details, see Cornish and Clark (fn 206) 2-3. On the land-owners, see also Encyclopaedia Britannica, 'United Kingdom' (fn 166) at 'British Society by the mid-18th Century'.

313 See Cornish and Clark (fn 206) 2.

314 See Encyclopaedia Britannica, 'United Kingdom' (fn 166) at 'The State of Britain in 1714'. One facilitation of trade may have been the unification of Great Britain, as it created 'the largest free-trade area in Europe', see ibid at 'Britain from 1742 to 1754 '. 
country, but on a large and global scale by the beginning of the nineteenth century. ${ }^{315}$ Its prosperity was initially generated predominantly through work in agriculture, which sank to one third at the turn of the nineteenth century, while the work force in industry and commerce increased to $40 \%$ at that time. ${ }^{316}$ By virtue of the technological advances in agriculture and industry - the latter under the Industrial Revolution - labourers moved from the tertiary to the secondary labour sector, so that a shift in balance may have occurred in the mid-nineteenth century: over 50\% were employed in industry, which would increase to almost $70 \%$ by the end of the century. ${ }^{317}$ On the other hand, the almost one century long 'consumer revolution' between the beginning of the nineteenth and the twentieth centuries and the stark rise in consumption in English society led to a rise in employment in the primary sector: services. ${ }^{318}$ These were not only found in retail, whereby a move from street vending to individual shops, grocery chains, and department stores will have accounted for part of the numbers; rather, there was a diversification of services, particularly with regard to insurance and transport by railway. 319

This change in employment was not paralleled in the distribution of the nation's wealth, which was starkly skewed in favour of the upper class: $5 \%$ of the British received over $30 \%$ of the profits generated in trade and commerce. ${ }^{320}$ Nevertheless, the income of the working class rose from the mid-nineteenth century, ${ }^{321}$ which allowed consumption and leisure activities to be enjoyed by an increasing number of people, both in London and

315 See Baker and others, 'Oxford Legal History Vol XII' (fn 220) 324.

316 Compare Cornish and Clark (fn 206) 4.

317 A succinct account of the Industrial Revolution is given by Matthew White, The Industrial Revolution (British Library, 14 October 2009), www.bl.uk/georgian-britain/articles/the-industrial-revolution. The figures of employment were taken from Encyclopaedia Britannica, 'United Kingdom' (fn 166) at 'The Industrial Revolution' and Cornish and Clark (fn 206) 4 respectively. of the figures given in the tables by Geoff Timmins, Working Life and the First Modern Census (BBC History, 18 September 2014), www.bbc.co.uk/history/trail/victorian_britain/earning_a_living/working_life_census_05.shtml, also showing a rise of work in services.

318 Compare Baker and others, 'Oxford Legal History Vol XII' (fn 220) 326, 327.

319 On both of these developments, see ibid 327.

320 See Encyclopaedia Britannica, 'United Kingdom' (fn 166) at 'The State of Britain in 1714'. cf the situation in the mid-eighteenth century, in which only $14 \%$ of the wealth trickled down to the lower classes, but which made up $40 \%$ of the population. See ibid at 'British Society by the mid-18th Century'.

321 Baker and others, 'Oxford Legal History Vol XII' (fn 220) 326. 


\section{B. Comparative Background}

other towns, even drawing in people from the countryside. ${ }^{322}$ As will be seen shortly, these positive developments in commerce effected the law and that of contracts. ${ }^{323}$

\section{ii. The General Structure of Law}

The union emerging in other areas, eg, in terms of social integration, did not encompass the law, since Scotland - but not Ireland - maintained its own jurisdiction. ${ }^{324}$ Thus, the political union did not automatically turn the common law into the one binding 'British' law. ${ }^{325}$ On the contrary, there was no central court system but a series of parallel jurisdictions, where different strands of law were heard in separate, independent courts, namely: ecclesiastical courts (canon law) from the eleventh century, the Court of Admiralty (common maritime law, law merchant), the Court of Equity (equity), as well as commercial courts (law merchant). ${ }^{326}$ Nevertheless, there was only one legal regime applicable to all strata of society, with local customs acting as a diversifier. ${ }^{327}$ A unified court system would only come about some 800 years later, in the nineteenth century. ${ }^{328}$ Similarly, although case law accumulated over time, there was initially no notion of precedent, nor of stare decisis, so that case law was not a body of fixed

322 See Encyclopaedia Britannica, 'United Kingdom' (fn 166) at 'British Society by the mid-18th Century'.

323 The facts explained above were not the only reasons for contract law being developed in the nineteenth century; however, they relate most to the discussion in this dissertation. For details on the other factors, namely, family settlements (of land), commercial negotiable instruments, and investments in stock companies, see Baker and others, 'Oxford Legal History Vol XII' (fn 220) 323-325, 328.

324 See Encyclopaedia Britannica, 'United Kingdom' (fn 166) at 'History: Great Britain, 1815-1914' and 'History: 18th-century Britain, 1714-1815' (Scotland). On Ireland, see Encyclopaedia Britannica, 'Act of Union' (fn 309).

325 This had already been true in Norman times, on which see Glenn (fn 167) 246247. On the common law appearing after the Norman conquest, see ibid 252.

326 Ibid 247, 248, 269. For details on the civil courts, see Cornish and Clark (fn 206) 23-33, noting at 26-27 that the Court of Equity was 'an addendum' to the Common law.

327 See Cornish and Clark (fn 206) 3.

328 Glenn (fn 167) 253, 254; and see 270-271 for a summary of this unification process. See also Baker and others, 'Oxford Legal History Vol XII' (fn 220) 322. The common law courts already began to make inroads into the commercial jurisdiction in the eighteenth century, see Cornish and Clark (fn 206) 198-199. 
rules. ${ }^{329}$ This constituted 'formal, internal limits on the growth and reach of the common law'. ${ }^{330}$ Furthermore, as already noted above, it was only during the nineteenth century that the idea of judicial law-making and stare decisis began to emerge. ${ }^{331}$ With this congealing coherence also came the idea of a unified common law system. ${ }^{332}$ There also seems to have been an interest in the mid-nineteenth century to codify English law; however, this endeavour failed as far as the general law of contracts is concerned. Nevertheless, special legislation, such as for sale of goods and other commercial matters, was enacted. 333

In terms of the law's focus, the shift from manorialism to employment of farmers and craftsmen might have put labour law issues at the centre; it seems, however, as if this was not the case. Instead, there was more concern for protecting private property, 'the fundament of political thought' since the seventeenth century, enforcing contracts (on which see the subsequent section), ${ }^{334}$ and in regards to other issues arising in commerce. ${ }^{335}$ One example is the predecessor of the SGA 1979: the Sale of Goods Act 1893.

\section{iii. The Law of Contracts}

Already in the seventeenth century, changes were perceptible in English law that brought both the understanding of and the law on contracts closer to today's structure. The approximation was completed in the eighteenth and nineteenth centuries, both in terms of the definition (see Section aa) below), as well as the conclusion process (Section bb)). As will be seen shortly, this was due to the influence of Thomas Hobbes' theory on and definition of social contract on the one hand and works by conti-

329 See Glenn (fn 167) 250-251.

330 See ibid 247.

331 Ibid 258-259. This late development may be due to the fact that juries traditionally decided cases, rather than judges; something which only changed in that period. On this, contrast Ibbetson, 'Historical Introduction' (fn 189) 220, 233, who uses this fact to support his thesis that the courts began to define contract rules more firmly only in the nineteenth century.

332 See Glenn (fn 167) 259.

333 On this movement, see Baker and others, 'Oxford Legal History Vol XII' (fn 220) 306-398.

334 See Cornish and Clark (fn 206) 4, 3, 6 .

335 For examples, see Baker and others, 'Oxford Legal History Vol XII' (fn 220) 324325. 


\section{B. Comparative Background}

nental-European Natural lawyers, in particular Robert-Joseph Pothier, on the other; however, rather than their theoretical framework, their vocabulary was to become of importance in English contract law. ${ }^{336}$ Their ideas were picked up in the English legal textbooks on contract law that were published starting from the end of the eighteenth century. ${ }^{337}$ On the other hand, there was a practical need for the courts to see the rules of contract law defined more clearly, as the decline of the use of juries in trials meant that judges could not leave cases to be decided by them any longer and had to deal with contract issues themselves. ${ }^{338}$ Therefore, the theorisation of contract law seems to have been worked on by using both a theoretical and a practical approach. Perhaps as a consequence of the concretisation of contract theory, an additional requirement was developed: an intention to create legal relations (see Section cc) below).

\section{aa) Definition of Contract}

The shift of the notion of an agreement as bilateral rather than unilateral was made by Thomas Hobbes in the mid-seventeenth century, defining contract 'as the mutual transfer of rights'. ${ }^{339}$ This idea echoes in the English legal treaties on contract law of the eighteenth century. By way of example, in the words of Powell from 1796, a contract under the common law was understood as: '[...] an agreement between two or more concerning something to be done, whereby both parties are bound to each other, or one is bound to the other. ${ }^{340}$ A similar but simpler definition describes '[a]n agreement [a]s aggregatio mentium, viz when two or more minds are united in a thing done, or to be done. ${ }^{341}$ The notion of agreement seems to have evolved, as Powell speaks of the parties consenting to an obligation

336 See Ibbetson, 'Historical Introduction' (fn 189) 215, 218, who goes on to note at 219 that 'the terminology and ideas of the Natural lawyers [...] were freely plundered to give expression to the rules of English law' in the nineteenth century.

337 See fn 220 above. On some of the problems faced by the writers in trying to align the 'foreign' natural-law concepts with the English common law of contracts, see Ibbetson, 'Historical Introduction' (fn 189) 217, 219.

338 See fn 331 above.

339 Ibbetson, 'Historical Introduction' (fn 189) 215.

340 Powell (fn 220) vi.

341 John Comyns, A Digest of the Laws of England Vol I ( $5^{\text {th }}$ edn, Collins \& Hannay 1824) 540 at A 1 (original emphasis). 
being created or dissolved, which again seems to be in line with Hobbes' view that contracts are based on the will of the parties; but it is also very close to Pothier's theory, according to which contracts became binding for the parties on the basis of their 'mutual assent'. ${ }^{342}$ It is notable that the nineteenth century definition of a contract (not under seal) already sounds quite similar to our modern understanding:

A [...] mutual assent of two or more persons, competent to contract, founded on a sufficient and legal motive, inducement, or consideration, to perform some legal act, or omit to do any thing, the performance whereof is not enjoined by law. ${ }^{343}$

While this definition contains the essence of the modern legal notion of a contract, there are points which foreshadow changes in the canon. One relates to a missing element, namely, the reference to the mechanism leading to mutual assent: the interplay of offer and acceptance (on which see Section bb) below). Linked to this development is the appearance of what is known as the 'postal rule', a doctrine regulating the coming into effect of a declaration of intention. While the content of this rule will be considered later in Section 3.a.iii.cc), its origin will be outlined briefly below. Finally, the words 'founded upon [...] legal motive, inducement or consideration' are connected with another dogmatic change that will be explored in connection with the requirement for an intention to create legal relations.

Further changes in legal practice were also to come, in particular, standard terms and standard form contracts, eg, order forms, came into use, so that the content of contracts were no longer individually negotiated. ${ }^{344}$ As a consequence of the arising imbalance between parties, the law increasingly intervened in contracting to protect 'the vulnerable and the exploited' and legislation such as the Unfair Contract Terms Act 1977 came into existence. ${ }^{345}$

342 Compare and contrast Powell (fn 220) vi, and Ibbetson, 'Historical Introduction' (fn 189) 216 (on Hobbes) and 220 (on Pothier, whose work seems to have become available in English at the beginning of the nineteenth century).

343 Chitty (fn 220) 8.

344 For further details on this, see Atiyah, 'Introduction' (fn 33) 15-18. He notes that this standardisation meant that the contract did not represent a true agreement, ie, a bargain. Rather, as the terms were often imposed by one party, the content might, at most, represent that party's intentions.

345 See on this ibid 20-22, 25-26. It ought to be noted that this piece of legislation incorporates a traditional English approach. In contrast, The Unfair Terms in 
bb) The Conclusion of Contracts: Emergence of the Doctrine of Offer and Acceptance and the Postal Rule

In the eighteenth century, a contract was concluded through an agreement and the giving of consideration, ${ }^{346}$ because, as stated above, the doctrine of offer and acceptance was only developed in the nineteenth century. ${ }^{347}$ This rather late emergence can be simply explained by considering two aspects of contracting: what the nature of the agreement was, and the way in which contracts were normally concluded. The first aspect relates to the kind of agreement that was typically concluded. There was a move away from the immediate processes of exchange of, say, goods and money, so that a contract would often consist of promises by one or both of the parties to do something in future (executory contract). ${ }^{348}$ Furthermore, the usual way to negotiate and conclude contracts was historically 'têtề-à-têtê", ie, while in each other's presence (inter presentes). ${ }^{349}$ With the expansion of the postal service and a rise in the exchange of letters in the nineteenth century, however, the law had to provide answers to two related issues: whether an agreement had been reached in the exchange; and, if so, at what point in time. ${ }^{350}$ The former was solved by the mechanism of offer and acceptance, which became an additional requirement to consideration, ${ }^{351}$ while the latter was managed by the postal rule.

The idea that a promise on one side, which would later be termed an offer, must be accepted by the other party, developed over time; however, it seems that the time of establishment is around the beginning of the nineteenth century. An agreement was first described in terms of a propos-

Consumer Contracts Regulations 1999, SI 1999/2083 implemented a EU-Directive (see fn 396 below). See on this Law Commission and Scottish Law Commission, Unfair Terms in Contracts Summary [of Report] (Law Commission No 298; Scottish Law Commission No 199; 2005) para 3. For a brief account of the English statute's history, see ibid, Unfair Terms in Contracts: A Joint Consultation Paper (Consultation Paper 166, 2002) paras 2.10 et seq. Both documents are available online at www.lawcom.gov.uk/project/unfair-terms-in-contracts/.

346 See Ibbetson, 'Historical Introduction' (fn 189) 204.

347 See Simpson, 'History' (fn 232) 5. cf Cornish and Clark (fn 206) 204, noting that the concept of offer and acceptance already appeared in two late eighteenth century cases, discussed subsequently.

348 Compare Cornish and Clark (fn 206) 203.

349 Stoljar (fn 194) 133.

350 See ibid 133-134. See also Simpson, 'Innovation' (fn 231) 257, 258; Cornish and Clark (fn 206) 203.

351 Simpson, 'Innovation' (fn 231) 258. 
al or an offer on the one side and assent or acceptance on the other in two late eighteenth century cases: Payne $v$ Cave $e^{352}$ and Cooke $v$ Oxley ${ }^{353} .354$ The first case concerned a sale by auction, in which the defendant had been the highest bidder but had withdrawn their bid before the hammer came down. The court acknowledged that such a withdrawal was possible, since "[e]very bidding is nothing more than an offer on one side, which is not binding on either side till it is assented to', whereby the assent by the seller is made through their agent, the auctioneer, in 'knocking down the hammer, which was not done here till the defendant had retracted. ${ }^{355}$ In the second case, the defendant had 'proposed' (offered) to sell goods to the plaintiff. The latter wanted time to consider the offer and the defendant said they would sell if notice to purchase was given before a particular time on the same day. The plaintiff alleged to have accepted the proposal on time, but the defendant refused to contract. The court held the promise by the plaintiff to sell to the defendant if they accepted before the appointed time to be one-sided, as it lacked consideration on the defendant's part and was therefore a nudum pactum. ${ }^{356}$ Despite the vocabulary for the two declarations of intention varying in both cases ('offer' and 'assent', 'proposal' and 'acceptance' respectively), the underlying notion is the same, namely, of these two elements making up the contract. ${ }^{357}$ Around the same time, the idea was also first expressed in a treatise on contract law, in which reference was made to Roman law. 358

352 (1789) 3 Term Reports 148 (KB); 100 ER 502.

353 (1790) 3 Term Reports 653 (KB); 100 ER 785.

354 Compare Cornish and Clark (fn 206) 204.

355 Payne $v$ Cave (fn 352) 503.

356 Cooke v Oxley (fn 353) 786.

357 On this point, contrast Cornish and Clark (fn 206) 204 in fn 35 and Simpson, 'Innovation' (fn 231) 260, the latter of which states that the terms were used in Payne $v$ Cave (fn 352) in a descriptive rather than a legal-technical manner.

358 See Simpson, 'Innovation' (fn 231) 259. The work in question was that of Powell from 1790. The same description is found in the 1796-edition (fn 220) 334, using the terms 'promise' and 'acceptance', although Powell also speaks of 'consent' as an element of a contract, see ibid vii. It is perhaps due to this reliance by Powell on Roman law that Schmidt J (fn 25) 66, 95 has stated that the model is a legal transplant from continental-European law or legal theory. Compare on this also Simpson, ibid 260. Contrast Baker and others, 'Oxford Legal History Vol XII' (fn 220) 302, 303 who reject the argument that continental-European legal theory ('civilian ideas') were received in England; selected influential authors, such as Pothier, were cited in the nineteenth century works - apparently not used to develop ideas, but rather to explain existing English case law. 


\section{B. Comparative Background}

The case that seems to have established the doctrine was Adams $v$ Lindsell ${ }^{359}$, in which both the terms of 'offer' and 'acceptance' are used. ${ }^{360}$ The issue was whether a contract of sale of wool had come into existence by way of an exchange of letters, whereby the letter of the seller (offeror, defendant) had been misdirected, so as to reach the prospective buyer (plaintiff) later than anticipated, with the result that the reply (purported acceptance), despite having been sent promptly, reached the seller one day too late, namely, after the wool had been sold to a third party. The court found that the delay had been the defendant's fault, that the plaintiffs had reacted 'in due course of post', as had been requested by the defendants, so that the latter were liable for the plaintiff's loss. In their reasoning, the court used the words 'offer' and 'acceptance' when referring to the declarations of intention of the parties and found - using a fiction - that an offeror making an offer by letter was bound by their offer because they

must be considered in law as making, during every instant of the time their letter was travelling, the same identical offer to the plaintiffs; and then the contract is completed by the acceptance of it by the latter. ${ }^{361}$

This fiction of perpetual offers was necessary, as the legal thought of that time was that a promise could only be consideration for another promise if made at the same time as the other promise. ${ }^{362}$ This case was thus important in two respects: it applied the offer-and-acceptance model to bilateral contracts, and it established what would later become known as the postal rule: a declaration of intention of acceptance made by post becomes effective once it is sent. Having said this, both the doctrine and the rule only became settled law after application in a number of subsequent cases. $^{363}$

359 (1818) 1 Barnewall and Alderson 681, 106 ER 250 (KB).

360 See Simpson, 'Innovation' (fn 231) 260.

361 Adams v Lindsell (fn 359) 683.

362 Simpson, 'Innovation' (fn 231) 261.

363 On the latter, see Stoljar (fn 194) 134; see further Atiyah, 'Introduction' (fn 33) 71 , who states that the rule was only 'confirmed by the [CA] in 1879.' The case of Adams $v$ Lindsell (fn 359) was applied and settled in Dunlop v Higgins (1848) 1 House of Lords Cases 381, 9 ER 805 (HoL), see McKendrick (fn 48) 106. The facts somewhat resemble those of Adams. The case concerned an exchange of letters, through which a contract for the sale of iron was to be concluded; however, as the buyer's (offeree, plaintiff, and appellee) purported acceptance letter reached the seller (offeror, defendant, and appellant) at a later date than would be customary between merchants, the seller refused to transact. The court found that the plaintiff had 'done every thing [they were] bound to do' by 


\section{cc) The Further Requirement of an Intention to Create Legal Relations}

Beside the doctrine of consideration, another requirement developed in English law to distinguish binding from non-binding agreements: the intention to create legal relations. ${ }^{364}$ As the name suggests, it concerns the earnestness of a person to enter into a contract, just like consideration; however, there is a subtle difference. As its name suggests, it concerns the animus contrahendi (intention to contract) 365 and 'serves [...] to explain in terms of the consensus theory of contract the absence of contractual liability for jokes, promises of gifts, domestic and social arrangements, pre-contractual remarks which sensible people do not take seriously', and other situations. ${ }^{366}$ It is thus a distinct requirement from consideration. ${ }^{367}$

Similar to the offer-and-acceptance model, the requirement for an intention to create legal relations seems to have been first advanced in English legal literature beginning in $1818,{ }^{368}$ and was only taken up by the courts some 75 years later, albeit indirectly at first. Thus, in the case of Carlill $v$ Carbolic Smoke Ball $\mathrm{Co}^{369}$, the CA decided whether a newspaper advertisement for a product was meant to be a contractual offer, or whether it was a 'mere puff which meant nothing' by looking at the offeror's

posting their letter of acceptance 'on the correct day' (ie, within the time frame that was usual between merchants for responses) and that 'whether that letter be delivered, or not, is a matter quite immaterial', since they were not liable for any delays of the postal service. The case of Adams was cited as authority on the point that an acceptance becomes effective upon being sent. See Dunlop, ibid, 805-806, 812-813 (Lord Chancellor).

364 It has been suggested that this requirement arose because consideration did not fulfil the function of making such a distinction, see Simpson, 'Innovation' (fn 231) 263. See also Cornish and Clark (fn 206) 208, stating that the policy objectives of consideration and the doctrine of an intention to create legal relations were different. According to Schmidt J (fn 25) 66, this requirement was a legal transplant from continental Europe. cf Baker and others, 'Oxford Legal History Vol XII' (fn 220) 302, 303, generally rejecting such a reception.

365 Translation by this author, with reference to the entry for 'animus' in Oxford Dictionary of Law ( $\mathrm{fn}$ 62) 26. The term is used by, eg, Simpson, 'Innovation' (fn 231) 265.

366 Simpson, 'Innovation' (fn 231) 265. Emphasis added.

367 See Treitel/Peel (fn 65) para 4-001.

368 For a list of the authors and works which successively introduced the notion, see Schmidt J (fn 25) 96-97.

369 [1893] 1 QB 256 (CA). Further details of this case can be found in McKendrick (fn 48) 57-60. 


\section{B. Comparative Background}

intention (sincerity) and came to the conclusion that it was the former. ${ }^{370}$ The term was subsequently used in other contexts, such as in relation to the establishment of a collateral contract, which is used for 'vary[ing] or $\operatorname{add}[\mathrm{ing}]$ to the terms of the principal contract', ${ }^{371}$ or with respect to family relationships. ${ }^{372}$ The requirement is analysed in detail in Section 3.a.iv. below.

\section{c. The Subsequent Development of English Contract Law in Windsor Times (20 th $C e n t u r y-)$}

The twentieth century saw many changes in England: politically, socially, and economically. Naturally, this caused English law to be amended. As the changes are too numerous to elaborate in this work, only a sketch of the country's historical development will be given below in Section i. Similarly, only a couple of legal developments of interest will be highlighted in Section ii.

\section{i. Overview of Political and Social Developments}

The two World Wars and the period of intermission saw fluctuations in the UK's population and its economy. Both only grew again from the 1980s, whereby the population rose by a total of 4 million people until

370 See Carlill (fn 369) 261-262, 263 (Lindley LJ), 266, 268 (Bowen LJ), 273 (Smith LJ). The case will be discussed in further detail in Section 3.a.ii.bb) below. Compare Simpson, 'Innovation' (fn 231) 265, speaking of the 'animus contrabendi featur[ing] with reasonable prominence in Carlill [...]'. Similar: McKendrick (fn 48) 272.

371 Heilbut, Symons \& Co v Buckleton [1913] AC 30 (HoL), 47 (Moulton L). In the event, '[i]t was held that nothing said by the defendants' manager was intended to have contractual effect', see Treitel/Peel (fn 65) para 4-007. In particular, it was said that the reply of the defendants' manager to a question by the plaintiff was 'a mere statement of fact [...] and nothing more', see Heilbut (ibid) 48 (Moulton L). According to Simpson, 'Innovation' (fn 231) 265, the case 'canonises' the requirement of an intention to be legally bound. cf McKendrick (fn 48) 272 , according to whom the requirement became settled law after the ruling in Balfour v Balfour [1919] 2 KB 571 (CA). The case is discussed in detail in Section 3.a.iv. below.

372 Balfour v Balfour (fn 371). 
the end of the twentieth century. ${ }^{373}$ That period also meant the end of the British empire; it crumbled, with only parts remaining, when several countries, particularly India and Pakistan, became independent during WWII. ${ }^{374}$ Political structures also changed in the UK: Scotland and Wales gained devolved political power over their lands in 1997.375 While the UK was one of the world's 'three superpowers' among the US and Russia after WWII, the continuously struggling economy meant the subsequent loss of that status. ${ }^{376}$

There has been a steady immigration of people from the New Commonwealth countries, including India, Pakistan, and the West Indies since the 1950s. ${ }^{377}$ This has diversified the ethnicity and culture of an otherwise ageing British population. ${ }^{378}$ In terms of labour, formerly strong sectors like textile production and coal mining declined to only $5 \%$ of the workforce in 1961, and manufacture shifted to consumer goods, including automobiles. ${ }^{379}$ These transitions created divisions within the country - both geographically and economically; and has thus transformed British society. ${ }^{380}$ From the former working class emerged a class of 'middle England' that enjoyed better income and lifestyle; nevertheless, the divide among these people and the affluent grew, creating a new class of the 'new poor'. ${ }^{381}$ The continued struggling economy and labour market drove politics and even affected the law (see below).

373 See Encyclopaedia Britannica, 'United Kingdom' (fn 166) at 'Economy' and 'Population Growth'. See also ibid at 'Economy and Society'.

374 See Jeremy Black, Overview: Britain from 1945 Onwards (BBC History, 3 March 2011), www.bbc.co.uk/history/british/modern/ overview_1945_present_01.shtml. For further details on the fall of the empire, see John Darwin, Britain, the Commonwealth and the End of Empire (BCC History, 2011), www.bbc.co.uk/history/british/modern/endofempire_overview_01.shtml.

375 Black (fn 374).

376 On this, see Dennis Kavanagh, Thatcherism and the End of the PostWar Consensus (BBC History, 2011), www.bbc.co.uk/history/british/modern/ thatcherism_01.shtml.

377 Compare Encyclopaedia Britannica, 'United Kingdom' (fn 166) at 'Migration Patterns'.

378 Black (fn 374); compare also Encyclopaedia Britannica, 'United Kingdom' (fn 166) at 'Population Growth', and at 'Cultural Life'.

379 Encyclopaedia Britannica, 'United Kingdom' (fn 166) at 'Economy and Society'.

380 See ibid.

381 Ibid. 


\section{B. Comparative Background}

\section{ii. Overview of (Contractual) Legal Developments}

A range of legal changes were made in relation to the events just described above. An example is the successive amendment of labour law to curb strikes in the 1970s and 1980s due to the struggle between Margaret Thatcher's government and British trade unions. ${ }^{382}$ On a more social note, the rise of consumerism was aided by changes to the trading hours of shops, which were now allowed to open for twenty-four hours and on Sundays. ${ }^{383}$

One legal development that is of interest to the subsequent discussion is a change in land law. The transformation began in the nineteenth century with amendments to the statutory law on conveyances, the transfer of land. At that time, sales of land typically progressed in a two-step process: First, what was known as an 'open' contract between the buyer and seller containing basic terms like the object (property) and price, and terms (special conditions) reducing the seller's obligations with respect to the next step. ${ }^{384}$ This contract would often be concluded through an exchange of letters; however, the courts would look for an offer and acceptance in order to find that an open contract had been concluded. ${ }^{385}$ The second step was the actual conveyance of the land, which involved an often complex investigation of title and was therefore undertaken by professionals. ${ }^{386}$ Apart from the conveyance, solicitors were also involved with the sale contract; however, it seems that this was not true before 1820 , but that they took on an increasing role only thereafter. ${ }^{387}$

While this legal practice remained almost the same until the beginning of the twentieth century, the common law changed in this period. ${ }^{388}$ The transformation of the legal framework was achieved through a series of successive pieces of legislation that would eventually lead to the enactment of the LPA 1925. The overall aim of these legislations was to make the conveyancing process easier, in particular, to lower the labour and risks of title investigation. Therefore, a registration system for titles to land was introduced in the Transfer of Land Act 1862; however, this modernisation

382 For further details, see ibid.

383 Compare Black (fn 374).

384 Stuart Anderson, Part One: Property, in: Cornish and others (fn 220) 1, 94, 102, 95, 97.

385 See ibid 97, 109.

386 See ibid 94, 95, 97.

387 See ibid 95, 97. Compare also ibid 107.

388 Compare ibid 108-109. 
would not bear substantial fruits for some time, due to resistance from several sides, in particular the professionals involved. ${ }^{389}$ Another important legislation in relation to conveyancing of land that was enacted in the twentieth century was the LPMPA 1989. While the content of this statute and of the LPA 1925 will be examined in the subsequent section, it may be noted at this point that the changes affected some of the English form requirements, namely, deeds and the practice of sealing. ${ }^{390}$ While the basic contract rules had been settled, new regimes have been created around contracts. Consumer contracts are one important field that has developed since the 1960 s, ${ }^{391}$ labour law is another. ${ }^{392}$

\section{Contracts in Current English Law and Legal Practice}

After the gradual yet laborious historical development of the modern concept of contract, the common law viewed a contract as an exchange of promises that it ought to protect if particular requirements were met. These prerequisites are the existence of the declarations of offer and acceptance, both of which are made with the intention of creating a binding legal relationship, whereby the exchange of promises is either in the form of a deed, or supported by consideration. ${ }^{393}$ There may be further formalities, which also have to be taken into account at contracting. Each of these requirements will be explored in depth in Sections a. (Basic Principles), b. (Formalities), and c. (Other Requirements), before attention is given to aspects of current legal practice in Section d. below.

389 For details of this development, see ibid 196-230.

390 See Sections 3.b.iii. and iv. below.

391 Some prior attempts in single cases of consumer protection notwithstanding, the foundation of consumer law lay in the enactment of the Restrictive Trade Practices Act 1956 on the one side and in the establishment of the Molony Committee on Consumer Protection in 1959 on the other, as the committee's report from 1962 would inspire several legislative measures in the following years. For details on the Committee and its influence, see Iain Ramsay, Consumer Law and Policy: Text and Materials on Regulating Consumer Markets ( $3^{\text {rd }}$ edn, Hart Publishing 2012) 2-4.

392 While this deviation includes aspects of the contract conclusion process, these particularities will not be discussed in this dissertation. Interested readers are referred to, eg, John C Wood (founder) and Ian T Smith and Gareth Thomas, Smith \& Wood's Employment Law (9 ${ }^{\text {th }}$ edn, OUP 2008).

393 See Simpson, 'Innovation' (fn 231) 257. See also the discussion of the definition of contract in Section 1. above. 


\section{B. Comparative Background}

It should be noted that the common law rules apply to all kinds of contracts; however, many regimes have been regulated separately through statute, like consumer law. Deviations under consumer law will be highlighted during the discussion of the basic rules. Another aspect to keep in mind is that the majority of statutory provisions are dispositive, ${ }^{394}$ with most exceptions found in relation to consumers and formalities. In the following, the definition that will be adopted for the term 'consumer' under English law will be that of a natural person acting (almost entirely) for private - as opposed to trade or professional - purposes. ${ }^{395}$ A consumer's counterpart in B2C transactions, a trader, will be understood as 'a person acting for purposes relating to that person's trade, business, craft or profession' (s 2 subs 2 Consumer Rights Act 2015, 'CRA 2015'). In this respect, two points require brief comment.

First, regarding the nature of the term 'person', as this notion is different for consumers and traders. For the former, the CJEU (then still known as ECJ) rejected the notion that a legal person can be treated as a consumer in relation to Council Directive 93/13/EEC of 5 April 1993 on Unfair Terms in Consumer Contracts ${ }^{396} .397$ While this Directive allows the EU Member States freedom in transposing the rules, the UK adopted the same definition of a consumer as the one contained in the Directive; the UK therefore chose to limit the term to 'natural persons'. ${ }^{398}$ It did so both in this and in other consumer legislation, including the CRA 2015, 399 so that in general, only natural persons count as consumers, whereas 'small

394 This is true, for example, for most implied terms. Compare Treitel/Peel (fn 65) paras 1-003 and 6-067.

395 Compare the definitions found in r 3(1) Consumer Distance Selling Regulation, in s 2 subs 3 CRA 2015, and in r 2(1) E-Commerce Regulations.

396 [1993] OJ L95/29. Note that the Directive was repealed by Council Directive 2011/83/EU of 25 October 2011 on Consumer Rights [2011] OJ L304/64. This did not affect the definition.

397 This was laid down in ECJ Case C-541/99 Cape v Ideal Service [2001] ECR I-9049. For an extract of the judgement and commentary, see Jules Stuyck, Setting the Scene, in: Hans-Wolfgang Micklitz and Jules Stuyck and Evelyne Terryn (gen eds), Cases, Materials and Text on Consumer Law (Hart Publishing 2010) 29-31.

398 Compare the wordings of art 2 para b of the Directive and of r 3(1) The Unfair Terms in Consumer Contracts Regulations 1999, SI 1999/2083.

399 See fn 395 above. On the CRA 2015 and 'consumer', see also Treitel/Peel (fn 65; $14^{\text {th }}$ edn 2015) para 23-007. 
businesses or legally incorporated organisations' do not. ${ }^{400}$ In contrast, a trader can be both a natural or a legal person, such as a company. 401

Secondly, in terms of the nature of the person's activities, the ECJ held in another case from 2004 that a mixed purpose contract, ie, one made for both private and business reasons, does not fall into the scope of consumer protection, unless the business purpose is negligible. ${ }^{402}$ An example might be a person buying an article for their home, but which is used for work one day a week. ${ }^{403}$ The reason given by the ECJ was that consumer protection is not warranted in such situations, as the business entity 'must be deemed to be on an equal footing with the other part to the contract', ${ }^{404}$ in terms of the comprehension of the 'professional risk' involved in contracting. ${ }^{405}$ Whether this justification also applies in relation to other EU legislation remains open. ${ }^{406}$ In relation to the CRA 2015, it has been stated that a trader could usually rely on the Sale of Goods Act 1979 ('SGA $1979^{\prime}$ ), so that they would not be without protection. ${ }^{407}$

\section{a. The Current Legal Background}

\section{i. Basic Principles: Agreement Through Offer and Acceptance}

What Treitel refers to as an 'agreement' is essentially the outcome of an offer being accepted by the other party (see Sections ii. and iii. below

400 See CRA 2015 Explanatory Notes (fn 78) para 36.

401 See ibid para 35.

402 ECJ Case C-464/01 Gruber v Bay Wa AG [2005] ECR I-439, paras 39-45. The issue in this case surrounded the application of a jurisdiction rule contained in what was then the Brussels Convention (today Council Regulation (EC) No 44/2001 of 22 December 2000 on Jurisdiction and the Recognition and Enforcement of Judgments in Civil and Commercial Matters [2001] OJ L 12/1, the Brussels I Regulation, as recast in Regulation (EU) No 1215/2012 of the European Parliament and of the Council of 12 December 2012 on Jurisdiction and the Recognition and Enforcement of Judgments in Civil and Commercial Matters OJ L [2012] 351/1). For an extract of the judgement and commentary, see Stuyck (fn 397) 50-54.

403 Adapted example given in CRA 2015 Explanatory Notes (fn 78) para 36.

404 Gruberv Bay Wa AG (fn 402) para 40.

405 Stuyck (fn 397) 53.

406 Ibid.

407 Compare CRA 2015 Explanatory Notes (fn 78) para 36. 


\section{B. Comparative Background}

respectively). 408 Once this has occurred, consensus is said to have been reached, ${ }^{409}$ and the contract comes into existence. ${ }^{410}$ This process poses no problems where the contract is concluded with all of the parties being (physically) present; complications may arise where, in contrast, the parties are at a distance. ${ }^{411}$

The analysis in terms of offer and acceptance may likewise be problematic in particular cases. Multilateral contracts provide one example in which several agreements on the same subject are formed in parallel, between one 'offeror' and several 'offerees', such as in a competition. ${ }^{412}$ Another difficult case concerns contracts that have arisen from - usually lengthy - negotiations, during which 'offer' and 'acceptance' cannot always be clearly identified. ${ }^{413}$ Despite these difficulties and existing criti-

408 See Treitel/Peel (fn 65) para 2-001. This 'conventional approach' of analysing a contract in terms of offer and acceptance has been criticised for the difficulties it presents with some types of agreements, see McKendrick (fn 48) 46. Although this problem has been acknowledged by the courts and in academic writing, the approach is adhered to for reasons of legal certainty, even if some cases do not fit the model (easily) and thus may lead to the analysis seeming very artificial, see McKendrick, ibid 47-49 and Treitel/Peel, ibid para 2-076.

409 Whincup (fn 34) 47 para 2.1. Another term used is 'consensus ad idem', see Halsbury's Laws Vol 9 (fn 33) para 206.

410 See, eg, Simpson, 'Innovation' (fn 231) 257.

411 The term 'distance' is used in this sense by Consumer Distance Selling Regulations, see the definition given for the term 'means of distance communication' in $\mathrm{r} 3(1)$ as '[...] any means which, without the simultaneous physical presence of the supplier and the consumer, may be used for the conclusion of a contract between those parties' (emphasis added), as well as the explanation contained in the second paragraph of the Explanatory Note.

412 Treitel/Peel (fn 65) para 2-077.

413 An excellent example is the case of Golden Ocean Group Ltd $v$ Salgaocar Mining Industries Pvt Ltd [2012] EWCA Civ 265, [2012] 1 WLR 3674, in which a sequence of e-mails between the parties regularly containing the phrase 'agreed', but then going on to suggest some modification of an aspect of the contract being negotiated was held to be an agreement in writing of a contract of guarantee, see [22] (Tomlinson LJ). The case will be discussed further in Section b. below. More complicated situations may exist in business, eg, where a contract has apparently arisen 'partly by reason of written exchanges, partly by oral discussions and partly by performance of the transactions', see Percy Trentham Ltd v Archital Luxfer Ltd (1993) WL 963649 (official transcript, CA), in which Steyn LJ found a contract to have arisen by these means. On the general analysis of written contracts in terms of offer and acceptance, see Halsbury's Laws Vol 9 (fn 33) para 283. Apart from contractual negotiations, see the example of two parties eating at a restaurant without 'agreeing' on who will pay, given by McKendrick (fn 48) 50-51. 
cism, ${ }^{414}$ the offer-and-acceptance model continues to be used as the basic standard. It seems that where the parties have signed a written contract, the need for identifying offer and acceptance will generally not arise; ${ }^{415}$ only where a dispute arises in relation to the terms agreed will this aspect be usually looked into. ${ }^{416}$

An agreement is seen as a binding contract when the parties make the agreement with the intention to create a legal relationship (see Section iv. below), and either give consideration for the promise (Section v.) or fix the agreement in the form of a deed (Section b.iii.). In contrast, other requirements as to form (Sections b.ii., b.iv.-b.v., c.) are more of an exception rather than the general rule, so that oral contracts, especially in commercial situations, are often sufficient. ${ }^{417}$ In this way, English law implicitly recognises the freedom of form, albeit not universally. The substance of these requirements will now be examined more closely.

Before doing so, it should be noted that the English courts evaluate these requirements using an objective approach, so that the question is not what the parties themselves, but what a reasonable person in the position of the parties intended. ${ }^{418}$ This test is used to provide legal certainty and enhance 'commercial convenience':419 it is easier to predict how a neutral person in a similar position, rather than one or the other of the parties, would interpret a situation. Therefore, what is of importance is

414 See the judicial discussion outlined and the alternatives suggested by McKendrick (fn 48) 47-49.

415 This can be deduced from the opinion of the court in Blue $v$ Ashley (fn 174) [50] (Leggatt J), in which a written agreement and the process of offer and acceptance were given as alternative ways of reaching an agreement.

416 This becomes apparent when examining the case law concerning the formation process, as discussed in the subsequent sections.

417 See, eg, Griffith and Harrison (fn 26) 637.

418 More accurately, the court begins from an objective perspective of a reasonable person in the position of the promisee (wanting the promise to be enforced), but it also examines the perspective of a reasonable person in the position of the promisor (wanting the promise not to be enforced), see McKendrick (fn 48) 27. This can be problematic where the parties' conduct cannot be interpreted externally, see the example mentioned in fn 413 above. This approach is different from German legal theory, which applies a subjective standard (see Section B.III.3.a.i.cc) below).

419 See Treitel/Peel (fn 65) para 1-002, who refers to this as the 'objective principle' but admits a certain subjective qualification where, eg, a party knows the facts to be different from their intention. 


\section{B. Comparative Background}

not the (internal) intention of a party, but the party's actions. ${ }^{420}$ There is another important reason for using this test, however: If the courts were to set out to discern the actual intention of the parties, this might lead them, quite often, to hold 'that the parties were not ad idem', ie, that the minds of the parties do not meet, so that there is no agreement. Thus, for practical reasons, the parties' 'actual intentions are happily irrelevant'. ${ }^{421} \mathrm{~A}$ similar statement had been made in an earlier case ${ }^{422}$ and has since been restated by the English courts, even recently. ${ }^{423}$ This objective standard will resurface in relation to various issues, as will be seen in the subsequent discussion.

420 This was noted by the CA in the case of Storer $v$ Manchester City Council [1974] 1 WLR 1403, 1408 (Denning LMR). The issue was whether a sale of land had been concluded without an exchange of contract documents, since the contract form contained a 'subject to contract' clause (this will be discussed in Section b. below). The court held that a contract had been formed, although the form had only been signed by the buyer (plaintiff) and not by the seller (defendant, a town clerk), since the defendant had already expressed their willingness to contract in a signed letter and the use of the form by the defendant was aimed at dispensing with formalities. See ibid 1407-1408 (Denning LMR), 1409 (Stephenson LJ), 1410 (Lawton LJ).

421 Summit Invest Incorporated v British Steel Corporation [1987] 1 Lloyd's Report 230 (CA), 1987 WL 492632 (official transcript; Donaldson MR). The case concerned the interpretation of the words 'or for grates and stoves' contained in a clause varying the allocation of payment of fuel costs (generally borne by the charterers) in a form of the New York Produce Exchange used for time charters of ships. The chartered ship in question was not equipped with either grates, nor stoves, and the point at issue was how the cost of fuel (oil) was to be shared between the owner and the charterers of the ship in question. By adopting the approach of placing themselves in the same factual matrix as that in which the parties were', the Court found that the variation clause was intended to make the owners liable for 'all fuel used for crew domestic purposes' (official transcript; Donaldson MR, Lloyd LJ, Nicholls LJ).

422 Smith v Hughes (1870-71) LR 6 QB 597, 607 (Blackburn J): 'If, whatever a man's real intention may be, he so conducts himself that a reasonable man would believe that he was assenting to the terms proposed by the other party, and that other party upon that belief enters into the contract with him, the man thus conducting himself would be equally bound as if he had intended to agree to the other party's terms.' The case concerned a sale of oats by sample and also concerned the issue of mistake, which will not be discussed in this dissertation. The facts and extracts from the case can be found in McKendrick (fn 48) 22-25.

423 See, eg, Steyn LJ in Percy Ltd v Archital Ltd (fn 413), or RTS Flexible Systems Ltd v Molkerei Alois Müller GmbH \& Co KG (UK Production) [2010] UKSC 14, [2010] 1 WLR 753, 771 (Clarke LJSC). 


\section{ii. Offer}

The first element found in the basic model of a contract is the declaration of intention termed 'offer'. Its definition (see Section aa) below) and differentiation from other statements (Section bb)), as well as its requirements (Sections cc)-dd)) and its effectiveness (Sections ee)-ff)) will be considered subsequently.

\section{aa) 'Offer' Defined}

As with the general concept of a contract, there is no universal, explicit definition of an offer ${ }^{424}$ — nor of acceptance - in English law. In a recent case, it was held to be 'an expression, by words or conduct, of a willingness to be bound by specified terms as soon as there is acceptance by the person to whom the offer is made'. ${ }^{425}$ In academic writing, the term is normally defined as consisting of a statement which expresses both a willingness to enter into a contract with the other party, and which also sets out what each party will undertake to do (or not do), ie, what the terms of the contract are to be. ${ }^{426}$ Having said this, the offer need not state all the terms of the contract, as the English courts have the general power to imply reasonable terms that are missing from the agreement; furthermore,

424 It ought to be noted that legislation may not always refer to an offer using that word; it may also be termed, eg, 'order' (reg 12 E-Commerce Regulations).

425 Blue $v$ Ashley (fn 174) [52] (Leggatt J). On the aspect of an intention to be bound 'as soon as [the offer] is accepted by the person to whom it is addressed', see Sergio Cámara Lapuente and Evelyne Terryn, Consumer Contract Law, in: Micklitz and Stuyck and Terryn (fn 397) 172; Treitel/Peel (fn 65) para 2-002. See also Storer $v$ Manchester CC (fn 420) 1409 (Stephenson LJ), 1410 (Lawton LJ). The principle was restated more recently in, eg, Air Transworld Ltd v Bombardier Inc [2012] EWHC 243 (Comm), [2012] 1 CLC 145 (QB), 175 at [75] (Cooke $\mathrm{J})$. This case concerned the sale of an aircraft, in relation to which the issue arose whether the contract was international within the meaning of $s 26$ Unfair Contract Terms Act 1977 and whether the claimant had acted as a consumer for the purposes of $s 12$ of the Act. This would have meant that certain limitations of responsibility of liability would be prohibited. Note that the Act no longer applies to B2C cases by virtue of the CRA 2015, see fn 78 above.

426 See McKendrick (fn 48) 44, 45; Treitel/Peel (fn 65) para 2-002; Atiyah, 'Introduction' (fn 33) 56. 


\section{B. Comparative Background}

legislation may also provide for implied terms. ${ }^{427}$ At the same time, the agreement must fulfil the requirement of being certain, ie, of not being too vague or incomplete. ${ }^{428}$

The offer can be in the form of an oral statement, or that of written messages like letters, fax, or e-mail. ${ }^{429}$ The statement does not necessarily have to be made expressly, but can be implied from the conduct of the party, ${ }^{430}$ as long as a reasonable person would interpret that party's behaviour as a willingness to be bound. ${ }^{431}$ In contrast, inactivity will usually not count as an offer by way of conduct, unless other circumstances in the case (other actions of the party) point to the objective conclusion that the inactivity was an offer. ${ }^{432}$ An offer can be directed at one or several specified persons, or be addressed to the public in general ('the world at large'). ${ }^{433}$ In case of the latter, the issue may arise whether the statement amounts to an offer or whether it is a mere invitation to treat.

\section{bb) Offers and Invitations to Treat}

Not every statement or conduct amounts to an offer. English law generally differs between offers and what are known as 'invitations to treat', statements which do not possess an intention by the party making the statement to be legally bound. ${ }^{434}$ Instead, the intention is to bargain, ${ }^{435}$ to open negotiations, ${ }^{436}$ and, as its name suggests, to have the other side make an offer. ${ }^{437}$ The distinction between offers and invitations to treat is often difficult in practice, but is an important one, as an offer will lead

427 On implied terms, see Treitel/Peel (fn 65) paras 6-050 et seq. Examples of statutorily implied terms include ss 10-14 SGA 1979, as well as ss 9-11 and 13-14 CRA 2015.

428 See on this generally McKendrick (fn 48) 125-145. More details on certainty will be given in Section cc) below.

429 Richard Stone, The Modern Law of Contract (11 ${ }^{\text {th }}$ edn, Routledge 2015$) 37$.

430 Atiyah, 'Introduction' (fn 33) 56; Treitel/Peel (fn 65) paras 2-004, 2-002.

431 Treitel/Peel (fn 65) para 2-002.

432 Ibid para 2-005.

433 Andrews (fn 70) 39.

434 McKendrick (fn 48) 54; Treitel/Peel (fn 65) para 2-006. There may be other situations in which there is no intention to be legally bound, as discussed in Section iv. below.

435 Whincup (fn 34) 47 para 2.2.

436 Stone (fn 429) 38.

437 See Treitel/Peel (fn 65) para 2-006. 
to a contract being formed once it is accepted. In contrast, in the case of invitations to treat, the formation process has not yet begun, so that an extra step is necessary here to begin the process.

A series of legal presumptions ${ }^{438}$ exist to distinguish invitations to treat from offers, but it is often ultimately the objective intention of the party, not these rules nor the wording of the statement that identifies it as being the former or the latter. ${ }^{439}$ According to one legal presumption, advertisements, ${ }^{440}$ and similar materials like catalogues or brochures constitute invitations to treat. ${ }^{441}$ Similarly, tenders to bid for the supply of goods

438 Both Treitel and McKendrick use the term 'prima facie rule of law'. See Treitel/Peel (fn 65) para 2-007. McKendrick (fn 48) 54 states the reason for the use of such presumptions to be 'certainty in commercial transactions'.

439 See Treitel/Peel (fn 65) paras 2-006-2-007; also see Whincup (fn 34) 48-49 para 2.4.

440 This certainly includes 'offline' advertisements in newspapers or on television, see Stone (fn 429) 43. It might also apply to 'online' advertisements, see ibid 70-72, who interprets the wording of the E-Commerce Regulations to mean that it is the purchaser, not the seller, who makes an offer on a website. Similar: McKendrick (fn 48) 69, who thinks it likely that online advertisements would be treated like other advertisements, ie, as an invitation to treat. McKendirck cites a Singaporean case (which is only of persuasive authority in England, see Section I.2.a.iii. above), Chwee Kin Keing v Digilandmall.com Pte Ltd [2004] SGHC 71 (Singaporean High Court), in which such an analogy is made. The facts and extracts from the case can be found in McKendrick, ibid, 34, 69-70, 112-113. Also see Whincup (fn 34) 48 para 2.2, who gives a similar opinion regarding prices displayed online, and goes on to say at para 2.3 that there is no fixed rule on contracts made online. cf Andrew D Murray, Entering into Contracts Electronically: The Real W.W.W., in: Lilian Edwards and Charlotte Waelde (eds), Law \& the Internet: A Framework for Electronic Commerce ( $2^{\text {nd }}$ edn, Hart Publishing 2000) 22, stating that online advertisements are 'clear[ly ...] invitation $[s]$ to treat unless [they] clearly indicate[... that] the webvertiser intends to be bound upon acceptance. cf again Michael Furmston and Greg J Tolhurst, Contract Formation: Law and Practice ( $2^{\text {nd }}$ edn, OUP 2016) 158-159 para 6.13, who have a stronger opinion with regards to differentiating between statements on websites, arguing that some cases are more akin to advertisements, while others are better treated akin to vending machines. Online transactions are considered in detail in Section D.IV. below.

441 Atiyah, 'Introduction' (fn 33) 57. A case example is Patridge $v$ Crittenden [1968] 1 WLR 1204 (QB) in which it was held that an advertisement in a magazine simply stating 'Quality British [birds...] 25s each' amounted to an invitation to treat, not to an offer. Interestingly, Ashworth J noted at 1207 that '[i]n no place $[\ldots]$ is there any direct use of the words "Offers for sale." I ought to say I am not for my part deciding that that would have the result of making this judgment any different $[\ldots]$ '. This suggests that even if the words had been used, the result 


\section{B. Comparative Background}

or the provision of services are generally treated as invitations to treat; however, where the advertisement contains a phrase to the effect that the invitor will be bound by the highest or lowest bid, as the case may be, this declaration is, in effect, treated as an offer. ${ }^{442}$ Although this presumption is rebuttable by evidence to the contrary, ${ }^{443}$ it operates without taking into consideration the subjective intention of the maker of the statement. ${ }^{444}$

Unlike the foregoing examples, vending machines are not invitations to treat, but generally constitute offers. ${ }^{445}$ Seeing as the transaction is executed immediately by the user obtaining the product in question after having paid the appropriate amount, the only considerations against this classification are the possible dysfunction of the machine and the desired item being out of stock. Both the functionality of the machine and the availability of the item in question are therefore presupposed. ${ }^{446}$

An exception to this presumptive rule consists of cases of 'unilateral contracts', eg, when a reward is promised for returning a lost article: the advertisement is then treated as an offer instead. 447 The reason is that bargaining in such situations is not expected; the other party will simply act upon the advertisement, so that the statement maker's intention to be legally bound is assumed. ${ }^{448}$ The leading case on this is Carlill $v$ Carbolic Smoke Ball $\mathrm{Co}^{449}$, in which the defendant advertised for its product, a 'smoke ball', which purportedly prevented the user from catching influenza or a cold if used according to the instructions, by promising $£ 100$ (approx. $€ 12,000$

would still have been that the advertisement constituted an invitation to treat only.

442 For further details, see Treitel/Peel (fn 65) para 2-013.

443 McKendrick (fn 48) 54.

444 Treitel/Peel (fn 65) para 2-007.

445 See Thornton $v$ Shoe Lane Parking Ltd [1971] 2 QB 163 (CA), 169 (Lord Denning MR, obiter), in which it was held that an automatic ticket machine constitutes an offer if 'the proprietor of the machine holds it out as being ready to receive the money'. Acceptance was made by the user in inserting money, see ibid. The case concerned a claim for damages due to an accident having occurred in a car park operated by the defendants. The CA dismissed the appeal and rejected the defendant's claim that an exemption clause freed them from liability for the damage suffered by the plaintiff because the conditions containing the clause had not been incorporated into the contract.

446 Compare Schmidt J (fn 25) 222.

447 Treitel/Peel (fn 65) para 2-010.

448 See ibid.

449 See fn 369 above. 
today $)^{450}$ to 'any person' who contracted one of the illnesses the product was said to prevent. The plaintiff claimed the reward for having caught influenza despite having used the product as prescribed. The CA found that the advertisement was not an invitation to negotiate, nor a 'mere puff [... but] an offer which was to be acted upon', 451 since the defendants had deposited a sum of $£ 1,000$ (approx. $€ 130,000$ today) 452 in a bank account, 'shewing [their] sincerity in the matter'. ${ }^{453}$

Invitations to treat also include the transmission of information, ${ }^{454}$ or the display of goods in shelves or shop windows with prices. ${ }^{455}$ An example of the former situation is the case of Harvey $v$ Facey, ${ }^{456}$ in which a telegraph by the defendant in response to an enquiry of sale by the plaintiff, stating the lowest price at which the defendant would be prepared to sell the good in question, was not held to be an offer but a simple statement of information. ${ }^{457}$ Consequently, the statement of a price alone does not make an offer, so that it is up to the buyer to make an offer to buy at the

450 The worth of $£ 100$ in 1893 would be over $£ 10,000$ today, see, eg, www.measuringworth.com/calculators/ppoweruk/.

451 Carlill (fn 369) 268 (Bowen LJ). Advertisements that constitute 'mere puffs' or 'sales talk' do not entail legal consequences for being too vague or not containing a serious intention to contract, as the language is filled with superlatives or other promises and because no action on part of the addressees is being demanded, see Whincup (fn 34) 20-21 paras 1.7 -1.9. See also Treitel/Peel (fn 65) para 4-006, who states that 'puffs' may be an opinion only. This suggests that a statement will not be binding if it is not one of fact.

452 The worth of $£ 1000$ in 1893 would be approx. $£ 110,000$ and more today, see fn 450 above.

453 Carlill (fn 369) 268 (Bowen LJ). The words cited are those of the defendants' advertisement, see ibid 257. A similar case was Lefkowitz $v$ Great Minneapolis Surplus Stores (1957) 86 North Western Reporter, 2nd Series 689, in which the Supreme Court of Minnesota found a newspaper advertisement for fur coats at a bargain price to constitute an offer by the defendant, as it was 'clear, definite, and explicit, and left nothing open for negotiation.' This had been accepted by the claimant in fulfilling the 'first come first served' condition written in the advertisement. The court held further that the defendant could not change the offer after it had been accepted, while it affirmed a general right of the offeror to alter the offer before acceptance is made.

454 Treitel/Peel (fn 65) para 2-006.

455 Ibid para 2-009. Slightly critical on maintaining this traditional interpretation: Stone (fn 429) 41-42.

456 [1893] AC 552 (Privy Council).

457 For details on the exchange of correspondence, see McKendrick (fn 48) 55. 


\section{B. Comparative Background}

stated price. ${ }^{458} \mathrm{With}$ regard to products displayed on shelves in self-service shops, the court in the leading case, Pharmaceutical Society of Great Britain $v$ Boots Cash Chemists (Southern) Ltd ${ }^{459}$, held that the contract between the customer and the shop did not come into being until the customer indicated the goods that they wished to purchase (thus making an offer) and the shop, through one of the shop assistants, accepted this (at the cashier). Under this general construction, the contract will not automatically arise when the customer picks up an item; indeed, the shop assistant has control over the process and may decide to reject the customer's offer. ${ }^{460}$ Thus, in a self-service shop, the displaying of goods will normally be an invitation to treat, not an offer; ${ }^{461}$ although it ultimately depends on the intention of the party making the advertisement or display. ${ }^{462}$

In cases where the nature of the goods do not allow a subsequent change of mind, like petrol having been filled into a car, the best analysis of the process is suggested to be that the petrol station offers the fuel at a set price, which the customer accepts upon filling his tank. ${ }^{463}$ Although one might expect restaurants to follow the same analysis, since the payment is made by the customer after having consumed the food, the cases are arguably analogous to shops. This is because food menus in restaurants are deemed as invitations to treat in academic circles. ${ }^{464}$ Accordingly, the customer makes an offer when placing an order, which the waiter - just like the shop assistant - may accept or reject. The situation with food that is taken out rather than being consumed in a restaurant, or with delivery services, would presumably be treated the same, so that the menus ought to be classified as invitations to treat. This would only be consistent, given

458 In effect, the court in Harvey $v$ Facey (fn 456) held the purported acceptance by the appellants as an offer, which would have been, but was not, accepted by the respondent in order for a contract to arise, see ibid 555.

459 [1953] 1 QB 401 (CA). The relevant extract of the decision (the opinion of Somervell LJ) is quoted in McKendrick (fn 48) 63-64.

460 See Andrews (fn 70) 41 para 3.04, who also gives a list of the different reasons that the shop assistants may use, such as the person intending to buy tobacco or alcohol being a minor.

461 Another key case is Fisher v Bell [1960] 3 WLR 919, [1961] 1 QB 394, in which it was likewise held that the displaying of a flick knife with a price indication in a shop window was not an offer of sale but an invitation to treat under general English contract law, see 394-395, 399 (Parker LCJ).

462 See Treitel/Peel (fn 65) para 2-009.

463 This has been suggested by Whincup (fn 34) 48 para 2.3.

464 Compare McKendrick (fn 48) 50-51. 
that a delivery service's menu displayed online or in paper form arguably counts as an advertisement and thus constitutes an invitation to treat.

In relation to sales by auction, s 57 subs 2 SGA 1979 provides that such a sale 'is complete when the auctioneer announces its completion by the fall of the hammer, or in other customary manner'. Consequently, the offer is made by the bidder and this is accepted by the auctioneer when acting in the customary manner of completing the auction. ${ }^{465}$ This means that the auction (lot) itself constitutes an invitation to treat. ${ }^{466}$

Another complex area relates to (public) transport. Operators of railway and bus services have in the past been found to make offers by advertising the operating timetable or simply by running the service. ${ }^{467}$ The offeree would accept this proposal through some conduct which showed their willingness to contract, eg, by getting on the bus. ${ }^{468}$ It is submitted that, at least in cases where the ticket is purchased prior to boarding the vehicle, the service provider could be said to be making an invitation to treat only, whereas it is the customer who makes the offer when making a booking. This is because the contract in such cases is said to have been concluded when the service provider either accepts the booking, or when the ticket is issued. ${ }^{469}$ Indeed, the terms and conditions of some English

465 Treitel/Peel (fn 65) para 2-008.

466 See McKendrick (fn 48) 76. This is the situation of auctions with a reserve price. For a discussion of the situation without reserve price, see ibid 76-80, noting that there is an academic divide on the issue whether the auctioneer makes an offer when advertising the auction without reserve price, or whether the offer is made only when the auction for the object is conducted. While not deciding this point, the CA in Barry $v$ Heathcote Ball \& Co (Commercial Auctions) Ltd [2000] 1 WLR 1962, 1965-1966 followed the obiter dictum in Warlow $v$ Harrison (1858) 1 Ellis and Ellis 295, 120 ER 920 that a collateral contract arose between an auctioneer and a bidder to sell to the highest bidder. For further details on the case, see McKendrick, ibid.

467 For trains, see, eg, Denton $v$ Great Northern Railway Co (1856) 5 Ellis and Blackburn 860 (QB), 119 ER 701, 703-704 (Campbell LCJ). Cf the view expressed by the other sitting judge, Crompton, at 705, who doubted whether any consideration had been provided by the plaintiff in this case and consequently doubted the existence of a contract. The issue of consideration will be discussed in Section iv. below. An extract of the case can be found in Courtney Stanhope Kenny, A Selection of Cases Illustrative of the Law of Contract (CUP 2014) 14-16. For buses, see, eg, Treitel/Peel (fn 65) para 2-012 in fn 61.

468 Treitel/Peel (fn 65) para 2-012.

469 A case example of the latter is Daly $v$ General Steam Navigation Co (The Dragon) [1979] 1 Lloyd's Rep 257 (QB). See also the general terms and conditions for carriage of the bus service provider Flixbus at www.flixbus.co.uk/terms-andconditions-of-carriage, namely, at ' 3.3 .1 ', where it is stated explicitly that the 


\section{B. Comparative Background}

train, subway, and bus operators state that a 'binding contract [...] comes into effect between you and the [service provider] when you purchase a Ticket'. ${ }^{470}$ The analysis of the timetable as an invitation to treat therefore seems to be closer to practical reality. It would also be in line with the thought that the provision of information discussed above in the form of, eg, catalogues, does not constitute a legally binding act. ${ }^{471}$ Moreover, the consideration underlying the $\mathrm{QB}$ decision from $1856^{472}$ of needing to protect a person who acts in reliance of the timetable can be assumed to be a lot less pressing today, seeing as the frequency of train (and bus) services is considerably higher now than it was 150 years ago.

Similarly, when hiring a private hire vehicle (private taxi), it is the customer who makes the offer. ${ }^{473}$ The situation is not as clear with taxis operating under a public licence (termed cabs ${ }^{474}$ or hackney carriages ${ }^{475}$ ). Applying the general considerations for distinguishing between offers and

information displayed on the website is 'a non-binding online catalogue which prompts potential passengers to submit offers', so that the offer is made by the customer in booking a journey and is accepted by the company when issuing the ticket or sending an 'acceptance confirmation'. See further Treitel/Peel (fn 65) para 2-012.

470 National Rail, National Rail Conditions of Travel (11 March 2018) 3, 4, available online at www.nationalrail.co.uk/times_fares/ticket_types.aspx\#National\%20Rail\%20Conditions. See also https://uk.megabus.com/conditions/conditions-of-carriage-megabus.com at '3. Introduction'. Compare www.nationalexpress.com/en/help/conditions-of-carriage at '2.3 Your ticket', where it merely states that '[y]our ticket is a record of our agreement to carry you [...]'. A similar term is found in the general conditions of carriage of EasyBus, see www.easybus.com/en/terms-and-conditions at '2.5 Your Booking Confirmation'. cf Transport for London, Transport for London Conditions of Carriage - Bus and Underground Services (2 September 2018) 2, available online at https://tfl.gov.uk/corpo rate/terms-and-conditions/ticketing-and-travel-conditions-of-carriage?intcmp $=37$ 74 , which seems to suggest that a contract is made when the passenger 'travel[s] on our services, having bought a ticket [...]'.

471 See also fn 469 above.

472 Denton (fn 467) above.

473 This can be deduced from the description of the booking process using the service Gett, see https://gett.com/uk/legal/terms/ at '3.1': 'If you [...] select the order button $[, \ldots]$ you will be connected with a Driver for Transportation Services and this shall constitute an Order. By selecting the order button, you will enter into a contract for Transportation Services with a Driver [...]'.

474 See, eg, Transport for London, which licences cabs in London, see https:// tfl.gov.uk/modes/taxis-and-minicabs/what-to-expect-from-your-journey. No information is provided on the contracting process.

475 See, eg, ss 37 et seq Town Police Clauses Act 1847. 
invitations to treat, it would appear that a cab, at least when waiting at a taxi rank, constitutes an offer, which the customer generally accepts upon boarding the vehicle. This has the following reasons: First, publicly licenced cabs are normally obliged to transport a potential customer, unless a 'reasonable excuse', such as the customer being intoxicated, exists. ${ }^{476}$ Thus, cab drivers cannot usually reserve themselves the right to decide on whether to contract with the other party, which means one typical characteristic of invitations to treat is missing. Secondly, the rates, that is, the usual price, is fixed by the operator and is usually non-negotiable. ${ }^{477}$ Thus, the other typical characteristic of an invitation to treat, negotiability, is missing as well. Taken together, this leads to the result that a cab would normally constitute an offer. While this is the situation for the discussed group of cases, it is ultimately a question of the facts of the case whether a statement is deemed to be an offer, or a mere invitation to treat. ${ }^{478}$

\section{cc) Certainty of Offer, Terms}

A statement amounting to an offer must be certain. In this regard, the case of Carlill is interesting, since the court dismissed the defendants' argument that the advertisement was too vague to constitute an offer. ${ }^{479}$ This is in line with the doctrine that English law will only enforce contracts that are certain, since the court has to be able to determine what the agreement is. ${ }^{480}$ This principle has several reasons. First, a proprietary right under

476 This is implicit in s 53 Town Police Clauses Act 1847, which foresees a penalty where a driver refuses to carry a customer without an excuse. The example was given in Starline and Wessex Taxis Ltd $v$ The Commissioners for Her Majesty's Revenue \& Customs (London Tribunal), 2007 WL 2187088 (official transcript) [4] (Mr Hellier). This seems not to be true for cabs that are not at a taxi rank, at least when ordered online or by telephone; however, it seems that refusals are rare in practice, as this 'could be commercially damaging'. See Starline, ibid.

477 This applies to the usual operating area of the cab. In case of a city such as London, this would be within Greater London. See on this and on the normal rates for a London cab https://tfl.gov.uk/modes/taxis-and-minicabs/taxi-fares.

478 Compare Schmidt J (fn 25) 195.

479 Carlill (fn 369) 266-268 (Bowen LJ).

480 Atiyah, 'Introduction' (fn 33) 42-43. The certainty requirement encompasses the aspects of vagueness and of incompleteness of a contract. The former relates to a contract's term being too ambiguous or unclear while the latter means that certain — important - points are not stipulated, see Treitel/Peel (fn 65) 54-69 for details. The second aspect will not be considered further. Suffice it 


\section{B. Comparative Background}

English law can only arise if the thing in question has been sufficiently identified, as 'a property right is exigible against a thing' ${ }^{481}$ Put another way, a property right does not exist unless attached to something. ${ }^{482}$ As a consequence, there has to be certainty as to the subject matter of a transaction. ${ }^{483}$

Secondly, certainty becomes necessary due to the accepted principle that the courts will not make a contract for the parties; but as long as there is 'sufficient evidence' that an agreement exists between the parties, the court will find the contract enforceable. ${ }^{484}$ Thus, not all cases of uncertainty will lead to the agreement being unenforceable. As the parties cannot be expected to foresee every possible future development, the courts will enforce contracts which lay down the 'essential terms' 1 either directly

to restate that legislation may provide default terms and that the courts have certain powers to imply terms (see fn 427 for further references).

481 Michael Bridge, Certainty, Intention and Identification in Personal Property Law, in: Paul S Davies and James Penner (eds), Equity, Trust, and Commerce (Hart Publishing 2017) 87.

482 Section 16 SGA 1979 contains a stipulation in this vein, so that property will not pass under a commercial transaction in 'unascertained' goods 'unless and until the goods are ascertained.' The Act gives no definition of the term; however, it is interpreted to mean that the goods are identified, usually by an act of factually 'earmarking' them, see Bridge, 'Certainty' (fn 481) 93. While this is true, if a sale is for a specified quantity of unascertained goods, this is unproblematic where the source of the goods is an identified bulk (s 20A subs 1(a) SGA 1979), ie, an identified mass of one kind of interchangeable goods contained in a defined space (s 61 subs $1 \mathrm{ibid}$ ). Similarly, the transfer of only a portion of property, ie, a share of goods, is possible under the SGA, provided that the share qualifies as 'specified goods' due to being 'specified as a fraction or percentage' (ibid). For a more detailed discussion of this topic, see Bridge, 'Certainty' (fn 481) 93-96. cf Everwine Ltd and Ors $v$ The Commissioners of Customs and Excise [2003] EWCA Civ 953, 2003 WL 21353475 (official transcript), in the case of which the issue of ascertaining goods held in a warehouse under rotation numbers with no physical movement upon being sold to other users of the warehouse is discussed at length by Keene LJ. The court found that goods had been ascertained where the whole or remainder of goods owned by the appellant in a rotation lot had been sold; but that where not all the goods in a lot were exhausted by sales, property had not passed as per s 16 SGA 1979 , as it was not possible to tell which out of the goods belonged to the appellant and which belonged to the new owner(s). See [15] et seq of the decision.

483 See Bridge, 'Certainty' (fn 481) 87. Problems may arise in situations where the thing in question is either not ascertained or not identified at the time of contracting, so that issues of property of a share of things may arise. See fn 482.

484 McKendrick (fn 48) 124-125. 
or by providing ways (mechanisms, criteria) of determining a term. ${ }^{485}$ In this way, the trend is for the courts to supplement a priori incomplete contracts, especially in commercial contexts. ${ }^{486}$ The situation is not clearly regulated, however, and the case law is full of conflicting rulings. ${ }^{487}$

In this sense, one related issue is which terms are essential to a contract. This depends on the situation. As the price would be expected to be an indispensable contract term, it may be surprising to discover that the SGA 1979 (s 8 para 2) and the Supply of Goods and Services Act 1982 ('SGSA 1982 ', s 15 para 1) provide for a default rule where a contract is silent on the subject: a reasonable amount of money must be paid for the goods or services respectively. ${ }^{488}$ Other terms like the contract's commencement date may also be essential in this sense. ${ }^{489}$ Nevertheless, the court will typically find a contract enforceable, even if it is not entirely certain, as long as it finds that the parties intended to be bound by the agreement. ${ }^{490}$

485 Atiyah, 'Introduction' (fn 33) 45; see further Treitel/Peel (fn 65) paras 2-0972-098.

486 Atiyah, 'Introduction' (fn 33) 45. He also states that the courts have more references to draw upon when filling the (intentional or unintentional) gaps in contractual terms of commercial agreements, namely, past dealings of the parties, as well as commercial customs or usages, see ibid 45-47. Also see McKendrick (fn 48), who explores the tools available to the court in detail at 136-143: using the mechanisms provided in the contract; referring to default rules contained in statutes, like the SGA 1979; severing vague or uncertain terms if these are severable in order to maintain the remainder of the contract; implying terms, where necessary.

487 McKendrick ( $\mathrm{fn} 48$ ) 143. This is especially true for two of the leading cases in this area: May and Butcher Ltd $v$ The King [1934] $2 \mathrm{~KB} 17 \mathrm{n}(\mathrm{HoL})$ takes a restrictive approach, while Hillas \& Co Ltd v Arcos Ltd (1932) 147 Law Times Reports (LT) 503 (HoL) is more lenient and arguably more in line with contemporary commercial requirements. Both cases are discussed by McKendrick, ibid 126-133.

488 See Treitel/Peel (fn 65) para 2-086.

489 The lack of such a clause in a lease contract was fatal to the contract's existence in Harvey $v$ Pratt [1965] 1 WLR 1025 (CA), see 1026-1028 (Lord Denning MR, Davies LJ, Russell LJ). Similarly, it was held in the case of Blue $v$ Ashley (fn 174) [97] that a period needed to have been specified in which the target (a certain share price) ought to have been achieved and for how long the target ought to be maintained (Leggatt J), presumably in order to have certainty on when performance could be seen to have been completed.

490 See Treitel/Peel ( $\mathrm{fn}$ 65) para 2-087. The reason is that English courts will avoid finding a contract ineffective if the parties accepted it as being effective, see McKendrick (fn 48) 125. 


\section{dd) Communication of Offers}

An offer can only have an effect if it is received, since it must be known to the recipient for that person to be able to act upon it. ${ }^{491}$ Thus, the offer must be communicated in some form first, either through an advertisement addressing several people (potentially the whole world) like in the case of Carlill, or directly to the intended recipient. ${ }^{492}$ In line with this thinking, English law treats two offers with identical terms made by each party to the other ('cross-offers') as not making a contract if the parties do not communicate after having received each other's offer, because the parties did not know of the other party's intention at the time of making their declaration of intention. Consequently, there can be no acceptance. ${ }^{493}$

\section{ee) Coming into Effect of Offers: The Mailbox Rule}

Following from the communication requirement, an offer is generally effective upon receipt by the offeree. ${ }^{494}$ Thus, a person who acts in a way that corresponds to the offer but who had no knowledge of it is not considered as having acted upon the offer, and therefore did not accept the offer. Consequently, it is said that no agreement has arisen between them. ${ }^{495}$ Having said this, it has been stated generally that a message containing an offer need not actually be read; receipt, ie, the possibility of having knowledge of the message, is sufficient for its effectiveness. ${ }^{496}$ The question

491 Treitel/Peel (fn 65) para 2-015.

492 Whincup (fn 34) 49 at 2.5. cf the opinion of Cooke J in Air Transworld Ltd $v$ Bombardier Inc (fn 425) at [75], who stated that the offer itself and its communication 'may be seen as distinct'. He gives the case of unilateral contracts, in which the fact of the offer being perceived (read if made in paper form) by anyone is irrelevant for the offer having been made.

493 See Treitel/Peel (fn 65) para 2-049.

494 See Stone (fn 429) 63; Halsbury's Laws Vol 22 (fn 172) para 243. Compare Treitel/Peel (fn 65) para 2-015. See also the obiter dictum by Kay LJ in the case of Henthorn v Fraser [1892] 2 Ch 27 (CA), 37: 'An offer to sell is nothing until it is actually received.'

495 See Treitel/Peel (fn 65) para 2-049; McKendrick (fn 48) 128. Compare the situation of cross-offers, mentioned in Section dd) above.

496 This can be deduced from the ruling in the case of Stidolph $v$ American School in London Educational Trust Ltd (1969) 20 P\&CR 802 (CA) in relation to a notice under the Landlord and Tenant Act 1954, which the claimant (tenant) had received but nevertheless claimed partial ignorance of. Edmund Davies LJ 
then becomes at which point in time something is deemed as having been received.

While there seems to be no discussion of when exactly something is seen as received with respect to offers, under a general legal presumption, letters are deemed to be received if they are addressed correctly, posted, and not returned. ${ }^{497}$ Therefore, letters are deemed to be received when having been inserted into the recipient's mailbox. Furthermore, the Civil Procedure Rules 1998, SI 1998/3132 ('CPR 1998') lay down presumptive points in time at which documents are deemed to be served for the purposes of civil litigation. Accordingly, documents are deemed to be served: on the second day after having been posted when sent by first class post, or where being transmitted by 'other electronic means'; the next day when delivered directly (leaving it at the person's address); on the same day if the document is sent by fax before $4 \mathrm{pm}$ on a business day; on the next business day if it is sent by fax after $4 \mathrm{pm}$ or on a non-business day. ${ }^{498}$ For fax communication, it seems that the relevant point in time is the completion of the transmission. ${ }^{499}$ The meaning of 'transmission' has been

stated at $805-806$ that the objective of the presumption that letters addressed correctly, posted, and not returned are deemed as having been received by the recipient would be defeated if the recipient were allowed to claim ignorance of the letter's contents. Denning L MR expressed a similar opinion at 805, adding that destroying the unopened letter would not alter its effectiveness. In relation to fax, see Anson $v$ Trump [1998] 1 WLR 1404 (CA), 1411 (Otton LJ; quoted subsequently). It can be concluded from this that knowledge of the content of the message is irrelevant where a letter or fax has been actually received. The same should be true for e-mails or statements displayed on websites, though this is not discussed in academic literature. On knowledge being irrelevant, cf Stone (fn 429) 63, who notes that the recipient must be 'aware' of the offer, which might imply 'knowledge' being required; cf also Percy H Winfield, Some Aspects of Offer and Acceptance (1939) 55 LQR 499, in particular 503.

497 See, eg, Stidolph v ASLET Ltd (fn 496) 805 (Edmund Davies LJ). Despite this presumption, the Royal Mail in the UK offers a special service 'Royal Mail Signed For', whose one highlighted features is 'proof of delivery including a signature from the receiver', see www.royalmail.com/personal/uk-delivery/ signedfor-1st-class and www.royalmail.com/personal/uk-delivery/signed-2nd-class. The meaning of 'posted' will be explored in relation to acceptance in Section iii.cc) below.

498 Rule 6.7 (1) CPR 1998. See also ibid (2), which stipulates that documents served after $5 \mathrm{pm}$ on a business day or on another day will be deemed to have 'been served on the next business day.'

499 This can be deduced from the wording of example 3 ( $\mathrm{r}$ 10.4, Deemed service of a document other than a claim form) of Ministry of Justice, Practice Direction 6A - Service within the United Kingdom (updated 30 January 2017): 'Where the 


\section{B. Comparative Background}

interpreted in light of $\mathrm{r} 5$ (2B) Rules of the Supreme Court (RSC) Order 65 in the case of Anson $v$ Trump $p^{500}$. The court held that 'transmission' was

the process from the moment that the document is dispatched by the sender to a time when the complete document has been received into the recipient's fax equipment. [...] The fact that it may remain in the fax memory before being printed or read is to my mind irrelevant. ${ }^{501}$

While these rules relate to actions in court, they hint at least as to what time frame might be deemed reasonable in a general context. With regard to e-mails, the Law Commission has noted that these 'need only be available to be read; [they] need not actually be read in order to be effective.' ${ }^{502}$ Accordingly, e-mails ought to be deemed to be received when they have reached the addressee's mail box (provider). ${ }^{503}$

Similarly, offers made online are deemed to be received when they can be accessed. This is laid down in $\mathrm{r}$ 11(2)(a) E-Commerce Regulations, whereby the provision generally speaks of an 'order' as an offer ( $\mathrm{r} 12 \mathrm{ibid}$ ) being made by electronic means other than by e-mail or 'equivalent individual communications' (see r 11(3) ibid). It can be deduced from r 11(1) (b) that the usual process of the offer will be a customer going through a set process on the website of the seller or service provider, towards the end of which the customer must be able to verify and alter 'input errors'. The 'placing of the order' will then be made by clicking a button that confirms

document is sent by fax on a Saturday and the transmission of that fax is complet$e d$ by $4.30 \mathrm{pm}$ on that day, the day of deemed service is the following Monday (a business day)' (emphasis added). The Practice Direction is available online at www.justice.gov.uk/courts/procedure-rules/civil/rules/part06/pd_part06a.

500 See fn 496 above.

501 Anson $v$ Trump (fn 496).

502 See Law Comission, Electronic Commerce: Formal Requirements in Commercial Transactions (advice paper, 2001; hereinafter 'Formal Transactions Advice Paper') at 3.21-3.22.

503 Compare Stone (fn 429) 70. For a short description of the sending process of e-mails, see Murray (fn 440) 18. A distinct issue is when the e-mail can be expected to have been read, so that Stone, ibid, argues that e-mails ought to be deemed to be received once the expected time for checking e-mails has passed. It ought to be noted that he supposes that e-mails are checked only one or two times each day. With the advance of smartphones, which allow access to e-mails outside the home, expecting a higher rate for checking e-mails might be closer to current reality. 
that the customer agrees to the terms displayed. ${ }^{504}$ Despite the Regulations stating that an order under $\mathrm{r} 11(1)$ (a) need not be an offer, the fact that the service provider must acknowledge the order indicates that it is the customer who makes the offer and the service provider who accepts it. ${ }^{505}$

Two related issues stem from the question of where and how long an offer is legally effective. This relates to the time frame during which an offer can be said to be 'open' and so can be accepted by another party. The first part of this issue is simple: an offer sent via postal mail service is made at the place from which it is sent (posted). ${ }^{506}$ Arguably, this will also be true for offers made by other means, including e-mail or online; however, there has been no discussion of this.

\section{ff) Loss of Effect of Offers}

The second issue as to how long an offer is effective becomes trickier, since it relates to the question of when an acceptance is effective. The latter aspect will be discussed in the following section (iii.cc)). As the two are not wholly dependent, however, a number of points can be observed here. Before addressing this question, it is worth noting that if an offer that is no longer effective is purportedly accepted, the offeree's act does not constitute acceptance but amounts to a new offer, identical to the original offer. ${ }^{507}$ In this case, the contracting process begins anew and the original offeror becomes the party to accept or reject the new offer.

Where an offer states a fixed term for acceptance ('firm offer'), 508 this period will be the time during which it can be accepted. After the lapse of the stipulated period, the offer is said to have expired, ${ }^{509}$ or terminated. ${ }^{510}$ If no expiration date is given, the offer will no longer be valid after a reasonable period has passed, whereby the determination of 'reasonable'

504 Stone (fn 429) 72. See also Murray (fn 440) 19, who likens the process of clicking the button to 'taking the goods to the cash register in a shop, except that the cashier will usually be a computer instead of a person.'

505 See Stone (fn 429) 72.

506 Treitel/Peel (fn 65) para 2-015.

507 Ibid para 2-062 only refers to a 'withdrawn offer', but it is submitted that the situation should be the same if the offer was no longer 'open' to being accepted, eg, through lapse of the specified acceptance period.

508 Ibid para 3-162.

509 Atiyah, 'Introduction' (fn 33) 47.

510 McKendrick (fn 48) 136. 


\section{B. Comparative Background}

depends on the circumstances. ${ }^{511}$ This also seems to be true for offers made electronically. Having said this, it would seem that such orders are not open for a long period of time, because the recipient has to acknowledge an electronic order 'without undue delay' (see r 11(1)(a) E-Commerce Regulations). There is, however, no further explanation of this in the Regulations.

In general, the speed of transmission of the offer to the offeree may have an impact on the length of time for which the offer will be effective: where the offeree receives the offer shortly after it was sent out by the offeror, an equally swift reply (acceptance) may be expected. ${ }^{512}$ Similarly, in cases where the offeree's conduct by itself is not sufficient to constitute acceptance, eg, because the parties stipulated a different method of acceptance, the offeree's act in response to the offer can nevertheless have the effect of extending the period of time that would normally be reasonable in terms of leaving the offer open to being accepted. ${ }^{513}$ Where no actual time-period but some condition is (implicitly) stipulated as the termination of the offer, the offer will expire through the fulfilment of that condition..$^{514}$

Before the offer is accepted by the offeree, an offer can lose its effectiveness if it is revoked by the offeror. ${ }^{515}$ This revocation has to be explicit;

511 Atiyah, 'Introduction' (fn 33) 47-48, who states that with, eg, perishable goods, the period will be short, while it may be longer if the offeror leads the offereee to believe by his conduct that the offer is still valid. See also McKendrick (fn 48) 136. Conversely, the offeree will be given more time to consider offers in transactions involving, say, land, see Whincup (fn 34) 50 para 2.8. If the arrival of the offer is delayed through the offeror's fault, eg, due to indicating an incorrect address leading to a misdirection of the letter, the delay will not invalidate the offer, see Treitel/Peel (fn 65) para 2-015.

512 See, eg, Quenerduaine v Cole (1883) 32 Weekly Reporter (WR) 185, in which the offer was sent as a telegram. cf Treitel/Peel (fn 65) 30 para 2-033.

513 Treitel/Peel (fn 65) para 2-066. The methods of acceptance will be discussed in Section iii.bb) below.

514 Ibid para 2-067.

515 Atiyah, 'Introduction' (fn 33) 49, who states that this is possible even where the offer states a time-period for acceptance, if no consideration has been given by the offeree for the offer. See also McKendrick (fn 48) 135-136 and Treitel/Peel (fn 65) para 3-162, both citing the case of Dickinson $v$ Dodds (1876) 2 Chancery Division 463 (CA) as authority. Something similar was said by Lindley J in the case of Byrne \& Co $v$ Van Tienhoven \& Co (1880) 5 Common Pleas Division (CPD) 344 (HC). This promise of leaving the offer open for acceptance for a time can be made revocable if consideration is provided, see Section v.aa) below. 
it will not be implied from conduct that is inconsistent with the offer. ${ }^{516}$ In the case of unilateral contracts, this means the offeror can only revoke the offer before the offeree begins to act in accordance with it. ${ }^{517}$ The revocation only becomes effective upon reaching the offeree, whereby this principle is altered where businesses are concerned, so that the revocation only takes effect from the point in time at which it would normally be read, ie, within normal business hours. ${ }^{518}$ It is due to this principle that, where an overlap in time occurs between the notice of revocation and of acceptance reaching their respective recipients, the former must arrive before the declaration of acceptance is sent out in order for the offer to be terminated. This rule was laid down in the case of Byrne $v$ Van Tienhoven, ${ }^{519}$ in which the revocation of the offer was sent out by the offeror before the offer itself reached the offeree, yet it arrived only after the latter had sent out their acceptance of the offer. The court held the offer to be effective for reasons of 'both legal principles, and practical convenience', so that an offeree can accept an offer without having to worry whether it might have been revoked without their knowledge..$^{520}$ Knowledge by the offeree of the revocation is thus essential, meaning that the revocation has to be successfully communicated to, ie, actually reach the offeree, in order to be effective. ${ }^{521}$ At the same time, the revocation need not be communicated by the offeror directly: information provided by a third party considered to be a 'reliable source' is sufficient. ${ }^{522}$

516 Treitel/Peel (fn 65) para 2-059.

517 McKendrick (fn 48) 127. This is due to the way in which acceptance takes effect in unilateral contracts, which will be discussed in Section ii.cc) below.

518 See ibid 132. This is true even if the offeree does not read the notice of revocation when it arrives, unless the offeror knew that the offeree was not actually present at the time of the revocation's arrival, Treitel/Peel (fn 65) para 2-061.

519 See fn 515. See also Henthorn v Fraser (fn 494) 32 (Herschell L).

520 See the opinion of Lindley J in Byrne $v$ Van Tienhoven (fn 515) at 348-349.

521 See Treitel/Peel (fn 65) para 2-059.

522 Ibid para 2-060, who is critical of this rule. Also critical: Whincup (fn 34) 50-51 para 2.10; Atiyah, 'Introduction' (fn 33) 49. An example of such a reliable source could be the offeree's agent, like in the case of Dickinson $v$ Dodds (fn 515). The facts of the case and extracts from the judgment can be found in McKendrick (fn 48) 133-135. 


\section{B. Comparative Background}

\section{iii. Acceptance}

The recipient of an offer has a choice: they can either reject or accept the offer. While a rejection will terminate the offer, ${ }^{523}$ acceptance will lead to the formation of a contract. This section will consider the latter choice, this being the second basic element of a contract.

\section{aa) 'Acceptance' Defined}

Acceptance has been defined in academic literature as a 'final and unqualified expression of assent to the terms of an offer'. ${ }^{524}$ There are two aspects to this definition that need to be considered. First, the statement of acceptance has to show the offeree's willingness to be bound. ${ }^{525}$ This requirement is straightforward and relates to the issue that not all statements made by a person will amount to a declaration of intention, ie, here, acceptance. Thus, a mere acknowledgement of the offer or of its receipt is not automatically acceptance as it is neither 'final' nor an 'assent'. 526 In contrast, there may be instances in which the word 'acknowledgment'

523 Treitel/Peel (fn 65) para 2-063. Like other statements of intention, the rejection has to be communicated to the offeror to be effective, see ibid at 2-063. Atiyah, 'Introduction' (fn 33) 48 notes that the terminated offer can be renewed by the offeror, thus practically reviving it.

524 McKendrick (fn 48) 90; Treitel/Peel (fn 65) para 2-016. See further Air Transworld Ltd $v$ Bombardier Inc (fn 425) 176 at [79] (Cooke J). cf Blue v Ashley (fn 174) [50] (Leggatt J), where it is stated that acceptance normally means a promise to do something in return for another promise given by the offeror; however, that this is not true in instances of unilateral contracts, in which the required act is simply performed.

525 This has to be contrasted with the offeree's motive in accepting. The motive does not have to be primarily to accept the offer, as long as 'the existence of the offer plays some part, however small, in inducing a person to do the required act'. This will be sufficient to constitute acceptance, see Treitel/Peel (fn 65) para 2-051. An example given there is Carlill (fn 369), who is presumed to have been primarily motivated to use the smoke ball to keep from becoming ill.

526 See Treitel/Peel (fn 65) para 2-016. 
means acceptance. ${ }^{527}$ Similarly, a conditional acceptance is not sufficient ('unqualified'). 528

Secondly, acceptance must relate to the offer. It was already noted above that an offeree must act upon the offer, rather than in accordance with but ignorant of the offer. ${ }^{529}$ Therefore, the declaration of acceptance has to identify the offer that is being accepted. ${ }^{530}$ Furthermore, the offeree's response must mirror the terms contained in the offer ('the terms proposed by the offeror'). ${ }^{531}$ Consequently, if the offeree varies the terms of the original offer, this does not constitute acceptance but a rejection of it and will be considered a new offer (a counter-offer). ${ }^{532}$ This notwithstanding, it is not necessary to use the exact wording of the offer. Moreover, it is

527 See, eg, the interpretation by Maugham LJ in the case of L'Estrange $v$ F Graucob Ltd [1934] $2 \mathrm{~KB} 394,405-406$, according to which the formation was said to have been effected through an order form on the one hand and an order confirmation on the other. For the facts and dicta of the case, see Section b.iv.aa) below. See also r 11 E-Commerce Regulations, which seems to use the terms 'order' and 'acknowledgement' as meaning 'offer' and 'acceptance'. A similar interpretation is made by Treitel/Peel (fn 65) para 2-016. of The UK's E-Commerce Regulations (Pinsent Masons LLP, guide 2013), available online at www.out-law.com/page-431, where it is stated at 'Placing of the order' that sellers do not need to accept an order when acknowledging it. Similar: Stone (fn 429) 72.

528 Atiyah, 'Introduction' (fn 33) 50, who draws a distinction between conditional acceptance and conditional contracts, ie, between 'I agree to the offer if...' and '[A] (and [B]) will do [X] if [Y] occurs'. The latter is permitted at common law.

529 See Section ii.dd) above.

530 Treitel/Peel (fn 65) para 2-016.

531 See McKendrick (fn 48) 81. Stone (fn 429) 51 uses the analogy of jigsaw puzzle pieces. Various examples of unmatching declaration of offer and acceptance are given by Treitel/Peel (fn 65) para 2-019, all of which relate to the contract's basic terms, ie, the price or goods, etc.

532 McKendrick (fn 48) 81; Treitel/Peel (fn 65) paras 2-063, 2-019. Problems arise in distinguishing counter-offers from mere enquiries by the offeree, which do not amount to counter-offers, see Whincup (fn 34) 51 para 2.14. The phrasing of the statement can be decisive for this distinction, as shown in the case of Stevenson, Jaques \& Co $v$ McLean (1880) 5 QB Division 346, where the offeree's telegram in reply to the offer was held to be 'a mere enquiry' (ibid 350, Lush $\mathrm{J}$ ) and neither counter-offer nor rejection. It stated: 'Please wire whether you would accept forty for delivery over two months, or if not, longest limit you would give' (emphasis added). It was held that since the defendant did not communicate their intention to withdraw the offer and that the cited telegram was no rejection, the plaintiffs had accepted the offer and communicated the same before having received the defendant's notice indicating that the offer was no longer valid. See 348-352 of the decision (Lush J). 
equally permissible to express terms that, while not included in the offer, would have been implied by law. ${ }^{533}$

\section{bb) Communication and Method of Acceptance}

In order for the statement of acceptance to be legally effective, it has to be communicated. ${ }^{534}$ Moreover, this communication must normally be directed at the offeror, so that he can have knowledge of the declaration of acceptance. ${ }^{535}$ There are two instances in which communication may not be necessary: when there is a unilateral contract; or where the acceptance requirement is waived, expressly or impliedly, in the offer. ${ }^{536}$ Normally, acceptance will be by conduct in such instances, ie, through a positive act on part of the offeree. ${ }^{537}$ Consequently, silence or inactivity is not generally treated as acceptance in English law, because it does not constitute 'positive conduct' and is usually equivocal in terms of its interpretation. ${ }^{538}$

533 Treitel/Peel (fn 65) para 2-019.

534 Atiyah, 'Introduction' (fn 33) 51. cf Air Transworld Ltd v Bombardier Inc (fn 425) [79], in which Cooke J makes the distinction between a declaration of acceptance and its communication. As with offers, he gives the case of unilateral contracts, in which the carrying out of the required act is sufficient without prior communication.

535 McKendrick (fn 48) 110. See further Treitel/Peel (fn 65) para 2-024. Whether the offeror actually has to have knowledge of the acceptance, eg, by hearing or reading the offeree's statement, will be discussed subsequently.

536 An example of an implied waiver would be a stipulation that acceptance can take the form of acting consistently with the offer (acceptance by conduct), see Treitel/Peel (fn 65) para 2-028. But see Atiyah, 'Introduction' (fn 33) 51, who is sceptical of contracting parties being able to waive the communication requirement for acceptance.

537 In the case of Marshall $v$ N M Financial Management Ltd [1997] 1 WLR 1527 (CA) between an agent (plaintiff) and his former principal (defendant), it was held that a conditional clause for renewal of the commission in an agency contract was a unilateral ('if') contract, since the agent had not promised to fulfil the conditions; however, that such performance would constitute both acceptance of the offered remuneration (commission) and consideration for the promise by the defendants to pay it, see ibid 1533-1534 (Millett LJ). This principle of unilateral contracts being formed through an exchange of a promise and performance has recently been confirmed in Rollerteam (fn 173) [45] (Henderson LJ). See generally Treitel/Peel (fn 65) paras 2-028-2-029. Consideration will be discussed in Section v. below.

538 McKendrick (fn 48) 115; Treitel/Peel (fn 65) para 2-044. This rule was laid down in the case of Felthouse $v$ Bindley (1862) 11 Common Bench Reports (New 
There are only very limited exceptions that always depend on the facts of the case. ${ }^{539}$ One relevant circumstance is the relationship of the parties: where there is 'a course of dealing' between them, acceptance can be by silence. $^{540}$

Acceptance can generally be communicated in several different ways: It can be expressed in oral or written form, as well as by electronic means, and it can sometimes even be implied from the offeree's conduct as an 'external manifestation' of acceptance. ${ }^{541}$ Thus, the conduct has to indicate the offeree's acceptance and must be made with the intention to accept. ${ }^{542}$ English law therefore differentiates between an offeree's silence or inactivity as not constituting acceptance on the one hand, and their acting on the offer (conduct) on the other.

This begs the question whether the offeror must have actual knowledge of the offeree's conduct. The decision in Carlill has made it clear for unilateral contracts that this is not the case, because the offeror in such contracts (impliedly) waives the requirement of 'notification of acceptance' by stipulating that a particular conduct is sufficient. ${ }^{543}$ Whether an offeror's waiver of communication of acceptance in bilateral contracts is possible, is as yet undecided. ${ }^{544}$

Series) 869, 142 ER 1037 (HC) and although the decision might be criticised on the facts (see, eg, Treitel/Peel, ibid para 2-044 in fn 232), the rule remains valid.

539 See Treitel/Peel (fn 65) para 2-045-2-046, who argues at para 2-047 that an offeror stipulating that silence would be considered as acceptance ought to be bound.

540 For further details, see Treitel/Peel (fn 65) para 2-045.

541 See Stone (fn 429) 59-68. The court's decision in Brogden v Metropolitan Railway (1877) 2 App Cas 666 (HoL) made it clear that conduct is a sufficient form of accepting an offer in bilateral contracts. It should be noted, however, that in this case, the conduct in question was the placement of an order with the other party, so that the conduct was in fact communicated to the other party. With unilateral contracts, acceptance will invariably be through conduct, as an offeree's counter-promise to act in accordance with the offeror's promise will not be sufficient, as that 'would not be what the offeror had bargained for', see Treitel/Peel (fn 65) para 2-054. One recent example in which acceptance 'by word or conduct' was generally acknowledged is Blue $v$ Ashley (fn 174) [50] (Leggatt J).

542 The offeree does not need to primarily have the intention of accepting; the offer must, however, induce the offeree to act in accordance with the offer to some (minor) extent, see Treitel/Peel (fn 65) paras 2-018, 2-051. As long as the offeree had knowledge of the offer, the courts will presume an intention to accept, unless there is evidence to the contrary, see McKendrick (fn 48) 129.

543 Carlill (fn 369) 269-270 (Bowen LJ).

544 See Stone (fn 429) 62; doubtful Atiyah, 'Introduction' (fn 33) 51. 


\section{B. Comparative Background}

Parties are free to stipulate a method of acceptance. The agreed method will then be the only effective way to accept, unless the aim underlying the stipulation can be fulfilled by a different method. 545 In this sense, it has been suggested that a deviation from the prescribed method may lead to the declaration of acceptance being deemed as a counter-offer for not mirroring the offer. ${ }^{546}$ Irrespective of this, the choice of method has to be reasonable under the circumstances, ie, it must be an appropriate form of response in terms of, eg, the transmission time. ${ }^{547}$

\section{cc) Coming into Effect of Acceptance: The Mailbox and Postal Rules}

When and where the declaration of acceptance's effect begins and whether the statement actually has to reach the offeror to be effective depends on: first, the nature of the contract; and second, on the method of acceptance. In terms of the former, unilateral and bilateral contracts must be distinguished. In unilateral contracts, acceptance is usually by conduct,

545 Treitel/Peel (fn 65) paras 2-041-2-042. cf McKendrick (fn 48) 102-103, who seems to suggest that the method is binding only if its mandatory nature is made clear. Furmston and Tolhurst (fn 440) 163-164 para 6.24 suggest that the words specifying the acceptance method need not always be interpreted strictly. Thus, where acceptance is stipulated as to be made 'by return post', this ought to be understood to mean that a 'prompt reply' rather than acceptance by way of letter is being required, see ibid, 164. Nevertheless, they state further that the chosen method must be presumed to be the 'most advantageous', see ibid. The offeror can waive the stipulated method, but only if the offeree is not put at a disadvantage, see McKendrick, ibid, 102. The opposite is also true, so that where the method is for the offeree's benefit, they may waive it unless this would prejudice the offeror, see Treitel/Peel, ibid para 2-043.

546 See Furmston and Tolhurst (fn 440) 164 para 6.25.

547 Compare Treitel/Peel (fn 65) para 2-033, according to whom a slower response method (eg, letter) would not be reasonable if the offer was received by a faster method (eg, e-mail). Similarly, if the offeree is aware of any problems with a particular method, they ought to use a different method, see ibid. Furmston and Tolhurst (fn 440) 164 para 6.24 argue that a choice of method may not simply be about the transmission speed, but about other factors, such as having bad phone connection in the foreseeable future. Furthermore, use of a different method by the offeree means the offeror needs to monitor several communication channels. Another consideration to be made is the business relationship: with solicitations by a new potential partner, traditional communication methods may be more appropriate than electronic methods, whereas it may be acceptable if dealings had been had before. Compare Furmston and Tolhurst, ibid, 165 para 6.26 . 
but it is only once the required act has been completed that acceptance is considered to have been made. ${ }^{548}$ With bilateral contracts, the deciding factor is whether the communication is between physically present parties or whether the communication is through some medium. ${ }^{549}$ Interestingly, the differentiation is not simply whether the communication is direct or at a distance, but seems to depend further on the time taken for its transmission. ${ }^{550}$ Before going into this differentiation, it ought to be noted that the declaration of acceptance does not always have to reach the offeror directly. Thus, where the offeror has an agent who is authorised to receive a declaration of acceptance on the offeror's behalf, acceptance is effective from the moment the agent receives it; otherwise, the effect will be deferred until the offeror himself receives the declaration. ${ }^{551}$

548 McKendrick (fn 48) 127; Treitel/Peel (fn 65) para 2-053. Compare the opinion of Bowen LJ in Carlill (fn 369) 267, where this issue was contemplated and it was held that acceptance is made once the course of acting has been completed. Due to this, the offeror, although unable to extract himself from his promise through revocation, is not bound to comply with his promise (usually payment) until that point in time, see McKendrick (fn 48) 127. Thus, the delay in the effect of the act of acceptance could be said to mitigate the harshness of the offeror not being able to revoke his offer after the offeree has begun to perform. For a more theoretical analysis of the reasoning behind part-performance being insufficient, see Treitel/Peel (fn 65) paras 2-054. Treitel further advocates that an offeree performing in part should be able to recover something from the offeror, whether this be their expenses or a 'reasonable sum', see ibid para 2-058. Cf also Air Transworld Ltd v Bombardier Inc, as noted in fn 534 above. While part-performance therefore does not amount to acceptance, it at least protects the offeree from having the offer withdrawn after having started to act. See on this Stone (fn 429) 74-75.

549 Schedule 1 Consumer Distance Selling Regulation lists the following examples of distance communication: unaddressed and addressed printed matter, letters, press advertisings with order forms, catalogues, telephone with or without human intervention, radio, videophone or videotext, e-mail, fax, and television (teleshopping). This is equivalent to the list found in Annex 1 Council Directive 97/7/EC on the Protection of Consumers in Respect of Distance Contracts (hereinafter 'EU Distance Selling Directive'), which was transposed through the Consumer Distance Selling Regulation.

550 The meaning of communication in terms of transmission or notification is discussed succintly by Furmston and Tolhurst (fn 440) 169-170 para 6.34: Even if a communication method is instantaneous, ie, without delay in its transmission, this is not equal to instantaneous notification due to the possible absence of the recipient. What matters is the 'actual communication' (original emphasis).

551 Treitel/Peel (fn 65) para 2-026. This may also be applicable to 'instantaneous communication', see ibid at para 2-035 in note 188. 


\section{B. Comparative Background}

For communications at a distance, Lord Denning in the case of Entores Ltd $v$ Miles Far East Corporation ${ }^{552}$ distinguished between acceptance sent through means of 'instantaneous communications' (then: telephone, telex) and those sent through the post. For agreements made via such 'instantaneous communications', Lord Denning held that the declaration of acceptance is effective once and at the place where it reaches the offeror. ${ }^{553}$ This rule was confirmed in the case of Brinkibon Ltd $v$ Stahag-Stabl und Stablwarenhandelsgesellschaft $\mathrm{mbH}^{554}$, which also dealt with the question of the place of contract formation where the relevant communication was via telex. In effect, the ruling in Entores extended the application of the general rule for the formation of contracts (the mailbox rule) from those made 'oral[ly and] in writing inter praesentes' (emphasis added) to encompass cases where the instantaneity of the communication method (named examples: telephone, radio) compensates for the physical distance. ${ }^{55}$ The rule has also been applied to e-mail, ${ }^{556}$ in which case receipt is complete once

552 [1955] 2 QB 327 (CA). The case concerned a contract that had been concluded by telex between two parties, one of which was in England while the other was in the US. The issue of interest for the present discussion was whether the contract was made in England (as opposed to New York), ie, whether acceptance was effective from the time that it was sent or from the moment in which it was received. Further facts and excerpts of the judgment can be found in McKendrick (fn 48) 110-112.

553 Entores (fn 552) 334 (Lord Denning).

554 [1983] 2 AC $34(\mathrm{HoL})$. In this case, the parties were in the UK and Austria and had negotiated a contract via telephone and telex. The issue was whether acceptance, having been made by telex, fell under the postal rule (on which, see below). The court found that it did not. See ibid 41-42 (Lord Wilberforce). In a more recent case, Mann J was of the opinion that the reality of the 'post-Brinkibon world', ie, the possibilities of modern technologies, sometimes made the analysis of the formation of a contract difficult in terms of the traditional offer and acceptance model. Therefore, where the facts of a case allowed, a contract might be found to have been made in several places at once. This would be the case in a transnational telephone conversation, or a video-conference. See Apple Corps Ltd v Apple Computer Inc [2004] EWHC 768 (Ch), [2004] 2 CLC 720 at [37]-[39], [42] (Mann J). Irrespective of whether this statement forms part of the case's ratio decedendi (doubting: Stone (fn 429) 68), the statement will be persuasive authority at least.

555 See the opinion of Lord Wilberforce in Brinkibon (fn 554) 41 at [D]-[F].

556 See Air Transworld Ltd $v$ Bombardier Inc (425) 176 at [79] (Cooke J). See also Stone (fn 429) 70. Similarly it is presupposed in Law Commission, 'Electronic Commerce' (fn 502) 21 para 3.56 that e-mails become effective upon receipt. cf Murray (fn 440) 22-25, arguing that the postal rule ought to apply. It ought to be noted, however, that this view was expressed some twelve years before 
the message has been recorded on the recipient's mail server. ${ }^{557}$ Similarly, acceptance made online, ie, through a web browser, need to be received in order to be effective. ${ }^{558}$ In this case, it has been suggested that the effect of acceptance sets in 'at the time when it would be reasonable for the [offeree] to assume that it will have been read', namely, immediately. ${ }^{559}$

Another principle relating to oral statements of acceptance made to a physically present offeror was applied to 'instantaneous communication' in Entores: the offer must have actually been heard or received by the offeror in order to be effective. ${ }^{560}$ Thus, if there is some form of disruption in the ('instantaneous') communication, like loud noises or technical problems, the offeree has to make sure that his declaration of acceptance was received by the offeror by repeating the statement if they know or should know that the statement was not received. ${ }^{561}$ The situation is different where the offeror's conduct (not asking for the statement to be repeated or re-sent) leads the offeree to reasonably believe that the declaration of acceptance was received, when in fact it was not: here, acceptance is effective. ${ }^{562}$ This principle also applies to acceptances sent by fax, ${ }^{563}$ and perhaps also to e-mails. ${ }^{564}$

The distinction made in Entores between 'face-to-face' conversations and 'instantaneous communications' has been criticised by some authors, on the basis that not all statements will be immediately perceived (read) by the offeree upon its arrival. Accordingly, 'face-to-face' and electronic conversations (telephone and other real-time online communication services $^{565}$ ) ought to fall into one category. The other category would then consist of postal messages, fax, and e-mail. It has been suggested that while

the English high courts ruled on the matter. For a thorough analysis of how e-mail ought to be classified, see Furmston and Tolhurst (fn 440) 167-171 paras 6.29-6.35, who decide on it being non-instantaneous.

557 See Law Commission, 'Electronic Commerce' (fn 502) 21 para 3.56.

558 On this, see Murray (fn 440) 25-25, using the term 'click wrap acceptance'.

559 Stone (fn 429) 72.

560 Entores (fn 552) 332-334 (Lord Denning).

561 Ibid 333 (Lord Denning).

562 Ibid. It should be noted that the principle coming into play here is estoppel and was held to prevent the offeror from denying having received the declaration of acceptance due to his own omission. Further explanation of this principle in relation to contracts can be found in McKendrick (fn 48) 236-271.

563 McKendrick (fn 48) 112; Treitel/Peel (fn 65) para 2-035.

564 Whincup (fn 34) 56 para 2.28; Stone (fn 429) 66-68.

565 Although no examples were given, it is submitted that instant messaging or video conferences would fit this description. 


\section{B. Comparative Background}

the rules regarding the coming into effect of acceptance through 'face-toface' communication should apply to the first category, the postal rule (discussed subsequently) should apply to the second category, especially in a business context. ${ }^{566}$ Indeed, this is a point that was considered and dismissed by the court in Brinkibon. ${ }^{567}$ Part of Lord Fraser of Tullybelton's reasoning for its dismissal was that it was '[the offeror's] responsibility to arrange for prompt handling of messages within his own office', making it reasonable to assume that a message received was a message delivered to the offeror. ${ }^{568}$ The English Law Commission has held a similar view with regard to the question whether e-mail constituted a written notice and gave the opinion that it was, irrespective of whether it was actually read. ${ }^{569}$

Regarding the moment at which the contract is formed, it has been suggested that the business-hour-rule for revocations of offers set out above ${ }^{570}$ could be applied to acceptance made via telex by analogy. ${ }^{571}$ Another author went on to treat faxes the same way, but not e-mail, because the latter may not be checked as often and the effect should thus be delayed until the 'expected time for checking has passed'. 572 It is submitted that the business-hour-rule should be applicable to all forms of modern 'instantaneous communications' used in business - telex, fax, e-mail, perhaps even mobile text messages. This is because the offeree's concern is always the same: not knowing when the offeror will (have) read the declaration of acceptance. Alternatively, the well-established criteria of 'reasonable time' passing after the sending of the message could be applied.573 As for contracts made online, ie, on websites, the E-Commerce Regulations provides that 'acknowledgement of receipt' of the order (ie, acceptance) will be deemed to be received once the offeror can access it $(\mathrm{r} 11(2)(\mathrm{a}))$. Thus, it is argued that since the supplier of the goods or services in question

566 See Stone (fn 429) 66-68.

567 See Brinkibon (fn 554), eg, 43[D]-44[A] (Lord Fraser of Tullybelton).

568 Brinkibon (fn 554) 43[G] (Lord Fraser of Tullybelton).

569 See Law Commission, 'Electronic Commerce' (fn 502) at 3.21-3.22. See also the summary provided in Email, e-signatures and e-commerce (Reed Smith LLP, 2 February 2002), available online at http://m.reedsmith.com/email-e-signaturesand-e-commerce-02-02-2002/.

570 See fn 518 .

571 See McKendrick (fn 48) 114.

572 Stone (fn 429) 70.

573 This is suggested by ibid for telephone answering machines. 
will be the offeree, acceptance will occur when the customer's offer is acknowledged, irrespective of whether this happens online or via e-mail. 574

On the other hand, Lord Denning reiterated the settled law that declarations of acceptance sent through the post will be effective from the time and at the place where they are posted. ${ }^{575}$ This postal rule was developed as an exception to the default rule regarding the formation of contracts for reasons of commercial expediency or 'practical convenience' and is applicable to 'non-instantaneous communication at a distance' (letters, telegrams). ${ }^{576}$ In contrast, it does not apply to 'instantaneous communication', like telephone, telex, and probably also not to fax and e-mail..$^{577}$ As to the exact meaning of 'posting', it was merely stated in Dunlop $v$ Higgins $^{578}$ that 'if the party accepting the offer puts his letter into the post on the correct day, has he not done every thing he was bound to do? How can he be responsible for that over which he has no control? ${ }^{579}$ It can be deduced from this that putting a letter 'into the post' is sufficient. Arguably, this would encompass sending the letter from within a post office, or by inserting it into a post box. Indeed, the moment of posting is said to occur when the letter is 'in control of the Post Office, or one of its employees authorised to receive letters'. 580

A declaration of acceptance by post does not actually have to reach the offeror; it is 'deemed to be complete' upon posting, even if its receipt is delayed or completely frustrated (eg, by being lost). ${ }^{581}$ It is this aspect

574 See ibid 72.

575 Entores (fn 552) at 332 (Lord Denning).

576 Brinkibon (fn 554) 41[F]-42[A] (Lord Wilberforce), 43[D] (Lord Fraser of Tullybelton). Treitel refers to this principle as the 'posting rule', see Treitel/Peel (fn 65) para 2-031. See also Atiyah, 'Introduction' (fn 33) 52.

577 Atiyah, 'Introduction' (fn 33) 53. Similar: Treitel/Peel (fn 65) para 2-035, though he suggests that acceptance sent by fax, e-mail, or made online (on a website) should be effective even if the received message is (partly) illegible. See also McKendrick (fn 48) 124-126, who would generally distinguish between contracts concluded via e-mail and via the internet (websites) by referring to the Singaporean case of Kin Keong $v$ Digilandmall.com (fn 440), but concludes that neither should be governed by the postal rule.

578 See fn 363 above.

579 Dunlop v Higgins (fn 363) 812 (Lord Chancellor).

580 Treitel/Peel (fn 65) para 2-031.

581 Atiyah, 'Introduction' (fn 33) 52. See also Treitel/Peel (fn 65) para 2-036, who has suggested at para 2-037 that where the delay is due to one party's fault, eg, by indicating a wrong or incomplete address, the effect of the declaration of acceptance should arise at the point in time that is 'least favourable' to the responsible party. 


\section{B. Comparative Background}

that makes this rule, which is only adopted in few other countries, ${ }^{582}$ so striking: Even if the letter or telegram is lost so that the offeror cannot have knowledge of the declaration of acceptance, a contract is formed. The justification for this exception is unclear and continues to be discussed in academic literature. ${ }^{583}$ It ought to be noted that while a party is usually free in choosing a means of accepting, it has been ruled by English courts that the use of postal mail must have been 'within the contemplation of the parties'. ${ }^{584}$ It is possible for the parties to exclude the postal rule. ${ }^{585}$ One final matter to note is that acceptance must be made either within the period set in the offer or within a reasonable period; otherwise the offer will have expired and acceptance cannot be effective. ${ }^{586}$

\section{dd) Loss of Effect of Acceptance}

One way in which acceptance can lose its effectiveness is through the offeree's own revocation. For this, the offeree must communicate the revocation to the offeror before or simultaneously to the declaration of acceptance reaching the offeror; however, this will not be possible where the postal rule applies, since acceptance would have been made upon posting. ${ }^{587}$ At common law, the offeror can therefore not change his mind once the declaration of acceptance is posted. The situation is different where a contract made at distance involves a consumer: $r 10$ Consumer Distance Selling Regulation gives that party a special cancellation right ( $r$ 10(1) ibid), which, if exercised, will lead to the contract being treated

582 McKendrick (fn 48) 119. As will be seen in Section C.IV.1.a.iii.cc) below, Japan is among these.

583 See, eg, Atiyah, 'Introduction' (fn 33) 52 (sceptical); McKendrick (fn 48) 124 ('English law goes too far in laying down [this] rule'); Treitel/Peel (fn 65) para 2-032 (more neutral). An interesting reason for the initial adoption of the postal rule, the (political) enthusiasm for and innovation of the newly established mail services in the mid-nineteenth century, and the later decline through further innovation in the field of communication (telephone, telex), is suggested by Simon Gardner, Trashing with Trollope: A deconstruction of the Postal Rule in Contract (1992) 12 OJLS 170, 178-180, 184.

584 Henthorn $v$ Fraser (fn 494) 33 (Lord Herschell), 36 (Kay LJ).

585 McKendrick (fn 48) 122.

586 This expiry of offers was discussed in Section ii.ff) above.

587 See Treitel/Peel (fn 65) para 2-039. 
as if it had never been made ( $\mathrm{r} 10(2) \mathrm{ibid}) .{ }^{588}$ In effect, a consumer can therefore change his mind even after having acceptanced.

\section{iv. The Further Requirement of an Intention to Create a Binding Legal Relationship}

As has already been seen in relation to declarations of offer and acceptance, a contractual intention is required of the parties so that statements will amount to an offer or acceptance. More precisely, the requirement is that the parties must have had an intention to create a binding legal relationship when concluding a contract. This essentially means that the parties must have meant to become obliged under the agreement made between them, so that the agreement may be legally enforced. ${ }^{589}$ Distinguishing between cases in which this is so and situations in which the parties do not intend to be so bound is important, both inside and outside commercial settings. Indeed, one of the aspects used to decide this issue is the 'social context'. The other two factors are the language of the statement, ie, whether it is clear or vague, and, finally, whether the statement was made in anger or jest, rather than in a serious manner. 590

The issue of an intention to be bound typically arises where there is no express intention, ie, in cases of implicit manifestations of intention. ${ }^{591}$ The assessment of the parties' implied intention is made on an objective

588 The time frame during which the contract can be cancelled depends on whether the 'supplier' of goods or services has provided information regarding the contract to the consumer prior to or on contracting in accordance with $\mathrm{r} 8$ : if this has been done, the consumer has seven working days from the time of receipt of the goods or the conclusion of the service contract, or receipt of the information under $\mathrm{r}$ 8. Where no information has been provided, the cancellation period is three months and seven working days from the receipt of the goods or conclusion of the service contract. See rr 11 and 12 for sale of goods and services respectively.

589 See Blue v Ashley (fn 174) [55] (Leggatt J).

590 Compare Blue v Ashley (fn 174) [56] (Leggatt J). In the event, the alleged contract was held not to be legally binding on these grounds, see [80] et seq of the decision.

591 Compare Treitel/Peel (fn 65) para 4-004. Having said this, explicit agreements may equally lead to a dispute. One example might be a stipulation to make an arrangement a 'gentleman's agreement', ie, binding not in the legal sense but in honour only. In the leading case, such a clause had been drafted in a document and both the CA and the HoL found it to be valid, see Rose and Frank Co $v$ Crompton and Brothers, Ltd [1923] 2 KB 261 (CA), eg, at 288-289 (Scrutton 


\section{B. Comparative Background}

basis; however, if one party knows of the other party's intention, this knowledge is taken into account. ${ }^{592}$ The court's investigation is aided by the following two presumptions: On the one hand, an intention to create a binding legal relationship will be presumed in a commercial context, ${ }^{593}$ or where an agreement is made expressly. ${ }^{594}$ This requirement will therefore normally not constitute a problem during the formation of an ordinary business contract and consequently usually does not become an issue in court litigation. ${ }^{595}$ Where, on the other hand, particular facts indicate otherwise, such as a family relationship existing between the parties or there being a 'social agreement', the presumption is that there is no intention for a legal relationship to arise between the parties. ${ }^{596}$ In these cases, the probability of the issue of contractual intention arising is therefore higher.

Both presumptions are rebuttable, whereby the context of the agreement and the nature of the relationship between the parties are important and constitute differentiating factors. ${ }^{597}$ The hurdle that has to be overcome for a rebuttal is generally higher in a commercial context. ${ }^{598}$ Where

LJ); Rose and Frank Co v Crompton and Brothers, Ltd [1925] AC 445 (HoL), 454 (Phillimore LJ).

592 See Treitel/Peel (fn 65) para 4-002. See also the point made in Section 3.a. above.

593 McKendrick (fn 48) 295. Sometimes a statute may provide for a different presumption, see, eg, s 179 Trade Union and Labour Relations (Consolidation) Act 1992, which provides that a collective agreement between a trade union and an employer (see s 178 subs 1 ) will be 'conclusively presumed' not to create legal relations between the parties if the requirements of para 1 are satisfied; otherwise the general commercial presumption applies under para 2.

594 Compare Treitel/Peel (fn 65) para 4-005.

595 McKendrick (fn 48) 309. cf the situation where the terms of an (express) agreement are too vague or uncertain, so that doubt concerning the seriousness of the parties' intention may arise, see ibid 314. This may be the case if the terms confer great discretion to one or both parties regarding their performance, see Treitel/Peel (fn 65) para 4-023. Similarly, if the document in question is a letter of intent (hereinafter 'LOI'), the parties' intentions may not always be clear, but their mere expectation that the LOI will subsequently be replaced by a contract is not by itself conclusive, see Treitel/Peel, ibid para 4-024.

596 See Treitel/Peel (fn 65) paras 4-019-4-022.

597 See Sadler v Reynolds [2005] EWHC 309 (QB) [52] (Slade QC), in which both of these aspects are listed together with express statements of intent (on which see further below). Treitel/Peel (fn 65) paras 4-026 gives the unusual examples of the relationships between a Minister and the Methodist Church (no contractual intention) or the Crown and civil servants (contractual intention).

598 McKendrick (fn 48) 295-296, 309, 311. The opinion of Viscount Dilhorne in the case of Esso Petroleum Ltd $v$ Commissioners of Customs and Excise [1976] 1 WLR $1(\mathrm{HoL}) 4[\mathrm{H}]-[\mathrm{I}]$ that an intention to create legal relations could be 
a commercial element is introduced to family relations, as in a family business, the presumption is more easily rebutted than would normally be the case in a family or social context. ${ }^{599}$ Another factor is whether one party relied on the agreement to their detriment, in which case the presumption that there is no legal relationship in a family or social context will normally be rebutted. ${ }^{600}$ These factors notwithstanding, it is ultimately the intention of the parties that is relevant for the question whether a presumption is rebutted. ${ }^{601}$ Accordingly, the commercial presumption can be rebutted by an express stipulation to this effect between the parties. ${ }^{602}$

The case that laid down the general rule for family relationships that there is no intention to create a binding legal relationship was Balfour $v$ Balfour ${ }^{603}$. The court differentiated between the 'domains of a contract' and 'domestic arrangements' and found that the agreements of married couples 'living together in friendly intercourse' or 'in amity' did not belong to the former but were a matter of the latter and therefore outside

inferred where the thing that was promised to a purchaser was 'something of value' to them but that the World Cup coins involved in the case were of 'little intrinsic value' has been interpreted as evidence of how high the hurdle is.

599 See McKendrick (fn 48) 303, 307. Similarly, a social element may be introduced to a priori commercial relations, thus lowering the bar for an intention to create a legal relationship in a social context, see Stone (fn 429) 144-145 and Sadler v Reynolds (fn 597) [56] (Slade QC).

600 This factor is not as strong as the one previously mentioned, because even where a detriment is suffered due to reliance being placed on an agreement, this may not be sufficient to rebut the presumption. Compare Treitel/Peel (fn 65) para 4-005. McKendrick (fn 48) 303-304 suggests that the point in time of the 'transaction' may also play a role in this regard, so that, depending on whether a purported contract has already been performed (executed) or not (executory), the position may be different. See on this also Stephen Hedley, Keeping Contract in its Place: Balfour $v$ Balfour and the Enforceability of Informal Agreements (1985) 5 OJLS 391, 408: "If it is the "reasonable man" we are consulting, then the "reasonable man's" opinion [regarding the enforceability of the contract] may change in the course of the transaction.'

601 See McKendrick (fn 48) 304.

602 Whether such a stipulation was made is a matter of construction, so that the words by themselves are not necessarily conclusive, see Edwards $v$ Skyways Ltd [1964] 1 WLR 349 (QB), 356 (Megaw J), in which it was held that the words 'ex gratia' did not convey an intention for the promise to not be legally enforceable. Phrases like 'subject to contract' will similarly indicate no intention to be bound, see Treitel/Peel (fn 65) para 4-011 et seq. Where such phrases are contained in commercial contracts, the wording may not be conclusive as to the contractual intention, see Stone (fn 429) 150-151.

603 See fn 371 above. 


\section{B. Comparative Background}

the law's jurisdiction. ${ }^{604}$ If there were to be a contract arising between a married couple - a possibility confirmed by the court - there had to be more than an exchange of promises: the agreement had to either have been made expressly, or circumstances justifying an implied contract had to have existed. ${ }^{605}$ On the facts, the court did not find such an intention. ${ }^{606}$ Where a couple makes an agreement after or on separation, however, a contract can be concluded between them, since such parties are said to bargain with an intention to create a legal relationship. ${ }^{607}$

Apart from these presumptions, general factors such as whether statements were made in a 'social context', using vague language, or 'in anger or jest' will indicate no intention to be bound. ${ }^{608}$ In the case of Blue $v$ Ash$l e y^{609}$, in which the intention to be legally bound was a central issue, these and the following circumstances were examined by the court: the place and background ('setting'; in this case: drinking in a pub) and 'nature and tone' of the conversation in the course of which an agreement was allegedly made (casual, 'obviously jocular'); the purpose of the setting (statement maker meeting with people for prospective new business relations, appealing to these people); 'lack of commercial sense' of the alleged offer of remuneration (no reasonable basis, arbitrary amount); '[i]ncongruity with [claimant's] role' (impossible for claimant to realise desired result alone); vagueness of the statement (especially: essential terms such as time for realisation not specified); perception of witnesses to the conversation in question and of the claimant (statement not serious, no agreement made). ${ }^{610}$ In this way, it remains a question of the circumstances of a case whether the parties had an intention to be legally bound.

604 Balfour $v$ Balfour (fn 371) 574 (Warrington LJ), 579 (Atkin LJ); see also ibid 576-577 (Duke LJ). This rule also normally applies to other cohabiting persons like unmarried couples, and other family relations like those between parents and their children, see McKendrick (fn 48) 301-302; Treitel/Peel (fn 65) paras 4-021-4-022.

605 Balfour v Balfour (fn 371) 574 (Warrington LJ), 577 (Duke LJ). Treitel gives the example of a husband being the tenant of his wife, Treitel/Peel (fn 65) para 4-020 at 101 .

606 Balfour $v$ Balfour (fn 371) 571.

607 Merritt v Merritt [1970] 1 WLR 1211 (CA) 1213 [A]-[C] (Lord Denning MR).

608 Blue v Ashley (fn 174) [56] (Leggatt J).

609 See fn 174 above.

610 Ibid [81]-[107] (Leggatt J). 


\section{v. The Requirement of Consideration}

From the viewpoint of other jurisdictions, the requirement that a contract must either be supported by consideration or be made in the form of a deed is one of the most striking aspects of English contract law. ${ }^{611}$ For foreign lawyers, it is not so much the deed as the concept of consideration that seems to cause confusion. The first and obvious reason would be that jurisdictions outside the common law do not have such a requirement, ${ }^{612}$ and therefore often lack a directly comparable reference. Secondly, the fact that the concept of consideration seems to be founded on rules with no clearly defined criteria makes it less approachable and only exacerbates the problem. ${ }^{613}$ The following discussion gives an overview over the doctrine by explaining the most important aspects but must leave an in-depth treatment of finer points to others. ${ }^{614}$

The function of the doctrine of consideration is to enable the courts to differentiate between gratuitous promises and non-gratuitous promises, whereby only the latter will generally be enforceable at law, unless the former is in the form of a deed. ${ }^{615}$ The reasoning is that only when there

611 It should be noted that consideration is not a form requirement like a deed, although both can affect the legal enforceability of the contract. Compare Treitel/Peel (fn 65) para 5-002. See further Cartwright (fn 181) 134 para 4-15.

612 Having said this, there may be other requirements fulfilling a similar function, such as the French causa. This is true at least for its function to differentiate enforceable from unenforceable promises. For a brief account of how causa is applied in this sense in French law, see Whincup (fn 34) 99 para 3.78. See further ibid 100 paras 3.80-3.81 for a comparison with the English concept of consideration.

613 In the words of McKendrick (fn 48) 161, consideration 'is now a very technical doctrine'.

614 See, eg, Halsbury's Laws Vol 22 (fn 172) paras 308-327; Cartwright (fn 181) 235288.

615 See McKendrick (fn 48) 147. It seems that no consideration is required with a deed because the document creates a presumption concerning consideration. Compare in this respect s 1 subs 2 (d) SGSA 1982. cf McKendrick, ibid, 261, who merely speaks of a deed 'render[ing] a promise binding'. Similarly, Stoljar (fn 194) 6 points out that a seal on a document did not 'import' consideration even in the Middle Ages. He cites the case of Sharington $v$ Strotton (fn 292), in which the court found for the defendant concerning use of land and denied the plaintiff's action of trespass, since the defendant was found to have given consideration for the agreement - in the form of, inter alia, brotherly love. In contrast, the plaintiff's argument that where a deed is made, it imported consideration (in the form of the maker's will) was not considered. Stoljar, ibid, interprets this to mean that the argument was rejected by the court. Indeed, 


\section{B. Comparative Background}

is an exchange of promises, ie, reciprocity, can there be a bargain, an agreement. ${ }^{616}$ Put in simpler terms, consideration is "the "price" for the promise', ${ }^{617}$ so that 'both sides to the agreement [are required to] bring something to the bargain'. ${ }^{618}$ This requirement is thus founded on the traditional basis of a contract, namely, promises and a bargain; and while this theoretical foundation was later replaced by the offer-and-acceptance model in the nineteenth century, consideration was retained. ${ }^{619}$ It should be noted that where no intention to create a legal relationship is found, the question of consideration becomes irrelevant as there can be no contract between parties having no contractual intention. ${ }^{620}$

Similar to the situation with the requirement of there being an intention of creating a binding legal relationship, consideration will not usually be an issue in practice. This is because providing consideration can be easily achieved, and, if in doubt, using the form of a deed will suffice to relieve this insecurity. ${ }^{621}$ This is especially true for agreements involving the payment of money in return for goods or services that constitute a monetary benefit for the payor. ${ }^{622}$ The issue of a lack of consideration is in fact often brought up before the courts as an argument advanced

the court did not mention the argument in its reasoning, see Sharington at 471. cf the discussion in Section 2.a.iv. above. See also Treitel/Peel (fn 65) paras 3-001 and 3-172, who suggests at para 3-014 that gifts supported by nominal consideration (see below), though practically being gratuitous, are still enforceable while informal gifts, ie, those not supported by any consideration, are not. Contrast Bridge, 'Property' (fn 182) 171, who states that gifts are not contracts per se since consideration is not generally required; however, where nominal consideration is provided, gifts may look like a contract. They will be legally enforceable if in the form of a deed or if the promise of the gift is accompanied by the 'physical delivery' of the object. Similarly, gratuitous services are not contractually enforceable for lack of consideration, Treitel/Peel, ibid para 3-170.

616 See McKendrick (fn 48) 161-162.

617 Kötz and Flessner (fn 19) 9. Cf Stoljar (fn 194) 6, according to whom consideration relates to the reason or the motive for making a contract.

618 Stone (fn 429) 92.

619 The philosophy underlying English contract law was already discussed in Section 1. above.

620 This is true even if under other circumstances consideration would be found, see Balfour v Balfour (fn 371) 578-579 (Atkin LJ).

621 See McKendrick (fn 48) 162. Indeed, it does not seem to be a contemporary issue, as Leggatt J noted in Blue $v$ Ashley (fn 174) [58] that '[...] I am not aware of any case in the twenty-first century in which a claim founded on an agreement has failed for want of consideration.'

622 McKendrick (fn 48) 164. The question of what kind of non-monetary benefit will be held to be consideration is explored in Section bb) below. 
by a party that wants to be released from the contract. Having said this, when the question of consideration does come up, it is important, as the existence of a contract has often hinged on whether consideration was provided by the parties. ${ }^{623}$

Promises not being supported by consideration or not having been made in the form of a deed are not invariably unenforceable or completely ineffective in English law. In some cases, the principle of estoppel may preclude a party from going back on their promise, ${ }^{624}$ and the promise may therefore be given effect indirectly. This is illustrated by the leading case for estoppel, Central London Property Trust Ltd v High Trees House $L t d^{625}$, in which it was said that on the basis of the contemporary developments in the case law on applying an estoppel to a promise regarding the future, a full sum initially agreed upon could not be claimed by the promisor if a reduced sum was agreed and also acted upon later and that this later agreement was binding irrespective of consideration having been provided. ${ }^{626}$ The full requirements of the principle will not be discussed

623 This argument is not new either, see the argument brought forward by the defendants' attorneys in Carlill ( $\mathrm{fn}$ 369) at 258, which led the court to give attention to the issue - and in this case to find consideration, see ibid at 264-265 (Lindley LJ), 270-272 (Bowen LJ), 274-275 (Smith LJ). An example of a case contemporary with Carlill but where an agreement was held not to be supported by consideration and therefore not to be enforceable is Foakes $v$ Beer (1884) 9 App Cas 605 (HoL). The agreement in question was a promise by the defendant not to enforce a judgement against the plaintiff for a debt owed if the plaintiff paid the outstanding money in six-month instalments. Although the plaintiff paid the defendant thereafter, this was held not to constitute consideration on the plaintiff's part, since the payment formed part of an 'antecedent obligation', see ibid 611-614 (Selborne LC). See also Section dd) below.

624 McKendrick (fn 48) 161, 236. cf Stone (fn 429) 93, stating this concept to be a 'secondary test of enforceability' that 'does not replace 'consideration'.' There are several different types of estoppel. For an overview, see Hanbury and Martin (fn 63) paras 27-019-27-029. One recent case law example is Seward v Seward (2014) WL 3535431 (official transcript; HC) on a promise between parents and son to convey land in exchange for the conveyance of other property to a third party (family member).

625 [1947] $1 \mathrm{~KB}$ 130. The case concerned an agreement to vary a lease contract between affiliated companies by reducing the rent of several properties. While no consideration had been provided for the variation agreement, the court held that the plaintiffs were estopped from enforcing the original agreement while the properties in question could not be rented out fully (due to external circumstances), but that the rent originally agreed applied after the properties were fully rented out.

626 High Trees (fn 625) 134-135 (Denning J). See also Treitel/Peel (fn 65) para 3-114. 


\section{B. Comparative Background}

here; ${ }^{627}$ however, it should be noted that estoppel does not arise simply from a subsequent change to a contract (variation). Rather, the promisor's representation or conduct has to have an 'effect on the position of the other party'. ${ }^{628}$ Thus, it is through this principle - which would later be termed promissory or equitable estoppel ${ }^{629}$ — that variations not supported by consideration are now regarded as being effective at common law. ${ }^{630}$

In the following sections, the term consideration will be defined first (in Section aa)) before the following three rules of the doctrine are explained: first, consideration must be sufficient but need not be adequate (Section bb)); secondly, consideration cannot be past (Section ee)); and, thirdly, consideration must move from the promisee (Section $\mathrm{ff}$ )). In addition, the issues of nominal and insufficient consideration will be addressed (see Sections (c)-dd)). The requirements for a valid deed will be set out in Section b.iii. below, together with the other form requirements for contracts that exist in English law.

\section{aa) 'Consideration' Defined}

Consideration can be defined as 'something of value' that is given in exchange for a promise, ${ }^{631}$ whereby this 'something' can be a 'right, interest, profit, or benefit accruing to one party, or some forbearance, detriment, loss, or responsibility, given, suffered, or undertaken by the other'. ${ }^{632}$ More

627 For a succinct account of the concept, see Hanbury and Martin (fn 63) paras 27-021. For further details on the requirements of promissory estoppel, see Stone (fn 429) 120-130.

628 See Treitel/Peel (fn 65) paras 3-077 and 3-114, where another important case in the development of this principle, Hughes $v$ Metropolitan Ry (1877) 2 App Cas 439 (HoL), is briefly discussed.

629 See McKendrick (fn 48) 243.

630 Treitel/Peel (fn 65) para 3-077.

631 Ibid para 3-002. Alternative definitions have been suggested by various legal academics, such as 'the price for which the promise is bought' (Frederick Pollock); however, as pointed out at ibid para 3-007, they all have shortcomings.

632 Currie v Misa (1875) LR 10 Exchequer 153, 162 (Lush LJ), quoted by McKendrick (fn 48) 163. Although the authority relied on was not Currie v Misa, Bowen LJ in Carlill (fn 369) 271 found that an 'inconvenience sustained by one party at the request of the other is enough'. Treitel/Peel (fn 65) para 3-005 notes that it is sufficient if there is either a benefit to the promisor, or a detriment to the promisee. In Denton (fn 467) 703-704, Campbell LCJ held that a person who, having made their plans according to a schedule issued (a promise) by the train operator, provided good consideration in coming to a train station in 
simply put, consideration can be an advantage obtained by one party, or an inconvenience suffered by the other in relation to the promises made or accepted, as the case may be, or both. ${ }^{63}$ This is not an exhaustive list. Thus, the provision of information or data is said to constitute valid consideration, ${ }^{634}$ as is the transfer of possession or ownership of a chattel. ${ }^{635}$ Furthermore, a promise can also be consideration, so that mutual promises, whether implied or express, can be sufficient for forming a contract. ${ }^{636}$ Similarly, the performance of a counter-promise will normally be consideration, even if the counter-promise itself is not legally valid (see Section bb) below). By way of example, consideration for a promise that an offer will be kept open for a specified period (firm offer) can be provided by promising to pay a sum of money for this promise, or to undertake to do some other act indicating the offeree's serious intent, or by actually doing such acts. ${ }^{637}$

In relation to unilateral contracts, it has been stated that the act requested by the promisor will constitute both the promisee's acceptance and

the expectation of taking a particular advertised train; cf Crompton J, in whose opinion at 704-705 such an action did not form part of consideration for a promise, or if it did, only a small part. Indeed it may seem strange to think that train operators could be held liable for compensatory damages to persons who simply come to the train station (as opposed to those who purchase a ticket); however, it must be borne in mind that this case dates back over 150 years, a time when transport and communication systems and thus the setting of the case were very different from today.

633 See Morley v Boothby (fn 292) 456 (Best CJ); Stone (fn 429) 96.

634 See Furmston and Tolhurst (fn 440) 154 para 6.08.

635 Compare Treitel/Peel (fn 65) para 3-032.

636 Andrews (fn 70) 115 notes that such an exchange of promises leads to an executory contract (on which see fn 173 above). The caveat is that the performance of the promise in question has to be seen as constituting consideration in order for the promise itself to be good consideration, Treitel/Peel (fn 65) para 3-008. A further caveat is that the promise(s) cannot be defective in the eye of the law, eg, because of illegality or duress, see ibid 3-155-3-159. In some cases, performance of an a priori defective promise can sometimes provide consideration, eg, where the party having suffered duress indirectly affirms the contract by suing on it, ibid 3-157. Whether this applies to defects arising from a statutory provision depends on the stipulation in question, ibid 3-158-3-159. Interestingly, the explanation given by Treitel for equating a benefit and a detriment with the expectation in commercial practice that promises are to be kept is 'commercial morality'. This is yet another example of English law taking commercial notions into account.

637 Otherwise, the firm offer will be revocable, see Treitel/Peel (fn 65) para 3-162 and Section ii.ff) above. 


\section{B. Comparative Background}

provide consideration; ${ }^{638}$ but only once it has been wholly performed. ${ }^{639}$ Consideration can also be made up of different components, like the payment of a sum of money and another act by the promisee that is of value to the promisor. ${ }^{640}$ By way of summary and stated in more basic terms, there therefore has to be something done or given by the promisee in return for the promise received. ${ }^{641}$

The breadth of the definition's scope has led to criticism, since it seems to give the courts very wide discretion, almost as if the judges were able to 'invent consideration', 'as they please'. ${ }^{642}$ As will be seen, this description is a bit harsh when bearing in mind the three rules discussed below. Furthermore, the following two points need to be noted in relation to the definition of consideration.

First, the courts have tended to analyse the existence of 'benefit' or 'detriment' in two different ways. ${ }^{643}$ One view is that either a benefit or a detriment has to factually arise, so that it is actually perceived by either one of the parties. ${ }^{644}$ It must also be 'causally linked to [the] promise'. ${ }^{645}$ In contrast, the other view focuses on whether the promisee's act constituted something that they were (not) already legally bound to do: If the promisee was legally bound to act, however much of a benefit or detriment may arise, there will be no consideration; conversely, if the promisee is not legally bound to act, it is irrelevant if their conduct is beneficial

638 See KW Wedderburn, Contract. Consideration. Retail Price. Copyright (1959) 17 No 2 CLJ 160, 161. The case on which Lord Wedderburn comments, Chappell \& Co Ltd v Nestlé Co Ltd [1960] AC 87 (HoL), will be discussed in Section cc) below. See also Marshall v N M Financial Management Ltd (fn 537). Compare Cartwright (fn 181) 136 in fn 124, who speaks of the promisee 'earning the reward' (original emphasis) through their consideration, namely, performance of the required act.

639 Treitel/Peel (fn 65) para 3-160.

640 This view was expressed by Lord Reid in the case of Chappell $v$ Nestlé (fn 638) at 108.

641 This simple approach, rather than the 'out of date' language of benefit and detriment, is advocated by John C Smith, The Law of Contract - Alive or Dead? (1979) 13 The Law Teacher 73, 77.

642 Treitel/Peel (fn 65) para 3-009.

643 McKendrick (fn 48) 146 sees the disparity in application of these tests as a conflict.

644 See Treitel/Peel (fn 65) para 3-006. According to McKendrick (fn 48) 161, the court's argumentation in Williams $v$ Roffey Bros \& Nicholls (Contractors) Ltd [1991] QB 1 is an example of this test.

645 Halsbury's Laws Vol 22 (fn 172) para 309. 
or detrimental and consideration is found. ${ }^{646}$ The latter view is no longer accurate; the courts circumvented the rule by holding that performance of an already existing obligation will suffice if the other party receives a practical benefit from the performance. ${ }^{647}$ As a court found recently, this 'will invariably' be so. ${ }^{648}$

Secondly, what is provided as consideration has to be 'something of value in the eye of the law', so that there has to be some sort of economic value to the act or promise, even if this value cannot be specified exactly. ${ }^{649}$ This aspect will be discussed in more depth in the following section, as it closely relates to what constitutes sufficient consideration.

\section{bb) Rule 1: Sufficient Consideration, not Adequate}

The first requirement for consideration is that, although it must be sufficient, it need not be adequate. The first part of the requirement, ie, sufficiency, relates to the issue whether consideration exists. The second part, adequacy, concerns the question of whether the value of the consideration corresponds to the value of what the offeree obtains under the contract. ${ }^{650}$ The reason for this curious rule is based on the requirement for a bargain to be made between the parties in contracting, whereby the law is not concerned whether this is a fair one. ${ }^{651}$ For this reason,

646 Treitel/Peel (fn 65) para 3-006. Also see McKendrick (fn 48) 167, according to whom this approach was taken in Foakes $v$ Beer (fn 623). An example can be found in the opinion of Selborne LC at 613-614. This case will also be discussed in the following section.

647 This was done by the court in Williams $v$ Roffey Bros (fn 644), discussed subsequently.

648 Blue v Ashley (fn 174) [59] (Leggatt J).

649 Treitel/Peel (fn 65) paras 3-002, 3-027. See also Halsbury's Laws Vol 22 (fn 172) para 316, noting that nominal consideration is acceptable. On this, see Section cc) below.

650 Stone (fn 429) 98.

651 Unfairness is therefore not an aspect affecting the formation of a contract, Treitel/Peel (fn 65) para 3-013. It is an aspect to be considered under legal principles other than consideration, like duress or undue influence, see McKendrick (fn 48) 164; and also with illegality, see Treitel/Peel, ibid, para 11-073. Having said this, equity may step in under certain circumstances where a bargain is 'unconscionable', unless the parties have negotiated the (inadequate) consideration while being on an equal footing. Details of the operation of equity in this context can be found in Treitel/Peel, ibid, paras 10-046-10-048. 


\section{B. Comparative Background}

the courts do not question whether what was given was adequate, ${ }^{652}$ as long as what the parties consider being of value is not something 'wholly illusory'. ${ }^{653}$ Accordingly, an agreement to transfer the legal title of land or of a business for a mere $£ 1$ consideration will in principle be enforceable at law. ${ }^{654}$ Such trivial amounts are referred to as nominal consideration (see Section cc) below) and are regarded as being sufficient. ${ }^{655}$ Although they might be thought to be an inadequate expression of reciprocity, that is irrelevant. This general rule notwithstanding, adequacy of consideration can be important, in particular if a statutory provision expressly requires it. ${ }^{656}$

In terms of what can be sufficient, the caveat that what is provided has to be valuable in the eye of the law can potentially cause problems in contracting practice if the opinion of the parties and that of the law deviate on what is sufficient, so that a contract might be 'struck down' by the courts for lack of consideration. ${ }^{657}$ This does not mean, however, that the courts completely disregard the parties' intentions. ${ }^{658}$ On the contrary, it has been stated that

whilst consideration remains a fundamental requirement before a contract not under seal can be enforced, the policy of the law in its search to do justice between the parties has developed considerably since the early $19^{\text {th }}$ century [...]. [T] he courts nowadays should be more ready

652 Halsbury's Laws Vol 22 (fn 172) para 317. This was stated, for example, by Lord Blackburn in Foakes $v$ Beer (fn 623) 616. Stone (fn 429) 98-99 suggests freedom of contract as the reason for the courts not inquiring into the adequacy of consideration.

653 Wedderburn (fn 638) 162. Treitel/Peel (fn 65) para 3-028 interprets this to mean that the promise constituting consideration must be - to the knowledge of both parties - capable of being fulfilled at the time when the promise is made. Furthermore, the performance of this promise should not be left to the promisor's (offeree's) discretion and the promise itself must consist of something that the promisor would not have done or given but for the promise, see Treitel/Peel, ibid paras 3-030 and 3-029 respectively.

654 See McKendrick (fn 48) 165, 162.

655 Halsbury's Laws Vol 22 (fn 172) paras 316, 314.

656 Treitel/Peel (fn 65) para 3-014 in fn 67 gives the example of 'valuable consideration' in the LPA 1925, which, in accordance with s 205 subs 1(xxi) LPA 1925, 'does not include nominal consideration'. Halsbury's Laws Vol 22 (fn 172) para 317 notes that the amount of consideration may also 'be evidence of duress or mistake' among other issues.

657 Treitel/Peel (fn 65) para 3-003.

658 See McKendrick (fn 48) 164. 
to find its existence so as to reflect the intention of the parties to the contract where the bargaining powers are not unequal and where the finding of consideration reflect the true intention of the parties. ${ }^{659}$

Furthermore, the courts have tended to be more lenient in assessing the value of consideration in cases of a commercial nature. ${ }^{660}$

A claim given up by the promisee is good consideration, because the promisee suffers the loss of the claim and its value. ${ }^{661}$ The same is true where the claim is 'doubtful'; but it is debatable whether a 'worthless' claim can suffice. ${ }^{662}$ Having said this, where the party giving up the claim does not know that the claim is worthless and acts in good faith, this is sufficient to constitute consideration. ${ }^{663}$ Irrespective of the claim being valid or not, there can be no consideration if the promisor does not ex-

659 Williams v Roffey Bros (fn 644) $18[\mathrm{G}]-[\mathrm{H}]$ (Russel LJ). The parties were builders and had entered into a subcontract for carpentry work on a number of properties. The plaintiffs, the subcontractor, agreed orally with the defendants, the main contractor, on extra payments when the plaintiffs ran into financial difficulties due to miscalculations and could not continue working without extra funds. The court found the plaintiff's promise to perform their existing obligation on time to be a commercial benefit and sufficient consideration and thus held the agreement enforceable. See ibid 15-16 (Glidewell LJ).

660 McKendrick (fn 48) 169; Stone (fn 429) 99.

661 See Treitel/Peel (fn 65) para 3-034, who applies this principle to giving up a defence or a remedy at 3-035.

662 See McKendrick (fn 48) 170-171. Cf Halsbury's Laws Vol 22 (fn 172) para 321, stating that a compromise is good consideration 'even if the claim ultimately turns out to be unfounded'. Cf again Treitel/Peel (fn 65) para 3-036, who states that where a worthless ('invalid') claim is given up, this will not constitute consideration if that was the only consideration provided. Therefore, where the act of giving up such a claim is merely a part of the consideration, there is good consideration. Similarly, it was stated in Balfour v Balfour (fn 371) 577 (Duke LJ) that where a claim (right) did not exist, relinquishing it is not consideration. See also Section dd) below.

663 Thus held in Cook $v$ Wright (1861) 1 Best and Smith 559 (QB), 121 ER 822, which concerned a suit against the defendant for not honouring two promissory notes, issued to the plaintiffs in order to avoid legal proceedings being initiated against him even though there was in fact no legal basis for the underlying claim and the defendant was aware of this. The court held the factual detriment suffered by the plaintiffs in abstaining from litigation to be good consideration for the promissory notes, since they had believed in good faith that they had a claim against the defendant and acted on that belief. Contrast Wade v Simeon (1846) 2 Common Bench Reports 548 (Court of Common Pleas), 135 ER 1061, in which the giving up of a claim was not held to constitute consideration because the party knew they did not actually have a claim. 


\section{B. Comparative Background}

pressly or at least implicitly request the promisee to give up the claim. ${ }^{664}$ In addition to acts of giving something up, promises of taking on obligations can constitute consideration. This is even true for gratuitous gifts of real or personal property, where the recipient of the gift (donee) promises to take over obligations of the donor in relation to the property, like paying mortgage instalments or fulfilling covenants. ${ }^{665}$

\section{cc) Nominal Consideration}

A somewhat extreme example of nominal consideration that shows the court's leniency at the same time is the case of Chappell $v$ Nestlé, in which a HoL majority held that chocolate bar wrappers can form part of the promisee's consideration. ${ }^{66}$ The argument that the wrappers themselves were of no value to the defendant and that they were actually thrown away after their receipt was held to be irrelevant, because, in the words of Lord Somervell of Harrow:

A contracting party can stipulate for what consideration he chooses.

A peppercorn does not cease to be good consideration if it is established that the promisee does not like pepper and will throw away the corn. ${ }^{667}$

It was held further that the value of the request of sending in the chocolate bar wrappers was the increased sale of the defendant's chocolate. ${ }^{668}$ Lord Reid's statement to the effect that the number of cases where the wrap-

664 On this, see Treitel/Peel (fn 65) para 3-042.

665 See ibid. para 3-033.

666 Chappell v Nestlé (fn 638) 109 (Lord Reid), 115 (Lord Somervell of Harrow). The case concerned a suit for copyright infringement by the plaintiffs on the ground that the defendants had sold records to which the plaintiff's held the copyright. The defendants had in fact run a campaign under which customers who sent in three Nestlé chocolate wrappers and a sum of money could purchase the record in question. The court held the transactions under the campaign to be 'sales by retail'. In the present case, the other part of the consideration was the sum of money. See also the commentary by Wedderburn (fn 638) 162.

667 Chappell v Nestlé (fn 638) 114 (Lord Somervell of Harrow).

668 Ibid 105 and 108 (Lord Reid), 114-115 (Lord Somervell of Harrow). Bowen LJ stated something similar in Carlill (fn 369) at 271, namely, that the defendants received an indirect benefit from the use of their products by customers because it increased their sales. This is an important point, since McKendrick (fn 48) 168 identifies the indirect commercial benefit that the promisor receives from the 
pers might not have conferred a direct benefit on the defendants being negligible is interesting, as this would seem to correspond to a reasonable calculation merchants would make when initiating such campaigns. ${ }^{669}$

It may be equally surprising that not only trivial things like chocolate wrappers, but also seemingly trivial acts can constitute (nominal) consideration. Examples include the promise of the payment of a sum of money to the promisee if they simply go to a particular place or show a particular document, ${ }^{670}$ or return a missing pet. ${ }^{671}$ What all these examples have in common is that they are part of unilateral contracts, in which the acts were requested by the promisor. This begs the question whether such seemingly trivial things or acts would be sufficient if the promisor were not to explicitly or implicitly demand them. This issue has been discussed in English academic literature:672 The argument has been put forward that an offer in unilateral contracts need not include a request by the promisor; ${ }^{673}$ all that matters is that there be reliance by the promisee in acting on the promise, ${ }^{674}$ and that the offer or promise be serious. ${ }^{675} \mathrm{In}$ light of the judgment rendered in Chappell and the fact that commercial concerns seem to underpin English contract law in general, it is submitted that inconsequential things or acts will not be sufficient in themselves, unless they are of some value or benefit to the promisor. ${ }^{676}$

requested act as being an objective justification of the promisor's request, which is arguably preferable to a 'subjective whim'.

669 Chappell v Nestlé (fn 638) 108 (Lord Reid).

670 See Treitel/Peel (fn 65) para 3-031.

671 Cartwright (fn 181) 136 in fn 124.

672 See on this the debate the following exchange of articles: Arthur L Goodhart, Unilateral Contracts (1951) 67 LQR 456-460; John C Smith, Unilateral Contracts and Consideration (1953) 69 LQR 99-106; Arthur L Goodhart, A Short Replication (1953) 69 LQR 106-110.

673 Smith, 'Unilateral Contracts' (fn 672) 100; Goodhart, 'Replication' (fn 672) 107, who goes on to note at 108 that a request is only required in cases where the promise is not express but implied.

674 Goodhart, 'Unilateral Contracts' (fn 672) 458.

675 Goodhart, 'Replication' (fn 672) 108.

676 In this respect, see Shadwell v Shadwell (1860) 9 Common Bench Reports (New Series) 159, 142 ER 62, 68 (Erle CJ and Keating J) and 69 (Byles J). The plaintiff's uncle promised in writing to pay the plaintiff a sum of money yearly to support his engagement as long as the plaintiff's salary did not amount to a particular sum. The uncle defaulted. Although the judges were not unanimous in their conclusion, the statement of law on this point was that the consideration given (ie, the act of getting married) either had to be a loss suffered by 


\section{B. Comparative Background}

\section{dd) Insufficient Consideration}

While a promise in return for a promise is good consideration, money in return for money is not necessarily sufficient: if a smaller and a larger sum of money are exchanged simultaneously, this is not normally enough; although it is where, for example, the two sums are in distinct currencies or have different values. ${ }^{677}$ Another example of what is not sufficient is the parties' motives. These cannot by themselves constitute consideration, though they may form part of it. ${ }^{678}$ This is especially true if the motive is 'merely sentimental', since 'natural affection' will not by itself provide consideration. ${ }^{679}$ Similarly, a condition that is fulfilled by the promisee can be consideration, although the condition itself cannot. ${ }^{680}$

Apart from the issue of doubtful or worthless claims discussed in Section bb) above, another problematic situation is the fulfilment of a pre-existing obligation as consideration. It is problematic, because English law sometimes finds such an act to be sufficient, while it will not do so at other times. One distinguishing factor is whether the obligation is owed to the promisor or to a third party; however, the law goes further in the former case and has traditionally differentiated between contractual obligations and those imposed by law. ${ }^{681}$ While the result is straightforward with duties owed to third parties (a promise to as well as the actual discharge of such a duty can be consideration for the offeror's promise), ${ }^{682}$ the situation is more complicated with a duty owed to the offeror. If the act fulfilled by the promisee is an existing contractual obligation towards the promisor, this would traditionally not be sufficient for constituting fresh consideration (see subsequent section). ${ }^{63}$ In all of these cases, the promisee can

the promisee or be a benefit gained by the promisor — at the request of the promissor. It was this last point that divided the court's opinion.

677 Treitel/Peel (fn 65) para 3-014.

678 See Halsbury's Laws Vol 22 (fn 172) para 310.

679 Treitel/Peel (fn 65) para 3-027.

680 Ibid para 3-011, who explains that the performance must have been explicitly or implicitly requested by the offeror. See also Halsbury's Laws Vol 22 (fn 172) para 311.

681 See McKendrick (fn 48) 174-175.

682 See Pao $v$ Lau (fn 88) 631-632 (Scarman L), discussed below. See further Treitel/Peel (fn 65) paras 3-054-3-055; McKendrick (fn 48) 160-161.

683 This is the traditional view, laid down in the case of Stilk $v$ Myrick (1809) 2 Campbell 317 (Assizes), 170 ER 1168. Note that in a second report of the case in (1809) 6 Espinasse's Nisi Prius Reports (Esp) 129, the reason for the judgment is made out to be duress, not consideration. A discussion of these two 
ensure that consideration is provided by promising or actually doing more than they are obliged to do. ${ }^{64}$ Similarly, where the basis of an obligation is a statutory provision, the mere discharge of such an obligation does not constitute consideration; ${ }^{685}$ however, where more is done than is required, this will be consideration. ${ }^{686}$

It is again equity that provides an exception to this common law rule. Where a party is considered to require special protection, the court may examine the adequacy of the consideration provided, and, if inadequate, apply equitable remedies to alleviate the situation. ${ }^{67}$

\section{ee) Rule 2: No Past Consideration}

The second requirement for consideration is that it has to be provided in response to the promise. In other words, there has to be a strong connection in time, so that something from before the offeror's promise

interpretations is given by McKendrick (fn 48) 168-172. It suffices for present purposes that the interpretation of consideration is acceptable (see Treitel/Peel (fn 65) para 3-048) and will therefore be assumed here. This traditional view was adopted by the court in Foakes $v$ Beer (fn 623). Accordingly, where an agreement was for the payment of money, a variation of this agreement could not be supported by consideration in the form of a payment of money, because this was not a new act but part of the 'discharge of the original liability', see the opinion of Earl of Selborne (LC) in ibid 613-614. The general rule deduced from this case is that the partial payment of a debt will not provide consideration for the promise of paying the owed sum entirely. See McKendrick, ibid, 203 and 209-220 for criticism and justifications of this rule. Cf Williams $v$ Roffey Bros (fn 644), in which it was held that performance of an existing duty could be sufficient consideration where the offeror received a practical benefit from the offeree's additional promise, see 15[G]-16[D] (Glidewell LJ). This decision has thrown doubt on the traditional rule, see McKendrick, ibid, 183-184. See also Treitel/Peel, ibid para 3-051, who suggests tentatively that the Williams $v$ Roffey Bros-rule now prevails. But see McKendrick, ibid, 216-217, who states that the relationship between these two cases has not yet been clarified.

684 Stone (fn 429) 112.

685 McKendrick (fn 48) 177. Again, this is the traditional view that has also been challenged but has not yet been revoked. For further details, see ibid 178-183. The reason behind the traditional rule is public policy, see Treitel/Peel (fn 65) para 3-044.

686 See Stone (fn 429) 106-108.

687 Treitel/Peel (fn 65) para 3-016. 


\section{B. Comparative Background}

('past consideration') is not good consideration. ${ }^{688}$ Therefore, the offeree or promisee has to provide fresh consideration: something new has to be given or done, normally very shortly after the offer or promise ${ }^{689}$ or the contract is made. ${ }^{690}$ A previous act will not suffice. ${ }^{691}$ Whether consideration is past or fresh depends not on the intention or stipulation of the parties but on the facts. ${ }^{692}$ In essence, the question is whether the two events (promise and consideration) are 'sufficient[ly] connect[ed]' so that they may be regarded as making up a bargain rather than two distinct acts. ${ }^{693}$ Where this is not the case and therefore no consideration exists for the two events, the courts may turn to estoppel (see Section aa) above). ${ }^{694}$

Having said this, past consideration can be sufficient under particular circumstances. ${ }^{695}$ Accordingly, where something was done or promised at the request of the offeror, with remuneration being intimated for it, and a legal claim for the remuneration exists, the act or promise will constitute consideration for the (implied) promise of payment. ${ }^{696}$ There may also be situations in which a statutory provision allows past consideration, like s 27 subs 1 (b) Bills of Exchange Act 1882 (hereinafter 'BEA 1882') admitting '[a]n antecedent debt or liability' as 'valuable consideration' for a bill of exchange.

688 Ibid para 3-017, giving the example of two acts which are a year apart as not being consideration for each other. This general rule was laid down in the case of Eastwood v Kenyon (1840) 11 Adolphus and Ellis 438 (QB), 113 ER 482. cf Halsbury's Laws Vol 22 (fn 172) para 320, noting that the relation is more important than the chronological order, so that something given just before the other party's promise may be sufficient.

689 According to Treitel/Peel (fn 65) para 3-018, the order does not strictly have to be an offer followed by a promise together with consideration, as long as both the offer and the promise can be seen as being 'substantially one transaction'.

690 Stone (fn 429) 102.

691 Treitel/Peel (fn 65) para 3-017 gives the example of a promise of extra remuneration to a retired person based on the (past) employment being unenforceable.

692 McKendrick (fn 48) 226. See also Halsbury's Laws Vol 22 (fn 172) para 320.

693 See Halsbury's Laws Vol 22 (fn 172) para 320; McKendrick (fn 48) 223.

694 McKendrick (fn 48) 231.

695 This seems to be especially true in a commercial setting, see Goode and McKendrick (fn 48) 5 at 1.04 .

696 Treitel/Peel (fn 65) para 3-019. A modern case law example is Pao v Lau (fn 88), in which the plaintiffs' promise not to sell the shares obtained under a contract for the sale of a building for a fixed time, given at the request of the defendants, was consideration for a guarantee by the defendants to buy back the shares at a particular price if the market price was lower than that price (see ibid 628-631 (Scarman L)). 


\section{ff) Rule 3: Consideration of the Promisee}

The third requirement is that consideration must 'move from the promisee' and means that it has to be provided by the promisee, not by a third party, ${ }^{697}$ in order for it to be enforceable. ${ }^{698}$ In accordance with the definition of consideration given above, consideration can be either a detriment suffered by the promisee, or a benefit conferred by him. ${ }^{699}$ It is noteworthy that while the consideration has to come from the promisee, it need not have to be given to the promisor: as noted above, something given or promised to a third party constitutes consideration. ${ }^{700}$

\section{b. Form Requirements in English Law}

While a legal system may foresee a range of requirements for a valid and enforceable contract, formalities require a specific form or method. ${ }^{701}$ This can be contrasted with the general 'outward conduct' that is expected from the parties, namely, that of offer and acceptance having been made. ${ }^{702}$ In

697 McKendrick (fn 48) 230. It is sufficient that part of the consideration is provided by the promisee and another by a third party, Treitel/Peel (fn 65) para 3-023. cf Morley $v$ Boothby (fn 292) 457 (Best CJ), in which it is stated in relation to a guarantee that it is not necessary for the guarantor (promisor) to provide consideration, but that either the person for whom the guarantee is provided (principal) or the creditor (promisee) do so. For a more extensive discussion on this, see Geraldine Andrews and Richard Millett, Law of Guarantees ( $7^{\text {th }}$ edn, Sweet \& Maxwell 2015) 31-34.

698 Treitel/Peel (fn 65) para 3-023. Again, a deviation is found in commercial settings, see Goode and McKendrick (fn 48) 5 at 1.04.

699 Treitel/Peel (fn 65) para 3-025.

700 McKendrick (fn 48) 230.

701 Compare Cartwright (fn 181) 111 para 4-01, who speaks of the procedure that ought to be followed. See in this sense entry number 5 for the term 'form' in the Oxford English Dictionary Online at www.oed.com. cf Treitel/Peel, ibid para 5-001, who limits the scope of form to recording or labelling.

702 According to Cartwright (fn 181) 112 para 4-02, offer and acceptance is the mechanism through which a contract comes into being, but it is not a formality. This is apparently also true of the physical handing over of things, which, despite being a way to effect a transfer of property, is no formality requirement, since no one method is prescribed. Having said this, delivery may in some instances be the way to transfer legal ownership other than by deed, see Clarke and others (fn 99) 80. On the transfer of property by delivery relating to gifts - which are said not to be even unilateral contracts - see Bridge, 'Property' (fn 182) 171-172. On negotiable instruments, see Clarke and others, ibid 655. 


\section{B. Comparative Background}

this sense, as was already mentioned above, contracts are sometimes categorised according to the mode of formation as either 'simple' (any form) or 'speciality' (in deed form) contracts. ${ }^{703}$ An identical way of classifying contracts but using different labels is to contrast contracts in deed form and all other contracts, termed parol contracts, irrespective of whether they are made orally, in writing, ${ }^{704}$ or by conduct. ${ }^{705}$ Finally, contracts may be more widely categorised as those made under seal (including deeds) and those 'made under hand only', ie, in writing or evidenced in writing. ${ }^{706}$

There are several instances in English contract law in which a particular form is prescribed for an agreement. ${ }^{707}$ It should be borne in mind, however, that these cases constitute exceptions to the general rule of formlessness in English contract law. ${ }^{708}$ It is due to this deviation that particular requirements have been imposed on documents in order for these to be legally valid. The situations which are regulated as well as the methods (modes) are diverse. Similarly, the consequences may vary: The form requirement may be a substantive one, rendering the undertaking without legal effect if not observed, ${ }^{709}$ or it may simply have evidentiary character, so that it relates to the enforceability of the contract. ${ }^{710}$ These types relate to the three aims that are typically used to justify form requirements:

For further details on how to effect delivery, see Clarke and others, ibid 78, and Bridge, ibid 172-174.

703 See Halsbury's Laws Vol 9 (fn 33) paras 210, 212.

704 Cartwright (fn 181) 112 in fn 5. Interestingly, the authority cited by him states the division as between contracts under seal and those 'which are not', see Beckham v Drake (1841) 9 Meeson and Welsby 79 (Exchequer), 152 ER 35, 40 (Abinger L). Sealing will be discussed in Section iv. below.

705 Halsbury's Laws Vol 9 (fn 33) para 214 note 3.

706 See ibid paras 214, 209; Halsbury's Laws Vol 32 (fn 62) paras 201, 339, 341.

707 There are, at the same time, instances in which formlessness is explicitly allowed, see, eg, s 54 subs 2 LPA 1925: leases for a duration of up to three years can be concluded orally.

708 One reason behind this may be the importance placed in English law on the autonomy of contracting parties, especially when these are merchants. Compare Griffith and Harrison (fn 26) 657. On the written form having been viewed as something deviating from the general common law rules in the past, see fn 302 above.

709 This is true for the requirement of consideration, discussed in the previous section. While perhaps not truly a formality, it does at least seem to fulfil a similar function, in that it raises the question of whether the parties have agreed on a bargain, but not how this was done. See on this Cartwright (fn 181) 112 in fn 4 and 134 para $4-15$.

710 See ibid 111 para 4-01. 
cautionary, ensuring the parties' awareness of the legal (trans)action; evidential as to the existence and content (terms) of a contract; labelling, so that third parties can know what kind of contract it is and what its consequences are. ${ }^{711}$ Related to these aims, it can be stated at the outset that the stringency of the regulation depends on the situation envisaged. Thus, in contrasting commercial and consumer contracts, regulation of the former is normally more lenient, but stricter for the latter. Reasons for this difference are commercial convenience (cost of time and money) on the one hand and better protection of the consumer on the other. ${ }^{712}$ Where no form is prescribed by law, the parties may nevertheless choose to use one, the reasons for which may be manifold: to obtain an advantage that a chosen form entails, ${ }^{713}$ such as the evidentiary weight, the enforceability against or by third parties, ${ }^{714}$ or the limitation period $;{ }^{715}$ or simply for commercial convenience. ${ }^{716}$

This section will analyse the different forms found in English contract law and their application. First, a brief note will be made on the classification of things in the English legal system in Section i. below, as this has a bearing on the kinds of formalities that are required. Subsequently, the different methods and the consequence(s) in case of their non-fulfilment will be explored: writing (in Section ii.), deeds (Section iii.), the signs used

711 These aims were set out by the Law Commission in relation to deeds; they may, however, be said to be of more general validity. See Law Commission, Transfer of Land: Formalities for Deeds and Escrows (Working Paper No 93, 1985) 4-5 at 3.2. Instead of labelling, the third aim is sometimes stated as being that of channelling, see, eg, Law Commission, Transfer of Land: Formalities for Deeds and Escrows (Law Com No 164, 1987) 7 at 2.11. For further references and discussion of these reasons, see Cartwright (fn 181) 113-115 para 4-03.

712 Compare the statement made in Golden Ocean v Salgaocar (fn 413) [28] (Tomlinson $\mathrm{LJ}$ ) that '[i]t is in the interests of those who deal with consumers to keep the documentation clear and simple, otherwise they may find that the cost and complexity of attempted enforcement outweighs the potential benefit.'

713 See Cartwright (fn 181) 111 para 4-01, who also names optional formalities as sometimes being alternatives to substantive requirements.

714 Compare Andrews and Millet (fn 697) 43 at 2-021, who name a deed poll, under which the benefiting third party may enforce the deed against the executing party. See further Halsbury's Laws Vol 9 (fn 33) para 211.

715 For example, a deed running twelve years in contrast to six years for simple contracts, see s 8 and s 5 Limitation Act 1980 respectively. For further details on the limitation period for deeds, see Andrews and Millet (fn 697) 43 at 2-021, 325-329 at 7-012 et seq.

716 See Griffith and Harrison (fn 26) 655, noting recording as a reason for both efficiency and certainty in transactions. 


\section{B. Comparative Background}

to authenticate a document (Section iv.), and electronic forms (Section v.). Other formal requirements, namely, registration of title to land and stamp tax, are considered in Section c.

Before addressing these topics, an issue that sometimes arises with what are known as 'subject to contract' clauses will be discussed briefly. ${ }^{717} \mathrm{Hav}$ ing said that particular forms are sometimes prescribed by law, the parties are of course free to agree - in other instances - on formalities which ought to be observed before an agreement is seen as binding and enforceable. ${ }^{718}$ In one case, Eccles $v$ Bryant and Pollock, ${ }^{719}$ the parties had agreed on the sale of a house 'subject to contract'. The documents were drawn up, but their exchange was not completed. The issue was whether an exchange of formal contractual documents had formed part of the parties' intention or whether signing without the exchange had concluded the contract. Greene LMR stated: 'Parties become bound by contract when, and in the manner in which, they intend and contemplate becoming bound.' 720 The court went on to find that in this case the parties' contemplation 'was the ordinary, customary, convenient method of exchange. 721 As a consequence, the purchaser, in not posting his signed contract, refused to exchange contracts, and it was held that no contract had formed.

The existence of a subject to contract clause will not, however, be conclusive. This is illustrated by Storer $v$ Manchester City Counci $7^{722}$, in which a contract was held to have been concluded despite the contract form containing a subject to contract clause. The reason given was that the defendant's objective in providing the form was 'to dispense with legal formalities'. ${ }^{723}$ In contrast, where there is no express clause, the court will not infer such an intention readily. ${ }^{724}$

717 For further details on this issue, see Treitel/Peel (fn 65) paras 2-090, 4-011 et seq.

718 This has been called 'formality as choice' in order to obtain certain benefits as opposed to statutory (mandatory) formality requirements by Cartwright (fn 181) 129 para 4-10.

719 [1948] Ch 93 (CA).

720 Eccles v Bryant (fn 719) 104 (Greene LMR).

721 Ibid.

722 See fn 420 above.

723 Storer v Manchester City Council (fn 420) 1408 (Denning LMR). Another reason, despite not stated explicitly, was a policy consideration: The defendant's refusal to complete the contract was due to a change in local (political) policy. See ibid 1406 (Denning LMR).

724 A recent example is the case of Dayman $v$ Anfield Services Ltd [2006] EWHC 2937 (QB), 2006 WL 3485359 (official transcript). The issue was whether a contract on the transfer of a share in a taxi license had been concluded through an 


\section{i. Excursus: The Classification of Things in English Law}

The way English law classifies objects differs from that of other legal systems, in particular those of continental Europe. This is because objects are not grouped into movable and immovable property, which is a distinction derived from Roman law. ${ }^{725}$ Instead, English law has traditionally divided things into real and personal property, sometimes also termed realty and personalty respectively. ${ }^{726}$ Personal property is a residual class, since everything that is not realty (land) is personalty (chattels). ${ }^{727}$ The first step is therefore to see what the term 'land' means.

A short definition of 'land' can be found in sch 1 Interpretation Act 1978 , according to which the term 'includes building and other structures, land covered with water, and any estate, interest, easement, servitude or right in or over land'. The definition contained in s 205 subs 1 (1)(ix) Law of Property Act 1925 ('LPA 1925') is more detailed. It states:

'Land' includes land of any tenure, and mines and minerals, whether or not held apart from the surface, buildings or parts of buildings (whether the division is horizontal, vertical or made in any other way) $[\ldots]$; also $[\ldots]$ a rent $[\ldots]$, and an easement, right, privilege, or benefit in, over, or derived from land; ... and "mines and minerals" include any strata or seam of minerals or substances in or under any land, and powers of working and getting the same $[\ldots]$.

Thus, land includes the ground itself, and all that is fixed to it, or beneath and above it, in other words: from the core of the earth to the heavens. ${ }^{728}$ Consequently, plants, such as timber or crops, are deemed as being part of land if grown naturally; otherwise, if they are fructus industrialis, they will

exchange of correspondence. Seymour J held at [33], [27], [39]-[40] that it had and rejected the claimant's argument that the agreement had been made subject to contract. While a formal document had been drawn up, discussions ensued over one point, so that it was never signed by both parties, but only by the claimant.

725 See Bridge, 'Property' (fn 182) 20-21, explaining succinctly how the other classification is applied in English choice of law rules.

726 Ibid.

727 Ibid 10 and 12, who goes on to give a brief historical explanation for this distinction at 11-12.

728 See Kate Green and Joe Cursley, Land Law ( $5^{\text {th }}$ edn, Palgrave Macmillan 2004) 8,48 . 


\section{B. Comparative Background}

be treated as separate things. ${ }^{729} \mathrm{~W}$ ithin this category, a distinction is made between land itself and fixtures of land.

An issue that may arise in relation to fixtures is whether these are attached to the land so as to form part of it or whether these remain separate chattels. ${ }^{730}$ The answer depends on two things: the method and degree to which the thing in question is attached to the land; and for what purpose it is attached, whereby the second limb is of greater importance than the first. This was laid down by the CA in the case of Berkley $v$ Poulett $^{731}$, in which pictures affixed to a wall panelling were not held to be fixtures but chattels, as the purpose of attaching them to the land were to better enjoy them, not to improve the land; while a statute standing on a plinth and a sundial on a pedestal, neither attached, were equally held to be chattels. ${ }^{732}$ Irrespective of whether a thing is attached to land in some way, if it cannot be removed without doing damage to the land or suffering damage (or destruction) itself, it will become a fixture, or part and parcel of the land..${ }^{73}$ Consequently, buildings will usually form part of the land that they are erected on; unless they can be dismantled and erected in a different place. ${ }^{734}$

In this way, an object forming part of land can become a chattel upon being severed from the land, ${ }^{735}$ such as crops or wood being cut down. Thus, the distinction between real and personal property can be illustrated as follows: for the purposes of the Law of Property (Miscellaneous Provisions) Act 1989 ('LPMPA 1989'), a sale of naturally grown crops or timber will be a sale of an interest in land if property in these crops is to pass before having been severed from the land; whereas it will be a sale of goods if the crops are severed from the land before property passing, which

729 Compare Halsbury's Laws of England Vol 23 ( $5^{\text {th }}$ edn, LexisNexis 2016) para 32.

730 Only a rough sketch can be provided here. Readers interested in further details are referred to, eg, Bridge, 'Property' (fn 182) 127 et seq.

731 [1977] 1 Estates Gazette Law Reports (EGLR) 86 (CA); (1977) 241 Estates Gazette (EG) 911; [1976] EWCA Civ 1 [12]-[13] (Scarman LJ).

732 Ibid [14]-[15] (Scarman LJ), [41], [43] (Stamp LJ).

733 In ibid [13] (Scarman LJ), it was held that 'serious damage' or destruction of even part of land due to removal of something makes that thing a part of land. As to damage to the thing, see Elitestone Ltd $v$ Morris [1997] 1 WLR 687 (HoL), 690-693 (Lord Lloyd), 697-699 (Lord Clyde), which concerned a wooden bungalow resting on a concrete foundation and despite this was found to have become part and parcel of the land.

734 This was suggested by Lord Clyde in Elitestone Ltd v Morris (fn 733) 699.

735 Bridge, 'Property' (fn 182) 13. 
will then fall within the scope of the SGA $1979 .{ }^{736}$ Presumably, if the crops are produced (cut) before contracting, the time of property passing becomes irrelevant in this sense, as the sale will in no case be a sale of land, but a sale of chattels.

Coming back to personal property, chattels are divided into chattels real and chattels personal. The former basically consists of leases (leasehold interests), whereas the latter are again a residual class encompassing all chattels that are not real. ${ }^{737}$ These are then divided further into things (traditionally referred to as 'choses') in possession and things in action. ${ }^{738}$ The former are all tangible or corporeal things that can be physically possessed, such as clothes or vehicles, while the latter are any thing intangible or incorporeal, such as debt, company shares, bills of lading, or intellectual property. ${ }^{739}$ Issues have arisen in recent times on the classification of digital items such as software, and, in particular, whether these can constitute goods in contract of sales. It seems that the common law and English legislation currently do not recognise software by itself as property capable of constituting goods. ${ }^{740}$ Intangible things such as software, information, and electricity are therefore regularly not goods. ${ }^{741}$

736 Halsbury's Laws Vol 23 (fn 729) para 32, giving further references. The intention for a sale of goods may be demonstrated if the contract foresees, eg, that the seller is to harvest or fell and deliver the crops or trees. See on this ibid.

737 See Bridge, 'Property' (fn 182) 12.

738 Ibid 12-13.

739 For further details, see ibid 13-20, in particular on the further distinction made between 'pure intangibles' (eg, debt) and 'documentary intangibles' (eg, bills of lading).

740 This was held in an obiter dictum by Glidewell $\mathrm{J}$ in St Albans City and DC $v$ International Computers Ltd [1996] 4 All ER 481, [1997] Fleet Street Reports (FSR) 251 (CA), 265-266, in which software was held to constitute goods within the meaning of the SGA 1979 only when contained on a physical device like a computer disc. While not constituting binding authority, the CA has recently held software not to be goods within the meaning of another piece of legislation, the Commercial Agents (Council Directive) Regulations 1993, SI 1993/3053, see Computer Associates UK Ltd v The Software Incubator Ltd [2018] EWCA Civ 518, 2018 WL 01382596 (official transcript) [21] et seq (Gloster LJ). Indeed, as the court noted at ibid [64]-[65], [67], the CRA 2015 'opted to create a sui generis obligation - the supply of digital content - rather than widening the meaning of "goods." (original emphasis). In effect, digital products and goods are thus kept separate in relation to consumers as well, see $s 2$ subs 8-9 CRA 2015. See also Treitel/Peel (fn 65) para 7-088, who note that a contract for digital content and goods or services makes a mixed contract.

741 See on this Clarke and others (fn 99) 302-303 for the SGA 1979. cf s 2 subs 8 CRA 2015, which allows electricity, water, and gas to be goods 'if they are put 


\section{B. Comparative Background}

Two terms appearing in the definition of land given above will be explained briefly before leaving the topic of property: 742 'estate' and 'interest' both relate to the English concept of ownership in land, which is legally complex. Rather than one or several persons together simply owning something, the correct legal term is to say that someone has an interest in real property. ${ }^{73}$ There are two greater interests, properly called estates, namely, the freehold and the leasehold, and several lesser interests, such as rights of way (a type of easement) or mortgages. ${ }^{74}$ Interests can be of legal or equitable nature, ${ }^{745}$ but relate directly to the land, not its 'owner', so that the rights or obligations arising from interests in some particular real property pass onto the new 'owner' due to being attached to the property itself. ${ }^{746}$ Thus, taking the example of an apartment owner, who rents it out, the land lord has the freehold estate and retains the title of ownership, ${ }^{747}$ while the tenant has the leasehold and will be in possession of the apartment during the term of the lease. ${ }^{78}$ With these terms and denominations in mind, the different form requirements will now be analysed.

up for supply in a limited volume or set quantity.' cf also Saidov and Green (fn 111), who analyse software in terms of the requirements of goods to be tangible and moveable and argue that it ought to be allowed to be goods under the SGA 1979 and the CISG in the right circumstances, but in the end call for an international instrument on the matter.

742 For a brief explanation of the whole definition, see, eg, Green and Cursley (fn 728) 9.

743 See ibid 3.

744 Ibid 10, 9.

745 In s 1 LPA 1925, an exhaustive list of the legal estates and interests in English law is given. Equitable interests are any other interests (s 1 subs $3 \mathrm{ibid}$ ).

746 Green and Cursley (fn 728) 10-11. The distinction is important not only because different remedies are available, but because enforcement of the interest may be (im)possible, see ibid 11-12.

747 In English law, the concept of property rights is a relative one. Thus, ownership can be described as 'the best available possessory right'. It is viewed as a bundle of rights, including the rights to possess and enjoy the object and its fruits. Consequently, where rights concerning the object are granted to other persons, the owner basically retains the other remaining (residual) rights over the object. See Bridge, 'Property' (fn 182) 30, 45, 46, and, more generally, ibid 43-48.

748 Possession is a factual state under English law, legally consisting of factual control over an object and the intention to exclude other persons from exercising such control. See Bridge, 'Property' (fn 182) 33 and 32-43 for further details on the concept. 


\section{ii. Written Forms: Standard Written Form and Evidence in Writing}

The first and perhaps most basic kind of form requirement relates to a contract being in written form. In English law, two methods must be distinguished: legislation may either require an agreement to be 'made in writing' or to be simply 'evidenced in writing'. The difference between these two forms will be discussed by briefly analysing the requirements for each in Section aa). Examples of situations in which these forms are required are then given in Section bb).

\section{aa) The Requirements of Writing and of Evidence in Writing}

As the terminology already suggests, the difference between the written and the written evidence form is that the former requires a document that contains the contract, whereas a memorandum of an agreement that has been either previously or subsequently reached through other means, ie, orally, suffices for the latter. ${ }^{749}$ The liberalism of the requirement of a memorandum becomes apparent when considering that the note need not even be made in order to satisfy the evidentiary purpose, so that a letter from one party to their agent or a written offer that is accepted orally are both equally sufficient. ${ }^{750}$ Unless provided for otherwise by statute, the generally applicable definition of the interpretation of 'writing' is that it 'includes typing, printing, lithography, photography and other modes of representing or reproducing words in a visible form [... ${ }^{7}{ }^{751}$

A written contract is deemed to indicate a stronger intention of the parties to contract; ${ }^{752}$ however, it has been stated that this form requirement

749 On the latter, compare the wording of s 4 Statute of Frauds 1677 ('SOF 1677'), speaking of an agreement in writing on the one hand, and a memorandum or note of the same on the other. On the time of creation of the latter document, see Treitel/Peel (fn 65) para 5-025.

750 See Treitel/Peel (fn 65) para 5-025.

751 Section 5, sch 1 Interpretation Act 1978. Sometimes, a statutory provision will reiterate the definition of what 'writing' constitutes, see, eg, s 2 BEA 1882. The question whether electronic documents fall within this definition will be discussed in Section v. below.

752 This has been indicated indirectly by the courts in, eg, Pao v Lau (fn 88) 631 (Scarman L): 'It matters not whether the indemnity thus given be regarded as the best evidence of the benefit intended to be conferred in return for the promise not to sell, or as the positive bargain which fixes the benefit on the faith of which the promise was given - though where, as here, the subject is a 


\section{B. Comparative Background}

may not be an efficient caution to persons considering whether to enter or about to enter into a contract. The reason is said to be that it does not to pose a 'significant hurdle' for parties, since it forms an integral part of our everyday lives. ${ }^{753}$ If this is true for the requirement of writing, it must be equally, if not even more strongly applicable to instances of evidences in writing, seeing as the contract itself will often have been concluded orally and been put into writing only later. Indeed, it seems that a written document traditionally only had an evidentiary, rather than a dispositive function. ${ }^{754}$

This danger inherent in both methods could explain why a statute may not simply foresee for something to be made in writing, but to prescribe other details. ${ }^{755}$ At a minimum, this will normally include a signature. ${ }^{756}$ Furthermore, what were known as contracts under seal had to bear a seal impression. ${ }^{757}$ Rather than an additional act being required, particular phrases or manners of expression for the text may be prescribed for a written document. ${ }^{758}$ Other provisions for a document's content may be made, for example, a written contractual document may have to contain all express terms of the agreement. ${ }^{759}$ Similarly, the common law required that the inducement or consideration for a contract be stated in a written

written contract, the better analysis is probably that of the "positive bargain' (emphasis added). A written document thus aids the courts to find a bargain or an agreement.

753 See Cartwright (fn 181) 116, who says it does not 'make the parties stop and think'.

754 Simpson, 'History' (fn 232) 15-16.

755 Cartwright (fn 181) 116.

756 Ibid 117 in fn 21. An exception is found in, eg, reg 4 (1) Financial Collateral Arrangements (No 2) Regulations 2003 (SI 2003/3226), which disapplies several statutory provisions requiring evidence in writing of more than financial collateral arrangements (on which see reg 3). Signing is discussed in Section iv. below.

757 Halsbury's Laws Vol 9 (fn 33) para 282. Sealing is also discussed in Section iv. below.

758 A classic example is a deed, which has to state 'on its face that it is intended to be a deed' (s 1 subs 2 para a LPMPA 1989). Further examples in relation to consumers (information duties) are given by Cartwright (fn 181) 119.

759 See, eg, s 2 subs 1 LPMPA 1989. As has been mentioned above in fn 173, this provision does not apply to actual land conveyance documents (executed contracts; regulated in ss 51-55 LPA 1925), but only to agreements to sell (executory contracts). As regards guarantees, see Andrews and Millet (fn 697) 68 para 3-022 and 71 para 3-023, who go on to note at 73 that the parties must be identified. 
contract. ${ }^{760}$ Sometimes, requirements in relation to a document evidencing a contract can be greater than for the written contract. ${ }^{761}$ Conversely, it is at least true for memoranda of agreements of guarantee that these may be contained not in a single document but in a series of these, if all of them are signed by the guarantor. ${ }^{762}$ Details on the signature and seal will be given in Section iv., after a particular form of written documents, the deed, has been discussed in Section iii.

\section{bb) Instances of the Written and the Written Evidence Forms}

There are only few situations in which writing or a memorandum are required for contracts in English law. Two typical examples of the written and the written evidence forms are s 2 subs 1 LPMPA 1989 (Contracts for sale etc of land to be made by signed writing) and s 4 SOF 1677 (Contracts of guarantee) respectively, which not only require a document or memorandum, but that these be signed. ${ }^{763}$ Other examples of signed writing being required are bills of exchange ( 3 subs 1 BEA 1882) and consumer credit agreements ${ }^{764}$ (s 61 Consumer Credit Act 1974).

760 Morley $v$ Boothby (fn 292) 456-457 (Best CJ): There is no set form; however, there must be 'clearness enough for the courts to judge [on the consideration's] sufficiency'. At least for guarantees, this is no longer necessary (s 3 Mercantile Law Amendment Act 1856). For a discussion of the issue of proving consideration, see Andrews and Millet (fn 697) 42-43 at 2-020.

761 This is the case with a guarantee, for example. In a similar fashion to conveyances and agreements to sell land, the courts have distinguished between guarantees concluded in written form and those which are only recorded in writing after having been concluded: The latter must contain a statement to the effect that the guarantor acknowledges the contract. See Golden Ocean v Salgaocar (fn 413) [24] (Tomlinson LJ).

762 See Andrews and Millet (fn 697) 69 para 3-022.

763 For further discussion of s 2 LPMPA 1989, see, eg, Treitel/Peel (fn 65) para 5-009; Halsbury's Laws Vol 22 (fn 172) para 224. For the SOF 1677, see, eg, Cartwright (fn 181) 117-118 para 4-05. For guarantees, see, eg, Andrews and Millet (fn 697) 2-10 paras 1-004 et seq. On the purpose of the SOF 1677, see, eg, Golden Ocean v Salgaocar (fn 413) [21], [29] (Tomlinson LJ). Note that s 53 subs 1 LPA 1925 seems to be applicable to equitable dispositions of (interests in) land, compare Halsbury's, ibid, para 226.

764 Section 8 subs 1 Consumer Credit Act 1974 provides that these are 'agreement $[s]$ between an individual ("the debtor") and any other person ("the creditor") by which the creditor provides the debtor with credit of any amount.' 


\section{B. Comparative Background}

iii. Special Instrument: Deed

Rather than a simple written form, a handful of special kinds of documents developed throughout the history of English law. In essence, these documentary instruments fulfil particular requirements as to their style or content. Focus in this dissertation will be on the deed, the perhaps most prominent and important of these instruments in transactions. ${ }^{765}$ It can also be termed the most formal requirement in English law. Its requirements (see Section aa) below) and examples of situations in which a deed is necessary (Section bb)) will be examined subsequently.

\section{aa) Requirements of Deeds}

Contracts that are made in the form of a deed are traditionally and formally referred to as 'contracts under seal' or 'by speciality'. ${ }^{766}$ This terminology may have been derived from the formalities applicable to this special kind of document. They relate to several aspects, namely, the intention of the party or parties in making the instrument, its form (execution), and its content.

In terms of intention, the instrument must be meant to be a deed ( $s$ 1 subs 2 (a) LPMPA 1989). While use of the word 'deed' is not required, 'what is needed is something showing that the parties intended the document to have the extra status of being a deed' ${ }^{767}$ Interestingly, the fact that a document is 'executed under seal' does not on its own satisfy s 1 subs

765 Other instruments include bonds and instruments under hand only. On these, see Halsbury's Laws Vol 32 (fn 62) paras 289 et seq and paras 339 et seq respectively.

766 Halsbury's Laws Vol 9 (fn 33) para 210. Having said this, a deed is not the only contract under seal, but one important form. Another example is a will, or a document signed and sealed by a company director, see Halsbury's Laws Vol 32 (fn 62) para 201.

767 HSBC Trust Co (UK) Ltd v Quinn [2007] EWHC 1543 (Ch), 2007 WL 1942791 (official transcript) [51] (Nugee QC). The case concerned an alleged sale of land between a third party (decedent) and the claimant. The defendants were the executors of the decedent's will. In that case, an intention for a written endorsement on a valuation of the property to be a deed was rejected by the court, although it was not denied that the document was meant to be void of legal effect, see ibid at [48]-[49], [51] (Nugee QC). 
2 (a) LPMPA 1989 (s 2A LPMPA 1989), whereas formerly, ie, before the LPMPA 1989, deeds had to be sealed in order to be validly executed. ${ }^{768}$

The requirements as to the valid execution of a deed are set out in $s$ 1 subss 3 et seq LPMPA 1989. Accordingly, a deed must be signed by an individual before a witness ${ }^{769}$ (ibid subs $3(\mathrm{a})$ ) and be delivered (ibid subs 3 (b)). Contrary to what one might expect, the latter requirement does not mean physical delivery, but rather that the signing person has the intention to be bound by the deed. This must be shown by some act - arguably one other than signing, ${ }^{770}$ whereby this act or conduct can be express or even implied. ${ }^{771}$ In practice, this seems to be the case when a solicitor enters a date into a deed instrument that has already been signed, as this addition apparently shows that the deed has been adopted by the signatory. ${ }^{772}$ Formerly, the party making the deed would speak some words affirming that the instrument was their 'act and deed' while holding a finger over the seal on the deed; a practice that seems to have gone out of use today. ${ }^{773}$

Finally, as for the content of a deed, it has been stated that it must 'purport to convey property, title, interest, or authority', or at least confirm the passing of an interest or property. ${ }^{774}$ Initially, the common law rule was that a deed had to be written on parchment or paper, not on other materials such as wood or cloth, as the former were deemed less corruptible. ${ }^{775}$ Nevertheless, even seemingly more durable materials such as stone or steel were not permissible. ${ }^{776}$ These restrictions - like those on the form of deeds - were abolished by s 1 subs 1(a) LPMPA 1989. A deed need not be written on individual sheets of paper, but may be recorded in a book, using any marking material such as ink, graphite, or

768 See Bridge, 'Property' (fn 182) 174. See further Section iv. below.

769 Where the person does (can) not sign themselves, the deed can be signed by someone else instead at the person's 'direction and in his presence' (s 1 subs 3(a)(ii) LPMPA 1989). In this case, two witnesses need to be present (ibid). These provisions do not apply to companies, see ibid subs 10 .

770 See Bridge, 'Property' (fn 182) 175.

771 Halsbury's Laws Vol 32 (fn 62) para 231.

772 Green and Cursley (fn 728) 28.

773 Halsbury's Laws Vol 32 (fn 62) para 231.

774 Reg v Morton (1872-75) LR 2 Court for Crown Cases Reserved (CCR) 22 (Criminal Appeal Court), 27 (Bovill CJ).

775 See Cartwright (fn 181) 119 in fn 34.

776 Halsbury's Laws Vol 32 (fn 62) para 202. 


\section{B. Comparative Background}

paint; any mode of recording, including handwriting, printing (including lithography), or even photography; and even any language or characters. ${ }^{777}$

bb) Instances of Deeds

The most prominent use of deeds in practice today is in transactions relating to land. This includes ${ }^{778}$ conveyances, ie, the transfer of property of land, and leases for more than three years, both of which are void at law if not contained in a deed (see s 52 subss 1, 2(d), s 54 subs 1 LPA 1925). This is in stark contrast to leases whose term is for less than three years, which can be concluded orally (s 54 subs 1 ibid). ${ }^{779}$ Instances of a deed being required other than in relation to land include another kind of document of importance in contracting, namely, powers of attorney (s 1 subs 1 Powers of Attorney Act 1971). A deed may furthermore be used in connection with gratuitous transactions, ${ }^{780}$ ie, gifts. ${ }^{781}$ This is necessary where a gift is made of tangible goods (choses in possession) and the goods are not delivered at the time of making of the gift. ${ }^{782}$ In this regard, a promise of a gift does not become binding until the deed is created; or, alternatively, until the gift is otherwise executed, such as through delivery of the object. ${ }^{783}$

Apart from the prerequisites just described, another important difference exists between deeds and the other documentary forms discussed in the previous section: a deed on its own is sufficient to render a contract binding, while the latter constitute a requirement that has to be fulfilled in addition to those of offer, acceptance, consideration, and contractual intention. ${ }^{784}$ In other words, a contract which does not have to take the form of a deed and which fulfils all criteria except for having been made or being evidenced in writing may be held to be unenforceable in court, although the agreement itself may still be valid. ${ }^{785}$ Whether the agreement

777 See ibid with further references.

778 Other examples, such as mortgages, can be found in ibid para 214.

779 For further discussion, see Green and Cursley (fn 728) 28.

780 This use is stipulated in $s 1$ subs 2 (d) SGSA 1982, according to which such instruments are not covered by the stipulations of the Act.

781 Reg $v$ Morton (fn 774) 27 (Bovill CJ).

782 On this, see Halsbury's Laws Vol 32 (fn 62) para 213.

783 See Bridge, 'Property' (fn 182) 171.

784 See Treitel/Peel (fn 65) para 5-002; McKendrick (fn 48) 259.

785 Stone (fn 429) 33-34. 
is void depends on the statutory provision in question. ${ }^{786} \mathrm{An}$ example for voidness is s 2 subs 1 LPMPA 1989 regarding 'contract[s] for the sale or other disposition of an interest in land', which are to be made in writing (see Section ii. above). ${ }^{787}$ Bills of exchange that do not fulfil the requirements set out in the BEA 1882 are not invalid, but will not be regarded as bills of exchange, ${ }^{788}$ and as such will not display the effects of these bills. ${ }^{789}$ Similarly, contracts of guarantee not in writing or at least evidenced in written form are not invalid, only unenforceable (s 4 SOF 1677). ${ }^{790}$ Where the agreement is not void, it can still be enforced outside the courts, eg, if the other party recognises their liability. ${ }^{791}$

\section{iv. Signing and Sealing}

The requirements that a written document be either sealed or signed has long tradition in English contract law. ${ }^{792}$ Having said this, there was a period of 75 years during which a particular instrument had to be both signed and sealed: a deed. ${ }^{793}$ This rule was changed with effect from 1990, and the regulation now varies slightly depending on whether the party is an individual or (forms part of) a legal entity. This will be discussed further below. First, the terms 'signature' and 'sealing' will be defined.

786 Whincup (fn 34) 108 para 4.4.

787 Although the provision does not state this consequence, McKendrick (fn 48) 262 deduces it. of Treitel/Peel (fn 65) para 5-011: the contract 'does not come into existence' if the statutory requirements are not met.

788 Section 3 subs 2 BEA 1882.

789 In other words, they cannot be negotiated (transferred, s 31 subs 1 BEA 1882). Compare Treitel/Peel (fn 65) para 5-006. For details on negotiability, see ibid paras 15-046-15-049.

790 See on this further Treitel/Peel (fn 65) para 5-027.

791 Arthur T von Mehren, Chapter 10: Formal Requirements, in: David and others (fn 21) Vol VII/1 52-53.

792 Sealing will be explored in more depth in Section D.III.2.b. below.

793 This was required by s 73 subs 1 LPA 1925, which was repealed by s 1 subs 1 LPMPA 1989. See on this Halsbury's Laws Vol 9 (fn 33) para 282 and Halsbury's Laws Vol 32 (fn 62) para 201. See also the previous section. 
aa) 'Signing' and 'Sealing' Defined

While there is no exact statutory definition, a signature is recognised as a physical mark on a document indicating consent to the document's content, ${ }^{794}$ so that anything from an 'X', over a person's initials, to one's full name is sufficient, whereby it may be written by hand, stamped, typewritten, or printed. ${ }^{795}$ Indeed, s 1 subs 4 LPMPA 1989 provides that 'signing' generally 'includes making one's mark on the instrument'. It is not the form, but the intention with which the signature is made, namely, that the signatory accepts the content and intends to be bound by it (authenticates the document), that is important. ${ }^{796}$ Thus, a signature need not be personalised, ${ }^{797}$ or even forgery-proof, ${ }^{798}$ so that even 'a pseudonym or a combination of letters and numbers' can be sufficient, provided that these are used with the intention to function as a signature. ${ }^{799}$ Similarly, where a person is represented through an authorised person, this person may sign in their own name or in the name of their principal. 800

794 See Griffith and Harrison (fn 26) 654. Compare s 1 subs 4 LPMPA 1989.

795 See Law Commission, 'Electronic Commerce' (fn 502) 12-13 at 3.25 with further references to case law. Similarly, the court in the case of Mackenzie $v$ Coulson (fn 65) 374 (Sir James Vice Chancellor) held that writing one's initials on a slip of paper meant that the persons (underwriters) were willing to be bound by the terms (of an insurance policy) stated on the paper.

796 See Griffith and Harrison (fn 26) 654; Law Commission, 'Electronic Commerce' (fn 502) 13 at 3.26.

797 Law Commission, 'Electronic Commerce' (fn 502) 13 at 3.25.

798 Griffith and Harrison (fn 26) 654.

799 See J Pereira Fernandes SA v Mehta [2006] EWHC 813 (Ch), [2006] 1 WLR 1543 [27] (Pelling J). In that case, the question was whether an e-mail, which did not contain a signature in the normal sense but showed the sender's e-mail address, was a signed memorandum for the purposes of s 4 SOF 1677. The court found this not to be the case. The argument will be discussed further in Section v. below.

800 Compare s 2 subs 3 LPMPA 1989 ('[... signed by or on behalf of each party'). This seems to be true at least for persons authorised by a power of attorney. It seems that solicitors may only sign on behalf of their client, and only when they have express authority to do so, see Halsbury's Laws Vol 23 (fn 729) para 186. Where more than one person is a client, express authority must be given from all, see Suleman $v$ Shahsavari (1989) 57 P\&CR 465 (HC Chancery Division). In this case, a married couple at first intended to sell their house and then changed their minds after contracts, purportedly signed on both their behalf by their solicitor, had been exchanged. The issue was whether the solicitor had been authorised. Although the court found the solicitor to have been expressly authorised by the wife, he found no authorisation of any kind from the husband, so 
Despite this liberalism, ${ }^{801}$ it is generally said that signing a document adds to the level of seriousness of an act, ${ }^{802}$ although — similar to the case for writing - the hurdle for this requirement is said to be low. ${ }^{803}$ Indeed, it might in some circumstances be dangerously low, as is exemplified by L'Estrange v F Graucob Ltd ${ }^{804}$. The case concerned the sale of a slot machine. The order form contained a number of terms, some of them in small print, including an exclusion of liability clause. The plaintiff signed the order form and failed in her case against the defendants for delivering a machine not fit for its intended purpose. The court's reasoning was that a person having signed a document cannot claim ignorance of its terms and thus not being bound. Indeed, knowledge of its contents was said to be irrelevant where a document was signed without fraud or misrepresentation by another party. ${ }^{805}$

As with signatures, there seems to be no statutory definition of a seal, or the act of sealing; rather, it seems to be a presupposed notion. ${ }^{806}$ Hereinafter, 'seal' will refer to the object used to leave an ink mark or an impression in other materials; 'sealing' or 'seal impression' will be used for the actual mark or impression made by the object. ${ }^{807} \mathrm{~A}$ seal is no longer necessary today, specifically not for a deed (s 1 subs 1 (b) LPMPA 1989; see also Section iii. above). Even before this statute came into force, it was held by English courts that a real seal impression was no longer necessary. It was sufficient instead for the document to show where the seal ought to

that the contract was not properly concluded, see ibid 473-475 (Andrew Park QC).

801 By way of example, the court in the case of Stidolph $v$ ASLET Ltd (fn 496) found the lack of a signature on a notice to have been healed by the notice having been sent together with a signed covering letter and a stamped and addressed envelope, which was deemed to be 'substantially to the like effect' of the form foreseen in the notice regulations to the Tenant and Landlord Act 1954 (see ibid at 803-805 (Denning L MR), 807 (Edmund Davies LJ, Cross LJ)).

802 Compare Cartwright (fn 181) 117 para 4-05. In Golden Ocean v Salgaocar (fn 413) [21], Tomlinson LJ noted that a signature was an acknowledgement 'of the solemnity of the undertaking'.

803 See Griffith and Harrison (fn 26) 654.

804 See fn 527 above.

805 L'Estrange v F Graucob Ltd (fn 527) 404 (Scrutton LJ), 405-406 (Maugham LJ).

806 Thus, eg, s 45 Companies Act 2006 (hereinafter 'CoA 2006') relates to the 'common seal' of companies but provides no explanation of what the term means. It merely states in subs 2 that such a seal should bear the company's name by having it engraved.

807 This follows the definitions used by Dominique Collon, 'Glossary', in: ibid, 7000 Years of Seals (British Museum Press 1997) 223-224. 


\section{B. Comparative Background}

be, eg, by having a circle with the letters LS (for locus sigilli) printed on it, and the signature being placed there. ${ }^{808}$

\section{bb) Instances of Signing and Sealing}

The instances requiring a signature include the provisions relating to land already mentioned above, namely, s 53 LPA 1925 (dispositions, declarations of trusts), s 2 LPMPA 1989 (contracts for sale) ${ }^{809}$, and s 4 SOF 1677 (guarantees). It becomes apparent from this enumeration that the requirement of signing normally accompanies that of writing. Under the LPMPA 1989 , the contract will come into existence when all parties ${ }^{810}$ have signed the contract document, or, as the case may be, a copy of the contract each that is exchanged with that of the other party. ${ }^{811}$ In terms of the consequences of the prescribed form not being fulfilled, at least guarantees are said to be unenforceable, but not void of effect inter partes. ${ }^{812}$

As for the employment of seals, the most prominent example is that of a deed. Since 1990, private persons are no longer required to seal deeds, although companies must still employ the company seal when executing instruments (s 74 LPA 1925), including deeds. ${ }^{813}$ Having said this, subsequent to the abolition in 1990 of the rule that companies must have a seal, ${ }^{814}$ and in case of companies formed under the Companies Act 2006 ('CoA 2006'), a signature by either two 'authorized signatories' or one

808 In First National Securities Ltd v Jones [1978] 2 WLR 475 (CA), [1987] Ch 109, the issue before the court was whether a mortgage had been duly executed as a deed. In the event, the instrument was titled legal charge, but contained the typical formulation of a deed at the end, in particular the words 'IN WITNESS whereof the mortgagor has hereunto set his hand and seal the day and year first before written' and 'SIGNED SEALED AND DELIVERED by the above-named mortgagor in the presence of [...]'. The purported mortgagor's (defendant's) signature was placed on top of the printed LS-circle for the seal. This was sufficient, see ibid 114-118 (Buckley LJ), 119-120 (Goff LJ), 121 (Sir David Cairns).

809 The distinction between contracts for sale (executory) and sales itself (executed contracts) was already discussed in fn 173 above.

810 In case of co-owners, co-trustees, or partners, one person may sign on behalf of the others, see Halsbury's Laws Vol 23 (fn 729) para 186.

811 See ibid paras 2, 185-186.

812 See, eg, Golden Ocean v Salgaocar (fn 413) [15] (Tomlinson LJ). For further discussion, see Andrews and Millet (fn 697) 7 at 1-007 and 89-91 at 3-028.

813 Halsbury's Laws Vol 32 (fn 62) paras 227, 232, 240.

814 See Andrews and Millet (fn 697) 43 at 2-021. 
director in the presence of a witness seems to suffice for the execution of contracts if the company does not have a seal (s 44 subss 1,2 CoA 2006). ${ }^{815}$ Where a company has laid down its own requirements for deeds in its articles of incorporation, these must be adhered to. ${ }^{816}$ Consequently, deeds executed by companies need not necessarily bear a seal. Where they do and this is not done, the document will not count as a deed, which in turn may mean that the transaction for which the deed ought to have been executed is invalid (compare Section iii.bb) above). ${ }^{817}$

A deed is not the only example of a sealed document. Legal entities, such as societies, or institutions such as the Church, may seal and sign documents executed by them, so that various kinds of certificates, such as a for admissions or awards, are not deeds despite bearing seal imprints. ${ }^{818}$ Similarly, seals are still used in particular professions, such as notaries public. $^{819}$ In line with these facts, statute precludes a sealed document from being automatically deemed to have been intended to be a deed (s $2 \mathrm{~A}$

815 Halsbury's Laws Vol 32 (fn 62) para 241. See also Leonard S Sealy and Sarah Worthington, Sealy and Worthington's Cases and Materials in Company Law $\left(10^{\text {th }}\right.$ edn, OUP 2013) 131. As mentioned above, the company seal, termed 'common seal', is regulated in s 45 CoA 2006.

816 On the 'mode of execution' of deeds, see generally Halsbury's Laws Vol 32 (fn 62) para 241.

817 cf OTV Birwelco Ltd $v$ Technical \& General Guarantee Co Ltd [2002] EWHC 2240 (TCC) (QB), 2002 WL 31050475 (official transcript), in which the court found that a bond (deed) sealed with a company's trading name instead of its registered name did not invalidate it. The court held that s 36 and s 36A Companies Act 1985, dealing with the execution of documents and deeds by companies, concerned the manner of making a deed and the identities of the persons sealing or signing it but not the company's name that is used. Nevertheless, the company in question was found to have contravened s 350 subs 1 of the same Act in using a seal that did not bear its registered name and thus incurred a fine. See paras 22, 28-29, 32-33, 40, 45-46, 49 et seq of the decision.

818 A letter of orders to ordain a deacon in the Church of England, although sealed, has been held not to be a deed for the purpose of a criminal statute relating to the forgery of deeds, see Reg $v$ Morton (fn 774) 26-27 (Bovill CJ), in which a range of examples are given of what are not deed instruments, though sealed. See also ibid 27 (Blackburn J). Further references can be found in Halsbury's Laws Vol 32 (fn 62) para 201. For companies, see ss 43-45 CoA 2006 and Sealy and Worthington (fn 815) 131.

819 See on this the description of the organisation of notaries public given by the Notaries Society at www.thenotariessociety.org.uk/pages/the-notarial-profession. 
LPMPA 1989).${ }^{820}$ In conclusion, in order for an instrument to be a deed, other requirements must be met, as explained above.

\section{v. Electronic Communication: Writing and Signatures}

As was already illustrated by the discussion above concerning the effectiveness of declarations of offer and acceptance, the development of new technologies has made it necessary from time to time for certain principles of English contract law to be examined and adapted to new frameworks. The main issue that arose with respect to digital communication was whether electronic forms of correspondence and of contracting ought to be given the same treatment as traditional, ie, paper, forms. To put it in another way: The question was whether it was (or is) desirable to accord electronic documents the same legal effect as paper documents. ${ }^{821}$ In line with the nature of the common law, it has been not solely the work of legislation but also of case law to deal with this situation. ${ }^{822}$ In fact, there are only few explicit regulations in English law that provide for electronic forms of contracting. This may be due to the fact that previously existing rules are adaptable. ${ }^{823}$ Consequently, English law does not contain definitions for terms such as 'electronic contract'. Having said this, there has been legislative activity, in particular with regard to electronic signatures. This will be examined in Section bb), after the legal situation for electronic documents, ie, things in electronic forms of writing, has been considered in Section aa).

820 This seems to be in line with a long-standing construction as enunciated over 100 years earlier by Blackburn J in Reg $v$ Morton (fn 774) 27: '[T]he affixing of a seal does not make a deed.'

821 See on this Cartwright (fn 181) 120-121 para 4-06.

822 Indeed, the English courts first embarked on the venture of accommodating the new technologies and changing business practices. Apart from the cases discussed in Section a.iii.cc) above in relation to the effectiveness of acceptance in particular, more recent concerns were related to formal documents like guarantees and the requirement of a signature.

823 Compare Cartwright (fn 181) 121. 
aa) Electronic Documents: Writing

As mentioned above, there seems to be no statutory definition of what an electronic document is. This may not be necessary, as the definition of 'writing' is wide: It may be in any kind of form, as long as it is visible (see Section ii.aa) above). This wide notion has been applied in Golden Ocean $v$ Salgaocar ${ }^{824}$, in which it was held on the question whether a guarantee in relation to a charter party existed that a sequence of e-mails can constitute an agreement in writing for the purposes of s 4 SOF 1677.825 Therefore, standard forms of writing or written evidence ought to be fulfilled where the documents in question are digital, ${ }^{826}$ including where the document is digitalised by scanning it. ${ }^{827}$ Having said this, caution is advisable where a contract must fulfil other requirements (see Section c. below) that might require a paper document. ${ }^{828}$

\section{bb) Electronic Signatures: English and EU Law}

English legislation does not contain a rule on the validity of electronic signatures. Section 7 Electronic Communications Act 2000 (hereinafter 'ECA 2000 ') provides that an electronic signature is admissible as evidence in civil litigation if it is 'incorporated into or logically associated with a particular electronic communication' (ibid subs 1(a)), whereby the communication method can be through an 'electronic communications network' or 'other means but while in electronic form' (s 15 subs 1 ibid). ${ }^{829}$ While the provisions do not lay down exact requirements, they generally allow electronic forms of documents, signatures, and seals to be used in court as

824 See fn 413 above.

825 Golden Ocean v Salgaocar (fn 413) [10], [20]-[22], [38] (Tomlinson LJ).

826 Compare the opinion expressed in Law Society, Execution of a document using an electronic signature (Practice Note, 21 July 2016), www.lawsociety.org.uk/support-services/advice/practice-notes/execution-of-a-document-usingan-electronic-signature/.

827 Compare Law Society, Execution of documents by virtual means (Practice Note, 16 February 2010), www.lawsociety.org.uk/support-services/advice/practice-notes/ execution-of-documents-by-virtual-means/.

828 Compare Law Society, 'Virtual Documents' (fn 827).

829 Similar provisions are made for electronic seals (in s 7A ECA 2000) and electronic documents (in s $7 \mathrm{C}$ ibid). 


\section{B. Comparative Background}

evidence, thus supporting the move towards electronic documents. ${ }^{830}$ Consequently, the issue of validity has to be considered under the common law rules, unless the EU Regulation on electronic documents, signatures, and seals that has generally come into force in all EU Member States on 1 July 2016, applies. ${ }^{831}$

Under that Regulation, an electronic document is 'any content stored in electronic form, in particular text or sound, visual or audiovisual recording' (art 3 para 35 eIDAS Regulation 2014), while an electronic signature is data that is used by a person ('signatory') to sign and is associated with or attached to other data (art 3 paras 10,9 ibid). Apart from this simple type, the Regulation defines two varieties: the 'advanced' and the 'qualified' electronic signatures. Despite their slightly misleading denominations, it seems to be the 'qualified' electronic signature that has the highest rank. While the 'advanced' electronic signature must fulfil a range of criteria under art 26 of the Regulation, the 'qualified' signature is an advanced signature which has a 'qualified' certificate and was created using a special ('qualified') electronic signature creation device (ibid paras 11-12, 14-15, 22-23). The latter requirements for a qualified signature, regulated in art 28 and Annex I (certificates) as well as in arts 29-31 and Annex II (creation devices) of the Regulation, will not be discussed further. ${ }^{832}$ For the purposes of the current discussion, it suffices to state that the certificate must contain particular information, including the name or pseudonym of the signatory and the electronic signature (Annex I points $\mathrm{c}$ and g). ${ }^{833}$

830 Compare Law Society, 'Electronic Signatures' (fn 826), where it is noted that the ECA 2000 does not regulate the validity of electronic signatures.

831 See art 52 para 2 Regulation (EU) 910/2014 of the European Parliament and of the Council of 23 July 2014 on Electronic Identification and Trust Services for Electronic Transactions in the Internal Market and Repealing Directive 1999/93/EC [2014] OJ L 257/73 (hereinafter 'eIDAS Regulation 2014'). Note that the Regulation deals exclusively with electronic identification service schemes and trust service providers, ie, with the legal-technical matrix for e-commerce, thus leaving all laws relating to the conclusion of contracts and form requirements untouched, whether on EU or national level (see art 2 paras 1 and 3, recital 2).

832 The same goes for the rules found in arts 35 et seq (Regulation on electronic seals), which, in parallel to signatures, can be simple, 'advanced', and 'qualified' (art 3 paras 25-27 eIDAS Regulation 2014).

833 On this regime, see also the discussion in Section III.3.b.v.bb) below. 
Where the signature is not to be 'qualified' or 'advanced' within the meaning of the eIDAS Regulation 2014, ${ }^{834}$ a signature can be electronic in the following sense: a scanned image of a hand-written signature being inserted into an electronic document; writing a signature into an electronic document by using a finger, computer mouse or other device; using an e-signature platform to insert a hand-written or typed signature into the document; or, by typing one's name into the document. ${ }^{835}$ The last of these methods was considered in Golden Ocean v Salgaocar ${ }^{836}$. It was held that an e-mail signed by one of the shipbrokers of the defendants (charterer) using only his first name constituted a signature within the meaning of writing of s 4 SOF 1677 for guarantees. ${ }^{837}$ Similarly, in the case of J Pereira Fernandes SA $v M_{\text {ehta }}{ }^{838}$, an e-mail that was not signed in the traditional sense but contained the sender's e-mail address and had been accepted orally (by telephone) was held to be able to constitute a written and signed memorandum as required by s 4 SOF 1677; however, the e-mail address was not seen as equivalent to a signature, as it had been inserted automatically by a technical process rather than by the sender themselves or their agent. ${ }^{839}$ Nevertheless, typing one's name or that of one's principal as part of the main text in the e-mail can amount to an electronic signature. ${ }^{840}$

Another specific ruling was made by the CA concerning a proxy form, purportedly issued according to the Insolvency Rules $1986^{841}$ in the case of Re a Debtor. ${ }^{842}$ The issue was whether a faxed proxy form could be deemed to have been signed according to those rules. The court held that it was

834 It was suggested in Law Commission, 'Electronic Signatures' (fn 826) that such signatures were 'not commonly used in England' in 2016.

835 See Law Society, 'Electronic Signatures' (fn 826). It is suggested in Department for Business, Energy \& Industrial Strategy, Electronic Signatures and Trust Services (Guide, August 2016) 4 that there are yet other ways of signing electronically, like '[a] unique representation of characters', or '[a] digital representation of characteristics, for example, fingerprint or retina scan'. The Guide is available online at www.gov.uk/government/publications/electronic-signatures.

836 See fn 413 above.

837 Golden Ocean v Salgaocar (fn 413) [30]-[35], [38] (Tomlinson LJ).

838 See fn 799 above.

839 J Pereira Fernandes SA v Mehta (fn 799) [27], [29]-[32] (Pelling J).

840 Ibid [29]-[32] (Pelling J). See also Golden Ocean v Salgaocar (fn 413) [32] (Tomlinson LJ): using one's first name, initials or nickname, as (well as) an electronic signature can be sufficient.

841 SI 1986/1925.

842 [1996] British Company Cases (BCC) 189. 


\section{B. Comparative Background}

sufficient, although the court emphasised that the result may be different if other legislation applied. ${ }^{843}$ In its reasoning, Laddie J stated that the signature requirement existed to 'indicate, but not necessarily prove' that the document has been authenticated by the principal. Moreover, and the judge noted that signatures other than those by hand, ie, a signature made with a stamp, as well as a faxed signature, would be deemed sufficient both from the standpoint of being done by the principal or on his authority and from the point of view that it afforded no less authenticity than other forms of signature of a person unknown to the recipient. ${ }^{844}$ This case has been cited as authority for a scanned signature sent in electronic form to be sufficient for authentication purposes, and has been applied to e-mail and other forms of 'electronic transmission'. ${ }^{845}$

Another manner in which digitalisation is promoted in legislation is through ss 91 et seq Land Registration Act 2002 (hereinafter 'LRA 2002'), which foresee a system of electronic conveyancing. ${ }^{846}$ This system allows electronic documents to be recognised as documents 'in writing' or as deeds, and to be signed and sealed, where applicable (s 91 ibid). Although s 92 gives the registrar the power to provide 'an electronic communications network', plans were at first put on hold. ${ }^{847} \mathrm{~A}$ business e-services portal has been launched since, allowing regular business customers to, inter alia, submit applications and documents online. ${ }^{848}$ As will be seen, the fact that individuals cannot use the registration service is only logical, since it is professionals who normally take on this task.

\section{c. Other Requirements under English Law}

There may be other requirements related to contracts which are not one of form and yet have a bearing on its legal effectiveness, or at least on its enforceability. Two instances that will be considered subsequently are the

843 Re a Debtor (fn 842) 195 (Laddie J).

844 Ibid 194.

845 Law Commission, 'Electronic Commerce' (fn 502) 14 paras 3.32-3.33.

846 The registration of property in land will be discussed in Section c.i. below.

847 See Cartwright (fn 181) 121 in fn 41, citing a report by the Land Registry from 2011.

848 For further details, see www.gov.uk/guidance/hm-land-registry-business-e-services and www.gov.uk/guidance/hm-land-registry-electronic-document-registration-service. 
need to register one's title to land (in Section aa) below) and stamp tax duty $($ Section bb)).

\section{i. Registration of Title to Land}

Before going into the topic of registration, it should be noted that title to land in the UK is largely (around 85\%) registered and only a small portion remains unregistered. ${ }^{849}$ This becomes relevant not only for the conveyance procedure, but - more importantly - for the effect that the completion of the contract has. ${ }^{850}$ This latter aspect will now be considered.

Whenever a contract effects the transfer of a freehold or leasehold estate in unregistered land, the title must be registered in the Land Register (ss 4, 6 LRA 2002). ${ }^{851}$ Similarly, if a title has previously been registered, the change in title resulting from the conveyance must be registered before the transaction will display its legal effects (s 27 subs 1 LRA 2002). ${ }^{852}$ Conversely, legal title to unregistered land will pass by virtue of the deed. ${ }^{853}$ In either case, failure to register will render the conveyance void as regards the creation or transfer of the legal estate (s 7 subs 1 LRA 2002); in other words, the title will revert to the original owner. ${ }^{854}$ Consequently, while registration has no bearing on the contract, it does affect the contract's legal consequence, namely, the transfer of the legal title, and is therefore relevant in transactions.

849 Gavin Curry, Why the missing owners are missing out (HM Land Registry Land and Property blog, 9 October 2014), http://blog.landregistry.gov.uk/giving-85per-cent/.

850 There is another effect, which relates to interests of third parties in the land in question. For details on this, see Green and Cursley (fn 728) 148-160.

851 The requirements for registration are set out in sch 2 LRA 2002. One related requirement found outside the LRA is the submission of a certificate issued by the Inland Revenue that revenue requirements have been met. Unless this certificate is presented, the registration cannot be made (s 79 Finance Act 2003).

852 While no legal title will be transferred, equitable title will pass to the buyer, see Green and Cursley (fn 728) 161. Thus, the transaction will have some but not its full effect.

853 Ibid 18.

854 Having said this, that party will then hold the land on trust for the buyer ( $\mathrm{s} 7$ subs 2(a) LRA 2002). Therefore, the buyer will still have equitable title to the land, see Green and Cursley (fn 728) 161. 


\section{B. Comparative Background}

In practice, it is the buyer's solicitor who will effect the registration. ${ }^{855}$ This has to be done within two months of the conveyance (s 6 subs 4 LRA 2002), unless an application for extension has been granted (s 6 subs 5 ibid). Registration of unregistered land can be made voluntarily where no event requiring compulsory registration occurs. ${ }^{856}$ The amount payable as the registration fee depends on several factors: the type or reason for the transfer; the value of the property (in case of commercial property under scale 1, including Value-added Tax); whether the registration is voluntary, or, where it is compulsory, the method used for registration. ${ }^{857}$ Using a simple example, the registration of title for real property to the value of $£ 300,000$ (approx. $€ 350,000$ ) would range between $£ 135$ and $£ 270$ (approx. $€ 160-€ 315$ ) under scale 1 , and would be $£ 40$ or $£ 80$ (approx. €46-€95) under scale $2 .{ }^{858}$

\section{ii. Stamp Tax on Land Transactions}

The other requirement that will be considered is stamp tax. First, it ought to be noted that the following discussion will focus on what is termed 'stamp duty land tax', the stamp tax applicable to transactions concerning land (see s 42 subs 1 Finance Act 2003; hereinafter 'FA 2003'). The other two kinds of stamp taxes imposed today are 'stamp duty' on instruments relating to corporate transactions, such as transfers of interests in partnership holding stock or marketable securities, and 'stamp duty reserve tax' on, inter alia, transfer agreements of securities for money or money's worth. ${ }^{859}$

While the history of stamp taxes goes back to the seventeenth century, it has been changed over time, with the last comprehensive change to stamp

855 Halsbury's Laws Vol 23 (fn 729) para 2.

856 Section 3 LRA 2002. This has the advantage of securing a discount on the registration fee, see Curry (fn 849 ). On the events triggering compulsory registration, see s 4 LRA 2002. These include 'transfer[s ...] for valuable or other consideration, [or] by way of gift' (s 4 subs a (i) LRA 2002).

857 For details on the fees, see HM Land Registry, Registration Services Fees (Guide, March 2017), available online at www.gov.uk/guidance/hm-land-registry-registration-services-fees.

858 See ibid.

859 For further information on these two duties, see Halsbury's Laws of England Vol 96 ( $5^{\text {th }}$ edn, LexisNexis 2012) paras 301-424. 
duty land tax in 2003 under the FA $2003 .{ }^{860}$ It is a charge imposed on instruments (ie, any kind of written document, see s 122 subs 1 Stamp Act 1891; hereinafter 'SA 1891') upon their execution, ${ }^{861}$ meaning upon being signed (see ibid). Where the instrument is subsequently altered in any material way, it needs to be stamped anew. ${ }^{862}$ Payment of this duty must be made by the purchaser ${ }^{863}$ within 30 days from the execution of the instrument (inferred from s 15A subs 1 (b) and s 15B subs 1 SA 1891) and should not be omitted or circumvented, as the consequences not only encompass a monetary fine (interest on the duty and a penalty), but furthermore make the document unenforceable in court and unregistrable in a public register ${ }^{864}$ Thus, although a contract's validity will not be affected by a failure to pay stamp tax, there may be practical disadvantages where the contract document has to be presented in court or to a register. ${ }^{865}$ Although s 122 subs 1 SA 1891 provides that 'stamp' means an impression with a die as well as adhesive stamps applied to a document, in practice, only the former is used today. ${ }^{866}$ The stamp must be placed on the face of the instrument (s 3 subs 1 SA 1891).

Whether, and if so, how much duty is payable depends not on the document's title, but on its content, that is, its legal effect. ${ }^{867}$ If several instruments are contained in one document, each is taxable separately, so that each must be stamped (see s 3 subs 2 SA 1891). ${ }^{868}$ With land, taxable instruments concern 'land transactions', meaning 'any acquisition of a chargeable interest' (s 43 subs 1 FA 2003), whereby this interest encompasses not only estates, interests, rights, or powers in or over land,

860 See ibid paras 303, 304.

861 Ibid para 303. For further details, see ibid para 310.

862 See on this ibid para 317.

863 See s 85 subs 1 FA 2003: 'The purchaser is liable to pay the tax in respect of a chargeable transaction.' In practice, it is their solicitor who pays the tax, see Halsbury's Laws Vol 23 (fn 729) para 2.

864 See on this Halsbury's Laws Vol 96 (fn 859) paras 307, 322-323. Thus, unstamped documents cannot be used as evidence in civil proceedings, see s 14 SA 1891. Other consequences are foreseen in ss 15-17 SA 1891. On the registration issue, see Cartwright (fn 181) 115 in fn 14.

865 This is the same for the Japanese stamp tax, discussed in Section C.IV.1.c.ii. below.

866 See Halsbury's Laws Vol 96 (fn 859) para 325.

867 See ibid para 311.

868 Similarly, if one instrument contains several separate taxable matters, each must generally be taxed distinctly (s 4 SA 1891). See on this further Halsbury's Laws Vol 96 (fn 859) para 315. In this respect, where an exchange of land is agreed, each piece of land and its transfer is taxable separately, see s 47 FA 2003. 


\section{B. Comparative Background}

but also options to enter into a legal transaction (s 46 subs 1 (a) ibid) and obligations affecting the same ( $\mathrm{A} 48$ subs $1 \mathrm{ibid}$ ). In particular, sales by conveyance (see s 44 FA 2003) and leases are included, the latter being 'an interest or right in or over land for a term of years (whether fixed or periodic)' (s 120 subs 1 (a) FA 2003). ${ }^{869}$ Exceptions include licences to use or occupy land, and tenancies at will (s 48 subs 2 ibid). ${ }^{870}$ Furthermore, it ought to be noted that the tax is owed irrespective of whether the transaction is effected through an instrument or not, and, where an instrument exists, whether it is executed in- or outside the UK (s 42 subs 2 FA 2003).

The amount of stamp tax depends on the 'chargeable consideration', ie, the money or its worth given for the land (s 55 subs 1, sch 4 FA 2003). In case of a lease, it depends on the rent over the term of the lease ( $s$ 56, sch $5 \mathrm{ibid}$ ). In either case, it is a percentage of the amount that differs for residential and non-residential (or mixed) property. 'Residential' means that the property can be used as a place to live (dwelling, see s 116 subs 1(a) Finance Act). The difference is best illustrated by using examples. Supposing a sale of land with residential property was for $£ 1,000,000$ (approx. $€ 1,150,000)$, the applicable percentage would be $4 \%$, so that the stamp tax would amount to $£ 40,000$ (approx. $€ 47,000$ ). ${ }^{871}$ If residential property were to have an annual rent of $£ 24,000$ (approx. $€ 28,000$ ) and the lease was for a term of two years, the total amount would fall below the $£ 60,000$ (approx. $€ 70,000)$ threshold, so that no stamp tax would be due. ${ }^{872}$ Anything over that amount would be taxable at $1 \%$, so that if the term were for three years instead, the stamp tax would amount to $£ 720$ (approx. $€ 840$ ). If the property were commercial or mixed, the threshold would be $£ 150,000$ (approx. $€ 175,000$ ) with anything above that amount taxable at $1 \% .{ }^{873}$

\section{d. Current Legal Practice in England}

Several trends exist in English legal practice. These will only be alluded to briefly. One is the use of standard contracts or pre-printed forms that are

869 For further details on the meaning of lease, see Halsbury's Laws Vol 96 (fn 859) para 435.

870 See further sched 3 FA 2003.

871 In fact, the result would be the same for commercial or mixed property, since the percentages are the same for values of more than $£ 250,000$ (approx. $€ 292,000)$, see Tables A and B under s 55 FA 2003.

872 See Table A in sch 5 FA 2003.

873 See Table B in sch 5 FA 2003. 
filled out by one or both parties. ${ }^{874}$ In this context, a prominent problem in business situations arises from the phenomenon called the battle of forms. It occurs where both contracting parties insist on using their contract templates, including standard terms. ${ }^{875}$ Issues often arise in relation to these terms, their inclusion, and their validity, none of which will be contemplated in this dissertation. ${ }^{876}$ Another development - which seems to run counter to the previous trend - is that of reduced formalism in commercial contracts. It seems that this practice has increased due to the rise of e-commerce, ${ }^{877}$ as discussed in Section b.v. above.

\section{Summary of Results}

As we have seen in this section, the law of contract under the common law system in England developed out of procedural law and individual strands of notion of contract were gradually combined to make a - perhaps patchwork-like - fabric. A contract is understood as a bargain and is typically formed through matching declarations of offer and acceptance. These declarations of intention are distinguished from invitations to treat and other non-binding statements and acts. In order to constitute legally relevant statements, the declarations must furthermore be certain and be communicated to the other party. Two doctrines are applied to the coming into effect of these declarations: the mailbox and postal rules. The latter accelerates the contracting process, as a declaration of acceptance already becomes effective on being sent out. Nevertheless, this rule is only applied to letters and telex; for all other methods of acceptance and other declarations of intention, the mailbox rule and thus receipt is the pertinent point in time.

Contracting is facilitated further by the fact that only few legislative provisions require the agreement to be made in a mandatory form. Exceptions are transactions involving land and singular cases like guarantees. Forms include a standard and a simple written form, as well as a special kind of document called 'deed'. Nevertheless, offer and acceptance alone are not

874 See Whincup (fn 34) 125 at 5.2.

875 Ibid.

876 Interested readers are referred to the discussion in, eg, McKendrick (fn 48) 315 et seq.

877 Unnamed author, Email, e-signatures and e-commerce (Reed Smith LLP Client Alert, 2 February 2002), www.reedsmith.com/en/perspectives/2002/02/email-esignatures-and-ecommerce. 


\section{B. Comparative Background}

sufficient, even if no mandatory form applies: the parties must have the intention to enter into a legally binding relationship when contracting, and - unless the agreement is contained in a deed - consideration must be paid by the offeree. Moreover, while of no effect on the contract's validity, practical concerns demand that changes in property of land be registered, and that stamp tax be paid, where applicable. There is therefore often more to a contract that is concluded under English law than a consensual agreement.

\section{Contracts in German Law}

The analysis of the German law of contract will begin by defining the German term for 'contract', Vertrag (in Section 1. below), and exploring its historical development from Modern times (Section 2.). As will be seen from this analysis, the notion of contract and its legal regulation was based on Roman law initially, but has transformed and evolved to become distinct. This is visible in the current requirements of a contract, as well as in German legal practice, which will be the focus of Section 3. In this respect, German law has taken a different development route from English law, although, as will become clear later, the practical result is not so very different. ${ }^{878}$

\section{1. 'Vertrag'(Contract) Defined}

German law contains no statutory definition of a contract, nor detailed rules on its formation. Given that Germany is a civil law system and thus regularly relies on codified law, as well as the fact that the Bürgerliches Gesetzbuch (German Civil Code, 'BGB') was seen as one of the most systematic and advanced codifications of its time, ${ }^{879}$ this seems surprising. ${ }^{880}$

878 On the development of English contract law, see Section II.2. above. A comparison of current English, German, and Japanese law is made in Section D. below.

879 Compare Whincup (fn 34) 38 para 1.48, who states the BGB to be 'one of the last but most important expressions of the age of codification of the $19^{\text {th }}$ century.' Similar: John O Haley, Rivers and Rice: What Lawyers and Legal Historians Should know about Medieval Japan (2010) 36 Journal of Japanese Studies 313, 314.

880 Even more so, when considering that one of the aims of the codification of the BGB was to provide 'a complete and exhaustive legal regulation' ('eine 
The reason for this omission is two-fold. One the one hand, there was an academic divide at the time when the BGB was drafted concerning the definition of two terms that are closely linked to that of Vertrag, namely, 'legal transaction' (Rechtsgeschäft) ${ }^{881}$ and 'declaration of intent' (Willenserklärung). ${ }^{882}$ On the other hand, an explicit provision concerning the formation process was seen as superfluous for being 'a matter of course' (selbstverständlich). ${ }^{883}$ Furthermore, the opinion was that the elements necessary for the conclusion of a contract could be deduced from the other provisions on contracts. ${ }^{884}$

Despite the lack of a legal definition, descriptions found in German legal academic works state that a 'contract is a bi- or multi-lateral legal regulation of a legal relationship, which is made consensually by the contracting parties'. ${ }^{885}$ In other words, a contract is formed when the parties reach a consensus with regard to the rights and duties that they owe each other. ${ }^{886}$ Thus, a contract is a legal transaction through which the parties regulate their legal relationships. ${ }^{887}$ It becomes obvious from these

abschließende und erschöpfende gesetzliche Regelung'). Franz J Säcker, Einleitung (Einl. BGB) [Introduction (Intro. Civil Code)], in: ibid and others (fn 158; $8^{\text {th }}$ online edn 2018) paras 1, 26. cf Honsell (fn 140) 68, who notes that the BGB's drafters were aware that the creation of a code without gaps was not viable. The creation of the BGB is considered in Section 2.b.ii. below.

881 The term is also sometimes translated as 'juridical act', see, eg, Smits (fn 37) 9, 23.

882 The term is sometimes translated as 'declaration of will', see, eg, Youngs ( $\mathrm{fn}$ 34) 546; Whincup (fn 34) 39 para 1.53. Both of these terms will be explored further in Section 3. below.

883 See Schmidt J (fn 25) 26-28. While a proposal in the draft version of the BGB had foreseen an explicit provision on the conclusion of contracts, this was subsequently deleted. See on this Benno Mugdan (ed), Die gesammten Materialien zum Bürgerlichen Gesetzbuch für das Deutsche Reich [The Complete Materials to the Civil Code of the German Empire] (R v Decker's Verlag 1899) Vol I 688. This development will be discussed further in Section 2.b.iii. below.

884 See Mugdan (fn 883) Vol I 688; Reinhard Bork, Vorbemerkungen zu SS 145-156 [Preliminary Notes on Ss 145-156], in: von Staudinger and others (fn 140; 2015) para 36.

885 Bork, 'Vor $\mathbb{} 145$ BGB' (fn 884) para 1: 'Der Vertrag ist die zwei- oder mehrseitige rechtsgeschäftliche Regelung eines Rechtsverhältnisses, die von den Vertragsparteien einverständlich getroffen wird.' The theoretical basis of this understanding goes back to Werner Flume, Allgemeiner Teil des Bürgerlichen Rechts Zweiter Band Das Rechtsgeschäft [General Part of the German Civil Code Vol 2 The Legal Transaction] (4 ${ }^{\text {th }}$ edn, Springer Verlag 1992) 602.

886 See Hein Kötz, Vertragsrecht [Contract Law] (Mohr Siebeck 2009) 37 para 80.

887 See Bork, 'Vor $\$ 145$ BGB' (fn 884) para 1. 


\section{B. Comparative Background}

statements that the general principle of the formation of a contract under German law follows the model of the consensual contract. ${ }^{88}$ This is not only true for private transactions under the BGB, but also for commercial transactions (Handelskäufe) governed by the Handelsgesetzbuch ('HGB'), since the formation rules contained in the BGB also apply to commercial transactions. ${ }^{889}$

The parties' consensus is made up of matching declarations of intention aiming at the same result (legal consequence), ${ }^{890}$ and usually come in the form of an offer (Angebot) ${ }^{891}$ and acceptance (Annahme). ${ }^{892}$ There are instances in which the identification or separation of these two kinds of intention is difficult, such as during contractual negotiation processes; it is sufficient in these cases that all the parties have expressed their agreement with the result. ${ }^{893}$ The intentions necessarily need to foresee that the stipulated regulation is to be binding and must correspond in terms of their content. ${ }^{894}$ Although this is not regulated explicitly in the BGB, a contract is formed once an offer is accepted. ${ }^{895}$ These two elements, as well as other requirements to a contract, will be analysed in Section 3. below. Before turning to this, the different types of contract will be set out briefly.

There are numerous types of contract under German law that must be distinguished, whereby the classification can be made according to the

888 Indeed, it has been stated that contractual obligations derive their validity from the parties' consensus (Konsens), see Wolf and Neuner (fn 48) 433 para 66.

889 See Adolf Baumbach (founder) and Klaus J Hopt and others, Beck'sche KurzKommentare Band 9 Handelsgesetzbuch [Beck's Concise Commentary Vol 9 Commercial Code] (38 $8^{\text {th }}$ online edn, $\mathrm{CH}$ Beck 2018) at 'Einleitung vor $\$ 373$ ' [Introduction before s 373] para 2. The authors go on to state at para 9 that most of the provisions on commercial transactions formerly contained in the Allgemeines Deutsches Handelsgesetzbuch, the forerunner of the HGB, were mostly incorporated into the BGB. On this commercial code, see Section b.ii. below.

890 Compare Bork, 'Vor $\$ 145 B G B$ ' (fn 884) para 2.

891 The formal term used in the BGB is 'Antrag', see, eg, $\mathbb{S} 145$ (Bindung an den Antrag; Binding effect of an offer).

892 Kötz, 'Vertragsrecht' (fn 886) 37 para 80; see also Schmidt J (fn 25) 7.

893 This requirement can be deduced from the rule found in $\$ 154$ para 1 BGB (Offener Einigungsmangel; Overt lack of agreement). cf Wolf and Neuner (fn 48) 417 para 2. On the difficulty of identifying the declarations of intention, see also Jan Busche, $\mathbb{\int} 145$ Bindung an den Antrag [Section 145 Binding effect of an offer], in: Säcker and others (fn 158) para 4. This problem was already discussed under English law in Section II.3.a.i. above.

894 See Wolf and Neuner (fn 48) 417 para 1.

895 See Bork, 'Vor $\int 145 B G B$ ' (fn 884 ) para 37, noting that this can be deduced from the provisions in $\$ 145$ et seq BGB. 
nature of the agreement, the obligatory relationships that arise from it, or according to its content. ${ }^{896}$ Consequently, a distinction can be made, firstly, depending on whether a contract foresees that something of value be given either in return for something, or in return for nothing, so that a contract will be either for value (entgeltlich) or gratuitous (unentgeltlich) respectively. ${ }^{897}$ A second way is to contrast two constellations with respect to the contractual obligations. On the one side, there are einseitig verpflichtende Verträge (unilaterally obliging contracts), under which only one party is legally bound to do or to refrain from doing something. ${ }^{898}$ Conversely, the other party or parties are not required to act in any way, so that there is only one side that must fulfil their obligation while the other(s) do not have any obligations. ${ }^{899}$ In other words, the legal consequence is

896 The different classifications are discussed succinctly by Bork, ibid paras 87-90.

897 Compare ibid para 87. For further details on the distinction between these two kind of acts, see Wolf and Neuner (fn 48) 335 paras 81-82. The latter type of contract is also referred to as Gefälligkeitsverträge (accommodation agreements), compare, eg, Dirk Olzen $\$ 241$ Pflichten aus dem Schuldverhältnis [Section 241 Duties Arising from an Obligation], in: von Staudinger and others (fn 140; 2015, updated 21.12.2017) para 71. These kind of contracts will be considered in further detail in Section 3.a.iv. below.

898 See Wolf and Neuner (fn 48) 326 para 29. Contrast von Mehren, 'Introduction' (fn 21) 7 , who states that pure unilateral acts are distinguished from contracts and are deemed unenforceable. He bases his argument on what was $₫ 305$ BGB (now $₫ 311$ para $1 \mathrm{BGB}$ ), which 'respect[s] autonomous ordering', see ibid 8 in fn 29. The provision says: 'In order to create an obligation by legal transaction and to alter the contents of an obligation, a contract between the parties is necessary, unless otherwise provided by statute' ('Zur Begründung eines Schuldverhältnisses durch Rechtsgeschäft sowie zur Änderung des Inhalts eines Schuldverhältnisses ist ein Vertrag zwischen den Beteiligten erforderlich, soweit nicht das Gesetz ein anderes vorschreibt.'). This provision will be discussed further in Section 3. below. A similar statement to that by von Mehren is made by Bork, 'Vor $\$ 145$ $B G B$ ' (fn 884) para 2, who stresses that a contract must be '(at least) two-sided' ('(mindestens) zwei-seitig[...]'), so that '[a] one-sided legal transaction can never be a contract; at most, it can be equated to one' ('Ein einseitiges Rechtsgeschäft kann niemals ein Vertrag sein, sondern diesem allenfalls gleichgestellt werden').

899 See Bork, 'Vor $\mathbb{S} 145$ BGB' (fn 884) para 88. This type of contract is therefore radically different from the English unilateral contract: Under the German model, there is no exchange of any kind between the parties, whereas under an English unilateral contract, both parties act in a certain way, albeit only one side being legally bound to do so. For further details of this distinction, see Schmidt $\mathrm{J}$ (fn 25) 125-126. In order to avoid any conceptual misunderstanding with the English notion, the German model will therefore not be translated as 'unilateral contract', but as 'unilaterally obliging contract'. 


\section{B. Comparative Background}

brought about through the act of one party. ${ }^{900}$ On the other side, there are two kinds of contracts under which all parties are obliged to act: gegenseitige Verträge (reciprocal contracts, $\$ \$ \$ 320$ et seq BGB), under which the parties have mutual obligations forming a synallagmatic exchange; ${ }^{901}$ and zweiseitig verpflichtende Verträge (bilaterally obliging contracts), under which the parties' obligations are independent and do not make up an exchange. ${ }^{902}$ By way of example, a Schenkung (gift) is a gratuitous and unilaterally obliging contract, while a contract of sale (Kaufvertrag) is a reciprocal contract for value. ${ }^{903}$ Finally, a gratuitous loan (Leihe, $\$ 587$ et seq BGB) is an example of a bilaterally obliging and gratuitous contract. ${ }^{904}$

Contracts are thirdly classified according to their content. ${ }^{905}$ Apart from the examples just given, the BGB contains regulations for other agreements, such as exchanges (Tausch, $\$ 480 \mathrm{BGB}$ ), leases (Mietverträge, $\mathbb{S} 535$ et seq BGB; or Pachtverträge, $\mathbb{S} 5581$ et seq BGB). ${ }^{906}$ While these

900 See Reinhard Bork, Allgemeiner Teil des Bürgerlichen Gesetzbuchs [General Part of the Civil Code] (4 ${ }^{\text {th }}$ edn, Mohr Siebeck 2016) 170 para 424.

901 See Wolf and Neuner (fn 48) 326 para 29.

902 See on this ibid.

903 See Bork, 'Allgemeiner Teil' (fn 900) 193 para 491. cf English law, under which gifts are not contracts as such, although the estimation of a sale is the same. On this, see Section II.1. above.

904 See Wolf and Neuner (fn 48) 326 para 29. It is also an example of a Gefälligkeitsvertrag, see Olzen, ' $\mathbb{} 241$ BGB' (fn 897) para 71.

905 It goes beyond the scope of this dissertation to enumerate all contract types; the following analysis covers a selection. For a brief discussion of special contract types not discussed, such as Rabmenverträge (basic or framework agreements) or körperschaftliche Satzungen (corporate bye-laws), see Busche, 'Vor $\$ 145$ BGB' (fn 158) paras 40 et seq.

906 Under German law, these two kinds of leases must be distinguished. This is first done by looking at the object in question. While Miete can be for movable or immovable property ('Sachen' within the meaning of $\$ \$ 90$ et seq BGB) including software, Pacht can be for both Sachen or incorporeal things such as rights. This can be deduced from the BGB's wording: $₫ 535$ BGB speaks of a 'Mietsache' ('leased property'), whereas $₫ 581$ BGB refers to a 'Pachtgegenstand' ('leased object'). The definition of things and legal objects will be discussed in more detail in Section 3.b.i. below. Seeing as there is an overlap in the objects of Miete and Pacht, a second criterion is necessary. As the English translation of the term as 'usufructory lease' suggests, Pacht allows the lessee to enjoy the fruits of the object ( $₫ 581$ para $1 \mathrm{BGB}$ ), which is not stated in $₫ 535$ BGB in relation to Miete (a standard lease). It seems that the latter is the more important criterion, compare BGH decision of 7 March 2018, XII ZR 129/16, NJW 2018, 1540-1542, para 13. The case concerned the question of whether a Mietvertrag had been concluded in written form. On the differentiation and further details on each of the two institutions, see Volker Emmerich, Vorbemerkung zu $\$ 535$ [Preliminary 
arrangements concern the obligation to transfer either the property or the possession of things, there is also a whole range of other contracts, such as Darlehensverträge (credit agreements ${ }^{907}, \mathbb{S} \$ 488$ et seq $\mathrm{BGB}$ ), or service or work contracts (Dienstvertrag and Werkvertrag, $\mathbb{S} 5611$ et seq BGB). A new category has recently been introduced, namely, the Bauvertrag (construction contract) with the subcategory of a Verbraucherbauvertrag (consumer construction contract), regulated in the newly-inserted $\$ \$ 650 \mathrm{a}-650 \mathrm{n}$ BGB. ${ }^{908}$ These are contracts that concern work contracts for construction (see $\$ 650$ a BGB, Bauvertrag; Construction contract), whereby the latter are between an entrepreneur and a consumer, ie, B2C contracts. ${ }^{909}$

Notes on S 535], in: von Staudinger and others (fn 140; 2018) paras 31, 1-2; ibid, Vorbemerkungen zu $\$ 581$ [Preliminary Notes on S 581], in: von Staudinger and others (fn 140; 2018) paras 33-34, $15,10-108$.

907 Interestingly, the source indicated in fn 131 above uses the term 'loan contract' to refer to 'Darlehensverträge', but translates 'Verbraucherdarlehensverträge' as 'consumer credit agreements' into English, see, eg, $\$ \$ 488$ and 491 BGB respectively. In order to avoid confusion with the notion of Leihe (gratuitous loan), the translation of 'credit agreement' will be used for Darlehensverträge.

908 These and other provisions concerning construction contracts were introduced by art 1 Gesetz zur Reform des Bauvertragsrechts, zur Änderung der kaufrechtlichen Mängelhaftung, zur Stärkung des zivilprozessualen Rechtsschutzes und zum maschinellen Siegel im Grundbuch- und Schiffsregisterverfahren [Law to Reform the Law on Construction Contracts, to Change the Liability for Defects under Sales Law, to Strengthen the Legal Protection in Civil Procedure, and [the Use] of Mechanical Seals in Procedures of the Land and of the Ship Register] of 28 April 2017, BGBl 2017 I 969 (hereinafter 'BauVertrRefG'). The provisions apply to contracts entered into after 1 January 2018 (art $229 \$ 39$ Einführungsgesetz zum Bürgerlichen Gesetzbuche ('EGBGB')), to be exact, from midnight on that day, see Sebastian Omlor, Der neue Verbraucherbauvertrag [The New Consumer Construction Contract] (2018) NJW 817. For a summary of the legislator's objectives, see Deutscher Bundestag, Beschlussempfehlung und Bericht des Ausschusses für Recht und Verbraucherschutz (6. Ausschuss) zu dem Gesetzentwurf der Bundesregierung - Drucksache 18/8486. Entwurf eines Gesetzes zur Reform des Bauvertragsrechts und zur Änderung der kaufrechtlichen Mängelhaftung [Final Recommendation and Report by the Commission on Law and Consumer Protection $\left(6^{\text {th }}\right.$ Committee) on the Government's Draft Law - Printed Matter 18/8486. Draft of a Law to Reform Construction Contract Law and to Amend Commercial Warranties] (8 March 2017), available online at http://dip21.bundestag.de/ dip21/btd/18/114/1811437.pdf. See also www.bundesgerichtshof.de/DE/Bibliothek/GesMat/WP18/B/Bauvertragsrecht.html.

909 The provisions will be discussed later in relation to formalities. 


\section{B. Comparative Background}

\section{The Historical Development of the German Law of Contract}

The concept of contract that was explored in the previous section is one that developed over time. While first traces of commerce and contract-like agreements go back to the times of the Romans, the following exposition will begin after the Middle Ages, at the dawn of modern times. ${ }^{910}$ To be precise, the account starts at the time of the alte Reich (Section a.), in which the first extensive legal codifications were drafted. The next section (b.) then goes on to examine the time of the drafting of the BGB, while the final section (c.) concludes with an overview of subsequent developments in German (contract) law to date.

a. Contracts in the Alte Reich $\left(16^{\text {th }} \sim 19^{\text {th }}\right.$ Century): Emergence of the First Great Private Law Codifications

The time until the nineteenth century in Germany is that of the Heiliges Römisches Reich deutscher Nation (Holy Roman Empire of the German Nation) - in academic literature known as the alte Reich, ${ }^{911}$ and marked the beginning of the Modern Era (Neuzeit). ${ }^{912}$ Not only was the structure of society and political power different from today (see Section i.), so was the law (Section ii.). In fact, a duality of a sort of German common law (Section iii.) and a pan-German codification of (private) law (Section iv.) existed, which only changed in the nineteenth century (on which see Section b. below).

910 A concise account of the earlier developments can be found in, eg, Schmidt J (fn 25) 7-19. See also Uwe Wesel, Geschichte des Rechts: Von den Frühformen bis zur Gegenwart [History of Law: From Ancient Forms to the Present] ( $3^{\text {rd }}$ edn, CH Beck 2006) 213-219 (Roman times), 276-277 (Germanic times), 294-295 (Franconian times), 332-334 (Middle Ages).

911 See Axel Gotthard, Das Alte Reich 1495-1806 [The Old Reich 1495-1806] (Wissenschaftliche Buchgesellschaft 2003) 1, who notes this to be an abbreviation of the empire's long name that was contrasted with the nineteenth-century Deutsche Reich (on which see Section b. below). The empire was established well before the sixteenth century and subsisted until 1806, see Encyclopaedia Britannica, Germany (Online Academic Edition 2018) at 'History', https:// academic.eb.com/levels/collegiate/article/Germany/106260 and ibid, Supplemental: Holy Roman Empire, https:/academic.eb.com/levels/collegiate/additionalcontent/10389182. On the fall of the empire, see the succinct account by Kroeschell (fn 141) 112-113.

912 Wesel (fn 910) 355. 


\section{i. Political and Social Background}

As was just intimated, the structural background during the alte Reich was very different from today. This concerned both society and politics. The society of that period was clearly divided into different classes, called estates (Stände), namely: Adel (nobility), Bürger (citizens), and Bauern (peasants), each of which had its own rules regarding work, obligations, even clothing and life style, as well as (criminal) punishments. ${ }^{913}$ At least at the beginning of the period, only a fraction of the people lived in cities; the majority of the population (around 95\%) lived in rural areas. ${ }^{914} \mathrm{~A}$ number of cities already existed at the end of the sixteenth century, including Hamburg, Lübeck, Augsburg, Nürnberg, and Vienna, which were of importance as centres of commerce or residences to rulers. ${ }^{915}$ It is interesting that some of these cities, notably Hamburg and Lübeck, formed part of the former commercial association of merchants and cities known as the Hanse or (German) Hanseatic League, ${ }^{916}$ which explains their importance due to the

913 Compare ibid 357, 416. On these three estates, see further the seventeenth-century German text reprinted in Kroeschell (fn 141) 39-40. There was also the Klerus (clergy) of the church, something like a fourth estate, see Wesel (fn 910) 357, 416; cf Barbara Stollberg-Rilinger and others, Einfübrung in die Frühe Neuzeit [Introduction to the Early Modern Period] (online resource available at www.uni-muenster.de/FNZ-Online/Welcome.html, 2003) at 'Soziale Ordnung' [Social Order], 2.1.2. Stände [Estates], naming three estates, whereby the clergy is said to have been counted as part of either the nobility or the citizens. This latter classification seems more accurate, as one territorial code, the Allgemeines Landrecht für die Preußischen Staaten (discussed in Section iii. below) contained regulations on the 'Bauerstande' ('peasant-estate'), the 'Bürgerstande' ('citizen-estate'), and the 'Adelstande' ('nobility-estate') in the Zweyter Theil (Part Two), Titles 7-9. In contrast, there is no section on a 'clergy-estate', although churches were generally regulated in Title 11.

914 Compare Barbara Stollberg-Rilinger and Ulrich Pfister, Einführung in die Frühe Neuzeit: Wirtschaftliche Grundstrukturen und Entwicklungen [Introduction to the Early Modern Period: Economic Basic Structures and Developments] (online resource available at www.uni-muenster.de/FNZ-Online/Welcome.html, 2003) at 2.2. Stadt und Land [City and Countryside]. City in this sense means a municipal with a population of at least 10,000 people; Großstädte are those cities with at least double that population; in contrst, Ackerbürgerstädte were one kind of small-scale cities with certain privileges, see ibid. On the development of the population-size, see Wesel (fn 910) 354; for further details, see Stollberg-Rilinger and Pfister ibid at 2.1. Bevölkerungsentwicklung [Population Development].

915 Compare Stollberg-Rilinger and Pfister (fn 914).

916 For a map showing all the cities in Germany and Europe that were connected to this association, as well as for further discussion of its development, see 


\section{B. Comparative Background}

reach and wealth that association afforded. The establishment of the postal service and, later, in the nineteenth century, railway connections, ${ }^{917}$ will have aided in this upturn; however, it also had an effect on the contract conclusion mechanism (see Section iii.bb) below).

Despite its denomination as an empire ('Reich'), there was as yet no unified German state during this period; instead, there was a Reichsverband, an association of a large number of individual territorial states and cities. ${ }^{918}$ One territory of importance was the Duchy (Kingdom from 1701) of Prussia, an absolute monarchy that would become one of the great European powers in the second half of the eighteenth century alongside England, while the power of, say, France, dwindled. ${ }^{919}$ Another was the Duchy, also later Kingdom, of Bavaria. ${ }^{920}$ For administrative purposes, German states were grouped into ten larger Reichskreise (Imperial districts). ${ }^{921}$ All of these conditions had an effect on the structure of the law.

Encyclopaedia Britannica, Hanseatic League (Online Academic Edition 2018), https://academic.eb.com/levels/collegiate/article/Hanseatic-League/39167.

917 Peter Oestmann, SS 130-132 Wirksamwerden von Willenserklärungen [Sections 130-132 Coming into Effect of Declarations of Intention], in: Mathias Schmoeckel and Joachim Rückert and Reinhard Zimmermann (eds), Historischkritischer Kommentar zum BGB Band 1 Allgemeiner Teil [Historical, critical Commentary on the Civil Code Vol 1 General Part] (Mohr Siebeck 2003) 532, 546547 para 20.

918 For further discussion of the structure of the Reichsverband, see Gotthard (fn 911) 1-9. See also Stollberg-Rilinger and others (fn 913) at 'Strukturen von Recht und Herrschaft' [Structures of Law and Governance], 1.2.1 Das 'Reich' [The 'Empire'].

919 See Stollberg-Rilinger and others (fn 913) at 'Politische Ereignisse und Entwicklungen' [Political Events and Developments], and at 5.3.5. Preußen [Prussia]. For further discussion, see, eg, Encyclopaedia Britannica, Prussia (Online Academic Edition 2018), https://academic.eb.com/levels/collegiate/article/Prussia/61665.

920 For further details on the history of Bavaria, see, eg, Encyclopaedia Britannica, Bavaria (Online Academic Edition 2018), https://academic.eb.com/levels/collegiate/article/Bavaria/13830.

921 See on this Stollberg-Rilinger and others (fn 913) at 'Strukturen von Recht und Herrschaft' [Structures of Law and Governance], 1.2.5. 'Reichskreise' [Imperial Districts]. See also Gotthard (fn 911) 25-28, stating that these circles gradually gained importance in terms of their role in the empire's political administration. Maps of the Reichskreise are available online at www.uni-muenster.de/FNZ-Online/recht/reich/quellen/kreise.htm (in German) and https://legacy.lib.utexas.edu/maps/historical/shepherd_1911/shepherdc-113.jpg (in English). 


\section{ii. The General Structure of Law}

It may already be evident from the foregoing exposition that each of the parts of the 'empire' were (legally) independent and had their own rulers. Due to this territorial and governmental fragmentation, the law was equally diverse. This is true both in terms of the sources and of the reach of the laws. On the one hand, there were distinct sources of law in the sense of laws having different origin(ator)s. First, there was Kirchenrecht (canon law), but also learned Roman law (gelehrtes römisches Recht), and customary law (Gewohnheitsrecht); on the other hand, in terms of positive (legislated) law, there were laws on three levels, namely, that of the imperial state (Reichsrecht), that of the individual territories (Landsrecht), and that of the cities (Stadtrecht).922 Finally, Canon and Roman law together formed the basis of the ius commune or gemeines Recht (common law) across the empire. ${ }^{923}$ All of these laws had different spheres of application.

Contrary to a common misperception, it was not the emperor (Kaiser) who had the sole or chief legislative power; he had to cooperate with the imperial estates (Reichstände) in order to legislate, so that there was little imperial law. 924 Even where it did exist, however, it was initially only a

922 Compare Stollberg-Rilinger and others (fn 913) at 'Strukturen von Recht und Herrschaft' [Structures of Law and Governance], 4.1.1. Wabrung des Rechts [Preservation of the Law]. cf Wesel (fn 910) 371, referring to the law having two layers (römisches- and Ortsrecht, Roman and local law) until the end of the period (first half of the eighteenth century), at which point a third layer, namely, a systematic blend of Roman law (in the form of what was known as the Usus Modernus) and natural law, was added. See on this further Wesel, ibid 370-371. Arguably, 'Stadtrecht' and 'Ortsrecht' have the same meaning, namely, that of a geographically closely-limited local law as opposed to the law of territories, which had wider application. The two terms will thus hereinafter be treated as being interchangeable. There was in fact one other law, the French Civil Code, which was applied in some Western territories, like Baden, see Wolf and Neuner (fn 48) 81-82. As it will not be discussed further in this dissertation, see Schmidt J (fn 25) 41-51 for a discussion of the development of the French code.

923 See on this Klaus Luig, Gemeines Recht [Common Law], in: Albrecht Cordes and others (eds), Handwörterbuch zur deutschen Rechtsgeschichte [Handbook on German Legal History] (online edn, Erich Schmidt Verlag 2018) Vol II paras 60-77, in particular at III., who states that the norms contained in the Corpus Iuris Canonici and the Corpus Iuris Civilis were changed by the different schools of thought of German legal theory, inter alia, natural law, Usus Modernus, and the pandectists.

924 See on this Wesel (fn 910) 366, 316. For more details on the competences of the emperor and the legislative process, see Gotthard (fn 911) 11-12, 20-21. Kroeschell (fn 141) 44 notes that the Reichsfürsten (princes) only became true 


\section{B. Comparative Background}

subsidiary source to the laws of the territories and of the cities. ${ }^{925}$ Thus, while the empire had over-arching institutions like a Reichstag (imperial assembly ${ }^{926}$ ) producing Reichsschlüsse (in effect, these were imperial laws approved by the emperor) and two imperial courts (the Reichskammergericht and the Reichshofrat), ${ }^{927}$ these played only a subordinate role. ${ }^{928}$

By definition, the laws of a territory or of a city were pertinent in their particular locality only. Having said this, the application of city laws was sometimes extended beyond a city's borders by agreements with other cities. This was the case for the law of Lübeck, which was applied in other German cities such as Hamburg from the thirteenth century. ${ }^{929}$ Beside all these laws, there were customs, which had a particularly strong influence on commercial law. ${ }^{930}$ These could be local or, as in the sphere of commerce, 'trans-regional'. 931

By virtue of a presumption of consistency (fundata intentio, Vermutung der Schlüssigkeit), gemeines Recht had priority over any special laws, ie, over the positive laws having a more particular focus (thus termed Partikularrecht), if the existence of the latter could not be proven.932 In essence, therefore, gemeines Recht was subsidiary to particular laws. ${ }^{933}$ Having said this, it seems that the regulated content of the common and of the particu-

sovereigns at the end of the alte Reich. Indeed, he goes on to note at ibid 80 that the idea of the ruler being vested with the sole legislative power penetrated the general perception in the seventeenth and eighteenth centuries.

925 Wesel (fn 910) 366.

926 This was a gathering of the Reichsstände, imperial estates, namely, of those natural or legal persons having some form of jurisdictional rights, and of representatives of cities.

927 For further details, see Gotthard (fn 911) 19-24 (Reichstag), 16-19 (Reichsstände), 9-13 (Kaiser), 28-30 (Reichskammergericht).

928 This is more true for the law than for the courts; in fact, Gotthard (fn 911) 30 calls these last-instance courts 'an important brace for the imperial association' ('eine wichtige Klammer für den Reichsverband').

929 See Encyclopaedia Britannica, 'Hanseatic League' (fn 916).

930 Compare Thomas Henne, Handelsgesetzbuch [Commercial Code], in: Cordes and others (fn 923) Vol II paras 712-714.

931 On the latter, see Karsten Schmidt, Vorbemerkung zu $\mathbb{} 1$ [Foreword to $S 1$ ], in: ibid (ed), Münchener Kommentar zum HGB [Munich Commentary on the Commercial Code] (4 $4^{\text {th }}$ online edn, CH Beck 2016) Vol 1 paras 1, 20: 'überregional verbreitete[...] Handelsbräuche'.

932 See Luig K (fn 923).

933 See Martin Schennach, Partikularrecht [Particular Law], in: Cordes and others (fn 923) Vol IV paras 408-410, who also gives a sketch of the meaning of the term. See also Honsell (fn 140) para 24. It ought to be noted that the gemeines Recht applied exclusively in some areas of the Reich, namely, in large parts of 
lar laws did not overlap too often, and where it did, the decision on which had priority was made on a case-by-case basis. ${ }^{934}$

The volume of positive law increased over time on all levels. ${ }^{935}$ A problem that arose with the particular laws was that the rules of, eg, private law, were scattered among these individual legal texts, which made an overview over this area of law difficult. ${ }^{936}$ At least in the territories, this increase in legislative activity was due to a shift in administrative power, which in turn led to a change in legislative authority in the individual states and was fully vested in the territorial rulers by the eighteenth century. ${ }^{937}$ As a consequence, this era brought forth a series of codifications of more general character, which were applicable in larger parts of the German territories. These include the Allgemeines Landrecht für die Preußischen Staaten (General State Laws of the Prussian States, enacted 1794, hereinafter 'ALR'), ${ }^{938}$ the Codex Maximilianeus Bavaricus Civilis (Maximilian Civil Code of Bavaria, enacted 1756), the Austrian Allgemeines Bürgerliches Gesetzbuch (General Civil Code, enacted 1811),939 and the Saxonian Bürgerliches Gesetzbuch (Civil Code, enacted 1863). ${ }^{940}$ In order to keep the length of the subsequent discussion brief, only the rules found in the ALR will be analysed more closely. The reason for this choice is that, as will become

northern Germany, in particular what is today Lower Saxony, and only partially in few others, see the map provided by Kroeschell (fn 141) 166.

934 Luig K (fn 923) at X.

935 Cf Stollberg-Rilinger and others (fn 913) at 'Strukturen von Recht und Herrschaft' [Structures of Law and Governance], 4.1.2. Rationale vs. traditionale Rechtsgeltung [Rational vs Traditional Application of Law], only explicitly naming the law of the territories and of the cities.

936 See Kroeschell (fn 141) 104.

937 Compare Wesel (fn 910) 367-368, 362-364. See also fn 924 above.

938 In the following, unless otherwise stated, sources used for the ALR are: a scan of the print version of the ALR from 1804, available online at http://digital.staatsbibliothek-berlin.de/suche?queryString=PPN646281224; and a text-version based on the 1794-edition, available at https://opinioiuris.de/quelle/1621. The ALR was divided into three parts: an Einleitung [Introduction], followed by Erster and Zweyter Theil [Part One and Two]. The Introduction and Part One (hereinafter 'Vol I') are of particular relevance to the discussion. Part Two was concerned with diverse topics such as family and succession law, the different social estates, tax, and even criminal law. It contained, furthermore, the first comprehensive regulation of 'German' commercial law, compare ClausWilhelm Canaris, Handelsrecht [Commercial Law] (24 ${ }^{\text {th }}$ edn, Beck 2006) 17 para 48.

939 See Wesel (fn 910) 414.

940 See Wolf and Neuner (fn 48) 81. A succinct account of the background of these codes is given by Kroeschell (fn 141) 68-72. 


\section{B. Comparative Background}

evident later, several of the concepts and norms of this codification in relation to the conclusion of contracts prefigure those of the BGB, enacted over one hundred years later, so that it could be said that the ALR constitutes the (doctrinal) foundation of the BGB, ${ }^{941}$ which replaced the ALR a little over one hundred years after it had come into force.

iii. The Law of Contracts: Gemeines Recht (Common Law) and the Allgemeines Landrecht für die Preußischen Staaten (General State Laws of the Prussian States)

The period between the sixteenth and nineteenth centuries was one of reception of Roman law, which saw the existing legal rules common to the different German states, ie, the gemeines Recht, being altered. ${ }^{942}$ This law was not merely applied, however; rather, as noted above, it seems to have been elaborated, as it departs from Roman law theory in several aspects. Moreover, the importance of the gemeines Recht was diminished by the appearance of codifications like the ALR. ${ }^{943}$ While the aim of this codification was to unify the territory on a legal level, its application was limited to some extent, as it came secondary to 'besondre Gesetze', special legislation (Introduction $\$ 1$ ALR). All of this affected the notion of contracts (see Section aa) below), the way these were concluded (Section $\mathrm{bb})$ ), the coming into effect of declarations of intention (Section cc)), the contract's forms (Section dd)), and a common legal practice of the time, the giving of arrha (earnest; see Section ee)).

941 The BGB's historical development will be explored in Sections b. and c. below, while its contract rules are discussed in Section 3.

942 Compare Ferdinand Gastreich, Die Draufgabe und ibre historische Entwicklung: Eine Darstellung arrhalischer Rechtsformen in ibrer essentiellen und funktionellen Bedeutung nach altem und neuem Rechte [Earnest and its Historical Development: An Account on the Legal Forms of Arrha in their Essential and Functional Meaning in Old and New Law] (Regensbergschen Buchdruckerei Münster i.W. 1933) 51, discussing earnest (Draufgabe, arrha). Cf Wesel (fn 910) 391, noting that the legal developments of this period were a continuation of those of the Middle Ages, albeit under the influence of Roman and Canon law.

943 Having said this, the former seems to have been effective until the BGB came into force, see on this Luig K (fn 923) at X. 


\section{aa) Definition and Types of Contract}

One departure from Roman law was that the Roman notion of pactum became stipulatio in obligatory contracts under the gemeines Recht, an important part of which was the parties' agreement. ${ }^{944}$ Accordingly, an eighteenth-century textbook describes a contract as 'agreements, which have a name or existing cause to be obligating, and are binding due to their nature' ${ }^{945}$ It is perhaps due to this development that the limitation of contract types under Roman law was abandoned, a freedom of form existed, and that consensual contracts were not only admitted but deemed to be the normal rule, so that real contracts (Realverträge) became the exception. ${ }^{946}$ An example of a real contract was the transfer of property in a sale of movable things (bewegliche Sachen). ${ }^{947}$

Under the ALR, a contract was seen as a 'mutual agreement on the purchase or sale of a right' (Vol I Title $5 \$ 1$ ALR). ${ }^{948}$ This definition is similar to current contract law. ${ }^{949}$ It seems that there were various contract types under the ALR. On the one hand, there could be mutual or one-sided obligatory contracts, called 'lästiger Vertrag' or 'wohlthätiger Vertrag' (Vol I Title $5 \$ 7$ and $\$ 8$ ALR respectively). On the other hand, the law allowed agreements to be made on any object capable of being contained in a declaration of intention (Vol I Title $5 \$ 39$ ALR); however, the object must have been capable of identification (Vol I Title $5 \$ 71$ ALR), so that certainty was required to some extent. ${ }^{950}$ Following this logic, even

944 See Wesel (fn 910) 391-392. On the term pactum, see also Ekkehard Kaufmann and Gerhard Köbler, Pactus, pactum, in: Cordes and others (fn 923) Vol IV paras 303-305.

945 The original text reads: 'CONTRACTUS sunt conventiones, quae babent nomen vel caussam praesentem, sua natura civiliter obligantem', reproduced in Kroeschell (fn 141) 17, with a German translation at 19.

946 Compare Gastreich (fn 942) 51-52, who notes that even where a real contract was to be concluded, a consensual agreement already meant a contract to enter into a real contract. In effect, the parties were thus already bound through the consensual agreement. On the question of form, see also Flume (fn 885) 246.

947 Wesel (fn 910) 390.

948 The original says: 'Wechselseitige Einwilligung zur Erwerbung oder Veräußerung eines Rechts, wird Vertrag genannt.'

949 Compare the notion of a contract under current German law as set out in Section 1. above.

950 This is still true today, see Sections 3.a.ii.cc) and iii.cc) below. Under the ALR, a contract foreseeing that the specification of the object be at the sole discretion of the obliged person (Verpflichteter) was not seen as binding (Vol I Title $5 \mathbb{\$} 71$ 


\section{B. Comparative Background}

rights could be the object of contracts, as Introduction $\$ 99$ ALR permitted non-personal rights to be transferred. In terms of a contract's content, a wide range of possibilities thus existed. Beside obligatory contracts, there were also real contracts, such as for loans (Leihvertrag, Vol I Title $21 \$ 229$ ) and credit agreements (Darlehnsvertrage, Vol I Title $11 \$ 653$ ALR). .951

\section{bb) Contract Conclusion: Offer and Acceptance}

Under the gemeines Recht, two ways of concluding contracts existed, depending on whether the contract was real or obligatory. The latter kind of agreement was based on a consensual agreement through the influence of natural law, in particular Hugo Grotius and his idea of a translative promise-agreement (translativer Versprechensvertrag). ${ }^{952}$ It was his work which first analysed the contract more closely and described it as a consensus that must be declared, and that the necessary declarations of intention be an offer (promissio, promise) and acceptance (acceptio). ${ }^{953}$ In this way, the idea that an agreement was formed by way of offer and acceptance was recognised. ${ }^{954}$ Due to the influence of Roman law, offers were not seen as binding, since they were deemed to be one-sided promises, which in turn were not recognised under Roman law. ${ }^{955}$

The offer-and-acceptance model was adopted in the ALR as well. Consequently, contracts were concluded consensually through an exchange of declarations of intention (Willenserklärungen, on which see Vol I Title $4 \mathbb{\$} 1$ et seq ALR), namely, of a Versprechen (promise, Vol I Title $5 \mathbb{} 2$ ALR; also referred to as Antrag, offer, see, eg, ibid \$91) and Annabme (also referred to as 'Acceptation', acceptance, ibid $\$ 78$ ALR). This can be deduced from Vol I Title $5 \mathbb{\$} 4$ ALR, which says: 'The reality of a contract

ALR), but if the specification was to be made by a third party, the contract came into effect once this was done (ibid $\$ 72$ ).

951 See Schmidt J (fn 25) 110.

952 See the succinct account of Grotius' contract theory by Schmidt J (fn 25) 20-21. She argues at 25 and 20-21 that Grotius' model was not consensual as such, but one of a 'translative promise-contract' ('translativer Versprechensvertrag'), since both parties made promises that included conferring the other party a right to claim the fulfilment of the promise; instead, it was due to the work of Friedrich Carl von Savigny that the contractual model became truly consensual. On this change, see Section b. below.

953 See Wesel (fn 910) 377-378.

954 Ibid 392.

955 See on this Flume (fn 885) 640-641. 
essentially requires that a promise be accepted. ( $\mathrm{S} 78$ et seq)'. ${ }^{956}$ Having said this, the ALR sometimes foresaw specific forms that, if constitutive and not fulfilled, affected the validity of the contract (see ibid $\$ 109-110$, discussed in Section cc) below). With respect to the declarations of intention, 'promises' were contrasted with 'mere utterances' ('bloße Aeußerung'), the latter of which were not seen as legally binding (compare Vol I Title $5 \$ 3$ ALR). Similarly, '[b]loße Gelübde' (mere vows) were deemed as onesided promises ('einsieitge[...] Versprechen') and as such were non-binding (ibid $\$ 5$ ). Acceptance had to be unconditional and unqualified ('unbedingt und uneingeschränkt, Vol I Title $5 \$ 84$ ALR). A degree of certainty was therefore required of both declarations, ie, of the offer and the acceptance.

The real contract (Realvertrag, also known as a Realkontrakt) required not only concurrent declarations of intention, but furthermore a Realakt (real or factual act ${ }^{957}$ ), namely, the delivery of an object (Sachübergabe) under the gemeines Recht. ${ }^{958}$ Delivery was sometimes substituted for a sign of earnestness, arrha (discussed in Section dd) below). Under a sale of movable things, the contract (agreement) was seen as the titulus (in Roman law it was a iusta causa), and the delivery was the external form, the modus (in Roman law known as traditio).959 Conversely, local law remained of importance for the transfer of property in land. Accordingly, a declaration by the owner had to be made before a court or the city council (städtischer Rat), which were followed by an Auflassung (conveyance) and an entry into the public records (öffentliche Bücher). ${ }^{960}$ Under the ALR, real contracts were also concluded through a real act (Realakt) in addition to mutual declarations of intention, the act of which was usually in the form of the

956 The original provision states: 'Zur Wirklichkeit eines Vertrages wird wesentlich erfordert, daß das Versprechen gültig angenommen worden. (\$S. 78. sqq.)' Vol I Title $5 \$ 78$ ALR reads: 'Durch die Annahme eines gültigen Versprechens wird der Vertrag geschlossen.' In English: 'The acceptance of an effective offer concludes a contract.'

957 As the name suggests, the legal consequence flowing from the act arises automatically, ie, without an intention for this to happen on part of the acting party being necessary, see Kaufmann (fn 112) 53. For further details on real acts, see Christian Armbrüster, Vorbemerkung (Vor $\$ 116$ ) [Foreword (to S 116)], in: Säcker and others (fn 158) para 14, who notes that the intention with real acts is to bring about something concrete, rather than a legal consequence (which is the case for declarations of intention of volitional acts).

958 See Schmidt J (fn 25) 110.

959 Wesel (fn 910) 390, who goes on to note that the effectiveness of the transfer depended on the effectiveness of the titulus.

960 See ibid. 


\section{B. Comparative Background}

handing over of the object. ${ }^{961}$ This was true for two kinds: Darlehnsvertrage (credit agreements, see Vol I Title $11 \$ 653$ et seq ALR) and the Leibvertrag (gratuitous loan contracts, see ibid Title $21 \$ 229$ et seq).

\section{cc) The Coming into Effect of Declarations of Intentions}

It seems that the issue of when declarations of intention come into effect only arose in the eighteenth century and became increasingly dire as commercial transactions concluded through the post across distances increased while the time required decreased through technological advances like the development of the railway system. ${ }^{962}$

In the spirit of this development, the ALR recognised two ways for the conclusion process of contracts: either in person, ie, between contracting parties or their agents who were physically present, or by letter (Vol I Title 5 \$86 ALR). While the former case seems straightforward, there is an inherent distance in terms of both space and consequently also time in the latter case. Rules to bridge this difference were therefore needed for legal certainty. Compared with current German law, a surprisingly detailed regulation of the formation process existed in the ALR with respect to the coming into effect of declarations of intention, ie, for offers and acceptance; perhaps because it was a novel legal issue.

It seems that offers came into effect upon their arrival, irrespective of whether their articulation was made orally or in writing. While this was not laid down explicitly, it can be deduced from Vol I Title $5 \$ 96$ ALR, which provides:

Where the offer between absent persons is made in writing, what matters is the point in time at which the letter could arrive at the place of the other person if the postal service operates in the usual manner. 963

Conversely, unless otherwise expressly provided, declarations of acceptance principally seem to have come into effect upon being uttered, or,

961 See Schmidt J (fn 25) 110-111.

962 Oestmann (fn 917) 546-547 para 20.

963 The original provision states: 'Ist der Antrag unter Abwesenden schriftlich geschehen, so kommt es auf den Zeitpunkt an, da der Brief an dem Orte, wo der Andre sich aufhält, nach dem gewöhnlichen Laufe der Posten hat eingehen können.' Note that the principle of receipt applies today, see Section 3.a.ii.dd) below. 
rather, once the offeree had done everything necessary in order to make the declaration known to the offeror. This can be inferred from Vol 1 Title $5 \$ 102$ ALR, which provides:

In all cases in which nothing to the contrary has been expressly agreed, it will be assumed that an acceptance be made at that point in time at which the offeree has done everything necessary on his part to make his declaration known to the offeror. ${ }^{964}$

This rule is interesting for two reasons. First, it seems close if not identical to the English postal rule. ${ }^{965}$ More importantly, this rule no longer exists today; the BGB contains one single rule for all declarations of intention, according to which receipt of the declaration is pertinent, not the moment when it has been sent out. ${ }^{966}$

Rules existed for the time frame of making acceptance. Thus, Vol I Title $5 \$ 97$ ALR stipulates that the response to an offer 'must be made by the next $[\ldots]$ post departing after [the offer has arrived]', where the contracting process was conducted by letter and no explicit stipulation was made. ${ }^{967}$ In contrast, where the parties were both present and no time frame was stipulated, a declaration of acceptance was normally expected immediately if made orally (ibid $\$ 94$ ALR), or within 24 hours if made in written form (ibid $\$ 95$ ALR). Otherwise, the stipulated time frame was pertinent (ibid $\$ 91$ ALR). Once the time for accepting had elapsed, the offeror was free to retract his offer by notifying the offeree of this (ibid $\$ 103-104$ ALR). It

964 The original provision reads: 'In allen Fällen, wo nicht ein Andres ausdrücklich bestimmt ist, wird dafür gehalten, daß die Annahme in dem Zeitpunkte geschehen sey, wo der Annehmende alles gethan hatte, was von seiner Seite zur Bekanntmachung seiner Erklärung an den Antragenden erforderlich war.'

965 On this rule, see Section II.2.b.iii.bb) above.

966 This is discussed further in Section 3.a.ii.dd) below. The reason for the ALR's rule not being used - although not stated expressly — seems to be the incompatibility of this rule (related to the 'Äußerungstheorie' [expression theory]) with the requirement that the addressee needs to have knowledge of the declaration. On the assessment of the different points in time in which a declaration of intention may come into effect during the creation of the BGB, see Mugdan (fn 883) Vol 1438.

967 The original provision says: 'Mit der nächsten [...] Post, welche nach [der Ankunft des Antrags] abgeht, muß der Antrag beantwortet werden.' While this is so, the offeree had to wait for the following day's post to arrive in case there was some incident preventing the declaration of acceptance from arriving sooner (ibid $\$ 98$ ALR). 
can be deduced from these rules that an offer was not generally revocable, at least where a time frame for acceptance had been stipulated. ${ }^{968}$

\section{dd) Contract Forms}

Both the gemeines Recht and the ALR foresaw different forms in which contracts had to be made. Under the former, legal practice had an increasing interest in fixing agreements, including contracts, in written form, whereby the document was authenticated by sealing. ${ }^{969}$ Other existing albeit far less common forms of authentication were signatures and handsigns (marks; Handzeichen). ${ }^{970}$ One particular documentary form was the Chirographierung, according to which a written instrument was cut apart so that its authenticity could be verified by placing the parts together once again. ${ }^{971} \mathrm{~A}$ similar procedure existed in the English common law: bilateral covenants were indented. This involved the deed containing the covenants being cut into pieces with a wavy line, thus allowing the veracity of the parts to be tested when the pieces were put back together. ${ }^{972}$

As was mentioned above, the ALR foresaw forms for contracts, namely, three types: Schriftliche Form (written form), Punctationen ('vorläufige Aufzeichnungen der Vereinbarung, ${ }^{973}$ a preliminary or provisional fixation of an agreement), and the gerichtliche Niederschrift (judicial record). ${ }^{974}$ Generally, writing meant that a document had to be signed in order to become effective (Vol I Title $5 \$ 116$ ALR), so that hand-written documents on their own were not sufficient (ibid $\$ 118$ ). ${ }^{975}$ Furthermore, documents needed

968 This remains true today, see Section 3.a.ii.ee) below. On the current rules on acceptance, see Section 3.a.iii. below. Busche, ' $\$ 145 B G B$ ' (fn 893) para 3, notes that a similar provision existed later in the forerunner of today's HGB, the Allgemeines Deutsches Handelsgesetzbuch. On this Code, see Section b. below. This situation is in contrast to English law, which generally deems offers to be revocable, see B.II.3.a.ii.ff) above.

969 Compare Andrea Stieldorf, Siegelkunde [The Study of Seals] (Hahn 2004) 44-45.

970 See Stieldorf (fn 969) 45.

971 On this, see ibid 44.

972 For further details on this, see Simpson, 'History' (fn 232) 35, 91.

973 Thus described in Mugdan (fn 883) Vol 1452.

974 This form is not considered further below; interested readers are referred to Vol I Title $5 \$ 126$ ALR.

975 At least in contracts concluded in court (gerichtliche Verträge), illiterate persons could use a mark or an $\mathrm{x}$ instead of writing their signature, see Vol I Title 5 $\$ 175$ ALR. This was also true later in the Deutsche Reich, where a Handzeichen 
to be sealed, unless the document was signed, delivered, and mentioned or was otherwise treated as bearing a seal. This can be deduced from the wording of Vol I Title $5 \$ 119$ ALR, which says: 'A signed and delivered instrument need not be sealed, if it intends a seal'. ${ }^{976}$ Where it was not a legal requirement but the parties' stipulation that the contract be made in written form, it was presumed to be a constitutive requirement, without which the contract would not arise (ibid $\$ 117$ ).

Legal transactions of a certain value, namely, of 50 Taler (thaler) $)^{977}$ and more, had to be put in writing under the ALR (ibid $\mathbb{S} 131$ ). This rule applied to bilateral and unilateral transactions (see Vol I Title 5 $\$ 133$ ALR), and, furthermore, to renunciations or waivers ('Entsagungen und Verzichtleistungen'), land charges ('Grundgerechtigkeiten'), periodical performances ('terminliche Leistungen'), and what were known as 'gewagte Verträge', ie, bilateral contracts of uncertain content in the sense that its outcome was determined by chance, such as with insurance contracts or bets; ${ }^{978}$ it did not, however, apply to servant's contracts (Gesindemiethe; ibid $\$ 134-136,139,137)$.

Standard written instruments, namely, formal contracts, were distinguished from Punctationen (pre-contracts or contract drafts). This can be

could replace a signature if it was certified by a notary. See on this Mugdan (fn 883) Vol 1454.

976 The original provision reads: 'Die Besiegelung eines unterschriebenen und ausgehändigten Instruments aber ist nicht nothwendig, wenn gleich darin der Siegel gedacht wird.' On the meaning of 'gedenken' as to intend or mean to do something, see entry no 2 for 'gedenken' in Duden online at www.duden.de. The contemporary use of seals will be discussed in Section 3.b.iii., while the historical development will be explored further in D.III.2.b. below. On a seal being mentioned in the document, see Christian F Koch, Lehrbuch des preußischen gemeinen Privatsrechts Band 2 [Textbook on Prussian Common Private Law Vol 2] (Verlag der Trautw'in'schen Buch- und Musik-Handlung 1852) 198, who notes that 'die Besiegelung [der schriftlichen Aufsetzung der getroffenen Verabredungen] soll entbebrlich sein, selbst wenn der Siegel Erwähnung geschehen' ('sealing [of the written draft of the agreement] is unnecessary, even if the seal is mentioned').

977 Taler referred to silver Courant. For further details on the different currencies in the German states of that time, including Prussia, see, eg, Encyclopaedia Britannica, Coin (Online Academic Edition 2018), http://academic.eb.com/levels/collegiate/article/coin/105949, at 'The Later Medieval and Modern Coinages of Continental Europe'.

978 See the entry 'Aleatorische Verträge' in Brockhaus' Konversations-Lexikon Vol 1 [Brockhaus' Conversation Dictionary Vol 1] $\left(14^{\text {th }}\right.$ edn, FA Brockhaus Verlag 1898) 354 . 


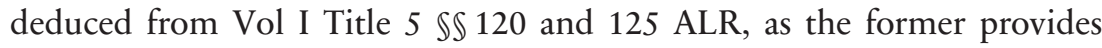
that:

A punctuation that is signed by both parties and contains their mutual consent to all essential conditions of the transaction has the same validity as a formal contract. ${ }^{979}$

This kind of written document therefore had to contain all of the contract terms; oral evidence as to any ancillary agreements were inadmissible and the court would determine any missing terms using normal interpretation rules (ibid $\$ 127-129$ ). .980

It is interesting to note that while the ALR did not actually prescribe form as a general constitutive requirement for all contracts, this was nevertheless the practical effect, as the scope of the cases which were caught by the form requirements was very wide. ${ }^{981}$ The consequence of non-fulfilment was invalidity (see Vol I Title $5 \$ 109$ ALR), or at least unenforceability of the agreement: In case of statutorily prescribed written requirements that were not fulfilled, the contract in question was not enforceable, unless one of the parties had begun to perform under it. ${ }^{982}$ Having said this, in cases where the ALR merely foresaw a penalty for non-fulfilment of a form requirement, the contract would not lose its validity (see ibid $\$ 110$ ).

ee) The Further Requirement of Giving Arrha or Draufgabe (Earnest)

As the notion of the real contract declined, the German arrha, an earnest that was traditionally given when concluding the agreement to symbolise the fulfilment of one's obligation and in so doing making it enforceable, would no longer be deemed as a constitutive requirement for a contract

979 The original provision states: 'Eine von beyden Theilen unterschriebene Punctation, aus welcher die gegenseitige Einwilligung derselben in alle wesentliche Bedingungen des Geschäfts erhellet, ist mit einem förmlichen Contract von gleicher Gültigkeit.'

980 Where the document only contained part of the contract's essential terms, whether by omission or due to an agreement between the parties to agree on certain points later, this was a Tractat (composition, see ibid $\$ 125$ ).

981 Compare the observations made in Mugdan (fn 883) Vol 1450.

982 See on this Koch (fn 976) 203, who states the reason to be that the contract is then seen as a kind of real contract. Arguably, that contract is enforceable because a real act is done. On this kind of contract, see also Section iii.aa) above. 
but rather as evidence of the same under German gemeines Recht. ${ }^{983}$ In practice, a plethora of different names were used in the German states instead of 'arrha', such as Lohngeld984, Gottespfennig, or Weinkauf (literally 'wine purchase'; reflecting the custom of the contracting parties and the witnesses drinking wine together after concluding an agreement), as well as Handgeld ('hand money') ${ }^{985}$, Schlüsselgeld ('key money', used in purchases of country estates) or Zaumgeld ('bridle money', used in purchases of horses). ${ }^{986}$ Initially, small personal objects such as rings or other jewellery and weapons were handed over; these were gradually replaced by money. ${ }^{987}$ The object had to be given and be received with the intention that the object be proof of the contract, ie, function as arrha.${ }^{988}$ In effect, the earnest thus given created a legal presumption that an agreement (an obligation) was made, ${ }^{989}$ and could consequently be a sign or indication of

983 See Gastreich (fn 942) 46-47, 52. In effect, arrha was initially used as a substitute for performance in real contracts in order to circumvent the usual contracting method requiring concurrent fulfilment by both parties. This was necessary, since only performance or use of a form would make a contract effective, see ibid 45,44 . The denomination as 'arrha' seems to go back to Roman law, which in turn derived the name from the Greek term 'arrhabo', see ibid 11. To be more precise, it was termed arrha conformatoria in accordance with its function, see ibid 7, 23. A similar notion is found in the concept of consideration of sixteenth- and seventeenth-century England, see Section II.2.a.iii.cc) above.

984 Compare the English notion of 'consideration', which also means 'payment for a service', see, eg, the entry in the Cambridge Dictionary (online version), https://dictionary.cambridge.org/. For details on the concept in English law, see further Section II.3.a.v. above.

985 Compare the name of the Japanese concept of earnest money, which literally means 'hand-touch' money (手付, tetsuke). See on this Section C.IV.1.c.iii. below.

986 See Gastreich (fn 942) 46, 49, 51. See also the ways to bind oneself in the Middle Ages in England, discussed in Section II.2.a.iii.cc) above.

987 See ibid 53, 28-29, who is of the opinion that only corporeal objects were capable of constituting arrha, namely, only if they could function as a symbol of the concluded agreement.

988 Ibid 28 notes that this would regularly be the case where the object given was commonly deemed as an 'arrhalisches Beweismittel' ('arrhalian means of evidence').

989 See ibid 52. This was achieved because the understanding of arrha, already in existence in Roman times, was that arrha would only be given where a contract had been concluded, so that such a contract would be a factual pre-requisite for arrha, see ibid 25. Having said this, arrha did not form part of that contract; rather, the giving and receiving of arrha with the required intention created a second contract ('pactum arrhale'), which was like an 'accessory contract' (asses- 
that party's earnestness. ${ }^{990}$ This use was reflected in particular laws, such as the city law (Statuten) of Hamburg from 1771991, which say in Part II Title 8 Art 10:

A lasting purchase and a lasting sale may be agreed in this good city, even without God's penny. If, however, it is given, the purchase will be all the more reinforced. 992

The fact that arrha, here called Gottes-pfenning, is mentioned in relation to a sale may not be coincidental, as this was the contract type for which arrha was predominantly used. Other uses included livestock trade, as well as lease and service agreements, although arrha could theoretically be given for any contract. ${ }^{993}$ The phrasing of Art 10 hints at another custom: while earnest could be given by either party, in practice, it was usually the purchaser who did so. ${ }^{994}$ A second use of arrha was as a kind of contractual

sorischer Vertrag) to the other agreement, see ibid 53, 25. This notion is the same in Japanese law, see Section C.IV.1.c.iii. below.

990 Compare Peter Gottwald, $\$ 336$ Auslegung der Draufgabe [Section 336 Interpretation of Earnest], in: Säcker and others (fn 158) Vol 2 ( $7^{\text {th }}$ online edn, CH Beck 2016) para 1, using the term 'Seriositätsindiz' (indication of seriousness) coined by Konrad Zweigert and Hein Kötz. See on this latter term fn 23 above.

991 Der Stadt Hamburg Statuten und Gerichts-Ordnung [Statutes and Court Rules of the City of Hamburg] (new unchanged edn 1771), available online at http:// reader.digitale-sammlungen.de/de/fs1/object/display/bsb11201503_00009.html.

992 The original provision reads: 'Ein Kauff und Verkauff kann in dieser guten Stadt, auch wol ohne Gottes-Pfennig, beständiglich getroffen werden. Wenn aber derselbige ergangen; ist der Kauff dadurch desto mehr bekräfftiget.' Transcription and translation by this author from the scanned print edition of 1771 ( $\mathrm{fn}$ 991). Translation note: the term 'beständiglich' is an old form of 'beständig', meaning something is enduring or of lasting nature, resistant. On the contemporary meaning, see the entry for 'beständig' in Duden online at www.duden.de.

993 See Gastreich (fn 942) 53. Note that 'service contract' refers to 'Gesindeverträge', whereby 'Gesinde' was the denomination for servants employed. Compare the entry for 'Gesinde' in Duden online at www.duden.de.

994 See Gastreich (fn 942) 31. It ought to be noted that the verb 'to give' does not merely refer to the physical handing over of the object. The act was one of transfer of property in the object that was handed over, whereby the receiver would be obliged to return the object once the contract had been fulfilled by the other party; or, where earnest was given as money, the amount received would be counted as part of the giver's fulfilment of their payment obligation, see ibid 54. Earnest in the form of arrha must be distinguished from a down payment (Anzablung). The reasons are their different natures. Most importantly, the latter did not have the same function as the former, namely, to act as evidence. Conversely, the former did not a priori function like the latter in that it counted as part-fulfilment of the giver's obligation, although arguably their 
penalty: either contracting party could cancel the contract, namely, as the giver by forfeiting the arrha, or as the receiver by returning it, as the case may be. 995

The ALR also foresaw different ways to strengthen the bindingness of contractual agreements ('Verstärkung der Verträge'), one of which was the giving of earnest ('Draufgabe', ibid $\$ 205$ et seq). ${ }^{996}$ It is interesting that the ALR stipulated these methods, as the legal thinking of that time already acknowledged the consensuality of contracts; it was only in particular limited situations that a specific form was required as a constitutional element, ie, in order to give effect to the agreement. This concept is of particular interest, as it can still be found in the current BGB ( $\$ 336$ et seq). ${ }^{997}$

As in the gemeines Recht, Draufgabe functioned as evidence that a contract had been concluded (Vol I Title $5 \$ 205$ ALR). ${ }^{998}$ Exceptionally, it

effect of reducing the amount of money the giver had to pay to the receiver was the same where money was provided as arrha. See on this ibid 37 and fn 998 below.

995 Ibid 53; cf ibid 20, where it says that in Roman law, the receiver had to return twice the amount of arrha. In accordance with this function, it is known as arrha poenalis, compare ibid 7; see also Gottwald (fn 990) para 1.

996 Note that the ALR uses the term 'arrba' (in ibid $\$ 205$ ) exclusively, without giving alternative denominations, such as Gottes-Pfennig, which might be explained on the continuing influence of Roman law in this era. See fn 983 above. The other ways to strengthen an agreement was by way of acknowledgement of the contract ('Anerkenntniß', Vol I Title $5 \mathbb{1} 185$ et seq ALR), by renouncing to object to the agreement ('Entsagung der Einwendungen', ibid $\$ 193$ et seq), and by judicial confirmation of the contract ('gerichtliche Bestätigung', ibid $\$ 200$ et seq).

997 For further details, see Section 3.c.ii. below. In contrast, the other methods are no longer contained in German law.

998 Similarly, Draufgabe was generally differentiated from an 'Angeld', a down payment; however, it seems that the stipulation of the parties was important: where something was given with the intention of constituting a down payment, it was deemed as such (compare ibid $\$ 206$ ); if nothing was stipulated, the object given was deemed to fulfil the function of both Draufgabe and Angeld (ibid $\$ 207)$. Compare Miethgeld with service contracts, which would normally be deducted from the servant's wages (Vol II Title $5 \$ 25-26$ ALR). This seems to suggest that it was the employers who gave the earnest. Indeed, compare ibid $\$ 27$, which speaks of the servant receiving Miethgeld: 'Hat sich ein Dienstbote bey mehrern Herrschaften zugleich vermiethet: so gebührt derjenigen, von welcher er das Miethgeld zuerst angenommen hat der Vorzug' (emphasis added). In English: 'Where a servant has loaned himself to several masters: so that master shall have preference, from whom he first accepts the Miethgeld' (emphasis added). This was not true where the object given did not correspond to what the giver was obliged to give under their contractual obligation (ibid $\$ 208$ ). Here, earnest would not, however, be returned to the giver upon fulfilment of their obliga- 


\section{B. Comparative Background}

would be constitutive for contracts of employment of servants (Gesindeverträge), as it could replace the required written form (see Vol II Title $5 \$ 22-$ 23 ALR). 999 This constituted a deviation from the gemeines Recht. Another deviation from the gemeines Recht was that, unless the parties explicitly provided for the possibility, Draufgabe could not generally be used to cancel a contract (see ibid $\$ \$ \$ 212,209-210$ ).

b. Contracts in the Time from the Deutsche Bund to the Deutsche Reich: The Drafting of the BGB and of the HGB (19 ${ }^{\text {th }}$ Century)

The nineteenth century was a turning point for Germany in terms of the political and social, as well as the legal developments: The country came together politically, its economy improved, and new comprehensive legislation in private law was created for the country (see Sections i.-ii. below). As a consequence, the rules on contract law were altered (see Section iii.).

\section{i. Political and Social Background}

After the end of the Holy Roman Empire of the German Nation at the beginning of the nineteenth century and following several internal and external political struggles, a somewhat stronger union emerged between a number of larger German states in 1815 in the form of the Deutsche Bund (German Confederation), each of the states of which retained their own sovereigns. ${ }^{1000}$ These rulers did not have sole legislative power; constitutions of some states, like Bavaria, required that legislation be enacted by the sovereigns together with the estates (Stände). ${ }^{1001}$ This was an expression of the fact that Bürger (citizens) - understood as encompassing both the old estate of citizens, ie, the educated middle-class, as well as part of the nobility - took on an increasingly important role, not only in terms

tion, but be treated as a Zugabe (bonus), which the receiver would keep. See Gastreich (fn 942) 55.

999 See also Gastreich (fn 942) 55.

1000 See Kroeschell (fn 141) 134. For further details, see, eg, Encyclopaedia Britannica, 'Germany' (fn 911).

1001 A quote from the Bavarian constitution can be found in Kroeschell (fn 141) 153. 
of economic contribution. ${ }^{1002}$ Despite these differences, the new political framework demanded a new legal order.

\section{ii. Structural Changes in the Law: Creation of an Imperial Supreme Court and the Codification of the BGB and the HGB}

Under the constitution of the Deutsche Bund of 1849, legal unification was required to be established in private and commercial law among others. ${ }^{1003}$ First attempts to unify the law were made, based on the emerging wish for 'a modern national Code'. ${ }^{1004}$ Accordingly, a commission drafted the Allgemeines Deutsches Handelsgesetzbuch (Common German Commercial Code, hereinafter 'ADHGB'), which was recommended by the confederation's assembly, the Bundesversammlung, in 1861, and subsequently enacted in most German states, ${ }^{1005}$ in the form of Partikularrecht. ${ }^{1006}$

In 1871, the Deutsches Reich (German Empire) was established, and full legislative competence was obtained by the Reich two years later, in 1873,

1002 Compare ibid 123, who refers to this period as the 'age of citizens' ('bürgerliches Zeitalter') and notes that members occupied in industry and commerce were not initially included in this notion. The class seems to have expanded subsequently. Nevertheless, with the advancement of industrialisation, the part of this class that was labourers split from the rest to form a distinct class, compare ibid 178. The interests of the different estates diverged further subsequently: At the end of the nineteenth century, 'almost every estate represent only their own particular interests', Honsell (fn 140) para 8: 'fast jeder Stand vertritt einseitig seine Sonderinteressen'.

1003 See Kroeschell (fn 141) 165. See also Honsell (fn 140) paras 19-20.

1004 Compare Kroeschell (fn 141) 124. See further ibid 165, where he notes that legal unification was thought to bring about national unification. See also Honsell (fn 140) para 19, according to whom a shared legal culture ('Rechtskultur') was seen as a strong bond for unifying the German people. In what follows, only the modification of civil and commercial law will be explored. For details on the new legislation in civil procedure and criminal law, see Kroeschell, ibid 167.

1005 See Canaris (fn 938) 17 para 51, who goes on to note at 18 para 52 that, due to the lack of a common civil code, the ADHGB contained numerous provisions which would normally be found in a civil code. For further details on the creation of the ADHGB, see Andreas M Fleckner, Allgemeines Deutsches Handelsgesetzbuch [Common German Commercial Code], in: Basedow and Hopt and Zimmermann (fn 16) Vol I 45-50.

1006 See Henne (fn 930). cf Kroeschell (fn 141) 165, stating the ADHGB to be 'general law' ('[a]llgemeines Recht') as opposed to 'common law' ('gemeines Recht'). 


\section{B. Comparative Background}

when the State's powers were broadened to encompass private law. ${ }^{1007}$ This paved the path for the enactment of pan-German legislation in the areas of commercial and private law. In this way, the ADHGB became part of the Reichsrecht and was thus applicable throughout the entire empire. ${ }^{1008}$ Seeing as Reichsrecht had to be enforced by a central institution, the Reichsgericht (hereinafter 'RG') was established in 1879 as the court of last instance in civil and criminal matters of the Deutsche Reich. ${ }^{1009}$ It seems that the higher courts began to include a reasoning in the decision and to publish these. This may have aided in the establishment of a culture of 'ständige Rechtsprechung' ('settled case law').1010

As a consequence of the legal unification, commerce flourished throughout the country, ${ }^{1011}$ which in turn necessitated a deviation from the formalism of the law of the Alte Reich, in particular that of the ALR. Work thus began on drafting both a pan-German civil and a new commercial codification. ${ }^{1012}$ The fact that the needs of commerce were heeded is visible in several regulatory approaches, whereby focus in the following account will be had on the formation of contracts and formalities.

\section{iii. Contract Law in the Draft Legislation}

One way in which commerce was encouraged was the provision of a smooth and speedy process by which contracts could be concluded. This was realised in several ways in the Erster Entwurf (first draft) of a 'German' civil code - what would eventually become the BGB (hereinafter 'BGB

1007 For details, see Honsell (fn 140) paras 1-2, 21-22. Previously, only the law of obligations and that of commerce were within the State's powers, see Wolf and Neuner (fn 48) 82 para 2. For further discussion of the political constitution of the Reich, see Kroeschell (fn 141) 221-223.

1008 See Canaris (fn 938) 17 para 52.

1009 See www.bverwg.de/gebaeude.

1010 See on this Kroeschell (fn 141) 171-172.

1011 cf Wolf and Neuner (fn 48) 82 para 1, stating that the legal diversity (Zersplitterung) hindered commerce. On the legal fragmentation, see also Honsell (fn 140) para 24.

1012 The drafting commissions were established in 1874 and 1856 respectively. On the latter, see Fleckner (fn 1005) 47; on the former, see Hans-Peter Haferkamp, Bürgerliches Gesetzbuch [Civil Code], in: Basedow and Hopt and Zimmermann (fn 16) Vol I 229. 
first draft') - published in 1888 after thirteen years of intensive work. ${ }^{1013}$ In particular, offers were made to be binding by default (in $\$ 80$ BGB first draft) and the default time frames for accepting offers (and thus completing the contract) were kept as short as possible (in $\$ \mathbb{S} 82-84 \mathrm{ibid}) .{ }^{1014}$ The underlying aim was also aided by the stipulations as to form.

The move away from the formalism that had determined the ALR by way of the freedom of form was accomplished by the gradual recognition of a rechtsgeschäftlicher Wille (legal volition) as the constitutive element of a contract, ie, of consensual contracts. ${ }^{1015}$ This trend is reflected in the BGB first draft, which contained the following two stipulations:

Section 77 For the conclusion of a contract, it is required that the contracting parties mutually declare their coinciding intention. ${ }^{1016}$

Section $91 \mathrm{~A}$ form is necessary for a legal transaction only if such is prescribed by statute or a legal transaction.

Where a special form is prescribed by law, the legal transaction will be void in case of non-observance of the form, unless something to the contrary is stipulated by law. In case of doubt, the same is true where a form agreed on in a legal transaction is lacking. ${ }^{1017}$

1013 For further details on the process, see, eg, Säcker, 'Einleitung BGB' (fn 880) para 9.

1014 On the arguments in favour of this regulation, see Mugdan (fn 883) Vol 1 443-444, 445-446.

1015 Compare Lutz-Ingo Plewe, Die gesetzlichen Formen des Rechtsgeschäfts: Eine Bestandsaufnahme zu Beginn des 21. Jahrbunderts [The Statutory Forms of Legal Transactions: A Review from the Beginning of the 21 $1^{\text {st }}$ Century] (Shaker 2003) 2. As to the theoretical foundation provided by von Savigny, see fn 952 above and further Schmidt J (fn 25) 25-26. cf the observations in Mugdan (fn 883) Vol 1450 , where it is stated that German civil codes other than the ALR, as well as the gemeines Recht already acknowledged the freedom of form.

1016 Text transcribed from Mugdan (fn 883) Vol 1 LXXIX; translation by this author. The original text reads: ' $\mathbb{5} 77$ Zur Schließung eines Vertrages wird erfordert, dass die Vertragsschließenden ihren übereinstimmenden Willen sich gegenseitig erklären.'

1017 Text transcribed from Mugdan (fn 883) Vol 1 LXXIX; translation by this author. The original text states: '\$91 Für ein Rechtsgeschäft ist eine besondere Form nur dann erforderlich, wenn eine solche durch Gesetz oder Rechtsgeschäft bestimmt ist.

Ist durch Gesetz eine besondere Form vorgeschrieben, so ist das Rechtsgeschäft im Falle des Mangels der Form nichtig, sofern nicht ein Anderes vorgeschrieben ist. Dasselbe gilt im Zweifel im Falle des Mangels der durch Rechtsgeschäft bestimmten Form.' 


\section{B. Comparative Background}

The quoted provisions were deleted in the course of the BGB's legislative process, as the opinion predominated that they were superfluous. ${ }^{1018}$ In the case of the freedom of form, because it was deemed to be a matter of course. ${ }^{1019}$

The respect for this freedom is also visible in the discussion surrounding the nature of the Draufgabe: While it was suggested to give constitutive meaning to arrha in accordance with the 'German' instead of the Roman tradition, this was rejected by the majority of the drafting commission, in order to avoid misunderstandings regarding the consensual nature of contracts. ${ }^{1020}$ Consequently, the wording of the provision was later amended to bring out more clearly the Draufgabe's default function as proof. ${ }^{1021}$

In contrast to this explicit regulation, it was stated in the motives (Motive) to the $\mathrm{BGB}^{1022}$ that the term Rechtsgeschäft (legal transaction) ought not to be defined; it was deemed better to leave it to the courts to demarcate its scope. ${ }^{1023}$ Arguably, this ought to extend to contracts, which were defined simply as 'zweiseitige Rechtsgeschäft [e]' ('two-sided legal transaction[s]') in the motives to the BGB. ${ }^{1024}$ The commission hesitated to make explicit statements in other respects as well. One example relates to Darleben (credit agreements) and the nature of this kind of contract: While traditionally a Realvertrag, arguments were put forward that loans

1018 Compare Mugdan (fn 883) Vol 1 688. For details on the discussion, see Schmidt J (fn 25) 26-29.

1019 Compare Plewe (fn 1015) 2. See also Mugdan (fn 883) Vol 1 696. While the text of the provision was altered only slightly in the second draft $(\mathbb{1 0 4})$, the final version ( $\mathbb{1 2 1}$; today found in $\mathbb{1} 125 \mathrm{BGB}$ ) constituted a complete deviation in that the freedom of form was no longer mentioned and only the legal consequence of non-fulfilment was contained. A juxtaposition of the three versions is provided in Mugdan (fn 883) Vol 1 LXXXI.

1020 See Mugdan (fn 883) Vol 2714.

1021 Compare the juxtaposition of the two drafts in ibid Vol 2 XLVIII at 'I $\$ 417$ '. For other changes regarding this legal institute, see ibid at 'I $₫ 418$ ' and 'I $\$ 419$, as well as at 715-717 (protocols to the commission's debate).

1022 This publication acted like a commentary or explanatory notes to the BGB first draft.

1023 See Mugdan (fn 883) Vol 1 421. cf Schmidt J (fn 25) 27, who states that the intention was to avoid impeding 'dogmatic developments' ('dogmatische Entwicklungen'); but that there was also an ongoing scientific debate. This latter fact possibly prevented an accord being reached on several definitions. Interestingly, it had been likewise suggested that the provision on Draufgabe was unnecessary in so far as it made the function of proof explicit, see Mugdan, ibid Vol 2 714-715.

1024 See Mugdan (fn 883) Vol 1422. 
were now consensual in nature; however, the commission decided to leave this scientific discussion aside and opted for letting the loan's nature be, focusing instead on regulating the consequences of that contract. ${ }^{1025}$

The deletion of $\$ 91$ from the BGB first draft is only one of several changes made after heavy criticism had been levelled at the composition. ${ }^{1026}$ A third draft was eventually enacted as law in 1986 and the BGB came into force on 1 January $1900 .{ }^{1027}$ The new commercial code, the Handelsgesetzbuch ('HGB'), which was the ADHGB adapted to the (existence of the) BGB, came into force on the same day. ${ }^{1028}$ Despite, or perhaps because of this difficult process, the contract law embodied in the BGB is liberal in nature and formulated on a general or abstract level that was applicable to the whole of German society for the first time; moreover, it bestows selfdetermination on the contracting parties due to the dispositive nature of most of its provisions. ${ }^{1029}$ As its rules will be analysed in detail in Section 3. below, no further discussion will be made at this point. Nevertheless, the following section will give a brief overview of the changes to contract law that were made subsequent to the BGB's (and the HGB's) coming into effect.

\section{c. The Subsequent Development of German (Contract) Law (20 th Century )}

German law experienced several changes from the twentieth century as well. These were due, in part, to the transformations on the political level (see Section i. below), but also due to other developments in society. As will be seen (in Section ii.), adjustments have been made to contract law in

1025 See ibid Vol 2 169-170. See on this further Schmidt J (fn 25) 111-113.

1026 Details on the ensuing criticism and the subsequent process can be found in, eg, Wolf and Neuner (fn 48) 82-83. See also Haferkamp (fn 1012) 230-231.

1027 On the process, see, eg, Kroeschell (fn 141) 180-181. See also Haferkamp (fn 1012) 231.

1028 See on this Canaris (fn 938) 18 para 53; see also Schmidt K (fn 931) paras 22, 24.

1029 Compare Karl Riesenhuber, Verbraucherschutz und Schuldrechtsmodernisierung [Consumer Protection and the Modernisation of the Law of Obligations], in: Makoto Tadaki and Harald Baum (eds), Saiken-hö kaisei ni kansuru hikaku-höteki kentō: nichidoku-hō no shiten kara [A Comparative Analysis of the Modernisation of the Law of Obligations in Japan: From the Perspective of Japanese and German Law] (Chūō Daigaku Shuppan-bu 2014) 147, 148. 


\section{B. Comparative Background}

general, but - apart from form requirements - the basic formation rules have been left almost untouched.

\section{i. Overview of Political Developments}

The Deutsche Reich was followed by a quick succession of different kinds of states in Germany: the Weimarer Republik (Weimar Republic, 1918-1933), the Dritte Reich (Third Reich, 1933-1945), the subsequent splitting of Germany into the Deutsche Demokratische Republik (German Democratic Republic) and the Bundesrepublik Deutschland (Federal Republic of Germany, 1945-1989), ending with its re-unification in 1989/1990. While the national political framework has remained constant since, other dimensions, particularly the EU, have had an impact on Germany and, of course, its law. ${ }^{1030}$ It goes beyond the scope of this dissertation to discuss all the historical events of these phases; only some legal developments in the area of contract law will be examined subsequently. ${ }^{1031}$

\section{ii. Overview of (Contractual) Legal Developments}

Both the BGB and the HGB have been in force for almost 120 years, despite all the changes in the political framework intimated above. ${ }^{1032}$ It may be needless to say that during this period, there have been developments in German society and its predominant thinking, commerce, and, especially in more recent times, technology. All of these changes have made the adaptation of the BGB's and of the HGB's rules necessary. Amendments relevant to contract law will now be considered cursorily.

1030 Compare Wolf and Neuner (fn 48) 87, 88.

1031 Interested readers will find a concise account of the historical events in the Encyclopaedia Britannica, 'Germany' (fn 911).

1032 This excepts the German Democratic Republic, which had its own civil code (Zivilgesetzbuch der Deutschen Demokratischen Republik of 19 June 1975) from 1 January 1976 to 3 October 1990. The legislation can be found online at www.jurion.de/gesetze/zgb_ddr/. For a brief discussion of the differences to the BGB, see Wolf and Neuner (fn 48) 86-87. Similarly, the HGB seems to not have been applicable in the Democratic Republic and only came back into force in 1990, see Schmidt K (fn 931) para 25; cf Henne (fn 930), who says the HGB was partially in force then. 
On the one hand, there have been alterations on a general level, especially in the areas of family law (Familienrecht) and consumer law (Verbraucherrecht). ${ }^{1033}$ On the other hand, different contract types, such as the package travel contract (Reisevertrag, $\mathbb{S} \mathbb{S} 651 \mathrm{a}$ et seq BGB) and brokerage contracts (Vermittlungsvertrag, $\mathbb{S} \$ 481 \mathrm{~b}$ para 1 et seq BGB), were added over time. In contrast, the basic formation rules remain almost unaltered until today. ${ }^{1034}$

Perhaps the most important amendments to the BGB to date - apart from reforms of German family law after WWII - were brought about under the Schuldrechtsreform (reform of the law of obligations), which entered into force in 2002 and, due to the changes made to over two hundred provisions, constituted the first mayor amendment of that part of the BGB. ${ }^{1035}$ It lead to the BGB's second book being rearranged, which was not only done in order to make the norms more easily understandable, but was necessary due to the fact that consumer law regulation was incorporated into the Code. ${ }^{1036}$ It furthermore adapted the form requirements to technological advancements and ended a long ongoing academic debate on the nature of credit agreements (Darlehensverträge) by explicitly providing that these create obligations to hand over the object ( $\mathbb{S} 488$ and 607 $\mathrm{BGB})$, rather than being created once the object is delivered, and thus moving these away from real- and to consensual contracts. ${ }^{1037}$

Since the 2002-reform, the next extensive amendments were made recently under the BauVertrRefG, which came into force on 1 January 2018 and created another new contract type, namely, the consumer construction contract (Verbraucherbauvertrag, $\mathbb{S}$ 650i et seq BGB). ${ }^{1038}$ Keeping these de-

1033 On these and other changes after WWII, see Säcker, 'Einleitung BGB' (fn 880) paras 15-23. For an overview over the changes in the commercial sphere, see Canaris (fn 938) 18 para 54; for more details, see Schmidt K (fn 931) para 27.

1034 See Schmidt J (fn 25) 32, who shows the low number of amendments in fn 231.

1035 Compare Säcker, 'Einleitung BGB' (fn 880) para 22. At least for the second book's first provision, $\mathbb{} 241 \mathrm{BGB}$, it was the first amendmend in over 100 years, see Olzen, ' $\$ 241 B G B$ ' (fn 897) para 1. A reform of commercial law of similar general importance, but not of relevance to the present discussion, occurred in 1998. See on this Canaris (fn 938) 18 para 55 and Schmidt K (fn 931) para 28.

1036 For an in-depth discussion of consumer law, see Riesenhuber (fn 1029) 147177.

1037 Compare Schmidt J (fn 25) 31-33 and 113. For a more in-depth discussion of this change, see Robert Freitag, $\mathbb{S} 488$ Vertragstypische Pflichten beim Darlehensvertrag [Section 488 Typical Contractual Typical Contractual Duties in a Loan Contract], in: von Staudinger and others (fn 140; 2015) paras 3 et seq.

1038 This law was already discussed briefly in Section 1. above. 
velopments in mind, focus will now turn to the current regulation of the formation of contracts in Germany.

\section{Contracts in Current German Law and Legal Practice}

While the BGB contains both general and specific rules for contracts, it should be noted that provisions of the first book (Allgemeiner Teil, General Part) apply automatically to all kinds of contracts, unless some provision foresees otherwise. ${ }^{1039}$ Thus, while specific regulations exists for electronic contracts (elektronische Verträge) or those involving a consumer (Verbraucher), these contracts are still principally governed by the general formation rules of the BGB as considered in Section a. below. Before attention is turned to this subject, a note needs to be made of the meaning of 'consumer'.

The term consumer (Verbraucher) has been defined in $₫ 13$ BGB as 'every natural person who enters into a legal transaction for purposes that predominantly are outside his trade, business or profession'. ${ }^{1040}$ As a consequence, legal persons are - just as under EU law - principally not consumers, although a civil law partnership (Gesellschaft bürgerlichen Rechts, hereinafter 'GbR') can be a consumer if it acts in such a capacity and its partners are natural persons. ${ }^{1041}$ The person's purpose is assessed objectively at the time of contracting, ${ }^{1042}$ and in case of doubt is to be deemed to be a consumer and not a commercial purpose. ${ }^{1043}$ As a consequence, it ought

1039 See Wolf and Neuner (fn 48) 70-71 paras 12-13.

1040 The original provision reads: 'Verbraucher ist jede natürliche Person, die ein Rechtsgeschäft zu Zwecken abschließt, die überwiegend weder ibrer gewerblichen noch ibrer selbständigen beruflichen Tätigkeit zugerechnet werden können.' This definition is complex, but, due to the provision's wide sphere of application, brings uniformity to German consumer law. Compare Jörg Fritzsche, $\mathbb{\$} 13$ Verbraucher [Section 13 Consumer], in: von Staudinger and others (fn 140; 2018) para 30. The requirements are discussed subsequently.

1041 See Fritzsche, ' $\$ 13 B G B$ ' (fn 1040) paras 31, 34-36. It was already noted in Section II.3. above that the meaning of 'consumer' is limited to natural persons under EU law.

1042 Fritzsche, ‘ $\mathbb{S} 13$ BGB' (fn 1040) paras 42-43.

1043 BGH decision of 30 September 2009, VIII ZR 7/09, NJW 2009, 3780-3781, para 10. In this case, the court ruled on the issue of whether a natural person acts as a consumer where the facts known to the other party seem to indicate a commercial purpose. Here, the fact in question was the address indicated by the claimant (buyer) as her place of work. The court held that $\mathbb{1 3}$ BGB 
to be presumed that a natural person enters into a contract as a consumer, unless there are unambiguous indications that the person is acting in a commercial capacity. ${ }^{1044}$ As to the question of how transactions relating to objects of dual use, ie, capable of both private and commercial use, are to be classified, it seems that the transaction ought to be deemed to be of a consumer. ${ }^{1045}$ This definition of a consumer is not only applicable to the BGB, but moreover to the HGB. ${ }^{1046}$ Moreover, it is important to note that the regulation is also applicable in $\mathrm{C} 2 \mathrm{C}$ transactions. ${ }^{1047}$

The term consumer is contrasted with that of an 'entrepreneur' (Unternehmer), which, according to $\mathbb{S} 14$ para $1 \mathrm{BGB}$, is 'a natural or legal person or a partnership with legal personality who or which, when entering into a legal transaction, acts in exercise of his or its trade, business or profession. ${ }^{1048}$ Here, legal entities include foundations (Stiftungen, $\$ \$ \$ 80-$ 88 BGB), companies with legal personality, like a stock company (Aktiengesellschaft, $\mathbb{S} 1$ Aktiengesetz ${ }^{1049}$ ), as well as public legal entities. ${ }^{1050}$ This definition must be contrasted with the one found in $\$ 1$ paras 1-2 HGB, under which a merchant (Kaufmann) 'is a person who carries on a commercial business', ie, 'any commercial enterprise unless, by reason of its nature or size, the enterprise does not require a commercially organised business

contained a presumption of a consumer purpose and that this remains true in case of doubt, but not if the commercial purpose is unequivocal from the point of view of the other party. It found the mere indication of the address of a place of business (office) not to be conclusive as to the purpose of the purchase and therefore regarded the claimant as having acted as a consumer. See paras 1-2, 10-13 of the decision.

1044 BGH decision of 30 September 2009 (fn 1043) para 11. For further discussion of the nature of the activity, see Fritzsche, ' $\mathbb{S} 13 B G B$ ' (fn 1040) paras 48-61.

1045 On this, see Fritzsche, ' $\mathbb{S} 13$ BGB' (fn 1040) paras 47-47d.

1046 Wolf and Neuner (fn 48) 141 para 2.

1047 Fritzsche, '\$ $13 B G B$ ' (fn 1040) para 41.

1048 The original reads: 'Unternehmer ist eine natürliche oder juristische Person oder eine rechtsfähige Personengesellschaft, die bei Abschluss eines Rechtsgeschäfts in Ausübung ibrer gewerblichen oder selbständigen beruflichen Tätigkeit handelt.' Jörg Fritzsche, $\mathbb{1 4}$ Unternehmer [Section 14 Enterpreneur], in: von Staudinger and others ( $\mathrm{fn} 140 ; 2018)$ para 2 notes that this notion of an entrepreneur is a 'mirror image' (Spiegelbild) of the one for consumers.

1049 Stock Corporation Act of 6 September 1965, BGBl 1965 I 1089; English translation available online at www.gesetze-im-internet.de/englisch_aktg/index.html.

1050 See Fritzsche, ' $\mathbb{S} 14 B G B$ ' (fn 1048) para 37. 


\section{B. Comparative Background}

operation.' ${ }^{1051}$ Since the BGB's 'entrepreneur' includes self-employed business ventures, whereas the HGB's 'merchant' does not, the former notion is wider than the latter. ${ }^{1052}$

\section{a. The Current Legal Background}

Although the BGB and the HGB contain no explicit rules on the formation of contracts, the generally accepted contract theory is that a contract in German law is formed through the agreement or consent of the parties. ${ }^{1053}$ This is usually achieved through the process of an offer being accepted (see Section ii. below). ${ }^{1054}$ While this is true, it is also necessary for the parties to have an intention to be bound by the agreement (Section iv.). ${ }^{1055}$ Moreover, the contract's terms contained in the declarations of intention must be certain. ${ }^{1056}$ Unless mandatory forms apply (Section b.), the parties may even freely stipulate in which way the agreement is to be brought about. ${ }^{1057}$ This consensuality may be seen as a deference to the principle of private party autonomy (Privatautonomie), in that it allows persons to regulate their own affairs by means of consensual acts (einverständliches Handeln). ${ }^{1058}$ The principle has several implications, of which the freedom of contract (Vertragsfreibeit) is the most important one for the

1051 The original provision reads: '(1) Kaufmann im Sinne dieses Gesetzbuchs ist, wer ein Handelsgewerbe betreibt. (2) Handelsgewerbe ist jeder Gewerbebetrieb, es sei denn, daß das Unternehmen nach Art oder Umfang einen in kaufmännischer Weise eingerichteten Geschäftsbetrieb nicht erfordert.'

1052 See Fritzsche, ' $\$ 14 B G B$ ' (fn 1048) para 17. For further details of the notion of merchant under the HGB, see Baumbach and Hopt (fn 889) at ' $\$ 1$ [Istkaufmann]' [Section 1 [Merchant]] paras 3, 5-10.

1053 Compare Gregor Christandl, Introduction before Art 2:101, in: Jansen and Zimmermann (fn 38) 231, 233 para 2. See also Bork, 'Vor $\$ 145 B G B$ ' (fn 884) para 1. Note that there used to be a theory of 'factual contracts' (faktische Verträge), which has not been followed since the mid-1950s. On this theory, which will not be discussed further, see Olzen, ' $\$ 241 B G B$ ' (fn 897) paras 94 et seq.

1054 Compare Bork, 'Vor $\mathbb{S} 145$ BGB' (fn 884) para 4, who notes that this is not reflected in the BGB's provisions.

1055 See Whincup (fn 34) 39 para 1.53.

1056 Compare Christandl, 'Before Art 2:101 PECL' (fn 1053) 233 para 2. See also Sections a.ii.cc) and a.iii.cc) below.

1057 See Wolf and Neuner (fn 48) 418 para 2.

1058 Compare Reinhard Singer, Vorbemerkungen zu SS 116-144 [Preliminary Notes on Ss 116-144], in: von Staudinger and others (fn 140; 2017) para 6. 
discussion of this dissertation. ${ }^{1059}$ This in turn entails several freedoms, such as the (either positive of negative) freedom of conclusion of a contract (Abschlussfreiheit), ie, to accept or decline to enter into a contract, or to be free to make an offer or an acceptance (Angebots- and Annabmefreiheit respectively). ${ }^{1060}$ And while there is also a freedom of form (Formfreiheit), there may be statutory requirements, including the involvement of third parties, through which the law recognises the legal validity of a contract, while they constitute a (limited) restriction of the parties' freedoms in relation to contract at the same time. ${ }^{1061}$ Other general limitations may stem from the objective to protect one party, usually perceived to be in a weaker position, such as under consumer law, or through the regulation of, eg, standard terms (Allgemeine Geschäftsbedingungen, hereinafter 'AGB') or anti-discrimination. ${ }^{1062}$ Furthermore, in cases of cross-border contracts, international law in the form of the United Nations Convention on Contracts for the International Sale of Goods ('CISG') will often be applicable. ${ }^{1063}$

A contract is generally necessary for the creation of an obligatory relationship ( $\$ 311$ para $1 \mathrm{BGB}) .{ }^{1064}$ This relationship bases itself on an obligatory act (Verpflichtungsgeschäft), according to which one party undertakes

1059 See on this generally Busche, 'Vor $\$ 145 B G B$ ' (fn 158) para 2, who goes on to emphasise at para 6 that it acts as a 'substantial possibility of contractual self-determination' ('substanzielle Möglichkeit zu vertraglicher Selbstbestimmung'). For a concise overview over its historical development in German law, see, eg, Busche, ibid para 5.

1060 See Wolf and Neuner (fn 48) 100 para 35, 99 para 32. On the exception to this freedom, known as 'Kontrahierungszwang' (obligation to contract), see Busche, 'Vor $\mathbb{} 145$ BGB' (fn 158) paras 12-23. Interestingly, Busche notes at para 12 that the freedom of contract is inherently limited whenever a contract is concluded, as each party's freedom confronts another party's freedom.

1061 Compare Wolf and Neuner (fn 48) 97 para 24. See further Busche, 'Vor $\$ 145$ $B G B^{\prime}$ (fn 158) para 4, mentioning restrictions stemming from EU law. Form requirements will be considered in Section b. below, while the involvement of third parties, particularly persons of public authority, will be discussed in D.III. and V. below.

1062 On the last of these, see Honsell (fn 140) para 113b.

1063 The rules of this Convention are considered in Section E.II. below.

1064 This norm was introduced by the 2002-reform of the German law of obligations, already discussed in Section 2.c.ii. above. An exception is found in, eg, $\mathbb{S} 657$ et seq BGB (Auslobung; Promise of a reward), as the promise is created one-sidedly, see Olzen, ‘ $\mathbb{S} 241$ BGB' (fn 897) para 69. 


\section{B. Comparative Background}

to do or omit from doing something. ${ }^{1065}$ It must be contrasted with a Verfügungsgeschäft (act of disposition), an act to immediately affect some existing right or legal relationship, ie, to execute the legal transaction. ${ }^{1066}$ As a consequence of the difference in the bases, the scope of effectiveness is different: obligatory acts are only effective relatively, ie, only affect the parties involved, whereas acts of disposition have an erga omnes effect absolutely, ie, against everyone. ${ }^{1067}$

These two kinds of acts are in two forms of contracts, called schuldrechtlicher and dinglicher Vertrag respectively. ${ }^{1068}$ They are separated in German law under the Trennungsprinzip (separation principle); ${ }^{1069}$ yet, they are both part of an acquisition of property. ${ }^{1070}$ This separation means that both kinds of acts are necessary in order to effect a transfer of property, since the obligatory act, like a sales contract, will only bind the parties. In order to effect the change of ownership, ${ }^{1071}$ ie, of the dingliches Recht

1065 See Wolf and Neuner (fn 48) 325 para 28. For further details, see, eg, Bork, 'Allgemeiner Teil' (fn 900) 177 paras 448-449. This type of act seems similar to the English executory contract, see Section II.1. above.

1066 See Bork, 'Allgemeiner Teil' (fn 900) 176 para 445. The object (right) can be affected in a number of ways, so that it may be changed, transferred, or even brought to an end. For further details, see Bork, ibid 177-178 paras 450-451. This type of act seems similar to the English executed contract, see Section II.1. above.

1067 See ibid 330 paras 52, 51.

1068 The terms are used by, eg, Wolfgang Ernst, Einleitung [zum Schuldrecht] [Introduction [to the Law of Obligations]], in: Säcker and others (fn 158) Vol 2 para 20; and by Reinhard Gaier, Einleitung zum Sachenrecht [Introduction to Property Law], in: ibid Vol 7 ( $7^{\text {th }}$ online edn, CH Beck 2017) para 7 respectively.

1069 See Jan Lieder and Daniel Berneith, Echte und unechte Ausnahmen vom Abstraktionsprinzip [Genuine and Artificial Exceptions to the Abstraction Principle] (2016) JuS 673.

1070 Bork, 'Allgemeiner Teil' (fn 900) 176-177 para 447, who notes that this kind of transaction will usually involve three contracts: one obligatory contract and two dispositions - one by the buyer for the transfer of money, and one by the seller for the transfer of the property in the thing in question. This is not true for gifts, which merely involve a disposition by the donor; nor for a loan, which involves a real act. See ibid.

1071 See Whincup (fn 34) 39 para 1.52. See further Andreas Wacke, Eigentumserwerb des Käufers durch schlichten Konsens oder erst mit Übergabe? Unterschiede im Rezeptionsprozeß und ibre mögliche Überwindung [Acquisition of Property of the Buyer by Consensuality or upon Delivery? Differences in the Reception Process and Possibilieties to Overcome these] (2000) ZEuP 254, 255; Lieder and Berneith (fn 1069) 673-674. 
(right in rem), an act of disposition is necessary. ${ }^{1072}$ This separation is highlighted in the structure of the BGB, in which obligatory transactions are regulated in book two (Schuldrecht, Law of Obligations) and acts of disposition are governed by the provisions found in book three (Sachenrecht, Law of Property). ${ }^{1073}$

Furthermore, according to the Abstraktionsprinzip (abstraction principle), the ineffectiveness of the former act does not affect the latter. ${ }^{1074}$ The abstraction principle is generally applicable to transactions over both movable and immovable property; however, the requirements beyond an agreement between the parties vary. ${ }^{1075}$ The advantage of this principle becomes apparent in instances of a series of sales over an object, whereby the buyer resells the object to a third party. As the acts concerning the obligation and the disposition are separated, the third party does not have to concern itself with the previous schuldrechtliche transaction; the acquisition by the third party is protected, if the act of disposition in the previous transaction between the original seller and buyer is effective. ${ }^{1076}$ By way of exception, the abstraction principle may not be applicable in two cases: First, if the acts of obligation and of disposition are connected under what is known as a Bedingungszusammenhang (conditional relationship). ${ }^{1077}$ Secondly, if the two acts may be seen as a Geschäftseinheit (transactional unit)

1072 For further information on this class of rights and their effects according to German academic opinion, see, eg, Gaier (fn 1068) paras 4-6.

1073 See Wolf and Neuner (fn 48) 70 para 9. See further Lieder and Berneith (fn 1069) 674, who also remark that the BGB does not contain the separation principle explicitly. It ought to be noted that contracts and their formation are regulated in the general part of the BGB.

1074 See Bork, 'Allgemeiner Teil' (fn 900) 176-177 para 478; Youngs (fn 34) 547. See also Wacke (fn 1071) 255. See further, eg, OLG Rostock order of 28 April 2006, 7 U 48/06, OLG-Report (OLGR) Rostock 2006, 601-602, para 16. This case is discussed in fn 1105 below. Compare Lieder and Berneith (fn 1069) 674, who speak of there 'not necessarily' ('nicht zwangsläufig') being a correlation between the ineffectiveness of one or of the other transaction. They go on to note, however, that the separation principle is the prerequisite for the abstraction principle.

1075 The classification of property and these requirements will be discussed in Section b. below.

1076 Compare Lieder and Berneith (fn 1069) 674.

1077 See on this ibid 675, who show the difference between this kind of stipulation and a condition (Bedingung) in the usual sense. This must be an explicit arrangement between the parties, as an implicit deviation from the abstraction principle is not possible, ibid. 


\section{B. Comparative Background}

within the meaning of $\$ 139$ BGB (Teilnichtigkeit; Partial invalidity). ${ }^{1078}$ This provision contains a presumption, according to which a legal transaction is void in its entirety when a part of it becomes invalid, save where the parties have provided otherwise. ${ }^{1079}$ Accordingly, the parties' agreement, often in the form of severability clauses (salvatorische Klauseln), displaces this dispositive provision. ${ }^{1080}$ In this way, the principle of party autonomy is safeguarded. ${ }^{1081}$

\section{i. Basic Principles: Contracts as Rechtsgeschäfte (Legal Transactions) and Willenserklärungen (Declarations of Intention)}

A contract is one, albeit perhaps the most important, legal transaction (Rechtsgeschäft) of the BGB. ${ }^{1082}$ Due to the tendency in German jurispru-

1078 See ibid 676, 675.

1079 See Herbert Roth, $\mathbb{} 139$ [Section 139], in: von Staudinger and others (fn 140; 2015) paras 1, 5. For a detailed discussion of the application requirements, namely, as to a transactional unit, its divisibility (Teilbarkeit), and whether the parties intended to go forward with the remaining contract, see ibid paras 26 et seq.

1080 ibid paras 4,8 . The author states furthermore at para 2 that this presumption is a 'rebuttable presumption of invalidity' ('widerlegliche Nichtigkeitsvermutung'). This is in line with a statement made by the BGH that a severability clause rebuts the presumption contained in $\$ 139 \mathrm{BGB}$, see, eg, BGH decision of 5 December 2012, I ZR 92/11, BGHZ 196, 254-270 para 53. The case concerned the sale of a pipeline through a public institution and the question whether the contract was void for contravening state aid law. The court found the stipulation on the sale price to be void, which, being an essential clause, rendered the whole agreement void, despite the parties having inserted a severability clause. See paras 48 et seq of the decision. For further discussion of severability clauses, see Roth, ibid para 22.

1081 See Roth (fn 1079) para 1. Nevertheless, even the use of such severability clauses cannot prevent that a contract becomes entirely ineffective if the affected (void) part is an essential provision, or if the parties knew of the invalidity, ibid paras 22, 24; see also BGH decision of 5 December 2012 (fn 1080) paras 55-56. Moreover, if upholding the remaining contract would go against the parties' intentions, the whole contract will become void despite the existence of a severability clause, $\mathrm{BGH}$, ibid, para 53 . It is important to note that a court must first attempt to interpret a contract in a way to fill a gap created due to partial invalidity of terms before resorting to $\$ 139$ BGB, Roth, ibid, para 25 .

1082 Compare Fritzsche, ' $\mathbb{1} 13$ BGB' (fn 1040) para 40; Bork, 'Allgemeiner Teil' (fn 900) 172 para 432, stating contracts to be the 'typical means of autonomous private legal ordering' ('das typische Mittel privatautonomer Rechtsgestaltung'). cf Flume (fn 885) 601, stating that '[t]he rules on legal transactions are applied 
dence to start from abstract rather than from specific principles, the theoretical foundation of contracts is rooted in that of the Rechtsgeschäft. This transaction is seen as 'a set of facts that is based on the will of the parties and which is to bring about the legal consequences that are foreseen in at least one declaration of intention'. ${ }^{1083}$ The 'act of will' in this definition means that there must be at least one declaration of intention (Willenserklärung). ${ }^{1084}$ In this sense, a declaration of intention, while being the main element of a legal transaction, is at the same time the vehicle used to create it. ${ }^{1085}$ At the conclusion of a contract, the declarations made are an Angebot (offer) and an Annahme (acceptance). ${ }^{1086}$ The terms of Rechtsgeschäft and Willenserklärung will be considered more closely in the following, in reverse order.

\section{aa) 'Willenserklärungen' Defined}

The term Willenserklärung is said to contain two parts: the 'will' or intention (Wille) of one person, which is announced (kundgegeben) to one or several other persons. Only by combining these two parts will an intention

mostly to contracts' ('Die Normen für das Rechtsgeschaft finden vornehmlich ibre Anwendung auf Verträge [...]').

1083 Fritzsche, ' $\mathbb{S} 13 B G B$ ' (fn 1040) para 40: 'Es handelt sich um einen auf dem Parteiwillen aufbauenden Gesamttatbestand, der einen mit mindestens einer Willenserklärung angestrebten Rechtserfolg herbeiführt.' cf the definition contained in Mugdan (fn 883) Vol 1 421: '[Ein] Rechtsgeschäft [...] ist eine Privatwillenserklärung, gerichtet auf die Hervorbringung eines rechtlichen Erfolges, der nach der Rechtsordnung deswegen eintritt, weil er gewollt ist' ('[A] legal transaction [...] is a private declaration of intention made in order to bring about a legal result that arises under the law because it is intended'). See also Kaufmann (fn 112) 53. On differentiating between legal transactions and transaction-like legal acts (Rechtsgeschäftsähnliche Handlungen), such as a notice (Mitteilung or Anzeige), see Bork, 'Allgemeiner Teil' (fn 900) 165-167 paras 412-416, who notes that the latter bring about legal consequences by reason of some legal provision, not based on the intention of the acting person. Other acts that must be distinguished from a legal transaction will be discussed in relation to the intention to be legally bound (Rechtsbindungswille) in Section iv. below.

1084 Compare Singer (fn 1058) para 5.

1085 See ibid.

1086 Sometimes other terms are used, like Antrag or Gebot for offer, or Zuschlag for acceptance. This will be discussed in Sections ii. and iii. below respectively. 


\section{B. Comparative Background}

be declared effectively, as an unannounced will is of no consequence. ${ }^{1087}$ Similarly, the announcing person must state that they will be obliged in some way in order to be bound by the declaration. ${ }^{1088}$

German jurisprudence differentiates between the inner and the outer state of affairs, sometimes also referred to respectively as the subjective and the objective matter of a declaration of intention. ${ }^{1089}$ The latter means that a declaration must be made in order to bring about a legal consequence (Rechtsfolge). ${ }^{1090}$ If such a result is not intended, ie, when facts are merely to be communicated, the statement is said to be merely declaratory (deklaratorisch), and may take the form of a Vorstellungs- or Willensmitteilung (communication of conception or volition). ${ }^{1091}$ The subjective matter relates to the substance of the will, ie, to the intention itself, in that there must be three types of volition: Handlungswille (volition to act), Erklärungswille (volition to declare, sometimes also referred to as 'declaration-awareness', 'Erklärungsbewusstsein'), and Geschäftswille (volition to transact). ${ }^{1092}$ These three kinds of intention are expressed when a person deliberately gives a declaratory sign with the intention for the statement be legally relevant, and where they intend a particular legal consequence to be effected by means of the declaration. ${ }^{1093}$ It should be noted that while

1087 Compare Wolf and Neuner (fn 48) 337 para 1, 338 paras 5-6. Thus, it was stated in the motives to the BGB that '[es s]elbstverständlich ist, daß die Willenserklärung dem anderen Theile in Folge des Willens des Erklärenden zugekommen sein muß; es genügt nicht, daß ein Unberufener den auf dem Schreibtisch liegen gebliebenen Brief befördert [...]' ('[it is $\mathrm{n}]$ atural, that a declaration of intention must have reached the other party with the will of the declaring person; it is not sufficient, that an unappointed person sends the letter left on the desk'), see Mugdan (fn 883) Vol 1 439. The theory underlying this principle is the Geltungstheorie (validity theory), which can be contrasted with the Willenstheorie (will theory) and the Erklärungstheorie (declaration theory). For a succinct account of these theories, see Singer (fn 1058) paras 15-17.

1088 Compare Wolf and Neuner (fn 48) 338-339 para 6. The issue of a 'will to be bound' will be discussed in Section iv. below. As to the interpretation of a declaration, see Section cc) below.

1089 See ibid 340 para 1.

1090 See Singer (fn 1058) para 1. On differentiating between binding and non-binding declarations, see the discussion in Sections ii. and iii. below.

1091 See on this Armbrüster (fn 957) paras 16-18. Compare Singer (fn 1058) para 2, who speaks of 'Willensäußerungen' (expression of one's volition) as a geschäftsähnliche Handlung (transaction-like act), as contrasted with a Willenserklärung.

1092 See Singer (fn 1058) para 26.

1093 See Wolf and Neuner (fn 48) 347 para 1 and 351 para 20. See also Armbrüster (fn 957) paras 22-28, who also describes the flaws in the different kinds of 
the majority opinion of German academics deems the first element to be essential in order for there to be a declaration of intention in the legal sense, there is a divide as regards the second and third elements: the former may or may not be constitutive, while only a minority deems the third absolutely necessary. ${ }^{1094}$

\section{bb) Types of Willenserklärungen and Methods of Declaration}

Declarations can be classified into those that need to be received by the other party (in German known as 'empfangsbedürftige Willenserklärungen') and those which do not need to be received ('nicht empfangsbedürftige Willenserklärungen'), whereby the latter exist only in special circumstances, ie, ordinarily where a declaration affects solely the affairs of the declaring person. ${ }^{1095}$ In other words, a declaration of intention will usually be one that needs to be received. ${ }^{1096}$ Thus, both offer and acceptance constitute declarations of intention requiring notice by another person, while promise of rewards are examples of declarations which do not require this. ${ }^{1097}$

Declarations which need to be received imply that they must reach someone, while, in contrast, a perceptible declaration is sufficient by

volition. See further Singer (fn 1058) para 27, who emphasises that the action be controlled (beherrscht) by the person.

1094 See on this Wolf and Neuner (fn 48) 347 para 1, 352 paras 21-22, 353 para 25. A succinct summary of the development of the jurisprudence concerning declarations of intention and the discussion surrounding the necessary requirements is given by Hans-Joachim Musielak, Zum Verhältnis von Wille und Erklärung: Eine Auseinandersetzung mit dem Tatbestand der Willenserklärung [Concerning the Relationship Between Volition and Declaration: A Discussion of the Requirements of a Declaration of Intention] (2011) 211 No 6 AcP 769802 , particularly at 777 et seq.

1095 See Armbrüster (fn 957) para 5.

1096 Dorothee Einsele, $\$ 130$ Wirksamwerden der Willenserklärung gegenüber Abwesenden [Section 130 Coming into Effect of the Declarations of Intention Between Absent Persons], in: Säcker and others (fn 158) para 1.

1097 See ibid paras 1, 5. Another example of acceptance not requiring receipt is acceptance of bids (Zuschläge) in auctions, see, eg, BGH decision of 24 April 1998, V ZR 197/97, BGHZ 138, 339-348, para 7. The case concerned the voluntary sale by auction of a piece of land and the question of form, namely, whether the auctioneer must be present during the notarial authentication (which the court affirmed). See paras 1, 6-9, 11 of the decision. 


\section{B. Comparative Background}

itself in case of those declarations that do not need to be received. ${ }^{1098}$ In either case, the intention must be manifested in some way and communicated. ${ }^{1099}$ In this sense, an intention is said to have been declared (abgegeben) when the declaring person has done everything that is necessary to effect the declaration of intention. ${ }^{1100} \mathrm{With}$ declarations not requiring reception, this is realised upon utterance of the intention; with the other kind, it is additionally required that the declaration be directed at the addressee. ${ }^{1101}$

Declarations of intention, once made, are seen as morally and legally binding for the purpose of legal certainty. ${ }^{1102}$ This general bindingness has been relaxed in particular circumstances, eg, by allowing a declaration to be revoked or for this right to be excluded, as will be seen in Sections ii. and iii. below. There are two ways in which an intention may be declared, unless the law or the parties foresee otherwise: explicitly (ausdrücklich), namely, by using express words or phrases which convey this, such as 'I hereby declare...' or 'accepted'; and implicitly (konkludent). ${ }^{1103}$ Activity can be deemed as an implicit declaration, namely, when there is a Willensbetätigung (exercise of one's volition), as is foreseen in $\$ 151$ BGB (Annahme ohne Erklärung gegenüber dem Antragenden; Acceptance without declaration to the offeror). ${ }^{1104}$ One special case of implicit declarations that deserves mentioning is silence (Schweigen; in adjective form 'stillschweigend'), where-

1098 Compare $\$ 130$ BGB, which speaks of '[a] declaration of intent that is to be made to another' ('Eine Willenserklärung, die einem anderen gegenüber abzugeben ist') as a declaration that needs to be received. See further Armbrüster (fn 957) para 5.

1099 See Wolf and Neuner (fn 48) 355-356 for further discussion.

1100 Einsele, ' $\mathbb{1} 130 B G B$ ' (fn 1096) para 13. The coming into effect of declarations of intention will be discussed in Sections ii. and iii. below.

1101 See ibid para 13.

1102 This is related to the principle of Selbstverantwortung (personal responsibility) underpinning the BGB. Compare Wolf and Neuner (fn 48) 97 para 23.

1103 See Armbrüster (fn 957) paras 6-7.

1104 See Armbrüster (fn 957) para 11. A Willensbetätigung differs from a Willenserklärung in that it need not be received, because it lacks a communication requirement. It is similar in that it intends to bring about some legal consequence. See on this Singer (fn 1058) para 4. In other words, a Willensbetätigung is an act that is manifested externally and confers the actor's acceptance uniquivocally, see, eg, BGH decision of 28 March 1990, VIII ZR 258/89, BGHZ 111, 97 paras 19-20. In this case, the court found that cashing a cheque obtained from the claimant in order to conclude a compensation agreement (Abfindungsvereinbarung) did not constitute implicit acceptance by the defendant, as other circumstances (letter by the defendant rejecting the proposal) 
by, in limited circumstances only, an inference as to a declaration of intention can be drawn from a person's silence or inactivity. ${ }^{1105}$ In instances where the parties agree on silence as a declaration, even as a standard term, this is usually unproblematic. ${ }^{1106}$ Some authors have stated that such cases amount to an explicit declaration. ${ }^{1107}$ Finally, a declaration can be created through a legal fiction, such as under $₫ 455$ BGB (Billigungsfrist; Approval period [in a sale on approval]).

\section{cc) Interpretation of Willenserklärungen}

Before turning to Rechtsgeschäfte, a quick note needs to be made on the interpretation of the parties' declarations of intention. ${ }^{1108}$ Two provisions are important: First, according to $\$ 133 \mathrm{BGB}$, the declared intention of the par-

indicated that the defendant had no intention of accepting the offer. See paras $2-6,12$ et seq of the decision.

1105 Armbrüster (fn 957) paras 6, 8, who says this is to be assessed from the addressee's perspective. A special case before the German courts concerned an entry of ownership in the German land register (Grundbuch), whereby one party to the transfer of the real estate in question, albeit being present during the notarial authentication (notarielle Beurkundung), had not signed the contract. The question was whether that party had consented to the transfer of the real estate implicitly, ie, by their silence. If this were so, the entry in the register was valid, despite the contract of disposition (Auflassung) being invalid due to non-fulfilment of the necessary form requirements. The court found that by attending and yet not objecting to the contract, the party had, despite not having signed the contract, implicitly assented to the transfer. See OLG Rostock order of 28 April 2006 (fn 1074) paras 1-4, 10-12, 15. In thus deciding, the court followed precedents and the leading opinion that a Auflassung, while needing to be declared before a notary, need not be authenticated. For a succinct discussion of this issue, see Rainer Kanzleiter, OLG Rostock: Vor dem Notar erklärte Auflassung ohne Unterschrift [OLG Rostock: Disposition Declared Before a Notary not Signed] (2007) DNotZ 220-225.

1106 This was held by the OLG Düsseldorf in the decision of 28 December 2004, 21 U 68/04, NJW 2005, 1515-1516, see paras 25-28, 36. The case concerned the sale of a heating system, whereby the contract had been allegedly concluded by way of an offer that had been accepted by silence. The contract stipulated that if no objection was raised against the offer within four weeks, it was deemed to be accepted. See para 25 of the decision.

1107 See, eg, Armbrüster (fn 957) para 8.

1108 These rules are of general application to Rechtsgeschäfte and Willenserklärungen, but of course encompass offer and acceptance as well, compare Schmidt J (fn 25) 135. For further details on the interpretation process, see Jan Busche, $\mathbb{S} 133$ Auslegung einer Willenserklärung [Section 133 Interpretation of a Declara- 


\section{B. Comparative Background}

ties is interpreted by ascertaining the parties' 'true intention rather than adhering to the literal meaning of the declaration' (emphasis added). ${ }^{1109}$ This has been interpreted to mean that the focus ought to be on the meaning of the declaration, rather than the way it is phrased and thus understood. ${ }^{1110}$ It is employed where the parties' understanding of the declaration is the same. ${ }^{1111}$ In contrast, where the recipient does not understand the declaration in the same way as the maker of the statement, what is referred to as a normative standard is usually used, which takes into account all relevant circumstances to the act of declaring. ${ }^{1112}$ Essentially, this method enquires what the recipient objectively ought to have understood. ${ }^{1113}$ Where an act is made orally, the wording is usually interpreted according to ordinary language usage; however, where the persons involved are professionals or members of another kind of community, any particular usage of language is taken into account. ${ }^{1114}$ Declarations having to be made in a particular form are likewise interpreted in this way, ${ }^{1115}$ namely, by asking whether the parties had the same understanding or whether it differed. ${ }^{1116}$ In terms of the point in time at which the meaning is interpreted, it is the time of receipt of the declaration that is relevant. ${ }^{1117}$

The other important provision is $\$ 157 \mathrm{BGB}$ and requires that contracts are interpreted in accordance with the principle of good faith and custom-

tion of Intention], in: Säcker and others (fn 158) paras 13 et seq. See also Bork, 'Allgemeiner Teil' (fn 900) 194-219.

1109 The original provision states: 'Bei der Auslegung einer Willenserklärung ist der wirkliche Wille $z u$ erforschen und nicht an dem buchstäblichen Sinne des Ausdrucks zu haften' (emphasis added).

1110 See Bork, 'Allgemeiner Teil' (fn 900) 198 para 501 and 197 para 499, stating that what matters is what is 'actually intended and not what is understood', whether by the parties or in general ('dass es auf das tatsächlich Gewollte und nicht auf das Verstandene oder auf das allgemeine Verständnis ankommt').

1111 See Busche, '\$ 133 BGB' (fn 1108) para 14. See also Bork, 'Allgemeiner Teil' (fn 900) 202-203 paras 518-519.

1112 Wolf and Neuner (fn 48) 394 para 29, 388 para 4 and 389 para 7. Compare also Busche, ' $\mathbb{S} 133 B G B$ ' (fn 1108) para 14.

1113 On this, see Bork, 'Allgemeiner Teil' (fn 900) 204-205 paras 525-527. This is the same as the English approach, discussed in Section II.3.a.i. above.

1114 Wolf and Neuner (fn 48) 388 para 5.

1115 The issue of whether the form requirement has been fulfilled is only considered in a second step, Wolf and Neuner (fn 48) 396 para 36. Form requirements are discussed in Section b. below.

1116 See Busche, ' $\$ 133 B G B$ ' (fn 1108) para 14.

1117 For further details, see ibid para 5. The coming into effect of declarations of intention will be discussed in Sections ii.dd) and iii.dd) below. 
ary practice (Verkehrssitte), so that an objective standard is applied. ${ }^{1118}$ The difference between these two rules is that $₫ 133$ BGB requires a 'simple interpretation' ('einfache Auslegung') of a declaration of intention, while $\$ 157$ BGB aims to fill lacunae through a 'complementary interpretation' ('ergänzende Auslegung'). ${ }^{1119}$ Consequently, the second rule is applied in cases where the other two interpretation standards described above do not aid in the interpretation of legal transactions, because there is a lacuna. ${ }^{1120}$ As the issue of incomplete agreements is outside the scope of this dissertation, this method is not considered further.

\section{dd) Rechtsgeschäfte (Legal Transactions)}

The number of declarations of intention that are necessary to constitute a legal transaction depends on the type of transaction, namely, on whether the legal transaction is one-sided or multilateral (ein-oder mebrseitiges Rechtsgeschäft $).{ }^{1121}$ Examples of particular interest are promises of rewards (Auslobung, one-sided) and contracts (bi- or multilateral). ${ }^{1122} \mathrm{~A}$ contract must thus be formed through two or more matching declarations of intention, namely, an offer and acceptance, as discussed in Sections ii. and iii. below. A Rechtsgeschäft may also be constituted by one declaration of intention and some other circumstance, such as a real act in a real contract. ${ }^{1123}$

Another way to classify legal transactions is to distinguish their function. In accordance with the distinction explained above between obligatory and dispositionary acts, these are closely related to obligatory or property transactions (schuldrechtliche and sachenrechtliche Rechtsgeschäfte) respectively, which in turn affect either an obligatory relationship or a

1118 See Bork, 'Allgemeiner Teil' (fn 900) 197 para 499.

1119 See Busche, ' $\mathbb{S} 133 B G B$ ' (fn 1108) para 6.

1120 On this, see Bork, 'Allgemeiner Teil' (fn 900) 206-209 paras 532-537 for further details.

1121 Wolf and Neuner (fn 48) 312 para 4, 320 para 1.

1122 Bork, 'Allgemeiner Teil' (fn 900) 170 para 427 and 172 para 432. Other examples include the granting of a Vollmacht (power of attorney; one-sided) and Beschlüsse (resolutions; multilateral) of legal entities, see on this Wolf and Neuner (fn 48) 320 para 2 and 322-323 paras 10 et seq.

1123 See on this Bork, 'Allgemeiner Teil' (fn 900) 162-163 para 399. For details on real acts, see ibid 165 paras $407-411$, where it is explained that these legal acts bring about legal consequences, while an intention of the acting person is not required. 


\section{B. Comparative Background}

property right. ${ }^{1124}$ Examples are those mentioned for one-sided and bilateral transactions as obligatory acts, while the giving up of a property right (one-sided), or the Einigung (agreement; bi- or multilateral) to transfer property are examples of proprietary acts. ${ }^{1125}$

\section{ii. Antrag or Angebot (Offer)}

The first element in a German contract is an Antrag or Angebot (offer). After analysing the meaning of this term in Section aa), the notion of Angebot is distinguished from invitationes ad offerendum (invitations to make an offer) in Section bb) below. Attention is then given to the requirement of certainty (in Section cc)) and the rules surrounding the effectiveness of an Antrag (in Sections dd)-ee)).

\section{aa) 'Antrag'or 'Angebot' Defined}

Despite the lack of an explicit legislative definition, the wording of $\$ 145$ BGB at least suggests that an offer, referred to in the code as an Antrag, is a proposal. In academic literature, it has been defined as 'a one-sided declaration of intention that needs to be received and that aims at the conclusion of a contract.' ${ }^{1126}$ Other descriptions add that the declaration needs to be capable of being accepted (annabmefähig). ${ }^{1127}$ Furthermore, whilst not explicit under the BGB, German private law requires offers to be certain and that the offeror have an intention to be bound. ${ }^{1128}$ Thus, the offer

1124 Wolf and Neuner (fn 48) 323 paras 15, 17. There are, furthermore, legal transactions in relation to family and succession law (familienrechtliche and erbrechtliche Rechtsgeschäfte). As family arrangements are not considered in this dissertation, interested readers are referred to ibid 323-324 paras 19 et seq for further details.

1125 Bork, 'Allgemeiner Teil' (fn 900) 174-175 para 441 and 177 para 447.

1126 Busche, '\$ 145 BGB' (fn 893) para 5: 'Der Antrag (Angebot, Offerte) ist eine einseitige, empfangsbedürftige Willenserklärung, die auf den Abschluss eines Vertrages gerichtet ist.'

1127 Reinhard Bork, $\mathbb{S} 145$ Bindung an den Antrag [Section 145 Binding Effect of an Offer], in: von Staudinger and others (fn 140; 2015) para 1; see also Schmidt J (fn 25) 130.

1128 Schmidt J (fn 25) 130. See also Bork, ' $\mathbb{S} 145 B G B$ ' (fn 1127) para 2. The former issue will be considered in Section $\mathrm{Cc}$ ); the latter issue will be discussed in Section iv. below. 
must contain all, or at least the essential terms (essentialia negotii) ${ }^{1129}$ of the contract, as the proposal must be accepted as is, ie, without modification, in order for a contract to arise. ${ }^{1130}$ For this reason, a draft contract (Vertragsentwurf) that is signed by one party constitutes an offer. ${ }^{1131}$ In contrast, if modifications to the offer are made by the other party, this counts as a rejection of the original offer and the purported acceptance becomes a counter-offer ( $\mathbb{1} 150$ para 2 BGB). ${ }^{1132}$ The offer may be in the form of a 'real offer' (Realofferte), where goods or services are made available to the potential offeree prior to contracting, ${ }^{1133}$ or through individualised or automatic declarations of intention. ${ }^{1134}$ An offer may thus be made

1129 Non-essential terms are referred to as accidentalia negotii, see, eg, Schmidt J (fn 25) 253.

1130 See BAG decision of 19 April 2005, 9 AZR 233/04, BAGE 114, 206-218, NJW 2006, 1832-1836, para 17, in which this was stated in relation to applications for the reduction of working hours by an employee during the period of child rearing (Elternzeit). This necessity can also be deduced from $\$ 154$ para $1 \mathrm{BGB}$, which states that a contract is not concluded until all contract terms have been agreed upon. The issue of essential terms will be discussed in further detail in Section cc) below.

1131 See BGH decision of 18 October 2001, XII ZR 179/98, NJW 2001, 221-223 para 14.

1132 This occurred in the BGH decision of 18 October 2001 (fn 1131), where the offeree signed the contract with a note saying 'valid only in conjunction with our letter dated [20 September 1993]' ('gilt nur im Zusammenhang mit unserem Schreiben vom 20.9.93'). The court stressed that a new offer had been made even though the proposed modifications concerned 'unimportant side issues' ('unbedeutende Nebenpunkte'). It stated that while such minor modifications exceptionally do not lead to a rejection of the original offer and the making of a new one, such instances were confined to insurance and international sale contracts (governed by the CISG) and were thus not applicable to the lease contract in question; nor was there reason to extend these exceptions to the current situation. Furthermore, since the offeree had explicitly stated in their letter that their agreement was only given for the modified contract, the modifications could not be disregarded. See paras 1-5, 14-18 of the decision.

1133 For further details, see Busche, ' $\mathbb{S} 145 B G B$ ' (fn 893) para 16. Examples given include offers of goods in vending machines and of public transportation, as well as the delivery of unsolicited goods.

1134 BGH decision of 16 March 2006, III ZR 152/05, BGHZ 166, 369-383, para 11. In this case, an automatic message stating what kind of service (telephone connection by reverse-charged call) would be provided and at what price was held to be sufficient. 


\section{B. Comparative Background}

both expressly or implicitly and can be in any form, including electronic means, unless the law or the parties have foreseen otherwise. ${ }^{1135}$

While an offer will usually be directed at a specific offeree, it is equally possible under German law for the declaration to be addressed to an undefined group of people (ad incertas personas), as is the case with a petrol pump, ${ }^{1136}$ or a sale by (online) auction. ${ }^{1137}$ These kinds of offers in particular must be distinguished from invitationes ad offerendum (invitations to make an offer), as discussed subsequently. Furthermore, the offer can be made by either party, ie, by the seller or the buyer. In fact, the latter occurs regularly in auctions, ${ }^{1138}$ or where the first declaration (made by the seller) is not an offer, but an invitation to make an offer.

\section{bb) Angebot and Invitatio ad Offerendum (Invitation to Make an Offer)}

Whether a declaration amounts to an offer or whether it is merely a nonbinding statement is an important issue. The answer first and foremost depends on the intention of the statement maker, so that it is an offer if

1135 Compare Busche, ' $\mathbb{S} 145 B G B$ ' (fn 893) para 5. On offers through electronic means, see ibid, 'Vor $\$ 145 B G B$ ' (fn 158) paras 37-38; on implicit offers, see BGH decision of 22 May 1991, IV ZR 107/90, NJW-RR 1991, 11771178. The court considered the question of whether an insurance contract (Versicherungsvertrag) had been concluded between the claimant (insured) and the defendant (insurer). The court found that the defendant had made an implicit offer (based on an expired offer made by the claimant) by collecting the first insurance premium, which had been accepted by the claimant in not objecting to this payment collection and by ensuring that his account always had sufficient funds for subsequent collections. Implicit offers were generally possible, at least for insurance contracts, because it was usual practice but not prescribed by law that these contracts be made in writing. The caveat with assuming an implicit offer, however, was that the claimant must have had no reason to doubt that the defendant was willing to conclude a contract on the original terms. This was not the case. See paras $2-5,10-14,16-17$ of the decision.

1136 Wolf and Neuner (fn 48) 419 paras 10-11.

1137 See LG Berlin decision of 20 July 2004, 4 O 293/04, NJW 2004, 2831-2833, para 40, discussed in fn 1155 below.

1138 See Wolf and Neuner (fn 48) 419 para 9. See further BGH decision of 24 April 1998 (fn 1097) para 7: the bid (Gebot) constitutes the offer. In the LG Berlin decision of 20 July 2004 (fn 1137) paras 42-43, the court left the question open whether the declaration of intention to sell an old-timer in an online auction constituted an offer, or whether the bid on the auction was the offer. 
the declaring party intends to be bound by their statement, otherwise it is an invitatio ad offerendum (invitation to make an offer, in German also referred to as 'Aufforderung zur Abgabe eines Angebots'). ${ }^{1139}$ Before going on to examining the issue of invitatio ad offerendum further, it ought to be noted that there is another class of cases that falls into neither the category of offers, nor of invitationes ad offerendum. This concerns what are termed Gefälligkeitsverhältnisse (literally 'courtesy relations', whereby 'Gefälligkeit' means favour or accommodation). ${ }^{1140}$ The difference between these two non-binding situations is that while an invitatio ad offerendum is made with the intention to bring about a contract by showing one's willingness to contract, statements in relation to Gefälligkeiten are not meant to establish a legally-binding relationship. ${ }^{1141}$ The latter will therefore be discussed together with the issue of the intention to be legally bound in Section iv. below.

The case of invitations to make an offer typically arise where the statement maker obviously reserves themselves the right to decide on the conclusion of a contract, for example. ${ }^{1142}$ This is not the only factor. Consequently, offers containing terms such as 'freibleibend' ('non-binding') do not automatically count as invitations to make an offer. ${ }^{1143}$ In other

1139 Compare Bork, ' $\mathbb{S} 145$ BGB' (fn 1127) paras $2-3$. Note that the evaluation is made from the position of the addressee, see Schmidt J (fn 25) 194.

1140 See Schmidt J (fn 25) 174.

1141 Ibid 173.

1142 cf Busche, ' $\mathbb{S} 145$ BGB' (fn 893) para 1 . See BGH decision of 4 February 2009, VIII ZR 32/08, BGHZ 179, 319-329, para 12, in which a catalogue containing the notice 'while stock lasts' was deemed as a form of advertisement and thus to be an invitation to make an offer. Similarly, a questionnaire containing a note that the filling out of the questionnaire would not form a basis of claim to the measures that had been described in a letter accompanying the questionnaire was held not to be an offer, see BAG decision of 17 December 2009, 6 AZR 242/09, NJW 2010, 1100-1103, para 21. The court also found that the letter and the questionnaire did not contain the esentialia negotii, see BAG ibid. It can be deduced from this that the submission of the filled-out questionnaire would constitute an offer, whereas the questionnaire itself only constituted an invitation to make an offer.

1143 See on this Wolf and Neuner (fn 48) 421 para 15, explaining that such declarations exclude both the statement maker being bound and the addressee being able to accept. They state further that there is no fixed rule as to the assessment of these declarations. Thus, other phrases such as 'soweit Liefermöglichkeit vorhanden' ('to the extent of delivery being possible') reserve the offeree a right to rescind the contract (zurücktreten). Where the addressee accepts the non-binding offer, the offeror must, if they are to refuse the transaction, react promptly (unverzüglich; ie, without undue delay, 'obne schuldhaftes zögern', as 


\section{B. Comparative Background}

circumstances, German law assumes that a declaration is an offer, namely, where it is directed at an unspecific group of people (ad incertas personas). ${ }^{1144}$ This will regularly be the case with a petrol pump. ${ }^{1145}$ Similarly, the provision of public transportation is deemed as an offer to the general public, since the providers have a general obligation to contract (Kontrahierungszwang). ${ }^{1146}$ This explanation is now doubtful, because it is no longer the leading doctrine, so that the normal process of offer and acceptance applies instead. ${ }^{1147}$ Accordingly, a customer will accept the offer made by the company operating the service by, eg, boarding the vehicle. ${ }^{1148}$ According to the majority of German academics, another example might be a vending machine. ${ }^{1149}$

Other instances in which declarations are deemed as mere invitations to treat in German law comprise advertisements, including price lists displayed in a shop or sent out (eg, in form catalogues), ${ }^{1150}$ as well as online

defined in $\$ 121$ para $1 \mathrm{BGB}$ ); otherwise, their silence will be deemed as assent under the principle of good faith. It ought to be noted that this is not the case with invitations to make an offer. See ibid.

1144 Ibid 419 para 10 . It has been stated that $\$ 156$ BGB makes it clear that conducting an auction is merely an invitation to make an offer, see BGH decision of 24 April 1998 (fn 1097) para 7.

1145 Here, the contract is formed as soon as the customer fills petrol into the tank of their car, see Schmidt J (fn 25) 224-225.

1146 See on this Wolf and Neuner (fn 48) 419 para 8.

1147 See on this Schmidt J (fn 25) 228.

1148 See ibid.

1149 See generally ibid 221. On this classification, see also, eg, Busche, ' $\mathbb{1} 145$ BGB' (fn 893) para 12, noting the caveat that the machine is functioning, be stocked and that it is used appropriately. cf Wolf and Neuner (fn 48) 419 para 11, who classify vending machines as invitationes ad offerendum, arguing that a contract will not automatically arise with a vending machine when money is inserted, because the machine may be empty or defective. See also Section aa) and fn 1133 above.

1150 See BGH decision of 4 February 2009 (fn 1142) paras 12-13, in which catalogues and newspaper advertisements were held to be invitations to treat, due to considerations such as willingness to contract with a particular other person, or the object still being in stock indicating that an intention to be bound immediately is not given. Note that this categorisation was already envisaged by the drafters of the BGB, see Mugdan (fn 883) Vol 1 444. The term used then was 'Anerbietungen' (offerings, in the sense of showing one's willing to do something or making a proposal (Vorschlag), see the entries for 'anerbieten' and 'Anerbieten' in Duden online at www.duden.de). Interestingly, the ADHGB explicitly differentiated between binding offers ('Anerbietungen zum Verkauf') and non-binding statements in art 337, see Schmidt J (fn 25) 194 
presentations of goods or services. ${ }^{1151}$ Similarly, goods displayed in shop windows or inside self-service shops regularly do not constitute offers. ${ }^{1152}$

\section{cc) Certainty of Angebote}

As has already been stated above, an offer must be sufficiently certain, which means that the contract's essential terms (essentialia negotii) must be contained in the declaration of intention. ${ }^{1153}$ What is deemed as an essential term may differ according to the type of contract in question. In general, the contract's type, object, performance and, where applicable, the counter-performance, as well as the parties must be stipulated. ${ }^{1154}$

For a sale, it is the object and its price, or a mechanism to determine these terms, that are necessary. ${ }^{1155}$ In instances of lease contracts under German law, the contracting parties, as well as the lease object, the beginning and the duration of the arrangement, ${ }^{1156}$ and the price must be

and Mugdan ibid. In contrast, the current HGB, just like the BGB, contains no such provision.

1151 For goods see, eg, BGH decision of 21 September 2005, VIII ZR 284/04, NJW 2005, 3567-3569, para 15. The case concerned the question whether a standard term (AGB) of the defendant contravened $\$ \$ 307-308$ BGB, which the court held to be true. For services see, eg, BGH decision of 16 October 2012 (fn 1110) para 14, in which an online booking service for flights has been deemed as an invitatio ad offerendum, whereby the offer was made by the service user in completing the booking form.

1152 Wolf and Neuner (fn 48 ) 419 para 7. Note that a discussion exists on whether goods on a shop's shelves constitute offers in German legal academia. For an overview of the arguments and an analysis, see Schmidt J (fn 25) 211-213 and 217-220, who comes to the conclusion that the treatment of display of goods in shelves as invitations to make an offer is preferable.

1153 Compare Bork, ' $\$ 145$ BGB' (fn 1127) para 17. The same is true for any additional, ie, non-essential terms; these must equally be certain, see Schmidt J (fn 25) 253.

1154 See ibid. On the contracting parties being an essential term, compare Wolf and Neuner (fn 48) 435 para 2.

1155 Compare LG Berlin decision of 20 July 2004 (fn 1137) paras 40, 38. In this case, the mechanism to determine the price was an online auction, whereby the price of the offer was to be set as the highest bid at the auction's end.

1156 See Volker Emmerich, $\mathbb{S} 550$ [Section 550], in: von Staudinger and others (fn $140 ; 2018$ ) paras $24,24 b, 24 f$. 


\section{B. Comparative Background}

stipulated. ${ }^{1157}$ Another particular case is that of a declaration of suretyship (Bürgschaft), which must state the surety giver's intention to take on the obligation in case of the original debtor's default, the obligation that is assumed, the surety creditor, and the debtor for whom the surety is given. ${ }^{1158}$

While it is not necessary that the parties be named explicitly, they must nevertheless be determined to a sufficient degree, which again depends on the legal transaction in question. It seems that where one party (the offeree) does not have particular interest in knowing the exact identity of the contracting partner, a general understanding by that one party of who the other party (the offeror) is, can suffice. ${ }^{1159}$ On the contrary, it seems plausible that where the offeree has a great interest in the identity of the contracting partner, that other party must be identified, ie, named. Arguably, this line of reasoning, namely, that the other party need not always be specified exactly, would apply to and help to explain offers ad incertas personas (to undefined person(s)). ${ }^{1160}$

As for the obligations of the parties, these will regularly constitute some performance on the one side and payment of a sum of money on the other, irrespective of whether the contract is for a sale, lease, or for the provision of some service. It seems that the price must be objectively determinable, whether directly or by the use of some method. ${ }^{1161}$ German

1157 See BGH decision of 27 September 2017, XII ZR 114/16, BGHZ 216, 68-83, JZ 2018, 789-792, para 17. The case will be discussed in relation to the written form in Section b.ii. below.

1158 Compare Plewe (fn 1015) 44.

1159 See BGH decision of 16 March 2006 (fn 1134), in which it was held that the provision of special telecommunication services, namely, of what are known as 'R-Gespräche' (reversed-charge calls), constituted 'every-day mass services' ('alltägliche Massendienstleistung[en]') that were preformed instantly and that the service user held no particular interest in the identity of the service provider. This was the case where a user accepted a service without information on the provider, so that it is sufficient if the offer indicates that the provider will be the user's contracting partner without being named. See paras 1, 12 of the decision.

1160 Compare Schmidt J (fn 25) 253.

1161 See BGH decision of 20 June 2000, IX ZR 434/98, WM 2000, 1600-1605, in which it was held that the parties had not agreed on a price, and, although a 'Freundschaftspreis' (special price for a friend) had been mentioned, it was impossible for a third party to determine the value of such a 'friendship price', so that none of the BGB's default rules could be applied. Consequently, the purported agreement contained gaps which could not be filled, leading to the conclusion that no contract had arisen. See paras 23-26 of the decision. 
legislation sometimes foresees presumptions concerning the counter-performance (remuneration or price). Thus, $\$ 612$ and $\$ 632 \mathrm{BGB}$ presume an implicit stipulation for the remuneration of services and work respectively and contain default rules to determine its amount. These regulations are said to be exceptions to the general principle that a price must be agreed. ${ }^{1162}$ Instead of fixing a price, it is possible for the parties to stipulate that the price be set by either of them, or by a third party. ${ }^{1163}$ This is generally possible by virtue of $\$ \$ 315-317$ BGB, which enable the specification of the extent of the main obligation or of the counter-performance ${ }^{1164}$ by either of the parties or by one or more third parties. In case of the main obligation, the determination of its extent is to be made using reasonable discretion (billiges Ermessen), unless provided for otherwise ( $\$ 315$ para 1 and $₫ 317$ para 1 BGB). ${ }^{1165}$

\section{dd) Coming into Effect of Angebote: Empfangstheorie (Receipt Theory)}

Due to the abstractness of its provisions, the BGB does not contain specific regulations for the coming into effect of offer and acceptance separately; instead, there are universal rules for all kinds of declarations of intention. Furthermore, the BGB only contains an explicit regulation for declarations of intention that need to be received (empfangsbedürftige Willenserklärungen), such as offer and acceptance, ${ }^{1166}$ and that are made between absent persons (Abwesenden) as coming into effect upon their receipt (Zugang, $\mathbb{\$} 130$ para $1 \mathrm{BGB}$, containing the Empfangstheorie, Receipt

1162 See Wolf and Neuner (fn 48) 435 in fn 7. For further details on these and other similar interpretation rules, see Schmidt J (fn 25) 253-254.

1163 See Wolf and Neuner (fn 48) 418 para 5.

1164 Note that $₫ 316$ BGB says 'specification of consideration' in the English translation. In order to avoid confusion with the English concept, the more general term 'counter-performance' will be used hereinafter.

1165 For further details on the (third) parties' power to determine the performance, see Schmidt J (fn 25) 254-256.

1166 See Einsele, ' $\mathbb{S} 130$ BGB' (fn 1096) para 1. A case example showing that declarations of acceptance belong to this category is the BGH decision of 26 November 1997, VIII ZR 22/97, BGHZ 137, 205-211. A letter sent as registered mail had not been picked up from the post office and was returned to the sender (offeree). The court held that the declaration contained in the letter, the acceptance, had not reached the addressee and no contract had been concluded. See para 13 of the decision. Note that implied acceptance under $\$ 151$ BGB need not be declared. This provision is discussed in Sections iii.aa)-bb) below. 


\section{B. Comparative Background}

Theory). ${ }^{1167}$ Having said this, even where the parties are in each other's presence (anwesende Personen), the addressee will normally have an interest in knowing of the addressor's intention, so that the provision is said to be applicable in this circumstance as well. ${ }^{1168}$ In contrast, it has been stated that declarations not needing to be received (nicht empfangsbedürftige Willenserklärungen), such as offers of rewards (Auslobung, \$657 BGB), come into effect upon being announced (verlautbart). ${ }^{1169}$

Whether persons are in each other's presence or not does not simply depend on physical proximity, ${ }^{1170}$ but on the way in which communication is possible. ${ }^{1171}$ Thus, where communication is instant and knowledge of the conveyed message can be had, those persons will be deemed to be 'present', as is the case with persons in physical proximity, but also with telephone calls (see $\$ 147$ para $1 \mathrm{BGB}$ ), and online chats or calls. ${ }^{1172}$ In contrast, persons are 'absent' whenever the communication is not immediate

1167 See Bork, 'Allgemeiner Teil' (fn 900) 284 para 723; Wolf and Neuner (fn 48) 335 para 1 and 357 para 10.

1168 Wolf and Neuner (fn 48) 357 para 10. See also Bork, 'Allgemeiner Teil' (fn 900) 234 para 602. cf Einsele, ' $\$ 130 B G B$ ' (fn 1096) para 2, who states that this is the leading opinion concerning 'corporeal' (verkörperte) declarations, ie, those made in a durable form such as in writing or those sent as electronic messages.

1169 Einsele, ' $\mathbb{S} 130 B G B$ ' (fn 1096) para 5. Compare Bork, 'Allgemeiner Teil' (fn 900) 234-235 paras 603-604, noting that only one parties' declaration of intention is required, as (the possibility of) knowledge by the recipient is not necessary.

1170 cf $\$ 312$ c BGB (Fernabsatzverträge; Distance contracts), in whose para 2 'means of distance communication' are defined as those communication methods used which do not require 'the simultaneous physical presence of the parties to the contract'. In this sense, the BGH has ruled recently that the contract between a lawyer and their client, which arose from the client filling out, signing, and sending several forms including a power of attorney through fax as an offer on the one hand, and the lawyer subsequently acting on the client's behalf without prior communication with the client as implicit acceptance on the other hand, was a distance contract in the sense of $\$ 312$ para 1 (former version). See BGH decision of 23 November 2017, IX ZR 204/16, paras 8-13, $15,17,19-20$. Even in cases of physical proximity, special circumstances such as the contracting process being conducted outside the merchant's business premises (Geschäftsräume) may lead to particular regulation being applicable, see $\mathbb{S} 312 \mathrm{~b}$ et seq $\mathrm{BGB}$.

1171 See Einsele, ' $\mathbb{S} 130$ BGB' (fn 1096) paras 1-2, who is critical of this traditional classification and advocates instead to differ between 'corporeal' and 'incorporeal' (nicht verkörperte) declarations.

1172 Bork, 'Allgemeiner Teil' (fn 900) 235 para 605. See also Niko Härting, Internetrecht [Internet Law] ( $6^{\text {th }}$ online edn, Verlag Dr Otto Schmidt 2017) para 664. 
and instantaneous, such as when it is made by letter, fax, or e-mail, ${ }^{1173}$ ie, whenever some non-instantaneous medium is interposed. ${ }^{1174}$

Zugang means that the declaration must reach the addressee $(\mathbb{1 3 0}$ para $1 \mathrm{BGB}$ ). As a consequence, the sender (offeror) bears the risk of the declaration being delayed, lost, or transmitted incorrectly from the time of sending it until it reaches the offeree. ${ }^{1175}$ Nevertheless, it is sufficient under what is known as the Empfangstheorie (receipt theory) that the addressee can have knowledge of the declaration; actual knowledge is not required. ${ }^{1176}$ Exceptionally, the Vernehmungstheorie (perception theory) is said to be applicable to oral declarations, as it is pertinent that the addressee hears the message as uttered by the declaring person. ${ }^{1177}$ Thus, oral declarations, including those communicated over the telephone, or in a chat message, come into effect upon being heard, as long as there are no problems in the auditory perception. ${ }^{1178}$ The Empfangstheorie implies that the addressee has access to the declaration; thus, it is required that the declaration has entered the sphere of influence (Machtbereich) of the addressee. ${ }^{1179}$ In this sense, postal mail such as normal letters or other

1173 See Wolf and Neuner (fn 48) 357 para 11. On the latter, see also Einsele, $\mathfrak{\$} 130$ $B G B^{\prime}$ ' (fn 1096) para 18; compare also Härting (fn 1172) para 664.

1174 Bork, 'Allgemeiner Teil' (fn 900) 235 para 605.

1175 On the risk, see Einsele, ' $\mathbb{S} 130 B G B$ ' (fn 1096) paras 3, 16. cf Härting (fn 1172) para 668 , who lists a range of possible reasons for a transmission being faulty (Störungen), some of which may put the risk on the sender. Two examples are the incompatibility of software or another error such as the recipient's mailbox being full, both of which will, if known or ought to have known by the sender, hinder a declaration from being deemed to be received.

1176 See Bork, 'Allgemeiner Teil' (fn 900) 237 para 609. See also Einsele, ' $\mathbb{S} 130$ BGB' (fn 1096) paras 9, 11. Other theories in this respect are the Äußerungs-, Entäußerungs-, Vernehmungs, and the Besitztheorie. Interested readers are referred to, eg, Einsele, ibid, paras 7-10 for further details.

1177 See Wolf and Neuner (fn 48) 362 para 37. On the interpretation of declarations, see Section a.i.cc) above.

1178 See on this further Einsele, ' $\mathbb{S} 130 B G B$ ' (fn 1096) para 28. On chats, see Härting (fn 1172) para 666.

1179 See Wolf and Neuner (fn 48) 358 para 14. Bork, 'Allgemeiner Teil' (fn 900) 237 para 609 speaks of the recipient's sphere of dominion ('Herrschaftssphäre'). Einsele, ' $\mathbb{1} 130 B G B$ ' (fn 1096) para 16 adds that the declaration must be brought within such proximity of the addressee that it is up to the addressee to take knowledge of the message. See further, eg, BGH decision of 3 November 1976, VIII ZR 140/75, BGHZ 67, 271 paras 12-14, in the case of which a notification that the registered mail (discussed further subsequently) containing the declaration was being held at the post office was not sufficient as nor did it substitute receipt. Although the notification had entered the addressee's sphere 


\section{B. Comparative Background}

written communication is deemed as received when it has been handed over to the addressee, or otherwise when delivered in the post box, while e-mails are received once they enter the addressee's mail server or customer message inbox on websites. ${ }^{1180}$ A declaration sent by fax or telex is generally deemed to be received once the addressee's machine has completed the printing process. ${ }^{1181}$ It ought to be noted that the effect is not always

of influence, the letter itself had not, so that the declaration could not be known to him. Nevertheless, the declaration of a lease contract termination was deemed to be effective in the sense of being on time (rechtzeitig), due to the special relationship between the parties, see ibid paras 18-19. cf BGH decision of 26 November 1997 (fn 1166), in which a declaration of acceptance sent by registered mail that had not been picked up from the post office by the offeror and was returned to the offeree was not held to have reached the offeror even though the parties were negotiating a contract, as the court found that the offeree ought to have tried to have the declaration delivered to the offeror once more, see paras 13-20. On another occasion, the BGH has held that the contractual relationship between two parties has the effect that refusing to accept the delivery of a document without cause counts as the document having entered the addressee's sphere of influence and thus as having been received by the addressee, see BGH decision of 27 October 1982, V ZR 24/82, NJW 1983, 929 at 930-931. For a critical discussion of the legal estimation of registered mail and their notifications, see Michael Behn, Das Wirksamwerden von schriftlichen Willenserklärungen mittels Einschreiben: Zur Bedeutung der Zurücklassung des Benachrichtigungszettels [The Coming into Effect of Written Declarations of Intention: On the Importance of the Notification] (1978) 178 No 6 AcP 505-532. The parties' relationship can also work the other way, see, eg, OLG München order of 15 March 2012, Verg 2/12, Neue Zeitschrift für Baurecht und Vergaberecht (NZBau) 2012, 460-464, discussed in fn 1192 below.

1180 Einsele, ' $\mathbb{S} 130 B G B^{\prime}$ ' (fn 1096) para 17 speaks of the declaration reaching the addressee's 'receiving equipment' (Empfangseinrichtung). Indeed, Bork, 'Allgemeiner Teil' (fn 900) 243 para 622 states that a voice message is received once saved on the recipient's answering machine. In case of e-mails, the address must be the one that the addressee usually uses for legal transactions, see on this further Einsele, ibid, para 18. Compare Härting (fn 1172) para 672, stating that sending a declaration to a wrong (misspelt) e-mail address will not lead to receipt being presumed.

1181 BGH decision of 21 January 2004, XII ZR 214/00, NJW 2004, 1320-1321, para 13. The case concerned a declaration of intention needing to be received (a contract termination notice) and its receipt if sent by fax and letter and where the recipient (plaintiff) is absent on vacation. In the event, the court held that the notice had been received after the fax message had been printed and that the defendant's absence was irrelevant, because it was for the defendant to arrange for the handling of postal or other messages during their absence. See paras $4,12-14$ of the decision. 
immediate: both business people and private persons are not assumed to have constant access to incoming communication. Therefore, a time lag is fictionally inserted between physical or digital receipt and legal effectiveness of the receipt. Furthermore, it is important to note that if a form is prescribed for a declaration, this must be fulfilled as well in order for the declaration to become effective. ${ }^{1182}$

Although it was stated above that actual knowledge is not required, a declaration is not deemed to have reached the recipient simply upon entering the addressee's sphere of influence. Rather, the concrete point in time at which the declaration comes into effect, ie, the moment it is deemed to reach the recipient, is the moment from which the recipient could under normal circumstances have knowledge of the declaration. ${ }^{1183}$ In the event that actual knowledge is had before the period for presumed knowledge has ended, the earlier moment is pertinent. ${ }^{1184}$ If a third person takes delivery of a declaration on behalf of the addressee, it will be deemed to have been received by the addressee if the person is their agent and that person is in the position to have knowledge of the declaration; if that person is merely a messenger, however, receipt occurs when the addressee can have knowledge of the declaration. ${ }^{1185}$

The length of the lag time between delivery and the possibility of knowledge varies according to the dispatch method used, but is generally based on prevailing opinion (Verkehrsanschauung) and is thus connected to business hours. ${ }^{1186}$ Consequently, letters, fax, and e-mails that arrive to a place of business outside standard business hours (after 6 pm$^{1187}$ ) will

1182 See Einsele, ' $\$ 130 B G B$ ' (fn 1096) para 33. Formalities are discussed in Section b. below.

1183 See Wolf and Neuner (fn 48) 359 para 21. Bork, 'Allgemeiner Teil' (fn 900) 243 para 623 notes that the relevant moment is when having knowledge of the declaration is reasonable ('zumutbar').

1184 Einsele, ' $\$ 130 B G B$ ' (fn 1096) para 16.

1185 See Wolf and Neuner (fn 48) 363 para 41, 364 para 46. Note that in the latter case, the risk is on the addressee, compare ibid para 46.

1186 Concretely, it relates to the time at which the emptying of the (e-)mail-box can be expected, Einsele, ' $\$ 130$ BGB' (fn 1096) para 19; Bork, 'Allgemeiner Teil' (fn 900) 243 para 623. Arguably, this is so because the addressee must first be aware of the existence of a declaration in order to be able to take notice of it. According to prevailing academic opinion, there may be other factors delaying receipt, such as the addressee not possessing sufficient language ability to understand the declaration. In this case, receipt is postponed until the time that a translation can normally be deemed to have been obtained, see Einsele, ibid, para 31, and Bork, ibid, 245 para 629.

1187 Compare Wolf and Neuner (fn 48) 359 para 24. 


\section{B. Comparative Background}

only be deemed to have been received when business hours begin on the next (working-)day. ${ }^{1188}$ Similarly, private persons will only be deemed to have received declarations sent to them by such means at the time that knowledge of these can be generally expected to be had, namely, at the earliest after business hours, ${ }^{1189}$ and at the latest one day after the declaration physically reaches the recipient. ${ }^{1190}$ Exceptionally, actual knowledge is pertinent where the e-mail address to which the declaration is sent is not the usual one used by the addressee, ie, is not generally known. ${ }^{1191}$

While the risk of loss or other negative circumstances, ie, the risk of (mis-)transmission, is usually on the addressor, if the cause relates to the addressee, either through wilful prevention of reaching of the declaration, or through other circumstances in their Risikosphäre (sphere of risk or responsibility), such as prolonged absence or computer problems, the addressee is deemed to have received the declaration. ${ }^{1192}$

1188 On letters and fax, see Einsele, ' $\mathbb{S} 130 B G B$ ' (fn 1096) paras 19-20; on e-mails, see Härting (fn 1172) para 668. Einsele, ibid, states that the pertinent moment for letters is the time at which an emptying of the mailbox can be expected. In this respect, the $\mathrm{BGH}$ has stated in an obiter dictum that subjective particularities as to mail delivery are irrelevant; prevailing opinion only is of importance for the question whether it can be expected that the mail be taken from the post-box on the same day as it being inserted, see BGH decision of 21 January 2004 (fn 1181) para 16. cf generally Wolf and Neuner (fn 48) 359 para 24 , stating the time to be by $6 \mathrm{pm}$ of the following working day. On business e-mails, cf AG Meldorf decision of 29 March 2011, 81 C 1601/10, NJW 2011, 2890-2892, in which the court held that e-mails were not deemed to have reached the recipient at the beginning of the following working day if sent outside business hours on the previous day; however, the court left the question of when a merchant ought to be deemed to have knowledge of an e-mail open, see paras 16-26 of the decision.

1189 See Wolf and Neuner (fn 48) 359 para 24.

1190 On letters and fax, see Einsele, ' $\$ 130 B G B$ ' (fn 1096) paras 19-20; on e-mails, see Härting (fn 1172) para 668.

1191 Compare Wolf and Neuner (fn 48) 359 para 24, speaking of the addressee not using the e-mail address in legal transactions ('Tritt der Empfänger im Rechtsverkehr nicht unter der E-Mail-Adresse auf [...]').

1192 See on this ibid 365-366 paras 49 et seq. See also the cases discussed in fns 1179 and 1180 above. The BGH decision of 21 January 2004 (fn 1181) para 14 is an example for absence due to being on vacation. An example of technical problems is the decision of the LG Hamburg of 7 July 2009, $312 \mathrm{O}$ 142/09, Kommunikation \& Recht (K\&R) 2010, 207-208, in which an e-mail containing a declaration of intention (Abmahnung, caution) that had been blocked by the addressee's firewall but had not been sent back to the addressor was deemed to have been received, since the risk was on the recipient, see paras 15-16, 18-21. On e-mails being deemed to be received, cf OLG München 
Seeing as $\$ 130$ para 1 BGB is dispositive, the parties may make stipulations as to the time of receipt of a declaration, ${ }^{1193}$ and to its method, ${ }^{1194}$ waive a right to revoke, ${ }^{1195}$ and even dispense with formalities altogether. ${ }^{1196}$ Where such provisions are made, these must be assessed separately from any form requirements of the declarations of intention stipulated by the parties. ${ }^{1197}$ Similarly, an offeror can freely stipulate a period of validity for their declaration of intention, ie, a period in which acceptance may be made. ${ }^{1198}$ This will be considered below, together with the issue of an offer's bindingness.

\section{ee) Bindingness and Loss of Effect of Angebote}

As was indicated above, a declaration is not automatically binding, ie, does not inevitably constitute an offer. Apart from merely being an invitatio

order of 15 March 2012 (fn 1179), in which the court held that the relationship of the parties, ie, being in the middle of a public bidding process, and good faith precluded the addressor from relying on an e-mail having been received by the addressee. The e-mail in question had in fact entered the addressee's sphere of influence; however, the addressor had received an automatic reply informing them of the addressee's absence; the addressor chose not to react and later claimed that the period set for making rebukes (rügen) against the addressor's decision had begun on the day of receipt. Compare paras 1, 8, 15, 50-54 of the OLG-decision.

1193 Wolf and Neuner (fn 48) 361 para 31. The authors note that standard terms creating fictions or special requirements for receipt are void under $\$ \mathbb{S} 308$ no 6 and 309 no 13 BGB respectively. The latter provision is found in the amended $\$ 309$ no 13 lit c BGB (in effect since 1 October 2016, see art $229 \$ 37$ EGBGB).

1194 Einsele, ' $\mathbb{S} 130 B G B$ ' (fn 1096) para 12.

1195 See ibid para 40.

1196 See BGH decision of 7 June 1995, VIII ZR 125/94, BGHZ 130, 71-76 para 13 , in which the dispensation of specific delivery methods by the parties was upheld by the court.

1197 This was stated in, eg, BGH decision of 21 January 2004 (fn 1181) para 11, in which the court distinguished between the stipulated form requirement for a declaration of intention (termination of a lease, to be made in writing) and its delivery method (by registered mail), whereby it considered only the former to be a constitutive requirement. Furthermore, it can be deduced from this that it is generally possible for parties to stipulate that the delivery method be an essential requirement, since the court stated that there were no indications as to the parties having agreed on this (see ibid).

1198 See $\$ 148$ BGB; see also Wolf and Neuner (fn 48) 274 para 2, speaking of time periods generally. 
ad offerendum, the statement or conduct may simply be one of kindness (Gefälligkeit). ${ }^{1199}$ Where a declaration amounts to an offer, the question then becomes whether, and if so, from what point in time the declaration of intention is binding and effective.

In general, an offer will be binding on the offeror and become effective upon reaching the addressee, ${ }^{1200}$ unless one of the following is true: First, that the offeror 'has excluded being bound by it' ('die Gebundenheit ausgeschlossen hat', $\mathbb{} 145$ BGB). ${ }^{1201}$ This means that an offeror is bound, by default, by their offer, ${ }^{1202}$ so that the offer is generally irrevocable (unwiderrufbar), unless the offeror's declaration of intention not to be bound reaches the offeree before or at the latest together with the offer itself. ${ }^{1203}$ This irrevocability will subsist until the offer's bindingness elapses, which

1199 On the former, see Section bb) above. On the latter, see Section iv. below.

1200 While not stated explicitly, this has been deduced for declarations of intention from $\ 130$ para 1 BGB. Compare, eg, Einsele, ' $\$ 130$ BGB' (fn 1096) para 3. In the LG Berlin decision of 20 July 2004 (fn 1137) para 38, the court was of the opinion that an offer in an online auction constituted a 'legally binding offer of sale' ('rechtsverbindliches Verkaufsangebot'). The court therefore held further that such an offer could not simply be 'deleted' in the sense of being revoked, but could only be avoided (angefochten), which had not been done in this case, ibid para 39. Something similar has also been stated by the $\mathrm{BGH}$ in relation to declarations of suretyships: the declaration must reach the other party, ie, come into their sphere of influence, in order to have been issued ('erteilt'), see BGH decision of 27 May 1957, VII ZR 223/56, WM 1957, 883, 885.

1201 Wolf and Neuner (fn 48) 421 para 15 note that this seems to occur only rarely in practice. Even if terms such as 'freibleibend' (non-binding) are used, these are often intended to give the seller the final decision whether to contract. It seems thus that such declarations are not offers but invitations to make offers (on which see Section bb) above). Similarly, while the possibility to modify the offer's bindingness exists, the stipulation might be found to be invalid, especially if in the form of a standard term (AGB). This was the case in BGH default judgement (Versäumnisurteil) of 7 June 2013, V ZR 10/12, NJW 2013, 3434-3436, which concerned the purchase of real estate. As the issue of AGB goes beyond the scope of this dissertation, readers are referred to paras 9-13, 18 et seq of the decision for further details on the argument used by the court. The gist was that the open-endedness of the offer's validity bound the offeror in an unreasonable manner, even though it was revocable, and contravened the objective of $₫ 146$ and $\$ 147$ para 2 BGB (discussed below).

1202 See Busche, ' $\$ 145$ BGB' (fn 893) para 1.

1203 See Wolf and Neuner (fn 48) 420 paras 12-13. Under the principle of good faith (Treu und Glauben), this is qualified for offers which are to be open for acceptance for a long stretch of time and where the circumstances change during the waiting period, so that it becomes unreasonable to keep the offeror bound, see ibid. 
occurs when the foreseen time frame for acceptance expires, or where the offer is rejected. ${ }^{1204}$ Secondly, a revocation is possible if the offeror reserves themself the right to do so, namely, by declaring a Widerrufsvorbehalt (revocation proviso). ${ }^{1205}$ Thirdly, an offer - like all declarations of intention - can be withdrawn before reaching the addressee. This can be achieved by a declaration to that effect reaching the addressee before or at least together with the offer itself. ${ }^{1206}$ If the offer's effectiveness ends, whether by revocation or otherwise, that brings the contract formation process to an end. A new process may be started by the offeror or the offeree making a new offer. ${ }^{1207}$

Where the offer made under German law is revocable (widerrufbar), the revocation is treated like other declarations in that its receipt, ie, entering the addressee's sphere of influence but not knowledge of its content, is of importance. ${ }^{1208}$ Revocations need not be made in the same form as the declaration that is to be revoked. ${ }^{1209}$ Note that revocation will no longer be possible once a declaration of acceptance has reached the offeror. ${ }^{1210}$ Arguably, a revocation will equally not be possible if the offer loses its effectiveness in accordance with $₫ 146$ BGB: ie, if it is either refused or not accepted on time by the offeree, as discussed in Section iii. Let it be noted at this point that while the offeror may foresee a period of acceptance, ie, a period of validity for the offer under $\mathbb{1} 148 \mathrm{BGB}$, an offer not making such stipulations will nevertheless not be open endlessly. This can be deduced from $\mathbb{S} 146,147$ para $2 \mathrm{BGB}$, so that an offer can be accepted during 'the time when the offeror may expect to receive the answer under ordinary circumstances' ( $\$ 147$ para 2 BGB). In other words, the offer will expire automatically after the lapse of this period of time. ${ }^{1211}$ Before turning to

1204 Bork, 'Allgemeiner Teil' (fn 900) 286 para 726. See also Busche, '\$ 145 BGB' (fn 893) para 1. This issue relates to $\mathbb{S} 147-148 \mathrm{BGB}$ and is discussed in the subsequent section.

1205 Wolf and Neuner (fn 48) 420 para 13. Bork, 'Allgemeiner Teil' (fn 900) 285 para 724 notes that the declaration made under such a proviso may only amount to an invitation to make an offer.

1206 To be precise, the revocation prevents the offer from coming into effect, see $\$ 130$ para 1 BGB; Einsele, ' $\$ 130 B G B$ ' (fn 1096) para 40.

1207 On the latter case, see $\mathbb{1} 150$ para 1 BGB. See also BGH decision of 22 May 1991 (fn 1135) para 10.

1208 Compare Einsele, ' $\mathbb{S} 130$ BGB' (fn 1096) para 40.

1209 See ibid.

1210 See Wolf and Neuner (fn 48) 420 para 13.

1211 See ibid 421 para 16. 


\section{B. Comparative Background}

the question of how long this period of time is, the same question will first be considered for the scenario of a period of acceptance being stipulated.

Determining the ordinary response period is not straightforward. Section 147 para $1 \mathrm{BGB}$ states that an offer made to a present person can only be accepted 'immediately' ('sofort'). In contrast, offers sent to an absent person will be open for some time. Three factors are considered in assessing the regular response period of $\$ 147$ para 2 BGB objectively: the transmission speed of the offer to the addressee; the consideration and response time of the addressee; and the duration for the communication of acceptance to the offeror. ${ }^{1212}$ Thus, atypically, the time period will be considered from the moment the offer is sent out, not once it reaches the addressee. ${ }^{1213}$ Letters sent within Germany are said to take two days to reach their destination. ${ }^{1214}$ As an offeror can expect the same communication method to be used for the offeror's response, ${ }^{1215}$ this means that an offeror can normally expect a response letter in at least four days, plus however long an appropriate consideration time is under the circumstances. A businessperson is normally expected to react quickly, within one or two days; if, however, the addressee is expected to take longer, due to first having to make some enquiries for example, the consideration period

1212 BGH decision of 11 June 2010, V ZR 85/09, NJW 2010, 2873-2876, para 11: 'Die nach objektiven Maßstäben zu bestimmende Annahmefrist [...] setzt sich zusammen aus der Zeit für die Übermittlung des Antrages an den Empfänger, dessen Bearbeitungs- und Überlegungszeit sowie der Zeit der Übermittlung der Antwort an den Antragenden.' The case concerned a purported sale of real estate, whereby the offer to buy was made by the purchaser. The declaration of intention contained a period of acceptance lasting almost three months. Although the seller reacted within this period, the court found the time stipulation to be invalid for being unduly long and restricting the offeror too strongly. Due to the individual stipulation being invalid, the rules of the BGB were applied. The court held that an appropriate time period for acceptance would have been four weeks, which the seller had not met. Consequently, no contract of sale had arisen between the parties. See paras 1, 5-6, 8, 11-14 of the decision. Another issue discussed by the court was that of an implicit acceptance of a new offer in accordance with $\mathbb{1} 150$ para 1 BGB. This point will be considered in Section iii.bb) below.

1213 See BGH decision of 11 June 2010 (fn 1212) para 11.

1214 See Wolf and Neuner (fn 48) 422 para 19.

1215 cf Bork, 'Allgemeiner Teil' (fn 900) 287 para 731, who notes that while it is not necessary to use the same communication method, where another mode is used, it is required that a faster method is chosen. 
is extended accordingly. ${ }^{1216}$ It is important to note that the assessment is made from a reasonable offeror's perspective, so that any unusual delays that occur during transmission are irrelevant. ${ }^{1217}$ Having said this, if the offeror knows of the existence of some reason hindering or delaying the addressee's response, this fact becomes pertinent for the calculation. ${ }^{1218}$

\section{iii. Annahme (Acceptance)}

The addressee of an offer has different options when receiving a proposal to contract: they may accept it, reject it, or do neither. Accepting means that a contract will normally arise in that moment, ${ }^{1219}$ unless other requirements need to be fulfilled. ${ }^{1220}$ In contrast, while the rejection of an offer brings the matter to an end, ${ }^{1221}$ doing nothing may have different

1216 See Wolf and Neuner (fn 48) 422 para 19. See also BGH decision of 11 June 2010 (fn 1212), in which four weeks were deemed an appropriate response time due to the complexity of the necessary preliminary enquiries and actions.

1217 See BGH decision of 11 June 2010 (fn 1212) para 14.

1218 See Bork, 'Allgemeiner Teil' (fn 900) 287 para 731.

1219 Compare Wolf and Neuner (fn 48 ) 417 para 2. Anticipating the discussion further below, it ought to be noted that this moment is usually the point in time at which acceptance comes into effect (see Section dd) below); however, there are exceptions. In cases where $\mathbb{S} 151,152$, or 156 BGB apply, the contract is concluded without acceptance being communicated to the offeror, so that the normal rule does not apply. Compare on this Jan Busche, $\mathbb{S} 147$ Annahmefrist [Section 147 Period for Acceptance], in: Säcker and others (fn 158) para 35.

1220 One example is an auction. While $₫ 156$ BGB (Vertragsschluss bei Versteigerung; Entry into contracts at auctions) provides that the contract will arise through the bid (Gebot) and 'the fall of the hammer' (Zuschlag), the contract will not be effective where other formalities are necessary and these have not been fulfilled. See BGH decision of 24 April 1998 (fn 1097), which concerned a sale by auction of immovable property. Anticipating the discussion in Section b.iv. below, contracts in relation to this kind of property must be made in a notarial form, called notarielle Beurkundung (notarial authentication). Since the authentication that had been made in that case was defective for procedural reasons (not discussed here), the contract was held to be void. Form requirements and the legal consequences of non-fulfilment are discussed in detail in Section b. below.

1221 This will of course not be true if the offeree then makes a (new) offer to the offeror. This can happen through modification of the original offer (see $₫ 150$ para 2 BGB), or the drafting of a completely new offer. Furthermore, late acceptance will be deemed as a new offer ( $\$ 150$ para $1 \mathrm{BGB})$. Both provisions will be discussed further below. 


\section{B. Comparative Background}

effects depending on the circumstances. This issue will be discussed subsequently, together with the meaning of the term 'Annabme'.

\section{aa) 'Annahme' Defined}

Similar to offers, acceptance is not defined in the BGB. It is ordinarily understood as a declaration of intention that needs to be received, and which furthermore expresses consent to the offer. ${ }^{122}$ There are exceptions to this, two of which are found in $\$ \$ \$ 151-152$ BGB (discussed subsequently). As a consequence of the receipt requirement, acceptance must be communicated in some way. ${ }^{1223}$ The declaration must therefore be directed at the offeror. ${ }^{1224}$ Moreover, it must constitute an unconditional assent to the offer. ${ }^{1225}$ This is in accordance with $\$ 150$ para 2 BGB, under which a declaration of acceptance cannot make alterations to the offer, as it will otherwise count as a rejection and the declaration will turn into a new offer (see Section ii.aa) above and Section dd) below). It ought to be noted that acceptance can only have the effect of concluding a contract if the offer does not foresee otherwise. Thus, where an offer is not 'acceptable' due to it excluding its bindingness, or because the offeror reserves themself the right to decide on whether to contract after a purported declaration of acceptance is made, ${ }^{1226}$ the contract does not arise at that point.

Indeed, not all declarations of intention made in response to an offer amount to acceptance. Apart from the obvious case of a rejection, or ineffective acceptance (discussed in Section dd) below), non-binding statements must be distinguished from acceptance. One illustration are confirmations, nowadays often in electronic form (e-mail), sent after an order or a booking has been made online. It has been held by the BGH that electronic booking confirmations will normally be a mere confirmatory statement but can be combined with a declaration of intention so as to constitute acceptance. In particular, where the confirmation is automatic, it will be a declaration of acceptance if it contains an unconditional notice

1222 Bork, 'Allgemeiner Teil' (fn 900) 290 para 738. See also BGH decision of 28 March 1990 (fn 1100) para 15. Busche, ' $\$ 147$ BGB' (fn 1219) para 2 adds that it is a one-sided declaration.

1223 On this, see the discussion in Section ii.cc) above.

1224 Wolf and Neuner (fn 48) 423 para 25.

1225 Bork, 'Allgemeiner Teil' (fn 900) 291 para 741.

1226 Compare Wolf and Neuner (fn 48) 421 para 15. 
that the order will be fulfilled. ${ }^{1227}$ Thus, in a sale transaction conducted online, an automatic e-mail confirming the receipt of the order will generally be deemed as a confirmatory statement only, unless the message shows the seller's unconditional intention to fulfil the order. ${ }^{1228}$

\section{bb) Method of Annabme}

Acceptance can be made in any form, unless the offer or statutory provisions provide otherwise. ${ }^{1229}$ Nevertheless, an offeree is not expected to use the same communication method for their response as the one used to make the offer; a faster method may be used, and this may even become necessary where the offeree's response might not reach the offeror on time. ${ }^{1230}$

Acceptance is usually made expressly. Examples include accepting a bid in an auction through the 'fall of the hammer' (Zuschlag), ${ }^{1231}$ the pressing of a combination of buttons on a telephone, ${ }^{1232}$ the signing and sending back of a contract draft, ${ }^{1233}$ or the simple statement of agreement, such as a 'yes' or 'agreed'. ${ }^{1234}$ Having said this, acceptance need not be express. Thus, where a seller in mail order or online businesses delivers the object to the buyer, this can be deemed as implicit acceptance on part of the seller of

1227 See BGH decision of 16 October 2012 (fn 1110) para 19. In this case, the automatic booking confirmation of a flight reservation for an accompanying person, having been named as 'as yet unknown' in the booking form, was held not to constitute acceptance. This was because the denomination of the accompanying person in the name field of the form violated the terms and conditions of transportation, see ibid paras 16-20. See also BGH decision of 21 September 2005 (fn 1151) para 16, in which emphasis was placed on how the buyer perceives the confirmation. Despite this, it was held that partial delivery combined with an announcement by the seller that the rest will be delivered later will usually be deemed as acceptance by the seller.

1228 Busche, '\$ $147 B G B$ ’ (fn 1219) para 4.

1229 Ibid para 2.

1230 See Wolf and Neuner (fn 48) 422 para 21.

1231 See $\$ 156$ BGB; BGH decision of 24 April 1998 (fn 1097) para 7. See further Wolf and Neuner ( $\mathrm{fn} 48$ ) 419 para 9, who note that online auctions do not fall within the scope of $₫ 156 \mathrm{BGB}$. This has been stated by the court on several occasions, see, eg, LG Berlin decision of 20 July 2004 (fn 1137) para 41.

1232 Compare BGH decision of 16 March 2006 (fn 1134) para 10.

1233 See BGH decision of 18 October 2001 (fn 1131) paras 19, 1-6.

1234 Busche, ‘S $147 B G B$ ’ (fn 1219) para 4. 


\section{B. Comparative Background}

an offer made by the buyer when ordering the object. ${ }^{1235}$ Vice-versa, if the buyer takes delivery of an object, this can be deemed as acceptance of an offer from the seller. ${ }^{1236}$ Similarly, payment of the contract price can be implied acceptance; however, in all cases of implicit acceptance, the offeree must have the necessary volition. This means that the person must at least have doubts concerning the contract having arisen without more and thus deem a declaration on their part as being necessary to bring the contract about. ${ }^{1237}$ Using mass services such as public transport is deemed to be implied acceptance. ${ }^{1238}$ In fact, any use of goods or services that are usually not provided gratuitously are deemed as declarations of acceptance. ${ }^{1239}$ In commercial settings, a merchant may furthermore accept a contract proposal implicitly if they do not react to a kaufmännisches Bestätigungsschreiben (commercial letter of confirmation) sent after the conclusion of negotiations. ${ }^{1240}$

German law assumes acceptance in some situations under legal fictions, such as with gifts $(\$ 516$ para $2 \mathrm{BGB})$, promises of rewards $(\$ 657 \mathrm{BGB})$, or, between merchants, with the solicitation of business transactions for other persons ( $\$ 362$ para 1 HGB: 'die Besorgung von Geschäften für andere’). ${ }^{1241}$

1235 See BGH decision of 21 September 2005 (fn 1151) para 15.

1236 Compare Wolf and Neuner (fn 48) 423 para 26.

1237 Compare BGH decision of 11 June 2010 (fn 1212) para 17-18, in which this volition was not given for the offeree and payment of the price was deemed as fulfilment of the contract, not as implied acceptance.

1238 See Armbrüster (fn 957) para 10; see also Busche, ' $\mathbb{S} 147$ BGB' (fn 1219) para 4.

1239 Singer (fn 1058) para 54. He gives the example of using a taxi.

1240 See Martin Rothermel and Julius Dahmen, Schweigen ist Silber [Silence is Silver] (2018) 4 Recht der internationalen Wirtschaft (RIW) 179, 180. See also, eg, BGH decision of 24 September 1952, II ZR 305/51, BGHZ 7, 187, in which the question arose whether an arbitration clause had been incorporated effectively into a contract by reference in a commercial letter of confirmation to some third party commercial standard terms. It was held that the defendant had implicitly accepted the claimant's offer to sell rice in the form of the confirmation letter sent after the parties' negotiations, because the defendant had not reacted (especially, rejected) the letter's proposal. In this way, the standard terms including the arbitration clause had become part of the contract. See paras 5-7, 9-11 of the decision.

1241 Section 362 para 1 HGB has been translated by Rittler (fn 132) 276 into English as follows: 'Should an offer be made to a merchant whose business includes solicitation or conclusion of business transactions for other parties, and such offer is from someone with whom the merchant has a business relationship and the offer concerns solicitation or conclusion of such transactions on behalf of the offeror, the merchant is obliged to reply promptly; a merchant's silence is deemed as acceptance of this offer. The same applies in 
According to the latter provision, acceptance is implied where an offer for the conclusion of a transaction on behalf of another is made to a merchant who regularly undertakes to conclude such transactions on behalf of other persons and receives this proposal from a party with whom the addressee has a business relationship, but the merchant-addressee does not react promptly (unverzüglich). ${ }^{1242}$ Since the provision speaks of Geschäftsbesorgung, the application of $\$ 362$ HGB is said to be limited to service contracts, but does not encompass sale transactions. ${ }^{1243}$ Similarly, under $\$ 454$ para 1 and $\$ 455$ BGB, a potential purchaser's silence regarding the approval of an object received under a proposed sale will be deemed as approval, ie, acceptance, upon which the contract of sale arises. ${ }^{1244}$ With regard to unilaterally-obliging contracts, such as a gift (Schenkung), acceptance by the donee is implied where the donor has fixed a period in which acceptance of the gift is to be made and this time elapses without the donee having reacted ( $\$ 516$ para $2 \mathrm{BGB}) .{ }^{1245}$

In contrast, silence or inaction generally does not constitute acceptance - neither in private nor in commercial law ${ }^{1246}$ — and it is even excluded in particular circumstances, such as in transactions involving real estate. ${ }^{1247}$ Caution is advisable where a clause that foresees silence or inaction by a party as being deemed as acceptance is inserted into a contract; the

case that a merchant receives an offer to conclude transactions from someone to whom he has offered his services in concluding such transactions.'

1242 See the translation by Rittler (fn 132) in fn 1241 above.

1243 See Rothermel and Dahmen (fn 1240) 180.

1244 In other cases, a provision may look like a legal fiction when this is not actually the case, such as with $₫ 377$ para 2 HGB on the notification of defects. This provision is not a rule on deemed acceptance but actually constitutes a shortening of the period of guarantee. See on this Armbrüster (fn 957) para 13.

1245 For further details, see, eg, Tiziana J Chiusi, $\$ 516$ Begriff der Schenkung [Section 516 Concept of Donation], in: von Staudinger and others (fn 140; 2013, updated 20 June 2018) paras 3, 2, 62. von Mehren, 'Introduction' (fn 21) 8 notes that acceptance of such contracts is sometimes also implied where the 'promisor does not seek a return act or performance'. The cited case, RG decision of 25 March 1930, VII 440/29, RGZ 128, 187-191, concerned a donation mortis causa in the form of the benefit under a life insurance. In the event, the court held at 189 that a declaration of acceptance by the donee-beneficiary was usually not expected by the insurer, so that it was not required by the provisions of the BGB.

1246 For further discussion, see Rothermel and Dahmen (fn 1240) 179 et seq.

1247 In BGH decision of 11 June 2010 (fn 1212) para 16, the court held that this was so for acceptance of a new offer arising from a delayed acceptance under $\$ 150$ para 1 BGB. 


\section{B. Comparative Background}

stipulation may be struck down as a standard term in accordance with $\$ 308$ no 5 BGB (Klauselverbote mit Wertungsmöglichkeit, Fingierte Erklärungen; Prohibited clauses with the possibility of evaluation, Fictitious declarations). ${ }^{1248}$ Where such a clause is used, the contract will arise once the period has elapsed in which the offeror can expect an explicit declaration from the offeree. ${ }^{1249}$ Conversely, where a commercial practice requiring express objection of a proposal exists, silence may exceptionally be seen as acceptance. ${ }^{1250}$ In conclusion, the presumptions just explained exceptionally allow inaction to be seen as assent, whereas mere silence or inaction will not suffice.

In accordance with $₫ 151 \mathrm{BGB}$, there may be no need for the declaration of acceptance to be received in exceptional circumstances. These are of two kinds: either where there is an express or implied waiver of receipt by the offeror, or where no acceptance is 'expected according to customary practice' (Verkehrssitte, $\mathbb{\$} 151 \mathrm{BGB}$ ). It seems that this provision is of little practical relevance and that express waivers are unusual. ${ }^{1251}$ Thus, it is often a question of interpretation of whether an implied waiver was made or whether a customary practice exists. ${ }^{1252}$ It ought to be noted that the provision does not automatically apply in relation to $\$ 241$ a BGB (Unbestellte Leistung; Unsolicited performance), namely, where a consumer receives goods or a service without having solicited them. In such instances, rather than mere receipt or the customer making use of the goods or service, it is required that the consumer declares their agreement (explicit acceptance) or pays (implied acceptance) in order for there to be a contract. ${ }^{1253}$ Other

1248 It will not be struck down if a 'reasonable period' ('angemessene Frist') is granted for an express declaration and the standard term's user has obliged themself to point out the significance of the provision to the other party when the period begins to run. See $₫ 308$ no 5 BGB.

1249 See Rothermel and Dahmen (fn 1240) 179. cf Armbrüster (fn 957) para 9, stating this principle to be applicable to both private and commercial instances.

1250 See Rothermel and Dahmen (fn 1240) 180.

1251 See Jan Busche, $\mathbb{S} 151$ Annahme ohne Erklärung gegenüber dem Antragenden [Section 151 Acceptance without declaration to the offeror], in: Säcker and others (fn 158) paras 2, 4. An example where it does become relevant is where a party is under an obligation to contract (Kontrahierungszwang). For further details, see Wolf and Neuner (fn 48) 419 para 8.

1252 Compare Busche, ' $\mathbb{S} 151$ BGB' (fn 1251) para 4, who notes that the differentiation often becomes blurred, since customary practices are used as an interpretation tool to determine whether an implied waiver existed. For further details on both cases, see ibid paras 5 et seq.

1253 See Singer (fn 1058) para 54. Note that discussion on this position is ongoing. For a succinct overview of this debate and references, see Schmidt J 
exceptions to the need for receipt of a declaration of acceptance are contained in $₫ 152$ and $\mathbb{1} 156 \mathrm{BGB}$, relating to notarial authentications (see Section b.iii.cc) below) and auctions respectively. ${ }^{1254}$

\section{cc) Certainty of Annahme}

Acceptance must, just like the offer, be certain. It is said that this follows from the requirement that acceptance has to correspond to the offer. ${ }^{1255}$ The declaration of intention must be meant to be binding and express this accordingly. In this sense, acceptance has to be differentiated from mere announcements of acceptance: phrases such as 'details to follow by letter' ('Einzelheiten brieflich') in, say, an e-mail, point towards the latter, whereas an e-mail or fax stating that it has been sent 'in advance' ('vorab') and that a letter will follow, is deemed as acceptance, because this is usually done in order to ensure the on-time arrival of a declaration. ${ }^{1256}$

\section{dd) Coming Into Effect and Loss of Effect of Annahme}

The BGB does not contain specific rules for the coming into effect of offer and acceptance but rather regulates declarations of intention generally in $\mathbb{S} 130-132$, so that what was stated in relation to offers in Sections ii.dd) and ee) above is equally true for declarations of acceptance. Consequently, acceptance becomes effective upon its receipt. ${ }^{1257}$ Acceptance made to an absent person can be withdrawn (widerrufen) if the declaration of intention to revoke acceptance reaches the offeror before or at the latest at the same time as the declaration of acceptance ( $\$ 130$ para 1 BGB).

There is a caveat regarding the coming into effect of acceptance. Seeing as acceptance is a declaration of intention that usually needs to be received

(fn 25) 488-489. For further details on $\$ 241 \mathrm{a}$ BGB, see, eg, Dirk Olzen, $\mathbb{S} 241$ a Unbestellte Leistungen [Section 241a Unsolicited Performance], in: von Staudinger and others (fn 140; 2015), in particular paras 19 et seq.

1254 Busche, ' $\mathbb{S} 147$ BGB' (fn 1219) para 2. On $\$ 152$ BGB, see also Bork, 'Allgemeiner Teil' (fn 900) 294 para 748.

1255 Busche, ‘\$ $147 B G B$ ’ (fn 1219) para 3.

1256 See ibid, who goes on to note that letters in the first case will constitute acceptance, whereas the ones in the second case are mere 'declaratory confirmation letters' ('deklarative [...] Bestätigungsschreiben').

1257 Bork, 'Allgemeiner Teil' (fn 900) 294 para 746. 


\section{B. Comparative Background}

(empfangsbedürftige or zugangsbedürftige Willenserklärung), acceptance made to an absent offeror must reach them within the specified time frame, ${ }^{1258}$ or, otherwise, 'until the time when the offeror may expect to receive the answer under ordinary circumstances' ('[...] bis zu dem Zeitpunkt [...], in welchem der Antragende den Eingang der Antwort unter regelmäßigen Umständen erwarten darf', $\mathbb{1 4 7}$ para 2 BGB). ${ }^{1259}$ If this is not the case, acceptance will regularly be invalid. Exceptionally, where it was sent out in a way so that 'it would have reached [the offeror] in time if the declaration had been forwarded in the usual way' ('sie bei regelmäßiger Beförderung ibm rechtzeitig zugegangen sein würde') and the offeror ought to have realised this, acceptance may yet be deemed effective, ie, not to be late, if the offeror does not immediately give notice of the delayed receipt ( $\mathbb{1 4 9} \mathrm{BGB}) .{ }^{1260}$ As it is of importance under these circumstances that the declaration of acceptance be sent out on time, this situation constitutes an exception to the general rule of receipt being pertinent; having said this, the provision does not aid an offeree who sends out their reply too late. ${ }^{1261}$ In this case, acceptance will not be effective. Furthermore, it ought to be noted that where an offer reaches an addressee so late so that a response may no longer be expected by the offeror, the offeree can no longer accept the offer as it has expired. ${ }^{1262}$

While this is true, a purported declaration of acceptance that is ineffective for being too late will count as a new offer by virtue of $\$ 150$ para 1 BGB. If this is accepted by the original offeror, a contract is formed. ${ }^{1263}$ Another instance in which a new offer may arise instead of acceptance is where the offeree's declaration or act does not conform with the offer, so as to change its terms. Thus, where goods different from those ordered are delivered, the act of delivery constitutes a new offer by the original offeree

1258 See Wolf and Neuner (fn 48) 276 para 12.

1259 The aspect of time has already been considered in Section ii.ee) above.

1260 The offeror could know of the delay by looking at the date of posting or sending as recorded on the letter or telegram, for example. See Wolf and Neuner (fn 48) 424 para 27. It ought to be noted that the provision does not apply if the delay was foreseeable to the offeree, eg, postmen being on strike, as the offeree ought to have used a different communication method in this case, see ibid para 28.

1261 Compare ibid. See also Bork, 'Allgemeiner Teil' (fn 900) 288 para 732.

1262 Compare Wolf and Neuner (fn 48) 422 paras 21-22, 423-424 para 27; $\$ \$ \$ 146-$ 147 para 2 BGB.

1263 Compare Bork, 'Allgemeiner Teil' (fn 900) 288 para 732. 
(seller) under $\mathbb{} 150$ para 2 BGB that needs to be accepted by the original offeror (buyer). ${ }^{1264}$

iv. The Further Requirement of a Rechtsbindungswille (Intention of Legal Commitment)

A Rechtsbindungswille (intention of legal commitment) ${ }^{1265}$ is another important element of a contract under German law. According to the prevailing German academic opinion, such an intention is necessary in a legal transaction in order to distinguish legal acts (Rechtshandlungen) from other, non-binding acts such as gentlemen's agreements, or acts of kindness (Gefälligkeitshandlungen), ${ }^{1266}$ already discussed briefly in Section ii.bb) above.

The latter two arrangements, while similar in not being legally binding, could be said to be opposites. This is because a gentlemen's agreement is an arrangement that is made under the premise that it is not to be legally binding. ${ }^{1267}$ In contrast, acts of kindness often arise out of social contexts,

1264 BGH decision of 21 September 2005 (fn 1151) para 15.

1265 Smits (fn 37) 64 uses the English phrase 'intention to create a legal commitment'.

1266 Compare Olzen, ' $\mathbb{S} 241 B G B$ ' (fn 897) para 79. cf Singer (fn 1058) para 29, who speaks of the objective requirement of a declaration of intention (and thus arguably also of a legal transaction) lacking if there is no intention of legal commitment. On Gefälligkeitshandlungen, see BGH decision of 22 June 1956, I ZR 198/54, BGHZ 21, 102-112. The case concerned the question whether the action of the defendant towards the claimant (providing a lorry driver) had the character of a mere act of kindness, or whether it was legally binding. The court found that it was binding, so that the defendant was legally responsible for the driver's act (ibid paras 16-18). It goes without saying that without legal bindingness, there can be no contractual claim against the other party. See on this Bork, 'Vor $\mathbb{} 145$ BGB' (fn 884) paras 83-86. cf Olzen, ibid para 90, according to whom some gentlemen's agreements are intended to be binding and yet are meant not to give rise to judicially enforceable claims. For further discussion of these unenforceable claims, see Olzen, ibid paras 129 et seq. of also what is referred to as betriebliche Übung (informal practice), a non-binding practice established through repetition, whereby the protection of a legitimate expectation (Vertrauensschutz) creates a claim for the beneficiary. See on this Olzen, ibid para 92.

1267 See on this Bork, 'Vor $\mathbb{} 145 B G B$ ' (fn 884) para 3, who goes on to state that the reason for such arrangements are two-fold: The parties either trust that the agreement be upheld, making it superfluous, in their opinion, to stipulate bindingness of the terms; although they think or know that if they tried to 


\section{B. Comparative Background}

whereby the parties never give a thought to the possibility of there being any legal bindingness to their arrangement. ${ }^{1268}$ It ought to be noted that Gefälligkeitshandlungen and the relationships arising from these acts (Gefälligkeitsverbältnisse) must be differentiated further from Gefälligkeitsverträge (accommodation contracts), which are legally binding. ${ }^{1269}$ It becomes clear from the existence of this range of relationships how important the element of an intention of legal commitment is, because it acts as the criterion used to differentiate between them.

Seeing as this intention is neither regulated in German legislation and only seldom addressed explicitly by the parties, it becomes a question of interpretation. ${ }^{1270}$ For this, an objective assessment has to be made. ${ }^{1271}$ In this respect, the BGH has held that the question of whether an act is of a legal(ly-binding) nature generally depends on the circumstances of each case. ${ }^{1272}$ The court went on to enumerate three indicators to aid in the determination. These will be analysed briefly.

The first indicator is gratuity (Unentgeltlichkeit). This is indispensable for a Gefälligkeit; however, it is not by itself conclusive as to the legal (non-)bindingness of an act, since the BGB foresees a range of gratuitous acts that are legally binding, such as gifts (Schenkung, $\$ \mathbb{S} 516$ et seq BGB). ${ }^{1273}$ The second criterion is obligation (Verpflichtung): the fact that one is not obliged to do the act in question does not automatically lead

make their agreement binding, it would not be deemed effective for some reason, such as it violating a statutory prohibition. Compare Olzen, ' $\mathbb{2} 241$ $B G B^{\prime}$ ' fn 897) para 89, who states that the parties may rely on, say, their word of honour (Ehrenwort) instead of legal bindingness, or that such bindingness is deemed superfluous due to the existence of (commercial) customs or practices.

1268 Olzen, ' $\$ 241 B G B$ ' (fn 897) paras 72, 74.

1269 See ibid para 71. See also Bork, 'Vor $\$ 145 B G B$ ' (fn 884 ) para 80 . As already mentioned in Section 1. above, examples of the latter include the gratuitous loan (Leihe, $\$ \int 598 \mathrm{BGB}$ et seq).

1270 Compare Wolf and Neuner (fn 48) 315 para 18. cf Bork, 'Vor $\$ 145$ BGB' (fn 884) para 81. cf further Olzen, ' $\mathbb{S} 241 B G B$ ' (fn 897) para 90, who notes that the normal rules for the interpretation of the parties' declarations of intention, ie, $\mathbb{1} 133$ BGB (discussed in Section i.cc) above), ought to be applied. Such an interpretation can lead to the agreement being found to be binding, see Olzen, ibid.

1271 See Singer (fn 1058) paras 1, 29.

1272 BGH decision of 22 June 1956 (fn 1266) Leitsatz (headnote) 1.

1273 Ibid para 12. Furthermore, Olzen, ' $\mathbb{S} 241 B G B$ ' (fn 897) para 72 notes that this criterium is generally shared with Gefälligkeitsverträge. It ought to be noted that gifts are not contracts and thus not automatically legally binding under English law, see Section II.1. above. 
to it not being legally binding, while, vice versa, an obligation designates a Rechtsgeschäft. ${ }^{1274}$ The third, and perhaps most important ${ }^{1275}$ indicator is intention (Wille): where the addressee of an act cannot objectively perceive an intention on the part of the statement maker to be bound, or where such bindingness has been excluded either explicitly or implicitly, the act will not have the nature of a legal transaction. ${ }^{1276}$ It is noteworthy that it is not the actual statement maker's intention, but the addressee's perception in good faith that is of importance in this respect.

This evaluation must take into account the circumstances of the case and any applicable usages (Verkehrssitten).1277 According to the court, other factors that may influence this assessment are circumstances such as the type of act, its reason, objective, meaning (legally and economically), the value of an entrusted object, ${ }^{1278}$ and the interests of the persons involved. ${ }^{1279}$ In particular, where the acting party has an interest in the act, this points towards an intention of legal commitment. ${ }^{1280}$ Conversely, it is said that there is no such intention where the fulfilment is left to the discretion of the debtor. ${ }^{1281}$ An act perceived to be one of everyday life, a Gefälligkeit, will be a strong argument against an intention of legal commitment. ${ }^{1282}$

In terms of the economic meaning of the act, one interesting situation is one person taking another person to someplace by car. It has been stated that a promise to take someone who is going on an important business trip to the airport amounts to a mandate (Auftrag, $\mathbb{S} 662$ et seq BGB). ${ }^{1283}$ Otherwise, unless no pressing interest exists, giving someone a

1274 See BGH decision of 22 June 1956 (fn 1266) para 13.

1275 See Olzen, ‘ $\$ 241 B G B$ ' (fn 897) para 77.

1276 BGH decision of 22 June 1956 ( $f$ 1266) para 14.

1277 Ibid. cf Bork, 'Vor $\$ 145$ BGB' (fn 884) para 81.

1278 cf BGH decision of 13 November 1973, VI ZR 152/72, NJW 1974, 234, para 13 , in which the court held that the act of letting someone ride a horse was a 'purely factual act of everyday life' ('rein tatsächlicher Vorgang des täglichen Lebens') and as such no legal intention to be bound could be attributed, so that the handing over of the horse did not constitute a gratuitous loan (Leibe).

1279 BGH decision of 22 June 1956 (fn 1266) para 15.

1280 Ibid.

1281 Olzen, ' $\mathbb{S} 241 B G B$ ' (fn 897) para 76.

1282 See Bork, 'Vor $\$ 145$ BGB' (fn 884) para 81.

1283 See Wolf and Neuner (fn 48) 316 para 19. A mandate (Auftrag) also counts as a Gefälligkeitsvertrag, see Bork, 'Vor $\$ 145$ BGB' (fn 884) para 80. 


\section{B. Comparative Background}

ride has been deemed to be a Gefälligkeit. ${ }^{1284}$ In this situation, the focus seems to be on the importance placed by the receiver on the act if relied upon. Thus, if, in the first example, the volunteering driver declined to drive the other person on short notice, this might - in the worst case - lead to that person missing their flight and not being on time for a business appointment, which in turn might have negative consequences. Conversely, if the promise involved the receiver being driven to, say, buy something heavy that needs to be transported by car, it can be argued that the consequence will not usually be as dire if the driver does not keep their word.

Similar considerations are made in cases of information being provided. Where the receiver of information relies on the information in making decisions of consequence, so that the piece of information is of obvious importance to the receiver, the conclusion of an Auskunftsvertrag (literally 'information contract') is implied. ${ }^{1285}$ While a large amount of case law exists for other situations as well, these are too numerous to be discussed here. ${ }^{1286}$

It is evident from this that anything less than an intention of legal commitment is insufficient. Consequently, a mere meeting of the minds or a schlichte Einigung (plain agreement) will not lead to a contract being formed. ${ }^{1287}$ At the same time, certain aspects of life have been held to fall outside the scope of legal arrangements and will thus regularly not lead to obligatory relationships, ${ }^{1288}$ such as those concerning procreation. ${ }^{1289}$ Similarly, there are instances in which legal bindingness is excluded. This occurs if the parties make an arrangement knowing that there is no legal bindingness due to some legal provision not being fulfilled, ${ }^{1290}$ such as requirements of form. ${ }^{1291}$ As a consequence, the knowledge by the parties that a part of an agreement is void means the lack of an intention of legal commitment, so that the void section will not form part of the legal

1284 See, eg, Schmidt J (fn 25) 175 and Bork, 'Vor $\$ 145$ BGB' (fn 884) para 82 with further references.

1285 See Schmidt J (fn 25) 175-176.

1286 For a succinct overview over these cases, see, eg, Olzen, ' $\$ 241 B G B$ ' (fn 897) para 87.

1287 See Busche, 'Vor $\$ 145 B G B$ ' (fn 158) para 31.

1288 Contrast Olzen, ' $\mathbb{S} 241 B G B$ ' (fn 897) para 80 , stating that all aspects of social life are in principle able to create claims and responsibilities.

1289 See on this Wolf and Neuner (fn 48) 316 para 20 with further references.

1290 Busche, 'Vor $\$ 145 B G B$ ' (fn 158) para 32.

1291 See Armbrüster (fn 957) para 23. 
transaction. ${ }^{1292}$ At the same time, there are grey zones, instances which sometimes form obligatory relations and at other times do not. One example in German law is a form of business letter, the LOI. ${ }^{1293}$

\section{b. Form Requirements in German Law}

As a general rule, no formalities are applicable when concluding a contract under German law, ${ }^{1294}$ so that the parties are free to agree and use any form under the principle of freedom of form. ${ }^{1295}$ While this is true, there are a couple of explicit exceptions in German private law. ${ }^{1296}$ In such cases,

1292 See on this Roth (fn 1079) para 24.

1293 Busche, 'Vor $\mathbb{S} 145 B G B$ ' (fn 158) para 31 refers to it as a hybrid form, which can contain both binding and non-binding stipulations. For further discussion, see, ibid paras 58-59.

1294 See, eg, ibid para 29; Christian Hertel, $\$ 125$ [Section 125], in: von Staudinger and others (fn 140; 2017) para 3. Indeed, form requirements have been called 'Ausnahmevorschriften' ('exception rules') by Hans Köbl, Die Bedeutung der Form im heutigen Recht [The Importance of Form in Current Law] (1983) DNotZ 207, 213.

1295 Wolf and Neuner (fn 48) 101 para 39, 509 para 3. Compare Busche, 'Vor $\$ 145$ $B G B^{\prime}$ (fn 158) para 29. In a similar manner, the parties are equally free to do away with the stipulated form. This may be done informally, in certain circumstances even by conduct, see Wolf and Neuner, ibid 524 para 83 . This is not true for cases of what are known as 'double written-form requirements' (doppeltes Schriftformerfordernis). On this, see BGH decision of 2 June 1976, VIII ZR 97/74, BGHZ 66, 378-384, paras 45-49, which concerned a contract between merchants containing a clause that '[a]uf das Formerfordernis kann nur durch eine schriftliche Erklärung verzichtet werden' (' $\mathrm{t}] \mathrm{h}$ he stipulation as to form may only be varied in writing'). Accordingly, an oral offer to cancel the contract was held to be void. See also BAG decision of 24 June 2003, 9 AZR 302/02, BAGE 106, 345-352 paras 35-37 on an employment contract between non-merchants with a formality clause that was held to inhibit a betriebliche Übung (informal practice), ie, a variation by conduct, from arising.

1296 The origin of these compulsory legal forms seems to be Roman law, under which form was the general rule; however, the strict regulation was successively relaxed over time, leading to formlessness becoming the standard rule with formalities becoming the exception. For a brief account of this historical development, see Plewe ( $\mathrm{fn}$ 1015) 1-2. It seems to flow from the freedom of form that statutory form requirements, being deviations from that principle, must be explicit, compare Köbl (fn 1294) 207. See also Peter Mankowski, Formzwecke [Functions of Forms] (2010) 65 No 13 JZ 662, 663. 


\section{B. Comparative Background}

it is a necessary requirement that the form be fulfilled, ${ }^{1297}$ whereby the form requirement is an additional step the parties need to take; it does not do away with the other requirements discussed above. Thus, even where a form requirement such as writing applies, the elements of offer and acceptance, ${ }^{1298}$ as well as the essentialia negotii must still be present. ${ }^{1299}$

Under the Gesetz zur Anpassung der Formvorschriften des Privatrechts und anderer Vorschriften an den modernen Rechtsgeschäftsverkehr [Act on the Amendment of Provisions of Form in Private Law and Other Provisions in Accordance with Modern Legal Transaction Methods] (hereinafter 'FormAnpG' $)^{1300}$, two new statutory forms were created that relate to electronic commerce. These are the electronic form and the text form $(\mathbb{1} 126 \mathrm{a}$ and $\$ 126 \mathrm{~b}$ BGB respectively; introduced by art 1 paras 2-3 FormAnpG). As a consequence, the spectrum of forms for contracts has been broadened, with the range now spanning a simple text form (Textform, see Section ii. below) and the electronic form (elektronische Form, Section v.) as a variation of the written form (Section ii.) on one end, and a notarial authentication (notarielle Beurkundung, Section iii.cc)) on the other, whereby

1297 Hertel, ‘ $\$ 125 B G B$ ’ (fn 1294) para 1. On the consequences of non-fulfilment, see Section vi. below.

1298 This has been true since the times of the Deutsche Reich, see RG decision of 21 June 1918, II 121/18, RGZ 93 175-176: 'Zum Abschluß eines schriftlichten Vertrags genügt nun aber keineswegs [...] die Unterzeichnung derselben Vertragsurkunde durch die Vertragsschließenden. Vielmehr kann [...] auch ein schriftlicher Vertrag zwischen zwei Parteien nur dadurch zustande kommen, daß die eine die Schließung des Vertrags der anderen anträgt $(\$ 145)$ und daß die andere den Antrag rechzeitig annimmt (\$S 146 flg.) [...].' ('It is by no means sufficient [...] for the conclusion of a written contract that the same contract document be signed by the contracting parties. Rather, [...] a written contract can likewise only arise between the parties where one proposes the conclusion of the contract to the other $(\mathbb{1 4 5})$ and the other accepts the offer on time ( $\mathbb{S} 146$ et seq)').

1299 In the BGH decision of 27 September 2017 (fn 1157) para 17, the court stated this opinion with regard to $\$ 550 \mathrm{BGB}$. The case is discussed further in Section ii.aa) below.

1300 Law of 13 July 2001, BGBl 2001 I 1542. For a brief overview over the law's legislative process, see Reinhard Nissel, Rechtsgeschäftsmodernisierungsgesetz [Legal Transaction Modernising Law] ( $1^{\text {st }}$ edn, online, Nomos 2001). According to Nissel, this was the first major modification of the form requirements found in German private law. A further albeit minor addition to the form requirements was made quite recently through the BauVertrRefG in 2018 (see Section ii.cc) below). The partially increasing regulation of form, especially in the area of consumer law, has been said to amount to a 'renaissance' of form, compare Bernd Mertens, Die Reichweite gesetzlicher Formvorschriften im BGB [The Scope of the Statutory Form Requirements of the BGB] (2004) 59 No 9 JZ 431. 
the latter is more complex and deemed to be higher in rank. ${ }^{1301}$ The aspect that all required forms have in common, namely, the signature, will be considered in Section iv. below.

Form requirements are foreseen not only for contracts, but also for other related documents, in particular for preliminary contracts, ${ }^{1302}$ or power of attorneys granted for the purpose of a legal transaction that is subject to form requirements. ${ }^{1303}$ Conversely, non-binding documents

1301 See Wolf and Neuner (fn 48) 508 para 1. cf Köbl (fn 1294) 208, speaking of formalities being tiered (abgestuft). See also Hertel, ' $\mathbb{S} 125$ BGB' (fn 1294) para 4, who goes on to note at para 6 that there used to be a requirement of an explicit oral declaration for the making of a will under $\$ 2232$ BGB (Öffentliches Testament, Public will), which was eliminated in 2002.

1302 One example of preliminary contracts subject to form requirements are those in relation to termination agreements conerning employment contracts. In this sense, the BAG held in its decision of 17 December 2009 (fn 1142) para 25 that while $\$ 623$ BGB (Schriftform der Kündigung; Written form of termination) applied to the main termination contract only; ' $[\mathrm{h}]$ owever, it can not be inferred that a preliminary contract which requires the parties to conclude a termination agreement does not require the written form' ('Daraus kann aber nicht abgeleitet werden, dass ein Vorvertrag, der die Parteien zum Abschluss eines Aufhebungsvertrags verpflichtet, nicht der Schriftform bedarf'). The court explained that whether a preliminary agreement was governed by the same form requirements as the main contract depended on the function of the requirement. Where it was to caution ('Warnfunktion'), such as is the case with $\$ 623 \mathrm{BGB}$, the form requirements applied to both; whereas an evidentiary function ('Beweis- und Klarstellungsfunktion') did not necessitate such prerequisites to be fulfilled. See ibid. Cf Marius Mann, Commercial Contracts in Germany $(\mathrm{CH}$ Beck 2015) 22, stating that all kinds of agreements relating to real estate, including preliminary agreements, require a notarial recording, since $\mathbb{3} 311 \mathrm{~b}$ para 1 BGB fulfils a cautioning function. Similar: Georg Maier-Reimer, Die Form verbundener Verträge [The Form of Connected Contracts] (2004) NJW 3741. The different functions will be discussed in more detail subsequently.

1303 This has been argued by, eg, Plewe (fn 1015) 7, 30-32. Although this seems to contradict $\$ 167$ para 2 BGB (Erteilung der Vollmacht; Conferment of authority), under which no form is applicable to power of attorneys, this view can be supported by German case law, such as the BGH decision of 29 February 1996, IX ZR 153/95, BGHZ 132, 119-132, in which it was held that a power of attorney to modify a guarantee required a written form in accordance with $\$ 766 \mathrm{BGB}$, see paras 6-19 of the decision. The court also noted that powers of attorney in relation to real estate transactions that were governed by $₫ 313 \mathrm{BGB}$ (as it was then; now $\$ 311 \mathrm{~b}$ para $1 \mathrm{BGB}$ ) required a notarial authentication, see para 11 of the decision. This case is considered further in Sections iii. and iv. below. cf Mertens (fn 1300) 434-435, who is critical of the court's reasoning and advocates a focus on the internal relationship (Innenverbältnis) between the giver and receiver of the power of attorney. Accordingly, he would make 


\section{B. Comparative Background}

such as LOI are not governed by form requirements. ${ }^{1304}$ Unless stipulated otherwise, the rules on these forms will also apply to a mutually agreed form $(\mathbb{S} 127$ para $1 \mathrm{BGB})$, although in such a case the requirements may be less stringent, as discussed for each form in the subsequent sections. It goes without saying, however, that mandatory requirements cannot be circumvented by the parties stipulating otherwise. ${ }^{1305}$ Apart from prescriptions of a particular form, it ought to be remembered that the abstraction principle of German law demands more than a consensual agreement in order to deem a transfer of ownership to be legally effected. These requirements are set out in Section c. below, together with another act that relates to the conclusion of contracts: Draufgabe (earnest). The consequences of not fulfilling the requirements, as well as ways to heal the imperfection, will be set out in Section vi. Before going into these matters, the functions of the different form requirements will be considered briefly. ${ }^{1306}$

The broad function of the formality provisions is to allow the law to recognise a contract or other legal act to be legally effective. ${ }^{1307}$ As such, one function of a form can thus be said to be one of clarification (Klarstellung), which permits the differentiation between these binding and other non-binding acts such as contract negotiations. ${ }^{1308}$ Several other functions exist besides, namely: as proof, foremost of the agreement, but also sometimes of the identity of the parties; for information about or disclosure

those appointments subject to form in which the principal leaves the decision on the legal transaction to the agent, ie, gives up control, see Mertens (fn 1300) 435. For a concise overview of the discussion in academic literature and in case law, see Plewe, ibid 25-30. The issue of the scope of form requirements will be considered once more in Section vi.cc) below.

1304 See Wolf and Neuner (fn 48) 512 para 22. Arguably, the parties may nevertheless subject such documents to a form by agreement.

1305 See, eg, BGH decision of 7 June 1995 (fn 1196) para 9 (notarial deed). See also Köbl (fn 1294) 209.

1306 For a detailed discussion of the different functions, see, eg, Plewe (fn 1015) 7-18, or Hertel, ' $\$ 125 B G B$ ' (fn 1294) paras 34-53.

1307 Wolf and Neuner (fn 48) 97 para 24. cf Plewe (fn 1015) 5, who states one function as 'the recognisability of the legal transaction for third parties' ('die Erkennbarkeit des Rechtsgeschäfts für Dritte').

1308 See Hertel, ' $\$ 125 B G B$ ' (fn 1294) para 42. Interestingly, the author goes on to note that a handshake (Handschlag) is an act used like a kind of form in that it signalises that an (informal) agreement has been reached. In contrast, with formal agreements that are put into writing, the signature marks the concluded contract. 
(Publizität) of the transaction; as a caution to prevent hasty actions; ${ }^{1309}$ to ensure instruction and counselling of the parties; or for control through public authorities. ${ }^{1310}$ Another important role is the protection of the contracting or third parties, as well as of the general public. ${ }^{1311}$ Particularly this last function explains why, under certain circumstances, not all but only one party's declaration of intention necessitates a particular form, as is the case for $₫ 518$ para 1 (Schenkungsversprechen; Promise of donation) or $\$ 766$ para 1 (Bürgschaftserklärung; declaration of suretyship) BGB, discussed in Sections iii. and ii. below respectively. ${ }^{1312}$

It is noteworthy that the statutory forms usually relate to obligatory acts (Verpflichtungsgeschäfte) in order to ensure their purpose, which is particularly true for those requirements seeking to caution, like a declaration of suretyship; in contrast, requirements as to acts of disposition (Verfügungsgeschäfte), such as the Auflassung (Declaration of conveyance, $\mathbb{9} 925 \mathrm{BGB}$ ), normally ensure broader, public interests. ${ }^{1313}$

\section{i. Excursus: The Classification of Things in German Law}

The German legal system classifies Rechtsgegenstände or Rechtsobjekte (legal objects), which are made up of 'property protected by law' ('rechtlich geschützte $[s]$ Gut [...]'), 1314 in two steps. First, legal objects are divided into two orders. Herrschaftsobjekte (objects under control) are things over which

1309 During the drafting process of the BGB, it was stated that formalities raise the parties' 'legal awareness' ('juristisches Bewußtsein') and facilitate meditated rather than hasty decisions, see Mugdan (fn 883) Vol 1451.

1310 See Wolf and Neuner (fn 48) 509-511 paras 4 et seq for further details. See also Busche, 'Vor $\$ 145 B G B$ ' (fn 158) para 30; Mann (fn 1302) 22. A more precise differentiation between the above-named functions and a concise discussion of a range of fourteen (!) different functions can be found in Mankowski (fn 1296) 663-668.

1311 See Busche, 'Vor $\$ 145 B G B$ ' (fn 158) para 29. This function is sometimes said to relate to that of the cautioning function, see, eg, Köbl (fn 1294) 208. See further Köbl, ibid 226.

1312 See Wolf and Neuner (fn 48) 511 paras 18-19. Note that a contract to terminate (Aufhebungsvertrag) a guarantee or a promise for donation does not require any particular form, see ibid, 512 para 22.

1313 For further details on this, see Köbl (fn 1294) 210-212. See also Maier-Reimer (fn 1302) 3744.

1314 Malte Stieper, Vorbemerkungen $z u$ SS 90-103 [Preliminary Notes on Ss 90-103], in: von Staudinger and others (fn 140; 2017) para 7. 


\section{B. Comparative Background}

a right can subsist and make up the first order, whereas Verfügungsobjekte (objects of disposition) are the rights over Herrschaftsobjekte and form the second order. ${ }^{1315}$ There are, however, cases that overlap, such as Forderungen (claims), which can be both a right relating to a legal object or the subject of rights. ${ }^{1316}$

In a second step, the two categories are defined further. Accordingly, Verfügungsobjekte include not only rights, but also legal relationships (Rechtsverhältnisse), such as rights in rem and contractual relationships. ${ }^{1317}$ Herrschaftsobjekte include körperliche (corporeal) and unkörperliche (incorporeal) things. ${ }^{1318}$ Only the former category is regulated in $\$ 90$ et seq BGB. It encompasses objects that are tangible (greifbar) and 'space-filling' (raumfüllend), so that liquids and gases in containers or software on data mediums are included. ${ }^{1319}$ Having said this, not all corporeal things are automatically Sachen. Thus, $\$ 90$ a BGB explicitly excludes animals, although the provisions on things may be applied by analogy where appropriate. Accordingly, animals form a separate category of corporeal things. ${ }^{1320}$ Furthermore, anything that cannot be controlled by humans, such as clouds, stars, or running water, as well as things in which the general public interest is strong, such as religious objects, or administrative seals, cannot be things in the sense that private (exclusive) ownership may be established over them. ${ }^{1321}$

1315 See Wolf and Neuner (fn 48) 71 para 14, 279-280 paras 2-3.

1316 See further ibid 280 para 3.

1317 See ibid 279 para 2, 280-281 para 6.

1318 See Bork, 'Allgemeiner Teil' (fn 900) 100 para 228.

1319 Ibid 103 para 234, who notes at 100 para 228 that corporeal objects can be 'seen and touched' ('sehen und anfassen'). cf Stieper, 'Vor \$S 90-103 BGB' (fn 1314) para 9, stating that coporal things must be perceptible by human senses ('sinnliche Wabrnehmbarkeit') and enclosed ('Abgegrenztheit') in order to be capable of being controlled ('beherrschbar'). Note that academic opinion is divided on the question whether software by itself constitutes a thing. While both sides vary in their classification-method, they nevertheless agree that sales law (Kaufrecht) is applicable to software. For the purposes of this dissertation, this common point suffices. Readers interested in the discussion are referred to Wolf and Neuner, ibid, para 2 for further references on the two sides of the debate. A similar difficulty has arisen under English law; however, it seems that software alone does not constitute goods for the purpose of sales law, see Section II.3.b.i. above.

1320 Stieper, 'Vor $\int S 90-103 B G B$ ' (fn 1314) para 1. Critical of this new categorisation: Bork, 'Allgemeiner Teil' (fn 900) 103 para 235. Note that English law does not have a special rule for animals, see Section II.3.b.i. above.

1321 See Wolf and Neuner (fn 48) 285 paras 3-4. 
Albeit not being included in the BGB, German law recognises rights over certain incorporeal objects. One area of importance relates to intellectual property (Gewerblicher Rechtsschutz), the different forms of which are regulated in patent (Patent-), trademark (Marken-), and copyright law (Urheberrecht). ${ }^{1322}$ Another type of incorporeal object is a right relating to other rights, such as pledges (Pfand) or beneficial interests (Nießbrauch; usufruct). ${ }^{1323}$ The third category of incorporeal objects consists of parts depicting one's personality, such as one's name, or a photograph. ${ }^{1324}$

Of particular interest to the discussion in this dissertation is the implicit differentiation in provisions of the BGB between movable (bewegliche) and immovable (unbewegliche) things. This conceptual differentiation is reflected in the structure of the BGB, which has both general and specific rules for each category. The property law of the former is called Mobiliarsachenrecht (law of movable property) and that of the latter is Immobiliarsachenrecht (law of immovable property). ${ }^{1325}$ Both of these categories have further subdivisions that need to be considered.

When referring to immovable property, the BGB uses the term Grundstück (plot of land) and sometimes Gebäude (building), although these are seen as a part of land ( $\$ 94$ para 1 BGB). ${ }^{1326}$ The reason is that immovable property is any thing that cannot change its physical situs (räumliche Belegenheit), ${ }^{1327}$ so that 'things firmly attached to the land' form an essential part of it ( $\$ 94$ para $1 \mathrm{BGB}) .{ }^{1328} \mathrm{~A}$ similar provision for buildings is found in $\$ 94$ para $2 \mathrm{BGB}$, according to which materials used for its construction become an essential part of that building. In more general terms, things that cannot be detached from another thing without being damaged, ie, without being changed in their nature ${ }^{1329}$, or even destroyed, are deemed

1322 While it goes beyond the scope of this dissertation to treat this fascinating subject in detail, it can be stated in summary that this area of law concerns products of intellectual processes, such as inventions or artistic creations and designs. For a concise overview, see, eg, ibid 296-297 paras 1 et seq.

1323 See on this ibid 297 para 11.

1324 For further information on this category, see ibid 297 para 10.

1325 See Gaier (fn 1068) para 2. As noted in Section II.3.b.i. above, English law makes a different distinction, namely, between land and personalty (chattels).

1326 For further details on this, see Malte Stieper, $\mathbb{S} 94$ [Section 94], in: von Staudinger and others (fn 140; 2017) para 10.

1327 Compare Bork, 'Allgemeiner Teil' (fn 900) 105 para 241.

1328 By the same token, $\mathbb{\$} 96 \mathrm{BGB}$ provides that rights relating to land are deemed to form a part of it.

1329 The BGH has held that the question of whether a thing is changed in its nature depends on whether the separated parts can be used in the same man- 


\section{B. Comparative Background}

to be an 'essential part' of another thing ( $\left.\int 93 \mathrm{BGB}\right)$. This is also true for plants, whether grown naturally or cultivated, which become part of the land as soon as the seed or plant is planted ( $\$ 94$ para $1 \mathrm{BGB}) .{ }^{1330}$

Having said this, not all things which are attached to one thing form part of it. This is particularly true in relation to immovable property and objects that are attached 'only for a temporary purpose' ('nur zu einem vorübergehenden Zweck', $\$ 95$ BGB). This principally depends on the intention of the person in the moment of attaching the object. ${ }^{1331}$ An example is a tree that has been planted only temporarily. ${ }^{1332}$ Another example is a fitted kitchen (Einbauküche), which is sometimes seen as a component, sometimes merely as an accessory (Zubehör) of a building. ${ }^{1333}$

In this sense, Sachbestandteile (components of things) ${ }^{1334}$ as just discussed must be contrasted with mere Zubehör (accessories, \$\$ 97-98 BGB). This is important for the former category of Sachebstandteile, because all things are legally treated as one, so that any legal act or change of circumstance affecting one will affect all parts. In contrast, the same consequence

ner after having been separated, see BGH decision of 27 June 1973, VIII ZR 201/72, BGHZ 61, 80, para 9. Where this is not possible, the unusable parts lose in value, ibid para 12 . The things in question were a car and a motor, which had been inserted into the car. The court found that a motor could be used in other cars of the same type as well as on its own as a standalone motor, so that it was not a component (Bestandteil) of a car, see ibid paras 9, 11. Furthermore, the two things were easily separable without being damaged and without great effort (ibid para 13), which seems to favour the view of the two things being separate. In consequence, it seems that a motor and a car merely form a Sachgesamtheit (collective of things).

1330 For further discussion, see Stieper, ' $\int 94 B G B$ ' (fn 1326) paras 17-18.

1331 See on this further Wolf and Neuner (fn 48) 292-293 paras 33-34.

1332 Bork, 'Allgemeiner Teil' (fn 900) 109 para 249.

1333 See BGH decision of 1 February 1990, IX ZR 110/89, WM 1990, 603, which includes references to academic literature and court decisions on both sides in para 7. The court held in this case that the kitchen was an accessory (paras 13-14, 19); it could not be seen as forming a part of the land, since it could be separated without damage and used in another kitchen (paras 11-12).

1334 This general term has two subdivisions: there may be wesentliche (essential) or unwesentliche (non-essential) Bestandteile. This differentiation is important in considering whether the component in question can be subject to a special right (Sonderrecht), such as an Eigentumsvorbehalt (retention of title, $\mathbb{S} 449$ BGB). This aspect will not be discussed further in this dissertation. Instead, see Wolf and Neuner (fn 48) 289-291 paras 21 et seq. Further details on essential parts of buildings and land can be found in ibid 291-292 paras 28 et seq. 
is not automatically applied to the latter. ${ }^{1335}$ Having said this, there is a presumption that an obligatory transaction over the main object covers any accessories ( $\$ 311 \mathrm{c} \mathrm{BGB})$, and, similarly, accessories to land are included in any acts of disposition over the land ( $\$ 926$ para $1 \mathrm{ibid})$ whenever doubt over whether an agreement was made exists. Things will be considered to be an accessory where the things are only put together with other things for a single purpose, namely, in order for the accessory to serve the main object. ${ }^{1336}$

The distinction among movable objects is more straightforward. They are simply divided into fungible things (vertretbar, $\mathbb{\$} 91 \mathrm{BGB}$ ) as 'movable things that in business dealings are customarily specified by number, measure or weight' on the one hand and consumable things (verbrauchbar, $\$ 92$ BGB) as 'movable things whose intended use consists in consumption or in disposal' on the other. ${ }^{1337}$

\section{ii. Written Forms: Schriftform and Textform}

German private law originally only knew one standard written form, namely, $\mathbb{S} 126$ BGB; however, since 2001 , a simpler form called 'text form' (Textform) is found in $\$ 126 \mathrm{~b}$ BGB. ${ }^{1338}$ The differences of the requirements are best brought to light through a juxtaposition of the two provisions. Section 126 BGB (Schriftform; Written form) requires:

(1) If written form is prescribed by statute, the document must be signed by the issuer with his name in his own hand, or by his notarially certified initials.

1335 Compare Bork, 'Allgemeiner Teil' (fn 900) 107-108 para 246 (Sachbestandteile) and 111-112 paras 258-260 (Zubehör).

1336 Compare the phrasing of $\$ 97$ para 1 BGB. See further, Wolf and Neuner (fn 48) 294 para 37.

1337 The original $\$ 91$ BGB reads: 'bewegliche Sachen, die im Verkehr nach Zabl, Maß oder Gewicht bestimmt zu werden pflegen'; while $\$ 92$ states 'bewegliche Sachen, deren bestimmungsmäßiger Gebrauch in dem Verbrauch oder in der Veräußerung besteht'. For further details, see, eg, Bork, 'Allgemeiner Teil' (fn 900) 105-106 paras 242-243.

1338 The introduction of this form was already considered in Section b. above. It has not been changed since then, see Christian Hertel, $\mathbb{S} 126$ [Section 126], in: von Staudinger and others (fn 140; 2017) para 1. Plewe (fn 1015) is critical of this form, see 178-179, 182-184. 
(2) In the case of a contract, the signature of the parties must be made on the same document. If more than one counterpart of the contract is drawn up, it suffices if each party signs the document intended for the other party. ${ }^{1339}$

Two components are required: first, a written instrument called Urkunde; and, second, a hand-written or notarially-certified signature. As signatures are considered in Section iii. below, ${ }^{1340}$ only the meaning and requirements as to the document will be explored here. Before doing so, it ought to be noted that the other provision, $\$ 126 \mathrm{~b}$ BGB (Textform), stipulates:

If text form is prescribed by statute, a readable declaration, in which the person making the declaration is named, must be made on a durable medium. A durable medium is any medium that

1. enables the recipient to retain or store a declaration included on the medium that is addressed to him personally such that it is accessible to him for a period of time adequate to its purpose, and

2. allows the unchanged reproduction of such declaration. ${ }^{1341}$

Instead of a document, a 'readable declaration' ('lesbare Erklärung') containing the statement maker's name ${ }^{1342}$ made on a 'durable medium'

1339 The original provision states: '(1) Ist durch Gesetz schriftliche Form vorgeschrieben, so muss die Urkunde von dem Aussteller eigenhändig durch Namensunterschrift oder mittels notariell beglaubigten Handzeichens unterzeichnet werden.

(2) Bei einem Vertrag muss die Unterzeichnung der Parteien auf derselben Urkunde erfolgen. Werden über den Vertrag mehrere gleichlautende Urkunden aufgenommen, so genügt es, wenn jede Partei die für die andere Partei bestimmte Urkunde unterzeichnet.'

1340 Signatures certified by a notary are included in Section iii.

1341 The original provision reads: 'Ist durch Gesetz Textform vorgeschrieben, so muss eine lesbare Erklärung, in der die Person des Erklärenden genannt ist, auf einem dauerhaften Datenträger abgegeben werden. Ein dauerhafter Datenträger ist jedes Medium, das

1. es dem Empfänger ermöglicht, eine auf dem Datenträger befindliche, an ihn persönlich gerichtete Erklärung so aufzubewahren oder zu speichern, dass sie ihm während eines für ihren Zweck angemessenen Zeitraums zugänglich ist, und

2. geeignet ist, die Erklärung unverändert wiederzugeben.'

1342 'Name' does not necessarily mean a person's full name; just a first name or even a pseudonym is sufficient, as long as this identifies the declaring person to the addressee. It thus depends on the circumstances, see Deutscher Bundestag, Gesetzentwurf der Bundesregierung: Entwurf eines Gesetzes zur Anpassung der Formvorschriften des Privatrechts und anderer Vorschriften an den modernen Rechtsgeschäftsverkehr [Draft Law of the Government: Draft of a Law to Adapt the Form Requirements in Private Law and other Provisions to Modern Legal 
('dauerhafter Datenträger') is required here. ${ }^{1343}$ This form was apparently created to fill a gap: While there was a need to have some written and readable record of declarations, both legal and business practice required a less cumbersome, speedy method to the standard written form. ${ }^{1344}$ The text form can thus be seen as a compromise between a need for legal certainty and swift and simple procedures, ${ }^{1345}$ but which fulfils the function

Transactions] (Drucksache [printed matter] 14/4987, 14 December 2000; hereinafter 'FormAnpG Draft Law') 20. See also Dorothee Einsele, $\$ 126 b$ Textform [Section 126b Text Form], in: Säcker and others (fn 158) para 7. All first names are equal, so that any of several first names can be used on its own. See on this Dirk-Ulrich Otto, Grundstückskaufverträge [Contracts for the Sale of Land], in: Sebastian Herrler (ed), Münchener Vertragshandbuch Band 5: Bürgerliches Recht 1 [Munich Handbook on Contracts Vol 5: Civil Law 1] (Beck 2013) 9. Apparently, it is without consequence where the declaring party's name appears in the document: It can be contained in the header of the document, in the text, or as a(n inserted) signature, see Einsele, ibid. cf the situation with a signature, discussed in Section iv. below.

1343 of Plewe (fn 1015) 177, who states that a signature must be reproduced or otherwise denoted at the end of the declaration. Indeed, the FormAnpG foresaw such a phrase in art 3; however, it is no longer contained in the current version of the $\mathrm{BGB}$, as the provision was amended by art 1 para 3 Gesetz zur Umsetzung der Verbraucherrichtlinie und zur Änderung des Gesetzes zur Regelung der Wohnungsvermittlung [Law to Transpose the Consumer Regulation and to Regulate Accommodation Services] of 20 September 2013, BGB1 2013 I 3642. Einsele, ' $\mathbb{S} 126 b B G B$ ' (fn 1342) para 8 notes that this requirement, while no longer stated explicitly, is nevertheless still necessary to show that the declaration is complete and meant to be legally binding. She also argues that the German legislator stated that although the wording of the provision was altered, no changes in content were intended. While this may be true, it begs the question why the words were eliminated completely, rather than substituted, as had been done with the phrase 'auf andere zur dauerhaften Wiedergabe in Schriftzeichen geeignete Weise' (substituted by 'dauerhaften Datenträger'). The requirement is easily met, however, as stating the declaring person's name, $\mathrm{a}(\mathrm{n}$ inserted) signature, phrases such as 'Diese Erklärung ist nicht unterschrieben' ('this declaration is not signed'), or even just a greeting is sufficient, see Einsele, ibid para 8. Contrast Truiken J Heydn, Germany, in: Dennis Campbell (ed), E-commerce and the Law of Digital Signatures (Oceana Publications 2005) 221, 236, who states that a signature is not required under the text form.

1344 Compare Nissel (fn 1300).

1345 Compare ibid, who states that the text form was created for instances in which a signature was deemed 'dispensable' ('entbehrlich'). See also Einsele, ' $\mathbb{1} 126 b B G B$ ' (fn 1342) para 1. Plewe (fn 1015) 182-184 is critical of this form, deeming it more of a superfluous requirement, and not facilitating contracting as much as a simple de-regulation (elimination of form requirements) would have. 


\section{B. Comparative Background}

of ensuring documentation. ${ }^{1346}$ How documentation is achieved becomes apparent when considering the requirements in $\$ S 126,126 \mathrm{~b}$ BGB. These come down to two differences: whether a physical document containing the declaration is required (see Sections aa)-bb) below); and whether the written declaration must be signed (see Section iv. below).

\section{aa) The Requirements of the Urkunde}

The term Urkunde is not defined in the BGB, but has been described as 'eine schriftlich verkörperte Gedankenerklärung' ('a statement embodied in writing'), ${ }^{1347}$ namely, one document that must contain the whole legal transaction in question. ${ }^{1348}$ Furthermore, the document needs to be understandable generally, or at least to the persons privy to the document in question; it has to show the document's creator; and it must be intended as proof of a legally relevant fact. ${ }^{1349}$ There may be further requirements in specific cases, such as the parties to a contract of guarantee (Bürgschaftserklärung) and its object being stated in the document. ${ }^{1350}$

It is irrelevant if the document is drawn up by hand or using a machine, ${ }^{1351}$ such as a personal computer; ${ }^{1352}$ it may even be based on a standard form or model contract. ${ }^{1353}$ In line with this, the document need

1346 See on this Einsele, ‘ $\$ 126 b B G B$ ' (fn 1342) para 9.

1347 Wolf and Neuner (fn 48) 513 para 25. On German civil procedural law, see also Klaus Schreiber, $\mathbb{S} 415$ Beweiskraft öffentlicher Urkunden über Erklärungen [Section 415 Evidentiary value of public records and documents regarding declarations], in: Wolfgang Krüger and Thomas Rauscher (eds), Münchener Kommentar zur ZPO [Munich Commentary on the Code of Civil Procedure] Vol $2\left(^{\text {th }}\right.$ online edn, CH Beck 2016) para 5: 'die schriftliche Verkörperung einer Gedankenerklärung durch Lautzeichen' ('the embodiment of a statement in writing by phonograms').

1348 See Plewe (fn 1015) 43-44.

1349 Jörg Bettendorf, Elektronische Dokumente und Formqualität [Electronic Documents and Quality of Form] (2005) Rheinische Notar-Zeitschrift 227.

1350 Plewe (fn 1015) 44.

1351 The LG Dortmund stated as much in its decision of 21 April 2017, 10 O 12/17, para 38, although the statement related to provisions of the ZPO. Cf Schreiber, ' $\$ 415$ ZPO' (fn 1347) para 9, who states that printouts of digital documents will regularly meet the requirements of an Urkunde, as discussed below. cf Wolf and Neuner (fn 48) 513 para 25, who make a similar statement to that of the LG, but without reference to German procedural law.

1352 Hertel, ' $\$ 126$ BGB' (fn 1338) para 109.

1353 See ibid. 
not be drafted by the declaring person, but can be created by a third party. ${ }^{1354}$ While the creation process is thus not important, the material used for the document is at least not entirely irrelevant. This is because the product must be 'visually ascertainable' ('optisch erfassbar'). ${ }^{1355}$ In addition, it has to be suitable for recording the content, the written characters, permanently. ${ }^{1356}$ While these characteristics are fulfilled by paper, this is not true for computer screens. ${ }^{1357}$ As a consequence, not only paper but other writing materials are acceptable, while electronic recordings are not. ${ }^{1358}$ As for the writing itself, the document need not be in German; foreign languages are normally unproblematic. ${ }^{1359}$ In contrast, as it needs to be in writing (schriftlich), ie, written in alphabetic characters ${ }^{1360}$, it cannot

1354 See Plewe (fn 1015) 43. This is also true for German procedural law. See on this Klaus Schreiber, $\mathbb{S} 416$ Beweiskraft von Privaturkunden [Section 416 Evidentiary Value of Private Records and Documents], in: Krüger and Rauscher (fn 1347) para 5. As will be seen below, this is particularly important for notarial authentications.

1355 Bettendorf (fn 1349) 277.

1356 See Plewe (fn 1015) 43. cf Hertel, ' $\mathbb{S} 126$ BGB' (fn 1338) para 108, stating durability to be a general requirement of the written form. Note that 'permanent' is not equivalent to 'eternal'; it need not even be long-term, compare Einsele, ' $\mathbb{S} 126 b B G B$ ' (fn 1342) para 6. It nevertheless seems a little surprising that a testament made on a blackboard (Schiefertafel) has been deemed sufficient in the past, at least when made by a farmer. See RG decision of 15 February 1910, IV 241/09, Deutsche Juristen-Zeitung (DJZ) 1910, 594. Having said this, it is questionable whether this ruling would be applied to contracts, especially nowadays.

1357 See Wolf and Neuner (fn 48) 513 para 25. More will be said on electronic forms in Section v. below.

1358 Hertel, ' $\mathbb{S} 126 B G B$ ' (fn 1338) paras 110-111.

1359 LG Dortmund decision of 21 April 2017 (fn 1351) para 41. The caveat seems to be that the language needs to be generally known ('bekannt'), see Plewe (fn 1015), which suggests that it has to be a real as opposed to an individually created language. Thus, Hertel, ' $\mathbb{S} 126$ BGB' (fn 1338) para 108 states that a secret code, which is not known by third parties, is not admissible. On this, see further Schreiber, ' $\mathbb{S} 415$ ZPO' (fn 1347) para 5, who states that the language at least needs to be accessible to experts or translators. Consequently, secret languages are not admissible, see Schreiber, ibid. If the Urkunde is recorded by a Notar (notary public), the language must be known to the notary ( $\$ 5$ para 2 Beurkundungsgesetz, Notarial Authentication Law of 28 August 1969, BGBl 1969 I 1513, hereinafter 'BeurkG').

1360 In line with what was said about the document's language, characters from other writing systems ought to be acceptable, like kanji. See Hertel, ' 126 $B G B^{\prime}$ ' (fn 1338) para 108, who names Chinese and Arabic characters. Compare 


\section{B. Comparative Background}

be recorded as sounds; nor as pictures or drawings. ${ }^{1361}$ As concerns the language, the choice is thus not important, as long as it is one that is generally comprehensible to third parties, so that, eg, secret codes would not be allowed. ${ }^{1362}$

As a consequence of the requirement that the document be one whole unit, an exchange of declarations is not sufficient for the statutorily-required written form. ${ }^{1363}$ This is in line with the wording of $\$ 126$ para 2 BGB, which suggests that there may be just one document, or several duplicates of an identical document, but does not state that separate declarations of intention are sufficient. ${ }^{1364}$ Connected to this, the issue may arise as to what constitutes a unit (Einheit) in a document. Formerly, it was necessary to physically connect all parts of a document or several documents, by stapling them together or by some other means so as to make a separation without damaging the document impossible. The BGH eased this requirement around 20 years ago, so that indicators such as consecutive numbering of pages or paragraphs, or text continuing over two pages, are deemed sufficient. ${ }^{1365}$ It seems that the mechanism used must - as had previously been required for the physical connection impede subsequent manipulation. ${ }^{1366}$ For there to be a unit consisting of several documents, like a contract and appendices, there needs to be a

further Wolf and Neuner (fn 48) 513 para 25, according to whom numbers, or even the dots used in sign language are adequate.

1361 Schreiber, ' $\$ 415$ ZPO' (fn 1347) paras 5-6.

1362 See Hertel, ‘ $\$ 126 B G B$ ' (fn 1338) para 108. See also fn 1359 above.

1363 See, eg, BGH decision of 18 October 2001 (fn 1131) para 19, in which the court went on to state that such an exchange would be sufficient for a written form agreed on by the parties.

1364 One exception is found in $\$ 492$ para 1 BGB, regulating the form of consumer credit agreements (Verbraucherdarlehensverträge) and providing that ' $\mathrm{t}] \mathrm{he}$ requirement of written form is satisfied if the offer and acceptance by the parties to the contract are declared in writing in separate documents' ('Der Schriftform ist genügt, wenn Antrag und Annahme durch die Vertragsparteien jeweils getrennt schriftlich erklärt werden').

1365 Compare BGH decision of 18 December 2002, XII ZR 253/01, NJW 2003, 1248-1249 paras 13 and 15, giving further references. For further discussion of this change, see Plewe (fn 1015) 44-47.

1366 Compare Wolf and Neuner (fn 48) 513 para 26, who suggests that signing each page will aid in this endeavour. See also Carolina M Laborde, Electronic Signatures in International Contracts (Peter Lang 2010) 23, making a similar statement also with respect to writing one's initials on each page or next to subsequent changes. Contrast Plewe (fn 1015) 43, who is generally critical of $\$ 126 \mathrm{BGB}$ protecting against forgeries. 
reference in the main document to the appendices, and each annex must be signed by the parties. ${ }^{1367}$

At least for the purpose of German procedural law, the instrument must be verkehrsfähig (negotiable), which implies that its content must be accessible directly at all times. ${ }^{1368}$ Anticipating the discussion in Section v. below, a consequence is that electronic mediums such as USB-sticks or other mobile data carriers, as well as audio- or video tapes in themselves cannot be an instrument in the sense of an Urkunde, as technical equipment is necessary for accessing the data contained on these mediums. ${ }^{1369}$ While this is true, a tangible copy of the data, like a printout, can be seen as a written instrument if the printed declaration is meant to replace the

1367 See BGH decision of 18 December 2002 (fn 1365) para 13, stating further that the lack of a reference in the annex to the main document is not detrimental. cf BGH decision of 27 September 2017 (fn 1157): While the court held at paras 17-18 that a 'gedankliche Verbindung' (literally 'mental connection', association) is sufficient and that it was not necessary that a subsequent reference to any appendices (Anlagen) be added to the original contract document, it did state that an annex must refer to the original agreement with sufficient clarity ('muss [...] binreichend deutlich auf den ursprünglichen Vertrag hinweisen'). The case concerned a commercial lease made in written form, whereby some essential terms had been amended subsequently in separate documents. The last of these, namely, an amendment of the price, was found not to fulfil the written requirement. This was because it consisted of a letter by the claimant, expressing the wish to amend the price index, to which the defendant responded by modifying the proposed term through a hand-written note and signing the letter before returning it. While it might be thought that this one-sided modification by the defendant would render the amended term ineffective, the court held instead at para 22 that the written form was not fulfilled because the letter did not refer to the original contract. As a consequence of the essential term regarding the price being void, the whole contract became ineffective, see ibid paras 22, 15.

1368 Schreiber, ' $\$ 415$ ZPO' (fn 1347) para 7. See also Bettendorf (fn 1349) 277. cf Wolf and Neuner (fn 48) 513 para 25, who state that the declaration 'must be directly accessible to human senses' ('muss der menschlichen Wabrnehmung unmittelbar zugänglich sein').

1369 In terms of proof, they may still count as Augenscheinsobjekte (objects of visual inspection) and be deemd as evidence taken by visual inspection under $\mathbb{\$} \$ 371$, 371a ZPO, see Schreiber, '\$ 415 ZPO' (fn 1347) paras 6-7. He points out further that written documents are more trustworthy as they can be manipulated less easily, which is their advantage over electronic mediums in particular, see ibid 7. 


\section{B. Comparative Background}

digital version. ${ }^{1370}$ It seems from this that it is not the creation process, but the end product as it were, that matters for the form. Thus, a digitally-created document that is printed and executed in print ought to fulfil the requirement of writing. ${ }^{1371}$ Note that Urkunden can be private or public in nature, which will have an effect on its evidentiary weight or authenticity in German civil procedure. ${ }^{1372}$

\section{bb) The Requirement of the lesbare Erklärung auf einem dauerhaften Datenträger}

Like the content of an Urkunde, the content of the text form must be 'readable' ('lesbar'; see $\$ 126 \mathrm{~b}$ BGB). It ought to be noted that this requirement concerns the message as received by the addressee. ${ }^{1373}$ This has several implications. First, that the declaration or information must reach the addressee, ie, at least enter their sphere of influence (Machtbereich),

1370 This regularly seems to be the case, unless the printout is made for mere information purposes only; in contrast, where the copy is of a paper document, the case is not as clear-cut. See on this ibid paras 9, 8 .

1371 cf the instance in which a document is created by a device autonomously by processing data and is printed out subsequently. See on this ibid para 9, who denies these documents the quality of being 'written'.

1372 A public record (offentliche Urkunde) is one that is drawn up by a public authority ( $\$ 415$ para $1 \mathrm{ZPO}$ ), whereas a private record (private Urkunde) is any record 'that does not count as a public one', see ibid para 3. For further details, see ibid paras 4 et seq. On public records, see Schreiber, ibid paras 1 et seq. It is noteworthy that the requirements of a public record are only met where the stipulated form is realised, see ibid, para 21. Private documents cannot be turned into public records as such. Even a Beglaubigung (certification) by, eg, a notary will not achieve this; however, the attestation clause (Beglaubigungsvermerk) on the document is deemed public, see ibid, para 22.

1373 See Einsele, ' $\$ 126 b B G B$ ' (fn 1342) paras 4, 11, who notes that the required conditions need to be met when the declaration is made and when it is received. See also BGH decision of 10 July 2013, IV ZR 224/12, BGHZ 198, 32 paras 17 et seq, in which the court found that while the making of a declaration may be subject to a form, delivery of the same is not. In that case, this was held for $\$ 2281$ BGB (Anfechtung durch den Erblasser; Avoidance by the testator); however, the same was said to be true for $\$ 766$ BGB (Schriftform der Bürgschaftserklärung; Written form of the declaration of suretyship). See also FormAnpG Draft Law (fn 1342) 19, 20. 
whereby the risk of the message being lost is on the declaration maker. ${ }^{1374}$ Secondly, as a consequence of the required 'readability' of the declaration, a message in, say, audio form is not sufficient, as there is no visible (readable) text that reaches the addressee. ${ }^{1375}$ Thirdly, displaying a text on a website is equally insufficient, ${ }^{1376}$ unless its content can be downloaded and printed and if no consumers are involved. ${ }^{1377}$ For similar reasons, displaying information as videotext on a television device, eg, in teleshopping, is not sufficient. ${ }^{1378}$ The reason is that such texts, whether on a computer monitor or on a television screen, although visible in writing as such, cannot be saved or retained as required by $\$ 126 \mathrm{~b}$ no 1 BGB. ${ }^{1379}$ It also follows from this that the declaration can be contained in a paper document under the text form as well, despite being a variation of the standard written form. ${ }^{1380}$

In parallel to the electronic form, discussed in Section v. below, a text form can also be an electronic document. ${ }^{1381}$ Furthermore, it can be transmitted as an e-mail ${ }^{1382}$ or fax, ${ }^{1383}$ or by being saved on a portable device such as a CD-ROM; ${ }^{1384}$ also on a DVD, USB-stick, or other storage

1374 Compare Einsele, ' $\$ 126 b B G B$ ' (fn 1342) para 11. On these issues, see also the discussion of declarations of offer reaching their recipient in Section a.ii.dd) above.

1375 See Einsele, ' $\$ 126 b$ BGB' (fn 1342) para 4.

1376 See Wolf and Neuner (fn 48) 518 para 44.

1377 Einsele, ' $\mathbb{S} 126 b B G B$ ' (fn 1342) paras 6,11 . The possibility alone is often sufficient; it need not actually be done, see Wolf and Neuner (fn 48) 518 para 44 and Einsele, ibid 6. See also FormAnpG Draft Law (fn 1342) 19, 20.

1378 See Einsele, ' $\mathbb{S} 126 b$ BGB' (fn 1342) para 11.

1379 Compare ibid para 4. Note that what was said for the Urkunde above on the fixation being permanent is also true for the text form, see ibid para 6. Thus, the information must be stored for an 'appropriate' length of time, ibid para 11.

1380 See ibid para 4.

1381 See Nissel (fn 1300).

1382 Einsele, ' $\mathbb{S} 126 b B G B$ ' (fn 1342) paras 6, 11. It ought to be noted, however, that where the declaration is sent to a non-existing e-mail address, the requirement is not fulfilled, ibid para 12 .

1383 As to a copy of a contract document sent via fax not being sufficient for $\$ 126$ BGB, see, eg, BGH decision of 7 March 2018 (fn 906) para 18. Note that other requirements of a written form, eg, $\$ 550$ BGB (Form des Mietvertrags; Form of the lease agreement), may not be as strict, so that in such cases a copy sent via fax, or arguably also by other means, is sufficient. See on the case of $\$ 550$ BGB, ibid, paras 19 et seq.

1384 See Mann (fn 1302) 22. 


\section{B. Comparative Background}

device. ${ }^{1385}$ In this sense, the words 'dauerhafter Datenträger' convey the meaning that an oral declaration is insufficient, but that the declaration needs to be fixed in some reproducible format. ${ }^{1386}$

Similar to $\$ 126 \mathrm{~b}, \mathbb{} 127$ para 2 BGB provides:

For compliance with the written form required by legal transaction, unless a different intention is to be assumed, it suffices if the message is transmitted by way of telecommunications and, in the case of a contract, by the exchange of letters. [... $]^{1387}$

Accordingly, a declaration of intention made in written form as stipulated by the contracting parties satisfies this form even if transmitted using, eg, e-mail or (e-)fax, ${ }^{1388}$ as long as the requirements for the text form contained in $\$ 126 \mathrm{~b}$ BGB have been met. ${ }^{1389}$ In contrast, a statutorily-prescribed written form or a contract will not be sufficient if the declaration is made by this method. ${ }^{1390}$ Instead, the former will be governed by $\$ 126$ $\mathrm{BGB}$, meaning that all declarations of intention, especially offer and acceptance, must be made in writing and reach the other party in that form, ${ }^{1391}$ whereas the latter must be made by 'exchange of letters' ('Briefwechsel',

1385 See Einsele, ' $\$ 126 b B G B$ ' (fn 1342) para 6.

1386 Compare the general explanations given by Nissel (fn 1300) on the former requirement being made 'auf andere zur dauerhaften Wiedergabe in Schriftzeichen geeignete Weise' (art 1 para 3 FormAnpG; 'by other means capable of being perpetually reproduced in written characters').

1387 The original provision states: 'Zur Wahrung der durch Rechtsgeschäft bestimmten schriftlichen Form genügt, soweit nicht ein anderer Wille anzunehmen ist, die telekommunikative Übermittlung und bei einem Vertrag der Briefwechsel. [...]'

1388 The German legislator in fact stated that 'all kinds of telecommunication using telecommunication devices' ('alle Arten der Telekommunikation mittels Telekommunikationsanlagen') were sufficient, see FormAnpG Draft Law (fn 1342) 2021 , and went on to enumerate examples, including those given above.

1389 Wolf and Neuner (fn 48) 525 para 87.

1390 On sending a declaration as a telegram, see BGH decision of 27 May 1957 (fn 1200) 884-885. The case concerned a declaration of suretyship, but the written requirement of $\mathbb{1} 126 \mathrm{BGB}$ was also discussed. Interestingly, the court noted at 884 that the drafters of the BGB had considered allowing transmissions as telegrams, or even of not having a written form for sureties, but eventually decided against both.

1391 See, eg, BGH decision of 7 March 2018 (fn 906) para 17: 'Ein Vertrag, für den die gesetzliche Schriftform vorgeschrieben ist, kommt grundsätzlich nur dann rechtswirksam zustande, wenn sowohl der Antrag als auch die Annahme ( $\$ S 145 \mathrm{ff}$. $B G B)$ in der Form des $\$ 126$ BGB erklärt werden und in dieser Form dem anderen Vertragspartner zugehen' ('A contract that is governed by the statutory written form will, as a general rule, arise only if both the offer and the acceptance 
$\$ 127$ para 2 BGB). In instances of letters, the exchanged documents need not be exactly identical in content. ${ }^{1392}$

\section{cc) Instances of Written or Text Form}

Instances of the text form being required are limited. In contrast, the written form is encountered more often in German legislation. Examples of the text form are found in relation to changes in tenancy agreements under the BGB, or for notifications of dangerous goods under the HGB. ${ }^{1393}$ As a consequence, this form will regularly not normally apply to the formation of a contract, unless the parties choose this form in accordance with $₫ 127$ BGB. ${ }^{1394}$ By way of exception, there is an obligation to document contracts and notify consumers in text form in three cases under the BGB: in contracts for delivery by instalments (Ratenlieferungsverträge; $\$ 510$ para $1 \mathrm{BGB}$ ); in credit intermediation contracts (Darlehensvermittlungsvertrag; $\$ 655 \mathrm{~b}$ para $1 \mathrm{BGB}$ ); and in consumer construction contracts (Verbraucherbauvertrag; $\$ 650$ i para 2 BGB). ${ }^{1395}$

Prominent examples of the standard written form are a declaration of suretyship (Bürgschaftserklärung), a promise to fulfil an obligation (Schuldversprechen) or an acknowledgement of a debt (Schuldanerkenntnis). Here, one has to differentiate whether the declaration is made by a merchant or by a private person. This is important, because only the BGB (in $\mathbb{S} \mathbb{S} 766,780$ and 781 respectively) foresees that declarations to such effect must be declared in writing; in contrast, $\$ 350$ HGB explicitly provides that

$(\mathbb{S} \$ 145$ et seq $\mathrm{BGB})$ are declared in the form under $\$ 126 \mathrm{BGB}$ and reach the other contracting party in this form').

1392 On this, see, eg, Hertel, ' $\mathbb{S} 126 B G B$ ' (fn 1338) para 15.

1393 A list of the provisions can be found in Nissel (fn 1300), and in Einsele, ‘ $\mathbb{S} 126 b$ $B G B^{\prime}$ (fn 1342) para 2.

1394 Compare Einsele, ' $\mathbb{1} 126 b B G B$ ' (fn 1342) para 9, who considers the text form not be part of declarations of intention, but about fulfilling obligations.

1395 There may be other information duties for a merchant who deals with a consumer, such as under $\$ 482$ para 1 BGB (Vorvertragliche Informationen $[\ldots]$; Preliminary contract information [...]), which may be fulfilled by providing the information in text form. Pre-contractual information duties (Aufklärungspflichten) exist beside this form requirement. See on this Martin Franzen, Vorbemerkung (Vor $\$ 481$ ) [Foreword (to S 481)], in: Säcker and others (fn 158) Vol 3 ( $7^{\text {th }}$ online edn, CH Beck 2016) para 3, and ibid, $\mathbb{S} 482$ [Section 482], in: ibid paras 1,5 . 


\section{B. Comparative Background}

the provisions of the BGB on the form of these three kinds of declarations are not applicable where a legal transaction is commercial. ${ }^{1396}$

Another example of relevance to this dissertation is contained in $\$ 484$ BGB and applies to the conclusion of three different B2C contracts: First, to Teilzeit-Wohnrechteverträge (time-share agreements), contracts under which an entrepreneur promises to or actually procures a right for the consumer to use a building 'several times for a period that is specified or to be specified, for the purposes of overnight stays, for the duration of more than one year' ( $\$ 481$ para $1 \mathrm{BGB}) .{ }^{1397}$ Secondly, Verträge über langfristige Urlaubsprodukte (contracts relating to long-term holiday products) for a period of over one year, under which an entrepreneur promises to procure or actually procures the right 'to receive price reductions or other benefits with regard to accommodation' for a consumer, are regulated in $\$ 481 \mathrm{a}$ BGB. Thirdly, contracts covered by $\$ \$ 481-481$ a BGB that are brokered by an entrepreneur, called Vermittlungsverträge und Tauschsystemverträge (brokerage contracts and exchange system contracts), are regulated in $\$ 481 \mathrm{~b}$ BGB. All three kinds of contract have a B2C constellation and a minimum period of over one year in common. Furthermore, they must all be made in writing, unless stricter provisions apply ( $\$ 484$ para $1 \mathrm{BGB}$ ). ${ }^{1398}$

Apart from such explicit regulation, the written form may appear as an implicit requirement. Thus, while not required directly under $₫ 550$ BGB (Form des Mietvertrags; Form of the lease agreement), the provision foresees that "[i]f a lease agreement for a longer period of time than one year is

1396 See the provision's wording, which says: 'Auf eine Bürgschaft, ein Schuldversprechen oder ein Schuldanerkenntnis finden, sofern die Bürgschaft auf der Seite des Bürgen, das Versprechen oder das Anerkenntnis auf der Seite des Schuldners ein Handelsgeschäft ist, die Formvorschriften des $\$ 766$ Satz 1 und 2, des $\$ 780$ und des $\mathbb{S} 781$ Satz 1 und 2 des Bürgerlichen Gesetzbuchs keine Anwendung.' Rittler (fn 132) 273 translates this as follows: 'The formal requirements of $\$ 766$ sentence 1 and 2 of the Civil Code do not apply to a suretyship, an admission of liability or a debt acknowledgement to the extent that a suretyship on the part of the surety, or an admission of liability or debt acknowledgement, on the part of the debtor, is a commercial transaction.' It has been stated that this deviation from the general (BGB) rule is made as merchants are deemed not to require protection (from making hasty decisions), see Köbl (fn 1294) 208. On suretyship, see also, eg, BGH decision of 27 May 1957 (fn 1200) 884-885. It ought to be noted that revocations of a declaration of suretyship are not governed by the provision, see Wolf and Neuner (fn 48) 512 para 22.

1397 The original provision states: 'für die Dauer von mehr als einem Jahr ein Wohngebäude mehrfach für einen bestimmten oder zu bestimmenden Zeitraum zu Übernachtungszwecken zu nutzen'.

1398 On pre-contractual information duties, see fn 1395 above. 
not entered into in written form, then it applies for an indefinite period of time'. ${ }^{1399}$ In this way, the stipulated consequence makes the written form applicable tacitly. ${ }^{1400}$

iii. Special Forms Involving Public Authorities: Öffentliche Beglaubigung (Official Certification) and Notarielle Beurkundung (Notarial Authentication)

Under German law, public authorities and in particular a Notar (notary public) may be involved in the contracting process. For the latter, this occurs mainly in two instances: either where a person's declaration is authenticated, or where a person's signature is certified in accordance with $\$ 128$ and $\mathbb{1} 129$ BGB respectively. As a variation of the latter, a notary may also certify a person's mark (Handzeichen, see $\$ 126$ para 1 BGB). These forms will be considered in reverse order. Before turning to this, a brief excursus will be made on the use of seals by public authorities.

\section{aa) Excursus: Seals of Public Authorities}

German public authorities wield seals even today. ${ }^{1401}$ Thus, the HGB refers to a Dienstsiegel (official seal), which is furnished by the German Ministry of Justice (BMJV) and bestowed on the legal person to whom the task of maintaining the Unternehmensregister (Business Register, $\mathbb{} \$ 8 \mathrm{~b} \mathrm{HGB}$ ) is transferred in accordance with $\$ 9$ a para 1 HGB (Übertragung der Fübrung des Unternehmensregisters; Verordnungsermächtigung; Transfer of Operation of the Business Register; Authorisation to Issue Ordinances). ${ }^{1402}$ This kind

1399 The original provision reads: 'Wird der Mietvertrag für längere Zeit als ein Jahr nicht in schriftlicher Form geschlossen, so gilt er für unbestimmte Zeit.'

1400 Hertel, ' $\mathbb{S} 126 B G B$ ' (fn 1338) para 4. Note that the provision applies to leases of land, both in the form of a Miete and those in the form of a Pacht, see $\$ \$ 578$ para 1 and 581 para 2 BGB respectively.

1401 On the use of seals by private persons, see Section iv. below. The historical development of these uses will be explored in Section D.III.2.b. below.

1402 For further information on this register, see, eg, Alexander Krafka, $\mathbb{S} 8 b U n$ ternehmensregister [Section 8b Business Register], in: Schmidt K (fn 931). For further discussion of the transfer of the task of maintaining the same, see, eg, ibid, ' $\$ 9$ Übertragung der Führung des Unternehmensregisters; Verordnungsermächtigung' [Section 9 Transfer of Operation of the Business Register; Authorisation to Issue Ordinances] in ibid. 
of seal is used by the legal person in charge only for 'certification of print outs from the Business Register' ('Beglaubigungen von Ausdrucken aus dem Unternehmensregister'). ${ }^{1403}$

\section{bb) Unterschrifts- and Handzeichensbeglaubigung (Certification of Signatures and Marks)}

One way in which a notary participates in the contracting process is where need exists for either a notarially-certified mark (notariell Beglaubigtes Handzeichen) in lieu of a hand-written signature under $\$ 126$ para $1 \mathrm{BGB}$, or for a certification of the person's signature or mark in a offentliche Beglaubigung (official certification) as required by $\$ 129$ para 1 BGB. ${ }^{1404}$ Despite the latter provision's title, the certification of the signature is done by a notary (see $\$ 129$ para 1 BGB in connection with $\$ 20$ para 1 Bundesnotarordnung ${ }^{1405}$, hereinafter 'BNotO'). It ought to be noted that while $\mathbb{} \$ 26$ BGB does not explicitly state so, it is accepted that a notarially-certified signature may replace a hand-written one, which is due to the principle that a certification by a notary is seen as a higher form than a standard signature. ${ }^{1406}$

In attesting that a particular person made the signature in a document, the notary certifies the signature, whereby the certification in turn needs to bear the notary's seal and signature. These two elements are the necessary constituents of a certification. ${ }^{1407}$ In accordance with $\$ \$ 39,40$ BeurkG, the certification is made in the following manner: The person whose signature or mark is to be certified must either sign in the presence of the notary, or their signature or mark has to be acknowledged (annerkannt) by the notary $(\$ 40$ para 1 BeurkG). The notary subsequently makes an endorsement on the document containing the signature or mark and signs and seals it ( $\$ 39$

$1403 \$ 2$ Verordnung über die Übertragung der Führung des Unternehmensregisters und die Einreichung von Dokumenten beim Betreiber des elektronischen Bundesanzeigers [Ordinance on the Transfer of the Management of the Business Register and the Submission of Documents to the Operator of the Electronic Federal Gazette] of 15 December 2006, BGBl 2006 I 3202.

1404 The characteristics of these two 'signs' are explored in Section iv. below.

1405 Federal Ordinance on Notaries of 13 February 1937, BGBl 1937 III No 303-1.

1406 Compare Hertel, ' $\$ 126$ BGB' (fn 1338) para 150.

1407 Christian Hertel, $\mathbb{\$} 129$ [Section 129], in: von Staudinger and others (fn 140; 2017) para 3. 
BeurkG). ${ }^{1408}$ All three things must be placed below the other person's signature, whereby this can be on the same page of the document or on a separate page that is attached to the rest by use of a string and an imprint of the notaries' seal. ${ }^{1409}$

In accordance with $\$ 39$ a BeurkG, the certification can be made electronically. In this case, the notary's 'qualified' electronic signature is added to the electronic document $\left(\$ 39\right.$ a para 1 BeurkG) ${ }^{1410}$ Both the document which is to be signed and the signature must meet the requirements laid down in $\$ 126$ BGB. ${ }^{1411}$ While this is true, signatures not meeting those standards, such as those not written by hand, may still be certified as a mark. ${ }^{1412}$

The effect of the certification is to furnish a private document with a public instrument (offentliche Urkunde) and to verify the authenticity of the signature. ${ }^{1413}$ Thus, while the notary verifies the signing person's identity and their signature, they do not generally concern themselves with the document itself; if this service is required, a notarial authentication (notarielle Beurkundung) is normally done instead. ${ }^{1414}$ In fact, under $₫ 129$ para 2 BGB, a notarial certification can be replaced by a notarial authentication, as discussed subsequently.

\section{cc) Notarielle and Öffentliche Beurkundung (Notarial and Official Authentication)}

In contrast with a certification, an authentication creates a public instrument (offentliche Urkunde). The latter process is more complex. In instances of declarations of intention, or of a whole contract being authenticated, $\$ 8$ BeurkG prescribes that the authentication be made by way of a notarial

1408 Note that this procedure is used for standard documents. For further details on this, see ibid paras 69 et seq. If the certification is to be made by way of a Niederschrift (notarial recording), $\mathbb{3 7}$ BeurkG is applicable. This provision is considered below.

1409 Compare Hertel, ‘ $\$ 129$ ’ (fn 1407) paras 103-104. On the attachment, see $\mathbb{} 44$ BeurkG.

1410 On electronic signatures, see Section v. below.

1411 See Hertel, ' $\mathbb{S} 129$ BGB' (fn 1407) paras 54 et seq.

1412 Ibid para 61.

1413 Ibid paras 2, 112-113.

1414 Bork, 'Allgemeiner Teil' (fn 900) 419 para 1070. 


\section{B. Comparative Background}

recording (Niederschrift). ${ }^{1415}$ A contract need not be contained in a single document; a successive authentication of the declarations of offer and acceptance is sufficient (see $\mathbb{S} 128 \mathrm{BGB}$ ). In essence, the process involves the parties making their declaration of intention before the notary, who then records this intention. ${ }^{1416}$

The document of the recording (Niederschrift) must identify the parties, as well as the notary, contain the declarations of intention ( $\$ 9$ para 1 BeurkG), and state the date and time of the authentication (ibid para 2). The notary must state their full name and function as notary, as well as their business address, ${ }^{1417}$ whereas the parties must be described in such a way that the possibility of mistakes as to their identity is avoided ( $\$ 10$ para 2 BeurkG). Thus, all first names and the family name, where applicable the maiden name, as well as the person's address are stated. ${ }^{1418}$ In this respect, the notary must be certain of the parties' identity and, where they do not know the persons personally, must verify the identities (see $\mathbb{1} 10$ paras 3, 1 BeurkG). This is usually done by verifying the person's details from an identity document containing a photograph (Lichtbildausweis). ${ }^{1419}$ The parties' relation to the notary must be stated in the instrument ( $\$ 10$ para 3 ibid).

The notary also plays a central role in the drawing up of the instrument: In practice, a draft contract is usually provided by the notary to the parties, who review the draft before the authentication. ${ }^{1420}$ At the time of the authentication, the notary will usually advise the parties on certain points of law (compare $₫ 17$ BeurkG). ${ }^{1421}$ In accordance with $₫ 13$ para 1 BeurkG, the document must be read out to the parties by the notary, ${ }^{1422}$ who then

1415 Christian Hertel, Beurkundungsgesetz [Notarial Authentication Law], in: von Staudinger and others (fn 140; 2017) para 225.

1416 Bork, 'Allgemeiner Teil' (fn 900) 418 para 1067.

1417 Hertel, 'BeurkG' (fn 1415) para 328, who goes on to note that the notary's details need not be written at the beginning of the document. It is sufficient if a reference to the notary's function as the authenticating person is contained in the text itself and the word notary is placed with the notary's signature.

1418 See ibid para 332.

1419 Compare ibid para 334.

1420 Ibid paras 229, 228.

1421 Bork, 'Allgemeiner Teil' (fn 900) 418 para 1069. Perhaps due to this advising practice, it is sometimes said that the function of the notarial authentication is to ensure that the parties have been properly counselled on the transaction, see Köbl (fn 1294) 208.

1422 Where the document makes reference to certain types of other documents, such as balance sheets or inventories, these need not be read out if the parties 
give their approval and sign it by hand. The notary must also sign the instrument and write down their function (ibid para 3). A phrase expressing these requirements, eg, 'verlesen, genehmigt und unterschrieben' ('read out, approved and signed'), is usually inserted into the instrument. ${ }^{1423}$ After signing, the authentication process ends and the document cannot be changed any longer; any subsequent necessary alterations must be made in an instrument called Nachtragsurkunde. ${ }^{1424}$

\section{dd) Instances of Beglaubigungen and of Beurkundungen}

The certification of a person's signature (Unterschriftsbeglaubigung) is not typically required in relation to contracts. The most relevant instance is the making of declarations to or revoking the same before, eg, the German Land Register (Grundbuch, see $\mathbb{\$} \$ 29$ para 1, 31 Grundbuchordnung [Land Registration Law], hereinafter 'GBO'1425), ${ }^{1426}$ or the Commercial Register (Handelsregister, see $\$ 12 \mathrm{HGB}$ (Anmeldungen zur Eintragung und Einreichungen; Applications for Registration, and Submissions)). ${ }^{1427}$

In contrast, there are a numerous instances in which an authentication (Beurkundung) is required. This ranges from promises of donations (Schenkungsversprechen, $\$ 518$ para $1 \mathrm{BGB}$ ), whereby only the donor's promise needs to be recorded, ${ }^{1428}$ to contracts relating to land under $\$ 311 \mathrm{~b}$ BGB (Verträge über Grundstücke, das Vermögen und den Nachlass; Contracts on plots of land, assets and an estate). The latter provision

waive the reading, in which case this waiver must be noted in the instrument ( $(14$ paras 1,3 BeurkG). In such cases, the documents need to be provided to the parties for inspection and must be signed by them subsequently (ibid para 2).

1423 Hertel, 'BeurkG' (fn 1415) para 355.

1424 For further details, see ibid.

1425 Law of 26 May 1994, BGBl I (1994) 1114.

1426 Hertel, ' $\mathbb{1} 129 B G B$ ' (fn 1407) para 2. On acts required at the Land Register, see Section c.i. below.

1427 For a list of other instances of this form, see Hertel, ' $\$ 129 B G B$ ' (fn 1407) para 5.

1428 See Wolf and Neuner (fn 48) 511 para 19. Note that a revocation (Aufhebung) need not be in any particular form, see ibid 512 para 22. 


\section{B. Comparative Background}

applies to agreements of transfers of land and to obligations to purchase land (ibid para 1), even where the sale is by auction. ${ }^{1429}$

iv. Unterschreiben(Signing) and Siegeln (Sealing)

As was seen in the previous section, $\mathbb{1 2 6} \mathrm{BGB}$ explicitly requires either a personal signature (eigenhändige Unterschrift) or a notarially-certified mark (notariell Beglaubigtes Handzeichen) for the written form and the Urkunde. In contrast, a signature is not required under $₫ 126 \mathrm{~b}$ BGB. ${ }^{1430}$ Similarly, there is not one provision in the BGB that requires the use of a seal (Siegel). It is already discernible from this that private persons in Germany nowadays do not use seals in legal transactions, so that the focus in this section is solely on the signature. ${ }^{1431}$ Having said this, German public authorities still wield seals, as was pointed out in Section iii.aa) above.

\section{aa) 'Unterschrift'Defined}

Although it is a term often used in German law, there is no statutory definition of a signature (Unterschrift, also referred to as a Signatur ${ }^{1432}$ or a Namensunterschrift ${ }^{1433}$ ) in either the BGB or the HGB, nor in special laws such as the BeurkG. According to the common German definition, a signature is a "name written holographically at the bottom of a document

1429 This is because the contract concluded by virtue of $\$ 156$ BGB is of an obligatory nature and does not affect the disposition by way of conveyance. See on this BGH decision of 24 April 1998 (fn 1097) paras 6, 16.

1430 On this, see Einsele, ' $\mathbb{1} 126 b B G B$ ' (fn 1342) para 1 , who goes on to note at para 8 , however, that a signature can be inserted to satify the requirement that the end of the declaration be discernible ('Erkennbarkeit des Abschlusses der Erklärung').

1431 This is true for legal as well as private matters, as the signature took over the seal's function, see Stieldorf (fn 969) 52-53 and 35 respectively. The history of seals in Germany and their use is considered in further detail in Section D.III.2.b. below.

1432 See, eg, the entry for 'Signatur' in Duden online at www.duden.de.

1433 See, eg, Hertel, ‘ $\$ 126$ BGB' (fn 1338) para 2; Wolf and Neuner (fn 48 ) 515 para 32. 
or a text as a sign of one's confirmation, agreement, or similar'. ${ }^{1434}$ Even the BGH has defined a signature simply as 'ein Gebilde aus Buchstaben einer üblichen Schrift' ('a formation of letters of a common font'). ${ }^{1435}$ Nevertheless, German courts and academics have identified several important characteristics of a signature.

\section{bb) Characteristics of an Unterschrift}

A range of features have been identified in order to verify the existence of a signature. This is important for distinguishing this sign from mere marks (Handzeichen; see below). The first characteristic is that the writing or font must have individual character ('individuellen Charakter') and be difficult to forge for third parties. ${ }^{1436}$ In addition, it must identify the signatory. ${ }^{1437}$ While it need not be legible, so that the name need not be readable, the sign must clearly be made up of characters in the form of a signature. ${ }^{1438}$ Similar to the text of an Urkunde, the signature need not be in German; it can be in any common language, including foreign characters, but not,

1434 See the entry for 'Unterschrift' in Duden online at www.duden.de: '[Z]um Zeichen der Bestätigung, des Einverständnisses o. Ä. eigenhändig unter ein Schriftstück, einen Text geschriebener Name'.

1435 BGH decision of 4 June 1975, I ZR 114/74, NJW 1975, 1705-1706, para 6. The case concerned the question of whether the signature of a Rechtsanwalt (lawyer) on a brief fulfilled the requirements of $₫ 130$ no 6 ZPO. The court found that it had. The reasons will be discussed subsequently.

1436 BGH decision of 4 June 1975 (fn 1435) para 6. cf Plewe (fn 1015) 48, stating that the signature must denote the identity of the signing person: 'Mit der Unterschrift muß ein einmaliger, die Identität des Unterschreibenden ausreichend kennzeichnender, individueller Schriftzug vorliegen [...]'. Contrast the position in English law, on which see Section II.3.b.iv.aa) above.

1437 Bayerischer Verwaltungsgerichtshof [Bavarian Administrative Court] order of 16 August 1976, 118 VIII/75, NJW 1978, 510-511, para 20 (discussed below). This accords with the signature's function of associating a document with the signing person (in German: 'Zuordnungsfunktion'), compare Hertel, ' $\mathbb{S} 126$ $B G B$ ' (fn 1338) para 125. On its other function, namely, the Abschluss- und Deckungsfunktion (function of showing closure and coverage of a document), see Hertel, ibid para 126.

1438 BGH decision of 4 June 1975 (fn 1435) para 6. Exceptionally, the signature needs to be legible in particular instances, such as under labour law. On this, see Hertel, ' $\mathbb{S} 126 B G B$ ' (fn 1338) para 147 with further references. 


\section{B. Comparative Background}

say, in a secret code. ${ }^{1439}$ As the term 'Namensunterschrift' suggests, the signature must consist of a name, namely, of the family name, or, in case of a person acting on behalf of a company, the name of the company; in contrast, a first name only is not sufficient for common people, as opposed to the clergy or royals. ${ }^{1440}$ Similarly, a known pseudonym may suffice, while a purely made-up name or a description like 'your wife' will not. ${ }^{1441}$

A signature must be contrasted with a mark (Handzeichen). It is a written sign other than one's full name, ${ }^{1442}$ such as an abbreviation of one's (family) name, ${ }^{1443}$ one's initials, ${ }^{1444}$ or even just several Xs. ${ }^{1445}$ In contrast with a signature, it need not enable the writer to be identified, nor is it necessary that the same mark be used by the person every time. ${ }^{1446}$ Normally, such a mark will not be sufficient, so as not be deemed equivalent to a signature for the written form, ${ }^{1447}$ unless it is certified by a notary (see $\$ 126$ para 1 BGB). ${ }^{1448}$ Similarly, German procedural law, namely, $\mathbb{} 416$ Zivilprozessordnung (German Code of Civil Procedure, 'ZPO') speaks of 'private records and documents [...] signed by the parties issuing them, or have been signed using a mark that has been certified by a notary'. ${ }^{1449}$ It seems, therefore, that not only an Unterschrift (signature), but also an Unterzeichnung (literal-

1439 Accordingly, the Bayerischer Verwaltungsgerichtshof held a signature in Arabic characters to be valid for the purposes of German procedural law, see order of 16 August 1976 (fn 1437) para 21. Hertel, ' $\mathbb{S} 126$ BGB' (fn 1338) para 136 notes that block letters are admissible besides the cursive writing style, which is more common in Germany for signatures.

1440 See Wolf and Neuner (fn 48) 515 para 32; Hertel, ' $\$ 126 B G B$ ' (fn 1338) paras 137-138, 141. Interestingly, the latter notes at para 137 that using just one name of a double family name, or even a maiden name is acceptable.

1441 Hertel, ' $\mathbb{S} 126$ BGB' (fn 1338) paras 139-140; Wolf and Neuner (fn 48) 515 para 32.

1442 Compare the entry for 'Handzeichen' in Duden online at www.duden.de: ' $[M]$ it der Hand ausgeführtes Zeichen anstelle des Namenszugs' ('[A] mark executed by hand in lieu of the name').

1443 Compare BGH decision of 10 July 1997, IX ZR 24-97, NJW 1997, 3380-3381, para 7.

1444 Wolf and Neuner ( $\mathrm{fn} 48$ ) 515 para 32. On the differentiation between a mark or initials and a signature, see Hertel, ' $\mathbb{} 126 B G B$ ' (fn 1338) paras 143-146.

1445 Hertel, ' $\mathbb{S} 126 B G B$ ' (fn 1338) para 151.

1446 Ibid.

1447 See Wolf and Neuner (fn 48) 515 para 32.

1448 Compare Hertel, ' $\$ 126$ BGB' (fn 1338) para 150. Details on the certification were provided in Section iii.bb) above.

1449 The original text reads: 'Privaturkunden [... d] $]$ ie von den Ausstellern unterschrieben oder mittels notariell beglaubigten Handzeichens unterzeichnet sind [...]' 
ly 'under-signing'), and therefore a mark (Handzeichen) is equally sufficient for this purpose. ${ }^{1450}$

Another requirement of a signature is that the text and the signature be arranged in a way that show the signatory's authorship of the document, or which at least makes the text attributable to them. ${ }^{1451}$ Where, in contrast, the sign(ature) concludes the document, so that it is found below the text, this is normally assumed. Where the signature is found in other places, especially before the end of the text, eg, if something is inserted subsequently, this is not necessarily, or, as with the last example, usually not, the case. ${ }^{1452}$ No problems arise where the contract is a one-page document that is signed at its bottom. Similarly, where a contract has several pages, one signature at the end of the document suffices if the pages are either connected physically or conceptually ('gedanklich'), eg, by consecutive numbering of the pages. ${ }^{1453}$ Having said this, as long as a relation can be stablished in terms of its location, it seems that the time sequence of the drafting of the text and signing becomes irrelevant. ${ }^{1454}$ As a consequence, what is known as a Blankounterschrift (blank signature) or Blankett (blank form) is generally admissible, so that a blank paper that is signed first and text is added above subsequently, the content will be attributed to the signatory. ${ }^{1455}$

1450 Compare Schreiber, '\$ 416 ZPO’ (fn 1354) para 4.

1451 Compare ibid.

1452 See generally ibid.

1453 See Emmerich, ' $\$ 550$ BGB' (fn 1156) para 20, who notes that this is also true for instances of several contracts being concluded but it being intended that these belong together.

1454 Compare Schreiber, ' $\int 416$ ZPO' (fn 1354) para 4. Contrast the case of declarations of suretyship ( $\$ 766 \mathrm{BGB})$ : The $\mathrm{BGH}$ has held that a suretyship cannot be created with a blanc form, see BGH decision of 29 February 1996 (fn 1303) paras 6 et seq.

1455 See BGH decision of 29 February 1996 (fn 1303) para 17: 'Nach der Rechtsprechung des Bundesgerichtshofes muß in entsprechender Anwendung des $\$ 172$ Abs. 2 BGB derjenige, der ein Blankett mit seiner Unterschrift aus der Hand gibt, den durch dessen Ausfüllung geschaffenen Inhalt einem gutgläubigen Dritten gegenüber als seine Erklärung gegen sich gelten lassen, unabhängig davon, ob der vervollständigte Text seinem Willen entspricht oder nicht' ('According to the jurisprudence of the $[\mathrm{BGH}]$, by applying $\mathbb{} \$ 172$ para 2 BGB analogously, a person who gives a blanc form bearing their signature away must accept the content created by the filling out as being their declaration against third parties in good faith, irrespective of whether the completed text corresponds to their will or not'). 


\section{B. Comparative Background}

\section{cc) The Method of Unterschreiben}

German private and procedural law also vary in another respect, namely, in whether the signature needs to be 'eigenhändig' (by one's own hand). While $\$ 126$ para $1 \mathrm{BGB}$ clearly states that this is required, the ZPO provision does not contain the word 'eigenbändig'. This aspect in fact relates to two issues: First, whether the signature can be produced other than by hand, ie, by being copied or printed. Secondly, the question arises whether the signature can only be made by the signing person themselves, or if another person may sign on their behalf. In other words, it relates to agency. Each of these issues will be analysed briefly.

There seems to be no doubt in German academia that a signature under $\$ 126$ BGB needs to be written by hand with, say, pen on paper, rather than being printed or otherwise reproduced. ${ }^{1456}$ The same is true for a mark (Handzeichen). ${ }^{1457}$ In contrast, $\ 127$ para 2 and $\$ 550$ BGB seem not to require a hand-written signature, ${ }^{1458}$ so that a lower standard is set in this respect for contracts put into writing according to the agreement of the parties and for lease agreements. The ZPO is equally liberal: Although academic opinion seems divided on the point, it is generally accepted that a signature under $\sqrt{ } 416 \mathrm{ZPO}$ need not be written by hand; reproductions of a document, and thus, of a signature, seem to be admissible. ${ }^{1459}$

The ZPO is also more liberal concerning agents used for signing: It is sufficient for the purposes of procedural law if the text of a document is dictated to a third party, who then prints it and either signs it or lets the dictating person sign themselves. Moreover, it is equally sufficient if the

1456 Hertel, ‘ $\$ 126 B G B$ ’ (fn 1338) para 133; Wolf and Neuner (fn 48) 515 para 33. See also Schreiber, ' $\$ 416$ ZPO' (fn 1354) para 6. Hertel, ibid, notes, however, that being aided in signing by another person is not harmful, if the control of the signing hand is with the signatory and the sign is made with the will of that person. This is also admitted by Wolf and Neuner, ibid para 34, who go on to state that disabled persons may even use their feet or mouth to sign instead of their hand.

1457 Compare Hertel, ' $\mathbb{S} 126$ BGB' (fn 1338) para 151.

1458 On $\$ 127$ BGB, see BGH decision of 27 May 1957 (fn 1200) 884. See further Jochen Hoffmann and Ulrich Höpfner, Kündigung per E-Mail im elektronischen Geschäftsverkehr [Cancellation by E-mail in Electronic Commerce] (2016) 49 Betriebsberater (BB) 2952-2953, who note that a signature is not enough if the transmitted declaration is fixed as a text. On $₫ 550 \mathrm{BGB}$, see BGH decision of 7 March 2018 (fn 906) paras 18-21. cf Emmerich, ' $\$ 550$ BGB' (fn 1156) paras 11, 14a.1.

1459 Compare Schreiber, ' $\mathbb{S} 416$ ZPO’ (fn 1354) para 6. 
third party writes the dictating person's name as the document's creator under the text at the other person's direction. ${ }^{1460}$ This control by the dictating person is important, as the signatory or, where applicable, their representative (Vertreter), must be the person making the declaration. ${ }^{1461}$ It seems that this is not possible under the BGB, neither for a mark nor for a signature made in accordance with $₫ 126 \mathrm{BGB} ;{ }^{1462}$ however, an agent may sign with their own name or the name of the principal on behalf of the declaring person. ${ }^{1463}$

In the case of notarial authentications (notarielle Beurkundungen), explained in the previous section, the situation is clear: According to $₫ 13$ para 1 BeurkG, the parties must sign the notarial instrument by hand ('muß $[\ldots]$ eigenhändig unterschrieben werden'). Where this has been done, a legal fiction assumes that the instrument was either read out to the parties, or, where it was checked by them, acknowledged by the parties (ibid). This fiction of acknowledgement or consent can also be found in other parts of German law. Thus, under German civil procedural law for example, it is generally assumed that a declaration made in a document footed by an authentic signature expresses the intention of the signatory. ${ }^{1464}$ The requirements of an authentication further include the signature of the person doing the authentication, this usually being the notary, and that the pages of the document be bound with a cord that is fixed with a seal impression of the authenticating party. ${ }^{1465}$

1460 Ibid para 5. See also BGH decision of 27 May 1957 (fn 1200) 884.

1461 See Schreiber, ' $\$ 416$ ZPO' (fn 1354) paras 5, 4.

1462 Hertel, ' $\mathbb{S} 126 B G B$ ' (fn 1338) paras 151 and 109 notes that the mark or signature must be 'eigenhändig' (by hand).

1463 Ibid paras 148, 149. See also Wolf and Neuner (fn 48) 515 para 33. Whether the agent is authorised to do so is a separate issue, and therefore does not affect the question of form: Hertel, ibid para 148a.

1464 In the BGH decision of 29 February 1996 (fn 1303) para 14, the court stated that this presumption is contained in $\$ 440$ para 2 ZPO (Beweis der Echtheit von Privaturkunden; Evidence of the authenticity of private records and documents). See also Klaus Schreiber, $\mathbb{} 440$ Beweis der Echtheit von Privaturkunden [Section 440 Evidence of the Authenticity of Private Records and Documents], in: Krüger and Rauscher (fn 1347) para 5.

1465 See Schreiber, ' $\mathbb{S} 415$ ZPO' (fn 1347) para 21. In effect, these requirements are therefore the same as under the BGB, see Hertel, ' $\mathbb{\$} 126$ BGB' (fn 1338) para 125. 


\section{v. Electronic Communication: Data, Documents and Signatures}

Advances in technology have gradually changed the way in which legal transactions have been concluded. In particular, there seems to be a growth in what is termed 'electronic legal transactions' (elektronischer Rechtsverkehr; the term 'e-commerce' is also used often ${ }^{1466}$ ). This growth is not limited to transactions between contracting parties; endeavours have also been made in Germany in recent years to facilitate electronic communication with public institutions or facilities such as the courts and public registers. ${ }^{1467}$ It can therefore be expected that the volume of electronic transactions will rise further in future.

The increase in business opportunities and the facilitation of commerce notwithstanding, e-commerce brings with it certain risks, in particular

1466 See, eg, Heydn (fn 1343) 222.

1467 This has been expressed legislatively in two laws: On the one hand, the Gesetz zur Förderung des elektronischen Rechtsverkehrs mit den Gerichten [Act to Facilitate Legal Transactions with Courts] of 10 October 2013, BGBl 2013 I 3786. For a concise account of this law and its effects, see Hanseatische Rechtsanwaltskammer Hamburg, Aktuelles zum elektronischen Rechtsverkehr beim Finanzgericht [Latest News on Electronic Legal Transactions with the Finance Court] (Kammerreport No 4 2014, available at ww.rak-hamburg.de/f/ 100d606ffd.pdf) 12-14. On the other hand, the Gesetz zur Einfübrung des elektronischen Rechtsverkehrs und der elektronischen Akte im Grundbuchverfahren sowie zur Änderung weiterer grundbuch-, register- und kostenrechtlicher Vorschriften [Act to Introduce Electronic Legal Transactions and Electronic Records in Land Register Procedures as well as to Change Other [Related] Rules] of 11 August 2009, BGBl 2009 I 2713, introduced the possibility of, inter alia, electronic petitions and submissions to the land register, see art 1 para 1 no 19 of that Law. Further specifications were later laid down in regulations, particularly the Verordnung über die technischen Rahmenbedingungen des elektronischen Rechtsverkehrs und über das besondere elektronische Behördenpostfach [Ordinance on the Technical Conditions of Electronic Legal Tranasctions and the Special Electronic Mailbox of Authorities] of 24 November 2017, BGBl 2017 I 3803. Beside these endeavours, requirements of the written form in over 180 pieces of legislation and regulations of German administrative law were recently deleted or substituted for requirements of an electronic form by virtue of the Gesetz zum Abbau verzichtbarer Anordnungen der Schriftform im Verwaltungsrecht des Bundes [Law to Reduce Dispensable Requirements of the Written Form in Federal Administrative Law] of 29 March 2017, BGBl 2017 I 626. For a description of the aims of this law, see Bundesrat, Gesetzentwurf der Bundesregierung: Entwurf eines Gesetzes zum Abbau verzichtbarer Anordnungen der Schriftform im Verwaltungsrecht des Bundes [Draft Law of the Government: Draft of a Law to Reduce Dispensable Requirements of the Written Form in Federal Administrative Law], Drucksache [printed matter] 491/16, 02 September 2016. 
regarding the identity or the identification of the parties and the security of information. ${ }^{1468}$ The following exposition will consider electronic forms of contracts, in particular electronic documents and electronic signatures. This examination will begin with the meaning of electronic contracts and electronic declarations of intention (in Section aa)), and then turn to the form as regulated in $\$ 126 \mathrm{a}$ BGB and electronic signatures (in bb)). ${ }^{1469}$

\section{aa) 'Electronic Contract' and 'Electronic Declarations of Intention' Defined}

The BGB simply defines an electronic contract (Vertrag im elektronischen Geschäftsverkehr, literally 'contract in electronic commerce') in $\$ 312 \mathrm{i}$ para $1 \mathrm{BGB}$ as a contract that is concluded through the use of tele-media services (Telemedienste). According to the definition in $\mathbb{} 1$ para 1 Telemediengesetz (Tele-media Law, hereinafter 'TMG') ${ }^{1470}$, 'tele-media' means electronic information- and communication services ('elektronische Informations- und Kommunikationsdienste'). Tele-media services are thus said to include the use of the internet, telebanking, and online databases allowing the ordering of goods or services. ${ }^{1471}$ In contrast, the term does not encompass services using older (outdated) technologies such as telegram or telex. ${ }^{1472}$ While the provision only refers to tele-media services, it seems that another kind of service relevant in e-commerce, Mediensdienste (media-services), is included as well, since the regulation of tele- and mediaservices seems to be so similar as to make no difference in practice. ${ }^{1473}$ Consequently, teleshopping also seems to fall within this category. ${ }^{1474}$ As

1468 For further details, see Laborde (fn 1366) 21-25.

1469 Electronic communication methods such as e-mail have already been considered in relation to the declarations of offer and acceptance in Sections 3.a.ii. and iii. above respectively.

1470 Law of 26 February 2007, BGBl 2007 I 179.

1471 See Wolf and Neuner (fn 48) 431 para 58 (note that the authors refer to $\$ 312 \mathrm{~g}$, the former $\$ 312 \mathrm{i} \mathrm{BGB}$; on the history of the provision, see Christiane C Wendehorst, $\mathbb{S} 312 i$ [Section 312i], in: Säcker and others (fn 158) Vol 2 para 2).

1472 Heydn (fn 1343) 227.

1473 See on this ibid 224, 221-222. Indeed, the provision explicitly referred to both kinds of services until 2012 and it has been suggested that while the wording was changed, no alteration in the scope of its application was intended, compare Wendehorst, ' $\$ 312 i B G B$ ' (fn 1471) para 2.

1474 Compare Wolf and Neuner (fn 48) 431 paras 58, 57. 


\section{B. Comparative Background}

the provision does not make reference to particular kinds of persons, such as consumers, all kind of users of tele-media seem to be within the scope of the regulation. ${ }^{1475}$

In terms of general requirements for electronic contracts, the same rules as to analogue contracts apply. ${ }^{1476}$ Thus, a contract that is made in electronic form arises through the agreement of the parties by way of offer and acceptance as regulated in $\$ \mathbb{S} 145 \mathrm{BGB}$ et seq, unless the parties have stipulated otherwise. ${ }^{1477}$ As such, the basis of electronic contracts is still a congruency of declarations of intention; the difference being that here, these are electronic rather than oral or in writing. ${ }^{1478}$

It seems that the parties are not completely free in making deviating provisions. While $\$ 312 \mathrm{i}$ para 2 BGB allows contracting parties to stipulate something that departs from the obligations contained in $\$ 312 \mathrm{i}$ para 1 $\mathrm{BGB}$, this is only true if no consumers are involved. Thus, seeing as the provision speaks of a trader and a customer (Unternehmer and Kunde respectively), the provision will apply to $\mathrm{B} 2 \mathrm{C}$ and $\mathrm{B} 2 \mathrm{~B}$, but not to $\mathrm{C} 2 \mathrm{C}$ contracts. ${ }^{1479}$ Having said this, the provision is not applicable in any case where 'personal communication' ('individuelle Kommunikation') is used exclusively for the conclusion process ( $\$ 312 \mathrm{i}$ para $2 \mathrm{BGB})$, such as e-mail. ${ }^{1480}$

Where declarations of intention are transmitted through electronic communication devices, such as e-mail, one question is whether an addressee ought to expect a declaration to be sent by such means, and, in anticipating this, ought to have devices available to receive or otherwise handle such electronic declarations. This issue arises in relation to both the electronic and the text form of the BGB; however, it seems that it is sufficient that the declaration be sent in the required form. ${ }^{1481} \mathrm{~A}$ caveat is that the declaration's receipt must not be impossible, so that sending a declaration to a non-existent e-mail address does not meet the requirements. ${ }^{1482}$ In terms of fulfilling a formality, the moment of sending is important; where-

1475 Compare Heydn (fn 1343) 228, who states that the application of the TMG extends to legal and natural persons.

1476 Busche, 'Vor $\$ 145 B G B$ ' (fn 158) para 37. See also Wolf and Neuner (fn 48) 431 para 57.

1477 See, eg, BGH Decision of 16 October 2012 (fn 1110) para 13.

1478 Compare Heydn (fn 1343) 230, stating that declarations of intention 'can be in any form, such as over the internet.'

1479 See Wolf and Neuner (fn 48) 432 para 59.

1480 See ibid 431 para 58.

1481 See Einsele, ' $\mathbb{S} 126 b B G B$ ' (fn 1342) para 12.

1482 Compare ibid. 
as a declaration's general effectiveness, as seen in Section a. above, depends on its receipt. These two points must therefore be distinguished, which is also important because an addressee can waive receipt of a declaration made in a specific form but cannot do so for its dispatch. ${ }^{1483}$

bb) Electronic Form and Electronic Signatures

Section 126a BGB regulates the electronic form (Elektronische Form) of documents. It provides:

(1) If the electronic form is to replace the written form prescribed by statute, the issuer of the declaration must add his name to it and provide the electronic document with a qualified electronic signature.

(2) In the case of a contract, the parties must each provide a counterpart with an electronic signature as described in subsection (1). ${ }^{1484}$

Paragraph 1 makes it clear that the electronic form can generally act as a substitute for the standard written form. This rule is excluded in particular instances, such as in $\$ \$ 766,780,781$, and 623 BGB for declarations of suretyships, promises to fulfil an obligation, acknowledgements of a debt, and terminations of employment contracts respectively. ${ }^{1485}$ At least the first three examples mentioned should nevertheless be possible if the declaring person is a merchant, as $\$ 350 \mathrm{HGB}$ explicitly denies the application of the BGB provisions for these cases. ${ }^{1486}$

Where the parties mutually agree ${ }^{1487}$ on using the electronic form (allowed implicitly under $\mathbb{1 2 7}$ para 1 BGB), $\$ 127$ para 3 BGB lowers the

1483 Ibid.

1484 The original provision states: '(1) Soll die gesetzlich vorgeschriebene schriftliche Form durch die elektronische Form ersetzt werden, so muss der Aussteller der Erklärung dieser seinen Namen binzufügen und das elektronische Dokument mit einer qualifizierten elektronischen Signatur versehen.

(2) Bei einem Vertrag müssen die Parteien jeweils ein gleichlautendes Dokument in der in Absatz 1 bezeichneten Weise elektronisch signieren.'

1485 The reason lies in the function of the provisions in question. On this, see Wolf and Neuner (fn 48) 510 para 11, who go on to explain that the inhibition threshold (Hemmschwelle) to contract is perceived to be lower with electronic forms than with documents that are signed by hand.

1486 See Section b.ii.cc) above, where this issue has already been discussed.

1487 The decision cannot be one-sided: It is necessary that the addressee at least implicitly agrees on using the electronic form, see FormAnpG Draft Law (fn 1342) 41. Such agreement is deemed to have been given either where the 


\section{B. Comparative Background}

standard for the electronic signature: Generally, the signature need not satisfy the requirements of $\mathbb{S} 126 \mathrm{a}$ BGB; however, a signature that does meet those requirements may be requested by the parties subsequently. Nevertheless, it seems that where a party asks for an electronic signature in accordance with $\$ 126 \mathrm{a}$ BGB, this request only has declaratory but not constitutive character. ${ }^{1488}$ Consequently, if the request is not fulfilled, the contract will remain effective.

In laying down the requirements of form, the provision differentiates between electronic declarations of intention in general and contracts in particular. The former must contain two elements: first, an electronic document; and second, the declaring person's (being the 'issuer', 'Aussteller') ${ }^{1489}$ electronic signature ( $\$ 126$ a para $\left.1 \mathrm{BGB}\right)$. The same is true for contracts executed in electronic form; the only difference being that each party must electronically sign a contract document (para 2). While an exact definition is not given, it is clear that the document must include the declaring person's name (para 1), consist of the whole declaration, and be capable of being saved in a way that allows a perpetual and legible reproduction. ${ }^{1490}$ One suggested definition is more specific, as it states that

[a]n electronic document is a declaration that is embodied by technical means but is not fixed in writing, that can be made comprehensible generally, or at least to the persons privy to the document in question, that it shows the document's creator (declaring person) and that it be intended as proof of a legally relevant fact. ${ }^{1491}$

addressee does not reject the declaration and treats it as being valid, or where the transaction process is electronic, compare Wolf and Neuner (fn 48) 516 para 38.

1488 Wolf and Neuner (fn 48) 525 para 87.

1489 See Dorothee Einsele, $\$ 126 a$ Elektronische Form [Section 126a Electronic Form], in: Säcker and others ( $\mathrm{fn} 158$ ) para 5, who goes on to discuss the question of an agent or other third party in paras $5,21$.

1490 See Wolf and Neuner (fn 48) 516 para 39, using the term 'dauerhaft lesbare Wiedergabe'. See also Einsele, ' $\$ 126 a$ BGB' (fn 1489) para 3, noting that a 'continuous possibility to reproduce' ('dauerhafte Wiedergabemöglichkeit') the declaration is necessary in order for the form to fulfil its function as proof.

1491 Bettendorf (fn 1256) 278: 'Ein elektronisches Dokument ist eine mit einem technischen Mittel verkörperte, jedoch nicht schriftlich niedergelegte Erklärung, die allgemein oder für Eingeweihte verständlich gemacht werden kann, den Aussteller (Erklärenden) erkennen lässt und die zum Beweis einer rechtlich erheblichen Tatsache bestimmt ist.' 
This definition clarifies that a written fixation is not required. In addition, it implies that the declaration is composed of electronic data that is not comprehensible on its own, ie, without using technical equipment. ${ }^{1492}$ This seems to be in line with a definition found in EU law, namely, that "electronic document" means any content stored in electronic form, in particular text or sound, visual or audiovisual recording. ${ }^{1493}$ Under these circumstances, the fact that the declaration need not be visible for a long stretch of time is not surprising. ${ }^{1494}$ Thus, it is sufficient that the declaration can be read on a screen, or be saved on a hard disk or other medium. ${ }^{1495}$ Note that the rule concerning documentary unit (Dokumenteinheit) of written instruments apply. ${ }^{1496}$

As $₫ 126$ a BGB mentions the declaring person's name and a signature, it can be deduced that the former need not be in the form of the latter, so that the name may be written as normal text. ${ }^{1497}$ Consequently, the name does not need to appear at the end of the declaration, but may be stated somewhere within or even above the end of the text. ${ }^{1498}$ The function of completing the declaration (termed 'Abschlussfunktion' in German) is fulfilled by the electronic signature instead. ${ }^{1499}$ In this respect, the BGB has left open what a 'qualified' electronic signature is. This issue now seems

1492 Compare the explicit description by Einsele, ' $\$ 126 a B G B$ ' (fn 1489) para 3. See also FormAnpG Draft Law (fn 1342) 25; Wolf and Neuner (fn 48) 516 para 39.

1493 Article 3 para 35 eIDAS Regulation 2014. This Regulation was transposed into German law by virtue of the Gesetz zur Durchführung der Verordnung (EU) Nr.910/2014 des Europäischen Parlaments und des Rates vom 23. Juli 2014 über elektronische Identifizierung und Vertrauensdienste für elektronische Transaktionen im Binnenmarkt und zur Aufhebung der Richtlinie 1999/93/EG (eIDAS-Durchführungsgesetz) [Law to Implement Regulation No 910/2014 of the European Parliament and of the Council (EU) of 23 July 2014 on electronic identification and trust services for electronic transactions in the internal market and repealing Directive 1999/93/EC (eIDAS-Implementation Law)] of 18 July 2017, BGBl 2017 I 2745.

1494 Compare Einsele, ' $\mathbb{1} 126 a$ BGB' (fn 1489) para 3.

1495 Ibid; FormAnpG Draft Law (fn 1342) 19.

1496 See Wolf and Neuner (fn 48) 516 para 39.

1497 Compare ibid, who puts this down to the function of the statement of the name, namely, as an identification tool, rather than as an authentication mechanism.

1498 See Einsele, '\$ $126 a B G B$ ' (fn 1489) para 6.

1499 Ibid. 


\section{B. Comparative Background}

to be governed by the eIDAS Regulation 2014, discussed in II.3.b.v.bb) above. ${ }^{1500}$

The common requirements for advanced and qualified electronic signatures under art 26 of the Regulation compare to those of standard signatures under German law: First, the electronic signature must be 'uniquely linked to', and - very much like a hand-written signature - identify the signatory (art 26 points a and b). Furthermore, similar to an Urkunde, the electronic signature must be 'linked to the data signed therewith in such a way that any subsequent change in the data is detectable' (point d). Finally, the creation device used for the signature must be under the sole control of the signatory (point c). While the first two conditions relate to the identity of the signing person and its authentication, the latter two aspects relate to security. This is important, as the manipulation or faulty transmission of electronic documents is easier or more likely to happen than with paper documents. ${ }^{1501}$ A properly executed qualified electronic signature has the same legal effect as a hand-written signature (art 25 para 2 eIDAS Regulation 2014). Likewise, the Regulation gives protection to the other variations of electronic signatures by foreseeing that

[a]n electronic signature shall not be denied legal effect and admissibility as evidence in legal proceedings solely on the grounds that it is in an electronic form or that it does not meet the requirements for qualified electronic signatures. ${ }^{1502}$

In this way, EU law has created a minimum level of protection for electronic signatures, which is in line with the objective of enhancing trust in e-commerce (recital 2). ${ }^{1503}$

1500 Matthias Frohn and Vladimir Primaczenko, \$126a Elektronische Form [Section 126a Electronic Form], in: Johannes Hager and others, beck-online.GROSSKOMMENTAR: BGB [beck-online.Comprehensive Commentary: German Civil Code] (online edn, CH Beck 2018) para 1.

1501 On this and other weak points of electronic documents, including identity fraud (Identitätstäuschung), see Bettendorf (fn 1349) 278-279.

1502 Article 25 para 1 eIDAS Regulation 2014.

1503 This objective is realised further through another mechanism, namely, of ensuring mutual recognition by EU Member States of electronic signatures and electronic identification schemes, see art 25 para 3 and art 6 para 1 of the Regulation respectively. 


\section{vi. Legal Consequences of Non-Fulfilment and Healing Methods}

The BGB foresees various consequences that occur if the stipulated form requirements are not met. By default, this will be voidness of the transaction (see Section aa) below); however, there are, exceptionally, other consequences that apply (Section bb)). Beside the kind of consequence, an important consideration is to what extent the form requirements operate (Section cc)), and, where a consequence applies, if the imperfection can be healed or otherwise avoided (Section dd)).

\section{aa) General Consequence of Non-Fulfilment: Voidness}

In cases where a particular form is foreseen by statute and the prescribed requirements are not fulfilled, the contract will normally be nichtig (void; $\$ 125 \mathrm{BGB}$ ), so that the contract will not display effects. ${ }^{1504}$ As was intimated above, this rule is mandatory and may not be deviated from through individual arrangement by the parties; what is more, the courts must consider this issue ex officio, without either of the parties having to raise the question. ${ }^{1505}$

Where the parties agree on a particular form, the contract must generally be executed in that form before it will come into effect (see $\$ 125$ BGB). ${ }^{1506}$ In particular, $\mathbb{S} 154$ para 2 BGB prescribes that the contract in the case of a notarial authentication (notarialle Beurkundung) being foreseen will not arise 'until the recording has taken place'. ${ }^{1507}$ Seeing as the provision is an interpretation tool (Auslegungsregel), it will not apply

1504 See Hertel, ' $\$ 125 B G B$ ' (fn 1294) para 1. Use is apparently made of this drastic legal consequence in order to better enforce the form requirements, see Köbl (fn 1294) 209.

1505 See Wolf and Neuner ( $\mathrm{fn} 48$ ) 520 para 57. Under the principle of good faith, the voidness of a contract may - under very limited circumstances - not be claimed. See ibid $521-523$ paras 63 et seq.

1506 Hertel, ‘ $\mathbb{S} 125 B G B$ ' (fn 1294) para 2.

1507 Cf the original text, which reads: 'Ist eine Beurkundung des beabsichtigten Vertrags verabredet worden, so ist im Zweifel der Vertrag nicht geschlossen, bis die Beurkundung erfolgt ist.' The provision is said to be applicable to written and electronic recordings (schriftliche Beurkundung and elektronische Form) as well, as it explicitly mentions a 'Beurkundung', see Wolf and Neuner (fn 48) 437 para 11. 


\section{B. Comparative Background}

if an intention of the parties to the contrary can be discerned. ${ }^{1508}$ This can be deduced from the phrasing of the provision, which contains the words 'im Zweifel' (in doubt): These words indicate that non-effectiveness is not the necessary consequence; this will only be the case if the parties' intention does not indicate otherwise. ${ }^{1509}$ Similarly, $\mathbb{1} 125$ and $\$ 127$ BGB also contain 'in doubt'-clauses for formalities stipulated by the parties, so that the provisions only apply if the parties' intention is not clear and a contract is not necessarily ineffective even if the form stipulated by the parties is not fulfilled. ${ }^{1510}$

These provisions presume that the parties did not intend for a mutually agreed form to be constitutive (konsitutiv). ${ }^{1511}$ Moreover, unless indications of a contrary intention exist, the parties will be deemed to have stipulated the form by which they chose to execute the contract. ${ }^{1512}$ This conforms with the general principle that a form requirement is met where a declaration of intention is made in the prescribed manner. ${ }^{1513}$ By applying this principle, the parties' belief that the contract is valid is upheld. This is equally true where the parties have executed the contract, which is accomplished by presuming that, firstly, the parties abandoned the stipulated form, and, secondly, that the contract was subsequently confirmed (bestätigt) by the parties in accordance with $\$ 141$ BGB..$^{1514}$

1508 On this issue, see BGH decision of 29 September 1999, XII ZR 313/98, NJW 2000, 354-359, para 52. The case concerned a commercial lease agreement, which, according to the claimant, was void for non-fulfilment of the mandatory form. The court held that the parties had stipulated a form, but that, in any case, the statutory requirements had been met, so that the contract was valid. See paras 49-53 of the decision.

1509 See on this Wolf and Neuner (fn 48) 524 para 81.

1510 See Busche, 'Vor $\$ 145$ BGB' (fn 158) para 29.

1511 Wolf and Neuner (fn 48) 524 para 81.

1512 See BGH decision of 29 September 1999 (fn 1508) para 52.

1513 Einsele, ' $\mathbb{S} 126 b B G B$ ' (fn 1342) para 4 notes that where the declaration is one that needs to be received, it must of course also be received by the addressee in order to become effective.

1514 See Wolf and Neuner (fn 48) 524 para 82. 


\section{bb) Exceptional Instances of Other Consequences}

The sanction contained in $\$ 125$ BGB is heavily perforated by exceptions. ${ }^{1515}$ Thus, the different functions of the form in question as discussed above may influence the stringency of the legal consequence of a breach of form: A prerequisite aimed at protecting or warning a party will, if not fulfilled, usually lead to the purported transaction being wholly void; whereas a less strict or even no legal consequence may arise for forms with other functions. ${ }^{1516}$ One prominent example is a lease for a period of more than one year not in writing. Under $\$ 550 \mathrm{BGB}$, a mandatory provision, ${ }^{1517}$ the lease will be deemed to be concluded for an unlimited period that may not be cancelled within the first year after its conclusion. This relatively mild consequence may be explained by the function of the provision, which is said to be to warn and caution on the one hand, but, on the other hand, to ensure furthermore that the agreement be sufficiently documented so that a subsequent purchaser of the real estate may be able to have knowledge of the agreement. ${ }^{1518}$

\section{cc) Extent of Operation of Form Requirements and their Consequences}

One problem that arises in relation to form requirements is whether these apply to the whole legal transaction or only to certain parts. This becomes particularly relevant where two or more legal transactions are combined, whereby one of the acts may be governed by form requirements while the

1515 Köbl (fn 1294) 217. There is also the principle of good faith, which sometimes demands that an a priori void transaction be upheld so that a claim for performance (Erfüllungsanspruch) may arise. On this, see ibid 218.

1516 Compare in this respect BAG decision of 17 December 2009 (fn 1142) paras $24-25$, in which it was held that $\$ 623$ BGB (Schriftform der Kündigung [von Arbeitsverhältnissen]; Written form of termination [of employment]) was applicable to preliminary contracts concerning the termination of employment, because the provision's form requirement (written form) fulfilled a cautioning function. As this form had not been met, the preliminary agreement was held to be void. Compare also the exposition by Mann (fn 1302) 22 on a sale of real estate. The requirement's function may also affect the kind of alternative form that is available. Thus, as already mentioned in Section v.bb) above, the electronic form is explicitly excluded in some instances of a written form being required.

1517 See, eg, BGH decision of 27 September 2017 (fn 1157) para 35.

1518 Ibid paras 35-36, 29. 
other is not. ${ }^{1519}$ An example is the combination of the sale of a piece of land with a lease. In such situations, the question of whether the form governs only one or both parts seems to hinge on whether the transactions are one-sidedly or mutually dependent on the other transaction(s). ${ }^{1520}$

The important factor is whether the agreements form a 'rechtliche Einheit' (legal unit), ${ }^{1521}$ which is assumed where the parties' intention indicates that the agreements were meant to 'stand and fall' together ('miteinander "stehen und fallen" sollen'). ${ }^{1522}$ Thus, it is the parties' intention at the time of entering into the legal transaction that is of importance and not a later point in time. ${ }^{1523}$ This question seems to require a case-by-case examination of the parties' intention; however, a presumption that two transactions do not form a unit arises where the transactions are laid down in separate documents. ${ }^{1524}$ One party's unarticulated intention to connect

1519 See Mertens (fn 1300) 431. See generally Maier-Reimer (fn 1302) 3741-3745. It seems that the formless transaction does not become governed by form requirements; rather, a form must be respected in such cases due to the formless transaction's connection to another transaction that underlies some form, compare Maier-Reimer (fn 1302) 3743.

1520 See Maier-Reimer (fn 1302) 3741. A related issue, which will not be explored further in this dissertation, is the question of what forms part of the transaction and what constitutes mere Nebenabreden (ancillary agreements, sometimes also referred to as Nebenvereinbarungen). Where the latter are part of the main contract, any form requirements pertinent for the contract will apply to any ancillary agreements as well; whereas, otherwise, including the case that the arrangement is of no (legal) consequence, the form requirements do not automatically apply. On this, see Wolf and Neuner (fn 48) 512 para 21.

1521 The term 'verbundene Rechtsgeschäfte' is also sometimes used, see, eg, Roth (fn 1079) para 37.

1522 See, eg, BGH decision of 6 December 1979, VII ZR 313/78, BGHZ 76, 43-50 para 20. The case concerned a construction contract (Bawwerkvertrag), which, like other contracts for work and labour (Werkverträge; Contract to Produce a Work; $\mathbb{S} 631-651 \mathrm{BGB}$ ), is not governed by form. It was alleged that the contract was void for not having been authenticated by a notary (notariell beurkundet). This was argued to be necessary, because the contract apparently also contained an obligation of the defendant to purchase a piece of land on which the building was to be constructed. Due to this connection to real

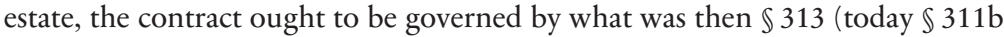
para 1) BGB. The court held that no such obligation had arisen form the work contract, so that it did not require a notarial recording in order to be effective. See paras 1, 8, 10-12, 20-22 of the decision.

1523 See BGH order of 12 September 2011, IV ZR 38/09, NJW 2012, 296-301, para 58.

1524 See BGH decision of 6 December 1979 (fn 1522) paras 21-22. For a discussion of the issues arising from this approach, see Mertens (fn 1300) 431-432. 
the legal transactions is not sufficient; the will must have been expressed in some way and at least acquiesced by the other(s). ${ }^{1525}$ If no express intention has been articulated, the apparent intention is examined by considering external signs, such as whether the transactions are contained in a single or several separate documents. ${ }^{1526}$ Finally, if no intention exists, the meaning of the transactions is assessed objectively in order to decide if a unit exists. ${ }^{1527}$

Intention of a legal unit means that the transactions are meant to be mutually dependent. ${ }^{1528}$ If one part of this unit, ie, one transaction, is governed by some form, this must logically be true for the other part as well. ${ }^{1529}$ As a consequence, if one part does not meet the requirements, all parts will be void. Using the example of a unit consisting of a sale of land and a lease, the whole transaction must be authenticated by a notary (notariell beurkundet), and, failing that, $\$ 311 \mathrm{~b}$ para $1 \mathrm{BGB}$ will apply to both parts, ${ }^{1530}$ rendering them void in conjunction with $\$ 125$ BGB. This test of a legal unit is applicable to other instances in which a notarial authentication is required; however, if only one party is meant to be protected, such as with declarations of suretyship, promises of gifts, or consumer contracts, ancillary agreements benefitting the protected party do not fall under the form requirement of the main agreement. ${ }^{1531}$

Where only one transaction is dependent on the other, it does not follow that the transaction is equally subjected to the form of the other or vice versa. Rather, it depends on whether the dependent or the independent transaction is bound by a form. The situation of a formless transaction (eg, a lease) depending on a form-bound transaction (eg, a sale of land) is simple: the formal transaction must meet the form required for it, whereas the formless one is not bound by the requirement, even though its effectiveness depends on the effectiveness of the formal transaction. ${ }^{1532}$ Thus, the form requirement of one transaction does not extend to the other. As a consequence, the formless transaction will not be invalid if not

1525 See Maier-Reimer (fn 1302) 3742.

1526 See Roth (fn 1079) paras 40-41. See ibid paras 42-59 for further discussion.

1527 See ibid para 38.

1528 See Maier-Reimer (fn 1302) 3742.

1529 See ibid 3743.

1530 Roth (fn 1079) para 31.

1531 For further details, see Mertens (fn 1300) 432.

1532 Compare Maier-Reimer (fn 1302) 3743. 


\section{B. Comparative Background}

made in the form of the formal transaction. ${ }^{1533}$ Conversely, where a formbound transaction is dependent on a formless transaction, but the second transaction is not made in the form required for the first transaction, the former will be void even if it meets the form requirements, while the latter will be effective, ${ }^{1534}$ since it is formless.

Apart from such units or dependent transactions, distinctions also need to be drawn between other arrangements which are not the main contract: Preliminary contracts (Vorverträge), but not LOI, usually need to fulfil the same form requirements as the main contract. ${ }^{1535}$ This is due to their nature: while the former is deemed to be binding if an obligation to conclude the main contract arises, the latter, just like other similar sounding documents, eg, a memorandum of understanding, are used during negotiations as tools to fix the status quo of the discussions. ${ }^{1536}$ Similarly, power of attorneys for such transactions require notarial authentication. ${ }^{1537}$

In cases of several transactions being joined as one contract and where that contract seems only partially invalid due to inobservance of a form requirement in one part, $₫ 139$ BGB (Teilnichtigkeit; Partial invalidity; see Section a. above) may apply, as a consequence of which the whole contract will become ineffective. ${ }^{1538}$ It provides that where related transactions are seen as one and the parts are not meant to 'fall together', the whole transaction is void, whereas only the non-conforming part will be void

1533 See ibid. cf Roth (fn 1079) para 31, stating that the latter does not require to be made in any form but does not mention the consequences.

1534 Maier-Reimer (fn 1302) 3743.

1535 Wolf and Neuner (fn 48) 512 para 22. Preliminary agreements only need to be made in the same form as the main contract where the function of the form requirement is to caution, not where it is for documentary purposes or otherwise, as the purpose can still be realised if the main contract is made in that form. See on this Mertens (fn 1300) 436.

1536 See Mertens (fn 1300) 436.

1537 See BGH decision of 29 February 1996 (fn 1303) para 11.

1538 This is the majority view in academic opinion (herrschende Lebre), see Roth (fn 1079) para 31. On this application, see Roth, ibid. See further Wolf and Neuner (fn 48) 520 para 57, who go on to state at para 58 that there are only a limited number of exceptions to this principle, eg, $\$ 550$ BGB (Form des Mietvertrags; Form of the lease agreement). Cf Maier-Reimer (fn 1302) 37443745 , who is critical of using this provision when there is a contract and a Nebenabrede and argues that $\$ 140$ BGB (Umdeutung; Re-interpretation) ought to be applied instead of $\$ 139$. Accordingly, the part fulfilling the form requirement would be valid, if the parties would have entered into the agreement without the void part, see ibid. 
if 'it is to be assumed that [the remaining transaction] would have been undertaken even without the void part'. ${ }^{1539}$

\section{dd) Healing and Other Ways of Avoiding the Consequences of Non- fulfilment}

There is, in some circumstances of voidness, a possibility to heal the imperfection, namely, where the contract's bindingness is ensured through some means other than the required form. ${ }^{1540}$ In relation to declarations of suretyship, $\$ 766$ BGB foresees that a lack of form will be healed by 'the surety discharg[ing] the main obligation' ('Soweit der Bürge die Hauptverbindlichkeit erfüllt [...]'). Similarly, effecting a gift will 'cure' the defect in form ( $\$ 518$ para 2 BGB). By analogy to these exceptions, the conclusion of a main contract (Hauptvertrag) is said to save a preliminary agreement (Vorvertrag) that did not fulfil some form requirement. ${ }^{1541}$ In cases of a signature being certified (see Section iii.bb) above), but where the notary's seal was not used, the notary's subsequent sealing of the document can heal the defect. ${ }^{1542}$ Furthermore, it has been held by German courts that registration of a fact can heal certain defects in the observation of formalities foreseen for the contract in question. ${ }^{1543}$ Similarly, $\$ 311 \mathrm{~b}$ para 1 BGB foresees that a contract for the sale of land not made in the form of a notarial authentication 'becomes valid with all its contents if a declaration of conveyance and registration in the Land Register are effected'. ${ }^{1544}$

1539 The original provision says: 'wenn [...] anzunehmen ist, dass es auch obne den nichtigen Teil vorgenommen sein würde.'

1540 Wolf and Neuner (fn 48) 519 para 56 and 520 para 59. cf Köbl (fn 1294) 217, who adds the caveat that the causal transaction (Kausalgeschäft) must have been fulfilled.

1541 See Köbl (fn 1294) 217.

1542 Hertel, ‘ $\$ 129 B G B$ ' (fn 1407) para 101.

1543 See, eg, BGH decision of 17 October 2017, KZR 24/15, paras 15, 34, 27-30, in which the defects in the form of an increase in capital of a German limited company (Gesellschaft mit beschränkter Haftung, $\mathrm{GmbH}$ ) and those in an acquisition through shares were held to have been healed through the registration of the former in the German Commercial Register (Handelsregister).

1544 The original provision reads: 'Ein obne Beachtung dieser Form geschlossener Vertrag wird seinem ganzen Inhalt nach gültig, wenn die Auflassung und die Eintragung in das Grundbuch erfolgen'. The declaration of conveyance (Auflassung) in accordance with $\$ 925$ para 1 BGB involves the buyer and seller of the land in question declaring their agreement to the transfer of ownership before a 


\section{B. Comparative Background}

While these statutory curing methods exist, the parties are not free to stipulate their own healing clauses. In practice, what are termed Schriftformbeilungsklauseln (literally 'written form healing clauses') are often used and oblige the parties to do everything necessary to ensure that a written form that has not been met be fulfilled. ${ }^{1545}$ It has been held by the BGH that such clauses are not admissible in relation to $₫ 550 \mathrm{BGB}$, as the provision on leases contains a mandatory regulation foreseeing a particular consequence if the prescribed form is not met. ${ }^{1546}$ Thus, it seems that where German law foresees a legal consequence deviating from the general rule contained in $\$ 127 \mathrm{BGB}$, the parties' Schriftformheilungsklausel will not be effective. Arguably, this should equally apply to instances in which the law foresees other healing mechanisms, such as performance of the transaction (see above).

Where healing is achieved, the legal transaction will usually display its effects ex nunc, ie, from the time of healing. ${ }^{1547}$ Furthermore, the parties may have foreseen a severability clause in their standard terms, which may provide that the contract be valid despite an agreed form requirement not having been met. ${ }^{1548}$ Under exceptional circumstances, the principle of good faith demands that a contract be upheld despite the required formalities not having been fulfilled. ${ }^{1549}$

The problem of non-fulfilment of a form can be avoided altogether, as it is possible to use a form which is seen to be on a higher level than the form that is required. ${ }^{1550}$ This has been expressly provided for in $\$ 126$ paras 3 and 4 BGB, which stipulate that the written form may be replaced by the electronic form or a notarial authentication respectively. Logically, while no corresponding provision is found for the text form, it should nevertheless be possible to replace this form with any other form, seeing as it is said to be the lowest level of form. ${ }^{1551}$

notary in the other party's presence (ibid). Although this declaration is made before a notary, just like the authentication procedure, the two are distinct acts. See Köbl (fn 1294) 209.

1545 See, eg, BGH decision of 27 September 2017 (fn 1157) para 27.

1546 See ibid paras 28-29, 36-37, 39.

1547 See Wolf and Neuner (fn 48) 520 para 59. See also Hertel, ' $\mathbb{1} 129$ BGB' (fn 1407) para 101.

1548 Compare Roth (fn 1079) para 22.

1549 See on this briefly, eg, BGH decision of 24 April 1998 (fn 1097) para 18.

1550 Wolf and Neuner (fn 48) 101 para 39, 508 para 1.

1551 See Einsele, ' $\$ 126 b B G B$ ' (fn 1342) para 10; FormAnpG Draft Law (fn 1342) 20. 


\section{c. Other Requirements under German Law}

As has been stated above, German law requires acts beyond a mere agreement between the parties to effect a change of ownership in particular cases, whereby these prerequisites do not count as form requirements. ${ }^{1552}$ Two types will be considered briefly. First, the delivery of the object and registration of title (Section aa) below). Secondly, another act that will be considered is the handing over of Draufgabe (earnest), but which is not constitutive for contracts (Section bb)).

\section{i. Delivery and Registration of Property}

Certain acts are required under German property law beyond an agreement in rem (dingliche Einigung; with immovable property known as 'Auflassung' $)^{1553}$ between the parties in order to effect the transfer of ownership of both movable and immovable property. ${ }^{1554}$ The kind of act that is necessary depends on whether the object is movable or immovable: The former is regulated in $\$ 929 \mathrm{BGB}$; whereas the latter is governed by $\$ 873$ and $₫ 925$ BGB. ${ }^{1555}$

While movable property must generally be delivered to the purchaser to effect a transfer of property ( $\$ 929 \mathrm{BGB}$, Einigung und Übergabe; Agreement and Delivery), the parties can substitute physical delivery by an agreement that gives the buyer 'indirect possession' ('mittelbarer Besitz',

1552 See Köbl (fn 1294) 209. cf Wolf and Neuner (fn 48) 312 para 4, who speak of 'acts of execution'. Similarly, Singer (fn 1058) para 5 speaks more generally of further requirements to legal transactions.

1553 See Gaier (fn 1068) para 7. It seems that the etymological origin of the word relates to a ritual that used to be practiced in former times: The former owner of a house would perform certain acts, such as opening (in German: aufmachen or öffnen) doors and windows, before leaving the house. Thus, the owner would leave the house open (in German: 'offen' or 'auf lassen'). Another person would then enter the house and close all openings, thus becoming the new owner. On this ritual, see Plewe (fn 1015) 1; Köbl (fn 1294) 216.

1554 The underlying reasons for these further requirements are transparency of law (Rechtsklarheit) on the one hand and legal certainty (Verkehrsschutz) on the other, see Ernst (fn 832) para 22. cf Wolf and Neuner (fn 48) 226 para 53, who speak of registration being a publication method (Publizitätsmittel).

1555 See Wacke (fn 1071) 255. 


\section{B. Comparative Background}

$\int 930$ BGB). ${ }^{1556}$ The law on immovable property is more complex: Ownership over land must be registered in order to be effective (see $\mathbb{S} 873$ para 1 BGB). ${ }^{1557}$ Thus, it could be said that a contract concerning land is not complete once the contract is formed, but when the registration of the new ownership is made. Having said this, once the Auflassung to real estate has been made and is binding under $\$ 873$ para $2 \mathrm{BGB}$, and either an application for the registration of the transfer of ownership has been made, or a Vormerkung (priority notice) has been registered in favour of the buyer, the seller cannot stop ownership from passing, as this will occur automatically ipso iure once the registration of the ownership change is effected. ${ }^{1558}$ When a right concerning real estate has been entered into the register, a legal presumption assumes that the entry is correct and, consequently, that the beneficiary is duly entitled to it ( $\mathbb{S} 891$ para $1 \mathrm{BGB})$. This promotes legal certainty in favour of the beneficiary.

\section{ii. Draufgabe(Earnest)}

Similar to the ALR, the BGB contains provisions designed to strengthen a contract. These relate to Draufgabe (earnest) in $\$ \mathbb{S} 336-338$ BGB on the one hand and Vertragsstrafe (contractual penalty) in $\$ \mathbb{S} 339$ et seq BGB on the other. Only the former will be considered in this dissertation. ${ }^{1559}$ The first provision on Draufgabe, $\mathbb{} 336$ BGB (Auslegung der Draufgabe; Interpretation of earnest) provides:

1556 This legal fiction is known as Besitzkonstitut (constructive delivery). For further details on this, see ibid 259-260.

1557 See Wolf and Neuner (fn 48) 313 para 7, discussing registration as a requirement for effectiveness.

1558 For further details, including the buyer's right of an Anwartsschaftsrecht (expectant right), see ibid 224-225 paras 46-47.

1559 Readers interested in the regulation of contractual penalties in German law are referred to, eg, Manfred Löwisch, Vorbemerkungen zu $\int S 339 f f$ [Preliminary Remarks on $\mathbb{S} 333$ et seq], in: von Staudinger and others (fn 140; 2015), and subsequent entries in ibid. 
(1) Where something is given as an earnest when a contract is entered into, this is deemed to be a sign that the contract has been entered into.

(2) The earnest is not deemed, in case of doubt, to be forfeit money. ${ }^{1560}$

Both parts of this norm have a clarification purpose. Paragraph 1 clarifies the default function of Draufgabe as proof of a concluded contract, whereby para 2 foresees that whatever is handed over as earnest money is not automatically deemed as a vehicle to end the contract by either the giver forfeiting it or by the receiver returning it (or, say, double its amount), as had been standard practice in the alte Reich. ${ }^{1561}$ Thus, where earnest is given, this creates a legal presumption that a contract has been concluded. ${ }^{1562}$ Due to this symbolic function, Draufgabe has been referred to as a Perfektionszeichen (sign of perfection), as contrasted with a Perfektionsform (form for perfection). ${ }^{1563}$ Indeed, it seems that Draufgabe is of little to no importance in current legal practice, since the symbolism embodied in the gesture is no longer required today. ${ }^{1564}$

Despite its title, the provision does not address the question of what may constitute Draufgabe. Rather, it is merely a statutory interpretation rule (Auslegungsregel). ${ }^{1565}$ The words 'etwas als Draufgabe gegeben' ('something is given as an earnest') of $\$ 336$ para 1 BGB have been interpreted to mean that any movable object that is corporeal is acceptable, eg, money, or even a glass of wine. ${ }^{1566}$ In particular where money is given, Draufgabe must be distinguished from an Anzablung (down payment): while both are a way to reinforce the formation of a contract, the latter constitutes partial

1560 The original provision states: '(1) Wird bei der Eingehung eines Vertrags etwas als Draufgabe gegeben, so gilt dies als Zeichen des Abschlusses des Vertrags.

(2) Die Draufgabe gilt im Zweifel nicht als Reugeld.'

1561 See Section 2.a.iii.ee) above. This notion is very different from the English doctrine of consideration, on which see Section II.3.a.v. above.

1562 This presumption is rebuttable by virtue of $\$ 292$ ZPO (Gesetzliche Vermutungen; Legal presumptions). See Manfred Löwisch, $\$ 336$ Auslegung der Draufgabe [Section 336 Interpretation of Earnest], in: von Staudinger and others (fn 140; 2015) para 1.

1563 See Gastreich (fn 942) 7.

1564 Indeed, this argument is used when criticising the fact that its provisions have been maintained when the BGB was reformed. Compare, eg, Löwisch (fn 1562) paras 4, 2. On the former use of Draufgabe, namely, as a substitute for performance in real contracts, see Section 2.a.iii.ee) above.

1565 See Löwisch (fn 1562) para 1.

1566 Ibid para 5. 


\section{B. Comparative Background}

performance, which the former does not, ${ }^{1567}$ although it can be 'credited against the performance owed by the giver of the earnest' ( $\mathbb{3} 337$ para 1 BGB). In accordance with $\$ 337$ para 2 BGB, Draufgabe must be returned if the contract is terminated; however, the receiver may keep it where the termination is due to the giver $(\mathbb{S} 338 \mathrm{BGB})$. Note that something that is given as earnest will only be deemed thus if the contract to which it relates comes into force. Conversely, if the contract is void ab initio and never comes into effect, the given object has no contract to relate to and thus cannot be earnest in the sense of $\$ \$ \$ 336$ et seq BGB. 1568

\section{d. Current Legal Practice in Germany}

Several legal practices exist in Germany that are of interest for the discussion of contract formation in this dissertation. It is often said that the aim for German lawyers in drafting contracts is to provide a framework for their clients that will enable them to have a well-functioning, often mid- or even long-term, relationship. ${ }^{1569}$ As such, care ought to be taken to ensure as much legal security as possible by means of the contract. ${ }^{1570}$ This does not entail that current legal practice is synonymous with contemporary legal regulation. Making use of statutory freedoms in arranging contractual relationships is of course one important part. Such freedom is provided

1567 See ibid para 7. See also Section 2.a.iii.ee) above.

1568 See OLG Köln decision of 27 April 1971, 15 U 126/70, NJW 1971, 1367-1369 paras 16 and 14, in which the court stated that Handgeld (money that is sometimes paid by soccer clubs to players with whom they wish to enter into a contract) might count as Draufgabe in the sense of $\$ 336$ BGB. It held that the provisions on this legal figure did not apply where the contract was void $a b$ initio, but only where a contract was rescinded after coming into effect. In this case, the contract negotiated between the claimant (soccer club) and the defendant (a potential new player of the claimant) was found to be void, since it had been agreed on the suspending condition (aufschiebende Bedingung) that the player's transfer from his current team be approved by the soccer association having jurisdiction in the applicable regional league. As this did not in fact occur, there was no contract and therefore no legal reason ('Rechtsgrund') for the payment. Accordingly, the court allowed the claimant's claim of the money under $\mathbb{8} 812 \mathrm{BGB}$ (Herausgabeanspruch; Claim for restitution) due to unjust enrichment. See paras 1-3, 13-14 of the decision.

1569 Compare, eg, Gerrit Langenfeld, Vorwort [Preface], in: Sebastian Herrler (ed), Münchener Vertragshandbuch Band 5: Bürgerliches Recht 1 [Munich Handbook on Contracts Vol 5: Civil Law 1] (Beck 2013) VI.

1570 Compare Langenfeld (fn 1569) VI-VII. 
principally by dispositive norms. In this sense, it is perhaps not surprising that the use of pre-formulated forms and standard terms (allgemeine Geschäftsbedingungen, AGB) is widespread in Germany. ${ }^{1571}$ These standard terms, as well as the different duties to inform consumers or provide documentation of a contract lead to long contract documents. ${ }^{1572}$ Furthermore, the regulation of these topics and of anti-discrimination is being critically discussed as a limitation of private autonomy. ${ }^{1573}$ Beyond the adherence to statutory requirements and voluntary regulation within the given statutory framework, some customary practices have been maintained despite having been deregulated, such as the handshake marking the conclusion of an agreement. ${ }^{1574}$ Conversely, there are former legal practices, such as Draufgabe (earnest), which, despite still being regulated, have gone out of fashion. ${ }^{1575}$

One important topic of late is related to digitalisation, namely, 'Legal Tech'. ${ }^{1576}$ It concerns the role of law and of legal practitioners in a world becoming increasingly run by automatic or otherwise digital processes, such as smart contracts, so that the law, or rather tools to wield it, become digitalised. ${ }^{1577}$ In this sense, the question is whether the practice of using individually pre-drafted clauses to 'build' contracts will in future be performed not by legal practitioners, but by any (lay)person through the use of contract generators (Vertragsgeneratoren), ie, collections of contract clauses that can be selected individually. ${ }^{1578}$ In contrast to this complete digitalisation, or rather, automatisation, the electronic contract form found in $\$ 126$ a BGB has not caught on in all areas, such as with lease contracts

1571 Compare Busche, 'Vor $\$ 145$ BGB' (fn 158) para 36.

1572 On these duties, see Section b.ii.cc) above.

1573 This topic goes beyond the scope of this dissertation. An excellent account of the discussion with further references are given by, eg, Karl Riesenhuber, Privatautonomie - ohne irrationale Schwärmerei [Private Autonomy - without Irrational Passion] (2019) Special Issue 14 ZJapanR / JJapanL 3-25.

1574 Compare Köbl (fn 1294) 220.

1575 This was discussed in Section c.ii. above.

1576 The following discussion draws from the work by Stephan Breidenbach and Florian Glatz (eds), Rechtshandbuch Legal Tech [Handbook on Legal Tech] $(\mathrm{CH}$ Beck 2018).

1577 Compare Stephan Breidenbach and Florian Glatz, Vorwort der Herausgeber [Foreword by the Editors], in: ibid (fn 1576) V, and ibid, Einführung [Introduction], in: ibid 2 para 7.

1578 Compare Breidenbach and Glatz, 'Einführung' (fn 1577) 2 para 7. 


\section{B. Comparative Background}

(Mietverträge). ${ }^{1579}$ The reason seems to be the strict requirements imposed on the electronic signature. ${ }^{1580}$

Another recent concern in German legal practice in relation to international contracts is the as yet unknown consequence of the exit of the UK from the EU (often simply referred to as 'Brexit'). ${ }^{1581}$ It is difficult, if not impossible, to foresee how the legal landscape will develop from the time of the UK's exit. Two popular alternatives are the continuation of the legal status quo on the one hand, versus a complete non-application of all EU law on the other. Due to this legal insecurity, German practitioners advise to regulate many aspects explicitly in the contract, especially terminology and rights of termination. ${ }^{1582}$ This may lead to longer contractual documents being drafted, which would mark a change in the established approach of concise phrasing and little if any inclusion of definitions in contracts, as reliance has traditionally been placed on statutory definitions or (German) interpretation rules.

\section{Summary of Results}

Modern German contract law has evolved from a mixture of customs, a German common law (gemeines Recht), and several eighteenth-century codifications, out of which the Allgemeines Landrecht für die Preußischen Staaten (General State Laws of the Prussian States) was discussed above. This Code in particular seems to be connected to the modern German Civil Code, the BGB, which was created at the end of the nineteenth century and is still the most important source for the rules on contract formation under German law.

Already in the eighteenth century, the modern basis of German contract theory, namely, the doctrine of a Rechtsgeschäft (juridical act) that is made up of and created by Willenserklärungen (declarations of intention) had emerged. Today, a contract is still analysed in terms of offer (Angebot or

1579 See Emmerich, ‘ $\$ 550$ BGB’ (fn 1156) para 17.

1580 See Wolf and Neuner (fn 48) 516 para 37. See further Section b.v.bb) above.

1581 On this event, see Section I.2.a.iv. above. On the German reaction, see, eg, Thomas M Grupp, Vertragsgestaltung in Zeiten von Brexit [Contract Drafting in Times of Brexit] (2017) NJW 2065, on which the following paragraph is based. The article discusses various aspects that may be affected, such as choice of law clauses or considerations of competition law, which will not be discussed here.

1582 See, eg, Grupp (fn 1581) 2067, 2070. cf the predictions made by English legal academics, discussed in Section I.2.a.iv. above. 
Antrag) and acceptance (Annahme). Both of these declarations are treated the same in their requirements. First, they must be certain and coincide in their content. Secondly, in order to become effective, the declaration must reach their addressee (Zugang). Before this occurs, they may be revoked (widerrufen), but become irrevocable thereafter. There are exceptions for offers, such as where the offeror has reserved themselves the right to withdraw the offer. In this way, the rules are simpler than under English law, where not only the rules on the effectiveness of declarations of intention are more diverse, but also because it has the requirement of consideration.

German private law, in contrast, does not foresee such a sign of earnestness as a constitutive element for concluding consensual contracts. In fact, although a concept vaguely similar to consideration and known as Draufgabe exists, it is no longer used in legal practice. Having said this, German law foresees a range of mandatory forms for contracts. These span a simple Textform to notarial deeds (notarielle Urkunden), a special document that is created in a highly formal procedure called a Beurkundung (authentication). Moreover, in a transaction involving immovable property, the transfer of property can only be effected by registering the change in ownership in the Grundbuch (land register). Having said this, everyday contracts, such as sales, can generally be concluded without adhering to any particular form, unless the parties have agreed on one. 


\section{Contracts in Japanese Law}

The conclusion of a contract under Japanese law follows the principle of consensuality and is governed uniformly on a national level. This was not always true. Over the course of history, contracts went from something regulated by local customs with variations across communities and, perhaps, social classes, to a pan-Japan standardised formula. The path of development shows radical changes, which have not only affected the way in which contracts are concluded, but also how they are understood. Before giving a definition of contracts in Japanese law in Section II. below and exploring the historical development of contract law and the current legal practice in Sections III. and IV. respectively, mention must be made of the exceptional character of Japanese law. In the final section (V.), the changes occurring in relation to the formation of contracts under the reform project of the Japanese Civil Code that has recently been completed will be considered.

\section{Classification of the Legal Tradition of Japanese Law and the Sources of $i$ ts Contract Law}

The Japanese legal system can be classified as a mixed legal system, ${ }^{1583}$ constructed from several inspirations, a composition referred to as unique. ${ }^{1584}$ The definition of the Japanese legal tradition will be elaborated further in the following section (1.), while its sources will be identified in Section 2.

1583 See Harald Baum and Moritz Bälz, $\mathbb{S} 1$ Rechtsentwicklung, Rechtsmentalität, Rechtsumsetzung [Chapter 1 Legal Development, Legal Mentality, Legal Implementation], in: ibid (fn 16) 2 para 2. Also see Keizō Yamamoto, Rechtsverständnis und Rechtsentwicklung: Die Erfahrungen der Rechtswissenschaft und Rechtspraxis in Japan [Understanding of Law and Legal Development: The Experiences of Legal Academia and Legal Practice in Japan], in: Grundmann and Thiessen (fn 40) 85, 90.

1584 Harald Baum and Eiji Takahashi, Commercial and Corporate Law in Japan: Legal and Economic Developments after 1868, in: Wilhelm Röhl (ed), History of Law in Japan Since 1868 (Brill 2005) 330, 331. 


\section{Classification of the Legal Tradition of Japanese Law}

The Japanese legal system can be described as a mixed system for several reasons. There is a general and a more detailed explanation. The basic idea comprises the following two aspects: First, the Japanese legal system has incorporated legal concepts from various countries, adapting these to its own needs. ${ }^{1585}$ Secondly, and more importantly, these principles stem from different origins: While 'traditional' Japanese law (ie, that law in existence before the reception of Western legal concepts; 'indigenous'1586) was influenced by Chinese norms, ${ }^{1587}$ the modern regime moreover incorporates concepts of both civil- and common law origin; namely, from France and Germany, and the US and the UK respectively. ${ }^{1588}$ As will be

1585 See Wilhelm Röhl, Generalities, in: ibid (fn 1584) 1, 23, who speaks of the foreign laws being 'japanized', meaning that the concepts were merged with 'indigenous ideas' and subsequently interpreted in a Japanese fashion by legal academics. Another term used in this context is 'assimilation', see Baum and Takahashi (fn 1584) 331. Also see Baum and Bälz (fn 1583) 2 paras 2-3, who use the term 'acculturation' ('Akkulturation') to describe this process.

1586 This term is used by several authors including Yamamoto K, 'Rechtsverständnis' (fn 1583) 86, who defines this as the law existing in Japan, different from the law received from the West, and reflecting the Japanese way of looking at law (Rechtsbewusstsein), ie, as the law that was marked by Japanese culture and society, see ibid 92-95.

1587 This occurred in the Ancient and the Classical eras (between sixth and eighth century), see Röhl, 'Generalities' (fn 1585) 23; see also Christiane C Wendehorst, Rezeption deutschen Zivilrechts - Was bleibt übrig im 21. Jahrhundert? [Reception of German Civil Law - What Remains in the $21^{\text {st }}$ Century?], in: Jörg-Martin Jehle and others (eds), Rezeption und Reform im japanischen und deutschen Recht [Reception and Reform in Japanese and German Law] (Universitätsverlag Göttingen 2008) 19, 20. For a brief summary of the objectives of this reception, see Yamamoto K, 'Rechtsverständnis' (fn 1583) 88. Contrast Paul H-C Ch'en, The Formation of the Early Meiji Legal Order: The Japanese Code of 1871 and its Chinese Foundation (OUP 1981) xix (foreword) and 21-24, who traces the main inspiration of law during the first years of the Meiji (明 治) era (between 1867 and 1882) back to Chinese institutions, in particular with regard to criminal law. He concedes, however, that this influence was only strong to begin with and declined as the interest in Western legislation increased. For further information on the periodisation of Japanese history adopted in this dissertation, see Carl Steenstrup, A History of Law in Japan Until 1868 ( $2^{\text {nd }}$ edn, Brill 1996) 192-195.

1588 These incorporations occurred mainly in the Meiji, Taishō (大正), and Shōwa (昭和) eras respectively, see Röhl, 'Generalities' (fn 1585) 23, 28. See Steenstrup (fn 1587) 194 for how these periods are identified. Depending on the system used to classify legal traditions, the civil law system inspiration can be broad- 
seen, the influence of German and English law is particularly relevant in the formation of contracts.

A more - perhaps even the most - comprehensive analysis of the nature of the Japanese legal system is achieved by applying five factors that Zweigert and Kötz have identified as those aspects which affect a country's 'legal style' (Rechtsstil): the legal system's historical origin and development; its predominant legal thinking; specific characteristic legal institutions; legal sources and their interpretation; and ideology, in particular religious or political factors. ${ }^{1589}$ These aspects will be analysed separately, starting with the sources (Section 2.) and the historical development of Japanese contract law (Section III.). Characteristic aspects of the law will be identified in Section IV.1. below. Finally, the legal way of thinking in Japan will be considered in Section IV.2.

It should be noted that while the origins of several legal concepts vary, ${ }^{1590}$ the Japanese tendency to interpret them according to German legal theory irrespective of their origin has led to the original connection being lost, ${ }^{1591}$ so that the current Japanese understanding of such concepts cannot be explained by mere reference to the legal theory of the country of

ened further, since the influence stems from civil-germanic (German law; see on this Section B.I.1. above) and civil-roman (French law) traditions, compare Zweigert and Kötz (fn 15) 68.

1589 Zweigert and Kötz (fn 15) 67-73, in particular 68-71. The authors note that the style of hybrid systems, which cannot be assigned to one tradition, should be categorised according to the current predominant legal orientation.

1590 This contrasts with the often-held misconception that modern Japanese private law is basically a replica of the German Bürgerliche Gesetzbuch ('BGB'). In fact, although it may appear to be so from its structure, the content of the Japanese Civil Code (Minpō, see fn 1606 below) follows first one and then another inspiration. See Roland R Bahr, Das rechtliche Verbältnis von Grundstück und Gebäude als Beispiel [The Relationship Between Land and Buildings as an Example], in: Heinrich Menkhaus (ed), Das Japanische im japanischen Recht [The Japanese in Japanese Law] (Iudicum 1994) 103, 111. Further reasons for this being a misconception are given by Zentarō Kitagawa, Rezeption und Fortbildung des europäischen Zivilrechts in Japan [Reception and Subsequent Development of European Civil Law in Japan] (Alfred Metzner Verlag 1970) 34-35, 43.

1591 Yamamoto K, 'Rechtsverständnis' (fn 1583) 91. See also Tanaka and Smith (eds), The Japanese Legal System: Introductory Cases and Materials (10 ${ }^{\text {th }}$ edn, UTP 2000; fn 2) 189-190, 242-245. 
origin. ${ }^{1592}$ This split between the country of origin of a legal provision and the legal dogma applied to it has thus created a dual structure system. ${ }^{1593}$

\section{Sources of Japanese (Contract) Law}

Japanese contract law has various sources on different levels. The first and most important one is naturally the contract itself. ${ }^{1594}$ The sources of the Japanese legal system are secondary, but they are numerous and of two natures. On the one hand, there are several 'legal' sources, namely: general and specific pieces of legislation (the specific term for enactments, like an act or a code, is horitsu, 法律; while the collective term for laws and regulations is horei, 法令 1595 , see Section b. below), and case law (hanrei, 判例, Section c.). Furthermore, there are international treaties, out of which the CISG is relevant for the present discussion, as it may come into play in relation to cross-border contracts.

On the other hand, the Japanese legal system, just like the English and German legal system, ${ }^{1596}$ has known a range of other, parallel forms of regulation besides law for a long time. These are: most importantly customs (kanshü, 慣習) ${ }^{1597}$, eg, in commerce, or of distinct classes of people

1592 This seems to be a natural consequence, since Alan Watson, Legal Transplants: An Approach to Comparative Law ( $2^{\text {nd }}$ edn, University of Georgia Press 1993) 27 notes that '[a] successful legal transplant [...] will grow in its new body, and will become part of that body [...].'

1593 See Kitagawa, 'Rezeption' (fn 1590) 24. He goes on to note that Japanese law has developed a kind of German legal character due to the double influence of German law and German dogmatism, ibid. It should be noted that this observation was made some 45 years ago, and indeed Kitagawa himself points out that the 'Germanness' of Japanese law is being questioned (see ibid), and proceeds by listing differences between the Japanese Civil Code and the BGB, see ibid 34-35.

1594 See, generally, Smits (fn 37) 16-17.

1595 This term ought not to be confused with the former Japanese legislation concerning the application of laws, '法例' (hōrei), which has been replaced by the Hō no tekiyō ni kansuru tsūsoku-hō, 法の適用に関する通則 法, General Rules for Application of Laws, Law No 78/2006. An English translation is available online at www.japaneselawtranslation.go.jp/law/detail/? $\mathrm{id}=1970 \& v m=04 \& \mathrm{re}=2 \&$ new $=1$.

1596 On this, see Sections B.I.2.a. and B.I.2.b. above respectively.

1597 A first official definition of the Japanese Justice Department from the end of the nineteenth century termed 'custom' to be 'whatever has been enforced by the prefectural offices and law courts', and later also included 'traditional pop- 


\section{Contracts in Japanese Law}

like samurai, villagers, or towns-people; ${ }^{1598}$ jöri (条理) ${ }^{1599}$; and giri (義 理). ${ }^{1600}$ These norms are of varying importance today; however, neither is relevant for the formation of contracts. Kansh $\bar{u}$, whether of civil or commercial nature, may generally come into play as a subsidiary source of law where a matter is not regulated by statutory provisions, ${ }^{1601}$ and are taken into account when interpreting the content of a contract, ${ }^{1602}$ whereas the courts sometimes rely on the principle of jori in their reasoning. ${ }^{1603}$ On the

ular practice' as that 'recognized by civil law'. The second official definition was: 'those usages not contrary to reason [ie, the logic of things, jöri, see below] which are recognised by civil law as popular practices and precedents heretofore in use between the government and the people'. See on this Ryōsuke Ishii (ed) and William J Chambliss (tr), Japanese Culture in the Meiji Era, Vol IX: Japanese Legislation in the Meiji Era (repr edn, The Toyo Bunko 1969) 5051; also see Röhl, 'Generalities' (fn 1585) 123. This definition coincides with the translations found in the Dictionary of Standard Japanese Legal Terms (fn 9) 569 as 'custom', 'usage', or 'practice'. A commercial custom is considered to be a use or convention (決まり, kimari) of commercial transactions that is promoted to the level of a custom by the legal consciousness (法意識, hō-ishiki), see Kiyoshi Endō and Kazuhisa Matsuda, Puchi konmentāru: shōōō sōsoku, shōkō'i-hō [Small Commentary: Commercial Law, General Provisions and Commercial Transactions] (revised edn, Zeimu Keiri Kyōkai 2015) 3.

1598 See Steenstrup (fn 1587) 122, 66, 136, and 137-139 respectively.

1599 Jöri is often translated as 'reason', 'Natur der Sache' (nature of things), 'natürliche Vernunft' (natural common sense), or 'natural reason'. See Wilhelm Röhl, The Courts of Law, Appendix: Execution of Penalty, in: ibid (fn 1584) 711, 731; Rahn, 'Rechtsauffassung' (fn 1600) 89, 88; and Tanaka and Smith (fn 2) 125 respectively. This seems to flow from the concept itself, which has been described as 'an ideal picture of how the law should be' ('ein Idealbild vom Recht, wie es sein sollte.'). See Wilhelm Röhl, Rechtsgeschichtliches zu Jöri [The Legal History of Jori ], in: Menkhaus (fn 1590) 39, 43. For an extensive account on the meaning of jori and its (etymlogical) development from the Ancient era onwards, see ibid 39-49.

1600 Guntram Rahn, Rechtsdenken und Rechtsauffassung in Japan [Legal Thinking and Legal Opinion in Japan] (Beck 1990) 51 describes giri as a social obligation to express one's thankfulness ('Dankespflicht').

1601 See Zentarō Kitagawa, Contracts and Business Activities, in: ibid (ed), Doing Business in Japan (Bender 1980, 2017 release of loose-leaf work) Vol $2 \$ 2.01[1]$ [a] at 2-20.1 and $\$ 2.01[3][\mathrm{a}]$ at 2-27-2-28. Nevertheless, this seems to not have happened in relation to contract formation.

1602 Sei'ichirō Ueda, Dai-3-hen dai-2-chō keiyaku [zenchü] [Part 3 Chapter 2 Contracts [Preliminary Note]], in: Hisakazu Matsuoka and Kunihiro Nakata (eds), Shin konmentäru minpō (zaisan-hō) [New Commentary on the Civil Code (Property Law)] (Nihon Hyōron-sha 2012) 753, 756.

1603 See Hans-Peter Marutschke, Einführung in das japanische Recht [Introduction to Japanese Law] ( $2^{\text {nd }}$ edn, Beck 2010) 11, who states that jöri is most often 
other hand, giri is of a social nature and thus embedded in the Japanese mentality, rather than its law. As none of these concepts is relevant, they will not be examined further in this dissertation. Before elaborating on each of the above-named sources, their inter-relationship will be briefly explored.

\section{a. The Inter-relationship of the Sources of Japanese (Contract) Law}

To avoid a clash of different sources on a single matter, Japanese contract law follows a specific order of application, ${ }^{1604}$ beginning with - where applicable - special commercial statutes (shöji tokubetsu-hō, 商事特別法), followed by the Japanese Commercial Code (Shōhō, 商法, hereinafter 'Shōhö'), ${ }^{1605}$ commercial customs (shō-kanshu, 商慣習); otherwise beginning with special civil statutes (minji tokubetsu-hō, 民事特別法), followed by the Japanese Civil Code (Minpō, 民法, hereinafter 'Minpō'1606), and (civil) customs (minji kanshū, 民事慣習). In accordance with art 98 para 2 Japanese Constitution (Nihon-koku Kenpō, 日本国憲法, hereinafter

used in relation to questions of private international law, although it has also been applied in, eg, tort cases. This practice seems to have existed before the Middle Ages and continued until the Meiji era, as evidenced by art 3 Rules for the Conduct of Court Affairs (Saiban jimu kokoro'e, 裁判事務心得) of 1875 (Government Decree No 103/1875; English translation available in Ishii and Chambliss (fn 1597) 307-308). In the wake of the modernisation of Japanese law during the Meiji era, jöri as a standard for (legislated) law disappeared; however, it may be that jori 'lives on as a source of law and therefore as a basis for decision-making in [legal] practice', see Röhl, 'Jöri' (fn 1599) 49. cf Marutschke, 'Einfübrung' (fn 1603) 12, who states that the Rules for the Conduct of Court Affairs are said to be still in force.

1604 Kitagawa, 'Contracts' (fn 1601) $\$ 2.01[1][\mathrm{b}][$ iii] at 2-20.2-2-21. In the sphere of commerce, this order may generally be preceded by commercial autonomous regulation (shöji jichi-hō, 商事自治法), such as company statutes, and commercial treaties (shöji joyaku, 商事条約) from international law, see Endō and Matsuda (fn 1597) 9.

1605 See arts 501-503 Shōhō (Law No 48/1899 as amended; English translation available online at www.japaneselawtranslation.go.jp/law/detail/? $\mathrm{id}=2135 \& \mathrm{vm}=04 \& \mathrm{re}=02 \&$ new $=1$ ).

1606 Law No 89/1896 and No 91/1889 as amended. An English translation (taking into account amendments until 2006) is available online at www.japaneselawtranslation.go.jp/law/detail/?id $=2057 \& v m=04 \& \mathrm{re}=2 \&$ new $=1$ (Books $1-3$ ) and www.japaneselawtranslation.go.jp/law/detail/?id $=2058 \& v m=04 \& \mathrm{re}=2 \& n e w=1$ (Books 4-5). 
'Kenpo' ${ }^{1607}$ ), international treaties (jōaku, 条約) 'concluded by Japan [...] shall be faithfully observed'. ${ }^{1608}$ While it is therefore clear that treaties such as the CISG are to be observed, the constitution does not state explicitly whether these have superior rank to other national laws (arguably, except for the constitution itself, as it is 'the supreme law of the nation' ('国の最 高法規であつて’, kuni no saikō hōki de ate, see art 98 Kenpōo). Nevertheless, as will be seen in Section E.I.1. below, the automatic applicability of the CISG to international contracts - unless the parties provide otherwise solves this question.

By way of exception, this order is not followed in relation to consumers. This is because Japanese consumer law is geared towards the protection of the consumer, ${ }^{1609}$ so that it is given priority over other enactments. As a consequence, consumer legislation is applied first; the Minpō - not the $S h \bar{o} h \bar{o}$ - only comes into play if there is no applicable consumer regulation. This means that $\mathrm{B} 2 \mathrm{~B}$ transactions are governed primarily by the $S h \bar{o} h \bar{o}$, while B2C or C2C transactions are governed either by Japanese consumer law or the Minpō.

In the exposition of Japanese contract law in Section IV. below, these two orders of application will be kept in mind; however, the rules contained in the 'basic' laws, ie, in the Minpō or the Shōhō, will be set out first, whereby deviating norms found in special regulation will be highlighted where appropriate.

b. Japanese Legislation: Hōrei (法令), Japanese Laws and Regulations

Japanese contract law is regulated in three main areas: First, the Minpo is the general, default source. ${ }^{1610}$ It sets out all the general rules for contracts

1607 Constitution of 3 November 1946. An English translation is available online at www.japaneselawtranslation.go.jp/law/detail/?id=174\&vm=04\&re=2\&new=1.

1608 The original provision states: ‘日本国が締結した条約[...]は、これを誠実に遵 守することを必要とする’ (nibon-koku ga teiketsushite joyaku [...] ha, kore wo seijitsu ni junshu suru koto wo hitsuyō to suru).

1609 See Section b. below.

1610 Despite its place at the end of the order of application (see Section a. above), the Minpo is of great importance in Japanese contract law, as the sources that have priority over it, like the $S h \bar{o} h \bar{o}$, do not regulate all matters exhaustively. Thus, the rules contained in the Minpo may apply, even when other sources are a priori applicable. On the $S h \bar{o} h \bar{o}$, see Kitagawa, 'Contracts' (fn 1601) $\$ 2.01[1]$ $[\mathrm{c}][\mathrm{ii}][\mathrm{D}][\mathrm{II}]$ at 2-26. 
in the fifth Part (boritsu köi, 法律行為; Juristic Acts) ${ }^{1611}$ of its first Book (sōsoku, 総則; General Provisions) and in the first two Parts (sōsoku, and keiyaku, 契約; Contracts, respectively) of its third Book (saiken, 債権; Obligations). ${ }^{1612}$

Secondly, the Shōhō contains contract rules for commercial transactions (sho-kōi, 商行為), ie, transactions between merchants (shönin, 商人), whereby 'merchant' is defined as 'a person who engages in the business of conducting a commercial transaction in his/her own name' (art 4 para 1 Shōhō). ${ }^{1613}$ Having said this, the Shöhö's provisions can also apply to transactions between a merchant and a private individual (a non-merchant, hi-shönin, 非商人) ${ }^{1614}$, where the transaction constitutes a commercial act for at least one of the parties (art 3 para $1 S h \bar{o} h \bar{o}) .{ }^{1615}$ This is true for,

1611 Translation taken from the source indicated in fn 1606. cf the translation contained in the Dictionary of Standard Japanese Legal Terms (fn 9) 246: 'juridical act'.

1612 Translation of 'saiken' as 'obligations' by this author. The translation of this term proves difficult, as there seems to be no one English word that reflects the meaning of the term in all situations, see Kashiwagi, '2014' (fn 6) 5-6. Thus, in relation to private law, a more specific translation may be 'claim', see, eg, the English translation of the Minpō (fn 1606) and the Dictionary of Standard Japanese Legal Terms (fn 9) 107. Legal academics also often use the German equivalent, 'Forderungen', see, eg, Keizō Yamamoto, $\mathbb{S} 10$ Vertragsrecht [Chapter 10 Contract Law], in: Baum and Bälz (fn 16) 465 para 5. A more literal translation might be 'obligatory rights', see, eg, Kitagawa, 'Contracts' (fn 1601) $\$ 2.01[1][\mathrm{c}] 2-23$, who also gives the German translation as 'Forderungen'. While the last translation perhaps expresses the meaning of the word more exactly than 'obligation', since the two kanji in this compound-word, sai (債) and ken (権), mean 'obligation' and 'right' respectively, 'obligation' will be used hereinafter. Nevertheless, the true (literal) meaning should be borne in mind.

1613 The original definition states: ‘自己の名をもって商行為をすることを業とす る者' (jiko no mei wo motte shō-kōi wo suru koto wo gyō to suru mono). 'Commercial' conduct is defined in arts 501-503 Shōhō. Endō and Matsuda (fn 1597) 82 state that an act counts as being commercial even where it is carried out only once. For further discussion of these provisions, see Endō and Matsuda, ibid 13-16 (art 4) and 81-86 (arts 501-503).

1614 The Japanese term is used by, eg, Endō and Matsuda (fn 1597) 11. Toshie Ōtsuki, Ippō teki shō-kōi ni okeru shōhō no tekiyō ni kansuru ichi-kōsatsu [Regarding the Application of the Shōhō to One-sided Commercial Acts] (1984) Chūō Gaku'in Daigaku Ronsō 87, at, eg, 92 uses the more complicated phrase 'bi-shōköi-sei toji-sha' (非商行為性当事者), which can be translated as 'a party acting non-commercially'.

1615 See Kitagawa, 'Contracts' (fn 1601) $\mathbb{2} 2.01[1][\mathrm{c}][\mathrm{ii}][\mathrm{D}]$ at 2-25, who points out that while the Shōbo will always be applicable when all the parties are merchants, it will 'often' be applicable where one party is a non-merchant. 
eg, arts 507 and 508 (Offer of contract between merchants — 'in direct communication' and 'at distance'1616);1617 but not for provisions which apply only where both parties are merchants, such as arts 524-528 (Sale, 売 買, baibai). ${ }^{1618}$

Thirdly, beside these general laws, ${ }^{1619}$ other special civil or commercial laws may apply in particular cases, ${ }^{1620}$ such as with transactions involving a commercial party (a merchant or business operator ${ }^{1621}$, jigyo-sha, 事業 者) and a private individual (a consumer, shōhi-sha, 消費者), which are regulated in a series of laws concerning consumers. ${ }^{1622}$ The regulation in

Arguably, the $S h \bar{o} h \bar{o}$ will not be applicable where a special commercial statute comes into play, see the inter-relationship of the laws outlined in Section a. above. Note that the provision contained in art 3 para $1 S h \bar{s} \bar{o}$ avoids the situation of two sets of laws being applicable simultaneously to the transaction, compare Endō and Matsuda (fn 1597) 11.

1616 The original titles are: ‘対話者間における契約の申込み’ (taiwa-sha-kan ni okeru keiyaku no möshikomi) and ‘隔地者間における契約の申込み’ (kakuchisha-kan ni okeru keiyaku no moshikomi) respectively. These two terms will be explained in Section IV.1.a.ii.dd below. Note that the slightly misleading translation of the provisions' titles as 'between merchants' is from the official English translation (fn 1605).

1617 Ötsuki (fn 1614) 98-100. The explanation for this interpretation lies in the historical development of the stipulation on the one hand, and on its location within the Shōhō on the other, see Seiji Tanaka and others, Konmentāru shō-kōihō [Commentary on the Law of Comemercial Acts] (Keisō Shobō 1973) 91, 93.

1618 Endō and Matsuda (fn 1597) 11.

1619 A succinct overview over the regulations contained in each of these laws can be found in Yamamoto K, 'Vertragsrecht' (fn 1612) 464-466. For a marginally more detailed outline, see Kitagawa, 'Contracts' (fn 1601) \$2.01[1][c][ii] at 2-22-2-26.

1620 Kitagawa, 'Contracts' (fn 1601) \$2.01[1][a] at 2-20.1.

1621 Dictionary of Standard Japanese Legal Terms (fn 9) 130.

1622 The first Japanese law to use the term 'consumer' explicitly was the Basic Consumer Act (Shōhi-sha kihon-hō, 消費者基本法，Law No 78/1968 as amended; hereinafter 'Shōhi-sha kihon-hö'. An English translation is available online at www.japaneselawtranslation.go.jp/law/detail/? $\mathrm{id}=2040 \& \mathrm{vm}=04 \& \mathrm{re}=02 \& \mathrm{new}=1$.), which initially bore the title of Basic Consumer Protection Act (Shōhi-sha kihon hogo-hō, 消費者基本保護法), see Kunihiro Nakata, Shōbi-sha-hō to ha nani ka [What is Consumer Law?], in: ibid and Naoko Kano (eds), Kihon kōgi shōhi-sha-hō [Basic Lecture of Consumer Law] ( $2^{\text {nd }}$ edn, Nihon Hyōron-sha 2016) 2, 3-4. Interestingly, the Shōhi-sha kihon-hō does not apply where both parties are merchants, see Nakata, ibid, 15 . Note that according to the predominant academic view, mixed purpose transactions (混合目的取引, kongō mokuteki toribiki) are treated as consumer transactions, unless purely for business purposes, see Nakata, ibid 15 . 
this field is not systematic, but rather developed on a piecemeal basis from high profile cases. ${ }^{1623}$ It is perhaps due to this unsystematic development that no uniform definition of the terms 'consumer' and 'merchant' exists; instead, some consumer laws contain their own definitions. ${ }^{1624}$ Nevertheless, there is some accordance. Thus, a consumer can be described as an individual who does not act for business but private reasons, whereas a merchant acts in the course of their business. ${ }^{1625}$ To complicate matters further, some laws deemed part of this field do not use the term consumer at all, such as Tokutei shö-toribiki ni kansuru höritsu (hereinafter 'Tokutei shö-toribiki-hö ${ }^{1626}$ ), the Shöbi-sha kihon-hö, or the Minpō. ${ }^{1627}$ Irrespective of this terminology problem, it should be noted that these consumer laws do not contain provisions that apply directly to the scope of this dissertation. This is because Japanese consumer law does not regulate the conclusion of contracts in terms of offer, acceptance, and formal requirements. And while it does foresee a range of provisions that relate to the conclusion process of a contract, these are often based on either misrepresentation

1623 See Marc Dernauer, $\mathbb{S} 13$ Verbraucherschutz [Chapter 13 Consumer Protection], in: Baum and Bälz (fn 16) 567, 569 paras 3, 7. Zentarō Kitagawa, Business Law in New Fields, in: ibid (ed), Doing Business in Japan (Bender 1980, 2010 release of loose-leaf work) Vol $5 \$ 15.04[3][\mathrm{b}][\mathrm{i}]$ at 15-35-15-36 likewise notes that Japanese administrative consumer regulation takes a 'product-by-product approach', whereby one product may be regulated in various laws due to its different purposes. The situation is complicated further by the fact that beside national civil and administrative legislation, regulations are also adopted by local governments, so that local variations may exist that also have to be taken into account, see Kitagawa, ibid $\mathbb{1} 15.04$ [3][b][iii] at 15-37.

1624 For details on this situation, see Dernauer, 'Verbraucherschutz' (fn 1623) 570 para 4.

1625 Compare, eg, art 2 para 2 Act on Special Provisions to the Civil Code Concerning Electronic Consumer Contracts and Electronic Acceptance Notice (Denshi shōhi-sha keiyaku oyobi denshi shödaku tsüchi ni kansuru minpō no tokurei ni kansuru bōritsu, 電子消費者契約及び電子承諾通知に関する民法の 特例に関する法律, Law No 95/2001; hereinafter 'Denshi keiyaku-hö'; English translation is available online at www.japaneselawtranslation.go.jp/law/detail/? $v m=04 \& i d=116 \& l v m=02 \& r e=02$ ). The notions of 'consumer' and 'merchant' are explained and contrasted by Nakata, 'Shōhi-sha-hö' (fn 1622) 14-17.

1626 Act on Specified Commercial Transactions, 特定商取引に関する法律, Law No 57/1976 as amended; English translation available online at www.japaneselawtranslation.go.jp/law/detail/?id $=2065 \& v m=04 \& \mathrm{re}=02 \& \mathrm{new}=1$. Note that the title of this law was formerly Hömon hanbai-tō ni kansuru hōritsu (訪問販売 等に関する法律, Act on Door-to-Door Sales etc) until it was amended by Law No 120/2000, Dernauer, 'Verbraucherschutz' (fn 1623) 575 in fn 15.

1627 Nakata, 'Shōhi-sha-hö' (fn 1622) 4-5. 


\section{Contracts in Japanese Law}

by the offeror, or mistake on part of the consumer, ${ }^{1628}$ both issues of which are not covered in the present discussion. ${ }^{1629}$ This is in line with the general aim of Japanese consumer law, namely, to protect consumers. It would therefore be more appropriate to refer to this area of law as that of Japanese consumer protection law. ${ }^{1630}$ One exception is the Denshi shöhisha keiyaku oyobi denshi shödaku tsüchi ni kansuru minpō no tokurei ni kansuru höritsu ('Denshi keiyaku-ho'-1631), which deals with contractual declarations of intention made through electronic means and is discussed in Section IV. below.

\section{c. Japanese Case Law: Hanrei (判例), Japanese Court Decisions}

Legislated law in Japan — as in Germany and elsewhere - is interpreted and supplemented by court decisions. ${ }^{1632}$ Having said this, legal academics note that there is comparatively little Japanese case law, especially in re-

1628 This is true for the Shōhi-sha keiyaku-hō (消費者契約法, Consumer Contract Act), Law No 61/2000 as amended. The title is misleading in that it suggests a wide field of application, whereas the content deals with a specific issue: the protection of consumers by permitting them to revoke their declaration of intention on the ground of misleading or pressurising conduct by the merchant (art 4) on the one hand, and by controlling unfair terms (arts 811) on the other. An English translation of this law is available online at www.japaneselawtranslation.go.jp/law/detail/?id=2036\&vm=04\&re=02\&new= 1.

1629 Interested readers are referred to Dernauer, 'Verbraucherschutz' (fn 1623) 575590, 597-600 and to ibid, Verbraucherschutz und Vertragsfreiheit im japanischen Recht [Consumer Protection and Freedom of Contract in Japanese Law] (Mohr Siebeck 2006), particularly 103-139, 252-259.

1630 Indeed, this term (Verbraucherschutz) is used by Dernauer, 'Verbraucherschutz' (fn 1623), particularly at 569-574; and ibid, 'Verbraucherschutz und Vertragsfreiheit' (fn 1629). Similarly, Kitagawa, 'Business Law' (fn 1623) \$15.04[3][a][i] at 15-33 states the aim of Japanese consumer law to be to 'promot[e] the interests of consumers who are [...] in a weaker position in relation to [a] business entity'. This helps to explain why the Shöhi-sha kihon-hö was initially enacted as the Basic Consumer Protection Act.

1631 See fn 1625 above.

1632 Keizō Yamamoto, Minpō kōgi I: sōsoku [Lectures in Civil Law I: General Provisions] ( $3^{\text {rd }}$ edn, $2^{\text {nd }}$ print, Yūhikaku 2012) 4. Hiroo Sono and others, Contract Law in Japan (Kluwer Law International BV 2019) 26 speak of the 'primacy of legislation over case law applications by the judiciary'. 
lation to contracts. ${ }^{1633}$ The Japanese court structure is divided into the Supreme Court (最高裁判所, Saiko Saiban-sho) on the one hand, and the lower instance courts (下級裁判所, kakyü saiban-sho) on the other (art 76 para 1 Kenpō; art 1 Saiban-sho- $\left.\bar{o}^{-1634}\right)$. In accordance with art 2 Saiban-sho$h \bar{o}$, the lower courts in civil matters are, in descending order: high courts (高等裁判所, kōto saiban-sho), district courts (地方裁判所, chiho saibansho), family courts (家庭裁判所, katei saiban-sho), and, lastly, the summary courts (簡易裁判所, kan'i saiban-sho). The court structure differed until 1947; for present purposes, it suffices to state that the highest court under that system in civil matters was the Dai-shin'i (大審院, Great Court of Judicature). ${ }^{1635}$

Surprisingly, there is no legal hierarchical order among the courts, so that these are, theoretically, independent. ${ }^{1636}$ Having said this, a higher court has the power to reconsider, change, or annul a lower court decision of a specific case, ${ }^{1637}$ with the effect that a decision by a higher court is binding on lower courts (art 4 Saiban-sho-hö). Furthermore, the Supreme Court has jurisdiction over final appeals (上告, jökoku; art 7 no i Saibansho- $h \bar{o})$.

\section{d. International Law: The CISG}

Finally, international law in the form of international treaties (joyaku, 条 約) can be a source of Japanese (contract) law. Before these treaties become national law, they need to be ratified by the Diet (see art 73 no 3 Kenpō, which speaks of '承認' (shonin), approval). ${ }^{1638}$ The CISG (in Japanese: 国

1633 Whitmore Gray, Use and Non-Use of Contract Law in Japan: A Preliminary Study (1984) 17 Law in Japan 97, 101.

1634 Japanese Court Act, 裁判所法, Law No 59/1947 as amended. An English translation is available online at www.japaneselawtranslation.go.jp/law/detail/? $\mathrm{id}=3225 \& v \mathrm{vm}=04 \& \mathrm{re}=2 \&$ new $=1$.

1635 For further details on this court, see Tanaka and Smith (fn 2) 53-54.

1636 Hideki Shibutani, Kenpō [English title: Japanese Constitutional Law] (3 $3^{\text {rd }}$ edn, Yūhikaku 2017) 669.

1637 Ibid. cf Sono and others (fn 1632) 27, stating that there is no doctrine of stare decisis in Japan, like there is in England (on which, see B.I.2.a.iii. above). On the jurisdiction of the high courts, see also art 16 no i Saiban-sho-hō.

1638 See also Kahei Rokumoto, $\mathbb{S} 2$ Institutionen: Recht und Juristen in der Transformation [Chapter 2 Institutions: Law and Jurists in Transformation], in: Baum and Bälz (fn 16) 1, 45 para 36. See further Shibutani (fn 1636) 656, 593. 
際物品売買契約に関する国際連合条約 ${ }^{1639}$, kokusai buppin baibai keiyaku ni kansuru kokusai rengo joyaku) has applied to international contracts for sale since 1 August $2009^{1640}$ where the prerequisites for its application (discussed in Section E.I.1. below) have been met. The CISG's provisions on the formation of contract will be contrasted with Japanese law in Section E.I.2. below.

\section{II. 'Keiyaku'(契約, Contract) Defined}

Japanese legislation in general and the Minpō in particular contain no definition of what the term 'contract' (keiyaku, 契約) signifies. Put simply in lay terms, a contract arises in Japan from the 'concurrence of intention with intention' ('意思と意思の合致”, 'ishi to ishi no gacchi'). ${ }^{1641}$ Similarly, academic literature generally defines a contract as the juristic act arising from the conformity of the declarations of intention of the parties involved; ${ }^{1642}$ or, more precisely, as the result of two or more persons exchanging declarations of intention with the purpose of creating a legal relationship. ${ }^{1643}$ These descriptions make it clear that the central element of a contract under Japanese law is the parties' consensus, their mutual

1639 See, eg, the official Japanese translation of the treaty, available at www.mofa.go.jp/mofaj/gaiko/treaty/treaty169_5.html (和文テキスト(訳文)(PDF)). Another denomination is ‘ウィーン売買条約' (uīn baibai jōyaku, Vienna Sales Convention), see Yasutomo Sugiura and Takashi Kubota, Uin baibai jöyaku no jitsumu kaisetsu [Practice Commentary on the Vienna Sales Convention] $\left(2^{\text {nd }}\right.$ edn, Chūō Keizai-sha 2011) 8 (foreword).

1640 While ratified on 1 July 2008, the convention was proclaimed on 7 July 2008 and came into force on 1 August 2009, see Sugiura and Kubota (fn 1639) 8 (foreword). See also Hiroo Sono, CISG ni okeru keiyaku no seiritsu to kaishaku ni kansuru kiritsu [The Rules of the Formation and Interpretation of Contracts under the CISG] (2008) Minshō-hō zasshi 138 No 1 1, 2. On the House of Representative's approval of the CISG, see www.shugiin.go.jp/internet/itdb_gian.nsf/html/gian/keika/1DA3FDA.htm.

1641 Daimon Noriaki, Sugu ni yakutatsu: keiyaku-sho, inkan, ryöshü-sho, tegata, kogitte no höritsu chishiki [Immediately Useful: Legal Knowledge on Contract Documents, Seals, Receipts, Promissory Notes, Cheques] (new revised edn, Sanshūsha 2011) 10.

1642 Yamamoto K, 'Minpō kōgi I' (fn 1632) 103; compare Endō and Matsuda (fn 1597) 88.

1643 See Kitagawa, 'Contracts' (fn 1601) \$2.01[2][a] at 2-27. 
assent. ${ }^{1644}$ The requirements for concluding a contract will be explored in Section IV.1.a. and contrasted with English and German law in Section D.I. below.

Under Japanese law, contracts are classified in different ways. First, according to whether the obligations are one-sided, which gives rise to a unilaterally obliging contract ${ }^{1645}$ (片務契約, henmu keiyaku); or whether the obligations are mutual, which lead to a bilateral or syllagmatic contract (双務契約, sómu keiyaku). The latter arises where both parties take on obligations of some value, such as is typically the case with contracts of sale (売買, baibai, arts 555 et seq Minpō, arts 524 et seq Shōhō) or employment (雇用, koyō, arts 623 et seq Minpō). ${ }^{1646}$ In contrast, gifts (贈与, zōyo, arts 549 et seq Minpō) are unilaterally obliging contracts. ${ }^{1647}$ Other classes are formal contracts (要式契約, yōshiki keiyaku), consensual contracts (諾 成契約, dakusei keiyaku), and real contracts (要物契約, yōbutsu keiyaku). Sales are one example of a formless and consensual contract, whereas a guarantee (保証契約, hoshō keiyaku, arts 446 et seq Minpō) is one example of a formal contract, and deposits (寄託契約, kitaku keiyaku, arts 657 et seq Minpō, arts 593 et seq Shōhō) and loans for consumption (消費貸借, shöhi taishaku, arts 587 et seq Minpō, art 513 Shōhō) are examples of real contracts. ${ }^{1648}$ Furthermore, there are onerous contracts (有償契約, $y \bar{u} s h \bar{o}$ keiyaku) and gratuitous contracts (無償契約, mushō keiyaku), such as sales and gifts respectively. ${ }^{1649}$ These contracts will be discussed in further detail in Section IV.1.a. below.

1644 See ibid, who contrasts this basis with that of English contract law. On the latter, see Section B.II.1. above.

1645 Translation note: This phrase is used instead of a simpler one such as 'unilateral contract' in order to avoid confusion with the English concept, which is different from the Japanese notion, as discussed in Section D.I. below. On the English unilateral contract, see Section B.II.1. above.

1646 See Keizō Yamamoto, Minpō kōgi IV-1: keiyaku [Lectures in Civil Law IV-1: Contracts] ( $1^{\text {st }}$ edn, $6^{\text {th }}$ print, Yūhikaku 2012) $75,11$.

1647 This can be deduced from the effects of gifts, which only oblige one, namely, the donating party (贈与者, zoyo-sha), while the other party, the donee (受贈 者, juzō-sha) has no obligation to do something. See on this ibid 342-343. See also art 549 Minpō.

1648 On consensual and formal contracts, see Yoshio Shiomi, Shin-saiken sōron I [New General Principles of Obligations I] (Shinzan-sha 2017) 11, 9-10. On real contracts in general, see Yamamoto K, 'Minpō kōgi I' (fn 1632) 120. On loans for consumption, see Yamamoto K, 'Minpō kögi IV-1' (fn 1646) 376.

1649 See the first table in Yamamoto K, 'Minpō kógi IV-1' (fn 1646) 11. 


\section{The Historical Development of the Japanese Law of Contract}

While the influences of German, French, and Anglo-American law are regularly mentioned by legal academics when sketching the development of Japanese law, references to the influence of English law are made fleetingly, if at all. In reality, there is also an English legal influence - albeit not a very strong one - on several specific matters, as will be pointed out subsequently.

This outline of the development of the law of contract in Japan begins in the Tokugawa era, a period of a little over 250 years in which the country was almost completely isolated from the rest of the world and therefore experienced no external influence. ${ }^{1650}$ It was only after the Meiji restoration that the country was re-opened, thus enabling the country to experience foreign interaction and its effects. The legal developments during these times will be explored in Sections 1. and 2. respectively. The subsequent changes, in particular in relation to contracts, will then be outlined in Section 3.

1. Contracts in Japan's Early Modern Period, the Tokugawa Era (17 ${ }^{\text {th }}$ $\sim 19^{\text {th }}$ Century): Legal Fragmentation in Peaceful Times of Growing Commerce, the Sowing Ground for Contract Law

\section{a. Political and Social Background}

The Tokugawa era, which is sometimes referred to as the Edo period, ${ }^{1651}$ can be roughly dated from the turn of the seventeenth to the end of the nineteenth century. ${ }^{1652}$ It was a time of political stability after 'almost a

1650 John Henry Wigmore, Law and Justice in Tokugawa Japan: Materials for the history of Japanese law and justice under the Tokugawa Shogunate 1603-1857, Part I: Introduction (UTP 1969) xii. cf other authors, who sometimes state shorter or longer durations. An example of the former is Röhl, 'Generalities' (fn 1585) 23, who states that the end of the Japanese seclusion occurred 230 years after its initiation; for an example of the latter, see Kitagawa, 'Rezeption' (fn 1590) 29, who describes the policy of seclusion ("Isolationspolitik") as having lasted 300 years.

1651 See, eg, Yutaka Yoshida, Tetsuke no kenkyū [A Study on Tetsuke] (Chūō University Publishing 2005) in the chapter 'Vertrag und Rechtsbewusstsein in Japan' [Contract and Legal Consciousness in Japan] 3.

1652 Academic literature seems to be divided over the exact dates of this period. While Steenstrup dates it between 1600 and 1867/1868, see ibid (fn 1587) 
century of intermittent warfare'. ${ }^{1653}$ Despite the fact that Ieyasu Tokugawa, Nobunaga Oda, and Hideyoshi Totoyomi are regularly referred to as the unifiers of Japan, ${ }^{1654}$ in reality, a centralised Japanese government already existed in the later Ancient as well as during the Classical era (Nara and Heian periods between the seventh and ninth centuries). ${ }^{1655}$

194; Yoshida (fn 1651) 3 states the period as 1603-1867. For the purposes of the present discussion, this deviation is of little importance. It can be easily explained, however, by looking at the events that occurred on these dates: Ieyasu Tokugawa won the (in)famous battle of Sekigahara in 1600 and through the defeat of his opponents factually unified Japan for the first time. Having said this, he only became Shögun (general, 将軍; kanji taken from Hadamitzky and others (fn 11) 248) three years later in 1603. The end of the period arose from what is referred to as the Meiji ishin (Meiji restoration, 明治維新; kanji taken from Hadamitzky and others (fn 11) 1118). As with the beginning of the period, the end is also marked by two important events: The resignation of Shogun Yoshinobu Tokugawa at the end of 1867 and the restauration of the Emperor at the beginning of 1868 . On the historical events, see Marius B Jansen, The Making of Modern Japan (Harvard University Press 2000) 310-311 and 334 respectively. For further details, see, eg, Günther Distelrath, Die Vorindustrielle Dynamik der Frühen Neuzeit [The Pre-industrial Dynamics During Early Modern Times], in: Josef Kreiner (ed), Geschichte Japans [Japan's History] (4 ${ }^{\text {th }}$ edn, Reclam 2016) 204, especially 208-209 (table of dates), 213-218 (establishment of the state), 250-254 (Meiji ishin), and Jansen, ibid 294-370.

1653 Jansen, 'Making Japan' (fn 1652) 2. See also Encyclopaedia Britannica, Tokugawa Period (Online Academic Edition 2017), http://academic.eb.com/levels/collegiate/article/Tokugawa-period/72774.

1654 See, eg, Josef Kreiner, Japan und die Ostasiatische Staatenwelt an der Wende vom Mittelalter zur Frühen Neuzeit [Japan and East Asian States at the Turn of Medieval to Early Modern Times], in: ibid (fn 1652) 149, 174-175. cf Jansen, 'Making Japan' (fn 1652) 11, who speaks of them as better being called 'innovators whose work brought Japan its greatest institutional change since the introduction of [centralised] governance in the seventh and eighth centuries.'

1655 Jansen, 'Making Japan' (fn 1652) 2; Maria-Verena Blümmel, Die Dominanz des Kaiserhofs vom Ende des 7. bis zum 12. Jabrhundert [The Dominance of the Imperial Court from the End of the $7^{\text {th }}$ to the $12^{\text {th }}$ Century], in: Kreiner (fn 1652) 52-54 (summary). For further details, see Blümmel, ibid 55-59 (table of dates), 60-65 (establishment of the state). Detlev Taranczewski, Der frühe Feudalismus [Early Feudalism], in: Kreiner (fn 1652) 94 refers to this centralised government as 'antique'. The system slowly disintegrated with the decline in power of the state, so that political turmoils led to times be(com)ing violent. For an overview of these developments, see, eg, Jansen, 'Making Japan' (fn 1652) 2-6; Blümmel, ibid 53-55. 


\section{Contracts in Japanese Law}

This period of peace brought about an increase in commerce and social changes. ${ }^{1656}$ A new administrative system known as bakuban was established, in which political power was centralised in the bakufu government (military government, 幕府, literally 'tent government') ${ }^{1657}$ and derogated to feudal lords (daimyō, 大名 ${ }^{1658}$ ). Around the daimyōs' place of residence people were gathered, from which emerged the first towns beside 'the former capital cities of Nara, Kyōto, and Kamakura', including Tōkyō (then called Edo). ${ }^{1659}$ Out of a population of approximately 12 million, 1,1 million lived in the Edo capital in the seventeenth century. ${ }^{1660}$ Villages also formed part of the administrative framework, and while government officers were selected from among them, various aspects of the villagers' lives were regulated strictly. ${ }^{1661}$ This was necessary in order to keep the thriving peasantry in their place inside the rigorous four-tier social hierarchy of samurai warriors ( $s h i, \pm)$, peasant farmers ( $n \bar{o}$, 農), artisans ( $k \bar{o}$, 工), and merchants (sho, 商); ${ }^{1662}$ the imperial family, the nobles, and minority

1656 See Encyclopaedia Britannica, Japan (Online Academic Edition 2015), http:// academic.eb. com/ levels/ collegiate/ article/Japan/ 106451\#23137.toc at 'Early modern Japan (1550-1850)', 'The enforcement of national seclusion'.

1657 On the meaning of the term, see, generally, ibid at 'The Heian Period (7941185 )', 'The rise of the warrior class'. See also Josef Kreiner, Vorwort [Foreword], in: ibid (fn 1652) 11, 14, where it is stated that the meaning of ' $b a k u$ ' is the three-sided cloth surrounding the headquarters of the military commander. Compare also entry nos 1 and 3 for '幕府' in the Japanese online dictionary Goo at http://dictionary.goo.ne.jp.

1658 Hadamitzky and others (fn 11) 29. These lords were warriors who governed lands of a certain size and provided service to the bakufu government, see Britannica, Japan (fn 1656) at 'Early modern Japan (1550-1850)', 'The bakuhan system'.

1659 See Britannica, Japan (fn 1656) at 'Early modern Japan (1550-1850)', 'The bakuhan system'. See also Haley, 'Medieval Japan' (fn 879) 335, noting that these 'castle towns marked the new urban centres of Japan.'

1660 Distelrath (fn 1652) 210, 224, who notes that the population more than doubled to 26 million in 120 years.

1661 See ibid.

1662 On this shimin (四民), see the respective entry in the Japanese online dictionary Kotobanku at https://kotobank.jp/. See also Distelrath (fn 1652) 206, who notes further at ibid and 224 that merchants were equally profiting from the rise in commerce. The ranks of the four classes are linked with Confucian philosophy, according to which samurai were deemed to have most and merchants least worth. On this, see Dan F Henderson and Preston M Torbert, Traditional Contract Law in Japan and China, in: David and others (fn 21) Vol VII/1 3, 6. 
groups were not classified. ${ }^{1663}$ Through this system, $7 \%$ of the population ruled the rest, of which $80 \%$ were peasants. ${ }^{1664}$ It seems that this class system was consequently weakened, but not formally abolished until the Meiji era (on which see Section 2. below).

\section{b. The General Structure of Law}

The first unified law in Japan was the ritsuryō, the penal and non-penal law encoded by the Imperial government in the Ancient era. ${ }^{1665}$ The uniformity was broken in the Middle Ages, ${ }^{1666}$ when the ritsuryo became applicable to the uppermost strata of society only, ie, to the nobility of the Imperial court, ${ }^{1667}$ the kuge. ${ }^{1668}$ The warrior-class, the buke (武家), was governed by its own law, the buke-hō (武家法), ${ }^{1669}$ but there was also the law of the daimyo in their district. ${ }^{1670}$ Furthermore, despite its existence on various levels, (formal) law was used by those in power as a mere administrative tool; it therefore did not usually regulate private matters between persons, ${ }^{1671}$ which is where local customs, the 'informal, living

1663 Distelrath (fn 1652) 215. cf Haley, 'Medieval Japan' (fn 879) 336, stating 'nonpersons' (非人, hinin) to form part of the existing groups, whereas the class of nobility (kuge, 公家) and of priests (sōni (僧尼) for Buddhidts, shinkan (神官) for Shintōs) to have been newly-added during the Tokugawa period. It seems that hinin, being outcases, were outside the four-tier system, see the entry for '非人' in the Japanese online dictionary Kotobanku at https://kotobank.jp/.

1664 Britannica, Japan (fn 1656) at 'Early modern Japan (1550-1850)', 'The Tokugawa status system'.

1665 See Ishii and Chambliss (fn 1597) 37 and 6. Yamamoto K, 'Rechtsverständnis' (fn 1583) 88 notes that ryō denoted provisions of administrative character.

1666 See Steenstrup (fn 1587) 66.

1667 Röhl, 'Jöri' (fn 1599) 43.

1668 Steenstrup (fn 1587) 127 and 154. For further details, see Wigmore, 'Introduction' (fn 1650) 8. It should be noted that Wigmore uses the term köke, which is an alternative reading of the kanji '公家', see the entry for ‘くげ' and ‘こうけ, in, eg, the Japanese online dictionary Goo at http://dictionary.goo.ne.jp.

1669 See Steenstrup (fn 1587) 83. This class included the daimyo across the whole of the country, see Wigmore, 'Introduction' (fn 1650) 3. Kanji taken from the Japanese online dictionary Goo at http://dictionary.goo.ne.jp.

1670 Compare Haley, 'Medieval Japan' (fn 879) 336, stating that daimyō had judicial authority.

1671 Henderson and Torbert (fn 1662) 17 note that the Tokugawa government did not concern itself much with private issues and concentrated on matters such as crimes and taxation. 
law', came in. ${ }^{1672}$ We therefore find a fragmented legal order focused on administration.

\section{c. The Law of Contracts}

The transformations occurring in the Tokugawa era not only began to reorganise Japanese society, but also had an impact on contracts. As the rigidity of the class system and social hierarchy lessened, contracts gained significance: contractual obligations supplanted hereditary ones. ${ }^{1673}$ These changes affected the notion of contract (Section i.), its law and forms (Sections ii. and iii.), but also the further requirements on contracts (Section iv.).

\section{i. Definition and Types of Contracts}

During this period, a distinction seems to have been drawn between a 'contract', meaning a promise enforceable in court, and an 'agreement', which was a promise that was not so enforceable. ${ }^{1674}$ Under neo-Confucianism, promises were seen as mutual voluntary acts (aitai, 相対) that were supported by interpersonal trust (jitsu'i, 実意) and therefore had strong moral overtones. ${ }^{1675}$ It has been argued that two distinct sorts of contracts existed: those which arose in villages and usually had a more administrative character, and those in towns, which were of a commercial

1672 Yamamoto K, 'Rechtsverständnis' (fn 1583) 89, 88, 99. See also Ronald Frank, Civil Code: General Provisions, in: Röhl (fn 1584) 166, 168.

1673 Compare Jansen, 'Making Japan' (fn 1652) 60-61.

1674 Compare the distinction drawn by Henderson and Torbert (fn 1662) 4. Indeed, as it is argued that such enforcement did not exist during this period (ibid 4,7 ), only the term 'agreement' is used during their subsequent discussion, see ibid at, eg, 9.

1675 See Henderson and Torbert (fn 1662) 18. Kanji and transcription adapted from the entries for '相対' and '実意' in the Japanese online dictionary Goo at http://dictionary.goo.ne.jp. In accordance with the former term, private documents as in a contract between the parties are sometimes referred to as aitai shōsho, 相対証書, compare John Henry Wigmore, Law and Justice in Tokugawa Japan: Materials for the history of Japanese law and justice under the Tokugawa Shogunate 1603-1857, Part II: Contract, Civil Customary Law (UTP 1967) 36; kanji taken from Götze, 'Rechtswörterbuch' (fn 10) 2 and 503. 
nature. ${ }^{1676}$ While this may be true, 'commercial' contracts were also to be found in villages in the form of sales and loans, or uses. ${ }^{1677}$ Similarly, 'administrative' arrangements were also found in cities like Ōsaka. ${ }^{1678}$ The distinction was thus not a strict one.

\section{ii. Contract Law}

While the law in general was fragmented, so too were the rules on contracts: These were governed by a multitude of customs, largely on a very local - village - level, ${ }^{1679}$ and morals during this period. ${ }^{1680}$ Having said this, commercial practices in large cities of commerce, like Edo and Ōsaka also played a role. ${ }^{1681}$ Furthermore, a kind of contract law seems to have existed on an overarching cross-regional level, arising from one standardised type of contract claim known as a 'money suit' (kane-kuji, 金 公事) in the cities of Ōsaka and Edo, ${ }^{1682}$ which began to become visible in the early nineteenth century. ${ }^{1683}$ Nevertheless, a framework for a law of contract(s) seems not to have existed yet. This may be due to the fact that the private law rules were only developed during this period from judicial decisions on, inter alia, the kane-kuji, which is comparable to the legal development in England of a theoretical basis from procedural actions during the Early Modern period. ${ }^{1684}$

1676 See Dan F Henderson, Village 'Contracts' in Tokugawa Japan: 50 Specimens with English Translation and Comments (University of Washington Press, 1975) 10; Henderson and Torbert (fn 1662) 6.

1677 Compare Henderson and Torbert (fn 1662) 9, 10.

1678 Compare ibid 12.

1679 Compare Henderson (fn 1676) 3.

1680 Henderson and Torbert (fn 1662) 4.

1681 See ibid 6. While Edo is said to have been a 'city of consumption', Ōsaka was its supplier and thus a thriving commercial centre, see ibid 12.

1682 Compare ibid 13, 16. There was also another claim, a 'main suit' (bon-kuji, 本 公事), ibid 16. For more on these suits, their distinction and remedies, see ibid 14-16, 17. Kanji and transcription adapted from the entries for '金公事' and ‘本公事' in the Japanese online dictionary Goo at http://dictionary.goo.ne.jp.

1683 Henderson and Torbert (fn 1662) 30.

1684 On this, see Haley, 'Medieval Japan' (fn 879) 348. On the development of English contract law, see Section B.II.2. above. 


\section{iii. Contract Forms}

Forms were required for some contracts during the Tokugawa era. In the nineteenth century, money suits (kane-kuji) required a written document that was witnessed and sealed as a basis of claim. ${ }^{1685}$ This requirement may be the explanation for the large volume of written contracts in this period; however, whether contractual documents established rights, or whether they were merely a means of enforcement is not clear. ${ }^{1686}$ Moreover, important contracts were expressly fixed in writing, eg, in commerce or in relation to the administration of villages. ${ }^{1687}$ Even family arrangements were thus formalised, such as adoptions or marriages. ${ }^{1688}$ For this purpose, standardised contract forms were often employed. ${ }^{1689}$

As early as the Ancient era (Nara period), common people would sometimes sign important documents such as sale contracts by hand (shimei wo jisho suru，氏名を自署する); illiterate people resorted to other forms of signing, such as fingernail-stamps ('爪印', tsume'in) or thumb prints (bo'in, 拇印). ${ }^{1690}$ Nevertheless, it generally seems to have been more common for documents to be sealed. ${ }^{1691}$ This appears to be a development of this era, since it is here that the exclusivity of seals for the upper strata of the Tokugawa society was reduced by merchants beginning to use seals for their activities. ${ }^{1692}$ In contrast, other commoners would resort to signatures or other authentication methods, unless they were in official positions, like the chief of the village-groups (known as kumi or 'five-men companies',

1685 See Henderson and Torbert (fn 1662) 30 14, 17.

1686 See ibid 17.

1687 Wigmore, 'Introduction' (fn 1650) 92 and Steenstrup (fn 1587) 149-150 respectively. On the latter, see also Henderson and Torbert (fn 1662) 8, 9, giving the examples of the selection process of the village headman or of the definition of the villagers' duties.

1688 Henderson and Torbert (fn 1662) 10.

1689 Ibid 9, 10.

1690 Nibon ni okeru hanko no rekishi: hanko mame-jiten [Japan's Seal History: Dictionary of Seal Trivia] (Mori'in-bō Hanko Mame Jiten), www.moriinbo.com/mame/rekisi.html at 'Inkan Seido no Hajimari' [The Origins of the Seal System]. These methods will be discussed further in Section D.III.2.c. below.

1691 Details of the (historical) sealing practices will be discussed in Section D.III.2.b.i. below.

1692 Details of this development are discussed in Section D.III.2.b.i.cc) below. 
gonin-gumi), who wielded the seal of the group in matters relating to its members. ${ }^{1693}$

Local custom would usually require some form of sealing of a written document, especially with sales or transactions involving land, although the kind of documents and seal impressions that were necessary varied. ${ }^{1694}$ An example from the area of Bizen (in today's Okayama prefecture) would be the sale of horses or cattle, whereby the document of sale had to be sealed by the village headman. ${ }^{1695}$ Due to local variations, there were references to 'attesting seals' (‘証印',1696 sho'in), 'counterseals' ('連判', 1697 renban), and 'divided seals' ('割判', warihan or '割印', wari'in $\left.{ }^{1698}\right)^{1699} .1700$ An example of counterseals having been employed was in the (commercial) sale of land in towns, whereby the written document was first sealed by the primary parties (buyer, seller); their relatives and companies (guilds) then countersealed the instrument before the transaction was completed at the local authority, this in turn being marked with a seal impression of the authority's official seal. ${ }^{1701}$ A divided seal might have been used on

1693 See Steenstrup (fn 1587) 150; Wigmore, 'Introduction' (fn 1650) 18-19. For other examples of when the seal of the kumi was employed, eg, sale of buildings, see Wigmore, 'Customary Law' (fn 1675) 1 (referring to the chief as 'company chief, kumigashira) and 4 (referring to the 'seal of the [...] companies'). An explanation for commoners not using seals may lie in the fact that commoners did not have surnames until the nineteenth century, see the table showing the 'selected chronology for the 1870s', in Marius B Jansen, Introduction, in: ibid (ed), The Cambridge History of Japan Volume 5: The Nineteenth Century (repr, CUP 2007) 1, 28. See also Section D.III.2.b. below.

1694 See, generally, Wigmore, 'Customary Law' (fn 1675) 1-5. See further Section D.III.2.b.i. below.

1695 Wigmore, 'Customary Law' (fn 1675) 38.

1696 Kanji taken from Götze, 'Rechtswörterbuch' (fn 10) 491.

1697 Kanji taken from the entry for '連判' in the Japanese online dictionary Goo at http://dictionary.goo.ne.jp.

1698 Wigmore, 'Customary Law' (fn 1675) 37.

1699 Kanji taken from the entry for '割判' in the Japanese online dictionary Goo at http://dictionary.goo.ne.jp and from Kei Ishii, Japanische Unterschriftsstempel: Gegenwart und Geschichte [Japanese Name-seals: Present and History] (Expert Opinion, Technische Universität Berlin 2000, available online at http://europa.ig.cs.tu-berlin.de/ma/ehemalige/ki/ap/2000-09/Ishii2000-Hanko.pdf/publication_view) 14 respectively.

1700 See Wigmore, 'Customary Law' (fn 1675) 1-5 for further details.

1701 Ibid 11. 


\section{Contracts in Japanese Law}

a contract of sale of land and the relevant entry in the land register, to evidence their connection and enhance security. ${ }^{1702}$

At the same time, local customs endeavoured to facilitate transactions by keeping requirements simple. In this way, in Kaga (today's Ishikawa prefecture) for example, the sale of ships could be effected by the simple exchange of the ship's receipts (kenjö, 券状, literally 'bond document', contract in writing). ${ }^{1703}$

Oral agreements were not generally seen as binding during the Tokugawa era. ${ }^{1704}$ Thus, if a man were to orally agree with the owner of a brothel on the terms to purchase the freedom of a lady of the night, the owner was not deemed to be bound unless he had received the agreed sum from the other party. If this were not the case, the owner could revoke his agreement (kuyamigaeshi, 悔み返し) and contract with another person who paid first. ${ }^{1705}$ This risk could be averted by effecting the payment in whole upon conclusion of the agreement.

This thinking notwithstanding, there seems to have existed a certain duality in contracting practice. On the one hand, oral agreements followed by touching or clapping of the other parties' hands would be sufficient to make a contract binding where the parties were part of a merchant guild (kabu-nakama，株仲間 1706), ${ }^{1707}$ although a simple receipt or sealed entry in a ledger were also seen as sufficient. ${ }^{1708}$ In contrast, trade outside these

1702 This was the custom in Iwami (in today's Shimane prefecture) for example, see ibid 37.

1703 See ibid 30. Kanji and transcription adapted from the entry for '券状' in the Japanese online dictionary Goo at http://dictionary.goo.ne.jp.

1704 Yoshida ( $\mathrm{fn}$ 1651) 7 goes so far as to say that it was out of question for contractual parties of that period that a naked agreement be sufficient to make it binding.

1705 See ibid 3. He explains the meaning of the words as 'to regret the conclusion of the contract and so to revoke it', ibid. See also ibid in the chapter 'Keiyaku to ho-ishiki' [Contract and Legal Consciousness] at 639-640. Kanji taken from the latter reference at 640 .

1706 Term used by, eg, Henderson and Torbert (fn 1662) 12; Steenstrup (fn 1587) 138. Kanji and transcription adapted from the entry for '株仲間' in the Japanese online dictionary Goo at http:// dictionary.goo.ne.jp. Other terms used include nakama (Steenstrup ibid 148), kumi or kumi'ai (Wigmore, 'Introduction' (fn 1650) 97). Another designation was 'ko', see Takeshi Toyoda, Japanese Guilds [1954] 5 No 1 The Annals of the Hitotsubashi Academy 72, 80. Guilds were not officially recognised as forms of organisation by the government until the 1721, see Wigmore, ibid, and Toyoda, ibid.

1707 See Yoshida (fn 1651) 8-9.

1708 See Henderson and Torbert (fn 1662) 13, 30. 
guilds was conducted with more formal contracts. ${ }^{1709}$ The reason for this different treatment was presumably a difference in the level of trust. ${ }^{1710}$

Witnesses would sometimes be present during the transaction; however, if the matter was of less importance, contracts were made orally and between the parties only. ${ }^{1711}$ An example of an oral contract (kuchi-yakusoku, 口約束, literally 'mouth-promise') might be the sale of personal property. ${ }^{1712}$ Persons other than the parties were also often involved in other ways, namely, as supervisors, record keepers, or as custodians of the document. ${ }^{1713}$ Another function of local authorities was the attestation of or permission for a contract, evidenced through the authority's seal impression on the document. ${ }^{1714}$

\section{iv. The Further Requirement of Giving Tetsuke (Earnest)}

Another method to bind a party to an oral agreement during the Tokugawa period other than through full performance was to pay a part of the agreed amount upon contracting, namely, a sum ranging between a quarter and up to half of the contract price. ${ }^{1715}$ This would normally constitute part-payment of the contract and was known as tetsuke (手付, earnest money). ${ }^{1716}$ In accordance with two commercial customs existing in the Tokugawa era known as 'tetsuke nagashi baimodoshi' ('手付 流し 倍戻し', literally 'forteiting tetsuke, paying back double') and 'tetsuke son

1709 See Yoshida (fn 1651) 8-9.

1710 Ibid describes it as a consciousness of keeping a promise existing or not; the former was the case within the guild but not outside.

1711 The latter was true in some regions at least, see Wigmore, 'Customary Law' (fn 1675) 6. In some regions, like in Iwashiro, 'witnesses' were sometimes not only observers but were treated as guarantors, bearing responsibility in case of default of payment, see ibid 7-8. See further Henderson (fn 1676) 13.

1712 See Wigmore, 'Customary Law' (fn 1675) 36 and 40, who uses the term 'personalty'.

1713 Henderson and Torbert (fn 1662) 30.

1714 On the former, see Wigmore, 'Customary Law' (fn 1675) 1. On the latter situation, see ibid 35, 39, where it is noted that the seller had to produce several copies of the sale instrument and the buyer's copy would be handed out to him by the officials if permission was granted.

1715 See ibid 5.

1716 Ibid 4, 3; he uses the German term 'Draufgabe' (earnest money). This concept will be discussed further in Section IV.1.b.vi. below. For the German historical concept, see Section B.III.2.a.iii.ee) above. 
baigaeshi' ('手付損倍返し'), the buyer forfeits the tetsuke that they paid, whereas the seller has to pay back twice the amount of tetsuke they received when a contract is cancelled before completion. ${ }^{1717}$ This practice seems to have been used in sale transactions of goods before this period, namely, since the time of the risturyo laws, ${ }^{1718} \mathrm{ie}$, since the Ancient era, ${ }^{1719}$ and its application merely increased during the Tokugawa era. ${ }^{1720}$ One could even venture to argue that tetsuke formed an essential part of contracting in that period, as naked agreements were not seen as binding. ${ }^{1721}$ As this practice still exists today, more will be said on tetsuke in Section IV.1.c.iii. below.

\section{Political and Legal Change during the Meiji Era: The Creation of the First Great Japanese Private Law Codifications (Turn of the 19 ${ }^{\text {th }}$ Century)}

The end of the Tokugawa period and of Japan's seclusion from foreign interventions came about through the Meiji restoration after the collapse of the bakufu government. ${ }^{1722}$ The political situation was not resolved thereafter, as will be seen in Section a. below. After this political turnaround, efforts were concentrated on reforming the country. This eventually led to

1717 See Yoshida (fn 1651) 606, 610. Word segmentation of customs altered by this author, originally reading 'tezukenagashi-baimodoshi' and 'tezukezon-baigaeshi'; kanji taken from ibid 641. On the meaning of the first custom, see, eg, Yügen Kaisha Atago Sangyō at www.025-377-6150.com/1fudousantorihiki/23. For the latter see, eg, the entry for '手付損倍返し' in the Japanese online dictionary Kotobanku at https://kotobank.jp/.

1718 See Kaoru Yunoki and Takio Takagi, Tetsuke: dai-557-jö ['Tetsuke: Art 577'], in: ibid (eds), Shinhan chüshaku minpō (14) saiken (5) [Japanese Civil Law Annotated Vol 14 Obligations Part 5] ( $1^{\text {st }}$ edn, Yūhikaku 1993) 168, 170, who note that it was initially termed 'akisasu' ('アキサス’) and differed in nature.

1719 See Ishii and Chambliss (fn 1597) 6. They refer to this period as 'Recent Antiquity'.

1720 Yunoki and Takagi (fn 1718) 170, who refer to this period as edo jidai (“江戸時 代, Edo period).

1721 See Yoshida (fn 1651) 7, who states that contractual parties did not regard keeping a promise as important. This mentality was reflected in all forms of tetsuke, ibid 7-8. The issue of bare agreements being deemed enforceable or not was already discussed in Section III.1.c.iv. above.

1722 For details on the historical events unfolding, see Jansen, 'Making Japan' (fn 1652), in particular 257-332, who provides an in-depth description of the incidents, also with respect to the relationships formed with the Western powers. 
the emergence of the two great codes that are relevant to the topic of this dissertation: the Minpō for private and the Shōho for commercial law. As this was not achieved in one single process, the progress will be examined in three phases: the initial projects (Section b.), the first real codification attempts (Section c.), and, finally, the successful creation of the Minpó and of the Shōhō (Section d.). As will be seen, influences from a range of sources were incorporated throughout the course of development. ${ }^{1723}$

\section{a. Political and Social Background}

During the fall of the Tokugawa regime, beginning in 1854, Japan entered into bilateral treaties with several powerful nations, inter alia the USA, the UK, Prussia, and Russia. ${ }^{1724}$ These contracts were viewed as unequal and the desire to renegotiate their terms was one of the driving forces behind the Meiji government modernising the Japanese legal system in general. ${ }^{1725}$ This was because a revision of the contracts required Japan to be recognised as a World Power, which in turn required the country to be reformed, including its legal system. ${ }^{1726}$ It seems that this political

1723 According to Kitagawa, 'Rezeption' (fn 1590) 51, it was 'more than thirty statutory laws, draft laws or legal systems'. See also ibid 43, where a partial list of the referred laws is given.

1724 See Kitagawa, 'Rezeption' (fn 1590) 29, 44, who names a few more out of the fifteen States involved. of Nobushige Hozumi, Lectures on the New Japanese Civil Code as Material for the Study of Comparative Jurisprudence (Maruzen Kabushiki-kaisha 1912) 10, who speaks of 'sixteen Treaty Powers of Europe and America'.

1725 See Frank, 'Civil Code' (fn 1672) 169. See also Kitagawa, 'Rezeption' (fn 1590) 47, who speaks of Japan's sovereignty having been partially lost. Similar: Baum and Takahashi (fn 1584) 336. Stronger: Jansen, 'Introduction' (fn 1693) 31, 'galling inequality'. For further details on these treaties, see, eg, Anja Eckey-Rieger, Der Kodifikationsstreit zum japanischen Bürgerlichen Gesetzbuch [The Codification Dispute Concerning the Japanese Civil Code] (Master thesis, University of Bonn 1993, Bonn 1994) 15-16 (summarised overview); Kitagawa, 'Rezeption' (fn 1590) 47-49 (details on the three central aspects of the treaties: freedom of foreigners to settle, consular jurisdiction, and custom tariffs).

1726 See Ishii and Chambliss (fn 1597) 16; compare Eckey-Rieger (fn 1725) 16, who identifies the existence of a modern legal system as being imperative for Japan obtaining the consular jurisdiction over foreigners. Similar: Baum and Takahashi (fn 1584) 336-337. Also including the aspect of custom tariffs: Kitagawa, 'Rezeption' (fn 1590) 49. A rather circumspect view is given by a contemporary of these events, Hozumi (fn 1724) 3-4, 10-12. 


\section{Contracts in Japanese Law}

motivation lessened subsequently; however, it remained an influencing factor for modernisation. ${ }^{1727}$

Further impetus for the reform of Japanese law stemmed from sudden developments in Japan, particularly political, but also social and economic changes. ${ }^{1728}$ Accordingly, a new framework was seen as necessary for the modernisation and strengthening of the Japanese economy. ${ }^{1729}$ Furthermore, the new governmental structure and the re-instatement of the Emperor made a legal regime necessary that reflected this centralised power. ${ }^{1730}$ In connection with the aim to garner support for the new government, an oath consisting of five articles (Gokajo no go-seimon, 五箇条の 御誓文, literally 'Oath in Five Articles') was promulgated. ${ }^{1731}$ It outlined the main aims and course of action for the new era and reads as follows:

1. Deliberative assemblies shall be established and all measures of government shall be decided by public opinion.

2. All classes, high and low, shall unite in vigorously carrying out the plan of the government.

3. Officials, civil and military, and all the common people shall, as far as possible, be allowed to fulfill their just desires, so that there may not be any discontent among them.

4. Uncivilized customs of former times shall be broken through, and everything shall be based upon just and equitable principles of nature.

5. Knowledge shall be sought throughout the world, so that the welfare of the Empire may be promoted.

Desiring to carry out a reform without parallel in the annals of Our country, We Ourselves here take the initiative and swear to the Deities of Heaven and Earth to adopt these fundamental principles of national government, so as to establish thereby the security and prosperity of

1727 Kitagawa, 'Rezeption' (fn 1590) 49.

1728 Hozumi (fn 1724) 10. Kitagawa, 'Rezeption' (fn 1590) 51-52 describes culture as one further factor. See also Ch'en (fn 1587) ix.

1729 Baum and Takahashi (fn 1584) 337. The evolution of this framework is described in ibid 340.

1730 See Kitagawa, 'Rezeption' (fn 1590) 44. See also Ishii and Chambliss (fn 1597) 577: what was needed was 'a uniform corpus of law that would have a unifying effect upon the country [...]'. Compare the motivation of the nineteenth-century codification of German private law, discussed in Section B.III.2.b.ii. above.

1731 It is also often referred to as the 'Charter Oath of Five Articles', see, eg, Ishii and Chambliss (fn 1597) 144. 
the people. We call you all to make combined and strenuous effort to carry them out. ${ }^{1732}$

Article five of this Oath is often cited as (further) explanation for the resort to 'Western' rather than traditional Japanese law as a basis for the reforms. ${ }^{1733}$

While doubts have been voiced by academics as to the strength of the government's desire to truly do so, ${ }^{1734}$ the fact remains that the Japanese government sent out a large party of its members to countries of the 'West', ${ }^{1735}$ notably England, but also France and the USA, to study foreign legal systems. ${ }^{1736}$ Having said this, interest in foreign (Western) culture had arisen prior to the Meiji restoration; in fact, an Institute for the Study of Western Books (Bansho Shirabe-sho, 蕃書調所) had already been estab-

1732 The original text reads: 一広く会議を興し、万機公論に決すべし

上下心を一にして、盛んに経綸を行ふべし

官武一途庶民に至る迄、各其志を遂げ、人心をして倦ざらしめんことを要 す

旧来の婳習を破り、天地の公道に基くべし

智識を世界に求め、大に皇紀基を振起すべし

我国未曾有の变革を為さんとし、朕躬を以て衆に先んじ、天地神明に誓 ひ、大いに斯国是を定め、万保全の道を立んとす。衆亦此旨趣に基き協心 努力せよ

(一 Hiroku kōgi wo kōshi, manki kōron ni kessubeshi

Jōka kokoro wo hitotsu ni shite, sakan ni keirin wo okonabeshi

Kanbu itto shomin ni itaru made, ono sono kokorozashi wo toge, jinshin wo shite umazarashimen koto wo yōsu

Kyūrai no rōshü wo yaburi, tenchi no kōdō ni motodzukubeshi

Chishiki wo sekai ni motome, öi ni kōki wo shinkisubeshi

Wagakuni mizo'u no henkaku wo nasantoshi, chinmi wo mote shù ni sakinji, tenchi shinmei ni chikahi, öi ni kono kokuze wo sadame, banmin hozen no michi wo tatentosu. Shü mata kono shishu motodzuki kyōshin doryoku seyo). Kanji and furigana taken from www.meijijingu.or.jp/about/3-3.html; translation by Hozumi (fn 1724) 5-7; transcription by this author. Compare the slightly deviating translation found in Ishii and Chambliss (fn 1597) 145.

1733 See, eg, Kitagawa, 'Rezeption' (fn 1590) 45. Weaker: Frank, 'Civil Code' (fn 1672) 166.

1734 See, eg, Kitagawa, 'Rezeption' (fn 1590) 45, inter alia naming a law prohibiting Christianity that was enacted at the same time as the Charter Oath.

1735 Jansen, 'Introduction' (fn 1693) 26; see also Kitagawa, 'Rezeption' (fn 1590) 29.

1736 Ch'en (fn 1587) 22. Among the academics that were sent out, Tamotsu Murata (to England, see Ch'en (fn 1587) 23) and Rinshō Mitsukuri (to France, see Frank, 'Civil Code' (fn 1672) 171) can be highlighted, as they would later influence the reform endeavours greatly. 


\section{Contracts in Japanese Law}

lished in the Tokugawa era. ${ }^{1737}$ It was created to study foreign languages, including Dutch, English, French, and German, and science, ${ }^{1738}$ including social sciences, thus forming a first basis for the knowledge necessary for the later reforms. ${ }^{1739}$

As the Meiji government aimed to modernise the country, the feudal system and the distinction between the four classes of Japanese society was abolished; ${ }^{1740}$ however, other, even more traditional aspects that were not seen as being crucial to the reforms, like the family structure under the 'house system' (ie seido, 家制度), were maintained. ${ }^{1741}$ It was a time of industrialisation, in which agriculture was commercialised, and the population and towns both grew in size. ${ }^{1742}$

\section{b. Initial Reform Projects in Japanese Private and Commercial Law}

In accordance with the Charter Oath and its agenda, the Meiji government soon began to reorganise the country's legal system. Before turning to Western ideas, there appears to have been a movement back to before the state of the Tokugawa era, and influence from Chinese law also seems to have been strong, particularly in criminal law. ${ }^{1743}$ In contrast, private law resorted to customs laid down in the Tokugawa era, which were gradually replaced by specific statutory laws. ${ }^{1744}$ The laws of that period were also

1737 See the entry for '蕃書調所' in the Japanese online dictionary Goo at http:// dictionary.goo.ne.jp. Cf the transcription and translation of the institute's name as given by Kitagawa, 'Rezeption' (fn 1590) 29. It was initially created under the name Yósho Shirabe-sho (洋書調所) and later renamed, see the entry in Goo, ibid. There were other endeavours that served as forerunners, see Jansen, 'Making Japan' (fn 1652) 265-266.

1738 See the entry for '開成所' (Kaisei-jo, the name that was later adopted for the Institute) in the Japanese online dictionary Goo at http://dictionary.goo.ne.jp.

1739 Compare Kitagawa, 'Rezeption' (fn 1590) 29.

1740 Hozumi (fn 1724) 7.

1741 Kitagawa, 'Rezeption' (fn 1590) 46. Readers interested in the development of this house system in the Meiji era and beyond are referred to, eg, Jörn Westhoff, Das Echo des Ie: Nachwirkungen des Haussystems im modernen japanischen Familienrecht [The Echo of the Ie: Repercussions of the House System in Modern Japanese Family Law] (Munich 1999).

1742 See Britannica, Japan (fn 1656) at 'Demographic Trends', where it says that the population exceeded 42 million in 1897.

1743 See Ishii and Chambliss (fn 1597) 17. For a more in-depth analysis of the influence of Chinese law, see Ch'en (fn 1587).

1744 Ishii and Chambliss (fn 1597) 17. 
examined and a compilation created in order to better understand the development of Japanese law. ${ }^{1745}$ Drawing on the knowledge acquired of Western laws and languages, the government then turned towards modernising its laws. The development of the two chief pieces of legislation in private and commercial law will be explored subsequently.

In the Bureau for the Investigation of Institutions (Seido Torishirabesho), ${ }^{1746}$ and through the work led by Rinshō Mizukuri, a translation of the French civil code was put forward as a first step in the reform of Japanese private law in the 1870s. ${ }^{1747}$ Based on this translation, several preparatory works were elaborated, but all were abandoned before being transformed into law. ${ }^{1748}$ While the compositions were not to last, the Japanese legal vocabulary that resulted, especially the term 'right' from the French droit as kenri (権利), would persist. ${ }^{1749}$ It would take almost another twenty years until the new Japanese Civil Code was completed (see Sections c.-d. below).

In contrast to the civil code project, the first efforts towards modifying Japanese commercial law were not orientated towards a single code, but rather seemed to concentrate on different aspects, in particular company law, which was based exclusively on English law, ${ }^{1750}$ and maritime com-

1745 See Ch'en (fn 1587) 11.

1746 Hozumi (fn 1724) 12; Kitagawa, 'Rezeption' (fn 1590) 30. Transcription based on latter source.

1747 See Frank, 'Civil Code' (fn 1672) 171; see also Ishii and Chambliss (fn 1597) 578-579. On the reasons for the choice of French law, see Frank, ibid 171, 172, and Marutschke, 'Einführung' (fn 1603) 84.

1748 Ishii and Chambliss (fn 1597) 579-580 speak of three works. The first of these seems to have been the Minpō ketsugi (Civil Code Resolution, 1871), see Frank, 'Civil Code' (fn 1672) 173. Kitagawa, 'Rezeption' (fn 1590) 30 names the other two as the Kökoku minpō kari-kisoku (1872) and the Minpō so'an (1873/1874).

1749 The kanji mean 'authority' or 'power' and 'benefit' or 'advantage' respectively, see Frank, 'Civil Code' (fn 1672) 171 and Hadamitzky and others (fn 11) 1061, 1372. This was not true for all new vocabulary, so that the term minken (民権) as 'civil right' from the French droit civil for example, which faced strong criticism, would not be used in this sense in legislation later on. Compare on this Ishii and Chambliss (fn 1597) 579; Marutschke, 'Einfübrung' (fn 1603) 85-86. Having said this, there are other combined words, such as citizenship (市民権, shimin-ken) which was used in, eg, art 5 para 2 Immigration Control and Refugee Recognition Act (Shutsu'nyü-koku kanri oyobi nanmin nintei-hō, Cabinet Order No 319/1951; a tentative English translation is available online at www.japaneselawtranslation.go.jp/law/detail/? id $=2647 \& v m=04 \&$ re $=02 \&$ new $=1$ ).

1750 See Baum and Takahashi (fn 1584) 350-351. 
merce. ${ }^{1751}$ The legislation thus enacted was not deemed satisfactory to achieve the underlying political aim of sufficiently modernising the country to re-negotiate the treaties with the Western powers, thus strengthening the desire for a comprehensive commercial code. ${ }^{1752}$ Any individual legislative projects were thus abandoned in favour of creating a unified commercial code. ${ }^{1753}$

\section{c. First Codification Attempts and the Codification Dispute}

\section{i. First Codification Attempt of a Civil Code}

After the first attempts to create a basis for a Japanese private law (civil code) had failed, a committee was established for the drafting of a civil code in 1875 and a first draft closely resembling the French code was completed in $1878 .{ }^{1754}$ Like the preceding works, it was not enacted, ${ }^{1755}$ as it was perceived too foreign (French). ${ }^{1756} \mathrm{~A}$ new start saw the French lawyer Gustave Émile Biossonade de Fontarabie employed in 1880 to draft provisions in relation to the law of property (zaisan-hō, 財産法). ${ }^{1757} \mathrm{He}$ drafted several parts: Property, Acquisition of Property (in two parts), Securities (of claims), Proof, and Persons. ${ }^{1758}$ While based on the French Civil Code, the product of his labours was an 'independent codification', ${ }^{1759}$ as it took into account Belgian and Italian law. ${ }^{1760}$ Nevertheless, there was still a

1751 See Ishii and Chambliss (fn 1597) 593-594.

1752 Compare ibid. In fact, representatives from Germany and Great Britain demanded a commercial code in a joint proposal for a possible renegotiation of the treaties, see Baum and Takahashi (fn 1584) 352.

1753 This was also, in fact, due to the demand just mentioned, see Baum and Takahashi (fn 1584) 352.

1754 Hozumi (fn 1724) 13; see also Ishii and Chambliss (fn 1597) 580.

1755 See Kitagawa, 'Rezeption' (fn 1590) 30; Hozumi (fn 1724) 13.

1756 Baum and Bälz (fn 1583) 8 para 16. Marutschke, 'Einführung' (fn 1603) 86 even calls it 'nothing more than an imitation of the Code civil' ('nichts mehr als eine Imitation des Code civil').

1757 Baum and Bälz (fn 1583) 8 para 16; Yamamoto K, 'Minpō kögi I' (fn 1632) 24. Note that the elaboration of family and succession law was left to Japanese lawyers, see Baum and Bälz, ibid. For further details, see Marutschke, 'Einführung' (fn 1603) 87.

1758 Marutschke, 'Einführung' (fn 1603) 87, naming, in German: Vermögen, Vermögenserwerb, Forderungssicherung, Beweis, Personen.

1759 Baum and Bälz (fn 1583) 8 para 16: 'eigenständige Kodifikation'.

1760 Marutschke, 'Einführung' (fn 1603) 87. 
strong French influence, both in terms of the structure and vocabulary, as well as in the legal concepts. ${ }^{1761}$

After a revision of the composition by Japanese lawyers, ${ }^{1762}$ a civil code was adopted in 1890, which was to come into force three years later; however, a dispute that had arisen in relation to the government's codification projects, known as the 'codification dispute' (法典論争, hōten ronsō), put a stop to this, so that the codification has become known as the 'old Minpö' (旧民法, kyü-minpō). ${ }^{1763}$ While it goes beyond the scope of this dissertation to go into details of the dispute, a brief overview will be given in Section iii. below, ${ }^{1764}$ preceded by an outline of the first endeavour to create a Japanese commercial code.

\section{ii. First Codification Attempt of a Commercial Code}

At around the time that the Meiji Government commissioned the drafting of a Japanese civil code by Boissonade, the German lawyer Carl Friedrich Hermann Roesler was similarly employed to draw up a plan for a commercial code: ${ }^{1765}$ Between 1881 and 1884, French, German, and Egyptian law, ${ }^{1766}$ as well as the Classified Collection of Japanese Commercial Practices (Nihon shöji kanrei ruishü, 日本商事慣例類集), which had been especially compiled for this purpose, were considered throughout the completion of the draft. ${ }^{1767}$ Due to political reasons, Roesler, while drafter of the code, was not privy to the discussions, and seemed to have no influence on any further modifications. ${ }^{1768}$

1761 Ibid.

1762 Baum and Bälz (fn 1583) 8 para 16.

1763 Compare ibid 8-9, paras 16, 18; Yamamoto K, 'Minpō kōgi I' (fn 1632) 24-25. Transcriptions and kanji taken from these sources respectively.

1764 Readers interested in further details are referred to Christoph Sokolowski, Der so genannte Kodifikationenstreit in Japan [What is Known as the Codification Dispute in Japan] (Iudicium 2010).

1765 See Baum and Bälz (fn 1583) 8 para 17.

1766 Baum and Takahashi (fn 1584) 356.

1767 Compare Ishii and Chambliss (fn 1597) 593-595. The collection was published, see Sei'ichi Takimoto, Nihon shöji kanrei ruishü [Classified Collection of Japanese Commercial Practices] (Hakutō-sha 1932). cf Baum and Bälz (fn 1583) 8 para 17, who note that Roesler did not bear in mind commercial customs, since he deemed them to be out of date.

1768 It is said that he strongly disagreed with these alterations, compare Baum and Takahashi (fn 1584) 353. 


\section{Contracts in Japanese Law}

The draft was promulgated in March 1890 under the title 'Shöhö'1769 (to avoid confusion, this code will hereinafter be referred to as 'Kyü-shöhö', 'former Commercial Code', 旧商法). ${ }^{1770}$ Despite its promulgation, the $K y \bar{u}$-shōho's effective date, which was originally to be 1 January 1891, was delayed repeatedly for around seven years; however, those portions that were becoming urgently necessary due to increasing commercial development came into force two years later, ${ }^{1771}$ with a few critical amendments. ${ }^{1772}$ The reasons for the delay came down to a strong opposition, similar to that which the Kyu-minpo faced, in the form of the codification dispute. ${ }^{1773}$

\section{iii. The Codification Dispute}

The codification dispute began in the 1880s during the time of completion of the $K y \bar{u}-m i n p \bar{o}^{-1774}$ and peaked in 1889 when a highly critical paper was

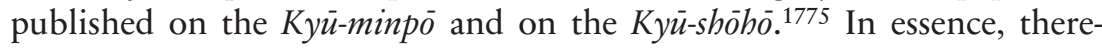
fore, it was a criticism of the new codifications, whereby several schools of thought were involved: On the one hand, there was the French school of legal thought, which strongly related to natural law; on the other hand, there was the English school of thought, which placed more importance on legal history. ${ }^{1776}$

1769 Law No 32/1890.

1770 See Ichirō Kobashi, Wagakuni ni okeru kaisha-hō-sei no keisei [The Formation of Corporate Legislation in our Country] (Kokusai Rengō Daigaku 1981) 6.

1771 These effective parts concerned legal persons (companies and partnerships), bills, and bankruptcy, see Ishii and Chambliss (fn 1597) 596. For further details, see Baum and Takahashi (fn 1584) 353-354; and Kobashi (fn 1770) 6-7, who also notes that the chapters on the commercial register (shogyo tökibo, 商業登記簿) and commercial books (shögyō chōbo, 商業帳簿) came into force at the same time.

1772 As foreseen by Law No 9/1893, Kobashi (fn 1770) 7. Details can be found in ibid $48-50$.

1773 Compare Baum and Bälz (fn 1583) 8 para 18.

1774 Compare Marutschke, 'Einführung' (fn 1603) 87.

1775 See Baum and Bälz (fn 1583) 8-9 para 18.

1776 For a succinct summary of the two schools of thought, see Yamamoto K, 'Minpó kogi I' (fn 1632) 25. It has been noted that there were other factions, namely, the German school, which was gaining popularity, while the French school was said to be losing popularity, see Rahn, 'Rechtsauffassung' (fn 1600) 105 and Tanaka and Smith (fn 2) 181 respectively. Furthermore, several au- 


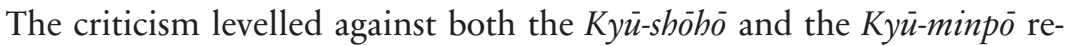
lated to the content of the codes, which were seen as (too) foreign, and furthermore did not respect Japanese (commercial) language and practices. ${ }^{1777}$ Similarly, the quality of the commercial stipulations was sometimes seen as unsatisfactory. ${ }^{1778}$ Another ground for delay of the com-

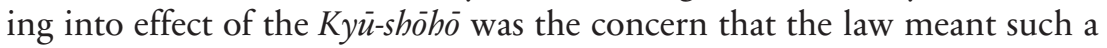
great change that the affected parties would not be able to handle the new situation in the slim period of time between publication and coming into force of the code. ${ }^{1779}$ Furthermore, there were concerns that the Ky $\bar{u}$-shōho and the Kyu-minpo were not well-matched, ${ }^{1780}$ as they were influenced by different legal traditions and were thus deemed to be incompatible. ${ }^{1781} \mathrm{Be}-$ side these technical aspects, emotions also played an important role. These were grounded in a strengthening feeling of Japanese nationality and pride in the same. ${ }^{1782}$

Irrespective of the reasons, the consequence of the dispute was that the coming into effect of both codes was delayed in 1892 until $1896 .{ }^{1783} \mathrm{It}$ was seemingly by accident, although it was certainly against the will of the government, that the parts of the Kyü-shōbo that had not yet become law came into force in $1898 .{ }^{1784}$ This may have been another factor motivating the government to commence new legislative action.

thors note a particularly strong role of the English school in the dispute: Kitagawa, 'Rezeption' (fn 1590) 27; Marutschke, 'Einführung' (fn 1603) 87.

1777 For criticism on the Kyü-shōhō, see Baum and Takahashi (fn 1584) 353; for the Kyü-minpō, see Marutschke, 'Einführung' (fn 1603) 87.

1778 Corporate law: Baum and Takahashi (fn 1584) 358-359.

1779 Moderate expression of this concern is made by Baum and Takahashi (fn 1584) 353 ; it is more drastically described as likely 'throw[ing] Japanese commerce into chaos' by Ishii and Chambliss (fn 1597) 596; similar phrasing is also used by Kobashi (fn 1770) 6.

1780 More precisely, the two were not deemed to be 'harmonius' (chōwa, 調和), see Kobashi (fn 1770) 6.

1781 See Marutschke, 'Einführung' (fn 1603) 87.

1782 See ibid 88; see also Baum and Bälz (fn 1583) 9 para 19.

1783 Marutschke, 'Einführung' (fn 1603) 87-88; see also Baum and Bälz (fn 1583) 9 para 19.

1784 See Ishii and Chambliss (fn 1597) 597. 
d. The Creation of the Minpō (Civil Code) and of the Shōhō (Commercial Code)

The Japanese government moved swiftly: Two commissions were established in 1892 in order to draft a new civil code and a new commercial code. ${ }^{1785}$ Both commissions were directed by three Japanese academics. Nobushige Hozumi, Masaaki Tomii, and Kenjirō Ume were in charge of civil law, whereas the last of the three also worked on the commercial code, together with Keijirō Okano and Yoshi Tabe. ${ }^{1786}$ Members of the commercial commission also included influential merchants. ${ }^{1787}$ Both commissions worked swiftly: The first three books of the new civil code, the Minpō, were enacted in $1896^{1788}$ and a new commercial code, based on revisions that had been previously foreseen for the $K y \bar{u}$-shōho, was completed three years later. ${ }^{1789}$ This was the current Shöhö, which came into force on 9 March 1899, only a couple of months after its promulgation. ${ }^{1790}$

The revision of the Kyü-minpo was made on the basis of the French draft, but was inspired greatly by the first draft of the German Bürgerliche Gesetzbuch ('BGB'). ${ }^{1791}$ The legal provisions were thus mainly of French and German origin, although twenty other laws were also considered. ${ }^{1792}$ One important difference between the Minpō and the Kyū-minpo $\bar{o}$ was that the former introduced the concept of a 'juridical act' (horritsu köi, 法律行 為), based on the German notion of Rechtsgeschäft. ${ }^{1793}$ It was conceived as

1785 Baum and Bälz (fn 1583) 9 para 19. See also Ishii and Chambliss (fn 1597) 597.

1786 Baum and Bälz (fn 1583) 9-10, paras 19, 21. See also Ishii and Chambliss (fn 1597) 597. Note that while Ume had studied in France, thus following the 'French school', Okano belonged to the 'English school', see Baum and Takahashi (fn 1584) 359.

1787 One example being the entrepreneur Shibusawa, see Baum and Takahashi (fn 1584) 359.

1788 Marutschke, 'Einführung' (fn 1603) 91, who notes that the books on family and succession law were enacted two years later.

1789 See Ishii and Chambliss (fn 1597) 597.

1790 Only the part on bankruptcy remained in force, see Ishii and Chambliss (fn 1597) 597.

1791 Marutschke, 'Einführung' (fn 1603) 90.

1792 See ibid 91, 90. See further Yamamoto K, 'Rechtsverständnis' (fn 1583) 90; Kitagawa, 'Rezeption' (fn 1590) 27, 32-34. Thus, Swiss law influenced the provisions on the rescission of contracts, while the English case of Hadley $v$ Baxendale (1854) 9 Exchequer 341 was the inspiration for the provisions on damages. See Kitagawa, ibid 39-40.

1793 See Yoshio Hirai, Zenchü (\$S 90-98 [höritsu köi]) [Preliminary Note (Arts 90-98 [Juridical Acts])], in: Takeyoshi Kawashima and ibid (eds), Shinhan chüshaku 
a 'legal act by virtue of law' (böritsu-jō no köi, 法律上の行為). ${ }^{1794}$ Anticipating the discussion in Section IV. below, where details on this notion are given, a juridical act is today defined as centring around declarations of intention aimed at bringing about particular legal effects. ${ }^{1795}$

One response to the criticism voiced against the $K y \bar{u}$-shōho is found in art 1, which now expressly included commercial customs as a source (para 2), albeit only coming second after the provisions of the Shōo $\overline{0} .{ }^{1796}$ In this way, two points were addressed simultaneously: the 'foreignness' of the Shōho was decreased, or rather, its 'Japaneseness' increased; and a historically important source, custom, ${ }^{1797}$ was acknowledged explicitly. Similarly, several changes were also made in the area of corporate law in order to improve the legal situation. ${ }^{1798}$ The revisions were based on the revised 1884-version of the Allgemeines Deutsches Handelsgesetzbuch ('ADHGB'), disregarding the German Handelsgesetzbuch ('HGB'). ${ }^{1799}$

3. The Subsequent Development of Japanese Contract Law during the Taishō, Shōwa, and Heisei Eras (20 ${ }^{\text {th }}$ Century $)$

The historical periods following the Meiji era each had their own distinct character, which was due to the political and social background of the time in question (see Section a. below). In comparison to the socio-cultural changes that came about in the twentieth century, particularly in the Taishō era, Japanese private law, even more so Japanese contract law, was modified little (Section b.). While there have been amendments to the legal framework, the scale of these modifications pales in comparison with

minpō (3) sōsoku (3) [Japanese Civil Law Annotated Vol 3 General Provisions Part 3] ( $2^{\text {nd }}$ edn, Yūhikaku 2003) 1,2 , 4. On the German notion, see Section B.III.3.a.i. above.

1794 Hirai (fn 1793) 3.

1795 See Kunihiro Nakata, Dai-1-hen dai-5-chō hōritsu kōi [zenchū]-[dai-98-jō no 2] [Part 1 Chapter 5 Juridical Acts (Preliminary Note)-(Article 98-2)], in: Matsuoka and ibid (fn 1602) 61.

1796 The order of application of the different sources of Japanese law was already explained in Section I.2.a. above.

1797 This was true especially in the Japanese Middle Ages, a period during which the central piece of the Japanese legal system was kanshü, not law, see Röhl, 'Jöri' (fn 1599) 43.

1798 Interested readers are referred to Baum and Takahashi (fn 1584) 360-362 for details.

1799 See Baum and Bälz (fn 1583) 10 para 21. 
the recent reform of the law of obligations, discussed in detail in Section V. below.

\section{a. Overview of Political and Social Developments}

As indicated above, the periods following the Meiji era were diverse in terms of their social and political events: The Taishō era was a time in which the modernisation efforts that had been begun in the Meiji era were realised. The industrialisation was advanced so far that Japan advanced to place two in terms of its GNP by the 1970 s. ${ }^{1800}$ Cities were rebuilt and their infrastructures, including public transport and public utilities, developed, so that the image of cities became one of a modern life rolemodel, thus moving beyond their existence as centres of commerce or administration. ${ }^{1801}$ Despite, or rather, because of the first World War, Japan's economy grew, especially the secondary sector, as the production of various everyday articles fulfilled the needs of the country's neighbours. ${ }^{1802}$ New kinds of jobs were created for men and especially women. ${ }^{1803}$ With these improvements came social change. Most importantly, social status was now identified by one's occupation, not one's origins. ${ }^{1804}$ Changes in the newly emerging middle-class people's circumstances also meant that the traditional family structure under the house system, while formally

1800 Peter Duus (ed), The Cambridge History of Japan Volume 6: The Twentieth Centu$r y$ ( $8^{\text {th }}$ edn, CUP 2005) $14-15$.

1801 On the changes in infrastructure, see Regine Mathias, Das Entstehen einer modernen städtischen Gesellschaft und Kultur, 1900/1905-1932 [The Creation of a Modern Urban Society and Culture, 1900/1905-1932], in: Kreiner (fn 1652) 332, 355-356, 373. For further details, see Duus (fn 1800) 391-421, who notes that not only such modern aspects, but also traditional parts of the Japanese economy, like agriculture and manufacture, were part of the reforms. On the image change and the remodelling of the large cities, particularly Tōkyō after the earthquake in 1923, see Mathias, ibid 352, 354-356, 360-363.

1802 See Mathias (fn 1801) 342-343, noting that the volume of workers in the secondary sector almost tripled between 1905 and 1920. The time during this war has been called 'Japan's "second industrial revolution"' by Duus (fn 1800) 20 , who goes on to note at 387 that the 'nonagricultural work force', including both secondary and tertiary sector work, 'doubled'.

1803 Beside in production, service jobs ranging from receptionist over conductress to doctor opened up new possibilities for women, although many only worked until they got married or their first child was born. On this, see Mathias (fn 1801) 333, 357-358; see also ibid 343.

1804 Mathias (fn 1801) 333. 
enshrined in the Minpō, was replaced by smaller, independent families with different life rhythms. ${ }^{1805}$

In terms of political developments, the authoritarian Meiji regime was liberalised through reforms towards democracy, although imperialism gained strength at the same time, and the expansion and ensuing battles of which would mount in the radical nationalism of the early years of the Shōwa era. ${ }^{1806}$

\section{b. Overview of (Contractual) Legal Developments}

The rules on the formation of contracts contained in the Minpo were not amended until around 120 years after the Code came into force (this reform will be considered in Section V. below). Of course, other changes were made after the twentieth century. This was done through special laws, which were used to amend regulation contained in the Minpō, one example being the Denshi keiyaku-ho from 2001. ${ }^{1807}$ Apart from this, the content of the Minpō has remained almost the same. The only changes that were made before the major reform of the 2010s occurred under a reform in 2004, in which the Minpöss language was changed from the original to modern Japanese. ${ }^{1808}$ Japanese private law was furthermore developed through case decisions and academic work. ${ }^{1809}$

In contrast with the Minpō, Japanese commercial law was amended after the Meiji period. This was because the drafting of the $S h \bar{o} h \bar{o}$, which was to replace the highly-criticised $K y \bar{u}-s h \bar{o} h \bar{o}$, had been somewhat rushed. As a consequence, it was deemed unrefined and underwent several major revisions after its promulgation. The first became law in 1911 and affected all parts of the Code, in particular the one on company law. ${ }^{1810}$ In this respect, it is interesting to note the influence of English law in this amend-

1805 On this change, see Mathias (fn 1801) 365, 366, 369. On the house system, see fn 1741 above.

1806 Mathias (fn 1801) 378-379, 332, 349. For details of the political movements, see ibid 337-350. The Japanese (colonial) empire developed between 1895 and 1945, see Duus (fn 1800) 2; for a detailed account of the political development in Japan from the Meiji period, see ibid 55-382.

1807 See Yamamoto K, 'Minpō kögi I' (fn 1632) 26. For a list of all the special laws amending the Minpō, see the table provided in ibid 30-31.

1808 For further details on this reform, see ibid 27-29.

1809 See on this ibid 26.

1810 Ishii and Chambliss (fn 1597) 597-598. 
ment. ${ }^{1811}$ Other major modifications were made in 1938 and $1950,{ }^{1812}$ which were followed by further key amendments approximately every six years. ${ }^{1813}$ The recession of the Japanese economy at the beginning of the Heisei era necessitated further reforms in the area of corporate law. ${ }^{1814}$ Another great amendment occurred in 2004-2006, which saw the regulation of corporate entities being taken out of the $S h \bar{h} h \bar{o}$ and re-promulgated in the form of a new piece of legislation, the Japanese Companies Act (Kaisha-hō, 会社法 $\left.{ }^{1815}\right) .{ }^{1816}$ During all this time, no amendments were made to the provisions concerning the conclusion of contracts contained in the Minpō.

\section{Contracts in Current Japanese Law and Legal Practice ${ }^{1817}$}

\section{The Current Legal Background}

The Japanese layman's view of the conclusion of contracts differs from the legal reality: Contrary to the popular belief that contracts must be made in writing, thus seemingly making it a complicated process, ${ }^{1818}$ Japanese contract law greatly facilitates contracting. Despite the multitude of sources (see Section I. above), the principles of the legal framework are relatively straight forward (Section a.) and the level of formality required

1811 Baum and Takahashi (fn 1584) 376.

1812 Again, both of these revisions concerned corporate law, see Baum and Takahashi (fn 1584) 360. Interested readers are referred to ibid 375-379 and 391395 for details.

1813 See the list of major amendments to the Shōho (mostly concerning corporate law) until 1981 in Kobashi (fn 1770) 8. Details can be found in Baum and Takahashi (fn 1584) 396-398.

1814 A brief outline can be found in Baum and Takahashi (fn 1584) 398-400.

1815 Law No 86/2005 as amended. An English translation is available online at www.japaneselawtranslation.go.jp/law/detail/? $\mathrm{id}=2455 \& \mathrm{vm}=04 \& \mathrm{re}=02 \& \mathrm{nnew}=1 \quad$ (Parts I-IV), and www.japaneselawtranslation.go.jp/law/detail/?id=2456\&vm=04\&re=02\&new $=1$ (Parts V-VIII).

1816 On this, see the succinct description by Hiroyuki Kansaku and Moritz Bälz, $\mathbb{S} 3$ Gesellschaftsrecht [Chapter 3 Corporate Law], in: Baum and Bälz (fn 16) 67, 79-80 paras 40-44.

1817 The following discussion is based on the law as of December 2019. The changes that have come about under the reform on 1 April 2020 are discussed in Section V. below.

1818 See Noriaki (fn 1641) 10. This belief will be explored in further detail in Section 2.b. below. 
is kept surprisingly low (Section b.). Furthermore, the rules relating to the formation process are dispositive (nin'i kitei, 任意規定), ${ }^{1819}$ acting as default rules. Consequently, the parties can make their own stipulations, allowing a great degree of flexibility. This should be borne in mind for the subsequent discussion.

\section{a. Basic Principles: Contracts as Matching Ishi Hyōji (意思表示, Declarations of Intention)}

As was seen from the definition of the term 'contract' given in Section II. above, the theoretical basis of Japanese contracts is the existence of matching declarations of intention (ishi byoji, 意思表示). These give rise to a juridical act (法律行為, höritsu kōi), out of which contracts are one prominent example of bilateral juridical acts. ${ }^{1820}$ This doctrine has been adapted from German legal theory. ${ }^{1821}$ A contractual agreement therefore regularly necessitates declarations of offer and acceptance (moshikomi, 申 込み, Section ii. below; and shödaku, 承諾, Section iii. below). ${ }^{1822}$ These declarations of intention are normally sufficient to constitute a contract, as the freedom of contract (keiyaku no jiyu , 契約の自由) and the freedom of form (hoshiki jiy $\bar{u}$, 方式自由) are important principles of Japanese private law. ${ }^{1823}$ As a consequence, there are form requirements in exceptional cases only (considered in Section b. below). It ought to be noted further that there is no separate requirement of an intention to create legal relations,

1819 Tsuneo Matsumoto, Denshi shakai no keiyaku-hö [Contract Law in the Digital Society], in: Tomohei Taniguchi and Kiyoshi Igarashi (eds), Shinhan chüshaku minpō (13) saiken (4) [Japanese Civil Law Annotated Vol 13 Obligations Part 4] ( $2^{\text {nd }}$ revised edn, Yūhikaku 2006) 288, 293. This is not only true for the Minpö's rules on formation, but contract law in general, see Ueda, 'Keiyaku (zenshü)' (fn 1602) 756. In relation to the rules contained in the Shōbō, see Tanaka and others (fn 1617) 90, 94. For further details on dispositiveness in general, see, eg, Toshio Tsubaki, Minpō ni okeru kyōkō-hō, nin'i-hō [Mandatory and Dispositive Law in the Minpō] (Nihon Hyōron-sha 2015).

1820 See Yamamoto K, 'Minpō kögi I' (fn 1632) 103; Sono and others (fn 1632) 39.

1821 Sono and others (fn 1632) 39. On the German theory of the legal transaction and declarations of intention, see Section B.III.3.a.i. above.

1822 See Sono and others (fn 1632) 51.

1823 See Shiomi, 'Shin-saiken' (fn 1648) 3 et seq, in particular 7; see also Kitagawa, 'Contracts' (fn 1601) $\$ 2.01[2][\mathrm{b}]$ at 2-27. 
like in English law. ${ }^{1824}$ Instead, the notion forms part of the requirements for möshikomi and shödaku, ${ }^{1825}$ which is similar to German law. ${ }^{1826}$

\section{i. Contracts as Ishi Hyōi}

At its most basic level, a bi- or multilateral agreement is formed under Japanese law when it is the intention of all of the parties to enter into a contract; in other words, when it is their intention to create a legal (obligatory) relationship. ${ }^{1827}$ This is the case where a moshikomi and shödaku ${ }^{1828}$ are made that correspond in terms of their content. ${ }^{1829}$ A simple example might be a seller having the intention to sell a product for $¥ 10,000$ (approx. €80) and the buyer intending to purchase the product at that value. ${ }^{1830}$ The contract is formed at the point in time when the declarations of intention (ishi byoji, 意思表示) of the parties clearly coincide. ${ }^{1831}$ As this is seen as a matter of course, the Minpo currently has no explicit stipulation on this point; however, as will be revealed in the subsequent analysis, it is contained implicitly in the rules regarding the declarations of

1824 See Section B.II.3.a.iv. above on the English requirement.

1825 On this, see Sono and others (fn 1632) 55-56.

1826 On which see Section B.III.3.a.iv. above.

1827 See Kitagawa, 'Contracts' (fn 1601) \$2.01[2][a] at 2-27.

1828 The term 'shödaku' can also mean 'consent' or 'approval', see Dictionary of Standard Japanese Legal Terms (fn 9) 149.

1829 Yamamoto K, 'Vertragsrecht' (fn 1612) 469 paras 20, 22; Yamamoto K, 'Minpō kögi IV-1' (fn 1646) 25-26. Kitagawa, 'Contracts' (fn 1601) \$2.01[3][i][ii] at 2-38 refers to the declarations of intention as necessarily being 'complementary'.

1830 See Tsuneo Matsumoto, Keiyaku no seiritsu [The Formation of Contracts], in: ibid and Masahiro Saitō and Yasutaka Machimura (eds), Denshi shō-toribiki-hō [The Law on Electronic Commercial Transactions] (Keisō Shobō 2013) 3, 18.

1831 See Shōji Kawakami, "Keiyaku no seiritsu" wo megutte (1) [Concerning the "Formation of Contracts" (1)] (1988) 665 Hanrei Taimuzu 11, 14. In relation to (changes to) real rights, it is the point in time at which all the validity conditions (y ūkō yōken, 有効要件) are fulfilled, see Shin'ichi Yamamoto, Dai-2-hen dai-1-chō sósoku: $\mathbb{} 176$ [Part 2 Chapter 1 General Provisions: $\mathbb{\$} 176$ ], in: Jun’ichi Funahashi and Mamoru Tokumoto (eds), Shinhan chüshaku minpō (6) bukken (1) [Japanese Civil Law Annotated Vol 6 Real Rights Part 1] (2 ${ }^{\text {nd }}$ revised ed, Yūhikaku 2009) 224, 257-258; whereby, according to the recent trend among Japanese legal academics, any requirements stipulated by the parties (payment of purchase price or handing over and registration, etc) in a contract act as suspensive conditions (teishi jöken, 停止条件), see Yamamoto S, ibid, 258. This latter aspect will be discussed further in Section b. below. 
intention (arts 521 et seq $M i n p o ̄) .{ }^{1832}$ In this respect, it ought to be noted that 'declaration of intention' generally means that there is an outward act showing the person's will to effect a legal consequence. ${ }^{1833}$

This principle is not only true for bilaterally obliging contracts. Even in the case of the unilaterally-obliging contract of a gift, the contract is formed once the required intention has been declared by the donor and the donee has accepted the donation offer (art 549 Minpō). Conversely, a contract for a loan for consumption (shōhi taishaku, 消費貸借, art 587 Minpō) arises when the borrower receives some thing (money or otherwise) and declares their intention to return a thing of 'the same in kind, quality and quantity’ (“種類、品質及び数量の同じ物’, 'shurui, hinshitsu oyobi sūryō no onaji mono', art 587 Minpō). Thus, while acts by both parties are required, only one party undertakes to do something. In fact, although the handing over of the object is a requirement for the loan to arise, there is no obligation on the lender (貸主, kashinushi) to do so. ${ }^{1834}$

The clear identification of two separate declarations of offer and acceptance is not always necessary, such as in cases where negotiations lead to the conclusion of a contract through a series of communications between the parties. ${ }^{1835}$ Under such circumstances, it is sufficient that all parties confirm the contract's contents. ${ }^{1836}$

1832 See Sei'ichirō Ueda, Dai-3-hen dai-2-chō dai-1-setsu dai-1-kan keiyaku no seiritsu [Part 3 Chapter 2 Section 1 Subsection 1 Formation of Contracts], in: Matsuoka and Nakata (fn 1602) 760. Previously, the Kyü-minpō contained an explicit statement to this purpose in arts 296, 304, 306. In future, this will be the case again, as the reform of the Minpō concerning the law of obligations contains such an articulation. This matter will be discussed in Section V.b. below.

1833 See Nakata, 'hōritsu kōi' (fn 1795) on [zenchū] (preliminary note) at 61.

1834 Yamamoto K, 'Minpō kögi IV-1' (fn 1646) 376.

1835 Ibid 26. Note that in the example given by Yamamoto, the parties fix their agreement in writing. Anticipating the discussion of the contractual formalities in Japanese law in Section b. below, it is noteworthy at this point that a written contract triggers the legal presumption that both parties agreed on concluding a contract, Kunihiro Nakata, Shōhi-sha-hō kōgi kyōzai 2 [Consumer Law Teaching Materials 2] (document date 15 April 2016) 3; compare also the legal presumption of a signed or sealed private document being authentic, as explained in Section b.ii. below. These legal presumptions would therefore normally make the identification of offer and acceptance in the example irrelevant.

1836 See Matsumoto, 'Keiyaku' (fn 1830) 18. 


\section{Contracts in Japanese Law}

Where the declarations of intention do not conform, no contract arises. ${ }^{1837}$ This issue is assessed on both an objective and a subjective standard. ${ }^{1838}$ This correspondence requirement seems to echo the certainty requirement of English contract law, since a contract of vague stipulation, which leads the parties to have different understandings of the contract's content, does not meet the standard in Japan. ${ }^{1839}$ Having said this, the basic terms of the contract (object, price) do not have to be precisely fixed, as long as they can be determined: for the object, through interpretation of the contract's terms, ${ }^{1840}$ ie, from specifications like colour or model; ${ }^{1841}$ for the price, by looking at the current market price. ${ }^{1842}$ This is thus no strict requirement, so that a simple 'please give me one of those' by a customer when indicating an article in a shop and a 'yes' by the shop clerk in response are sufficient to create a sales contract. ${ }^{1843}$ Other terms such as

1837 See Kitagawa, 'Contracts' (fn 1601) \$2.01[3][i][ii] at 2-38, who goes on to explain that this is true for 'substantial', ie, major non-conformity, whereas minor divergences only lead to partial voidness of the contract.

1838 See ibid $\$ 2.01[3][$ i] [ii] at 2-39, who speaks of the 'conformity as to the objective contents of the declarations of intention' and the 'subjective conformity'.

1839 This rule is deduced from the decision of the Great Court of Judicature (Dai-shin'i, 大審院) of 28 June 1944 (Shōwa 19), 23 Minshū 387. In this case of a sale of the right to produce silk thread, the contract failed to stipulate whether the contract price included a certain compensation money payable to the seller, equivalent to over ten percent of the purchase price. The court found that since the seller and the buyer held conflicting understandings on this point, there was no conformity between their declarations of intention and thus no contract. A summary of the case and a short commentary can be found in Arinobu Ōnaka, Naishin no ishi no fu-icchi ['Dissonance of the Real Intention'], in: Yoshio Shiomi and Hiroto Dōgauchi (eds), Minpō hanrei byakusen I: sōsoku, bukken [One Hundred Selected Cases on the Civil Code I: General Part, Property Law] (Yūhikaku 2015) 38-39. See also Kitagawa, 'Contracts' (fn 1601) \$2.01[3][i][ii] at 2-39. The connection to English law is not completely far-fetched, as some Japanese legal academics refer to both English and US-American law in discussing the issue of non-conformity of declarations of intention, see, eg, Tsuyoshi Kinoshita, Eibei keiyaku-hō ni okeru ishi byōji no $f u$-icchi [Dissonance of Declarations of Intention in Anglo-American Contract Law] (1972) 11 Shakai Gaku Jānaru 99-120.

1840 Kawakami (fn 1831) 15.

1841 Matsumoto, 'Keiyaku' (fn 1830) 18.

1842 Ibid; Kawakami (fn 1831) 15.

1843 See Kawakami (fn 1831) 15. Compare Kenjirō Egashira, Shō-torihiki-hō [The Law of Commercial Transactions] ( $7^{\text {th }}$ edn, Kōbundō 2013) 8, who states that commercial sale contracts will normally contain stipulations as to the object of sale, the price, delivery, and payment. 
the time and place of performance are seen as being merely incidental. ${ }^{1844}$ It can thus be concluded that Japanese law does not know a requirement like that of certainty in English law. ${ }^{1845}$

Anticipating the discussion below, may it be briefly stated at this point that no additional acts, like the handing over of the contractual object, are required for the contract to come into existence, since contracts under Japanese law are largely consensual (dakusei, 諾成). ${ }^{1846}$ This matter will be discussed again in Section b. below, together with exceptions to this principle.

Naturally, a contract will only arise where the declarations of intention have come into effect. ${ }^{1847}$ In relation to this, Japanese law distinguishes between two different situations: where the contracting parties are 'present', or where they are 'at distance' from one another. The question of the effectiveness of the declarations is a fundamental issue, as it has a bearing on the point in time at which a contract is formed. This question is addressed with each declaration of intention (offers in Section ii., acceptance in Section iii. below). It is noteworthy that while the formation rules contained in the Minpō currently only deal with contracts concluded while the parties are not in each other's presence, ${ }^{1848}$ the $S h \bar{h} h \bar{o}$ contains stipulations relating to both situations.

1844 See Matsumoto, 'Keiyaku' (fn 1830) 18.

1845 On which see Section B.II.3.a.ii.cc) above.

1846 See Tomohei Taniguchi and Shūsei Ono, Zenchū (SS 521-532) II: keiyaku no hōshiki [Preliminary Note (Articles 521-532) II: Contract Form], in: Taniguchi and Igarashi (fn 1819) 393. An example is the sales contract (art 555 Minpö), see Mika Yokoyama, Fudō-san baibai no purosesu [The Sale Process for Immovable Property] (2007) Juristo zōkan: Minpō no sōten [Jurist special edition: Points at issue in Civil Law] 91 and Egashira (fn 1843) 6. The inspiration for the consensuality principle seems to be rooted in French law, see Frederike Zufall, Das Abstraktionsprinzip im japanischen Zivilrecht [The Abstraction Principle in Japanese Civil Law] (2010) 29 ZJapanR / JJapanL 201, 204, 206; Yokoyama, ibid 93; cf Taniguchi and Ono (fn 1846) 393, who contrast Japanese and German contract laws as (purely) consensual with French and English contract laws as requiring some form of consideration (isshu no taika, 一種の対価). On the principles of the transfer of rights in rem, see the summary contained in Hans-Peter Marutschke, Übertragung dinglicher Rechte und gutgläubiger Erwerb im japansichen Immobiliarsachenrecht [The Transfer of Rights in Rem and Bona Fide Acquisition in Japanese Land Law] (Mohr Siebeck 1997) $1-6$.

1847 Kitagawa, 'Contracts' (fn 1601) \$2.01[2][a] at 2-27.

1848 This will change under the amendment of the Minpo, as discussed in Section V. below. 


\section{ii. Möshikomi (申込み, Offer)}

Japanese law differentiates between the declarations of intention made by one party to initiate a contract. Accordingly, there can be an offer (mōshikomi, 申込み), or a mere invitation to make an offer (möshikomi no $y \bar{u}$ in, 申込みの誘引). ${ }^{1849}$ First, the meaning of 'offer' will be set out in Section aa) below, before the distinction between these two statements is explored further in Section bb). Finally, the duration of the effectiveness of an offer is discussed in Section cc).

\section{aa) 'Mōshikomi'Defined}

A möshikomi is a one-sided declaration of intention of one party's willingness to enter into a contract of specific content (a proposal) with another party ${ }^{1850}$ This means that the offer will often be directed at a specific person, although this does not necessarily have to be the case. ${ }^{1851}$ The offer has to be declared while having the intention to make an offer. ${ }^{1852}$ Furthermore, the proposal must be definite; otherwise an invitation to make an offer' is made instead. ${ }^{1853}$

1849 English term for 'mōshikomi no yūin' taken from Kitagawa, 'Contracts' (fn 1601) $\$ 2.01[3][\mathrm{d}][\mathrm{ii}]$ at 2-30.

1850 See Shin'ichi Tōda, Keiyaku no seiritsu: dai-521-jö-dai-528-jö [Formation of Contracts: Articles 521-528], in: Taniguchi and Igarashi (fn 1819) on dai-521-jo [article 521] at 436.

1851 See Tōda (fn 1850) on dai-521-jö [article 521] at 436.

1852 See Matsumoto, 'Keiyaku' (fn 1830) 18. He gives the negative example of someone only intending to obtain some information from a website and mistakenly clicking on a button, leading them to a page showing the purchase is complete. If the button did not show clearly that clicking it would mean making an offer, no contract is formed, because there was no declaration of intention to make an offer.

1853 Kitagawa, 'Contracts' (fn 1601) $\$ 2.01[3][\mathrm{d}][\mathrm{ii}]$ at 2-30. 
bb) Mōshikomi and Mōshikomi no Yūin(申込みの誘引, Invitation to Make an Offer)

While möshikomi are intended to bring about a contract, as just explained, moshikomi no yüin are meant to make the other person make an offer. ${ }^{1854}$ The differentiation between these two types of statement is therefore not merely of theoretical, but of practical importance, as no legal obligations arise from an invitation to treat. Instead, the formation process as such only begins when an offer is made.

Examples of an invitation to make an offer are 'help wanted' advertisements, 'house for rent' signs, or cost estimates. ${ }^{1855}$ These declarations are considered to constitute invitations to make an offer because a contract will not automatically arise when a person responds to the advertisement by applying for the job or the house. ${ }^{1856}$ Rather, the other party will first consider the person and their qualities before deciding on whether to contract. ${ }^{1857}$ Thus, it is the application that will be deemed to be an offer, since it contains sufficient intention on the part of the applicant to enter into a contract with the advertiser. ${ }^{1858}$ Similarly, product advertisements are regularly deemed to be invitations to make an offer. ${ }^{1859}$ This must also be true for distance selling, including online shopping, for the very

1854 See Yamamoto K, 'Minpō kögi IV-1' (fn 1646) 26-27. See also Ueda, 'Keiyaku (zenshū)' (fn 1602) 760.

1855 See Kawakami (fn 1831) 14 and Kitagawa, 'Contracts' (fn 1601) \$2.01[3][d][ii] at 2-30.

1856 Kawakami (fn 1831) 14.

1857 See Matsumoto, 'Keiyaku' (fn 1830) 19.

1858 of Kawakami (fn 1831) 14-15, who states that the intention of a person making an invitation to make an offer is 'overly insufficient' ('極めて不十分', kiwamete $f u$-jübun) in that the person does not give enough thought to the process or relationship leading to the formation of a contract. Compare Yamamoto K, 'Minpō kögi IV-1' (fn 1646) 27, who speaks of cases as invitations to make an offer where 'the necessity of reserving the decision whether to contract or not is high’ (“契約するかどうかの決定を留保する必要性が高い’, keiyakusuru ka dou ka no kettei wo ryūhosuru hitsuyō-sei ga takai). He goes on to note at ibid 27 that this necessity may be due to: firstly, the main content of the contract not being specified; secondly, the importance placed by the invitor on the person who is to become the contracting party; or thirdly, the possibility of performance by the invitor. Similar: Matsumoto, 'Keiyaku' (fn 1830) 19.

1859 See Matsumoto, 'Keiyaku' (fn 1830) 19. 
practical reason that a seller must first check whether the product is still in stock before being able to enter into a contract. ${ }^{1860}$

There are cases where the personal qualities of the potential contracting party are irrelevant, and yet, a statement or act will not be an offer. This is true for the display of bus or train timetables, or the sending of product samples, both cases of which are deemed to be mere invitations to make an offer. ${ }^{1861}$ Although not discussed in Japanese academic literature, it would follow from this in the former situation that the purchase of a ticket for public transport will give rise to a contract, as might the mere act of getting onto the vehicle. ${ }^{1862}$ At least where the customer purchases the ticket beforehand, eg, online, it seems that it is the customer who makes an offer, which is then accepted by the train or bus company. ${ }^{1863}$ Similarly, with product samples, it seems logical that an enquiry by the sample receiver to the sender regarding a purchase of the product would be an offer.

There are yet other instances where the difference between an offer and an invitation to make an offer is not always clear-cut and highly depends on the circumstances. Thus, in the case of a shop, like a supermarket, goods being displayed with set prices are considered to be offers; however, when goods are merely displayed in the shop window (with no price), this generally constitutes an invitation to make an offer. ${ }^{1864}$ The 'offer' (the displayed goods) is incomplete in the latter case, as no price is set. Consequently, even if a potential customer stated their intention to purchase the item, this would not automatically lead to a contract being concluded. ${ }^{1865}$ On this basis, it might be argued that where prices are displayed for goods in shop windows, these might constitute offers; however, the seller may still have an interest in reserving themselves the decision of whether to contract with a potential customer with regard to a particular good displayed, for, eg, not wanting to have to destroy the shop display if it is the last item in stock. Therefore, the result might still be the same if a price were shown for the goods in shop windows.

1860 See ibid.

1861 See Tōda (fn 1850) on dai-521-jō [article 521] at 437.

1862 See on this the arguments advanced with respect to English law in Section B.II.3.a.ii.bb) above.

1863 See the terminology used, eg, in the online reservation portal of Japan Rail at www.eki-net.com; or the explanations given in the user guide at www.ekinet.com/top/jrticket/guide/?src=reservetop_main.

1864 See Kawakami (fn 1831) 13, 14. See also Noriaki (fn 1641) 10.

1865 Compare Kawakami (fn 1831) 14. 
Another case is a vacant taxi, which is considered to constitute either an 'invitation to make an offer' or a concrete offer: When the taxi is circulating in traffic while displaying the 'vacant' sign, this conduct will be deemed to be merely an 'invitation to make an offer'; however, when a taxi is parked in a taxi rank, this will be an offer. ${ }^{1866}$ The difference seems to lie in the state of mind of the offeror. In the former situation, the taxi driver may reject the customer by simply driving past so that no obligation to contract arises; however, in the latter situation, it is clearly more difficult for the driver to prevent a customer from entering the taxi, giving the driver an obligation to contract. ${ }^{1867}$ In other words, the contract is incomplete until the customer boards the taxi, since the intention of the parties to enter into a contract with each other only forms at that point. ${ }^{1868}$

\section{cc) Coming into Effect of Mōshikomi: Tōtatsu Shugi (到達主義, Arrival Rule)}

An offer always comes into effect upon its arrival, irrespective of whether the persons are physically in the same location or not. ${ }^{1869}$ Offers therefore follow what is known as the 'arrival rule' (tōtatsu shugi, 到達主義) ${ }^{1870}$, the general rule contained in art 97 para 1 Minpō:1871 'A manifestation of intention to a person at a distance shall become effective at the time of the arrival of the notice to the other party'.1872 'Arrival' (tötatsu, 到達) is interpreted to mean that the recipient should objectively be able to have knowledge of the declaration of intention (ryüchushi ubeki kyakkanteki jötai, 了知し得べき客観的状態, literally 'objective state of being able to notice'). ${ }^{1873}$ According to the Japanese court:

1866 Ibid.

1867 See ibid. See also the discussion of job advertisements above.

1868 Compare ibid.

1869 Tōda (fn 1850) on dai-521-jo [article 521] at 438.

1870 The term is used by, eg, Kawakami (fn 1831) 14.

1871 Yamamoto K, 'Vertragsrecht' (fn 1612) 469 para 21.

1872 The original provision states: ‘隔地者に対する意思表示は、その通知が相手 方に到達した時からその効力を生ずる。'(Kakuchi-sha ni taisuru ishi hyōji ha, sono tsüchi ga aite-kata ni tötatsu shita toki kara sono köryoku wo shözuru.) Emphasis added.

1873 See Keizai Sangyō-shō ('METI'), Denshi shō-toribiki oyobi jōhō zai-torihiki tō ni kansuru junsoku [Interpretative Guidelines on Electronic Commerce and Information Property Trading] (Guideline, April 2015) i.3; available online at www.meti.go.jp/press/2015/04/20150427001/20150427001-3.pdf. This 
it is not required that the other party personally receives or has knowledge of the declaration of intention or of the document recording the same; it is sufficient if either enters what is known as the other party's sphere of control' (shihai-ken, 支配圏). ${ }^{1874}$

This has been interpreted to mean that neither knowledge of the contents of the declaration, nor even of its existence is required, ${ }^{1875}$ as this would mean that the person had actual knowledge, ${ }^{1876}$ which is precisely what is not required. The underlying logic of the court's reasoning is that the recipient is placed in a position where it is possible for them to know of the declaration, because the declaration of intention has entered the recipient's sphere of influence. ${ }^{1877}$

Applied to letters, this means that a letter can be handed over to the recipient's relatives or to people living together with them instead of to the recipient and still be deemed to have arrived. ${ }^{1878}$ In fact, the declaration of intention already comes into effect when the letter containing it is delivered into the mailbox at the recipient's address. ${ }^{1879}$ With declarations transmitted electronically, 'arrival' means the point in time at which the recipient is able to access the electromagnetic record. ${ }^{1880}$ This will be the

Guideline will hereinafter be referred to as 'E-Commerce Interpretation Guideline'; a (tentative) English translation of the Guideline can be found online at www.meti.go.jp/english/press/2015/0427_01.html.

1874 Saikō Saiban-sho decision of 17 December 1968 (Shōwa 43), Minshū Vol 22 No 13 2998: “[...]相手方によつて直接受領され、または了知されること を要するものではなく、意思表示または通知を記載した書面が、それらの 者のいわゆる支配圈内におかれることをもつて足りるものと解すべきであ る' ('aitekata ni yotte chokusetsu juryōsare, mata ha ryōchisareru koto wo yōsuru mono de ha naku, ishi byöji mata ha tsüchi wo kisaishita shomen ga, sorera no mono no iwayuru shihai-ken-nai ni okareru koto wo motte tariru mono to kaisubeki de aru'). See further Saikō Saiban-sho decision of 20 April 1961 (Shōwa 36), Minshū Vol 15 No 4744.

1875 Nakata, 'Höritsu köi' (fn 1795) on dai-97-jö (article 97) at 131.

1876 Compare Hōsei Shingi-kai Minpō (Saiken Kankei) Bukai, Minpō (saiken kankei) no kaisei in kansuru chükan shi'an no hosoku setsumei [Supplementary Explanations with Regard to the Interim Tentative Plan for the Reform of the Civil Code (Law of Obligations)] (last amendment July 2013) 355, available online at www.moj.go.jp/shingi1/shingi04900184.html (hereinafter 'Chūkan shi'an Explanations') 31.

1877 See E-Commerce Interpretation Guideline (fn 1873) i.3 and Saikō Saiban-sho decision of 20 April 1961 (fn 1874).

1878 Compare Nakata, 'Höritsu köi' (fn 1795) on dai-97-jö (article 97) at 131.

1879 See ibid.

1880 See E-Commerce Interpretation Guideline (fn 1873) i.3. 
case where the declaration is sent to either the designated recipient's e-mail address, or to the e-mail address that can reasonably be believed to be used by the recipient in situations like the one in question. ${ }^{1881}$

Similarly, with online transactions in web-browsers, the declaration is received once the information has been saved on the recipient's web server. ${ }^{1882}$ Note that in cases where the declaration is - by way of exception deemed to have arrived upon the message being downloaded, the recipient does not have to have actual knowledge of the declaration (its content); the ability to access the declaration's notice and thus of being able to read it is sufficient. ${ }^{1883}$ Consequently, the message will not be deemed to have arrived where it is lost before being recorded at the recipient's end; however, if it is first recorded and consequently lost, the notice is deemed to have reached the recipient nonetheless. ${ }^{1884}$ Similarly, if the message is not in a 'state where reading [it] is possible' (yomitori kanōna jötai, ‘読み取 り可能な状態'), ie, is illegible (moji bake, 文字化け, literally 'corrupted'), it will be deemed to not have reached the recipient, whereby the onus is on the sender to ensure the notice is legible for the recipient. ${ }^{1885}$

1881 See ibid. cf Tökyō Chihō Saiban-sho decision of 13 April 2019 (Heisei 29), in which the court found that the recipient of an e-mail had not received the convocation notice of a board meeting although the e-mail had entered the recipient's e-mail server. The reasons given were that the recipient used a personal computer and an e-mail-address that the sender's company had provided, but that the sender did not handle the equipment himself and his secretary had also not accessed the account after the e-mail had been sent. Furthermore, the court saw no reason to hold that the recipient ought to have had knowledge of the e-mail. As a consequence, the recording on the recipient's e-mail server may, by way of exception, not be equal to 'receipt' of a declaration. The case concerned the annulment of a board meeting in which the plaintiff, the managing director, was dismissed. The plaintiff's claim was based on the fact that the convocation notice for the board meeting in question, which had been sent late at night before the morning on which the meeting took place, was invalid. The court found for the plaintiff.

1882 Compare E-Commerce Interpretation Guideline (fn 1873) i.4.

1883 See ibid i.3, i.2.

1884 See ibid.

1885 See ibid i.4. 
dd) Loss of Effect of Moshikomi: The Distinction Between Taiwa-sha-kan (対話者間, Between Present Persons) and Kakuchi-sha-kan (隔地者間, Between Persons at Distance)

Möshikomi can lose their effect in two ways, namely, by expiring or by being revoked. There are two instances for each of these ways. The first situation for expiry is an offer made to a present person (between present persons, taiwa-sha-kan, 対話者間)1886: an offer thus made is only valid while the parties remain together; once they separate, the offer expires. ${ }^{1887}$ In this regard, it ought to be noted that the term 'persons present' (taiwa-sha, 対 話者) is interpreted in several ways. First, it means that the parties are in each other's physical presence. ${ }^{1888}$ This becomes apparent from the words itself, which literally translate as 'between interlocutors', ${ }^{1889}$ whereby 'tai$w a$ ' on its own signifies 'dialogue', 'conversation', or 'interaction'. In this sense, the English phrase chosen by Kitagawa, 'during a conversation', 1890 is perhaps closest to the literal Japanese meaning. The translation as in direct communication' (eg, art $507 S h \bar{h} h \bar{o}$ ), supports the understanding that a declaration of intention made by one party is 'immediately' (tadachi $n i$, 直ちに) perceived by the other party. ${ }^{1891}$ This is because there is no time interval between transmission and receipt of the declaration of intention, so that an immediate response can be anticipated. ${ }^{1892}$ With regard to the methods of communication associated with this situation, taiwa is understood to include a telephone call. ${ }^{1893}$ Following from this, it could be

1886 English translation by this author.

1887 While an explicit rule exists for commercial cases (art 507 Shöhö), there is only a general non-written rule for situations in which the Minpō is applicable. See on this Yamamoto K, 'Vertragsrecht' (fn 1612) 471 para 30; see further Ueda, 'Keiyaku seiritsu' (fn 1832) on dai-524-jō at 765. According to the majority view in Japanese academic literature, art 507 Shöhō is applicable as long as the act is of a commercial nature for at least one of the parties; a partially dissenting view is that the commercial rule should be applicable only if the offeror is a merchant, see Ōtsuki (fn 1614) 98.

1888 Matsumoto, 'Denshi shakai' (fn 1819) 298 gives the example of direct contract negotiations.

1889 Götze, 'Rechtswörterbuch' (fn 10) 541 uses the German translation 'Anwesender'.

1890 Kitagawa, 'Contracts' (fn 1601) $\$ 2.01[3][\mathrm{d}][\mathrm{iii}][\mathrm{A}]$ at 2-30 and [B] at 2-31.

1891 See the definition of the term 'taiwa-sha-kan' given by Endō and Matsuda (fn 1597) 88.

1892 See Ueda, 'Keiyaku seiritsu' (fn 1832) on dai-524-jo [article 524] at 765.

1893 See Matsumoto, 'Keiyaku' (fn 1830) 14; see further Kitagawa, 'Contracts' (fn 1601) $\$ 2.01[3][\mathrm{d}][\mathrm{iii}][\mathrm{A}]$ at 2-30. This differentiation was already contem- 
argued that parties to a direct conversation via the internet, eg, in a video conference, might also be regarded as being 'in each other's presence'. ${ }^{1894}$ This is supported by the fact that instant messaging and chatting on the internet (but not e-mails) are deemed equivalent to being 'in conversation' (taiwa). ${ }^{1895}$

On the other hand, if an offer specifies a period in which it can be accepted, it will naturally expire if the offeree does not accept it within that period (see art 521 para 2 Minpō). This 'automatic expiration' of the offer is not absolute, however, since arts 522-523 Minpo and art 508 paragraph 2 Shōho provide some flexibility with regard to late acceptances: if the offeror does not give notice to the offeree that the declaration of acceptance arrived too late when the offeror ought to know that it was dispatched in a way so that it would normally have arrived on time, acceptance is treated as having been made on an effective offer (art 522 paras 2, 1 Minpō). Furthermore, art 523 Minpō and art 508 para 2 Shōhō give the offeror the discretionary power to consider a late acceptance as a new offer. If this is the case, the contract process begins anew with the original offeree now as the offeror and vice versa.

As for the offer being revoked, this can be done with an offer made between present persons at any time before the offer is accepted by the offeree. ${ }^{1896}$ This is not true where the offer specifies a period of acceptance, as it then becomes irrevocable (art 521 para 1 Minpō). This provision notwithstanding, an offeror may always, ie, independently of whether a period for acceptance has been stipulated, revoke an offer before it reaches the offeree. ${ }^{1897}$

In contrast to art 521 para 1, art 524 Minpo allows for the revocation of an offer not specifying a period of acceptance made to an offeree not in the presence of the offeror (ie, between persons at distance, kakuchi-sha-kan, 隔 地者間); however, this is only possible after a 'reasonable period' of time has elapsed, ie, a time during which the offeror should normally have re-

plated at the time of creation of both the Minpo and the Shōōo, compare Matsumoto, ibid.

1894 Indeed, it has been argued that a video chat is similar to a telephone call so that parties in such situations are treated as being 'in conversation', see Matsumoto, 'Keiyaku' (fn 1835) 14.

1895 See Matsumoto, 'Denshi shakai' (fn 1819) 299 and Matsumoto, 'Keiyaku' (fn 1830) 15.

1896 Yamamoto K, 'Vertragsrecht' (fn 1612) 471 para 30.

1897 Ueda, 'Keiyaku seiritsu' (fn 1832) on dai-524-jo [article 524] at 765; Yamamoto K, 'Minpō kögi I' (fn 1632) 129. 


\section{Contracts in Japanese Law}

ceived the offeree's declaration of acceptance. ${ }^{1898}$ The length of this period depends on the circumstances of the case in question, whereby factors such as the method of making the declaration, the importance of the contract's object or the customary practices in question have an influence on the time frame. ${ }^{1899}$ Having said this, it seems that three factors ought to be borne in mind when assessing the period: first, the time it takes for an offer to reach an offeree; secondly, the time an offeree would need to consider whether to accept or reject the offer, including the time needed to draft a reply; and thirdly, the time a declaration of acceptance would need in order to reach the offeror. ${ }^{1900}$

The term 'at distance' (kakuchi, 隔地) simply means that the parties are not in each other's physical presence, as is evidenced by the literal meaning of the kanji ' $k a k u$ ' as 'division', 'separation', 'interval', and 'chi' as 'position' or 'location'. 1901 Translations into German as 'Abwesenheit' (absence) and 'anderer Ort' (different place) reflect this meaning. ${ }^{1902}$ Letters are traditionally linked with this situation. ${ }^{1903}$ Furthermore, while it has been stated that telegrams, telex, and fax could spatially be seen as equivalent to the situation of being 'in conversation'; however, that these methods better resemble a letter in terms of the uncertainty of the other party being at the place these were sent. ${ }^{1904}$ It could therefore not be known if the fax has actually been read by the recipient, which is an argument also put forward in relation to e-mails. ${ }^{1905}$ Consequently, an immediate response cannot be expected, so that fax and e-mails are associated with the kakuchi situation. ${ }^{1906}$

An exception to art 524 is laid down in art 530 para 1 Minpō regarding offers of prizes in advertisements (kenshō kōku, 懸賞広告): the offeror may

1898 See Kitagawa, 'Contracts' (fn 1601) $\$ 2.01[3][\mathrm{d}][$ iii] [A] at 2-30, who phrases it as the time 'reasonably necessary' for the declaration of acceptance to arrive.

1899 Töda (fn 1850) on dai-524-jö [article 524] at 469.

1900 See ibid 469-670. This is similar to German law, see Section B.III.3.a.ii.ee) above.

1901 Hadamitzky and others (fn 11) 275 at $2 \mathrm{~d} 10.2$ and 604 at $3 \mathrm{~b} 4.9$ respectively.

1902 Götze, 'Rechtswörterbuch' (fn fn 10) 234.

1903 See Matsumoto, 'Keiyaku' (fn 1830) 14. See further Kitagawa, 'Contracts' (fn 1601) $\$ 2.01[3][\mathrm{d}][\mathrm{iii}]$ [A] at 2-30. This differentiation was already contemplated at the time of creation of both the Minpo and the Shōos, compare Matsumoto ibid.

1904 See Matsumoto, 'Denshi shakai' (fn 1819) 298 and Matsumoto, 'Keiyaku' (fn 1830) 14.

1905 See Matsumoto, 'Denshi shakai' (fn 1819) 299.

1906 See Ueda, 'Keiyaku seiritsu' (fn 1832) on dai-524-jö [article 524] at 765. 
revoke the offer so long as no offeree has completed the act. ${ }^{1907}$ It seems that any act of preparation or of actual performance by the offeree is irrelevant; it is only from the moment that the performance has been completed that the offer may no longer be withdrawn, whereby it is irrelevant whether the offeror has had notice of the completed performance. ${ }^{1908}$ This does not apply where the offer specifies a period for performance by those seeing the advertisement, since art 530 para 3 Minpo presumes the advertiser's waiver to revoke in this situation.

Where a revocation is possible and it is sent out by the offeror so that it reaches the offeree before the declaration of acceptance is dispatched, the offer is revoked effectively. ${ }^{1909}$ The situation becomes complicated if the revocation only arrives after the dispatch of the offeree's acceptance. Normally, acceptance would have rendered the revocation ineffective; however, art 527 Minpō provides that if the offeree knows or ought to have known that the notice would normally have arrived before the dispatch of their acceptance, and if the offeree does not give notice of this late arrival without undue delay, the revocation is deemed to be effective so that no contract is formed. ${ }^{1910}$ Where the contract in question is made through electronic means, like e-mail, art 527 Minpō does not apply (art 4 Denshi keiyaku-hō). ${ }^{1911}$

The non-revocability of an offer can be circumvented by the offeror reserving their right to withdraw the offer at the time of its making. ${ }^{1912}$ In this case, the offeror can revoke the offer at any point in time, even if the offer specifies a period of acceptance. ${ }^{1913}$ Another exception to the

1907 See ibid on dai-530-jö [article 530] at 770.

1908 For further details, see Hiroshi Uebayashi and Kiyoshi Igarashi, Keiyaku no seiritsu: dai-529-jō-dai-532-jō [Formation of Contracts: Articles 529-532], in: Taniguchi and Igarashi (fn 1819) on dai-530-jo [article 530] at 514-515.

1909 Cf Kappu hanbai-hō (Installment Sales Act, 割賦販売法, Law No 159/1961 as amended; English translation available online at www.japaneselawtranslation.go.jp/law/detail/?id=2334\&vm=04\&re=02\&new=1), which provides explicitly that withdrawals of offers are effective upon dispatch of the document containing the declaration of intention: inter alia, arts 35-3-10 paras 2 and 5, 35-3-11 para 4. Note that contradicting contractual stipulations are void, see paras 15 of arts 35-3-10 and 35-3-11 ibid. The same is true for retractions relating to both buildings or building lots (art 37-2 para 2 Takuchi-gyo-hö (fn 1915)) and in relation to door-to-door sales (art 9 para 2 Tokutei shö-torihiki-hö), both of which become effective upon sending ('発した時に', hasshita toki ni).

1910 See Yamamoto K, 'Vertragsrecht' (fn 1612) 470-471 para 28.

1911 Ibid 470 para 25.

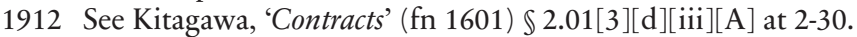

1913 Yamamoto K, 'Vertragsrecht' (fn 1612) 470 para 27. 


\section{Contracts in Japanese Law}

irrevocability of an offer is provided in consumer law by what has been called a 'cooling off period':1914 in door-to-door sales, the consumer has the right to withdraw their offer within eight days from the time that the document containing the details of the seller's offer was received (see arts 9 para 1, 4 Tokutei sho-toribiki-hö). A similar provision is found in connection to sale transactions of buildings and building lots: Article 37-2 para 1 no i Takuchi tatemono torihiki-gyo-ho' (hereinafter 'Takuchi-gyo-hö'1915) stipulates an eight-day revocation period for a person who makes a purchase offer on a building or a building lot, so that the prospective purchaser is given the right to retract their offer; however, this is only possible until the contract has been performed (ibid no ii). The provision is mandatory so that any agreement between the parties stipulating otherwise is 'invalidated' ('無効 とする’, mukō to suru, art 37-2 para 4 ibid).

If an offer made to a person at distance that does not stipulate a period for acceptance is not subsequently revoked, it will remain effective, but only for a limited time. ${ }^{1916}$ The time-limit is a 'reasonable period', ${ }^{1917}$ in which the declaration of acceptance should have been dispatched, as provided in art 508 para $1 S h \bar{o} h \bar{o}^{-1918}$ After this period, the offer will 'cease to be effective' ('効力を失う’, korryoku wo ushinau, ibid). Although this rule is set out in the $S h \bar{h} \bar{o}$, legal academics and practitioners alike admit its applicability to contracts falling under the Minpō. ${ }^{1919}$

\section{iii. Shōdaku (承諾, Acceptance)}

Under Japanese law, a moshikomi has to be accepted before a contract can form, as 'mutual assent' between the contracting parties is the essence of a Japanese contract. ${ }^{1920}$ This is even true for gifts (zōyo, 贈与): the donor's

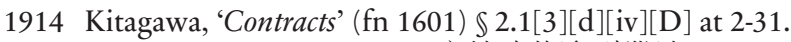

1915 Real Estate Brokerage Act, 宅地建物取引業法, Law No 10/1952 as amended; English translation available online at www.japaneselawtranslation.go.jp/law/ detail/?id $=2320 \& v m=04 \&$ re $=02 \&$ new $=1$.

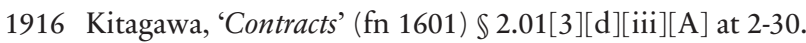

1917 Ueda, 'Keiyaku seiritsu' (fn 1832) on dai-524-jo [article 524] at 765. See the explanation above.

1918 See Kitagawa, 'Contracts' (fn 1601) \2.01[3][d][iii][B] at 2-302-31, who uses the term 'acceptability' to indicate that an offer is effective and can be accepted by the offeree so that a contract is formed.

1919 See ibid 2-31. See also fn 1887: what Ōtsuki states regarding art 507 Shōhō is also true for art 508 .

1920 See Kitagawa, 'Contracts' (fn 1601) \$2.01[3][a] at 2-27. 
(zoyo-sha, 贈与者) intention to give something has to be accepted by the donee (juzō-sha, 受贈者) before the act becomes effective (art 549 Minpō). The addressee of a moshikomi can react in different ways: They may reject the offer, or do nothing, in which case the offer will eventually expire (but see Section bb) below). They may, of course, accept (shödaku suru, 承諾 る; see the definition in Section aa) below). This requires a particular conduct or statement to be made (Section bb)). The issue of when shödaku comes into effect and how it may lose its effectiveness must also be considered (Sections cc)-dd)).

\section{aa) 'Shōdaku' Defined}

Shödaku can be defined as 'a declaration of intention made in reply to a specific offer to make a contract', ${ }^{1921}$ the content of which has to correspond with that of the offer. ${ }^{1922}$ Put more simply, it is the 'OK' given without reservations by the offeree to the proposed content of the moshiko$m i .{ }^{1923}$ Using the example of a supermarket again, the customer (buyer) accepts the seller's offer when handing the basket containing the goods over to the shop assistant at the register, since it is at this point that the intention to purchase becomes definite. ${ }^{1924}$ Again, it is the concurrence of the buyer's intention to purchase and that of the seller to sell the product that gives rise to the contract. ${ }^{1925}$ In this way, a mere confirmation of having received an offer is not acceptance. ${ }^{1926}$

Where the content of the declaration of acceptance does not correspond to the content of the offer, the ostensible declaration of acceptance is treated as a 'new offer' made by the offeree ('新たな申込み', aratana möshikomi, art 528 Minpō). This is true where the offeree changes the conditions of the offer, eg, the price, ${ }^{1927}$ or where acceptance is made conditionally; however, minor modifications are tolerated in practice. ${ }^{1928}$ Similarly, in sit-

1921 Ibid $\$ 2.01[3][\mathrm{e}][\mathrm{ii}]$ at 2-32.

1922 Yamamoto K, 'Vertragsrecht' (fn 1612) 469 para 22. See also Tōda (fn 1850) on dai-526-jo [article 526] at 482.

1923 Kawakami (fn 1831) 14.

1924 See ibid 13, 14. Another example is the insertion of a coin into a vending machine, ibid 14.

1925 Noriaki (fn 1641) 13.

1926 E-Commerce Interpretation Guideline (fn 1873) i.3.

1927 Tōda (fn 1850) on dai-528-jö [article 528] at 506.

1928 Kitagawa, 'Contracts' (fn 1601) \$2.01[3][e][iii][B] at 2-33. 


\section{Contracts in Japanese Law}

uations where the declaration of acceptance is made too late to be effective (see the subsequent section), ${ }^{1929}$ it is within the discretion of the offeror to

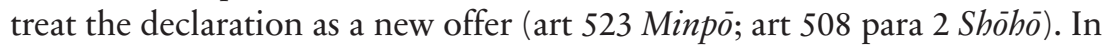
this way, a contract may still be concluded despite the original offer having expired. The ostensible declaration of acceptance can be treated as an offer, because the declaration contains the intention to conclude a contract. ${ }^{1930}$ There is nevertheless a caveat: if the offeror is or should have been aware that the late arrival of the declaration of acceptance is due to unusual circumstances and it would normally have been received on time, they are obliged to give notice of the late arrival (“延着の通知', enchaku no tsüchi) to the offeree (art 522 para 1 Minpō). A failure to do so will result in the declaration of acceptance being deemed as having arrived on time (art 522 para 2 Minpō), so that a contract is then formed. ${ }^{1931}$ This does not apply where the offeror has sent the offeree a 'notice of delay' ('遅延の通知', chi'en no tsüchi), ie, a notification that no acceptance reached the offeror before the expiration of the set time period, before the late acceptance arrives (art 522 para 1 Minpō). ${ }^{1932}$

\section{bb) Method of Shödaku}

Acceptance does not always have to be express; acceptance-like behaviour by the offeree can be sufficient in particular circumstances. ${ }^{1933}$ Thus, art 526 para 2 Minpo provides that a notice of acceptance is not necessary where either the way in which the offeror has made the offer or a trade custom does not require it. The contract is then deemed to be formed when the offeree acts in a way that can be interpreted as acceptance (art 526 para 2 Minpō). This might constitute commencing with preparations

1929 To be precise, the declaration of acceptance cannot become effective, because the bindingness of the offer expires after the specified time-limit ends, see art 521 para 2 Minpō.

1930 Compare Ueda, 'Keiyaku seiritsu' (fn 1832) on dai-523-jö [article 523] at 765.

1931 Yamamoto K, 'Vertragsrecht' (fn 1612) 469-470 para 24.

1932 See also Kitagawa, 'Contracts' (fn 1601) $\$ 2.01[3][\mathrm{e}][$ iii] [A] at 2-33. It should be noted that while art 522 Minpō uses the term 'notice of late arrival' (enchaku no $t$ suchi) to describe the notice that the offeror has to give where they are aware that acceptance would normally have reached them on time, the term 'notice of delay' (chi'en no tsüchi) is used to distinguish the notice the offeror can send out where they have received no declaration of acceptance within the specified period.

1933 Kawakami (fn 1831) 14. 
for performing their contractual obligations, ${ }^{1934}$ or exercising a right that the offeree would only obtain through the conclusion of the contract. ${ }^{1935}$ Advertisements that offer a prize are an example of legislation implying acceptance: where a person seeing the advertisement has acted (performed) according to the advertisement, the advertiser must hand over the reward to that person (art 529 Minpō). Irrespective of these situations, the parties can agree to dispense with (express) acceptance. ${ }^{1936}$

Due to the nature of commerce, the rule applicable to merchants deviates from the general principles on acceptance: where the offeree receives an offer from a regular business partner, acceptance will be implied if the offeree does not respond without delay (art 509 paras 1-2 Shōhō). ${ }^{1937}$ Academic opinion is divided on the question whether this rule also applies to 'civil' contracts. ${ }^{1938}$ Arguably, it should be applicable to 'semi-commercial' contracts, ie, B2C transactions in which one of the parties is a merchant. This is due to art $3 S h \bar{o} h \bar{o}$, which provides that the $S h \bar{o} h \bar{o}$ is applicable to all parties if an act is commercial for at least one of them. Exceptions to this rule include the right to claim interest on a loan for consumption (art $513 S h \bar{h} \bar{o}$ ) or the chapter on sales (arts 524-528 ibid), ${ }^{1939}$ but seem not to encompass art 508 Shōhō.

cc) Coming into Effect of Shōdaku: Hasshin Shugi (発信主義, Dispatch Rule) and Tötatsu Shugi (到達主義, Arrival Rule)

The coming into effect of shödaku is not governed by one rule, like mōshikomi, but by two doctrines: Beside the tôtatsu shugi (see Section ii.cc) above), what is known as the dispatch rule (hasshin shugi, 発信主

1934 Kitagawa, 'Contracts' (fn 1601) $\$ 2.01[3][\mathrm{e}][\mathrm{ii}]$ at 2-32.

1935 Yamamoto K, 'Vertragsrecht' (fn 1612) 471 para 31.

1936 See Masao Yanaga, A Bill Regarding the Electronic Declaration of Intention in Japan (2001) 11 ZJapanR / JJapanL 255, making this statement in relation to the formation rules in general. See also Kitagawa, 'Contracts' (fn 1601) \$2.01[3] [e][ii] at 2-32.

1937 See Kitagawa, 'Contracts' (fn 1601) \$2.01[3][e][ii] at 2-32.

1938 Marutschke, 'Einführung' (fn 1603) 153.

1939 See Endō and Matsuda (fn 1597) on dai-3-jö [article 3] at 11. 
義 $)^{1940}$ will often apply. ${ }^{1941}$ The latter is a special rule ${ }^{1942}$ that becomes evident from the provision contained in art 526 para 1 Minpo o: 'A contract between persons at a distance shall be formed upon dispatch of the notice of acceptance'. ${ }^{1943}$ It can be deduced from this that acceptance becomes effective upon its dispatch, ${ }^{1944}$ since a contract can only be formed when acceptance, made on a valid offer, is effected. ${ }^{1945}$ Although phrased in the negative and not stating the effectiveness of a declaration of acceptance as clearly as the Minpō, the dispatch doctrine is said to be contained in art 508 para 1 Shōhō: 1946

Where merchants are at distance from each other, if the party who has received an offer of a contract that was made without specifying a period for acceptance does not dispatch a notice of acceptance within a reasonable period of time, such offer shall cease to be effective. ${ }^{1947}$

'Dispatch' ( bassin, 発信) simply means being sent out, so that, if, for example, the notification is delayed or gets lost on the way and so does not

1940 The term is used by, eg, Kawakami (fn 1831) 14. Sometimes the term 'dispatch doctrine' is used instead of 'dispatch rule', see, eg, Kitagawa, 'Contracts' (fn 1601) $\$ 2.01[3][\mathrm{e}][\mathrm{iv}]$ at 2-33.

1941 Note that the situation has been simplified under the recent reform of the Minpō, as discussed in Section V.a. below.

1942 Chūkan shi'an Explanations (fn 1876) 355. See also Ueda, 'Keiyaku seiritsu' (fn 1832) on dai-526-jo [article 526] at 767.

1943 The original reads: “隔地者間の契約は、承諾の通知を発した時に成立する’ (Kakuchi-sha-kan no keiyaku ha, shōdaku no tsüchi wo hasshita toki ni seiritsu suru); emphasis added.

1944 Ueda, 'Keiyaku seiritsu' (fn 1832) on dai-526-jö [article 526] at 767. See also Kazuo Shinomiya and Yoshihisa Nōmi, Minpō sōsoku [Civil Code General Provisions] (9 ${ }^{\text {th }}$ edn, Kōbundō 2018) 290. See further Chūkan shi'an Explanations (fn 1876) 355.

1945 See Yamamoto K, 'Vertragsrecht' (fn 1612) 469 para 23. See also Ueda, 'Keiyaku seiritsu' (fn 1832) on dai-526-jō [article 526] at 767; Yamamoto K, 'Minpō kōgi IV-1' (fn 1646) 29, 30.

1946 See Tanaka and others (fn 1617) 92.

1947 The original reads: ‘商人である隔地者の間に打いて承諾の期間を定めない で契約の申込みを受けた者が相当の期間内に承諾の通知を発しなかったと きは、その申込みは、その効力を失う' ('Shōnin de aru kakuchi-sha no aida ni oite shödaku no kikan wo sadamenaide keiyaku no möshikomi wo uketa mono ga sōtō no kikan-nai ni shödaku no tsüchi wo hashinakatta toki ha, sono möshikomi ha, sono köryoku wo ushinau'), emphasis added. 
reach the recipient (offeror), a contract is still formed. ${ }^{1948}$ Where communication is made electronically, as in an e-mail or online in a web-browser, the meaning of dispatch is that the 'information [of the order] is sent'. ${ }^{1949}$

As mentioned above, the situation concerning the effectiveness of shödaku is more complicated, as the wording of art 521 para 2 Minpo, which speaks of the offeror 'not having receiv[ed the] notice of acceptance' (“承諾の通知を受けなかった’, shödaku no tsüchi wo ukenakatta) on time, seems to suggest that acceptance of an offer that specifies a period for doing so is governed by the general rule, ie, by the 'arrival rule'. ${ }^{1950}$ The question of which doctrine is applicable therefore seems to depend on whether an offer contains a period of acceptance. In this way, the risk of the declaration of acceptance being delayed or lost and the acceptor nevertheless being bound can be avoided by including a time frame for acceptance in the offer, since, by doing so, art 521 para 2 Minpo will apply, making acceptance effective only once it reaches the offeror. ${ }^{1951}$ As a similar provision to art 521 Minpō is not found in the Shōbo , it could be argued that the Minpō provision and thus the arrival rule applies to $\mathrm{B} 2 \mathrm{~B}$ situations, unless some commercial custom takes precedent. This result seems to contradict the underlying intention of the commercial rules, however, since the drafters of the Shōho decided against adopting the arrival rule due to the potential harm done to the (legal) certainty in commerce where a declaration of acceptance is either delayed or does not

1948 Ueda, 'Keiyaku seiritsu' (fn 1832) on dai-526-jö [article 526] at 767 and 768. See also Kitagawa, 'Contracts' (fn 1601) $\$ 2.01[3][\mathrm{e}][\mathrm{iv}]$ at 2-34; Yamamoto K, 'Minpō kögi IV-1' (fn 1646) 30.

1949 See E-Commerce Interpretation Guideline (fn 1873) i.4.

1950 See Kitagawa, 'Contracts' (fn 1601) \$2.01[3][e][iv] at 2-33-2-24. See also Yamamoto K, 'Vertragsrecht' (fn 1612) 469 para 24. For an overview of the ongoing discussion among Japanese legal academics relating to an interpretation of the stipulation to make it consistent with art 526 Minpō, see Ueda, 'Keiyaku seiritsu' (fn 1832) on dai-526-jö [article 526] at 767. In essence, it surrounds the issue of which provision represents the general rule and which is the exception for acceptance. While some academics are of the opinion that the arrival rule is an exception to the dispatch rule (see, eg, Kitagawa, ibid at 2-34); others see the dispatch rule as a deviation from the general rule for the effectiveness of declarations of intention (see, eg Yamamoto K, ibid para 23). Although the Japanese courts have not yet ruled on this question, it seems that deeming the dispatch rule to be the general principle for declarations of acceptance is closer to the legislator's intention, see Ueda ibid.

1951 Compare Ueda, 'Keiyaku seiritsu' (fn 1832) on dai-526-jö [article 526] at 768. 


\section{Contracts in Japanese Law}

arrive at all. ${ }^{1952}$ Having said this, using the arrival rule when a period has been stipulated seems natural, and, furthermore, will give the offeror an advantage. This is because the offeror will have certainty as to whether the offeree has accepted the proposal by the deadline, since the offeree's response must have arrived by the end of the stipulated period in order to make an effective declaration of intention. In this sense, the application of the arrival rule could be said to support commerce. Nevertheless, it is not clear whether the arrival rule can be applied in B2B situations.

The dispatch rule is also not applicable to shödaku made and transmitted electronically (art 4 Denshi keiyaku-hō), ie, those sent by e-mail, fax, or telephone. ${ }^{1953}$ Accordingly, electronic acceptance notices (denshi shödaku $t s \bar{u} c h i$, 電子承諾通知) are governed by the arrival rule contained in art 97 Minpo ${ }^{1954}$ According to the definition of the term 'electronic acceptance notices' contained in art 2 para 4 Denshi keiyaku-hō, the provision applies to declarations of acceptance transmitted via telephone, telex, fax, or a personal computer. And while the title of the Act suggests otherwise, this provision is deemed by Japanese legal academics to apply to electronic acceptance irrespective of whether a consumer is involved in the process. ${ }^{1955}$ This view is supported both by the wording of the provision, which simply refers to 'a contract made between persons at a distance' (“隔地者間の契 約に打いて', kakuchi-sha-kan no keiyaku ni oite), as well as the generalised definition given for electronic acceptance notices (arts 4, 2 para 4 Denshi keiyaku-hō). In fact, the intention behind this legislation seems to have been to provide a regulation for a lacuna, since the Minpō does not currently regulate electronic declarations of intention; therefore, the stipulation modifies the rules of the Minpō in cases of electronic acceptance between parties at distance. ${ }^{1956}$ Indeed, the purpose of the legislation reads:

1952 Compare Tanaka and others (fn 1617) 92. Indeed, the dispatch rule was deemed to suit the character of commerce better, ibid 93.

1953 See Sono and others (fn 1632) 55.

1954 Yamamoto K, 'Vertragsrecht' (fn 1612) 469 para 25; E-Commerce Interpretation Guideline (fn 1873) i.2-i.3. See also Tōda (fn 1850) on dai-526-jō [article 526] at 493; Kunihiro Nakata, Die Modernisierung des Willenserklärungsrechts in Japan [The Modernisation of the Law of Declarations of Intention in Japan] (2019) 47 ZJapanR / JJapanL 247, 264-265.

1955 See, eg, Yanaga, 'Electronic Declarations Bill' (fn 1936) 256; or Yamamoto K, 'Vertragsrecht' (fn 1612) 470 para 25.

1956 Interview with Kunihiro Nakata, Professor, Faculty of Law, Ryūkoku University (Kyōto, 12 May 2017) and subsequent personal correspondence. 
This Act shall provide special provisions to the Civil Code (Act No. 89 of 1896) in cases where [...] an electronic acceptance notice is dispatched $[\ldots]$ with respect to a contract made by persons at a distance. ${ }^{1957}$

The seeming contradiction in the rules regarding the time of coming into effect of declarations of intention can be explained on the basis that the dispatch and the arrival rules stem from different legal traditions: While the dispatch rule is a concept taken from English law, ${ }^{1958}$ the general rule for declaration of intention, the arrival rule, was originally adopted from French law; although it is also found in German law. ${ }^{1959}$ This case is an excellent example of the achievement of Japanese legislators to combine legal concepts of different origins. The reason for the adoption of the English dispatch rule is two-fold: to enable the offeree to begin performing the contract right away, while also making the declaration of acceptance binding for the offeree without delay; whereby both are important in legal practice. ${ }^{1960}$ A slightly different explanation is that the dispatch rule was inserted to promote commerce: Merchants desire a speedy formation process, and giving effect to acceptance upon its dispatch rather than its arrival contributes to a smooth and swift contract conclusion. ${ }^{1961}$ Irrespective of the reason, the rule results in contracts being concluded sooner than if the arrival rule were applied to acceptance, as a period of time usually

1957 Article 1 Denshi keiyaku-hō. The original states: ‘この法律は、[...] 隔地者間の 契約において電子承諾通知を発する場合に関し民法 (明治二十九年法律第 八十九号) の特例を定めるものとする’ (Kono höritsu ha, [...] kakuchi-sha-kan no keiyaku ni oite denshi shödaku tsüchi wo hassuru ba'ai ni kanshi minpō (meiji 29-nen höritsu dai-89-gō) no tokurei wo sadameru mono to suru').

1958 Yamamoto K, 'Vertragsrecht' (fn 1612) 469 para 23, who refers to the dispatch rule by the German term 'Abgabetheorie' (issuance theory). On the English postal rule, see B.II.3.a.ii.ee) above.

1959 On the German Empfangstheorie (receipt theory), see B.III.3.a.ii.dd) above.

1960 See Yamamoto K, 'Vertragsrecht' (fn 1612) para 23.

1961 Chūkan shi'an Explanations (fn 1876) 355. Compare also Tōda (fn 1850) on dai-526-jo [article 526] at 484 and 491. cf Nakata, 'Willenserklärungsrecht' (fn 1954) 264, who notes that the dispatch rule was meant to facilitate swifter contract conclusions. Indeed, the 'time is of the essence'-principle, (in)famous in English commercial law, may be said to be of great importance in Japanese commerce as well. This is not only reflected in the dispatch rule. The short time periods foreseen in the $S h \bar{o} h \bar{o}$, such as in art 507 or art 508, are designed to minimise unnecessary waiting time and can thus be said to support prompt commerce. On this last note, see Tanaka and others (fn 1617) 90, who observe that art 507 is based on art $293 \mathrm{Ky} \bar{u}$-shöhö (on which, see fn 1965 below). 
passes between sending and receipt of an acceptance declaration, which depends on the dispatch method used. Thus, the need for having a special provision for electronic acceptance, as found in art 4 Denshi keiyaku-hō, can be explained by the fact that modern digital technologies allow for a swift transfer of information, reducing the time lag to almost zero and thus rendering the dispatch rule unnecessary. ${ }^{1962}$

The time span during which acceptance can be made varies: If the offer stipulates a date, then, naturally, this point in time is decisive. Where an offer does not give a time frame, acceptance must be declared within a reasonable period. While this is expressly provided for in art 508 para 1 Shōo ${ }^{1963}$ a similar requirement can be implied from the wording of art 524 Minpō, which states:

An offer made to a person at a distance without specifying a period for acceptance may not be revoked until the lapse of a reasonable period for the offeror to receive a notice of acceptance. ${ }^{1964}$

Although the provision seems to concern the non-revocability of an offer that does not specify a period for acceptance, it implicitly requires that acceptance be made within a reasonable amount of time. This can be deduced from the circumstance that the offeror must wait for this period to end before the offer can be revoked. Due to the nature of commerce, the Shöhō contains another rule for acceptances that is stricter: When a party receives an offer for a contract directly from another party in a commercial setting, ie, when they are in each other's presence, they must accept immediately ('直ちに', tadachi $n i$ ), otherwise the offer expires (art 507 Shōhō $).{ }^{1965}$

1962 Compare in this respect Nakata, 'Willenserklärungsrecht' (fn 1954) 264.

1963 The provision says that acceptance must be dispatched within a reasonable period (‘相当の期間内に’, sōtōno kikan-nai ni).

1964 The original reads: ‘承諾の期間を定めないで隔地者に対してした申込み は、申込者が承諾の通知を受けるのに相当な期間を経過するまでは、撤回 することができない’ ('Shōdaku no kikan wo sadamenaide kakuchi-sha ni taishite shita mōshikomi ha, mōshikomi-sha ga shōdaku no tsūchi wo ukeru no ni sōtōna kikan wo keikasuru made ha, tekkaisuru koto ga dekinai'); emphasis added.

1965 Ötsuki (fn 1614) 98 notes that this stipulation was created to anticipate the promptness of commerce. The time-period for accepting an offer between persons present has been shortened: The stipulation's predecessor, art 293 $K y \bar{u}-s h \bar{o} h \bar{o}$, foresaw that acceptance had to be expressed 'promptly' (“即時に', sokuji ni), see Tanaka and others (fn 1617) 90. This meant that acceptance had to be sent by noon on the day after the offer was received (art $295 K y \bar{u}$-shōhō), see Tanaka and others, ibid 92. 
dd) Loss of Effect of Shödaku

According to the majority view in Japanese academic literature, acceptance, once dispatched, cannot be revoked by the offeree. ${ }^{1966}$ This is because, as was explained in the previous section, acceptance comes into force upon its dispatch. ${ }^{1967}$ As acceptance of an offer specifying a time period for a response seemingly comes into force upon its arrival, these cases could be an exception and thus be revocable until they reach the offeror, namely, by the revocation reaching the offeror before the declaration of acceptance. ${ }^{1968}$ Otherwise, shödaku do not lose their effect by, say, expiring, like moshikomi. This is generally due to the dispatch rule; but even where the arrival rule applies and a declaration of acceptance arrives too late, this scenario concerns the issue of the declaration's coming into effect, rather than loss of the same (see Section cc) above).

\section{b. Form Requirements in Japanese Law}

As has already been indicated above, generally, no formalities are required for contracts under Japanese law. ${ }^{1969}$ Agreement between the parties is sufficient, which is a principle that existed even before the Minpo was enacted. ${ }^{1970}$ According to Kitagawa, this is one aspect of the freedom of contract in Japan, which in turn is one of the three indispensable principles underlying Japanese private law. ${ }^{1971}$ Even real rights are transferable without more, as art 176 Minpō expressly allows this: 'The creation and

1966 Kitagawa, 'Contracts' (fn 1601) \$2.01[3][e][iv] at 2-34.

1967 See Yamamoto K, 'Minpō kögi IV-1' (fn 1646) 29.

1968 Compare Shiomi, 'Shin-saiken' (fn 1648) 20. See also the discussion in Section cc) above.

1969 This has been an implied principle to date; however, an explicit stipulation to this effect has been introduced into the Minpo under the recent reform. This will be discussed in Section V. below.

1970 See Nakata, 'Hōritsu kö̀' (fn 1795) 66, who notes that formalities in general were rarely required.

1971 Kitagawa, 'Contracts' (fn 1601) $\$ 2.01[2][\mathrm{b}]$ at 2-27. The other two principles are 'the doctrine of absolute ownership and liability for negligence', ibid. Another important principle of the modern Japanese law of contract is to keep to (mamoru, 守る, protect) the agreement, so that it is not easy to back out of the contract (without good reason), see Yamamoto K, 'Minpō kögi IV-1' (fn 1646) 222. 


\section{Contracts in Japanese Law}

transfer of real rights shall take effect solely by the manifestations of intention of the relevant parties' ${ }^{1972}$

It ought to be noted that the word 'intention' here means that the will must aim at effecting a change in a real right. ${ }^{1973}$ As a consequence of the provision, the registration of the transfer of ownership with the (Real Estate) Registry Office ( $t o k i-s h o$, 登記所), ${ }^{1974}$ or the delivery of (im)movables ${ }^{1975}$ are generally not constitutive acts. ${ }^{1976}$ Instead, they are merely required to make the right enforceable against third parties. ${ }^{1977}$ In this way, contracts over real estate are consensual in Japanese law; unlike German and English law, which require a conveyance of the property right beside a consensual contract. ${ }^{1978}$ Having said this, the parties may agree

1972 The original provision reads: ‘物権の設定及び移転は、当事者の意思表示の みによって、その効力を生ずる’ (Bukken no settei oyobi iten ha, töji-sha no ishi hyöi nomi ni yotte, sono köryoku wo shozuru). This stipulation is also an expression of the principles underlying the Minpo, namely, of the will theory (ishi shugi, 意思主義), see Yamamoto S, '\$ 176 Minpö' (fn 1831) 224, 230.

1973 See Yamamoto S, ' $\mathbb{S} 176 \mathrm{Minp} \vec{o}$ ' (fn 1831) 234-235, who also gives an overview of the academic discussion surrounding the meaning of this term. See further Yokoyama, 'Purosesu' (fn 1846) 93; Hisakazu Matsuoka, Dai-2-hen dai-1-chō sōsoku [Part 2 Chapter 1 General Rules], in: ibid and Nakata (fn 1602) 285, 288.

1974 The registration of immovable property is regulated in the Fudó-san tökihō (Real Property Registration Act, 不動産登記法), Law No 123/2004 as amended; English translation available online at www.japaneselawtranslation.go.jp/law/detail/?id=2016\&vm=04\&re=02\&new=1. This issue will be considered in further detail in Section c.i. below.

1975 The distinction between the two kinds of things will be discussed in Section i. below.

1976 On registration, see Andreas Kaiser, $\$ 16$ Immobilienrecht [Chapter 16 Real Estate Law], in: Baum and Bälz (fn 16) 699 para 40. Similarly, Taniguchi and Ono (fn 1846) call registration a requirement for the enforceability against others (taikō yōken, 対抗要件).

1977 See the provisions contained in art 177 Minpo on the registration of immovable property and in art $178 \mathrm{ibid}$ on the delivery of movable property. Both provisions contain what is called the publicity principle (koji no gensoku, 公 示の原則), on which see Matsuoka, 'Sōsoku' (fn 1973) 285. On immovables, see further Kaiser (fn 1976) 699 para 41. Matsuoka, ibid 287 states registration and delivery as being necessary for 'perfecting the effect' (“完全な効力を発 生し', kanzenna koryoku wo hasseishi) of the transfer. The inspiration for this regulation is French law, see Marutschke, 'Immobiliarsachenrecht' (fn 1846) 3; Yamamoto S, ‘S 176 Minpö’ (fn 1831) 230.

1978 On the conveyance and registration of title in English law, see Sections B.II.3.b.iii. and c.i. above. On the involvement of a notary in the conveyancing process and registration in German law, see Sections B.III.3.b.iii.dd) and c.i. 
otherwise, so that a particular form or act can become constitutive for the transaction. ${ }^{1979}$ A transfer will still have some effect even where stipulated further conditions (payment of purchase price, handing over, registration, etc) are not fully observed (tsukusarenakereba, 尽くされなければ). ${ }^{1980}$ This may be due to a recent trend in Japanese legal academia, in accordance with which any such contractual stipulations by the parties are deemed to act as suspensive conditions (teishi jokken, 停止条件). ${ }^{1981}$

This is not true for cases of transfers of possessory rights (sen'yu-ken, 占 有権, art 182 para 1 Minpō) or the creation of pledges (shichiken, 質権, art $344 \mathrm{ibid}$ ), as these constitute exceptions to art 176 Minpō. ${ }^{1982}$ To make them enforceable, the thing that is to be possessed or pledged has to be delivered (art 182 para 1 and art 344 Minpō respectively). ${ }^{1983}$ Other exceptions to this will theory (ishi shugi, 意思主義 ${ }^{1984}$ ) are real contracts (yöbutsu keiyaku, 要物契約), namely, loans for consumption (shōhi taishaku, 消費 貸借, arts 587 et seq Minpō, art 513 Shōhō), loans for use (shiyō taishaku, 使用貸借, arts 593 et seq Minpō), and deposits (kitaku, 寄託, arts 657 et seq Minpō, arts 593 et seq $S h \bar{o} h \bar{o})$, among others. ${ }^{1985}$ These contracts likewise only become effective once the money or other thing has been received by the recipient (arts 587, 593, and 657 Minpo respectively). The reasons are historical and will not be discussed further. ${ }^{1986}$ Similarly, although Japanese law recognises what under Roman law was termed as a nudum pactum (bare or naked agreement), ${ }^{1987}$ the giving of a token of one's earnest intention is normally observed in legal practice. This role is fulfilled by tetsuke (see Section c.iii. below), which, in this respect, bears similarities to the English requirement of consideration (on which, see Section B.II.3.v. above). ${ }^{1988}$

above. It seems that this regulation was also inspired by French law, see Sono and others (fn 1632) 45.

1979 See Kaiser (fn 1976) 692 para 9.

1980 Compare Yamamoto S, ‘\$ 176 Minpö’ (fn 1831) 231.

1981 See ibid 258.

1982 Matsuoka, 'Sōsoku' (fn 1973) 287.

1983 This is not necessary for the former where the object is already in the transferee's possession, art 182 para 2 Minpō.

1984 Matsuoka, 'Sōsoku' (fn 1973) 287. Translation by this author.

1985 Yamamoto K, 'Minpō kōgi I' (fn 1632) 120. See also Kawakami (fn 1831) 15; Taniguchi and Ono (fn 1846) 393.

1986 See Taniguchi and Ono (fn 1846) 393.

1987 Interested readers are referred to, eg, Kaufmann and Köbler (fn 944) for further details on this principle.

1988 Compare Sono and others (fn 1632) 56-57. 


\section{Contracts in Japanese Law}

While this is true, there are situations in which Japanese law requires a particular form; namely, for formal juridical acts (yoshiki köi, 要式行 為) like contracts of guarantee (hoshö keiyaku, 保証契約, art 446 para 2 Minpō). ${ }^{1989}$ Special requirements may also be foreseen in other areas, such as in relation to commercial instruments, real estate, or companies. It is interesting to note that some of these instances of form requirements were seemingly established due to the social and economic differences arising between the Japanese in the modern period. This was the case for, eg, collective labour agreements; however, similar provisions were not created in relation to consumers. ${ }^{1990}$ In fact, there are no general form requirements to be found in the Shöhi-sha keiyaku-hō. Details on the existing form requirements will be given in the subsequent sections.

The consequences attached to these form requirements have different effects, so that not adhering to form does not necessarily lead to the contract being void or legally unenforceable; other kinds of penalties may be imposed. ${ }^{1991}$ One prominent example of the latter is Japanese stamp tax (inshi-zei, see Section c.ii. below), which does not affect the legal effectiveness of the contract but gives rise to tax penalties. Thus, while these 'other' penalties may be seen to be irrelevant from a contractual-legal point of view, they are nevertheless important in contracting practice. For this reason, the subsequent discussion will focus on those requirements that have direct legal impact, but will also set out those other consequences, whereby their effect will be set out jointly with the regulation in question.

In line with the general principle, oral contracts are generally enforceable; ${ }^{1992}$ however, they are also revocable in so far as their performance has not yet been completed. 1993 This has been laid down explicitly in

1989 See Yamamoto K, 'Minpō kōgi I' (fn 1632) 119-120.

1990 See Taniguchi and Ono (fn 1846) 393.

1991 See Kitagawa, 'Contracts' (fn 1601) \2.01[3][h][v] at 2-37-2-38.

1992 Noriaki (fn 1641) 10 (generally), 13 (sales). In relation to gifts, the Japanese courts have held that these are not enforceable by their recipient, see Dai-shin'i decision of 25 April 1935 (Shōwa 10), (Hōritsu) Shinbun No 3835 5. An extract can be found in Nobuhisa Segawa and Takashi Uchida, Minpō hanrei-shū saiken kakuron [Cases and Materials Civil Code: Specific Provisions of the Law of Obligations] ( $3^{\text {rd }}$ edn, Yūhikaku 2008) 2-3. See also Segawa and Uchida, ibid 4-5 (retrial at district court after case had been reversed and referred back by the Dai-shin'i).

1993 Kitagawa, 'Contracts' (fn 1601) \$2.01[3][h][i]. See also Kawakami (fn 1831) 15. This is not a strict requirement, however, as the courts have held that 'performance completion' in relation to a sale of immovable property (see Section 2. below) means effecting the registration of the transfer. In contrast, 
relation to gifts (art 550 Minpō, Revocation of Gift Not in Writing, 書面に よらない贈与の撤回, shomen ni yoranai zoyo no tekkai). ${ }^{1994}$ Perhaps for this reason, contracts in Japan are often fixed in writing even where this is not required by law. Before turning to today's legal contract practice in Section 2. below, the exceptions to the general rule of formlessness will be examined by looking at the different kinds of requirements that exist under Japanese law in Sections ii.-viii. By way of an excursus, the classification of things into movable and immovable will be briefly set out first.

\section{i. Excursus: The Classification of Mono (物, Things) in Japanese Law}

Japanese law distinguishes between tangible (yütai-butsu, 有体物) and intangible (mutai-butsu, 無体物) things, whereby only the former are regulated in the Minpō (in arts 85-89). Tangible things are understood to mean an object that ' $\mathrm{n}]$ ormally [...] has a corporeal existence occupying a part of space [...]. [It] is a part of the physical world and can be perceived by the five senses [...]'. ${ }^{1995}$ This thus generally encompasses all kinds of solids, liquids, and gases, whereas light, electricity, and copyrights are classified as intangible things. ${ }^{1996}$ Similarly, data (データ, dèta) and information (情報, $j \bar{o} h \bar{o})$ are intangible things, but are not capable of being the object of rights

actual delivery of the property is not necessary. See Saiko Saiban-sho decision of 26 March 1965 (Shōwa 40), Minshū Vol 19 No 2 526. An extract and a short commentary can be found in Segawa and Uchida (fn 1992) 42-43.

1994 This issue will be discussed further in Section ii. below.

1995 Seiji Tanaka, Dai-1-hen dai-3-chō mono [Part 1 Chapter 3 Things], in: Ryōhei Hayashi and Tatsuaki Maeda (eds), Shinhan chüshaku minpō (2) sōsoku (2) [Japanese Civil Law Annotated Vol 2 General Provisions Part 2] (Yūhikaku 1997) 574, at \$85 II 588-589: ‘一般に、有体物とは空間の一部を占める有形 的存在である、ととかれる。これは、外界の一部であって人の五官により 知覚されうる形態を有するもので物理的考察を中心とする’ (ippan ni, yütaibutsu to ha kükan no ichibu wo shimeru yükeiteki sonzai de aru, to tokareru. Kore ha, gaikai no ibibu de atte hito no gokan ni yori chikaku sareuru keitai wo yūsuru mono de butsuriteki kösatsu wo chüshin to suru).

1996 Kunihiro Nakata, Dai-1-hen dai-4-chō mono, in: Matsuoka and ibid (fn 1602) 49, on dai-85-jo (article 85) at 51. Nakata goes on to note at 51 that electricity has been deemed to be a 'product for sale' ('産物の売却', sanbutsu no baikyaku) under a supply contract and thus as a kind of sales contract by the Japanese courts in the Showa era (in year 12, ie, 1937). 
by themselves, whereas information recorded on material such as paper or on an electronic device like a flash drive can. ${ }^{1997}$

Tangible things are divided further into movables and immovables. Movables (dosan, 動産) are defined in art 86 para 2 Minpō as a residual class, namely, as all things not constituting immovables (real estate or real property, fudo-san, 不動産). Under art 86 para 1 Minpō, the latter encompasses land and its 'fixtures' ('土地の定着物', tochi no teichaku-butsu), so that things like buildings and standing timber (ryüboku, 立木) ${ }^{1998}$ all count as immovables. ${ }^{1999}$ More generally, irrespective of the Minpō's provisions, 'things that are changed with difficulty' ('変えがたいもの', kaegataimono) are viewed as immovables. ${ }^{2000}$

While it may not be apparent from the wording of the Minpo, land and fixtures, particularly buildings, are seen as constituting separate things. This becomes evident from the definition of real property in art 2 para $\mathrm{i}$ Fudo-san tóki-hō, in which the separation of the two things is made clear by the insertion of the word 'or' ('又は', mata ha): ‘不動産 土地又は建物 をいう’ (fudo-san tochi mata ha tatemono, 'real property: land or building'; emphasis added). In fact, due to being separate objects, rights may exist in relation to one object independently of the other. ${ }^{2001}$ Consequently, a plot of land in Japan might be owned by one person, while a building erected on that land may belong to another. This is also true for things such as timber. In this respect, the Ryüboku ni kansuru höritsu ${ }^{2002}$ allows the owner of timber to transfer the ownership over it or to mortgage it (see art 2 para 2). Having said this, normally, a disposal of the land or rights over it

1997 Compare Nakata, 'Mono' (fn 1996) on dai-87-jö (article 87) at 56 and on zenchü (preliminary note) at 49.

1998 See Hisakazu Matsuoka, Dai-2-hen bukken [Part 2 Real Rights], in: ibid and Nakata (fn 1602) 281, 282. Article 2 para 1 Ryüboku ni kansuru höritsu (Act on Standing Timber, 立木二関スル法律, Law No 22/1909 as amended) provides that standing timber is treated as an immovable. Note that this Law defines standing timber in art 1 para 1 as 'a group of trees and shrubs that stand on a piece of land or on one part of a piece of land' ('本法二於テ立木卜称又 ルハ一筆ノ土地又ハ一筆ノ土地ノ一部分二生立スル樹木ノ集団ニシテ [...]', honhō ni oite ryūboku to shōsuru wa ippitsu no tochi mata ha ippitsu no tochi no ichi bubun ni oitasuru jumoku no shüdan ni shite [...]; translation by this author).

1999 The whole provision reads: ‘不動産以外の物は、すべて動産とする’ ('Fudosan igai no mono ha, subete dosan to suru' 'Land and any fixtures thereto are regarded as real estate').

2000 See Endō and Matsuda (fn 1597) 81.

2001 See Kaiser (fn 1976) 691 para 6.

2002 See fn 1998 above. 
also affects the timber (art 2 para 3 ibid). This suggests that ownership of standing timber is not necessarily separate from the land. Rather, it seems that ownership will normally pass together, unless it has been separated. As a consequence, fixtures may form part of land or constitute property by itself.

This separation of land and buildings (and of timber) as independent immovables follows traditional Japanese legal thought, while other provisions relating to Japanese property law follow German or French inspirations. ${ }^{2003}$ Tradition is also reflected in the fact that separate registers exist for land (tochi tōki-bo, 土地登記簿, land register), buildings (tatemono toki$b o$, 建物登記簿, building register), ${ }^{2004}$ and for timber (ryūboku tōki-bo, 立 木登記簿, standing timber register) ${ }^{2005}$. Further details on these registers will be given in Section c.i. below.

\section{ii. Written Form: Writing and Shomen (書面, Document)}

As has been stated, there is no general requirement that a contract be made in any form, which includes writing. There are, however, a few - quite specific - cases acting as exceptions. Irrespective of these, the parties may choose to conclude a written contract for several reasons. After looking at a couple of these grounds, the meaning of 'writing' (in Section aa) below) and a range of examples of statutory requirements (Section bb)) will be explored.

The reason why contractual parties may choose the written form freely is simple: In Japanese law, a distinction is made between a private deed

2003 See Bahr (fn 1590) 112, 103-106. Although the provision of the Minpo is referred to today as authority for the traditional Japanese view, ironically, at least some of the drafters of the provision, namely, Kenjirō Ume and Masaaki Tomī, had no intention to include this principle in the Minpō, see Bahr (fn 1590) 115. Rather, it seems that they merely meant to indicate what 'immovables' were and not whether land and its fixtures were one or separate things, see Makoto Nagata, Das Japanische im japanischen Sachenrecht [The Japanese in Japanese Property Law], in: Menkhaus (fn 1590) 123, 126, 127. Having said this, at least Tomì believed buildings and groups of standing timber - in contrast to other possible things attached to the land, such as single trees, walls, pipes, etc - to constitute property that is separate from the land itself, see Nagata, ibid 127. On the separation, see also Kaiser (fn 1976) 708 para 6.

2004 Kanji taken from Götze, 'Rechtswörterbuch' (fn 10) 560 and 546; transcription taken from Kaiser (fn 1976) 698 para 35.

2005 Kanji taken from Ryüboku ni kansuru höritsu, see, eg, art 12. 
(shisho shōsho, 私署証書) and a public or notarial deed (kósei shōsho, 公正証 書). While the former denotes a document drawn up by the parties themselves, the latter refers to a document that is drawn up by a Japanese public officer, namely, the notary (kosho-nin, 公証人). ${ }^{2006}$ Although both kinds of document have evidentiary value, ${ }^{2007}$ a public document is considered to have greater weight. ${ }^{2008}$ This notwithstanding, evidencing the agreement is surely one reason why parties may choose to formalise a contract in writing even where it is not required. Aside from this, a contractual document may aid in yet another way: when interpreting the contract. ${ }^{2009}$

aa) 'Writing' and 'Document' Defined

Japanese legislation does not speak of 'writing', but rather requires a 'document'. Denominations vary, so that one may often encounter references to shomen (書面, document) or shösho (証書, deed), but also to, eg, shi-bunsho (私文書, private document). While the terms 'writing' and 'document' are not defined in any of the provisions foreseeing the written form (Section $\mathrm{bb})$ ), it can be reasonably assumed that reference is made a priori to a tangible paper document as opposed to an intangible electronic document. This interpretation is supported by the following two considerations:

On one hand, there is the enactment time of the legislation. Both the Minpo and the Shöbo were enacted at the end of the nineteenth century, so that the contemplated ways of contracting were either through face-to-face negotiations (taimen kōshō, 対面交渉) if between present persons, or by

2006 A simpler term that is sometimes used for the former is 'private document' (私文書, shi-bunsho), see, eg, Endō and Matsuda (fn 1597) 78. On the differentiation between the two documents, see, generally, Köshö-ninhō, Japanese Notary Act, 公証人法, Law No 53/1908 as amended; English translation available online at www.japaneselawtranslation.go.jp/law/detail/? $\mathrm{id}=2267 \& \mathrm{vm}=04 \& \mathrm{re}=02 \& \mathrm{new}=1$. The function of a notary will be explored in more detail in Section iv. below.

2007 Article 228 paras (2) and (4) Minji soshō-hō (Japanese Code of Civil Procedures, 民事訴訟法, Law No 109/1996 as amended, hereinafter 'Minso') contains presumptions for the authenticity of public and private documents respectively. An English translation of the law is available online at www.japaneselawtranslation.go.jp/law/detail/?id=2053\&vm=04\&re=02\&new=1.

2008 See Taniguchi and Ono (fn 1846) 401.

2009 The wording of the contract is one factor which is considered for its interpretation, see Ueda, 'Keiyaku (zenshü)' (fn 1602) 756. For further details, see ibid. 
letter (tegami, 手紙) if between 'persons at distance'. ${ }^{2010}$ It is therefore logical that these statutes refer to physical paper documents when using the term 'writing'. Similarly, provisions found in special legislation, although enacted later, namely, between 1949 and 1952, still refer to physical paper documents, as they stem from a period in which the electronic transmission of documents, such as in the form of a fax, was not yet wide-spread and so would not, or rather could not have been contemplated by the legislator. ${ }^{2011}$

On the other hand, there is the wording of the provisions. While the above-mentioned norms do not contain explicit words referring to electronic forms, in contrast, the wording of special regulation has been subsequently amended to allow for the substitution of electronic documents. Thus, by virtue of the Law for Making Provisions on the Exchange of Documents etc by the use of Electronic Telecommunication Technology in Connected Laws ${ }^{2012}$, almost fifty different special laws on topics ranging from fishery, over medicine, to trade in securities, were amended. ${ }^{2013}$ The affected provisions included art 19 para 3 Kensetsu-gyo-hō (Construction Business Act $\left.{ }^{2014}\right)$, and art 3 para 2 Shita'uke daikin shibarai chi'en-tō bōshi-hō (Act against Delay in Payment of Subcontract Proceeds, Etc to

2010 See Matsumoto, 'Denshi shakai' (fn 1819) 298.

2011 Although the facsimile was first invented in the nineteenth century, it wasn't until over one hundred years later, in the 1970s, that the technology became standard practice in business, see Chris Baraniuk, Why the Fax Machine Isn't Quite Dead Yet, BBC (25 February 2015), www.bbc.com/future/story/20150224-why-the-fax-machine-wont-die. In Japan, it remains a popular communication method, including in business contexts, see Martin Fackler, In High-Tech Japan, the Fax Machines Roll On, The New York Times (13 February 2013), www.nytimes.com/2013/02/14/world/asia/in-japan-the-fax-machine-is-anything-but-a-relic.html?_r=0.

2012 書面の交付等に関する情報通信の技術の利用のための関係法律の整備に関 する法律, Shomen no kōfu-tō ni kansuru jōhō tsūshin no gijutsu no riyō no tame no kankei hōritsu no seibi ni kansuru hōritsu, Law No 126/2000, short title: I T 書 面一括法, IT shomen ikkatsu-hō, literally 'IT Documents Composite Law'.

2013 A list of the affected legislation is provided by the Kokuritsu Kokkai Tosho-kan [National Diet Library] online at http://hourei.ndl.go.jp/SearchSys/viewKaisei.do? $\mathrm{i}=$ spINCIstKBNdEDPEOogErw\%3d\%3d.

2014 建設業法, Law No 100/1949 as amended; English translation available online at www.japaneselawtranslation.go.jp/law/detail/? id $=2133 \& v m=04 \& \mathrm{re}=02 \&$ new $=1$. 
Subcontractors; hereinafter 'Shita' $u k e-h o^{-2015}$ ), both of which now expressly allow electronic transmission in lieu of a physical delivery of the contract document. In contrast, similar general amendments were not made to the Minpó or the Shōho at that time. ${ }^{2016}$ There is one exception: art 446 para 3 Minpō was inserted in 2004, ${ }^{2017}$ deeming a guarantee (hoshō, 保証) made as an 'electromagnetic record' ('電磁的記録', denjiteki jiroku) as having been made in writing.

Apart from this distinction, there is little discussion on what exactly 'writing' constitutes. Rather than elementary aspects such as the material of the document or the writing style, etc being discussed, the focus is on what needs to be contained in a document. One general point is that the party's or, as the case may be, the parties' intention must be expressed in the written record. ${ }^{2018}$ Consequently, it has been stated in relation to gifts that the document must clearly state the donor's firm intention to make a gift. ${ }^{2019}$ Similarly, a contract of guarantee has to contain a clear and express statement of the intention to take on the responsibility of a guarantee. ${ }^{2020}$ As for the content, the document must generally record the contract's terms. ${ }^{2021}$ When making a gift, at least the recipient's name and the object that is to be gifted must be stated; although there have been instances in which the donor's name and an express statement to gift have been held as not required by the Japanese courts. ${ }^{2022}$ In a similarly liberal manner, the subsequent drafting of the donation instrument has been admitted, while actual delivery of the instrument has been held unnecessary by the courts. ${ }^{2023}$ It could be argued that such leniency would not always apply.

2015 下請代金支払遅延等防止法，Law No 120/1956 as amended; English translation available at www.japaneselawtranslation.go.jp/law/detail/? $\mathrm{id}=40 \& \mathrm{vm}=04 \& \mathrm{re}=02 \&$ new $=1$.

2016 On the reform of the Minpō that has recently been completed, see Section V. below.

2017 Matsumoto, 'Denshi shakai' (fn 1819) 310.

2018 See Shiomi, 'Shin-saiken' (fn 1648) 10.

2019 Hiroe Moriyama, 'Zōyo to shomen' [Gifts and Documents] (2015) 224 Juristo bessatsu: Minpō hanrei hyakusen II saiken 98.

2020 For further details, see Shiomi, 'Shin-saiken' (fn 1648) 10.

2021 Masayuki Yamanushi, Keiyaku to höshiki: dakusei keiyaku ni okeru shösho no kino [Contract and Form: The Function of Formal Docments with Regard to Consensual Contracts], in: Keiyaku-hō Taikei Kankō I'in-kai [Publication Committee of the Contract Law Compendium], Keiyaku-hō Taikei 1: keiyaku sōron [Contract Law Compendium Vol 1: General Principles] (Yūhikaku 1962) 139, 143.

2022 For further discussion, see Moriyama (fn 2019) 98-99.

2023 See ibid 99. 
Gifts may be an exceptional case, as the instrument is not constitutive for the act to have effect (see below). Conversely, more strict criteria may apply to formal contracts, such as guarantees, where the need for proof of the agreement's content is higher. ${ }^{2024}$

\section{bb) Instances of the Written Form}

As was mentioned above, there are only a limited number of cases in which a written form is stipulated for contracts under Japanese law. Perhaps the strictest provision relates to contracts of guarantee and provides that these will not be effective unless made in writing (art 446 para 2 Minpō). This stipulation was introduced in 2004 with the aim of cautioning prospective guarantors from taking on another person's debt unilaterally and without payment. ${ }^{2025}$ This rule extends to bilateral guarantee contracts as well. ${ }^{2026}$ Further examples of writing being required include collective labour agreements, which will likewise only come into effect once put into writing. ${ }^{2027}$

The delivery of a written contract is also expressly required in, eg, art 19 para 1 Kensetsu-gyō-hō. Moreover, the furnishing of a document containing details of the already concluded contract is required in, eg, art 3 para $1 \mathrm{Shi}$ ta'uke-hō, and in arts 34-2 para 1 and 37 para 1 Takuchi-gyó-hō. Non-compliance with these provisions does not affect the legal validity of the contract; however, the non-compliant party will incur a monetary fine, ${ }^{2028}$ or be faced with other administrative measures, such as a temporary suspension of its business activities. ${ }^{2029}$

2024 Compare Shiomi, 'Shin-saiken' (fn 1648) 9-10, noting the different reasons why guarantees among others are formal contracts.

2025 Nobuyuki Yamamoto, Dai-3-hen dai-1-chō dai-3-setsu dai-4-kan hoshö saimu [Part 3 Chapter 1 Section 3 Subsection 4 Guarantee Obligations], in: Matsuoka and Nakata (fn 1602) 641, 642. He notes that unilateral declarations of guarantee constitute one-sided, non-compensatory, formal contracts. See also Sono and others (fn 1632) 220.

2026 See Yamamoto N (fn 2025) 642. cf Matsumoto, 'Denshi shakai' (fn 1819) 310, who does not differentiate between unilateral and bilateral guarantee agreements.

2027 Article 14 Rōdō kumi'ai-hō, 労働組合法, Labor Union Act, Law No 174/1949 as amended; English translation available online at www.japaneselawtranslation.go.jp/law/detail/?id $=17 \& v m=04 \&$ re $=02 \&$ new $=1$.

2028 Article 10 no i Shita'uke-hō; art 83 para 1 no ii Takuchi-gyō-hō.

2029 Article 65 paras 2 no ii and 4 no ii Takuchi-gyō-hō. 


\section{Contracts in Japanese Law}

There may also be instances in which a written contract is expressly optional, such as in art 737 Shōho (transportation contract with regard to the whole or part of a ship). Similarly, as has already been mentioned above, gifts do not require any particular form (art 549 Minpō); however, unless they are contained in a written document, they will be revocable until their performance has been completed (art 550 ibid). Consequently, putting a gift in writing is at least a compelling practical reason. In this regard, the Japanese courts were satisfied that a document drafted by the donor to a judicial scrivener (shibō shoshi, 司法書士), in which the donor requested the registration of the transfer of a piece of land to be effected in favour of the donee fulfilled the requirements. ${ }^{2030}$ Although it confirmed the purpose of the provision to be to protect donors from making gifts carelessly, the court deemed it satisfactory if a document's text 'allows the perception with a level of certainty' ('確実に看取しうる程度', kakujitsu ni kanshushi'uru hodo) that a gift is being made, thus making the donor's intention clear. ${ }^{2031}$ This was the case here, as the wording of the document gave rise to this perception, and, as a consequence, the gift could not be retracted.

In relation to consumers, perhaps to better protect them, ${ }^{2032}$ arts 4 and 5 para 1 (door-to-door sales), arts 18 and 19 para 1 (telemarketing Sales), and art 37 (multilevel marketing transactions) Tokutei shö-toribiki-hō require that a seller provide a consumer with a document containing the details of the offer or of the sales contract, as the case may be. ${ }^{2033}$ Again, non-compliance does not affect the formation or the effectiveness of the contract, ${ }^{2034}$

2030 Saikō Saiban-sho decision of 29 November 1985 (Shōwa 60), Minshū Vol 39 No 7 1719. An extract can be found in Segawa and Uchida (fn 1992) 4142. The function of a judicial scrivener will be described further in Section D.V.4.d. below.

2031 In contrast, a document does not have to actually state the intention as such, nor does it have to say that the act is non-compensatory. See fn 2030.

2032 This is an argument presented to explain the general rise in documentation requirements in consumer laws, by, eg, Taniguchi and Ono (fn 1846) 393.

2033 For further specifications of the necessary requirements, see arts 3-6 (door-todoor sales), 17-20 (telemarketing sales) Tokutei shö-toribiki ni kansuru höritsu shiko kisoku (Regulations for Enforcement of the Act on Specified Commercial Transactions, 特定商取引に関する法律施行規則), Ordinance of the Ministry of International Trade and Industry No 89/1976 as amended; English translation available online at www.japaneselawtranslation.go.jp/law/detail/? $\mathrm{id}=165 \& \mathrm{vm}=04 \& \mathrm{re}=02 \&$ new $=1$.

2034 See Kitagawa, 'Contracts' (fn 1601) $\$ 2.01[3][\mathrm{h}][\mathrm{v}]$ at 2-37. Non-compliance may lead to the violator being subjected to, inter alia, a suspension of their business 
since these are administrative provisions and as such do not have a bearing on the effect of a contract under private law. ${ }^{2035}$ In fact, rather than a requirement of form, these regulations are better classified as information duties (setsumei gimu, 説明義務). ${ }^{2036}$ Similar regulation can be found, inter alia, in the following provisions of the Kappu hanbai-ho: art 3 paras 2-3 and art 4 paras 1-2 (instalment sales, kappu hanbai, 割賦販売);2037 art 29-2 paras 1-2 and art 29-3 (loan-backed sales, rōn teikei hanbai, ローン提携 販売); and art 30 paras 1-2 and art 30-2-3 paras 1-2 (intermediation of comprehensive credit purchases, hōkatsu shin'yō kōnyū atsusen, 包括信用購 入あつせん). The consequence of non-compliance is a monetary fine up to $¥ 500,000$ (art 53 para iii Kappu hanbai-hō; approx. €4,000). Note that not only contracts, but some declarations of intention sometimes have to be made in writing, such as the withdrawal of an offer under arts 35-3-10 para 1, 35-3-11 para 1 Kappu hanbai-hō. This provision is not dispositive, so that contradicting contractual stipulations are void (see ibid para 15).

Although there is no legislative provision that requires a written document for the sale of immovable property, a difference of opinion seems to exist between academic literature and the judiciary in Japan on this point: While a part of the former would sometimes deny such sale contracts from arising until a formal document is drawn up where the parties agreed to make this a requirement, the latter would not deny formation on the ground of there being no (formal) contractual document. The courts thus affirm the traditional principle of formlessness. Nevertheless, it has been stated that the existence of a contractual document leads to the presumption that the parties have a 'definite intention' ('確定的な意思 表示, kakuteitekina ishi hyöji) to enter into a contract. ${ }^{2038}$ For this reason,

(arts 8 para 1, 23 para 1, and 39 para 1 Tokutei shö-toribiki-hö for door-to-door sales, telemarketing, and multilevel marketing respectively).

2035 Dernauer, 'Verbraucherschutz' (fn 1623) 572-573 para 9 notes that there is a general lack of interconnection between the regulations found in private law and those of administrative law; however, the latter will normally have no effect on the former.

2036 On these duties, see Dernauer, 'Verbraucherschutz und Vertragsfreiheit' (fn 1629) 173, 305-306, 311-312, 315-316. Similar duties are found in German law as well, see Section B.III.3.b.ii.cc) above.

2037 In accordance with art 4 para 1 Kappu hanbai-hō, delivery of the document must be made 'without delay' ('遅滞なく', chitai naku), which is interpreted as a time frame of three or four days, see Egashira (fn 1843) 115.

2038 See Mika Yokoyama, Fudō-san baibai keiyaku no seiritsu katei to seiritsu-mae no göi no böteki köryoku [The Formation Process of Contracts for the Sale of Immovable Property and the Legal Effect of Agreements Prior to Formation] 


\section{Contracts in Japanese Law}

there seems to be a tendency by the judiciary to find no formation where a contract has not been made in documentary form. ${ }^{2039}$ Conversely, there are also cases where a contract has been held not to have arisen despite a written contractual document. ${ }^{2040}$ Nevertheless, both academia and judiciary agree that a 'definite intention' exists in the following two cases: first, where central contractual matters (ie, defining the content of the parties' performance, like the object, price, etc) have been agreed upon; secondly, where - apart from any agreement in the first case - the agreement to conclude a contract is final, such as where the coming into effect of the sale is acknowledged in the parties' intentions. ${ }^{2041}$

\section{iii. Shomei suru(署名する, Signing) and O’'in suru (押印する, Sealing)}

Although normally an implicit requirement in Japanese law, documents will be expected to be either signed (shomei suru, 署名する) ${ }^{2042}$ or, more commonly, sealed (ó'in suru, 押印する, affixing a seal) ${ }^{2043}$ by a person. ${ }^{2044}$ The reason is that the signature or seal impression is deemed as evidence

(1992) 54 Shihō 193, 195. The presumption is strong but rebuttable under certain circumstances, such as where earnest money (tetsuke, see Section c.iii. below) has not been handed over, ibid, 'Purosesu' (fn 1846) 92.

2039 See Yokoyama, 'Purosesu' (fn 1846) 91; ibid, 'Seiritsu katei' (fn 2038) 195.

2040 See Yokoyama, 'Purosesu' (fn 1846) 92. An example is the Tökyō Chihō Saibansho decision of 25 December 1989 (Heisei 1), Hanrei Jihō Vol 1362 63, in which the court held no contract to have arisen although it found that a document titled 'contract for the sale of land' (“土地売買契約書', tochi baibai keiyaku-sho) was not forged as alleged by the plaintiffs. For further details on this, see Section iii. below.

2041 See Yokoyama, 'Purosesu' (fn 1846) 92.

2042 Outside Japanese private law, the Passport Act (Ryoken-hō, 旅券法, Law No 267/1951) requires in art 15 that a passport (ryoken, 旅券) be signed ('署名し なければならない’, shomei shinakerebanaranai), not sealed. See also art 11 (regarding applications for the issuance of a passport) Enforcement Regulations for the Passport Act (Ryoken-hō shikō kisoku, 旅券法施行規則, Regulation No 11/1989). A commentary is provided in Ryoken-hō Kenkyū-kai [Passport Act Research Society], Ryoken-hö chikujō kaisetsu [Commentary on the Passport Act] (Nihon Hyōron-sha 2016), particularly at 222-226.

2043 Translation of the term adopted from Götze, 'Rechtswörterbuch' (fn 10) 390.

2044 An example of such an implicit requirement is art 470 Minpo (examination right of obligor of debt payable to order), which gives the obligor the right 'to examine the authenticity of the [...] signature and seal' shown on the order. This presupposes that such orders are signed and sealed; however, the Minpō does not require this in any of the preceding provisions (but see art 365, which 
of a person's intent. ${ }^{2045}$ This legal thinking is reflected in the stipulation contained in art 228 para 4 Minso, according to which the signing or sealing (“署名又は押印”, shomei mata ha o’'in; emphasis added) of a private document (shi-bunsho, 私文書) triggers the presumption, for evidentiary purposes, that it is authentic. ${ }^{2046}$ Thus, signing and sealing are treated as equivalents in Japanese law. ${ }^{2047}$ Having said this, more importance is placed on sealing than on signing in Japanese legal contracting practice. $^{2048}$

The presumption of authenticity is rebuttable. One instance is where doubt as to a document's authenticity exists. Article 229 para 1 Minso provides for such cases that the handwriting or the seal impression will be compared. This occurred in a litigation surrounding ownership of land, in which the plaintiffs, the successors of a deceased person who had owned the land in question, used the fraud argument to dispute a transfer of own-

requires a written endorsement of a pledge of an order to make the pledge assertable against third parties).

2045 Andrew M Pardieck, Executing Contracts in Japan (2015) 40 ZJapanR / JJapanL 183, 184. In particular, it evidences a person's approval of the terms of a contract and their undertaking of the responsibilities arising from it, thus making it 'the ultimate formality', see Colin PA Jones, Making an Impression in Japan: A Hanko Primer, The Japan Times Online (Tōkyō, 13 March 2016). This is the traditional way of thinking, Kawakami (fn 1831) 14; however, it is a belief that is still firmly embedded in Japanese society today, as is evidenced by the 'catchphrases conveying the importance and the role of hanko' ('ハンコ の重要性と役目を伝えるキャッチフレーズ’, hanko no jūyö-sei to yakume wo tsutaeru kyacchi furēzu), like 'one’s sign: proof of one's resolution' (‘自分の証 決意の証', jibun no shirushi: ketsu'i no shirushi), or 'confirmation of intention, apparent proof: taking on responsibility’ (“意思の確認 示す証明 負う責 任', ishi no kakunin, shimesu shömei: ou sekinin), collected by the Zen-Nihon Inshō Gyō-kyōkai [Pan-Japan Seal Association], see www.inshou.or.jp/koryupege/catchphrase_h2.html.

2046 Note that the signature or the seal impression can be of the principal (contracting party) or an agent, see Kitagawa, 'Contracts' (fn 1601) \$2.01[3][h][iii] at 2-36; Endō and Matsuda (fn 1597) 78. Interestingly, the provision does not specify a particular kind of seal, namely, the jitsu'in ('registered seal', see below) to be used. Rather, it simply states o' in (affixing one's seal). This leads Pardieck (fn 2045) 185 to infer that Japanese law does not automatically confer greater importance to the registered seal.

2047 According to, eg, Ryōsuke Naka, Legal Practice of the Seal and Stamp Duty in Japan (Lecture, Heuking Kühn Lüer Wojtek, Düsseldorf, Germany, 14 November 2017), this is the interpretation given to the Minso provision.

2048 Interview with Mrs Mika Yokoyama, Professor, Faculty of Law, University of Kyōto (Kyōto, 7 September 2016); Sono and others (fn 1632) 60, 61. See on this also Section 2.c. below. 


\section{Contracts in Japanese Law}

ership to the defendants. ${ }^{2049}$ An expert compared the handwritten name and address, as well as the seal impression on the allegedly forged contractual document with handwriting and a seal impression on a document in relation to which the authorship was not disputed by the parties. Based on the expert's finding that the likelihood was high that the handwriting and the seal impression on both documents were the same, and as there was no proof to the contrary, the court assumed that the contractual document was signed and sealed by the deceased person. Despite this, the court voiced doubts as to the contract actually having arisen and concluded, based on the (highly contradicting and illogical progression of) facts of the case, that it had not come into effect. This case illustrates that even where a contractual document (and the signature or sealing) is not only presumed but actually found to be authentic, this is no guarantee that the contract will be held to be legally effective.

\section{aa) 'Signing' and 'Sealing' Defined}

In accordance with the general expectation, a contractual document may provide space for either a signature (jisho, 自署, or shomei, 署名), a seal impression (with the names of the parties printed next to the box, kimei o'in, 記名押印, literally 'affixing one's seal to typed name'; name sealing ${ }^{2050}$ ), or both, ie, a space for a signature and for sealing (shomei o' in, 署名押印). 2051 The different terms enumerated here have different connotations.

The words jisho (自署) and shomei (署名) are synonymous and both mean a handwritten signature, ie, written by the signatory themselves; however, the former seems to be wider in scope, as it apparently encompasses the use of stylised signatures (花押, kao), whereas shomei seems to mean a signature by writing one's name in Japanese script (kanji, hiragana,

2049 Tökyō Chibō Saiban-sho decision of 25 December 1989 (fn 2040). The facts of the case stated above have been simplified. The relationships of the 21 (!) plaintiffs and of the six defendants were more complex. Furthermore, the claims related to ownership of land and included the negation of (provisional) registrations of transfers of ownership.

2050 Compare Götze, 'Rechtswörterbuch' (fn 10) 292.

2051 Pardieck (fn 2045) 186. See also Sono and others (fn 1632) 62. Note that it is rare for Japanese to seal and sign (with a signature) a document; thus stated by Naka, Legal Practice Lecture 2017 (fn 2047). 
katakana) or using the Latin alphabet. ${ }^{2052}$ Similarly, a subtle difference in meaning exists between the words kimei (記名) and shomei (署名): while the latter denotes a signature made by the person themselves, the former term is used when another person makes the signature for the person in question, either by writing the name by hand, by printing the name, or otherwise. ${ }^{2053}$

As for the name that is used, this is usually the person's full name (shimei, 氏名) or, in a commercial context, the person's trade name (shōgo, 商号). ${ }^{2054}$ In fact, it has been stated that in business, 'signature' normally means 'affixing one's name seal to written name' ('記名捺印', kimei natsu'in). ${ }^{2055}$ This latter term has been interpreted to mean that a seal impression is affixed and one's name is either written by hand, printed, typed, stamped, or copied. ${ }^{2056}$ In this respect, it is noteworthy that natsu' in (捺印) seems to mean 'a name-seal or [...] proof of one's name and position', so that it displays only a 'limited legal effect' ('begrenzte rechtliche Wirkung'). ${ }^{2057}$ It is also important to note that there are several different types of seals that (legal) persons may own and use in Japan. An overview of these seal categories for private individuals will be given in Section cc) below. ${ }^{2058}$

\section{bb) Instances of a Requirement to Sign and Seal}

Both the Minpō and the Shōhō lack a requirement to sign or affix a seal to contracts. ${ }^{2059}$ This may be because the action is seen either as so obvious that it requires no explicit mention, or because it is simply left to legal

2052 Compare the entries for '自署' and '署名' in the Japanese online dictionary Kotobanku at https://kotobank.jp/. cf also the corresponding entries in Götze, 'Rechtswörterbuch' (fn 10) 195 and 498. Kao will be discussed further in Section D.III.2.c. below.

2053 See Ryoken-hō Kenkyū-kai (fn 2042) 224.

2054 See Endō and Matsuda (fn 1597) 77.

2055 See ibid 77-78.

2056 Ibid 78. Where a legal person is concerned, one of its organs or an agent may sign or seal the document, see ibid 77.

2057 See Götze, 'Rechtswörterbuch' (fn 10) 380: '[...] reines Namenssiegel oder [...] Nachweis mit Namen und Position'.

2058 Readers interested in company seals are referred to Ishii K (fn 1699) 12-15, and Pardieck (fn 2045) 184-186.

2059 An example of an explicit non-contractual requirement is the making of a will under arts 967- 970, 980 Minpō. 


\section{Contracts in Japanese Law}

practice. Having said this, the court may hold an agreement to be a mere pre-contract (kari-keiyaku, 仮契約) if it is signed but not sealed, as the earnestness expressed through a signature is deemed to be less than that for a sealed document; which is the common Japanese perception. ${ }^{2060}$

As mentioned above, some legal provisions treat sealing and signing as being equivalent. This is true for the $S h \bar{o} h \bar{o}$, which provides in art 32 that writing one's name and affixing one's seal can substitute a signature. As a result, its very own stipulations for signatures, like in art 570 (invoice for freight transport) and art 599 (deposit receipts) can be fulfilled by sealing instead. Other commercial statutes provide similar flexibility. One example is art 82 Negotiable Instrument Act (Tegata-hō, 手形法 ${ }^{2061}$ ), which provides that: 'In this law, where it says signature, this includes affixing one's name seal to [the written] name'. ${ }^{2062}$

Other provisions allowing signing and sealing to be used as alternatives include art 19 para 1 Kensetsu-gyō-hö for construction work contracts. Article 14 Ródo kumi ${ }^{\prime} a i-h \bar{o}$ is more elaborate, as it requires that the agreement be 'either signed by or affix the names and seals of both of the parties concerned'. ${ }^{2063}$ Similarly, art 34-2 para 1 and art 37 para 3 Takuchi-gyo-hō stipulate that the signature or a printed name and seal be affixed to the document (kimei ö'in shi, 記名押印し). In conclusion, it is therefore more common for the sealing of a document to be required, whereas a handwritten signature that is not a mere spelling of one's name is almost never required, although often permissible in commercial contexts at least.

cc) Excursus: The Different Types of Seals in Japan for Individuals

As has been mentioned above, several different seal types exist in Japan for private persons. Of most relevance for the present discussion is the jitsu'in (実印, literally 'real seal' or 'official seal'), as this is the seal that is commonly used in legal transactions. Its use is required for making applications for entries in registers, such as for real estate (land, buildings)

2060 Interview with Mrs Mika Yokoyama, Professor, Faculty of Law, University of Kyōto (Kyōto, 7 September 2016). More will be said on Japanese legal thinking and practice in Section 2.b. below.

2061 Law No 20/1932 as amended.

2062 The original provision reads: ‘本法二於テ署名卜アルハ記名捺印ヨ含ム, (Honhō ni oite shomei to aru ha kimei natsu' in wo fukumu).

2063 The original provision states: ‘両当事者が署名し、又は記名押印する’ $r y \bar{o}$ toji-sha ga shomeishi, mata ha kimei ö'in suru). 
or cars. ${ }^{2064}$ Due to its importance and to minimise the risk of the seal being used fraudulently, ${ }^{2065}$ the official seal has to be registered at the regional administration authority. Once completed, the official seal is linked to the person to whom it is registered. ${ }^{2066}$ A 'proof of seal registration certificate' (‘印鑑登録証明書', inkan tōroku shömei-sho; or ‘印鑑証明', inkan shomei ${ }^{2067}$ ) can be obtained for the jitsu'in, which may be required when the seal is employed. ${ }^{2068}$ In this sense, a jitsu'in can also have the function of proving one's identity, as there are no identity cards in Japan, like the German Personalausweis (identity card) for example. ${ }^{2069}$ Furthermore, an imprint of the jitsu'in, together with the seal's certificate, are seen as a legally binding signature of the seal's owner, and is functionally equivalent to a signature authenticated by a notary. ${ }^{2070}$ Before giving details on the registration process, it ought to be noted that each individual can only

2064 See Pardieck (fn 2045) 185. Sono and others (fn 1632) 61 note that the official seal must be used for the registration of real property.

2065 See Pardieck (fn 2045) 185. This is a pressing issue in Japan, as is evidenced by the fact that the Japanese Criminal Code (Keiho o, 刑法, Law No 45/1907 as amended) contains a subchapter dealing with counterfeited documents, including the (mis)use of (counterfeited or stolen) seals, see, eg, art 159 para 1 (counterfeiting of private documents). An English translation of the law is available online at http://www.japaneselawtranslation.go.jp/law/detail/? $\mathrm{id}=1960 \& \mathrm{vm}=\& \mathrm{re}=02 \& \mathrm{new}=1$. Other forms of misuse, such as burdening someone with debt by using their seal when filling out paperwork, or, similarly, obtaining a 'divorce by agreement' ('協議上の離婚', kyōgi-jō no rikon, see arts 763-769 Minpō) by using the spouse's seal without their knowledge are also common, see Jones (fn 2045).

2066 Jones (fn 2045). Anticipating the discussion in Section D.III.2.b.ii. below, a seal may not be registered by two different persons. Moreover, even if a seal is de-registered, it cannot be registered by a different person later on.

2067 Inkan shömei: Jörn Westhoff, $\mathbb{S} 5$ Formen und Bedingungen unternehmerischer Tätigkeit [Chapter 5 Forms and Requirements for Doing Business], in: Baum and Bälz (fn 16) 183, 190 para 8. Inkan tōroku shōmei-sho: Ishii K (fn 1699) 10.

2068 See Pardieck (fn 2045) 185.

2069 Interview with Mrs Mika Yokoyama, Professor, Faculty of Law, University of Kyōto (Kyōto, 7 September 2016).

2070 Ishii K (fn 1699) 11, 8. See also Westhoff (fn 2067) 190-191 para 8, who states that the notarial authentication of a signature, rather than that of a whole document signed by the person in question, is more easily accepted in Japan. As he explains, this is due to the fact that the seal's certificate is only a proof that the seal imprint on the certificate is linked to a certain person; which corresponds to the function of the notarial authentication of a person's signature. 
register one official seal. ${ }^{2071}$ As the regulation of seal registration may vary in each administrative region, the specifications will be illustrated in what follows for the city of Kyōto and the Chūo ward of Tōkyō. ${ }^{2072}$

Persons over the age of 15 are permitted to register a jitsu'in, either personally or through a representative. ${ }^{2073}$ If a seal has already been registered with one person, it cannot be registered a second time with another family member. ${ }^{2074}$ Accordingly, it must bear the full name (氏名, shimei) of the person to whom it is to be registered. ${ }^{2075}$ Furthermore, not all kinds of seals can be registered. Instead, restrictions apply: The seal cannot be an off-the-shelf product; it has to be of particular measurements and shape, and be made of material that cannot be altered easily; and it must bear the name of the person as it is shown in the Japanese Citizens Register (Jümin Kihon Daichō, 住民基本台帳). ${ }^{2076}$ As a consequence, jitsu'in have to be made especially for the owner and will usually be hand-crafted from materials of relatively high value, ${ }^{2077}$ such ebony or cherry wood, ivory, buffalo horn, amber, or titanium. ${ }^{2078}$

2071 See, eg, the information provided on the website of the Kyōto Shiyaku-sho [Kyōto Municipal Office], www.city.kyoto.lg.jp/bunshi/page/0000147302.html at 'Tóroku dekiru inkan no yōken' [Important Matters Regarding Seal Registration].

2072 For a more in-depth, though generalised, analysis of the specifications, see Eido Ino'ue, All about Japanese inkan/hanko/chops/seals (28 August 2013), www.turning-japanese.info/2013/08/all-about-japanese-inkanhankochopssea ls.html at 'The "real" registered seal: \{jitsuin\}', 'Making and registering your seal at your local municipal office'.

2073 For Kyōto, see Kyōto Shiyaku-sho (fn 2071) at 'Taishö' [Target] and 'Shinsei-sha' [Applicant] respectively. For Tōkyō, see the website of the Chūō Kūyaku-sho [Chūō Ward Office], www.city.chuo.lg.jp/kurasi/toroku/zyuminhyo/inkan.ht $\mathrm{ml}$ at 'Inkan töroku' [Seal Registration].

2074 See Kyōto Shiyaku-sho (fn 2071).

2075 See Kyōto Shiyaku-sho (fn 2071) for Kyōto. For Tōkyō, see Chūō Kūyaku-sho (fn 2073) at 'Hitsuyōna mono' [important matters]. Jones (fn 2045) adds that it should be the legal surname, ie, the name that appears on identification documents.

2076 For Kyōto, see Kyōto Shiyaku-sho (fn 2071). For Tōkyo's Chūō Ward, see Chūō Kūyaku-sho (fn 2073), specifically at 'Hitsuyōna mono' [Things Required], where it is also expressly stated that the seal has to be perfectly intact (no chips). Jones (fn 2045) suggests that another reason why seals with a rubber stamp-face are not allowed is because the easy degradability of the material makes comparisons of a seal imprint and the seal itself difficult after a period of time has passed.

2077 Ino'ue (fn 2072) at 'Cost of a real seal and accessories'.

2078 For a larger range of examples, see, eg, www.hankoya.com/shop/p_jituin.html. 
The second and equally important seal-type is the ginko-in (銀行印, literally 'bank seal', also known as todokede-in, 届出印, literally 'applicationseal' ${ }^{1079}$ ). It is a seal that is used for bank transactions inside the bank, ${ }^{2080}$ and the seal-imprint of which - similar to the jitsu'in - is registered at the bank and thus connected to the seal-owner's bank account. ${ }^{2081}$ Ginkoin are likewise made specifically for the owner. ${ }^{2082}$

The third category consists of the mitome'in (認印, also known as a sanmon-ban, 三文判, a 'common' or 'off-the-shelf' seal) ${ }^{2083}$, a simple and casual seal that is used for everyday matters such as accepting deliveries or private correspondence, and can accordingly be bought ready-made in shops. ${ }^{2084}$ As its impression will also show the owner's (sur-) name, 'common seals' can theoretically be used in contracting; in practice it will be a question of whether this possibility exists, ie, where use of the registered seal is not prescribed by law and where the parties agree to use this seal. ${ }^{2085}$

2079 The term todokede-in is given by Pardieck (fn 2092) 185. Kanji taken from Hadamitzky and others (fn 11) 986 at 3 r5.1 column no 5 .

2080 This can be anything from changing personal details to actually using the account, see the examples given by Pardieck (fn 2045) 185-186. For transactions made at ATMs, the bank card and a pin are required instead, which seems to lead to the ginkō-in being used less, see Ishii K (fn 1699) 12.

2081 Compare Westhoff (fn 2067) 190 para 8.

2082 See Ino'ue (fn 2072) at 'Cost of a real seal and accessories'.

2083 Pardieck (fn 2079) 184. Kanji and the definition of the term sanmon-ban are taken from Hadamitzky and others (fn 11) 19 at 0a3.1 column no 4.

2084 Westhoff (fn 2067) 190 para 8.

2085 See Pardieck (fn 2045) 185. One perhaps surprising example is the registration of marriage, made to the family register (koseki, 戸籍): As no specification is made as to which seal is required, even a mitome'in can be used. See, eg, the website of the city of Kyōto at www.city.kyoto.lg.jp/bunshi/page/ 0000145223.html. 
iv. Contracts and Köshōnin (公証人, Japanese Notaries)

A Japanese notary (kösho-nin, 公証人) is a public officer ${ }^{2086}$ that may be involved in contracting in several ways: ${ }^{2087}$ the issuing of a contract document (see Section aa) below); the certification of private documents (Section bb)); and the creation of execution deeds (shikko shosho, 執行証 書). The latter will not be discussed further; rather, the focus will be on the other two functions instead. Suffice it to note that such execution deeds allow the obligee to enforce repayment of a debt for a particular amount of money or other fungibles against the obligor (art 22 para 5 Minji shikkō-hō, Japanese Civil Execution Act $\left.{ }^{2088}\right) .2089$

aa) Drafting of Contract Documents by Japanese Notaries (Notarial Authentication)

A kosho-nin may be involved in the creation of the contract, ie, by drawing up and issuing the contractual document (kösei shösho no sakusei, 公正証 書の作誠, in German: Beurkundung, authentication). ${ }^{2090}$ The document

2086 Andreas Kaiser and Sebastian Pawlita, Das Notariat in Japan [The Notary's Office in Japan] (2005) 20 ZJapanR / JJapanL 163, 167-168. While this is true, the notary does not receive a salary from the State but is paid by the parties, see ibid 168. For this reason, the Japanese do not view a notary as a neutral party, personal interview with Mika Yokoyama, Professor, Faculty of Law, University of Kyōto (Kyōto, 7 September 2016). Cf Kaiser and Pawlita, ibid 173, who state that 'a notary must take a neutral stance' ('[...] der Notar eine unparteiische Position einnebmen muß.').

2087 The involvement of a notary, in particular with regard to the content of the contract being screened in the process, is sometimes seen as a control mechanism, see Taniguchi and Ono (fn 1846) 402.

2088 Law No 4/1979 as amended; English translation available online at www.japaneselawtranslation.go.jp/law/detail/?id=70\&vm $=04 \& \mathrm{re}=02 \& n e w=1$.

2089 For this, the obligee must obtain and attach a certificate of execution $(s h i k k \bar{o}-$ bun, 執行文) to the contract and serve this to the obligor (arts 25, 29 Minji shikko-hō). This certificate is obtained from the kosho-nin who retains the original execution deed (art 26 para 1 ibid). A court judgement is therefore not necessary for the enforcement of the debt. Compare on this Pardieck (fn 2092) 189. A similar method existed in the Tokugawa era, although the notary's function was then fulfilled by the headman of a village as recorder, and witnesses, see Henderson and Torbert (fn 1662) 10.

2090 The Japanese and German terms were taken from Kaiser and Pawlita (fn 2086) 177. See also art 1 para 1 Köshö-nin-hō. 
will be considered to be a notarial deed (kösei shōsho, 公正証書), and as such will have the character of a public document (kö-bunsho 公文書).2091 Public documents have the advantage of being presumed to be authentic (art 228 para 2 Minso) and thus possess 'greater evidentiary weight' in comparison with normal contractual documents. ${ }^{2092}$

As Japanese law foresees only few cases of compulsory form, ${ }^{2093}$ most contracts executed as a notarial deed will be voluntary. ${ }^{2094} \mathrm{~A}$ relevant exception is the requirement for lease contracts of land for a term of 50 years or more without a right to renewal and not for temporary use to be made in a notarial deed (arts 22, 23 paras 1, 3 (commercial property, term of over 30 but less than 50 years), and art 25 Act on Land and Building Leases, 借 地借家法, Shakuchi shakuya-hö ${ }^{-2095}$ ). ${ }^{2096}$ Irrespective of this provision, leases often seem to be concluded in notarial form in practice. ${ }^{2097}$ Similarly, in cases where a gift is made of real estate, the gift contract is sometimes authenticated by a koshō-nin. ${ }^{2098}$ This method may be chosen in order to make the gift irrevocable, as formless gifts are generally revocable until executed (compare arts 549-550 Minpō, discussed in Section ii. above). The reverse conclusion from these provisions is that a gift will only become binding once either performed or put into writing.

Where the kosho-nin is not yet acquainted with the person requesting the drawing up of the document, that person must prove their identity, prefer-

2091 Kitagawa, 'Contracts' (fn 1601) $\$ 2.01[3][\mathrm{h}][\mathrm{iv}]$ and [iii]. Note that he uses the term 'notarized document' to refer to notarial deeds. The Japanese terms stem from the Dictionary of Standard Japanese Legal Terms (fn 9) 94 and 126 respectively. See also Nihon Kōshō-nin Rengō-kai [Japanese Association of Notaries], How to make good use of Japanese Notaries (Guide, 2015; hereinafter 'Japanese Notaries Guide') 4. The Guide is available online at www.koshonin.gr.jp/index 2. html.

2092 See Pardieck (fn 2045) 188. cf the stipulation contained in art 228 para 4 Minso, according to which private documents are also presumed to be authentic if signed or sealed by the 'principal or an agent'.

2093 Kaiser and Pawlita (fn 2086) 178. In relation to transactions involving land, the fact that a notarial deed is not required under Japanese land law is a deviation from its original inspiration, French law, see Marutschke, 'Immobiliarsachenrecht' (fn 1846) 3-4.

2094 Pardieck (fn 2045) 189.

2095 Law No 90/1991 as amended; English translation available online at www.japa neselawtranslation.go.jp/law/detail/?id $=2302 \& v m=04 \& \mathrm{re}=02 \&$ new $=1$.

2096 For an account of the Japanese law on leases, see Sono and others (fn 1632) 206-216.

2097 Compare Kaiser and Pawlita (fn 2086) 179.

2098 Ibid 178. 
ably by presenting a registration certificate (inkan shomei) for that person's official seal (jitsu'in).2099 The drawing up can be requested by a person acting as an agent, ${ }^{2100}$ in which case the agent must prove their authority to act (arts 31, 32 Köshō-nin-hō) . ${ }^{2101}$ According to art 27 Köshö-nin-hö, a notarial deed can only be drafted in Japanese. This does not preclude foreigners who do not understand Japanese, as the Köshō-nin-hō provides for the possibility of an interpreter being present during the drawing up of the document (art 29; the interpreter has to be selected by the person requesting the drawing up, art 34 para $1 \mathrm{ibid}$ ).

While the kosho-nin has the obligation to investigate or to examine the circumstances of the notarisation (chosa gimu, 調査義務 or shinsa gimu, 審 査義務) in case of doubt about the legality or validity of the transaction, there is no obligation on the notary to advise the parties. ${ }^{2102}$ In case of doubt on either point, ' $[\mathrm{t}]$ he notary $[. .$.$] may not create [the] instrument'$ $\left(\right.$ art 26 Koshō-nin-hō). ${ }^{2103}$ In accordance with art 36 of that Law, in order to count as a notarial deed, the document must contain a deed number, personal details of the person commissioning the drafting, and, where applicable, their agent or interpreter, how the person's identity has been verified (known to the notary, seal registration certificate, etc), as well as the place and date of creation of the deed. The finished text is either read out to or given to the person(s) present for inspection and must be approved ('承認', shōnin) by them (art 39 para 1 Kóshō-nin-hō). Finally, the deed is 'sign[ed] and seal[ed]' ('署名捺印 スル', shomei natsu' in suru) by the attending person(s) and the kōsho-nin, whereby the notary must also seal all page intersections if the document is made up of several pages or where it refers to other documents and these are attached (art 39 paras 3 and 5, art 40 paras $1-2 \mathrm{ibid})$.

2099 See art 28 paras 1, 2 Köshō-nin-hō.

2100 Japanese Notaries Guide (fn 2091) 4.

2101 The document proving the agent's authority will normally be attached to the notarial deed and an impression of the notary's seal of office is placed over the joint between the deed and the annexed document (kei-in, 契印, art 41 paras 1, 2 Kosho-nin-hō). It is interesting to note that if there is a defect in the form or even the authority of the agent that is subsequently cured, the defect does not affect the validity of the notarial deed (art 32 para 3 Kosh $\bar{o}-n i n-h \bar{o})$.

2102 See Kaiser and Pawlita (fn 2086) 174-175.

2103 The original provision reads: “公証人八[...]証書 $习$ 作成スルコトヨ得ス’ (köshö-nin ha [...] shösho wo sakusei suru koto wo uzu). 


\section{bb) Notarial Certification of Private Documents}

Apart from authenticating documents, a kōshō-nin also certifies private documents (ninshō no fuyo, 認証の付与), the act of which may relate to the concordance of a copy and the original document (art 58 para 2 Kosho $\bar{o}^{-}$ nin-hō), ${ }^{2104}$ or the concordance between signature (or seal impression) and signatory (or seal owner). ${ }^{2105}$ In case of the latter, the signatory (or the agent, ${ }^{2106}$ see arts 60,31 ibid) can either sign or seal the document in the presence of the notary (art 58 para $1 \mathrm{ibid}$ ), or swear an oath to the effect that the signature or seal impression is their own (art 58-2 para 1 ibid). Similar to public documents, such certified documents will be presumed to be authentically created (executed).2107 The certification of private documents is often necessary where the documents are to be used abroad. ${ }^{2108}$

The certification of a contractual document has to be requested by all contracting parties, and their presence as well as the presentation of their official seals, together with its registration certificate are required. ${ }^{2109}$ Foreign documents (gaikoku-bun, 外国文), which are private documents in a language other than Japanese, can be authenticated in the same way. ${ }^{2110}$ Similar to a notarial deed, the Kösho-nin-hö foresees in art 59 that specific details be contained in the certification, namely: the registry number of the certified deed, and the place and date of certification. Furthermore, it is required that a witness and the kösho-nin must sign and seal the document, whereby the latter must also seal the entry in the registry for

2104 Kaiser and Pawlita (fn 2086) 177.

2105 Japanese Notaries Guide (fn 2091) 6; Nihon Kōshō-nin Rengō-kai [Japanese Association of Notaries], Shisho shösho no ninshō [Authentication of Privately-signed Documents], www.koshonin.gr.jp/sini.html (hereinafter 'Shisho ninshö'), first question under 'Ninshō no igi' [The Meaning of Authentication]. The purpose of the authentication in this instance is to prove that the signatory is the creator of the document, Japanese Notaries Guide (fn 2091) 7.

2106 This seems to be popular practice, see Kaiser and Pawlita (fn 2086) 177.

2107 Shisho ninshō (fn 2105), second question under 'Ninshō no igi' [The Meaning of Authentication]; Japanese Notaries Guide (fn 2091) 6.

2108 Japanese Notaries Guide (fn 2091) 7.

2109 Pardieck (fn 2092) 189. See also Japanese Notaries Guide (fn 2091) 7-8.

2110 Nihon Kōshō-nin Rengō-kai [Japanese Association of Notaries], Gaikokubun ninshō [Authentication of Foreign Documents], www.koshonin.gr.jp/sini.html\#11, under 'igi' [Meaning]. 
the certified document in a way that the seal impression is on both the register and the document. ${ }^{2111}$

\section{c. Other Requirements under Japanese law}

Japanese law sometimes foresees requirements other than a particular form that have no bearing on the contract's legal effectiveness but nevertheless bring about consequences of practical relevance if not observed. The nature of these is often administrative, with the objective being to monitor transactions that may be undesirable from a policy perspective. ${ }^{2112}$ Three examples will be discussed subsequently.

\section{i. Registration of Property}

The registration of the transfer of property in the Japanese real property register is relevant when concluding a sale of real estate. Depending on whether the immovable property is land, a building, or timber, this will occur in different registers, as these are kept separate: 土地登記簿, tochi tōki-bo, land register; 建物登記簿, tatemono toki-bo, building register; 立木 登記簿, ryüboku toki-bo, standing timber register. Nevertheless, the Registration Office (登記所, $t o \overline{k i}$-sho) ${ }^{2113}$ and the procedure (set out in arts 16 et seq Fudōsan tōki-hō and arts 3 et seq Ryüboku tōki kisoku ${ }^{2114}$ ) remain the same. ${ }^{2115}$ While the registration of a change in property is not constitutive for the sale of land or building in order for it to be legally effective between the parties, ${ }^{2116}$ it is required in order to make the transfer enforce-

2111 The registry and what must be entered into it is regulated in arts 61-62 Köshö-nin-hō.

2112 Any other, more specific policies, as in relation to ethical, moral, or criminal considerations are not discussed. Interested readers are referred to, eg, Yamamoto K, 'Vertragsrecht' (fn 1612) 486-490.

2113 These offices are run by the (District) Legal Affairs Bureau ((chibō) hömu-kyoku, (地方)法務局; see art 6 para 1 Fudö-san töki-hō) and are under the control of the Hömu-sho, see Kaiser (fn 1976) 698 para 35 in fn 38.

2114 Regulation for the Registration of Timber, 立木登記規則, Order (Hōmu-sho) No 206/2005 (Heisei 17) as amended.

2115 For further details on the registration process, see Kaiser (fn 1976) 698-699 paras 37-39.

2116 Ibid 699 para 40. See also art 1 Fudō-san tōki-hō, which provides: ‘この法律 は、不動産の表示及び不動産に関する権利を公示するための登記に関する 
able against third parties (art $177 \mathrm{Minpo}) .{ }^{2117}$ It could therefore be argued that the registration does not affect the contract or its validity; however, it protects the purchaser's property right and is therefore of practical relevance. In a similar manner, art 1 para 1 Ryüboku ni kansuru höritsu provides that the registration of the ownership of timber will protect that right. Accordingly, particular types of timber have to be registered and linked to the land on which they stand by indication of the name or number of the part of land on which the timber is located (arts 1 para 2, para 1 Ryüboku ni kansuru höritsu). ${ }^{2118}$

\section{ii. Inshi-zei(印紙税, Stamp Tax)}

One Japanese formality that has no bearing on the effectiveness of the formation of a contract but is nevertheless of practical relevance is stamp tax (inshi-zei, 印紙税). This is similar to the English stamp duty land tax, discussed in Section B.II.3.c.ii. above. As its name suggests, stamp tax is paid by purchasing a tax or revenue stamp (shü'nyū inshi, 収入印紙), a stamp-like piece of adhesive paper, of appropriate value from, eg, the local post office, ${ }^{2119}$ affixing it to the document, and validating it through the seal impression of the document's author, who is the person liable to pay

制度について定めることにより、国民の権利の保全を図り、もって取引の 安全と円滑に資することを目的とする’ (Kono höritsu ha, fudō-san no byōji oyobi fudō-san ni kansuru kenri wo köjisuru tame no tōki ni kansuru seido ni tsuite sadameru koto ni yori, kokumin no kenri no bozen wo hakari, motte toribiki no anzen to enkatsu ni shisuru koto wo mokuteki to suru. 'The purpose of this Act is to secure the rights of citizens by providing for a system concerning registrations to notify the public of descriptions of real property and rights relating to real property, thereby contributing to the safe and smooth conduct of transactions.'). Translation by this author.

2117 It ought to be noted that the effect of the register is not absolute. Rather, an entry in the register will trigger a presumption that it is correct; however, this presumption can be rebutted by proof to the contrary. See on this Kaiser (fn 1976) 699-700 para 43. On the effect of the register, see Hibiku Shimizu, $\mathbb{S} 177$ I [Article $177 \mathrm{I}$ ], in: Funahashi and Tokumoto (fn 1831) 264, 351-352. cf English law, where the registration of title does not affect the contract, but its legal effect, namely, the transfer or property, see Section B.II.3.c.i. above. cf, again, German law, under which the (non-) registration of the transfer affects the Verfügungsgeschäft (conveyance), see Section B.III.3.c.i. above.

2118 On the types of timber which have to be registered, see Imperial Edict (Chokurei, 勅令) No 12/1932 (Shōwa 7).

2119 Pardieck (fn 2092) 187. 
the tax (arts 8, 2 para 1 Inshi-zei-hō, 印紙税法, Stamp Tax Act $\left.{ }^{2120}\right){ }^{2121}$ This payment method of fees is used not only in relation to contracts, but for other acts in public offices, such as applications in relation to a visa, or in relation to registrations. ${ }^{2122}$ Where a kosho-nin is involved in contracting, the notary is obliged to ensure that the stamp tax is paid by affixing sufficient stamps on the document (art 43 Köhö-nin-hö).

Stamp tax is levied depending on two factors, namely, the contract type and its value; and is payable for each document that is drawn up ("作成し た課税文書につき', sakuseishita kazei bunsho ni tsuki, art 3 para 1 Inshi-zei$h \bar{o})$, ie, each (original) copy of the contract document ('一通につき' 'ittsu ni tsuki, table in annex 1 Inshi-zei-hö), is taxed. It is sometimes difficult to classify a contract type using the given criteria and, vice versa, there are contractual situations which may fall within or outside of the Act's scope depending on the terms of the contract. By way of example, a contract for work, ie, a contract under which the payment is related to the work's completion, is taxable, while a service agreement, according to which the work's completion and payment are not related, is not. ${ }^{2123}$ The amount of payable tax can be illustrated by a simple example. In the case of a sale of real estate, the amount of stamp tax due for two original contract documents and a sale price of $¥ 20$ million (approx. €165,000) would be two times $¥ 20,000$ (approx. €165), thus totalling $¥ 40,000$ (approx. €300). ${ }^{2124}$ This tax being an expense related to the contract, ${ }^{2125}$ both parties will automatically bear an equal share of the tax (art $558 \mathrm{Minpo})$ if no other stipulation has been made. ${ }^{2126}$

Not only the contractual document itself, but other documents relating to contracts, such as order acknowledgement receipts or contract modifica-

2120 Law No 23/1967 as amended.

2121 Also see Koku-Zeichō, Inshi-zei no tebiki [A Guide to Stamp Tax] (September 2015) 12, available online at www.nta.go.jp/shiraberu/ippanjoho/pamph/ inshi/tebiki/01.htm (hereinafter 'Inshi-zei Guide').

2122 For the latter, see Hōmu-shō Minji-kyoku, Tōki inshi no tori'atsukai ni tsuite [Regarding the Handling of Registration Stamps] (1 April 2011), available at www.moj.go.jp/content/000072037.pdf.

2123 Naka, Legal Practice Lecture 2017 (fn 2047).

2124 See the fourth column of category 1 of the table in annex 1 to the Inshi-zei-ho.

2125 Yamamoto K, 'Minpó kögi IV-1' (fn 1646) 235, who calls it '印紙代' (inshi-dai, stamp fee).

2126 Compare Kaiser (fn 1976) 708 para 81. Note further that the parties are jointly and severally liable for the stamp tax, Naka, Legal Practice Lecture 2017 (fn 2047). 
tion agreements fall within the scope of the Inshi-zei-ho..$^{2127}$ If the contract is drafted outside Japan, no tax will be levied, even if the place of contractual performance is in Japan. ${ }^{2128}$ In this sense, if the document is prepared and signed by one party and afterwards by the other party outside Japan, the document is not taxable. ${ }^{2129}$ Tax is also not levied in cases where the contract is made in the form of an electronic document. ${ }^{2130}$

While a contract on which stamp tax has not been paid will still be legally valid, there are other legal consequences in the form of penalties. ${ }^{2131}$ These are of two kinds: a monetary fine (bakkin, 罰金) or a penal servitude with hard labour (choeki, 懲役), whereby the amount of the fine or the length of imprisonment depends on the severity of the contravening act, including whether the act was committed fraudulently. In all cases, the highest penalty is a fine of $¥ 1$ million (approx. $€ 8,000$ ) or three years of imprisonment (art 21 Inshi-zei-hō).

2127 For details on the different document categories and the applicable stamp tax, see the table in annex 1 to the Inshi-zei-hö. For modification agreements, see also Inshi-zei Guide (fn 2121) 5.

2128 Kitagawa, 'Contracts' (fn 1601) \$2.01[3][h][vi] at 2-38.

2129 Naka, Legal Practice Lecture 2017 (fn 2047). This is different in England, see Section B.II.3.c.ii. above.

2130 In its Q\&A section, the Japanese National Tax Agency (Kokuzei-chō, 国税庁) has stated that at least an order acknowledgement (chümon ukesho, 注文請書) that is not delivered in paper form but through electronic means, such as e-mail or fax, is exempt from stamp tax, see www.nta.go.jp/fukuoka/shiraberu/ bunshokaito/inshi_sonota/081024/02.htm\#a01. As this document would normally fall within the wide meaning of 'contract' under the Inshi-zei-ho, it is submitted that an actual contractual document that is only contained in electronic form would be equally exempt. In contrast, it is unclear whether a contract that was concluded electronically and subsequently printed and signed by both parties is taxable, interview with Mr Ryōsuke Naka, Attorney at law, Associate, Kitahama Hōritsu Jimu-sho (Kitahama Partners) (Düsseldorf, 17 November 2017).

2131 See Pardieck (fn 2092) 188. The penalties are regulated in arts 21 et seq Inshi$z e i-h \bar{o}$. 


\section{iii. Tetsuke(手付, Earnest Money)}

Article 557 para 1 Minpo $^{-2132}$ contains a stipulation that seems to echo the Roman $\operatorname{arr}(h) a$ (earnest), ${ }^{2133}$ in that it provides that where a purchaser has effected tetsuke (literally 'hand-touch' money, ${ }^{2134}$ earnest money, 手付) to the seller, this can be used by either party to cancel (rescind) the contract:

When the buyer delivers earnest money to the seller, the buyer may cancel the contract by forfeiting his/her earnest money or the seller may cancel the contract by reimbursing twice its amount, until either party commences performance of the contract. ${ }^{2135}$

This earnest money for the cancellation of a contract (kaiyaku tetsuke, 解 約手付, 'cancellation tetsuke') is only one - albeit perhaps the predominant $^{2136}$ — form of Japanese earnest money. ${ }^{2137}$ Before turning to the other

2132 In fact, an almost identical provision is contained in art 39 para 2 Takuchi-gyobō. As its content does not differ significantly from art 557 para 1 Minpō, the provision will not be discussed further.

2133 For further details on the Roman arra, see George Long, Arra, in: William Smith, A Dictionary of Greek and Roman Antiquities (John Murray, London 1873) 137. On the Roman denomination, see also fn 983 above.

2134 Wigmore, 'Customary Law' (fn 1675) 14 explains in fn 7 that this term originates in the former practice of the contracting parties touching their hands at the beginning of a transaction.

2135 The original provision reads: ‘買主が売主に手付を交付したときは、当事 者の一方が契約の履行に着手するまでは、買主はその手付を放棄し、売主 はその倍額を償還して、契約の解除をすることができる’(Kainushi ga urinushi ni tetsuke wo köfushita toki ha, töji-sha no ippō ga keiyaku no köi ni chakushusuru made ha, kainushi ha sono tetsuke wo hōkishi, urinushi ha sono baigaku wo shökanshite, keiyaku no kaijö wo suru koto ga dekiru). Note that the wording of this provision will change once the reformed Minpō will come into force. This will be discussed in Section V. below.

2136 See Kitagawa, 'Contracts' (fn 1601) $\$ 2.01[3][j]$ at 2-43, who states it having 'a practical and far more important effect' than shoyaku tetsuke (on which see Section cc) below). For a historical example of this from the former province of Suruga (in today's Shizuoka prefecture), see Wigmore, 'Customary Law' (fn 1675) 18. This practice also existed in, eg, the former province of Shinano (today's Nagano), see Wigmore, ibid 22-23.

2137 See Naoko Kano, Dai-3-hen dai-2-chō dai-3-setsu dai-1-kan sōsoku [Part 3 Chapter 2 Section 3 Subsection 1 General Provisions], in: Matsuoka and Nakata (fn 1602) 806, on dai-557-jo [article 557] at 810. See also the summary table provided by Yamamoto K, 'Minpō kögi IV-1' (fn 1646) 220. English translation of the term by this author. 
two types (in Section cc) below), a note needs to be made on the meaning of tetsuke (Section aa)) and the way of effecting it (Section bb)).

Despite the resemblance with the Roman $\operatorname{arr}(b) a$, the origin of article 557 Minpō can be argued to be commercial customs existing in the Tokugawa era known as 'tetsuke nagashi baimodoshi' ('手付 流し 倍戻し') and 'tetsuke son baigaeshi' ('手付 損倍返し'). ${ }^{2138}$ The terms are still used today to explain the two application methods of art 557 Minpo.$^{-2139}$ Perhaps due to the resemblance with the Roman arrha, it has been argued that the existence of the provision on tetsuke means that contracts under the Minpo are not consensual, but real, because the mere agreement of the parties is not sufficient; rather, that contracts are not fully effective until performance has been commenced, since the contract may still be cancelled by using tetsuke. ${ }^{2140}$ This argument is not convincing. While it is true that tetsuke has the effect of reducing legal certainty about the contract's effect until performance is begun, this fact does not turn consensual into real contracts. The effect and function of tetsuke are too different from elements of a real contract, as will become evident from the subsequent discussion. ${ }^{2141}$ Most importantly, transactions in which tetsuke is paid do not constitute an exchange of the subject matter in question and tetsuke. Unlike a deposit, which only comes into existence when the thing in question is handed over (see art 657 Minpō), the coming into existence of the contract in relation to which tetsuke is paid, like a sale, does not depend on tetsuke. Indeed, the phrasing of art 557 para 1 Minpo - 'When the buyer delivery earnest money...' (emphasis added) - clearly indicates that tetsuke is not a mandatory part of sale or other onerous contracts. While it would be true to say that the tetsuke-contract (see Section aa) below) arising from the payment of tetsuke is a real contract, the base-contract is not.

2138 These customs were discussed in Section III.1.c.iv. above. Compare Yoshida (fn 1651) 4, who states that the notion of tetsuke was associated with these customs. See also Ronald Frank, Law of Obligations, in: Röhl (fn 1584) 227, 249. cf Kitagawa, 'Contracts' (fn 1601) $\$ 2.01[3][j]$ at 2-42, who states that tetsuke originated from the Roman arra (earnest) but goes on to say at 2-43 that art 557 Minpo 'reflects [an] old Japanese trade practice' from before the existence of the Minpō.

2139 For the former, see, eg, Yūgen Kaisha Atago Sangyō at www.025-377-6150.com/1fudousantorihiki/23. For the latter see, eg, the entry for '手付損倍返し' in the Japanese online dictionary Kotobanku at https://kotobank.jp/.

2140 Marutschke, 'Immobiliarsachenrecht' (fn 1846) 3. cf Yokoyama, 'Purosesu' (fn 1846) 91, who states that this perception is at least the practical reality.

2141 Real contracts have been discussed in Section b. above. 


\section{Contracts in Japanese Law}

The importance of tetsuke today, compared to that in history, has diminished. ${ }^{2142}$ While being 'commonplace' before, ${ }^{2143}$ it is now only used in particular transactions. Thus, although art 559 Minpo allows the application of art 557 to all 'contracts for value other than contracts for sale' ('売 買以外の有償契約', baibai igai no yūshō keiyaku), in practice, it is most commonly paid in relation to sale transactions involving real estate (land, buildings), ${ }^{2144}$ but is also used with leases, employment, and work contracts. ${ }^{2145}$ At least in former times, tetsuke was also paid in 'sale by sample' transactions. ${ }^{2146}$ The reason for adhering to the practice of paying tetsuke, at least in transactions involving immovable property, is to strengthen the bindingness of the contract: According to the majority view in Japanese legal academia, the notion of a formless agreement being binding is weak; however, where tetsuke is paid, the party's (buyer's) declaration of intention is deemed to be a lot stronger. ${ }^{2147}$ Conversely, where no tetsuke is paid, the buyer's agreement is not seen as 'final' ('終局的', shükyokuteki),

2142 See Yoshida (fn 1651) 13.

2143 Frank, 'Obligations' (fn 2138) 249.

2144 Kitagawa, 'Contracts' (fn 1601) \$2.01[3][j] at 2-43; Marutschke, 'Einführung' (fn 1603) 153-154. For an example from Japanese customary law, particularly from the former province of Settsu (today's Ōsaka), see Wigmore, 'Customary Law' (fn 1675) 14 and 32.

2145 Yunoki and Takagi (fn 1718) 171; Tōkō Aihara, Tetsuke to uchikin [Tetsuke and Deposits], in: Keiyaku-hō Taikei Kankō I'in-kai (fn 2021) Vol 2: zōyō, baibai [Gifts, Sales] 58.

2146 See Wigmore, 'Customary Law' (fn 1675) 30-31.

2147 See Mika Yokoyama, Tetsuke no seiritsu: shögaku no kinsen no juju [The Coming into Existence of Earnest Money: The Giving and Receiving of Small Sums of Money] (2008) 192 Juristo bessatsu: Fudō-san torihiki hanrei hyakusen 42, 43; Yoshida (fn 1651) 12. This is particularly true where the building in question is new. In contrast, with old buildings, tetsuke is often used as a kind of insurance against defects in the building, interview with Mrs Mika Yokoyama, Professor, Faculty of Law, University of Kyōto (Kyōto, 7 September 2016). A declaration of intention is thought to have most strength if contained in a written document and is supported by tetsuke, interview with Prof. Yokoyama (ibid). 
negating the formation of a contract. ${ }^{2148}$ Its role is also seen as ensuring performance. $^{2149}$

\section{aa) 'Tetsuke'Defined}

There is no statutory definition of the meaning of tetsuke. It is commonly understood, however, that tetsuke can be either money or 'other valuables' (“他の有価物', hoka no yüka-butsu). ${ }^{2150}$ The Japanese courts have generally ruled that a 'valuable other than money' (“金銭以外の有価物', kinsen igai no yüka-butsu) can be delivered instead of money where the parties have agreed on this. ${ }^{2151}$ It can be deduced from this that money will normally be given, unless the parties agree otherwise. One example of such an 'other valuable' is standing timber (ryüboku, 立木), which has been found to be sufficient by the courts. ${ }^{2152}$

One important point to note is that where tetsuke is handed over in a transaction, what is known as a tetsuke-contract (tetsuke keiyaku, 手付契約) is concluded. ${ }^{2153}$ This is a distinct, subordinated agreement from the contract concerning the transaction itself, eg, in a sale, the sales contract. ${ }^{2154}$ As a consequence, two contracts arise: a main contract and the tetsuke-con-

2148 See Yokoyama, 'Purosesu' (fn 1846) 92. In this sense, tetsuke is similar to consideration; however, a vital difference between them is that the latter is legally constitutive for a contract to be concluded, whereas the former is not. On consideration, see Section B.II.3.a.v. above. cf current German legal practice as discussed in Section B.III.3.c.ii. above, where Draufgabe plays no role nowadays.

2149 Aihara (fn 2145) 63. Although he also admits that the contract's bindingness is strengthened by tetsuke, he ascribes this property to iyaku but not to kaiyaku tetsuke (both discussed in Section cc) below), which he says weakens the binding force, see ibid. This may be true, since the former protects the party innocent of breaching it and thus endorses the contract, while the latter supports the contract's resolution.

2150 See Yunoki and Takagi (fn 1718) 171.

2151 See the decision of the Dai-shin'i of 8 May 1901 (Meiji 34), Minroku 7 Vol 5 52. The case concerned the sale of a mountain forest (sanrin, 山林). See on this further Aihara (fn 2145) $61 \mathrm{fn} 3$.

2152 See Dai-shin'i of 8 May 1901 (fn 2151).

2153 On this, see Yamamoto K, 'Minpō kögi IV-1' (fn 1646) 220-221. See also Sei'ichi Yamada, Tetsuke keiyaku no kaishaku [Interpretation of the Tetsuke-Contract] (2008) 192 Juristo bessatsu: Fudō-san torihiki hanrei hyakusen 38-39. See also Aihara (fn 2145) 38.

2154 See Aihara (fn 2145) 60-61 in fn 1. 


\section{Contracts in Japanese Law}

tract; however, the effect of tetsuke concerns only the tetsuke-contract and has no bearing on the other - main - contract. For this reason, tetsuke is not a formation requirement for Japanese contracts. ${ }^{2155}$ Having said this, tetsuke is not irrelevant to the main contract, since, where a tetsuke-contract arises, this is evidence of a main transaction, in relation to which tetsuke is paid, thus proving the existence of that (main) contract. Then again, where the parties agree, tetsuke can become a formation requirement for the contact that is to be concluded. ${ }^{2156}$

\section{bb) Method of Effecting Tetsuke}

The way to effect tetsuke concerns two issues: the method and the timing. With respect to the former, tetsuke is usually effected by being 'delivered' (交付した, köfushita, see art 557 para 1 Minpō). Nevertheless, tetsuke does not always have to be actually delivered. Thus, one alternative is that the value is set off with the seller's claim. ${ }^{2157}$ As for the appropriate moment of time, this will usually be the moment of concluding the contract; ${ }^{2158}$

2155 To be precise, tetsuke is no formation requirement for the main contract. Whether it and its delivery are required for the formation of the tetsuke-contract is an on-going debate, see fn 2153. The reason for it not being a constitutive requirement as pointed out in Yunoki and Takagi (fn 1718) 171 is that there is "[...] practically no place for a "contract conclusion tetsuke" as a contract formation requirement in a contemporary legal regime under which most contracts have been concensualised [...]' (“…]契約成立要件とし てのいわゆる「成約手付」なるものは、ほとんどの契約が諾成契約化した 現代法のもとでは、ほとんど存在の余地がない[...]'; keiyaku seiritsu yōken to shite no iwayuru 'seiyaku tetsuke' naru mono ha, hotondo no keiyaku ga dakusei keiyaku-kashita gendai-hō no moto de ha, hotondo sonzai no yochi ga nai).

2156 See Yunoki and Takagi (fn 1718) 171; Aihara (fn 2145) 60. During the Tokugawa era, what was known as seiyaku tetsuke ('成約手付', tetsuke for concluding a contract) existed beside the other forms explored in Section cc) below. Without this tetsuke, a contract was not considered to be formed. See Yoshida (fn 1651) 640. It seems that this type no longer exists today.

2157 Aihara (fn 2145) 61 in fn 2: ‘手付の交付は、現実に行われるのが普通だが、 売主の債権との相殺によって現実の交付にかえることも妨げない’(tetsuke no köfu ha, genjitsu ni okonawareru no ga futsū da ga, urinushi no saiken to no sosai ni yotte genjitsu no köfu ni kaeru koto mo samatagenai; 'Tetsuke will normally be handed over in practice; however, this does not impede a change to actual delivery by off-setting with the seller's claim').

2158 Dai-shin'i decision of 14 January 1933 (Shōwa 8), Dai-shin'i Saiban-rei Vol 7 $\min 4$. 
although it has also been noted that any time between formation of the agreement and commencement of performance is possible. ${ }^{2159}$

The question is therefore - also with respect to the possibility of cancelling the contract under art 557 para 1 Minpo - what the words 'commence[ing] performance’ (“履行に着手する’, rikō ni chakushu suru) mean. They have been interpreted to signify that while actual performance is not necessary, it is sufficient if the party having paid tetsuke is in a position to perform at any moment. Accordingly, it is sufficient if a buyer of real estate can demand its transfer from the seller due to being in the position of being able to pay the purchase price at any time. ${ }^{2160}$ Furthermore, it is important to note that the party who has not begun to perform cannot cancel the contract once the other party has done so; conversely, the party that has commenced performance may still cancel the contract. ${ }^{2161}$ The provision aims to protect the party who commences performance from incurring expenses only to have the contract cancelled by the other party, thus suffering unexpected damage; however, if it is the party who has initiated performance that cancels the contract, any losses will not be unexpected and so protection is not required. ${ }^{2162}$

2159 See Kitagawa, 'Contracts' (fn 1601) \$2.01[3][j] at 2-42.

2160 See Aihara (fn 2145) 62. Cf Saikō Saiban-sho decision of 4 October 1965 (Shōwa 40), Minshū Vol 19 No 82019 (contained in Segawa and Uchida (fn 1992) 50-53), in which the court held that commencing performance occurs when it is objectively possible for an outsider to deem the conduct as one part of performance. It found that simply paying tetsuke did not constitute 'commencing performance', but that payment of the price to the third-party owner and effecting the transfer of ownership from this party to the seller was sufficient. For a commentary with a more detailed explanation on the differentiation between 'mere preparation' and actual commencing of performance, see Shu'ichi Miyashita, Tetsuke to rikō no chakushu [Tetsuke and Commencement of Performance] (2008) 192 Juristo bessatsu: Fudō-san torihiki hanrei hyakusen 40-41.

2161 See Saikö Saiban-sho decision of 4 October 1965 (fn 2160), in which the court held that not only the party who had not yet commenced performance, but also the party which had commenced could cancel, since it was only the performing party that incurred expenses and was willing to bear this loss.

2162 Compare Saikō Saiban-sho decision of 4 October 1965 (fn 2160) and fn 2161. 
cc) Types and Functions of Tetsuke

There are three different types of Tetsuke. Beside the 'cancellation tetsuke', the other two types of tetsuke are 'earnest money for breach of contract' (iyaku tetsuke, 違約手付),2163 and 'earnest money as proof of contract' (shoyaku tetsuke, 証約手付).2164 Iyaku tetsuke is similar to kaiyaku tetsuke in that the money is forfeited by the giver if they do not perform and, vice versa, the receiver must pay back twice the amount to the giver if they do not perform. ${ }^{2165}$ Normally, between ten and twenty per cent of the purchase price are paid as tetsuke; however, shoyaku tetsuke usually arises when only a small sum of money (less than ten per cent) is handed over. ${ }^{2166}$ The latter therefore constitutes the tetsuke's basic function, so that where tetsuke has been delivered by a contracting party, it will at least have the effect of evidencing the contractual agreement. ${ }^{2167}$ Whether it

2163 Perhaps the purpose of this function of tetsuke was to provide the contracting parties with further incentive to perform, a function which is generally suggested for Pfand (securities) by Kötz, 'Europäisches Vertragsrecht' (fn 17) 9 (1996 edn). For examples from Japanese customary law, see Wigmore, 'Customary Law' (fn 1675) 19 (former province of Suruga, today Yamanashi), 27 (former province of Uzen, today's Yamagata), 32 (former province of Kaga, today's Ishikawa).

2164 See fn 2137. This form is apparently of particular importance for contracts concluded orally, compare fn 2172 below.

2165 See Yunoki and Takagi (fn 1718) 172.

2166 See Yokoyama, 'Tetsuke' (fn 2147) 43, who is sceptical of a payment of less than ten per cent of the purchase price being sufficient in order to constitute tetsuke and to lead to the conclusion of a sale contract according to current business practice. Aihara (fn 2145) 58 also states the usual amount to be around ten per cent. A range of $10 \%-20 \%$ is also stated by Masaaki Muramoto, Möshikomi shöko-kin to tetsuke no chigai ha? [What is the Difference Between Application Earnest Money and Earnest Money?] (1 August 2007), http://allabout.co.jp/gm/ $\mathrm{gc} / 10297 /$.

2167 See Aihara (fn 2145) 58-59. See also Yunoki and Takagi (fn 1718) 171, stating that all kinds of tetsuke share this common feature of proving the existence of a contract. This was confirmed in the Dai-shin'i decision of 14 January 1933 (fn 2158), in which the court found that 'tetsuke is something that is handed over for various purposes; [the understanding that] of these purposes [...] all serve also to prove the formation of a contract is common' ('手附八種 久ノ目的ノ為二交付セラルルモノニシテ其ノ目的[...] 孰レモ契約ノ成立 証明スル目的 ᄏ兼有スル 通常卜スル, tetsuke ha juju no mokuteki no tame ni köfuseraruru mono ni shite sono mokuteki [...] izuremo keiyaku no seiritsu wo shömeisuru mokuteki wo ken'yūsuru wo tsüjö to suru). 
also displays the other effects is another question. ${ }^{2168}$ This issue depends on several things: First, whether a tetsuke-contract has been formed at all, and, secondly, what effects were intended for tetsuke by the parties. ${ }^{2169}$ Moreover, it has been stated that where the intention of the parties as to the effect (type) of tetsuke is unclear, art 557 Minpo will apply; which thus seems to make kaiyaku tetsuke the default type. ${ }^{2170}$ Irrespective of this discussion, there seems to be no conflict between the functions of shoyaku and kaiyaku tetsuke. While the former is a very basic function that goes to the heart of the matter, namely, to the existence of a contract, the latter is more advanced in that it establishes a right. In a way, the latter thus implies the former, as - speaking in very general terms - the existence of an agreement is a preliminary condition for rights to come into existence in private law. Consequently, the Minpo explicitly endorses the stronger function.

Apart from these three functions, tetsuke can also be linked to liquidated damages, in that the contracting parties sometimes stipulate that the two-fold of tetsuke is to be paid as damages in case of non-performance. ${ }^{2171}$ These functions existed already in the Tokugawa era, whereby their application differed: While kaiyaku tetsuke seems to have been widely used in commercial contracts, something resembling iyaku tetsuke seems to have been used for what we would today term consumer contracts. ${ }^{2172}$

While tetsuke is paid prior to the contract being performed and will be considered to have been paid as part of the purchase price after the

2168 See Yamamoto K, 'Minpō kögi IV-1' (fn 1646) 220, 221.

2169 In other words, the parties have to agree on the type of tetsuke, see Aihara (fn 2145) 59 (for iyaku tetsuke). For a discussion of these issues, see Yamamoto K, 'Minpō kögi IV-1' (fn 1646) 221-225.

2170 See Yamada (fn 2153) 60, 61-62.

2171 See Kitagawa, 'Contracts' (fn 1601) \$2.01[3][j] at 2-43. Compare the historical examples given by Wigmore, see fn 2163. Contrast Aihara (fn 2145) 59, who states that iyaku tetsuke and damages are often linked in practice, although the two are not in fact the same. See also Yunoki and Takagi (fn 1718) 172, who explain the difference in the two applications.

2172 See Yoshida (fn 1651) 5-6, who uses the German terms 'Reugeld' and 'Anzahlungsdraufgabe und Vertragsstrafe' respectively; the Japanese terms being 'kaiyaku tetsuke' (解約手付) and 'uchikin tetsuke, iyaku tetsuke' (内金手付, 違 約手付) respectively, see ibid 642 . He defines uchikin tetsuke as tetsuke that is paid in order to bind the other party to the (oral) agreement, see ibid 4, 3, and 640. 
commencement of performance, ${ }^{2173}$ it ought not to be confused with other payments made prior to or at contracting, particularly a down payment (uchikin, 内金). ${ }^{2174}$ As the latter is paid in order to settle part of the purchase price, it is not the same as tetsuke, particularly not kaiyaku tetsuke. ${ }^{2175}$ Confusion may also arise with what is known as 'application earnest money' ('申込証拠金', mōshikomi shōko-kin, literal translation), a sum of money ranging between $¥ 5,000$ and $¥ 10,000$ (approx. $€ 40-€ 80$ ) that is paid by the prospective buyer of real estate to show that their interest is serious, or, more often, to gain a preferential purchase right. ${ }^{2176}$

\section{Legal Thinking and Current Legal Practice in Japan}

Having seen the legal framework for the conclusion of contracts, attention is now given to the social components, namely, Japanese legal thinking and current legal and business practice in contracting. It ought to be noted at the outset that the framework of this dissertation does not allow for an in-depth analysis of this fascinating subject. In light of this, three selected aspects will be highlighted in relation to the conclusion of contracts. These are the relationship between the Japanese and law in general (see Section a. below), their stance to contracts (Section b.), and, finally, the (popular) estimation of contract formalities (Section c.). While the first aspect will give an insight into the general appreciation of law and its bindingness in Japan, the latter two directly relate to contracts.

\section{a. Japanese Legal Thinking Generally}

It was mentioned in passing in Section III.2.b. above that the term 'right' - as in a person's subjective right that may be asserted against others

- had to be created in the Japanese language during the reception of 'Western' law during the Meiji era. The reason for this necessity was the simple fact that the notion of a citizen having subjective rights against oth-

2173 See Kitagawa, 'Contracts' (fn 1601) $\$ 2.01[3][\mathrm{j}]$ at 2-42-2-43. For an example from Japanese customary law, see Wigmore, 'Customary Law' (fn 1675) 30 (former province of Kaga, today's Ishikawa).

2174 Yamamoto K, 'Minpō kögi IV-1' (fn 1646) 220.

2175 See Yokoyama, 'Tetsuke' (fn 2147) 43. A down payment will usually be made in an amount equivalent to one third or half of the purchase price, see ibid.

2176 See ibid 43. 
er citizens was traditionally remote to the Japanese legal landscape, since the legal system had traditionally been based on public law, while private matters were customarily resolved on a non-litigatory basis, like through mediation. ${ }^{2177}$ Instead, the cooperation between citizens was governed by their relationships and social notions like jöri, giri, and wa, but not by abstract legal rules. ${ }^{2178}$ Nevertheless, this was a historical characteristic and is no longer true today.

One approach that has been adopted to analyse the attitude of the Japanese towards law in general and towards contracts in particular is to contrast this view with a 'Western' perception. The resulting differences appear greater when the perspective is that of a common law jurisdiction, like the USA. ${ }^{2179}$ While the particulars of the US-American legal system, including perhaps the country's legal thinking, are certainly different from the English legal system, shared features exist on a general level due to both belonging to the common law legal family. At least for the purpose of the present discussion, namely, to highlight some differences between Japan and 'the West' (Europe), it suffices to treat the approaches in the US as being similar to those in the UK.

One contrasting feature between Japan and the Anglo-American approach is legal language. As the Japanese language is generally more imprecise than, say, English, phrasings in Japanese legislation leave more room

2177 See Yamamoto K, 'Rechtsverständnis' (fn 1583) 92, who states this description as going back to the academic Takeyoshi Kawashima. On the nature of Medieval Japanese law and the settlement of disputes, see Haley, 'Medieval Japan' (fn 879), in particular 324-325, 342-347.

2178 For further details on this, see Guntram Rahn, Recht und Rechtsmentalität in Japan [Law and Legal Mentality in Japan] (Gebrüder Tönnes 1981) 22-24. See also Yamamoto K, 'Rechtsverständnis' (fn 1583) 92-93; Haley, 'Medieval Japan' (fn 879) 347.

2179 This consideration was made by Whitmore Gray in a study conducted in Japan in the early 1980s, the results of which were published in 1984. It should therefore be borne in mind that the data has somewhat aged since then. Irrespective of this, some of the insights still seem to be valid today. For the results, see Gray (fn 1633) 97-119. For more recent observations, see John O Haley, Rethinking Contract Practice and Law in Japan (2008) 1 Journal of East Asia \& International Law 47-69, noting, inter alia, how Japanese law is more favourable for contracting as contrasted with US law, since the former allows contracts to be concluded without requiring forms or consideration, while the Japanese courts seem to endeavour to find an agreement between parties in accordance with their expectations at the time of contracting. 


\section{Contracts in Japanese Law}

for interpretation. ${ }^{2180}$ The language itself thus provides greater flexibility in the law and allows the courts to adapt legal rules to the case at hand. ${ }^{2181}$

In terms of legal practice, there is one important observation to be made about Japan. From what has been discussed in the previous sections on Japanese law, it may have already been noted that the practices observed are not always identical to the legal framework. Thus, despite not being required under Japanese law, parties often conclude contracts in writing, or, where a transaction concerns real estate, pay tetsuke at the time of concluding the agreement (see Sections 1.b.ii. and 1.c.iii. above respectively). This phenomenon of formal and living law being incongruent exists in almost all areas of Japanese law and is addressed in legal reforms from time to time. ${ }^{2182}$ The success of legal reception in Japan has been put down to the effectiveness of this living law and the fact that the received law allowed the living law to be absorbed. ${ }^{2183}$

\section{b. Contracts in Japanese Legal Thinking}

With regard to contracts, a number of practical deviations are discernible. First, Japanese contracts are simpler than those drafted in England or Germany. Apart from the common lack of form requirements, this is because contracts are filled-out forms rather than free-text documents. ${ }^{2184}$ Moreover, they are also often shorter, which might be related to the use of such forms, but has furthermore been interpreted to reflect the parties'

2180 On the language differences, see the quotation in Rahn, 'Rechtsmentalität' (fn 2178) 19-20.

2181 An interesting example of an unfair competition court case concerning perfumes is given by ibid $20-21$.

2182 On this phenomenon, a range of examples, and how some aspects were addressed in legal reforms during the 1990s, see Kahei Rokumoto, Japanese Law Symposium: Law and Culture in Transition (2001) 49 The American Journal of Comparative Law 545-560, in particular 549-558. Some of the aims stated for the reforms of that time apply to the recent reform of the law of obligations, considered in Section V. below.

2183 Yamamoto K, 'Rechtsverständnis' (fn 1583) 86. He is critical of the reforms mentioned in the previous footnote, since these destroyed 'the previously existing protected spaces of the "living law"' ('die bislang geschützten Räume des "lebenden Rechts"; English and German original text).

2184 See Kaiser (fn 1976) para 57, noting this for contracts concerning sales of real estate. The written form was already discussed in Section 1.b.ii. above. 
expectations of a fruitful development of the contractual relations, ${ }^{2185}$ or to reflect the fact that only the transaction but not the parties' relationship is regulated in the contract. ${ }^{2186}$ Perhaps as a consequence of this non-regulation, but also to avoid disputes over stipulations and favour settlements, contractual regulations are kept short instead of seeking to regulate all the parties' rights and obligations. ${ }^{2187}$ While this is generally true, there are situations in which long, complex contracts are regularly concluded, such as with transactions involving real estate, corporate merger and acquisitions, or in cross-border business dealings. 2188

Nevertheless, it has been advised that the length of a contract cannot simply be put down to cultural differences. In particular, the fact that common law practitioners tend to define terms and include a range of default rules stems from a systemic and practical need to provide for legal certainty: in making the contract self-sufficient in terms of regulation, the insecurity of varying interpretation or application of statutory rules by the courts can be avoided. ${ }^{2189}$ Thus, while this legal practice has been established in the UK and the US, it was born from a practical necessity. This need seems not to exist in Japan. ${ }^{2190}$ Apart from this structural reason, there is a linguistic cause: the Japanese language allows a more concise expression than English, resulting in the same text being shorter when written in Japanese script. ${ }^{2191}$

While this may be true, it has been said that vague formulations in Japanese texts are often chosen with the purpose of supporting settlements in case of disputes. ${ }^{2192}$ In this sense, it has also been remarked that clauses to settle disputes out of court, in particular through conciliatory talks, are often found in contracts. ${ }^{2193}$ While vague stipulations may be advantageous in some situations, European academics have cautioned about the uncertainty arising as the flipside of flexibility and advise bearing this in mind in contract drafting. ${ }^{2194}$ Having said all this, contracts concluded

2185 See Axel Schwarz, Vom Wert des Lebens und der Normen [On the Value of Life and of Norms], in: Menkhaus (fn 1590) 63, 69.

2186 Rahn, 'Rechtsmentalität' (fn 2178) 23.

2187 Yamamoto K, 'Rechtsverständnis' (fn 1583) 93.

2188 Sono and others (fn 1632) 36, 48.

2189 This caution was given by Gray (fn 1633) 102.

2190 Sono and others (fn 1632) 48.

2191 See ibid.

2192 Schwarz (fn 2185) 69.

2193 Rahn, 'Rechtsmentalität' (fn 2178) 23.

2194 See, eg, ibid 21. 
with companies and institutions such as banks do tend to be long and detailed due to the use of comprehensive standard terms. ${ }^{2195}$ Furthermore, where contracts are concluded between Japanese and foreigners, detailed written contracts are often used. ${ }^{2196}$

\section{c. Contractual Formality in Japanese Legal Thinking}

In general, the Japanese tend to deem formalities in contracting more important than what is prescribed by law. This has led to a popular belief in Japan that contracts must be made in writing. ${ }^{2197}$ It has been stated, however, that not only one but two opposing convictions exist among the Japanese: On the one hand, a contract not contained in a formal document (shösho, 証書, more literally 'deed' or 'bond') being invalid; and on the other, a contractual document being a mere formality, reflecting the true agreement. ${ }^{2198}$ In line with the first school of thought, it is said that a written document strengthens a person's intention, their earnestness. ${ }^{2199}$ Indeed, it seems that the perfection of a sale of real estate through the drawing up of formal documents and registration of the change in property is used by the courts as an indication of the parties' earnestness. ${ }^{2200}$

Similarly, Japanese people often believe a written contract needs something more. Accordingly, it is believed by some that a contract is not concluded until a seal (see Section 1.b.iii. above, as well as Section D.III.2.b. below) has marked the document. ${ }^{2201}$ In fact, something like a scale of strength for a contract's bindingness seems to exist in Japanese culture with regard to the contract's formality. ${ }^{2202}$ According to this thinking, oral contracts are perceived as being weakest. Written contracts are deemed to be more binding, followed by contracts that bear a seal (of any kind);

2195 Compare Schwarz (fn 2185) 69.

2196 See Rahn, 'Rechtsmentalität' (fn 2178) 25, who states that this would not be the case among Japanese.

2197 See Noriaki (fn 1641) 10.

2198 See Taniguchi and Ono (fn 1846) 392.

2199 Interview with Mrs Mika Yokoyama, Professor, Faculty of Law, University of Kyōto (Kyōto, 7 September 2016).

2200 On this, see Sono and others (fn 1632) 59-60.

2201 Interview with Dr Shōji Kawakami, Professor, Faculty of Law, University of Tōkyō (Tōkyō, 19 December 2015).

2202 On this, see Yamanushi (fn 2021) 144, 151. See also Sono and others (fn 1632) 61,63 . 
however, if the seal is a jitsu'in, the strength of the contract's bindingness increases. Finally, the greatest force is achieved through a notarial deed (kösei shösho, 公正証書, see Section 1.b.iv. above).

Another commonly-held belief (which is reflected in business practice) about contracts for the sale of immovable property is that a formal document must be drawn up and tetsuke (see Section 1.c.iii. above) be handed over before the contract has been concluded effectively. ${ }^{2203}$ This legal thinking may be a remainder from the Tokugawa era, during which bare agreements were not deemed to be binding. 2204

\section{d. Current Legal Practice in Japan}

The exposition in the foregoing sections helps to delineate a number of legal practices observed in Japan. One concerns the form of contracts. As we have seen in Section 1.b. above, Japanese law does not require many formalities in contracting. Despite this fact, contracting parties may choose to - and in fact often do - put their agreement into writing for a number of reasons, including to avoid disputes, or to verify a party's intention. ${ }^{2205}$ Apart from these factual needs, written agreements are held in higher esteem than their oral counterparts, as noted in Section 1.b.iii. above. This may explain why the practice is followed for a whole range of contracts. ${ }^{2206}$ In particular, in sales of immovable property, the established business practice is to draw up a written document and hand over tetsuke (earnest money).2207 Another reason may be that some transactions, such as gifts, are revocable if not made in writing. ${ }^{2208}$ Furthermore, it is said that in transactions of high value, eg, in relation to immovable property, a written agreement prevents trouble. 2209

2203 See Yokoyama, 'Seiritsu katei' (fn 2038) 198.

2204 See Yoshida (fn 1651) 12. For further details, see Section II.1.c.iv. above.

2205 Compare Taniguchi and Ono (fn 1846) 393. For further details, see ibid 400402.

2206 An illustrative list of the contract types can be found in Taniguchi and Ono (fn 1846) 400.

2207 See Yokoyama, 'Seiritsu katei' (fn 2038) 198. On tetsuke, see Section 1.c.iii. above.

2208 On this, see the discussion in Section 1.b.ii. above.

2209 Noriaki (fn 1641) 13. 


\section{Contracts in Japanese Law}

As noted previously, the use of standardised forms rather than freely formulated text is common for contracts, both in business contexts, ${ }^{2210}$ and in sales of real estate. ${ }^{2211}$ And while contracts generally tend to be short, the duties to provide information on certain matters to consumers lead to long, detailed contract documents in B2C constellations.2212 The widespread use of standard terms (yakkan, 約款) may also contribute to this. In fact, in e-commerce, ie, online shopping, contractual terms like the price, object, the time and place of performance, etc are normally fixed in such standard terms. ${ }^{2213}$

While this is true for $\mathrm{B} 2 \mathrm{C}$ or $\mathrm{C} 2 \mathrm{C}$ contracts, the converse seems to be true in $\mathrm{B} 2 \mathrm{~B}$ situations. Thus, it has been stated that only few written contracts are concluded under Japanese commercial law. ${ }^{2214}$ The degree may vary in specific sectors, such as in the textile industry. ${ }^{2215}$ Where contracts are made in writing, it is standard practice to issue several copies of a contract, so that each party may obtain an original. ${ }^{2216}$ In commercial settings, contracting parties doing business together regularly will usually conclude not just one but a series of contracts: first, a framework agreement (kihon keiyaku, 基本契約, literally 'basic contract'), which contains a range of stipulations to configure the contractual relationship; on this basis, 'separate (sale) contracts’ (“個別(売買)契約’, kobetsu (baibai) keiyaku) are entered into when required. ${ }^{2217}$

\section{The Modernisation of the Saiken-hō (債権法, Japanese Law of Obligations)}

A comprehensive modernisation process in relation to the Japanese law of obligations has been recently completed. This took almost nine years, over the course of which different bodies have published a plethora of ma-

2210 Kitagawa, 'Contracts' (fn 1601) \$2.01[3][h][ii] at 2-36.

2211 See Kaiser (fn 1976) 704 para 57.

2212 Kitagawa, 'Contracts' (fn 1601) \$2.01[3][h][ii] at 2-36.

2213 See Matsumoto, 'Keiyaku' (fn 1830) 18.

2214 See Hideaki Seki, Das Japanische im japanischen Handelsrecht [The Japanese in Japanese Commercial Law], in: Menkhaus (fn 1590) 237, 240.

2215 On this, see Karl-Friedrich Lenz, Das Japanische im japanischen Handelsrecht [The Japanese in Japanese Commercial Law], in: Menkhaus (fn 1590) 219, 233, who notes that around $70 \%$ of contracts concluded in this commercial sphere in the 1990s were not in written form, but oral.

2216 Pardieck (fn 2079) 188.

2217 See Egashira (fn 1843) 6-8 for further details, especially as to the possible stipulations contained in the 'basic contract'. 
terials. After briefly exploring the general motives for the reform project (in Section 1. below), the modernisation process will be explained in more detail (in Section 2.). This includes an overview over the different parties involved and the most important materials that have been published. Finally, attention is given to the content of the reform, whereby only those rules relevant to this dissertation will be discussed here, namely, those in relation to the formation of contracts (Section 3.).2218

\section{Reasons Underlying the Reform Project of the Law of Obligations}

Seeing as the Minpō has been in force for over 120 years with little to no amendments during this time (see Section III.3. above), and with the social, economic, and technological changes occurring, it is not surprising that the Japanese legislator initiated a project to reform Japanese private law. Indeed, the motives for the reform admit that the 'changes in the state of affairs in relation to the socio-economic situation need to be heeded' (‘社会経済情勢の変化に鑑み’, shakai keizai jösei no henka ni kangami). ${ }^{2219}$ Furthermore, it was stated explicitly that certain provisions, such as in relation to extinctive limitation periods (sōmetsu jikōo no kikan, 消滅時効の 期間), or the protection of guarantors (boshö-nin no hogo, 保証人の保護) were in need of reform..$^{2220}$ Of course, amendments in private law were made subsequent to the Minpō coming into force; however, as this was done in special laws, ${ }^{2221}$ the regulation of some matters had become scattered and confusing. One pertinent example is the coming into effect of declarations of intention (see Sections IV.1.a.ii. and iii. above). There was thus a need to bring the regulation together, including legal developments made in court decisions or by legal academics. 2222

2218 Interested readers on other aspects of the proposed reform are referred to Yoshio Shiomi, Minpō (saiken kankei) kaisei hō'an no gaiyō [Overview of the Legislative Bill to Reform the Minpō (Law of Obligations)] (Kin'yū Zaisei Jijō Kenkyū-kai 2015).

2219 Hōsei Shingi-kai Minpō (Saiken Kankei) Bukai, Riyūu [Motives], document no 001142183. This document (hereinafter 'Riy u') and other documents related to the reform are available online from the Homu-sho's website at www.moj.go.jp/ MINJI/minji07_00175.html.

2220 See Riyū (fn 2219).

2221 See on this Yamamoto K, 'Minpō kögi I' (fn 1632) 26.

2222 Compare ibid 29-30. 
2. The Reform Process: Initiation, Intermediate Results, Coming into Effect of the Amendments

The Japanese Civil Code (Law of Obligations) Reform Commission (法 制審議会民法 ( 債権関係) 部会, Hösei Shingi-kai Minpō (Saiken Kankei) Bukai; hereinafter simply 'Kaisei-kai') was inaugurated in November 2009 by the Homu-sho. ${ }^{2223}$ Beside employees of the Homu-sho, the Commission's members comprise leading legal academics in the field of the law of obligations from several universities, as well as representatives of legal practitioners (including lawyers (affiliated with local bar associations), judges, consumer protection consultants) and the commercial sector (companies, banks). ${ }^{2224}$

After holding a series of meetings, the Kaisei-kai adopted an 'Interim Tentative Plan for the Reform of the Civil Code (Law of Obligations)' (hereinafter 'Chükan shi'an'2225) on 26 February 2013.2226 Based on this, the public were invited to comment on the proposed changes during a period of two months. ${ }^{2227}$ These comments were taken into account during subsequent debates of the Kaisei-kai, and the proposal underwent another series of changes before a final proposal, which was then translated into a

2223 See, eg, Chūkan shi'an Explanations (fn 1876) 1 (foreword).

2224 A list of the Commission's members names (meibo, 名簿) can be downloaded from the reform project website at www.moj.go.jp/shingi1/ shingikai_saiken.html. The list dated 23 July 2014 is used here, www.moj.go.jp/content/001127663.pdf.

2225 Hōsei Shingi-kai Minpō (Saiken Kankei) Bukai, Minpō (saiken kankei) no kaisei ni kansuru chükan shi'an [Interim Tentative Plan for the Reform of the Civil Code (Law of Obligations)] (March 2013, corrected July 2013). The document, which is often abbreviated to '中間試案' (chükan shi'an) in Japanese, is available online at www.moj.go.jp/content/000112242.pdf.

2226 It was first published on 11 March 2013, but subsequently underwent a series of corrections, so that the final version dates from 4 July 2013 (document no 000112242). See www.moj.go.jp/shingi1/shingi04900184.html, from which all the documents relating to the Chükan shi'an can be downloaded. In the following discussion, references to the Chükan shi'an are to this last version. Having said this, the corrections that were made did not affect the provisions discussed in this dissertation, see Hōmu-shō, Minpō (saiken kankei) no kaisei ni kansuru chükan shi'an seigö-hyō [Correction of the Interim Tentative Plan for the Reform of the Civil Code (Law of Obligations)] dated 4 July 2013, document no 000112240, available online at www.moj.go.jp/content/000112240.pdf.

2227 See the postscript dated 27 March 2013 at www.moj.go.jp/shingi1/ shingi04900184.html. 
legal bill to be submitted to the Japanese Parliament, was adopted on 10 February 2015.2228

The legislative bill (Kaisei hö'an, 改正法案) was presented to Parliament on 31 March 2015.2229 The Shü'in (Japanese lower house in the Diet, 衆 院) deliberated and approved the legislative bill on 14 April 2017.2230 The Lower House proposed no amendments concerning the content of the reform; it merely recommended changing the designation of what would become the reform law to reflect the new timeline, so that the law was now designated as '平成二十九年法律第[blank space]号' (Heisei 29-nen höritsu dai-[blank space]-go, Law No [blank space] of 2017) instead of bearing the year 2015 (Heisei 27-nen, 平成二十七年).2231 As had been anticipated, the San'in (Japanese upper house in the Diet, 参院) passed the bill without further amendments on 26 May 2017.2232 The Law (No $44 / 2017)^{2233}$ was officially proclaimed on 2 June 2017 and published in

2228 This final proposal was termed 'yōkō-an' (要綱案, draft of general plan) and published on 23 February 2015, see www.moj.go.jp/shingi1/ shingi04900244.html. In terms of the proposed changes, the content of this final proposal is identical with the Kaisei ho'an (reform bill, see subsequent fn).

2229 See Hōsei Shingi-kai Minpō (Saiken Kankei) Bukai, Minpō ichibu wo kaisei suru horitsu [Law to Amend one Part of the Civil Code] (submitted for consideration by the Japanese Parliament on 31 March 2015). This document (hereinafter 'Kaisei hö'an') is available online at www.moj.go.jp/content/ 001142186.pdf.

2230 See Unnamed author, Minpō kaisei-an ga Shü'in tsūka keiyaku rūru bappon minaoshi [Civil Code Refom Bill Passed by Lower House Drastic Review of Contract Rules], Nippon Keizai Shinbun (14 April 2017), www.nikkei.com/ article/DGXLASFS13H70_U7A410C1MM0000/.

2231 See Hōsei Shingi-kai Min̄pō (Saiken Kankei) Bukai, Minpō ichibu wo kaisei suru höritsu-an ni taisuru shüsei-an shinkyū taishō jöbun [Amendment Proposal to the Law to Amend one Part of the Civil Code, Old and New Text Contrasted], document no 001226884, available online at www.moj.go.jp/content/ 001226884.pdf. The same changes were proposed for the outline and the draft of the bill, see ibid, Minpō ichibu wo kaisei suru höritsu-an ni taisuru shüsei-an yōkō [Amendment Proposal to the Outline of the Law to Amend one Part of the Civil Code], document no 001226882, available online at www.moj.go.jp/ content/001226882.pdf, and ibid, Minpō ichibu wo kaisei suru höritsu-an ni taisuru shüsei-an-an [Amendment Proposal to the Draft Law to Amend one Part of the Civil Code], document no 001226883, available online at www.moj.go.jp/ content/001226883.pdf respectively.

2232 See fn 2230 and www.moj.go.jp/MINJI/minji07_00175.html, showing the bill's progress.

2233 Minpō ichibu wo kaisei suru hōritsu, 民法の一部を改正する法律, Law to Amend one Part of the Civil Code. 
the Japanese official gazette (Kanpō, 官報) no 116 on the same day. ${ }^{2234}$ Initially, no definite date was set for its coming into force; however, on 15 December 2017, the cabinet issued an order that the revised Minpo was to come into force generally on 1 April 2020 (Heisei 32). ${ }^{2235}$

On the day that the legislative bill to reform the Minpo was submitted for consideration to the Japanese Diet, another legislative bill of relevance was presented: the Law to Maintain Laws Affected by the Enforcement of the Law to Amend one Part of the Civil Code (hereinafter 'Kaisei kankei-hö). ${ }^{2236}$ It was passed as Law No 45/2017 and proclaimed on the same day as the Minpō reform law. It also generally came into force on 1 April $2020 .{ }^{2237}$ As its title suggests, it amends a series of laws that will be affected by the reform of the Minpo for, eg, stipulations that may become obsolete or contradict the new regulations. Any pertinent changes under these two laws are discussed below.

\section{Content of the Reform Project ${ }^{2238}$}

As the title of the reform project suggests, it encompasses amendments regarding several aspects of the Japanese law of obligations. In relation to the formation of a contract, the reform proposal contains several novel stipulations. The novelty stems not so much from the content itself, but often from the simple fact that the rules were codified in the Minpo for the

2234 See fn 2232. The amended bill that became law (document no 001226886) is available online at www.moj.go.jp/content/001226886.pdf. The proclaimed text is contained in pages 11-31 of the official gazette and can be viewed in the online edition at https:/kanpou.npb.go.jp/old/ 20170602/20170602g00116/20170602g001160011f.html.

2235 See Unnamed author, Kaisei minpō sekō-bi kakugi kettei heisei 32-nen 4-gatsu tsuitachi mi-harai-kin no shömetsu jikkō tō'itsu nado 200 kōmoku [Civil Code Reform Coming into Force on 1 April 2020: 200 Provisions on the Consolidation of the Limitation Period of Debts etc], Sankei News (15 December 2017), www.sankei.com/politics/news/171215/plt1712150011-n1.html. For further details on the coming into force of the amended law, see www.moj.go.jp/ MINJI/minji06_001070000.html.

2236 民法の一部を改正する法律の施行に伴う関係法律の整備等に関する法律, Minpō ichibu wo kaisei suru höritsu no shikō ni tomonau kankei höritsu no seibi-tō ni kansuru höritsu, available online at www.moj.go.jp/content/001226891.pdf.

2237 See www.moj.go.jp/MINJI/minji07_00176.html.

2238 As noted in Section IV. above, the following discussion is based on the law as of December 2019, ie, before the amendments came into force. 
first time. ${ }^{2239}$ One excellent example is the new art 521, the first stipulation in the subsection on the formation of contracts:

(Conclusion of a Contract and Freedom of Content)

Article 521 Anyone can choose freely whether to enter into a contract or not, unless the law prescribes otherwise.

2 The parties to a contract may freely stipulate the content of a contract within the limits prescribed by law. 2240

As was stated above, the principle of freedom of contract is not new to Japanese contract law; but it has existed as an unwritten rule thus far. For this simple reason, and because it is deemed desirable to make it an explicit principle, this stipulation is included in the reform. ${ }^{2241}$

Apart from making some principles explicit, the reform amends the stipulations concerning the declaration of one's intention (see Section a. below), and thus the time of formation of a contract (Section b.), the

2239 The following discussion is based on the Kaisei böan as published in March 2015 on the website indicated in fn 2229.

2240 The new provision states: (契約の締結及び内容の自由) 第五百二十一条 何人 も、法令に特別の定めがある場合を除き、契約をするかどうかを自由に決 定することができる。

2 契約の当事者は、法令の制限内に打いて、契約の内容を自由に決定す ることができる。

(Keiyaku no teiketsu oyobi naiyō no jiyū) Dai-521-jō Nanbito mo, hōrei ni tokubetsu no sadame ga aru ba'ai wo nozoki, keiyaku wo suru ka dō ka wo jiyù ni ketteisuru koto ga dekiru.2 Keiyaku no töji-sha ha, hōrei no seiken-nai ni oite, keiyaku no naiyō wo jiyū ni ketteisuru koto ga dekiru.) In what follows, unless stated otherwise, kanji for cited provisions will have been taken from Hōsei Shingi-kai Minpō (Saiken Kankei) Bukai, Minpō ichibu wo kaisei suru hōritsu-an shinkyü taishō jöbun [Comparison of New and Old Provisions of the Draft Law to Amend one Part of the Civil Code] (document no 001142671; hereinafter 'Minpō Provision Comparison') 99, available online at www.moj.go.jp/content/001142671.pdf. Similarly, transcriptions and English translations are by this author, unless stated otherwise, as no English translation of the amended provisions was available at the time of submitting the dissertation. Subsequently, a semi-official translation of the amended Minpo has been made available online at www.japaneselawtranslation.go.jp/law/detail/?id $=3494 \& v m=04 \& \mathrm{r}$ $\mathrm{e}=2 \&$ new $=1$. A German translation of the Minpö's affected provisions can be found in Hiroyuki Kansaku and others, Übersetzung des novellierten Zivilgesetzes 2020 [Translation of the Amended Civil Code 2020] (2018) 45 ZJapanR / JJapanL 183-305.

2241 Chūkan shi'an Explanations (fn 1876) 322, 324. cf Sono and others (fn 1632) 46,58 , who state that the freedom of form is now recognised explicitly be Japanese law. 
validity and revocability of declarations of intention (Section c.), as well as the formalities of contracts (Section d.).

a. Concerning the Coming into Effect of Declarations of Intention

While Japanese law traditionally differentiates between declarations of intention made between persons present and those at distance, the reform will radically change (simplify) this by making three alterations.

\section{i. Article 97 Minpō}

The first change under the reform concerns the general rule contained in art 97 Minpo . This rule is amended as follows (changes to the formulation are marked in the following manner - new text is underlined; old text is struck out):

(Time of Coming into Effect of a Declaration of Intention-to Person at a Distance, etc)

Article 97 A declaration of intention to a persen at distance shall become effective at the time of arrival of the notice to the other party. 2 Where the other party hinders the arrival of a notice of a declaration of intention without just reason, the declaration of intention will be seen as having arrived at the time that it would have arrived under normal circumstances.

3The validity of a declaration of intention to a persen at a distance shall not be impaired even if the person who made the declaration dies, loses their capacity to make declarations of intention, or becomes limited in their capacity to act after the dispatch of the notice. ${ }^{2242}$

2242 The amended provision reads: (一隔地者に対する意思表示の効力発生時期 等）第九十七条隔地者に対する意思表示は、その通知が相手方に到達し た時からその効力を生ずる。

2 相手方が正当な理由なく意思表示の通知が到達することを妨げたとき

は、その通知は、通常到達すべきであった時に到達したものとみなす。

3 隔地者に対する意思表示は、表意者が通知を発した後に死亡し、意思 能力を丳失し、又は行為能力を喪失したときであっても、の制限を受けた ときであっても、そのためにその効力を妨げられない。

((Kakuchi-sha ni taisuru ishi byōji no köryoku hassei jiki-tō) Dai-97-jō Kakuchi-sha ni taisuru ishi hyōji ha, sono tsüchi ga aite-kata ni tōtatsushita toki kara sono kōryoku wo shōzuru. 
While the content of paras 1 and 3 is basically identical to before, the difference lies in the elimination of the words 'between persons at distance' (“隔地者間', kakuchi-sha-kan). The effect of this amendment is that the arrival rule will no longer be applicable solely to declarations made to persons at distance, but will become a true general rule with regards to the coming into effect of declarations of intention. ${ }^{2243}$ This is underlined by a change relating to what is now art 526 para 1 Minpo (time of formation of contract between persons at distance; see subsequent section).

While the words 'to a person at distance' were at first replaced by the words 'to the other party (“相手方のある’, aite-kata no aru), ${ }^{2244}$ the words were later deleted completely in the Kaisei höan. ${ }^{2245}$ The reason for the initial change in the wording was to make it clear that the rule was now applicable to 'persons other than those at distance' (“隔地者以外の 者に対する’, kakuchi-sha igai no mono ni taisuru), ${ }^{2246}$ which was deemed appropriate in light of the commonly-held view that the arrival rule was equally applicable in cases where the parties where 'in conversation' ('対話 者, taiwa-sha). ${ }^{2247}$ This proposed revision thus makes an explicit statement of an existing assumption. Furthermore, while the dispatch rule served commercial purposes in facilitating swift and smooth contract formation, modern means of communication have drastically reduced the need for

2 Aite-kata ga seitō na riyū naku ishi byōji no tsūchi ga tōtatsusuru koto wo samatageta toki ha, sono tsūchi ha, tsūjō tōtatsusubeki de atta toki ni tōtatsushita mono to minasu.

3 Kakuchi-sha ni taisuru ishi byōji ha, byōi-sha ga tsüchi wo hasshita ato ni shibōshi, ishi nōryoku wo sōshitsushi, mata ha köi nöryoku wo sōshitsushita toki de attemo, no seigen wo uketa toki de attemo, sono tame ni sono köryoku wo samatakerarenai.)

2243 Interestingly, the special provision contained in current art 521 para 2, according to which acceptance of an offer containing a period for acceptance is governed by the arrival rule, will apparently be maintained although it will become superfluous. Compare Minpō Provision Comparison (fn 2240) 99-100: The document indicates that the provision will remain unchanged.

2244 See, eg, Chükan shi'an (fn 2225) 3.

2245 See Kaisei hö'an (fn 2229) 7-8. For a direct comparison of the old and new wordings, see Minpō Provision Comparison (fn 2240) 8.

2246 Hōsei Shingi-kai Minpō (Saiken Kankei) Bukai, Minpō (saiken kankei) no kaisei ni kansuru yōkō-an no tatakidai (1) [Draft Proposal for the Motion Outline in Relation to the Reform of the Civil Code (Law of Obligations) (1)] (September 2013) 7. This document (hereinafter 'Draft Proposal Outline (1)') is available online at www.moj.go.jp/content/000118124.pdf.

2247 See Chūkan shi'an Explanations (fn 1876) 29, 30. 
this exceptional rule. ${ }^{2248}$ The suggested elimination therefore also reflects social change.

The newly-inserted para 2 of art 97 Minpō contains a stipulation to regulate a deemed arrival, namely, where the recipient hindered (delayed) the arrival of the notice without just cause. Under such circumstances, the notice is deemed to have arrived at the time that it normally ought to have arrived. Interestingly, the Chükan shi'an originally included another paragraph that also concerned cases of deemed arrival ('dai-3 ishi byöji 4 ishi hyöji no köryoku hassei jiki nado (minpō dai-97-jō kankei)'):

(2) Arrival in the sense of paragraph (1) above, other than when the other party has knowledge of the declaration of intention, is defined as follows:

a) A document containing the declaration of intention being delivered to the domicile, habitual residence, place of business, or office of the other party or of a person who is authorised to receive a declaration of intention on behalf of the other party (subsequently referred to as the 'other party etc'), or to a place that the other party etc has designated as a place at which knowledge of declarations of intention can be had.

i) Otherwise, where the other party etc is placed in a position that lets them have knowledge of the declaration of intention. ${ }^{2249}$

2248 Ibid 354, 355. This is underlined by the fact that contracts concluded electronically are not within the scope of art 525 para 1 (art 4 Denshi keiyaku-hö), ibid 355. See further Tōda (fn 1850) on dai-526-jö [Article 526] at 493.

2249 The proposal stated: (2) 上記(1)の到達とは、相手方が意思表示を了知した ことのほか、次に掲げることをいうものとする。

ア 相手方又は相手方のために意思表示を受ける権限を有する者（以下こ の項目において「相手方等」という。) の住所、常居所、営業所、事務所 又は相手方等が意思表示の通知を受けるべき場所として指定した場所にお いて、意思表示を記載した書面が配達されたこと。

イその他、相手方等が意思表示を了知することができる状態に置かれた こと。

( (2) Jōki (1) no tōtatsu to ha, aite-kata ga ishi hyöji wo ryöchishita koto no boka, tsugi ni kakakeru koto wo iu mono to suru.

a) Aite-kata mata ha aite-kata no tame ni ishi hyöji wo ukeru kenken wo yüsurumono (ika kono kōmoku ni oite 'aitekata nado' to iu.) no jūsho, jōkyo-sho, eigyō-sho, jimu-sho mata ha aite-kata nado ga ishi byöi no tsüchi wo ukerubeki basho to shite shiteishita basho ni oite, ishi byöji wo kisaishita shomen ga haitatsusareta koto.

i) sono hoka, aite-kata nado ga ishi hyöji wo ryōchisuru koto ga dekiru jötai ni okakareta koto.) See Tentative Reform Plan (fn 2244) 3. Translation Note: The Japanese syllabary goes a, i, u, e, o, ka, ki, ku, etc and this sequence is followed in enumerations. Therefore, 'i)' would be written as 'b)' under the 'Western' enumeration system. 
In essence, this proposal contained criteria to determine the point in time at which a declaration of intention is deemed to have arrived where the recipient has no actual knowledge. Here, actual knowledge is understood to mean that the person has knowledge either of the existence or of the content of the declaration of intention. ${ }^{2250}$ Two instances had been foreseen: First, where the declaration is delivered to an address that is connected with the intended recipient (para a)). Secondly, where the recipient is otherwise in a position to know about the declaration (para i)). In all three instances under para a, the basis of the assumption lay in the fact that the declaration was deemed to have entered the recipient's area of control (shibai ryo'iki, 支配領域). ${ }^{2251}$ Similarly, for the case foreseen in paragraph i), this was based on the concept of the recipient's sphere of influence (seiryoku han'i, 勢力範囲) or sphere of control (shibai kennai, 支 配圈内). ${ }^{2252}$ Which circumstances were to fall under these cases was to be judged on the facts of each case; however, the provision strove to shed some light on the meaning of the state of 'arrival'.2253

This attempt to define the circumstances of when a declaration of intention is deemed to have arrived was abandoned, as no consensus could be reached on the question whether including such an abstract definition would make the concept of arrival clearer to laypersons. ${ }^{2254}$ Furthermore, a detailed regulation had been questioned in the public comment procedure, since it could be expected that methods of communication might change again in future, ${ }^{2255}$ which might then render any explicit regulation out of date shortly after the enactment of the law. As a consequence, the meaning of arrival has been left to interpretation. ${ }^{2256}$ Having said this,

2250 Chūkan shi'an Explanations (fn 1876) 31.

2251 Ibid 32, 31.

2252 This criteria is derived from two court decisions (on which, see the discussion in Section IV.1.a.iv.aa) above) on the meaning of the state of being able to have knowledge: ibid 31.

2253 See ibid.

2254 Specifically, the Kaisei-kai could not reach a consensus on the issue of arrival with electronic means of communication, see Draft Proposal Outline (1) (fn 2246) 7-8. Note that one of the objectives of the reform proposal is to make the law more accessible (easily comprehensible) to laypersons, see the restatement of the result of enquiry no 88 from 2009 in Hōsei Shingi-kai Minpō (Saiken Kankei) Bukai, Minpō saiken kankei no minaoshi ni tsuite [Concerning the Revision of the Civil Code's Law of Obligations] (date unknown), available online at www.moj.go.jp/content/000103338.pdf.

2255 See Draft Proposal Outline (1) (fn 2246) 7.

2256 On this, see Chūkan shi'an Explanations (fn 1876) 347. 


\section{Contracts in Japanese Law}

it is generally understood to mean reaching the recipient, ie, having been transmitted successfully, but does not require actual knowledge. ${ }^{2257}$ In this way, the interests of both parties are balanced concerning the point in time of the declaration of intention coming into effect. ${ }^{2258}$

It was pointed out in the discussion surrounding the proposed elimination of art 526 para 1 Minpō (containing the dispatch rule, hassin shugi) that art 97 para 1 was a dispositive rule (nin'i kitei, 任意規定), so that even after the explicit removal of the dispatch rule, the parties were still free to make a stipulation to that effect if they wished. ${ }^{2259}$ Nevertheless, as mentioned in the public comment procedure, there were concerns that this dispositive nature was not evident; however, even if the dispositive nature were made apparent for offers, that this problem would remain and might even cause misunderstanding in relation to the (non-) dispositive nature of other provisions. 2260

\section{ii. Article 526 Minpō; Article 508 Shōhō}

Under the reform, the dispatch rule contained in art 526 para 1 Minpo will be deleted, so that, taken together with the above change to the wording of art 97, the arrival rule will become applicable to declarations of acceptance directed at a person at distance. ${ }^{2261}$ This means that the dispatch rule, and thus the English influence stemming from the 'postal rule', has been effectively removed from Japanese private law. Having said this, the contracting parties are free to stipulate the dispatch rather than the arrival rule as applying to their declarations of intention, ${ }^{2262}$ so that the rule may still live on in legal practice. It will certainly still be used

2257 See Draft Proposal Outline (1) (fn 2246) 6-7.

2258 See ibid 7.

2259 On this, see Hōsei Shingi-kai Minpō (Saiken Kankei) Bukai, Minpō (saiken kankei) no kaisei ni kansuru yōko-an no tatakidai (2) [Draft Proposal for the Motion Outline in Relation to the Reform of the Civil Code (Law of Obligations) (2)] (September 2013) 52. This document (hereinafter 'Draft Proposal Outline (2)') is available online at www.moj.go.jp/content/000118482.pdf.

2260 Draft Proposal Outline (2) (fn 2259) 52.

2261 Sono and others (fn 1632) 54-55 note that the general rule in art 97 para 1 Minpō has been reinstated. Compare also the discussion in Section IV.1.a.ii. and iii. above. The rule contained in art 526 para 2 (formation of contract through other facts implying acceptance) is maintained, but re-numbered as art 527, see Minpō Provision Comparison (fn 2240) 101-102.

2262 See Chūkan shi'an Explanations (fn 1876) 354. 
with regards to commercial transactions that are governed by art 508 para $1 S h \bar{h} \bar{o}$, as this provision - like the former art 526 para 1 Minpo - foresees that acceptance for an offer which does not stipulate a period for acceptance is governed by the dispatch rule. ${ }^{2263}$ Under the Kaisei kankei-ho, the commercial (dispatch) rule found in art 508 para 1 Shōho will be maintained.

\section{iii. Article 4 Denshi keiyaku-hō}

As a side-effect of the deletion of art 526 para 1 Minpo, the provision found in art 4 Denshi keiyaku-hō, providing for an application of art 97 Minpō instead of art 526 para 1 Minpō to acceptances made per electronic means, becomes superfluous. 2264 In accordance with art 297 para 1 Kaisei kankei$h_{\bar{o}}$, art 4 Denshi keiyaku-hō will be deleted. Accordingly, the arrival rule contained in art 97 para 1 Minpō will apply to electronic communication methods such as fax and e-mail in future. ${ }^{2265}$

\section{b. Concerning the Time of the Formation of a Contract}

For the same reasons as stated for freedom of contract, ${ }^{2266}$ the offer-andacceptance model will be codified for the first time in a newly-inserted art 522 para 1, which reads:

(The Formation of Contracts and Form)

Article 522 A contract is formed when a declaration of intention, which indicates the content of the contract and proposes its conclusion (hereinafter referred to as 'offer'), is accepted by the other party. 2267

2263 This was already discussed in Section IV.1.iv.bb) above.

2264 See on this Nakata, 'Willenserklärungsrecht' (fn 1954) 264. See also Sono and others (fn 1632) 55.

2265 The exceptional rule has already been discussed in Section IV.1.a.iv.bb) above.

2266 See fn 2241.

2267 The new provision reads: (契約の成立と方式) 第五百二十二条 契約は、 契約の内容を示してその締結を申し入れる意思表示 (以下「申込み」とい う。) に対して相手方が承諾をしたときに成立する。((keiyaku no seiritsu to höshiki) Dai-522-jö keiyaku ha, keiyaku no naiyö wo shimeshite sono teiketsu wo möshi'ireru ishi hyöji (ika 「möshikomi」 to iu.) ni taishite aite-kata ga shödaku wo 
This rule makes the point at which a contract is formed explicit, namely, when an offer is accepted by the other party. In other words, the stipulation constitutes a codification of the basic principle of Japanese contract law. ${ }^{2268}$

A very similar provision had already been foreseen in the Chükan shi'an. It was more explicit than the final version, as it split two objectives into two paragraphs, namely, the codification of the principle of how a contract is concluded by way of offer and acceptance (para 1) and the definition of an offer (para 2):

\section{Number 28 The Formation of Contracts}

1 Offer and Acceptance

(1) A contract is considered to have formed when acceptance is made on an offer.

(2) An offer under the foregoing [paragraph] (1) is required to indicate the content of a contract to such an extent that the contract is concluded when acceptance is made. 2269

While both this proposal and the final draft opted to make the model for the conclusion of a contract explicit, it was admitted during the discussion that not all contracts fit this offer-and-acceptance model in terms of its conclusion process. Consequently, the stipulation was meant to be a general requirement, which allows the possibility of (ie, does not rule out) other formation processes through the method of interpretation. ${ }^{2270}$ While both objectives of the former proposal are still achieved, it could be argued

shita toki ni seiritsu suru.). The provision's second paragraph will be discussed in Section d. below and is therefore set out there.

2268 See Chūkan shi'an Explanations (fn 1876) 346. See further Shiomi, 'Hö'an no gaiyö (fn 2218) 194-195.

2269 The proposal stated: 第 28 契約の成立 1 申込みと承諾

(1) 契約の申込みに対して、相手方がこれを承諾したときは、契約が成立 するものとする。

(2) 上記(1)の申込みは、それに対する承諾があった場合に契約を成立させ るのに足りる程度に、契約の内容を示したものであることを要するものと する。

(Dai-28 keiyaku no seiritsu 1 mōshikomi to shōdaku

(1) Keiyaku no möshikomi ni taishite, aite-kata ga kore wo shödakushita toki ha, keiyaku no seiritsusuru mono to suru.

(2) Jōki (1) no mōshikomi ha, sore ni taisuru shödaku ga atta ba'ai ni keiyaku wo seiritsu saseru no ni tariru teido ni, keiyaku no naiyo wo shimeshita mono no de aru koto wo yösuru mono to suru.)

2270 On this, see Chūkan shi'an Explanations (fn 1876) 346, 347. 
that the former proposal is more reader-friendly and that by inserting the explicit definition of an offer, it is more accessible to laypersons than the indirect definition found in the final version. Moreover, the definition highlighted the difference to an invitation to make an offer (moshikomi no $y \bar{u}$ 'in), even though this was not explained explicitly in paragraph 1 of the proposal. Interestingly, the explanation given for defining an offer as a 'declaration suggesting the conclusion of a contract' rather than a 'declaration indicating the content of the contract' is to make the difference between an offer and an invitation to treat clearer. ${ }^{2271}$

c. Concerning the Effectiveness of Declarations of Intention: Validity and Revocability

The reform project also affects the rules on the duration of the effectiveness of offer and acceptance found both in the Minpō and the Shöhö, as five pertinent provisions are amended.

\section{i. Former Article 521, new Article 523 Minpō}

What was art 521 Minpō (Offers that Specify Period for Acceptance, 承諾 の期間の定めのある申込み, Shödaku no kikan no sadame no aru mōshikomi) has been re-numbered as art 523, maintaining both paras 1 and 2 . The change that has been made is the insertion of the following sentence: ‘ただし、申込者が撤回をする権利を留保したときは、この限り でない' (tadashi, mōshikomi-sha ga tekkai wo suru kenri wo ryühoshita toki $h a$, kono kagiri de nai; However, this shall not apply when the applicant reserves themselves the right to withdraw).2272 The effect is the creation of an exception to the rule of irrevocability of offers specifying a period for acceptance. Accordingly, even an offer that specifies a time frame for acceptance can be revoked where the offeror reserves themselves the right to do so. ${ }^{2273}$ It is interesting that this exception is a principle that had been long recognised by Japanese legal academics.

2271 On this, see ibid 43-44.

2272 See Minpō Provision Comparison (fn 2240) 99-100.

2273 On the current situation, see the discussion in Section IV.1.a.ii.dd) above. 
ii. Former Articles 522-523, new Article 524 Minpō; Article 508 Shōhō

Similar to art 521, the provision contained in art 523 Minpō (late acceptance can be deemed to be new offer by offeror) remains; however, the norm is re-numbered as art $524 .{ }^{2274}$ Due to this change, art 508 para 2 $S h \bar{o} h \bar{o}$ is amended to reflect this and refer to the new provision number. ${ }^{2275}$ As a consequence of this, the rule on late acceptance will still be applicable to $\mathrm{C} 2 \mathrm{C}$ transactions in future. While this is so, the special rule contained in art $522 \mathrm{Minpo}$, under which a declaration of acceptance that arrived late could still be effective where the delay was not due to the offeree's fault and the offeror failed to send a notice of delay, will be deleted. ${ }^{2276}$ In future, the only way to keep the contracting process moving is therefore through the offeror's discretion to deem the late declaration as a new offer.

\section{iii. Former Article 524, new Article 525 Minpō; Article 507 Shōhō}

Due to the moving of the provisions discussed above, what is now art $524 \operatorname{Minpo}$ (Offers that do not Specify Period for Acceptance, 承諾の期 間の定めのない申込み, Shödaku no kikan no sadame no nai mōshikomi) is re-numbered as art 525, but the rule itself remains the same. ${ }^{2277}$ Having said this, the same exception that has been introduced into art 521 (new 523) para 1 Minpō has also been inserted into para 1 of art 524/525, 2278 so that it is now explicitly possible for the offeror to reserve themselves the right to withdraw the offer. Moreover, the words '隔地者に対して' (kakuchi-sha ni taishite; to an absent person) are deleted, ${ }^{2279}$ so that it is now clear that the rule applies to contracting parties inter presentes and inter absentes. 2280

2274 See Minpō Provision Comparison (fn 2240) 100. See further Shiomi, 'Hö'an no gaiyö (fn 2218) 195.

2275 See art 3 para 1 Kaisei kankei-hö.

2276 See Minpō Provision Comparison (fn 2240) 100.

2277 For further details on this, see Shiomi, 'Hö'an no gaiyō' (fn 2218) 196.

2278 See Minpō Provision Comparison (fn 2240) 100.

2279 See ibid.

2280 See Shiomi, 'Hö'an no gaiyö' (fn 2218) 196, who states that this rule is now 'generally applicable' (“一般的に適用される', ippanteki ni tekiyó sareru). 
Beside this, two new paragraphs have been added to the provision:

2 Irrespective of the provision in the previous paragraph, an offer made to a present person in accordance with that provision can be withdrawn by the offeror at any time during the conversation.

3 Where the offeror does not receive acceptance of an offer made under paragraph 1 during the conversation, the offer shall become ineffective. However, this will not apply where the offeror has indicated that the offer shall not lose its effect even after the end of the conversation. 2281

Due to the insertion of para 3, art 507 Shōhō will be deleted ('削除', sakujo) in accordance with art 3 para 1 Kaisei kankei-ho ${ }^{.2282}$ This means that the special commercial rule leaving offers to a present person open only for as long as the parties are together, will not be maintained. It seems that this provision has become superfluous, which suggests in turn that the Minpo-rule will become applicable generally, ie, to B2B, B2C, and $\mathrm{C} 2 \mathrm{C}$ situations, in future.

\section{d. Concerning Formalities of Contracts}

There are a couple of changes in relation to the formalities of a contract under the Minpo-reform. These concern the form of a contract on the one hand (see Sections i.-ii.) and the legal practice of paying tetsuke upon the conclusion of a contract on the other (see Section iii.). Furthermore, loans for use and deposits, which used to be real contracts under Japanese law,

2281 The new provision says: 2 対話者に対してした前項の申込みは、同項の規 定にかかわらず、その対話が継続している間は、いつでも撤回することが できる。

3 対話者に対してした第一項の申込みに対して対話が継続している間に 申込者が承諾の通知を受けなかったときは、その申込みは、その効力を失 う。ただし、申込者が対話の終了後もその申込みが効力を失わない旨を表 示したときは、この限りでない。

(2 Taiwa-sha ni taishite shita zenkō no mōshikomi ha, dōkō no kitei ni kakawarazu, sono taiwa ga keizokushiteiru aida ha, itsu demo tekkaisuru koto ga dekiru.

3 Taiwa-sha ni taishite shita dai-ichi-kō no möshikomi ni taishite taiwa ga keizokushiteiru aida ni mōshikomi-sha ga shödaku no tsūchi wo ukenakatta toki ha, sono möshikomi ha, sono köryoku wo ushinau. Tadashi, möshikomi-sha ga taiwa no shüryō-go mo sono mōshikomi ga kōryoku wo ushinawanai mune wo byöjishita toki ha, kono kagiridenai.)

2282 Compare Shiomi, 'Hö'an no gaiyō' (fn 2218) 197. 
have now been turned into consensual contracts. ${ }^{2283}$ While these modifications are not major, they are nevertheless important in modernising the Minpo. This is because the changes discussed below basically constitute codifications of pre-existing legal rules or practices.

\section{i. New Article 522 Minpō}

A completely new stipulation is found in para 2 of the new art 522 Minpō. It concerns formalities and reads as follows:

2 Except where legislation provides otherwise, the drawing up of a document or the adoption of other formalities is not required for the formation of a contract. 2284

By adopting this provision, the general principle of freedom of form is made explicit. It is therefore not a novel creation, but a codification of an existing principle of contract law.

\section{ii. New Article 587-2 Minpō}

In art 587-2 Minpō, another new stipulation has been created that qualifies the rule in art 587, according to which a loan for consumption can only be created by the exchange of the delivery of the money or the object and a counter-promise to return money or an object of equal value. The new provision reads:

(Loans for Consumption in Writing etc)

Article 587-2 Notwithstanding the provision of the preceding article, a loan for consumption in writing shall become effective when one of the parties promises to deliver money or other things and the counterparty promises to return a thing of the same kind, quality, and quantity.

2283 See on this Sono and others (fn 1632) 41-42, who go on to note that loans for consumption keep their nature as real contracts. For further details, see ibid 181, 239, 236.

2284 The new provision states: 2 契約の成立には、法令に特別の定めがある場合 を除き、書面の作成その他の方式を具備することを要しない。(2 keiyaku no seiritsu ha, hörei ni tokubetsu no sadame ga aru ba'ai wo nozoki, shomen no sakusei sono boka no höshiki wo gubisuru koto wo yōshinai.) 
(2) A borrower under a loan for consumption in writing may cancel the contract until they receive money or other things from the lender. In this case, the lender may demand damages from the borrower, if they suffered a loss from the cancellation of the contract. [...]

(4) When a loan for consumption is made by an electromagnetic record that records the contents thereof, the loan for consumption shall be deemed to be in writing and the provisions of the preceding three paragraphs shall apply. ${ }^{2285}$

Paragraph 1 of the provision clearly allows an alternative mechanism for concluding a loan for consumption, namely, in writing. ${ }^{2286}$ By virtue of para 4 , the form can also be by electronic means. This provision seems to suggest that 'writing' does not automatically encompass an electronic form. The purpose of this new requirement is the protection of borrowers by stopping them from the 'careless conclusion of consumption loans' ${ }^{2287}$

2285 The new provision reads: (書面でする消費貸借等) 第五百八十七条の二 前 条の規定にかかわらず、書面でする消費貸借は、当事者の一方が金銭その 他の物を引き渡すことを約し、相手方がその受け取った物と種類、品質及 び数量の同じ物をもって返還をすることを約することによって、その効力 を生ずる。

2 書面でする消費貸借の借主は、貸主から金銭その他の物を受け取るま で、契約の解除をすることができる。この場合において、貸主は、その契 約の解除によって損害を受けたときは、借主に対し、その賠償を請求する ことができる。[...]

4 消費貸借がその内容を記録した電磁的記録によってされたときは、そ の消費貸借は、書面によってされたものとみなして、前三項の規定を適用 する。

( (Shomen de suru shōhi taishaku-tō) Dai-587 no 2 Zenjō no kitei ni kakawarazu, shomen de suru shōhi taishaku ha, töji-sha no ippō ga kinsen sono hoka no mono wo hikiwatasu koto wo yakushi, aite-kata ga sono uketotta mono to shurui, hinshitsu oyobi süryō no onaji mono wo motte henkan wo suru koto wo yakusuru koto ni yotte, sono kōryoku wo shözuru.

2 Shomen de suru shōhi taishaku no karinushi ha, kashinushi kara kinsen sono hoka no mono wo uketoru made, keiyaku no kaijo wo suru koto ga dekiru. Kono ba'ai ni oite, kashinushi ha, sono keiyaku no kaijo ni yotte songai wo uketa toki ha, karinushi ni taishi, sono baishō wo seikyūsuru koto ga dekiru. [...]

4 Shōhi taishaku ga sono naiyō wo kirokushita denjiteki kiroku ni yotte sareta toki ha, sono shōhi taishaku ha, shomen ni yotte sareta mono to minashite, mae san-kō no kitei wo tekiyō suru.)

2286 For a discussion of the requirements of this provision, see Shiomi, 'Hö'an no gaiyos' (fn 2218) 251.

2287 Sono and others (fn 1632) 236. 
iii. Article 557 Minpō; Article 39 Paragraph 2 Takuchi-gyō-hō

The provisions on tetsuke contained in the Minpo and the Takuchi-gyo-ho will be amended under the reform. The new wording of art 557 para 1 Minpō is as follows (changes underlined):

When the buyer delivers earnest money to the seller, cancellation of the contract may be effected by the buyer by forfeiting the earnest money, and by the seller by actually tendering twice its amount. However, this does not apply where the other party has commenced performance of the contract. ${ }^{2288}$

While these changes in the wording are made, the effect of the provision will remain the same. This is because the amendments relate to two aspects that have already been settled in case law: The first concerns the handing over of tetsuke; the second relates to the question who may cancel the contract after performance has been commenced. Regarding the former, the new words “現実に提供して' (genjitsu ni teikyöshite, actually tendering) concern a requirement for the seller to actually repay tetsuke that had already been laid down in a case in $1976 .{ }^{2289}$

The other change concerns the last sentence and the right to cancel before the commencement of performance. As the matter has already been considered in Section IV.1.c.iii. above, it will only be stated here that the added sentence is meant to clarify that the right to cancel a contract is no longer exercisable after performance is commenced, unless it is the party that has initiated fulfilment that cancels the contract. ${ }^{2290}$ In effect, exactly the same changes are made to art 39 para 2 Takuchi-gy $\bar{o}-\bar{b}$. Therefore, these will not be discussed here. ${ }^{2291}$

2288 The amended provision reads: 第五百五十七条買主が売主に手付を交付し たときは、買主はその手付を放棄し、売主はその倍額を現実に提供して、 契約の解除をすることができる。ただし、その相手方が契約の履行に着手 した後は、この限りでない。(Dai-577-jö Kainushi ga urinushi ni tetsuke wo köfushita toki ha, kainushi ha sono tetsuke wo hökishi, urinushi ha sono baigaku wo genjitsu ni teikyōshite, keiyaku no kaijo wo suru koto ga dekiru. Tadashi, sono aite-kata ga keiyaku no rikō ni chakushu shita nochi ha, kono kagiridenai.L

2289 Saikō Saiban-sho decision of 20 December 1976 (Shōwa 51), Hanji No 84346. On this, see Shiomi, 'Hö'an no gaiyö' (fn 2218) 228.

2290 For further discussion, see Shiomi, 'Hö'an no gaiyö' (fn 2218) 228.

2291 On the change, see art 316 para 1 Kaisei kankei-hō. See also Shiomi, 'Hö'an no gaiyo (fn 2218) 228-229. 


\section{Summary of Results}

The discussion in this section has shown that contracts under Japanese law are normally consensual and are therefore formed through acceptance of an offer. This theoretical basis was only introduced in the Meiji era, a period in which the modern Japanese legal system was established. Inspiration for the regulation of private law was drawn from several European laws, in particular German and French law, but in parts also from English law. One pertinent example is the adoption of the English 'postal rule' as the hasshin shugi (dispatch rule) for declarations of intention. In other areas, US-law was influential. While this is true, Japanese contract law is not simply a blend of European laws; rather, it incorporates Western ideas with Japanese traditional elements. Accordingly, land and buildings can constitute separate immovable property, which is not true under English or German law. Here, buildings form part of the land and are deemed as movable property where this is exceptionally not the case. ${ }^{2292}$

In terms of Japanese legal practice, the payment of tetsuke is of particular interest, which is a legal custom already existing in the Tokugawa period that is still practiced in selected transactions today. Weak similarities to the English doctrine of consideration and also to the German notion of Draufgabe can be found, although the latter is no longer used today. ${ }^{2293}$ The use of seals that still predominates in Japanese legal practice is also interesting from a comparative perspective, although handwritten signatures are recognised in Japan as forms of authenticating documents as well.

The blending of legal concepts from different legal orders has led to complex regulation. This is particularly true for the effectiveness of declarations of intention, as two doctrines traditionally compete: the hasshin shugi and the tôtatsu shugi (arrival rule). This situation is alleviated greatly by the comprehensive reform of the Japanese law of obligations: The former rule has been abolished, so that only the latter doctrine will be applicable from April 2020, like in Germany. ${ }^{2294}$

2292 See Sections B.II.3.b.i. and B.III.3.b.i. above respectively.

2293 See Sections B.II.3.a.v. and B.III.3.c.ii. above. For a further comparison, see Section D.II.4. below.

2294 See Section B.III.3.a.ii.dd) above. 


\section{Comparative Analysis of the Rules on the Formation of Contracts in Japanese, English, and German Law}

The exposition in Sections B. and C. above has so far focused on each of the three jurisdictions individually. In this section, selected aspects of the formation of contracts will be directly compared in order to show that there are many points of congruence as well as dissimilarities. The aspects considered relate to the following topics: Firstly, to the concept and types of contract (Section I.); secondly, to the pillars of contract formation (Section II.); and thirdly, to the form requirements (Section III.). Subsequently, the adaptation of the three legal systems to electronic communication will be considered (Section IV). Finally, the points of contrast will be highlighted by taking the sale of real estate as an example (Section V.).

\section{The Concept and Types of Contract}

Interestingly, neither English, German, nor Japanese law contain a statutory definition for the term 'contract'; however, it is a concept that has a long history in all three legal systems, during which it has evolved from one notion to another. There are nevertheless parallels, in that contract law as known today was established in the (Early) Modern age in all three jurisdictions, an era in which states were formed and liberalism allowed individuals freedom to act and thus to contract. ${ }^{2295}$ While the finer points in the underlying theories do deviate, there is nevertheless consensus that a contract is an obligatory relationship that arises through and due to the volition of the parties. In other words, where the intention of the parties coincide, a contract will arise consensually because the parties have the intention to bring about a specific legal consequence. While the basis of

2295 This was true for Europe at least; liberalism came to Japan a little later, in the Meiji era. On the development of society leading to the recognition of freedom of contract in Europe, compare Kötz, 'Europäisches Vertragsrecht' (fn 17) 7-10. For an overview of the situation in Japan from the seventeenth century onwards, see Steenstrup (fn 1587) 108-150. See also Sections C.III.1. and 2. Above. 
traditional English contract law theory is an exchange of promises and the making of a bargain, both Japanese and German contract law theory are based instead on the mutual assent of the parties. ${ }^{2296}$ Having said this, English academics have likewise emphasised the parties' agreement, ${ }^{2297}$ so that the basis for all is, in fact, consensuality. ${ }^{2298}$ As a corollary of the principles of consensuality and of freedom of contract, statutory rules in private law in all three jurisdictions are largely dispositive, while only particular norms have mandatory character. ${ }^{2299}$

The types of contract found in the three legal systems are the same. The synallagmatic or bilateral contract is recognised under all three laws. There are also one-sided contracts; however, their conceptual natures differ. A unilateral contract exists in English law only, ${ }^{2300}$ whereas German and Japanese law have 'unilaterally obliging contracts' (einseitig verpflichtende Verträge; henmu keiyaku, 片務契約). While it is true to say that under either model, only one party undertakes to do - and consequently is obliged to do - something, the contract arises at different points in time. Under German and partly also under Japanese law, these contracts arise as soon as the first party has declared their intention, whereas, in contrast, under the English model, an act or omission by another person is expected and, in fact, the contract will only arise once this act or omission occurs. ${ }^{2301}$ Taking the example of a gift (Schenkung; zoyo, 贈与), this can be a unilateral contract under English law if nominal consideration is provided, but

2296 On the difference between English and Japanese contract law theory, see Kitagawa, 'Contracts' (fn 1601) $\$ 2.01[2][\mathrm{a}], 2-27$. On the differences between German and English contract theory, compare Schmidt J (fn 25) 7, 65. Compare also Youngs (fn 34) 545, 546. For a comparative outline of the different contract theories justifying legal enforceability, see von Mehren, 'Introduction' (fn 21) 15-23.

2297 See, in particular, the definition of a contract by Treitel, given in Section B.II.1. above, which seems to approximate the Civil law theory. of the description by Atiyah at ibid, which is representative of the classical English contract theory.

2298 Schmidt J (fn 25) 128 states this congruence. Compare also Schlesinger (fn 25) 71.

2299 Compare Kötz, 'Europäisches Vertragsrecht' (fn 17) 10-11. The mandatory rules usually concern form requirements, as will be seen in Section III. below.

2300 Schmidt J (fn 25) 129 calls this type a particularity of the common law.

2301 These differences between the German and English contract types are succinctly explained by ibid $125-126$. 
it is seen as a unilaterally obliging contract under German and Japanese law. ${ }^{2302}$

It is highly interesting that contract types exist under the latter regime that resemble the English unilateral contract, at least in appearance. One example is a Japanese loan for consumption (shōhi taishaku, 消費貸借, art $587 \mathrm{Minpō}$ ), a real contract under which only the borrower undertakes an obligation, namely, to return an object of the same kind as the one received. In order for the contract to arise, the object to be loaned must be handed over, so that, while the lender is under no obligation to do so, their act is in fact required for the contract to come into existence. ${ }^{2303}$ It could thus be argued that these constellations are in effect equivalent to English unilateral contracts, as the acts of both parties are factually indispensable under either regime. In contrast with Japanese law, real contracts no longer exist as such in English and German law. ${ }^{2304}$ This will not be true for much longer, however, as real contracts have been abolished under the amendments of the Minpo that come into force in April 2020.2305

Coming back to English law, it has been argued that the English unilateral contract and the concept of consideration are related to the Roman institute of a real contract. ${ }^{2306}$ Indeed, the argument that consideration is like a real contract in the sense that it involves something being given - albeit not always physically - seems to have merit. If this is true, then the same argument might be advanced for the legal practices of the German Draufgabe and of the Japanese tetsuke (手付). Indeed, it has been noted that the predecessor of the Draufgabe, the Arrha or Handgeld, was used in Franconian times in the German territories as a fictional (part-) performance ('Scheinleistung') that substituted for the actual performance of contracts. In fact, the handing over of Arrha turned an informal contract into a real contract. ${ }^{2307}$ At that time, Arrha could therefore have been said to be constitutive for the conclusion of a contract; a property that was lost for the Draufgabe later on, during the alte Reich. ${ }^{2308}$ Tetsuke could be said

2302 For England, see Section B.II.1. above; for Germany, see Section B.III.1.; and for Japan, see Section C.II.

2303 See Section C.IV.1. b. above for further details on this kind of contract.

2304 See on this Schmidt J (fn 25) 110-129.

2305 Compare the outline of the changes given by Shiomi, 'Shin-saiken' (fn 1648) 11.

2306 See Schmidt J (fn 25) 120-127.

2307 On this, see Gastreich (fn 942) 45-47.

2308 Compare Gastreich (fn 942) 51-52. See also Section B.III.2.a.iii.ee) above. 
to have fulfilled a similar function historically, since it was used to make agreements binding for both parties by constituting part performance. ${ }^{2309}$ In a way, all three signs of earnestness therefore fulfilled a similar function in former times. Their present function will be discussed in Section II.4. below.

Another deviation in contract theory that needs to be borne in mind is the German Abstraktionsprinzip, according to which an act of disposition (Verfügungsgeschäft) and an obligatory act (Verpflichtungsgeschäft) are regarded as separate transactions, so that the legal effects of one does not depend on the other. ${ }^{2310}$ This is not the case in English and Japanese law: the latter usually sees the two as one action. ${ }^{2311}$ English law instead differentiates between executory and executed transactions, whereby the first is a promise to bring about some effect in the future, whereas the second actually brings about some effect. ${ }^{2312}$ In this sense, it could be argued that while the terminology is different, the concepts found in German and English law are similar: obligatory acts, creating an obligation to do something in the future, may be equated with executory agreements; similarly, acts of disposition under German law, which are intended to have an immediate effect so to speak, are like English executed (ie, performed) agreements.

This seeming coherence must not lead one to think, however, that the differences found in the details of the theory, although merely alluded to above, can be ignored in practice. Rather, it will be seen in the subsequent discussion that the points of disparity as well as the varying developments in each jurisdiction have led to the creation of legal devices that, while perhaps similar in appearance and even in their function, alter the conclusion process in ways not necessarily discernible from the final contract, but which can become pitfalls in practice. This is particularly true for the form of the contract.

\section{The Three Pillars of the Formation of Contracts and Indicia of Seriousness}

English, German, and Japanese law have the same three pillars in the formation process of a contract, namely, offer (see Section 1. below), accep-

2309 On this, see Section C.III.1.b. above.

2310 See Section B.III.3.a above.

2311 This action is effected by one declaration of intention with a 'double effect' (Doppelwirkung), see Marutschke, 'Immobiliarsachenrecht' (fn 1846) 133.

2312 See on the differentiation Section B.II.1 above. 
tance (Section 2.), and an intention to be legally bound (Section 3.). The reason is that all three legal systems have adopted the offer-and-acceptance model as the standard contracting process. ${ }^{2313}$ Accordingly, a contract will typically be formed once acceptance of a contractual offer becomes effective. ${ }^{2314}$ Nevertheless, the congruence in the conclusion process is not complete. In addition to the aforementioned requirements, English contract law has held onto a fourth pillar, an indicium of seriousness in the form of the (in-) famous doctrine of consideration. This and similar but not constitutive further requirements under German and Japanese law will be examined together with consideration in Section 4.

\section{Offer}

All three legal systems concur on the definition of an offer (Antrag or Angebot; moshikomi, 申込み) and that it needs to be differentiated from other statements that do not have a binding effect. In this respect, offers can be roughly characterised as unequivocal declarations of intention to be bound by the terms stated therein. ${ }^{2315}$ They can be addressed to one or more specific persons, but need not be; offers may equally be made to the general public, ie, to no one in particular. ${ }^{2316}$ Their counterparts are non-binding statements or acts, which are, in turn, distinguished from one another. Before going into further details about the requirements for offers in Section b. below, the classifications of offers and other statements will be briefly compared in Section a. Finally, the effectiveness of offers, ie, the issue of when and for how long they are capable of being accepted, will be considered in Section c.

2313 For English law, see Section B.II.3.a.i.; for German law, see Section B.III.3.a.; for Japanese law, see Section C.IV.1.a. above.

2314 This is currently not explicit in neither of the three contract laws but nevertheless forms part of their contract theories. See ibid. From 1 April 2020, Japanese law will have an explicit provision on this matter, see the discussion of art 522 para 1 Minpō in Section C.V.3.b. above.

2315 For further details on English law, see Section B.II.3.a.ii. above; for German law, see Section B.III.3.a.ii. above; and see Section C.IV.1.a.ii. above for Japanese law.

2316 See Section B.II.3.a.ii.aa) above for English law, Section B.III.3.a.ii.aa) for German law, and Section C.IV.a.ii.aa) for Japanese law. 
a. Differentiation Between Offers and other Statements or Acts

Acts or statements other than offers are divided into two: those that can lead to the contract process being initiated are referred to as invitations to treat', 'invitationes ad offerendum' or 'Aufforderung zur Abgabe eines Angebots', and 'möshikomi no yüin' (申込みの誘引) in English, German, and Japanese respectively. ${ }^{2317}$ These denominations already suggest that such statements will be made with the aim of having the other party make an offer, or to begin negotiations. In contrast, still other statements or even acts do not count as invitations of this kind and have no consequence whatsoever. These include, in particular, sales talk ('mere puffs'), and acts of kindness (Gefälligkeiten; köi, 好意 ${ }^{2318}$ ). ${ }^{2319}$

The kinds of circumstances in which invitations to make an offer occur can be grouped together. The interesting point is that while the definitions of the categories coincide in the three legal systems, the classifications of particular groups of cases do not. Furthermore, it ought to be noted that the types of cases discussed in academic literature from the three countries are often not the same; thus, a particular situation that might be the topic of ample discussion in one country might be given little if any attention in another.

\section{i. Statements and Acts Deemed as Offers}

One circumstance in which an act will be deemed to be an offer is the display of goods, whereby the nature of the goods will not allow the parties to change their mind subsequently. This is true for petrol stations, in which case the customer fills fuel into the tank of their vehicle prior to making the payment. Due to the nature of the goods (fuel), a subsequent change of mind would lead to disproportionate effort or expenses. Accordingly, self-service petrol pumps constitute offers made at the displayed price in

2317 See Sections B.II.3.a.ii.bb), B.III.3.a.ii., and C.IV.1.a.ii. above respectively.

2318 Götze, 'Rechtswörterbuch' (fn 10) 308.

2319 These instances will not be discussed here, but together with the intention to create legal relations in Section 3. below. 
England and Germany ${ }^{2320}$, rather than being mere invitations to treat. ${ }^{2321}$ While not discussed in Japan, it seems logical to deem self-service petrol stations as offers rather than moshikomi no yüin. The reason is that - as will be discussed in further detail below - one rationale for differentiating between möshikomi and möshikomi no yüin in Japanese law is whether a party reserves themselves the right to decide whether to contract with the other party. ${ }^{2322} \mathrm{As}$ it is not practical for the attendant at the self-service petrol station to refrain from contracting with the customer, seeing as the fuel is already inside the customer's tank when the customer comes to pay, the price displayed at the pump ought to be considered to be an offer.

Another instance of a deemed offer in Japan and England is a taxi waiting at a taxi rank: due to the fact that the taxi drivers only have very limited reasons for refusing a potential customer who wishes to use their service, the taxi constitutes an offer, rather than an invitation to begin negotiations. ${ }^{2323}$ It must be noted that a vacant taxi circulating in traffic in Japan is only deemed to be an invitation to treat, as the driver is a priori under no obligation to contract with the person signalling the taxi. In fact, if the circulating taxi were an offer, this might lead to several theoretical problems. Where a pedestrian signals to a circulating taxi that they wish to board and in so doing were accepting the 'offer' embodied by the taxi, the driver would fail to perform their contractual obligation if they did not stop, although this might in practice not be possible, as the driver might otherwise cause a traffic accident, for example. This might arguably also be true for England; however, it is not a question that has been discussed in legal academic literature. Similar consideration might be applicable in Germany as well, where this constellation is also not discussed in academic literature.

Other cases of deemed offers are not shared by the three countries. A perfect illustration is advertisements in unilateral contracts, a constellation

2320 To be precise, petrol pumps are deemed as offers ad incertas personas, see Wolf and Neuner (fn 48) 419-420 para 11.

2321 cf petrol stations at which attendants fill the car with fuel. In this case, English law deems the prices displayed for the fuel as an invitation to treat, see Treitel/Peel (fn 65) para 2-009.

2322 On the different differentiating factors, see Section C.IV.1.a.ii.bb) above.

2323 See Sections C.IV.1.a.ii.bb) and B.II.3.a.ii.bb) above for Japanese and English law respectively. 
that is unique to English law. ${ }^{2324}$ Further examples will be considered in the next section.

\section{ii. Statements and Acts Deemed as Invitations to Make an Offer}

A wide range of cases exists in which acts or statements are deemed to be mere invitations to treat. The consequence, as already explained, is that the contracting process does not begin with the act or statement in question, which instead constitutes a pre-step. Advertisements, both online or in print form are a prominent example of invitationes ad offerendum found in England, Germany, and Japan. These will include things like 'help wanted' signs, catalogues, and price lists. ${ }^{2325} \mathrm{~A}$ comparable item to price lists are cost estimates, which are also not binding under Japanese, German, or English law. ${ }^{2326}$ Although not expressly discussed in England, these might fall within the category of 'transmission of information', the example given being that of the statement of a price at which a person might be willing to sell that is made in response to an information request. ${ }^{2327}$ While this is a circumstance that is treated the same in all three countries, we see a divergence in the estimations of English, German and Japanese law in other instances.

Displays of goods are one such situation. English and German law concur that both a display of goods in a shop window (with or without prices being shown), as well as the display on shelves inside a shop are only invitations to treat. ${ }^{2328}$ In contrast, Japanese law differentiates between goods that are displayed in shop windows and those on shelves inside shops. In the former case, the window display is treated as an invitation

2324 See Section B.II.3.a.ii.bb) above. On unilateral contracts existing in English law only, see Section I. above.

2325 See Sections B.II.3.a.ii.bb), B.III.3.a.ii.bb), and C.IV.1.a.ii.bb) above for English, German, and Japanese law respectively.

2326 For Japan, see Section C.IV.1.a.ii.bb) above. For Germany, see, eg, Industrie- und Handelskammer Bonn/Rhein-Sieg, Kostenvoranschlag [Cost Estimate] (leaflet, May 2018) 1, available online at www.ihk-bonn.de/fileadmin/dokumente/Downloads/Recht_und_Steuern/Vertragsrecht/Kostenvoranschlag.pdf. For England, see, eg, the information provided on the difference between price estimates and quotations by Invest Northern Ireland at www.nibusinessinfo.co.uk/content/difference-between-quotation-and-estimate.

2327 See Treitel/Peel (fn 65) para 2-006 and Section B.II.3.a.ii.bb) above, where the leading case of Harvey $v$ Facey ( $\mathrm{fn} 456$ ) is discussed.

2328 See Sections B.II.3.a.ii.bb) and B.III.3.a.ii.bb) above respectively. 
to treat, whereas goods on shelves are deemed as offers. ${ }^{2329}$ It ought to be noted, however, that this is true where no price is indicated for the goods displayed in shop windows. As has already been argued above, ${ }^{2330}$ it would nevertheless seem most practical to deem such goods as only constituting invitations to make an offer, like in English and German law.

Another instance concerns public transport, like bus or train services. Under Japanese law, the display of timetables for these services is deemed to be an invitation to treat, whereas English case law treats it as an offer. ${ }^{2331}$ Similarly, the factual provision of the service in Germany is an offer ad incertas personas. ${ }^{2332}$ These circumstances ought to be distinguished from the case where a ticket is purchased prior to boarding the vehicle. In this case, the usual process of offer and acceptance ought to be applied, whereby the offer should be deemed as having been made by the customer. ${ }^{2333}$

\section{b. Requirements for Offers: Certainty and Communication}

Bearing in mind the definition of offers given in Section a. above, this section will set out the requirements for offers found in the three jurisdictions considered in this dissertation. In principle, these come down to certainty of the intention and of the content of the statement. With regard to intention, this means that the offeror as the statement maker has the aim of entering into a contract with the other party. ${ }^{2334}$ In relation to the content of the statement, the contract's essential terms must be either stated explicitly or at least be determinable through some mechanism contained in the offer. ${ }^{2335}$

2329 See Section C.IV.1.a.ii.bb) above.

2330 See ibid.

2331 See Sections C.IV.1.a.ii.bb) and B.II.3.a.ii.bb) above respectively, where it has been argued for the latter that these should be treated as invitations to treat as well.

2332 See Section B.III.3.a.ii.bb) above.

2333 For the arguments, see Sections B.II.3.a.ii.bb), B.III.3.a.ii.bb), and C.IV.1.a.ii.bb) above for English, German, and Japanese law respectively.

2334 See Section B.II.3.a.ii.cc) above for England, Section B.III.3.a.ii.cc) for Germany, and Section C.IV.1.a.ii.aa) for Japan.

2335 For German law, see Section B.III.3.a.ii.cc) above. For English and Japanese law, see Sections B.II.3.a.ii.cc) and C.IV.1.a.ii.aa) above respectively. 
English contract law alone foresees the additional requirement that an offer be communicated in some way in order to be effective, which means that it must be known to the other party. ${ }^{2336}$ It might be surprising at first that no similar requirement is discussed in German or Japanese academic literature; however, this lack can be explained very easily on the basis of the underlying contract theory. While English law traditionally considers contracts to be based on promises, German and Japanese law are based on the theory that transactions arise from declarations of intention (Willenserklärungen; ishi byōji, 意思表示).2337 Inherent in this latter notion is the requirement that the intent is announced; otherwise, the declaration is not effective. This is particularly true for offers, which are seen as empfangsbedürftige Willenserklärungen (declarations of intention that need to be received). ${ }^{2338}$ In effect, all three legal systems therefore require that offers be known by the other party in order to be effective; however, in Japan and Germany, this is not a requirement discussed specifically with offers, but rather on a general level with declarations of intention.

\section{c. The Effectiveness of Offers}

The question of when an offer comes into effect and whether and until when it may be revoked also reveals differences in the contract laws of England, Germany, and Japan. This is more so with the issue of (ir)revocability than with the time of coming into effect. All three countries concur that offers - made to a person at a distance, eg, by letter or e-mail - become effective upon their receipt by the offeree. ${ }^{2339}$ This generally occurs at the time when the offeree can access and therefore is able to have knowledge of the offer; actual knowledge of its content is not required. 2340

The situation is very different in relation to the revocability of offers. English law is the most liberal in that it generally allows offers to be revoked if the revocation reaches the offeree before acceptance is made

2336 On this, see the discussion in Section B.II.3.a.ii.dd) above.

2337 See Sections B.II.1., B.III.3.a.i. and C.IV.1.a.i. above respectively for further details.

2338 On this, see Section B.III.3.a.ii.aa) above.

2339 This is laid down in German law in $\$ 130$ para $1 \mathrm{BGB}$, and in Japanese law in art 97 para 1 Minpō. For English law, see Treitel/Peel (fn 65) para 2-015 and Henthorn v Fraser (fn 494) 37 (Kay LJ, obiter dictum).

2340 See Section B.II.3.a.ii.ee) above for English law, Secion B.III.3.ii.dd) for German law, and Section C.IV.1.a.ii.cc) for Japanese law. 
(sent). ${ }^{2341}$ The middle position is taken by Japanese law. It differs between offers made to persons present or at distance, and whether a period of acceptance has been specified in the offer when determining whether an offer is revocable. Generally, an offer without a period for acceptance is revocable until it is accepted; however, when it is made to a person at distance, the offeror must wait for a reasonable period before a revocation can be made (see art 524 Minpō). Where an offer made in the physical presence of a person specifies a period of acceptance, it becomes irrevocable (art 521 para 1 Minpō), unless the offeror reserves themselves the right to revoke. ${ }^{2342}$ German law is at the other end of the spectrum in that it generally deems offers to be irrevocable ( $\$ 145 \mathrm{BGB})$, unless one of the following three circumstances applies: the revocation reaches the offeree before the offer; the offer indicates clearly the offeror's intention not to be bound ( $(145 \mathrm{BGB})$; or the offeror reserves themselves the right to revoke (Widerrufsvorbehalt). In order to be effective, the revocation must reach the offeree but need not have been read. ${ }^{2343}$

Even without revocation, offers can expire and thereby lose their effectiveness. In this respect, the three countries' laws are again very alike. They concur in that offers will expire automatically after the stipulated period for acceptance ends, or, otherwise, when a reasonable period has elapsed. ${ }^{2344}$ German and Japanese (commercial) law have a special rule where the parties are in each other's presence: here, the offer will expire if it is not accepted immediately (Germany) or before the parties separate (Japan). ${ }^{2345}$ While no such rule seems to exist in English law, it may be that a similar result would be reached implicitly. This is due to the fact that the method of making an offer, or rather the speed of transmission, affects the length of time of the offer's validity where persons are at a distance from each other: the speedier the transmission, the shorter the time before the offer expires. ${ }^{2346}$ If the underlying principle were to be applied to offers made between persons in each other's presence, the fact that the offeree

2341 See Section B.II.3.a.ii.ff) for further details.

2342 For further details, see Section C.IV.1.a.ii.dd) above.

2343 See Section B.III.3.a.ii.ee) above for further details on revocations under German law.

2344 For English law, see Section B.II.3.a.ii.ff) above; for German law, see $\mathbb{S} \mathbb{\$} 146$, 147 para 2, 148 BGB and Section B.III.3.a.ii.ee) above; for Japanese law, see art 521 para 2 Minpō and Section C.IV.1.a.ii.dd) above.

2345 See Sections B.III.3.a.ii.ee) and C.IV.1.a.iii.cc) above for Germany and Japan respectively.

2346 On this, see Section B.II.3.a.ii.ff) above. 
knows of the offer immediately ought to lead to the conclusion that the offer will only be valid for a short period, or, as in Japanese law, until the parties separate.

\section{Acceptance}

Similarities and differences are also discernible between Japanese, German, and English law in relation to the second pillar of a contract, acceptance. The correlation begins with the definition of acceptance (Annabme; shödaku, 承諾) as an unconditional declaration of intention expressing assent to the terms of a specific offer, ${ }^{2347}$ and extends to the differentiation with other acts or statements and the methods of acceptance (on which, see Section a. below), although first small disparities appear here. While the requirements for acceptance are similar in all three legal systems (Section b.), the contrasts deepen in relation to the effectiveness of declarations of acceptance (Section c.).

\section{a. Acceptance and other Acts or Statements; Method of Acceptance}

Japanese, German, and English law concur in that acceptance has to be differentiated from other acts or statements, namely, mere confirmations. ${ }^{2348}$ This means that a simple acknowledgement of having received an offer will not be sufficient, unless a contrary intention is perceptible. Having said this, German law allows a confirmation to be combined with a declaration of acceptance. In practice, this often occurs with confirmations of goods or services being ordered, in which case acceptance consists of an unconditional notice that the order will be fulfilled. ${ }^{2349}$

All three contract law systems also recognise both express and certain kinds of implied forms of acceptance, but do not generally deem mere silence as a declaration of intention. ${ }^{2350}$ Implied acceptance will be allowed where the offeror has waived the need for a notice of acceptance in the

2347 For English law, see Section B.II.3.a.iii.aa) above; for German law, see Section B.III.3.a.iii.aa); for Japanese law, see Section C.IV.1.iii.aa).

2348 See ibid.

2349 On this, see BGH decision of 16 October 2012 (fn 1110) para 19 and Section B.III.3.a.iii.aa) above.

2350 For details, see Sections B.II.3.a.iii.bb), B.III.3.a.iii.aa), and C.IV.1.iii.aa) above for English, German, and Japanese law respectively. 
offer, or where custom does not require it. ${ }^{2351}$ Interestingly, it seems that implied acceptance is unusual in Germany, ${ }^{2352}$ whereas it is common in England. This is due to the existence of unilateral contracts in English law, under which acceptance normally consists of an act requested by the offeror and of which the offeror will only have notice when that act has been completed. ${ }^{2353}$ A similar provision exists in both Japanese and German law for advertisements offering prizes (kenshō kōkoku, 懸賞広告, art 529 Minpō; Auslobung, $\mathbb{} 657 \mathrm{BGB})$, according to which acceptance is implied where a person acts in accordance with the request of the offeror: performance of the act puts the offeror under the obligation to give the offered reward. Furthermore, implied acceptance under German law may consist of the performance of some act that is objectively seen as congruent with acceptance, such as payment of the purchase price or (taking) delivery of an object. ${ }^{2354}$ The situation is therefore comparable in all three countries' laws on this point.

\section{b. Requirements for Acceptance: Unconditionality, Congruence, and Communication}

As has already been noted when acceptance was defined in Section 2. above, the statement must be an unconditional declaration of intention to contract. It has also been noted previously that it must relate to the offer and be congruent with the terms of the same, as the statement will otherwise - unless the modification concerns an insignificant change be deemed as a rejection of the offer and constitute a new offer (with different terms) instead. ${ }^{2355}$ Unless exceptions (ie, implied acceptance) apply, declarations of acceptance must also be communicated to the offeror in order to be effective. ${ }^{2356}$ This leads to the next aspect, namely, from and until when a declaration of acceptance is effective.

2351 This is laid down in German law in $\$ 151 \mathrm{BGB}$, and in Japanese law in art 526 para 2 Minpō. For English law, see Section B.II.3.a.iii.bb) above.

2352 See Section B.III.3.a.iii.aa) above.

2353 On this, see Section B.II.3.a.iii.bb) above.

2354 See Section B.III.3.a.iii.aa) above.

2355 See $\mathbb{} 150$ para 2 BGB, art 528 Minpö, and, eg, McKendrick (fn 48) 81 for German, Japanese, and English law respectively. For further details, see Sections B.III.3.a.iii.aa), C.IV.1.a.iii.aa), and B.II.3.a.iii.aa) above respectively.

2356 See Section B.II.3.a.iii.bb) above for England, Section B.III.3.a.iii.aa) for Germany, and Section C.IV.1.a.iii. for Japan. Note that this requirement is again 


\section{c. The Effectiveness of Acceptance}

Apart from the requirements just discussed, there is also the question of when acceptance becomes effective (see Section i. below) and how it might become ineffective (Section ii.). The regulation found in English, German, and Japanese law is complex and diverges most in this respect. Moreover, the situation will change again in April 2020, when the Minpō reform takes effect in Japan. This change in the Japanese rules with regard to the coming into effect of declarations of intention is interesting from a comparative law perspective, because it will alter the law's alignment: under the current rule, acceptance follows the same rule as English law; in future, it will follow the model found in German law. ${ }^{2357}$

\section{i. Coming into Effect of Acceptance}

The rules for the coming into effect of acceptance is most straightforward in German law: Annahme made at a distance becomes effective upon its receipt (see $\$ 130$ para $1 \mathrm{BGB}$, embodying the 'receipt theory', Empfangstheorie), a rule which is said also to apply to declarations made in the physical presence of a person. ${ }^{2358}$

In English law, the situation is more complicated, as differentiations are made between unilateral and bilateral contracts on the one hand, and between declarations made by communication that is direct or at a distance on the other. Leaving unilateral contracts aside, ${ }^{2359}$ in bilateral contracts, acceptance made by direct or instantaneous communication (eg, face-to-face and telephone conversations, fax, e-mail) will come into effect once received by the offeree under the mailbox rule, while other communication at distance (eg, letters) come into effect once sent under the postal rule. ${ }^{2360}$ In this sense, receipt means that the declaration has

inherent in the notion of acceptance constituting a declaration of intention that needs to be received, on which see BGH decision of 28 March 1990 (fn 1100) para 15.

2357 For a discussion of this alignment, see Shinomiya and Nōmi (fn 1944) 292293.

2358 See Sections B.III.3.a.iii.dd) and B.III.3.a.ii.dd) above.

2359 Here, acceptance is by conduct and becomes effective only once the required act has been completed, see Section B.II.3.a.iii.cc) above.

2360 For details on the differentiation, see Section B.II.3.a.iii.cc) above, where it is also noted that this classification has been criticised but remains valid law. 
reached the offeree, whereby actual knowledge of its arrival or content is not necessary. ${ }^{2361}$ Sending means posting, ie, putting the letter into the post box, or handing the letter to a clerk at the post office. ${ }^{2362}$

Japanese law follows the English model in that shödaku generally become effective upon dispatch (art 526 para 1 Minpō, containing the dispatch rule, hasshin shugi, 発信主義; cf art 508 para 1 Shōhō). This simply means that the declaration has been sent out. ${ }^{2363}$ In contrast, where a period of acceptance is determined in the offer, art 521 para 2 Minpō implies that acceptance will come into effect once received. ${ }^{2364}$ Similarly, declarations of intention sent in an electronic form such as an e-mail are not governed by art 526 para 1 but by art 97 para 1 Minpo (codifying the arrival rule, tōtatsu shugi, 到達主義; see art 4 Denshi keiyaku-hō), so that shödaku made in this way will also only become effective once received. ${ }^{2365}$ In either case, receipt occurs when the addressee is objectively able to have knowledge of the declaration, namely, when it has entered the recipient's sphere of influence, such as a letter that is handed over to a member of the offeree's family or an e-mail that is accessible to the offeree. ${ }^{2366}$

We see, therefore, that different rules have been adopted for different situations. While German law has decided on one uniform rule for all declarations of intention, in fact, under English and Japanese law, the question of whether acceptance becomes effective upon being sent or upon being received depends not only on whether acceptance is made inter presentes or inter absentes, but also - and perhaps even more so - what communication method is used (England), or whether the offer stipulates a period of acceptance or is made in electronic form (Japan). Having said this, the rules in Japan will change in the near future, to the effect that all declarations of intention - irrespective of whether they are declarations of offer or acceptance and what form they take, or whether they are made between persons physically present or between absent persons - will come into effect upon being received. ${ }^{2367}$ This will approximate the situation in Japanese law to that in German law, namely, that all declarations of intention are governed by the arrival rule..$^{2368}$

2361 See on this further Section B.II.3.a.iii.cc) above.

2362 For further details, see Section B.II.3.a.iii.cc) above.

2363 See Section C.IV.1.a.ii.cc) above.

2364 See ibid.

2365 See ibid.

2366 See on this further ibid.

2367 On this, see in detail Section C.V.3.a. above.

2368 Compare Shinomiya and Nōmi (fn 1944) 292-293. 
One further aspect that needs to be considered with respect to the effectiveness of acceptance is that it will usually have to be made in the time period that is set in the offer, or, otherwise, within a reasonable period under English, German, and Japanese law. What is reasonable will depend on the circumstances of the case. ${ }^{2369}$ A connected issue is the effect of late declarations of acceptance. This matter is regulated in German and Japanese law, but not in English law, which may be due to the fact that the postal rule is often applicable to English contracts and thus makes delays in transmission irrelevant. It has been suggested for other cases that the late declaration of acceptance might be deemed as a counter-offer if the declaration fulfils the requirements of an offer. ${ }^{2370}$ This solution is also possible by virtue of art 523 Minpō and $\$ 150$ para 1 BGB in Japanese and German law. Nevertheless, both of these legal systems contain a provision modifying this situation: Under $\$ 149 \mathrm{BGB}$ and art $522 \mathrm{Minp} \overline{0}$, the offeror must give notice of the delay to the offeree if they are aware that the declaration ought normally to have arrived on time; otherwise, the declaration of acceptance will not be deemed to be late and thus display its effect. ${ }^{2371}$

\section{ii. Loss of Effect of Acceptance}

The rules regarding the withdrawal or revocation of acceptance also differ from each other. German law again has the most straightforward principle: Annabme, like an offer, can be withdrawn (widerrufen) through a declaration to that effect if it reaches the offeror before or together with the declaration of acceptance ( $\$ 130$ para $1 \mathrm{BGB}$ ), but not thereafter, unless the offeror has excluded being bound by the offer $(\$ 145 \mathrm{ibid}) .{ }^{2372}$ The situation is more complicated in both English and current Japanese law. Seeing as the postal or dispatch rule often applies, a declaration of acceptance cannot normally be withdrawn once it has been sent in either of these two countries, as it will already have come into effect. Having said this, in cases where the mailbox or arrival rule applies, the declaration will only come

2369 See Sections B.II.3.a.iii.cc), B.III.3.a.iii.dd), and C.IV.1.a.iii.cc) above respectively for details.

2370 On this, see Schmidt J (fn 25) 586.

2371 For a detailed discussion, see Section B.III.3.a.iii.dd) above for the German provisions and Section C.IV.1.a.iii.aa) above for the Japanese provisions. It ought to be noted that art 522 Minpo will cease to exist after the amended Minpō has entered into force, see Section C.V.3.c.ii. above.

2372 See on this further Sections B.III.3.a iii.dd) and B.III.3.a.ii.ee) above. 
into effect once it reaches the offeror, so that a declaration of withdrawal that arrives before or at least at the same time as the declaration of acceptance will revoke it. ${ }^{2373}$

One further point needs to be noted with regard to the effectiveness of acceptance inter absentes. It concerns the potential risk of declarations getting lost or distorted while being transmitted and which party must bear this risk. In Japan and England, the risk is divided between the parties, but not equally: Under the tōtatsu shugi or mailbox rule, the offeror bears the risk during the time the declaration is transmitted and until it is deemed to have been received. Consequently, if a fax message or an e-mail is sent by the offeror and it is recorded on the offeree's fax machine or e-mail provider's server, its loss or any distortion before this moment will be to the disadvantage of the sender, but any subsequent events are to the disadvantage of the recipient, since actual knowledge of the content is irrelevant for the effectiveness of acceptance. In contrast, under the hasshin shugi or postal rule, the sender has to bear the risk only until the declaration of acceptance has been sent, eg, until a letter has been handed over to the post office clerk, so that any subsequent loss or distortion is at the risk of the recipient. This means that the risk will in effect be on the offeree longer in both situations, since the interval between sending of a fax or e-mail message and its receipt is short; as is the time until a letter is in the post office's control. ${ }^{2374}$

As the German rules adopt the arrival rule only, a larger portion of the risk is always on the sender, namely, from the time of sending, during the transmission, and until receipt. ${ }^{2375}$ Nevertheless, seeing as declarations of offer and acceptance are treated the same way under German law, both parties will have to bear the same amount of risk: the offeror will bear more when making the offer; the offeree will bear more when making acceptance. It could thus be argued that the risk allocation is most balanced in German law as compared with English or Japanese law; nevertheless, this aspect ought not to be assessed in isolation. Rather, the possibility to revoke ought to be taken into account as well.

The current Japanese rule of irrevocability of the offer in combination with the general application of the dispatch rule for acceptance has been

2373 For further discussion on English law, see Section B.II.3.a.ii.ff) above; for Japanese law, see Section C.IV.1.a.iii.dd) above.

2374 The rules are discussed in detail in Sections C.IV.1.a.iii.bb) and B.II.3.a.ii.cc) above for Japan and England respectively.

2375 See Section B.III.3.a.ii.dd) above. 
criticised for favouring the offeree (sender of the acceptance) too much. ${ }^{2376}$ That said, an argument used in the past against the arrival rule (currently applied to acceptance in Germany and also to be applied in Japan in future) was that it slowed down transactions due to the lag time between the sending and receiving of the declaration of acceptance and the consequent delay in the conclusion of the contract; however, as has been rightly pointed out, this lag time has basically been eliminated due to the rise of e-commerce. $^{2377}$

It could be argued that the German position of applying the arrival rule to acceptance while not generally allowing offers to be revoked strikes a good balance: the arrival rule favours the offeror for acceptance, since the risk of the declaration reaching the other party is largely on the offeree; however, the offeree is protected as well, since the offeror cannot withdraw their offer once it has reached the offeree. The German model is therefore said to emphasise certainty. ${ }^{2378}$

In contrast, the English position of applying the postal rule to acceptance while allowing offers to be revoked is said to allow the parties to compete freely on an equal footing. ${ }^{2379}$ Indeed, while the fact that acceptance already comes into effect upon being sent burdens the recipient (offeror) with a larger portion of risk; however, the fact that the offeror is free to withdraw their offer at any time until acceptance has been made may well offset this risk in practice. This is not true where the mailbox rule applies to acceptance in England, since the risk is largely on the sender (offeree) - namely, from sending and during the whole transmission until the declaration is received - while the risk of the offer being withdrawn in the meantime is also disadvantageous for the offeree. Be this as it may, the fact that the communication methods to which the mailbox rule applies, such as e-mail or fax, have a fast transmission time, it is submitted that the risk in this situation is not as large as that under the postal rule. Nevertheless, it remains true that the offeror holds the greater advantage. In the end, all models have advantages and disadvantages, so that there is no perfect answer.

2376 On this criticism, see Shinomiya and Nōmi (fn 1944) 292.

2377 Compare ibid.

2378 Ibid.

2379 Ibid 293. 


\section{Intention to be Legally Bound}

It has already been mentioned during the discussion of the requirements for offer and acceptance in Sections 1. and 2. above that English, German, and Japanese law require that a person must have the necessary intention to contract. This is the intention to be legally bound - both by their statement and the consequences arising from the contract. What is interesting is that it is an aspect that is treated as a distinct requirement from offer and acceptance in English legal academic works, whereas it is discussed as an inherent part of declarations of intention in German and Japanese legal texts. 2380

At the same time, all three countries' laws set out situations - including those discussed above in relation to invitations to treat - which are deemed not to give rise to legal rights and obligations. This is particularly true for acts of kindness (Gefälligkeiten; köi, 好意), which can be defined as one-sided gratuitous acts by one person for the benefit of another, whereby no obligation is on the person to act. ${ }^{2381}$ Rather than an exhaustive account of this topic, which would go beyond the scope of this dissertation, only a brief overview will be given to contrast the situation in the three legal systems considered in this work.

Circumstances such as a social (more significantly: a family) relationship often lead to particular acts being deemed not binding. One example might be giving someone a ride in a car. ${ }^{2382}$ This issue can also arise in commercial contexts, although here the presumption will be that a legally binding arrangement is intended. ${ }^{2383}$ Nevertheless, this does not invariably make all acts or statements in such a context binding. It always comes down to an interpretation of the situation. Accordingly, statements termed as sales talk or 'mere puffs' will not be deemed as offers, nor as

2380 See, eg, Treitel/Peel (fn 65) paras 4-002 et seq, Wolf and Neuner (fn 48) 314-318 paras 17-28, and Yamamoto K, 'Minpō kögi IV-1' (fn 1646) 16-17 respectively.

2381 See Nobuhisa Segawa, Köi to keiyaku [Acts of Kindness and Contracts], in: Taniguchi and Igarashi (fn 1819) 51, 52-53.

2382 In Germany, such an act can amount to a mandate (Auftrag), if the circumstances are pressing enough for the beneficiary, see Section B.III.3.a.iv. above. Conversely, in England, this has been deemed a mere social arrangement, see Treitel/Peel (fn 65) para 4-019.

2383 This is true for English and Japanese law at least, see Section B.II.3.a.iv. above and Segawa (fn 2381) 53 respectively. 
invitations to treat in English law. ${ }^{2384}$ In contrast, providing a lorry driver for another company has been found to be a binding act in Germany. ${ }^{2385}$ The issue can be even more complicated, for example, with LOI. These are usually not binding under English, German, and Japanese law, but may still be relevant to some extent, at least in particular circumstances. ${ }^{2386}$ In the end, it comes down to an interpretation of the parties' intention in a particular situation on whether an act is legally binding.

\section{Indicia of Seriousness}

As has been seen in the discussion in Sections B. and C. above, English and Japanese law contain aspects and elements that are, or in some cases once were, what Hein Kötz terms 'indicia of seriousness': a way of differentiating between enforceable and unenforceable contracts. ${ }^{2387}$ These may be acts that are required in addition to a consensual agreement, like the payment of consideration, or (formerly) tetsuke (手付); or even that a particular form is used for an agreement. ${ }^{2388}$ In this section, consideration and tetsuke found in England and Japan respectively will be contrasted. The German concept of Draufgabe, albeit comparable, will only be considered marginally, as it is no longer used in practice. ${ }^{2389}$

Both English consideration and Japanese tetsuke have a long tradition in the two legal systems. Under English law, the sign of earnestness known as consideration has been a constitutive requirement for contracts since the mid-sixteenth century, although its roots go further back in history. ${ }^{2390}$ The origin of tetsuke may be older, as it is said to have arisen in the

2384 See Section B.II.3.a.ii.bb) above.

2385 See BGH decision of 22 June 1956 (fn 1266), discussed in Section B.III.3.a.iv. above.

2386 On the position in English law, see Treitel/Peel (fn 65) para 4-024. On German law, see Wolf and Neuner (fn 48) 411-412 para 12. On Japanese law, compare Yasutomo Sugiura, Column: CISG no moto de no kihon göi-sho [Column: Letter of Intent under the CISG], in: ibid and Kubota (fn 1639) 71-72. Note that while LOI may be deemed to be binding as a kind of contract in particular circumstances in England, this is not so in Germany. Rather than a contract itself, it is relevant for assessing culpa in contrahendo, see Wolf and Neuner, ibid 412. In Japan, these documents are not discussed in contract law texts.

2387 See Kötz, 'Europäisches Vertragsrecht' (fn 17) 71.

2388 Ibid.

2389 See on this Section B.III.3.c.iii. above.

2390 On this, see the account in Section B.II.2.a.iii.cc) above. 
Ancient era (approximately first century AD), although the peak of its importance - ie, its wide-spread use and potential to serve as a constitutive requirement for contracts - was during the Tokugawa era (around the seventeenth century). ${ }^{2391}$

The practical relevance of these signs of earnestness is also comparable in a way. While consideration remains of importance today in contract theory and is therefore executed in practice, it is seldom an issue. ${ }^{2392} \mathrm{Al}-$ though tetsuke does not have to be paid today when concluding a contract, it is used regularly in connection with particular transactions, such as with real estate. ${ }^{2393}$ As a consequence, it also does not generally become an issue in contracting practice. It is convenient to note at this point that German law knows of a figure that is similar to tetsuke, the Draufgabe; however, despite its long tradition (originating from Roman law) and continued use in the time of the alte Reich (sixteenth nineteenth century), ${ }^{2394}$ the provisions embodying the tradition ( $\$ \$ 336-338 \mathrm{BGB}$ ) are rarely applied today. ${ }^{2395}$ As it is no longer of practical relevance, it will not be considered further in the subsequent discussion.

The temporal development of these indicia of seriousness follows the same path as the reason they arose. In essence, both consideration and tetsuke are signs of earnestness that developed from a need to bind the parties to the promises they exchanged. Despite these similarities, both the function and the concept of the two figures differ in several respects. First and most importantly, consideration is a constitutive requirement for contracts under English law, whereas tetsuke is a purely voluntary act, executed due to continuing business practices. ${ }^{2396}$

Secondly, whereas tetsuke can be differentiated into three related yet different types with distinct functions, there is only one kind of consideration, serving one purpose only. The three kinds of tetsuke are shoyaku tetsuke (証約手付, 'earnest money as proof of contract'), kaiyaku tetsuke, (解約手付, 'cancellation earnest money'), and iyaku tetsuke (違約手付, 'earnest money for breach of contract'). As the denominations suggest, their primary function is to act as proof of a contract, as a mechanism for cancelling a contract, and as a kind of liquidated damages respectively.

2391 See on this Section C.III.1.c.iv. above.

2392 See Section B.II.3.a.v. above.

2393 For further examples, see Section C.IV.1.c.iii. above.

2394 On the origin of Draufgabe, see Section B.III.2.a.iii.ee) above.

2395 See Section B.III.3.c.iii. above.

2396 On this latter aspect, see Sections C.IV.2.b.-c. above. 
Having said this, the function of proving the existence of a contract is inherent in all types, whereas the default type of tetsuke is the cancellation earnest in accordance with art 557 para 1 Minpō. In order for tetsuke to be deemed to have the function of liquidated damages, the parties must have had an explicit intention to this effect at the time when tetsuke was paid. ${ }^{2397}$ In contrast to these multiple functions, consideration apparently serves one purpose: to aid the courts in differentiating between gratuitous and non-gratuitous promises. This is important, as only non-gratuitous promises are deemed legally enforceable. By providing consideration, a promise can thus be made enforceable. 2398

Thirdly, although shoyaku tetsuke in particular seems to echo the English doctrine of consideration in its form, ${ }^{2399}$ the two practices are not in fact comparable. This is because while consideration could be said to form part of the contract for which it is paid, tetsuke is related but distinct from the contract. In fact, the payment of tetsuke establishes a tetsuke-contract (tetsuke keiyaku, 手付契約). ${ }^{2400}$ As a consequence, a distinct agreement is concluded between the parties that relates to the main transaction in question. The content of this accord will be to either provide proof of the transaction agreement, furnish an uncomplicated cancellation mechanism, or constitute liquidated damages in case of a breach of contract, or even a combination thereof. ${ }^{2401}$ This is a considerable difference between the two concepts.

Fourthly, differences also pervade in terms of what constitutes consideration and tetsuke. Due to its functions, Japanese tetsuke will necessarily be in the form of money or things of (monetary) value, whereas the scope of things that may constitute consideration, in contrast, is very wide: anything from money and other things of some value to the receiver, to the giving up of a right or bearing of some loss are sufficient. English courts

2397 For further details on these types and the intention that is required, see Section C.IV.1.c.iii. above.

2398 For further discussion of the function of consideration, see Section B.II.3.a.v. above. Note that the alternative is for a promise to be made in the form of a deed. This instrument is discussed in Section III.1. below.

2399 Especially when reading the description made by Wigmore, 'Customary Law' (fn 1675) 32 concerning the practice in the former province of Echigo, today's Niigata: 'In Echigo kuni, [...] where residence land (in towns) is to be sold, the seller comes to an agreement with the buyer, and the latter then gives a temporary instrument (kari-shosho) to the former, also paying as earnest money about ten per cent of the price.'

2400 On this, see Section C.IV.1.c.iii. above.

2401 See ibid. 
have been far more liberal in assessing the existence of consideration than their Japanese colleagues when these determined whether tetsuke was given. In England, even trivial things such as pepper or doing something as simple as going to a particular place have been held to be sufficient, although in these extreme cases the things provided or done were executed at the request of the offeror. ${ }^{2402}$ In contrast, something more realistic, namely, standing timber, is an example of objects that have been held to be sufficient to constitute tetsuke in Japan. ${ }^{2403}$ Where money is paid, tetsuke will usually constitute $10 \%-20 \%$ of the purchase price, whereas $£ 1$ is sufficient consideration. ${ }^{2404}$ Leaving this issue of the value aside, both consideration and tetsuke are paid at the time when a contract is concluded. ${ }^{2405}$ In contrast, where tetsuke acts as a cancellation mechanism, it will be returned if it is the offeror who wishes to cancel the contract. As consideration is not used for this purpose, anything given as consideration will not be returned if the contract is not concluded. ${ }^{2406}$

In conclusion, both consideration and tetsuke can be labelled as external signs of the offeree's earnestness. Nevertheless, this is as far as the similarities go. The most important point to note is that consideration is a constitutive requirement for contracts concluded under English law not in the form of a deed, whereas tetsuke is an optional act, albeit at times required under Japanese business practice. Consequently, mere promises are not enforceable in England. It could be argued that this is also not true for Germany or Japan in instances where the contract laws require an arrangement to be in a particular form in order to be effective. This is because in all such cases, the legal systems require something that goes beyond mere agreement between the parties, as noted at the beginning of this section. The instances of mandatory forms will be contrasted in the following section.

2402 For further details on this, see Sections B.II.3.a.v.bb)-cc) above.

2403 See on this Section C.IV.1.c.iii. above.

2404 For tetsuke, see ibid. For consideration, see Section B.II.3.a.v. above.

2405 See Section B.II.3.v.ee) above on the rule against 'past' consideration, and Section C.IV.1.c.iii. on tetsuke respectively.

2406 At least it would appear so as there is no discussion of this kind nor case law to this effect in England. 


\section{The Form Requirements}

As noted above, agreements made up of an offer, acceptance, and an indicium of seriousness may furthermore have to fulfil various kinds of formal requirements that English, Japanese, or German law foresee for different types of contracts in order to be legally effective or enforceable in court. While the standards and their strictness vary, they nevertheless form exceptions to the general rule that informal contracts are enforceable. ${ }^{2407}$ A range of the instances of such required forms will be contrasted in the following. ${ }^{2408}$

In general, it can be said that English law has kept in line with its procommercial attitude when imposing form requirements. This is because such formalities are only imposed in particular circumstances, while commercial needs have also been addressed by minimising the cumbersomeness of the required forms. ${ }^{2409}$ This means that oral contracts are generally enforceable, unless particular form requirements apply. ${ }^{2410}$ In fact, while English law is famous for being liberal, Japanese law actually seems to be more deserving of this 'title' in this respect. This is because, as will become apparent, Japanese law contains even fewer and more lenient requirements for mandatory contract forms. In contrast, German law is more proscriptive, foreseeing strict forms in a range of circumstances.

2407 Indeed, this is true for all European contract laws. In commercial practice, however, contracts are normally fixed in some written form, see Kötz, 'Europäisches Vertragsrecht' (fn 17) 106 and 108-109.

2408 Only a selection will be considered here for the purpose of highlighting some of the similarities and discrepancies found in the three legal systems. For more detailed discussions of the form requirements, see Sections B.II.3.b., B.III.3.b., and C.IV.1.b. above for English, German, and Japanese law respectively.

2409 Compare Simpson, 'History' (fn 232) 113, who discusses the formalities for conditioned bonds.

2410 Such mandatory form requirements will often be imposed by statute; however, the contracting parties are free to make their agreement subject to a particular form, see McKendrick (fn 48) 281. Treitel notes that even the requirement of written form can be commercially inconvenient and that the general rule in English law is therefore that informality is sufficient, see Treitel/Peel (fn 65) para 5-003. In former times, English law had constitutive form requirements, such as the contract under seal; but after the advent of the freedom of contract, consensualism, and commercial liberalism, formalities were no longer viewed as being of utmost importance to the formation of a contract. See on this von Mehren, 'Formalities' (fn 791) 6. See also the discussion in Section B.II.2. above. 
In terms of the level of formality, English law generally distinguishes between two categories of contracts: 'simple' and 'speciality' contracts. While the latter have to be in the form of a deed (or a bond) today, the former can take various forms, namely, written, oral, or by conduct. ${ }^{2411}$ While both Japanese and German law equally allow oral agreements, only German contract law prescribes a special instrument beside a normal written form, namely, a notarial deed (notarielle Urkunde), created in a notarial authentication (notarielle Beurkundung). In contrast, Japanese contract law requires something to be in writing, but does not have a special instrument like the English deed. The following section will contrast these forms in further detail. Particular attention will be given to the method of authenticating written documents in Section 2. Below.

\section{Written Forms and (Notarial) Deeds}

All three legal systems foresee an array of different kinds of written forms for particular contracts in order for these to be effective or legally enforceable. In essence, one encounters three levels of formality, namely: first, an agreement may be concluded orally or otherwise, but must subsequently be put in writing (see Section a. below); secondly, a contract must be concluded in the standard written form (Section b.); thirdly, a special instrument containing the contractual arrangement has to be drawn up (Section c.). Each of these modes is closely related to an aspect that will be examined separately, namely, the document authentication method used by the parties (see Section 2. Below). Moreover, some of these forms have been adapted to the needs of e-commerce (considered separately in Section IV. Below).

Before turning to each of the written forms, one common issue to consider is the meaning of 'writing'. It seems that traditionally, English, German, and Japanese law all deemed this to mean something being marked on physical and more or less durable mediums, particularly paper. This can be deduced from the description that methods such as 'typing, printing, lithography, photography and other modes of representing or reproducing words in a visible form' are being understood to mean 'writ-

2411 Whincup (fn 34) 107 para 4.2. 
ing' in England. ${ }^{2412}$ These methods are equally acceptable in Germany, ${ }^{2413}$ and - despite not being discussed in academic literature - arguably also in Japan. ${ }^{2414}$ This traditional understanding explains the need for making explicit provision for new technologies and the spread of e-commerce.

\section{a. Simple Written Forms: Evidence in Writing and the Textform}

There are two basic written requirements: what is known as 'evidenced in writing' in English law and the Textform found in German law. While both are the simplest kind of contract forms, they are radically different from one another in that the latter must be created when concluding the contract, whereas the former can be drawn up both before and after the time of formation. This is because 'evidenced in writing' basically means that a memorandum is made in writing of the previously or subsequently concluded agreement. ${ }^{2415}$ At the same time, this note need not even be in the form of a memorandum in the usual sense, so that a letter or other written document referring to the contract (and/or its terms) is sufficient. ${ }^{2416}$ Japanese law apparently does not know such a simple form.

German law has a simple written form known as the text form (Textform) in $\$ 126 \mathrm{~b}$ BGB. Rather than the declaration being recorded on paper, it can be stored on a 'durable medium' ('dauerhafter Datenträger'), such as a USB drive or a CD-ROM; however, it is not the medium itself but the electronic document contained on it that constitutes the text form. ${ }^{2417}$ The flexibility that is thus provided makes this form easier to use than the standard German written from (see below). Instances of the simple written forms include contracts of guarantee in English law (see $s$ 4 Statute of Frauds 1677, 'SOF 1677') and relate to tenancies in German law (see, eg, $\$ 555 \mathrm{c}$ and 555d BGB (Ankündigung and Duldung von Mod-

2412 See s 5, sch 1 Interpretation Act 1978 and Section B.II.3.b.ii. above.

2413 The caveat is that the writing must be in alphabetic or other characters from a real language, but cannot be in pictures or other similar depictions. See on this Section B.III.3.b.ii.aa) above.

2414 It seems that the notion of something being in physical, ie, paper form, is presupposed and as such is not discussed as being a matter of course. For further details on the arguments supporting this hypothesis, see Section C.IV.1.b.ii.aa) above.

2415 On this, see Section B.II.3.b.ii. above.

2416 See ibid.

2417 See Section B.III.3.b.ii.aa) above. 
ernisierungsmaßnahmen, Announcement and Toleration of modernisation measures)).

The English written evidence form seems to echo the obligation of one party to provide particular documents concerning the contract's content to the other party after the contract's conclusion, as under Japanese law, ${ }^{2418}$ or the provision of pre-contractual information to consumers under German law. ${ }^{2419}$ Indeed, under both English and Japanese law, the document is created at a time other than that of the actual contract being concluded. Furthermore, in all three cases, the purpose is to protect one party, namely, guarantors and consumers respectively. Having said this, at least the requirements related to consumers have been treated as information duties (setsumei gimu, 説明義務; Aufklärungspflichten) and not as form requirements. ${ }^{2420}$ Indeed, an information duty and the form of its execution are distinct, just as they are in turn distinct from the required contract form. It is therefore not surprising that the non-fulfilment of information duties does not affect the validity of the transaction, but will extend the cancellation period for the consumer in German law or have administrative consequences for the merchant under Japanese law. ${ }^{2421}$ The effect of this extension of the cancellation period under German law is to increase legal insecurity, since the extended period of time during which a consumer may end the contract suspends the contract's bindingness - in effect for one party only.

\section{b. The Standard Written Form}

Turning to the standard written form, all three countries' laws differentiate it from electronic forms (see Section IV.2. below) on the one hand, and,

2418 For example, art 3 para 1 Shita'uke-hō or art 4 para 1 Kappu hanbai-hō. See Section C.IV.1.b.ii.cc) above for further details on these provisions.

2419 See, eg, $\mathbb{} 482$ para 1 BGB for Teilzeit-Wohnrechteverträge (time-share agreements), Verträge über langfristige Urlaubsprodukte (contracts relating to longterm holiday products), and Vermittlungsverträge und Tauschsystemverträge (brokerage contracts and exchange system contracts). On this, see fn 1395 in Section B.III.3.b.ii.bb) above.

2420 On the Japanese regulation, compare Dernauer, 'Verbraucherschutz und Vertragsfreiheit' (fn 1629) 173 and, eg, 305-306; see also Section C.IV.1.b.ii.bb) above. On the German regulation, see Franzen, 'Vor $\$ 481$ BGB' (fn 1395) para 3 and ibid, ' $\$ 482 B G B$ ' (fn 1395) para 1.

2421 See $\$ \$ 356$ a para 3, 482 para 1 BGB for German law, and Section C.IV.1.b.ii.bb) above for Japanese law. 
where applicable, simpler written forms as outlined above on the other. As already mentioned in relation to the meaning of 'writing', the three legal systems concur in that this form is limited to declarations made on paper. Furthermore, it is always required that the document be signed (discussed in Section 2. Below). Apart from these specifications, the document's content tends to receive more attention in academic literature than the external form.

In this respect, the document must state the party's or, as the case may be, the parties' intention and contain the whole agreement, unless (some of) the terms are incorporated through some other express or implied means. ${ }^{2422}$ In particular, Japanese and German law require that the parties to a contract of guarantee (hoshō keiyaku, 保証契約, and Bürgschaftserklärung respectively) be named. ${ }^{2423}$ One great difference is that whereas a German Urkunde can only be in the form of a single document, the written memorandum of a contract in English law can be composed of any number of documents, as long as all refer to the same transaction and are signed. ${ }^{2424}$ In addition, English law may also require that the consideration for the contract in question be detailed in the document. ${ }^{2425}$

Written forms are required for a number of contracts in the three legal systems, some of which are the same, while others are not. Contracts of guarantee are one example of agreements that must be made in writing in English, German, and Japanese law (see s 4 SOF 1677, $\$ 766$ BGB, and art 446 para 2 Minpō respectively). There are three caveats to this congruence: In Germany, this form is only obligatory for declarations made by private persons. Where merchants are concerned, $\$ 350$ HGB expressly provides that $\$ 766 \mathrm{BGB}$ and thus the written form does not apply to commercial contracts of guarantee. ${ }^{2426}$ In England, guarantees do not need to be made in writing; it is one alternative provided in s 4 SOF 1677, whereby the other is to evidence the agreement in writing, as discussed in the foregoing section. Similarly, in Japanese law, an electro-magnetic record of a guarantee is sufficient to constitute writing (art 446 para 3 Minpō; see also Section IV.2.a. below).

2422 See Section B.II.3.b.ii. above for English law, Section B.III.3.b.ii.aa) for German law, and Section C.IV.1.b.ii.aa) for Japanese law.

2423 See Sections C.IV.1.b.ii.aa) and B.III.3.b.ii.aa) above respectively.

2424 On this, see Sections B.III.3.b.ii.aa) and B.II.3.b.ii. above respectively.

2425 See Section B.II.3.b.ii. above.

2426 For further details, see Section B.III.3.b.ii.bb) above. 
Other particularly interesting examples include sales of land in English law (see $s$ subs 1 Law of Property (Miscellaneous Provisions) Act 1989, 'LPMPA 1989'). These agreements are regulated differently in the other two legal systems. Dispositions of land under German law must be made in the form of a notarial deed (see Section c. below), whereas it is a formless transaction in Japanese law. Nevertheless, as will be seen in Section V. below, such contracts are nevertheless often concluded in written form in accordance with current Japanese business practice.

Another interesting example concerns two instances in which use of the written form is - effectively - optional. This is the case for a 'lease agreement for a longer period of time than one year' ('Mietvertrag für längere Zeit als ein Jahr', $\$ 550$ BGB) under German law, and gifts (zōyo, 贈与, arts 549-550 Minpō) under Japanese law. In both situations, the effect(iveness) of the contract is impinged if not made in the written form: Gifts are revocable until performed, unless made in writing (art 550 Minpō), whereas German leases not in writing are deemed to have been concluded 'for an indefinite period of time' ('für unbestimmte Zeit', $\$ 550 \mathrm{BGB}$ ) and can be terminated in accordance with the regular rules contained in the BGB after one year. ${ }^{2427}$ Gifts and leases are regulated differently in the other two countries, whereby both need to be in the form of a (notarial) deed.

\section{c. Special Instruments: (Notarial) Deeds}

English, Japanese, and German law all recognise special instruments beside the standard written form. These are deeds under English law and notarial deeds as found in German and Japanese law (termed 'notarielle Urkunde' and '公正証書', kōsei shōsho, respetively). As their names suggest, they are created by individual persons (laymen) in the former case and by notaries (Notare; köhö-nin, 公証人) in the latter case. ${ }^{2428}$ As such, an English deed is a private document, while German and Japanese notarial deeds are public documents. ${ }^{2429}$ Accordingly, the strictness of the requirements for executing these instruments is higher in German and Japanese law than

2427 See Sections C.IV.1.b.ii.bb) and B.III.3.b.ii.bb) above respectively.

2428 See generally Sections B.II.3.b.iii., B.III.3.b.iii.cc), and C.IV.1.b.iv. above for English, German, and Japanese law respectively. The role of notaries will be discussed in further detail in Section V.4.b. below.

2429 See ibid. 
in English law (see Section i. below). Moreover, the creation process is necessarily different. While this is true, it has been noted that the underlying aim of both English deeds and (German) notarial deeds is the same, namely, as proof that the creator seriously intended to undertake what is promised. 2430

It has been suggested that the reason for the lack of notarial form like the German Beurkundung in English law is that the English courts, which developed English contract law throughout history, could not create such a form if the English legislator did not, particularly because the English institution of a notary public is not comparable to the German Notari$a t .2431$ This is different from the situation under Japanese law, which has a notarial form but has chosen not to make it constitutive for contracts. ${ }^{2432}$ The cases in which this instrument is prescribed are discussed in Section ii. below.

\section{i. Requirements of (Notarial) Deeds}

Turning to the requirements, the first thing to note is that an English deed is said to be sufficient, rather than being a 'necessary' form. This means that the deed itself is enough to render a contract binding and effective, whereas a necessary form would additionally require the usual elements of an agreement, consideration, and an intention to create legal relations. ${ }^{2433}$ From this definition, it would seem that the German form requirements are 'necessary' rather than 'sufficient' forms, since offer, acceptance, and an intention to be bound are required in addition to the form in question. ${ }^{2434}$ Although this is not discussed in Japanese academic literature, it would seem that the same is true for Japan, ie, that all elements of an agreement plus the form in question is necessary. This is because the Japanese notarial system, like the German system, falls under the Latin type. ${ }^{2435}$

2430 Compare Zweigert and Kötz (fn 15) 390 and 394-395, speaking about promises of gifts.

2431 Compare von Mehren, 'Formalities' (fn 791) 15, 55, who discusses the existence of consideration and contrasts this with the German notarial deed.

2432 See on this generally Section C.IV.1.b.iv. above.

2433 See Treitel/Peel (fn 65) para 5-002. See also McKendrick (fn 48) 261.

2434 On this, see Section B.III.3.b. above.

2435 On the notarial systems, see Kaiser and Pawlita (fn 2086) 164. 
Despite this difference, all three countries' laws require that the (notarial) deed contain the parties' declarations of intention. ${ }^{2436}$ In Germany and Japan, it is also an explicit requirement that the parties to the notarial deed be identified in the instrument, whereby the identification method used must also be stated. ${ }^{2437}$ Of course, the party or parties are also named in English deeds; however, this is more a consequence of conveyancing practice, rather than due to some legal requirement. ${ }^{2438}$ All three kinds of deeds must also contain the date and place of execution. ${ }^{2439}$ With regard to the implementation method, it has the formal name of Niederschrift (notarial record, $\mathbb{8} 8$ BeurkG) in German law, whereas it is simply referred to as execution in English law (see, eg, s 1 subs 3 LPMPA 1989), or as 'creation of deeds' (shōsho no sakusei, 証書, 作成, see Chapter 4 Köshö-nin-hō) in Japanese law.

The individual requirements differ as well. The procedure is adapted to the fact that notaries are involved in Germany and Japan while no professionals are a priori involved in England. Accordingly, the finished text of the instrument is read out to the parties by the notary, and must be approved and signed or sealed by them (see $\$ 13$ para 1 BeurkG and art 39 paras 1, 3 Köshō-nin-hō respectively). In contrast, English deeds must be signed and delivered (s 1 subs 3 LPMPA 1989). ${ }^{2440}$ Nevertheless, the executor of a deed in England likewise ought to read it through before executing it. ${ }^{2441}$ Two further points need to be noted on the execution of English deeds. First, the deed has to be signed before a witness attesting the signatory's signature (s 1 subs 3 (a) (i) LPMPA 1989). Secondly, the

2436 For England, compare s 1 subs 2 (a) LPMPA 1989, which requires that the instrument be created with the intention of making a deed; as for the content being, eg, the conveyance of property, see Section B.II.3.b.iii. above. For Germany, see $\$ 9$ para 1 no 2 BeurkG and Section B.III.3.b.iii.cc) above. See Section C.IV.1.b.iv. above for Japan, where this seems to be an implicit requirement.

2437 See $\$ S 9$ para 1 no 1,10 para 3 BeurkG and art 36 paras ii, iv, vi Köshō-nin-hō respectively.

2438 See Halsbury's Laws Vol 32 (fn 62) para 205.

2439 This is a strict requirement in German and Japanese law, see $\$ 9$ para 2 BeurkG and art 36 para x Köshö-nin-hö respectively. For England, see Halsbury's Laws Vol 32 (fn 62) para 205, who states that at the very least, the date of the deed's creation is one of the 'formal parts' of the instrument.

2440 Note that formerly, a deed required a seal impression as well, but since 1989, a signature alone suffices in England. See Whincup (fn 34) 107 para 4.2. The use of signatures and seals will be discussed further below.

2441 On this, see Halsbury's Laws Vol 32 (fn 62) para 235. 
requirement of delivery of the deed does not mean that the instrument must be physically handed over to someone; rather, an act or conduct on the signatory's part is necessary to show their intention to be bound by the deed. 2442

It is perhaps due to the nature of the execution process that German and Japanese law seem to presuppose that notarial deeds be created on paper, rather than on other materials. ${ }^{2443}$ In contrast, while the English common law once specifically required paper - or very similar materials like parchment or vellum - to be used for the making of a deed, this restriction has since been lifted by s 1 subs 1 (a) LPMPA 1989. Similarly, German law usually requires that the notarial deed be contained in one document, although special provision is made for contracts, allowing the declarations of offer and acceptance to be recorded separately (see $\mathbb{} 128$ BGB). This seems to be true for deeds made under English and Japanese law as well, although no similar explicit rule exists in either legal system. The reason is that both Japanese and English law seem to presuppose that only one document will be made, whereby it is unproblematic if the document consists of several pages. ${ }^{2444}$ While this may be true, it seems that references to and annexing of other documents is permissible in all three legal systems.

\section{ii. Instances of (Notarial) Deeds}

(Notarial) deeds are sometimes prescribed by law but are at other times chosen in contracting practice for the added legal security they afford in terms of bindingness and enforceability. Gifts or the promise of the same are one instance found in all three legal systems. While English and German law require a (notarial) deed in such cases, it seems to be due to

2442 For details, see Section B.II.3.b.iii. above.

2443 This matter seems to be presupposed, since there is no discussion on this topic in either German or Japanese legal academic literature. Nevertheless, seeing as a normal Urkunde in Germany can be written on paper as well as on other materials, this might also be true for a notarial deed. On the Urkunde, see Section B.III.3.b.ii.aa) above. Similar considerations seem to apply to Japanese law, see Section C.IV.1.b.ii.aa).

2444 At least in Japanese law, there is the caveat that the notary must seal the intersections of all pages of the notarial deed, see art 39 para 5 Koshö-nin-hö. For English law, see Halsbury's Laws Vol 32 (fn 62) paras 201 et seq, in particular para 231, where it says '[...] the document as $a$ deed [...]' (emphasis added). 
legal practice in Japan that gifts, in particular of real estate, are recorded as a notarial deed. ${ }^{2445}$ This is because the promise of a gift only becomes effective by creating the instrument, or by performance of the promise. ${ }^{2446}$

Transactions concerning real estate are another example. Both Japanese and English law require leases of a particular duration (between eleven and over fifty years, and over three years respectively) to be made in the form of a (notarial) deed. ${ }^{2447}$ In contrast, German law is very lenient and merely requires leases for more than one year to be made in writing in order to be deemed to be concluded for a finite term. This means that the lease contract will still be valid even if not made in writing, but will simply have a different effect, namely, as a contract with an indefinite term. On the other hand, a notarial deed is required under German law for agreements (promises) to sell or buy land (see $\$ 311 \mathrm{~b}$ para $1 \mathrm{BGB}$ ). This is in stark contrast with English law, which only requires a standard written form (see Section b. above), and even more so with Japanese law, which even allows oral agreements in these cases (see Section C.IV.1.b. above).

\section{Seals, Signatures, and Other Forms of Signing}

Having seen what kinds of different written forms exist in English, German, and Japanese law, attention is now given to one element of documents which is of particular comparative interest. This is the way in which agreements or instruments are authenticated by the parties. In accordance with what has been said above, documents have to be signed in some way for them to obtain a legally binding effect. This requirement is the same in England, Germany, and Japan. While this is so, differences in the typically foreseen forms of signing arise between the 'Western' and the 'Asian' rules.

2445 For England, see Section B.II.3.b.iii. above. For Germany, see $₫ 518$ para 1 BGB. For Japan, cf art 549 Minpō, which explicitly allows gifts to be made solely through the parties' manifestation of intention.

2446 See Section B.II.3.b.iii. above for English law, and $\$ 518$ para 2 BGB for German law. For Japanese law, see art 550 Minpō, providing gifts not in writing to be revocable until they are performed. By deduction, this means that such gifts will only become binding once performed or put into writing.

2447 For Japanese law, see arts 22-23, 25 Shakuchi shakuya-hö, which applies to any kind of non-renewable lease and commercial leases of between thirty and fifty years, and ten to thirty years respectively. For English law, cf ss 52 subs 1, 2 (d), 54 subs 2 Law of Property Act 1925, 'LPA 1925', which provide that leases for less than three years taking effect in possession may be concluded orally. 
Nowadays, only two such forms remain: (handwritten) signatures (see Section a. below) and sealing (see Section b.). The requirements for each will be analysed subsequently. It is also interesting to note that other forms of signing were once accepted. For reasons of completion, a brief excursus will give an overview of these (Section c).

\section{a. Signatures}

The provisions discussed in Section 1. above will explicitly or implicitly require that a document be signed in order for the requirement of writing or of a (notarial) deed to be satisfied. ${ }^{2448}$ Accordingly, a German Urkunde - irrespective of whether it is a private or a notarial instrument - has to be signed by the party or parties ${ }^{2449}$ (see $\$ 126$ para 1 BGB and $\$ 13$ para 1 BeurkG). Similarly, English statutory provisions sometimes expressly require that a contractual document be signed. The most prominent example is a deed under s 1 subs 3 (a) LPMPA 1989. Other examples are bills of exchange (s 3 subs 1 Bills of Exchange Act 1882, 'BEA 1882'), contracts for the disposition of interests in land (s 2 subs 3 LPMPA 1989), and contracts of guarantee (s 4 SOF 1677).

Although rarely used today, signing has a long tradition in Japan, having been used since the Ancient era (eighth century).2450 Examples of signatures being explicitly required in Japanese law are rare in general and non-existent for standard contracts; however, there are cases of special contracts such as contracts for construction work (kensetsu köji no ukeoi keiyaku, 建設工事の請負契約, art 19 para 1 Kensetsu-gyō-hō) and other commercial documents such as invoices for freight transports (art 570 $S h \bar{h} h \bar{o}$ ) and deposit receipts (art $599 \mathrm{ibid}$ ), for which a signature is required or at least allowed in lieu of a seal being used. Note that in some instances, the signature of third parties may be required: Notaries must sign (and, in Japan, seal) the notarial deed in Germany and Japan (see $\$ 13$ para 3 BeurkG and art 39 para 3 Köshö-nin-hö respectively), whereas a witness is required to sign a deed in England (see s 1 subs 3 (a) LPMPA 1989).

2448 An exception is the German Textform, of course, as a signature is not required under that form. On this, see Section B.III.3.b.ii. above.

2449 In this case, the parties must sign the same contractual document, see $\mathbb{} 126$ para 2 BGB.

2450 For further discussion, see Section C.III.1.c. above. 
The meaning of 'signing' is essentially the same in the three countries considered in this dissertation. In England, the meaning is broad: 'signing' generally 'includes making one's mark on the instrument' (s 1 subs 4 LPMPA 1989) and can be made by the party themselves or by their representative ('an individual in the name or on behalf of another person', $s$ i subs 4A LPMPA 1989. Similar: s 91 BEA 1882). Moreover, a signature in a contract relating to land may consist of the handwritten name of the person, or their initials. ${ }^{2451}$ The interpretation of the term in relation to contracts of guarantee is much wider, so that a person's initials or even a printed signature may suffice. ${ }^{2452}$ The meaning in Germany is similar, with a handwritten signature generally being understood to be a sign of authentication. ${ }^{2453}$ In like manner, there is a presumption in Japanese civil procedural law that signed (or sealed) private documents are authentic (see art 228 para 4 Minso). It can be deduced from this that the signature (or seal impression) acts as an authentication method. Indeed, the term used in the provision, shomei (署名), means writing one's name in Japanese characters (kanji, hiragana, katakana) or using the Latin alphabet. ${ }^{2454}$ The signature need not be of the contracting party themselves, but can be that of an agent. ${ }^{2455}$ This is not to say, however, that English law does not deem a signature as an authentication. In fact, it is normally seen as making the document (and its terms) binding for the signatory. ${ }^{2456}$ Indeed, the general common law test for a signature is simply whether the act (signing) was done in order to authenticate the document. ${ }^{2457}$

2451 See Treitel/Peel (fn 65) para 5-009. See also the cases of Firstpost Homes Ltd $v$ Johnson [1995] 1 WLR 1567 (CA) and Newell v Tarrant [2004] EWHC 772 respectively.

2452 Treitel/Peel (fn 65) para 5-024.

2453 On this, see Section B.III.3.b.ii. above.

$2454 \mathrm{cf}$ the terms jisho (自署), which encompasses more stylised signatures, and kimei (記名), which includes the printing of names. See Section C.IV.1.b.iii.aa) above for details on these terms.

2455 See Section C.IV.1.b.iii. above, in particular fn 2046.

2456 Compare McKendrick (fn 48) 316-317 See also Treitel/Peel (fn 65) para 8-086. This is true irrespective of whether the document's content has been read or is known to the signatory or not. An exception was developed under the non est factum (it is not my deed) doctrine for illiterate, incapacitated persons, or those 'ignorant of the language' of the document, see Treitel/Peel, ibid para 8-086 et seq for details. See further McKendrick (fn 48) 563-568.

2457 Compare Treitel/Peel (fn 65) para 5-030, who applies the test to electronic signatures. The issue of electronic transactions is discussed in Secton IV.2.b. below. For further details on the meaning of a signature in England, see Section B.II.3.b.iv. above. 
A signature made under German law must be individualised, yet identify the signatory, and be difficult to forge. This is in total contrast with English law, which does not require these characteristics. ${ }^{2458}$ As this is not discussed in Japanese legal academic literature, it seems that such requirements also do not exist under Japanese law. The discrepancy may exist due to the differentiation in German law between signatures (Unterschriften) and mere marks (Handzeichen), which seems not to be made in England (nor Japan). This is because a simple ' $\mathrm{X}$ ' has been deemed sufficient as a signature in English law, while it would be deemed to be a mere mark in German law. ${ }^{2459}$ A mark in the form of an ' $\mathrm{X}$ ' probably would not usually be used in Japan, because the Japanese script is different; however, as will be seen in Section c. below, signs other than signatures and seal impressions have, at least in the past, been accepted in Japan.

\section{b. Seals}

From a 'Western' point of view, the use of seals in contemporary Japan is an exoticism. While this is not true with regard to public institutions, the fact that private individuals in Japan regularly rely on sealing rather than handwritten signatures might seem mystifying. Similarly, seen from a 'Western' legal perspective, the employment of seals in lieu of handwritten signatures when concluding contracts is equally unexpected. It is interesting to note, however, that until around two hundred years ago, seals were also in common use among private individuals in European countries.

In Europe, seals were already employed during Roman times. Before the third century AD, the custom of sealing letters and contracts developed in the Roman Empire from the lack of a script with a level of development that would have allowed the identification of a person by their signature. ${ }^{2460}$ In like manner, the high rate of illiteracy in Medieval Europe made the employment of seals necessary. ${ }^{2461}$ The reason for the employment of seals in Asia seems to be similar: While the Chinese script had already been invented by the time the first seals were brought to Japan,

2458 Contrast Section B.III.3.b.iv. above on German law and Section B.II.3.b.iv. on English law.

2459 Ibid. See also the definition of 'sign' found in s 1 subs 4 LPMPA 1989, given above.

2460 Martin Henig, Roman Sealstones, in: Collon (fn 807) 88.

2461 Compare Gertrud Seidmann, Personal Seals in Eighteenth- and Nineteenth-Century England and their Antecedents, in: Collon (fn 807) 143, 153. 
knowledge of this script was only for those of highest rank. ${ }^{2462}$ In fact, commoners in Japan did not have surnames, as this was prohibited until $1870 .{ }^{2463}$ The low rate of literacy, which would only rise rapidly in the Tokugawa era (fifteenth-nineteenth century), ${ }^{2464}$ precluded the development of handwritten signatures and favoured other means of 'signing', like sealing; although other forms of authentication also developed in Japan (see Section c. below). The reasons why seals fell into disuse in Europe while they continue to play a significant role in Japan will be explored in the following discussion.

i. The Use of Seals in England, Germany, and Japan until Modern Times (19 $9^{\text {th }}$ Century)

The importance of seals (inkan, 印鑑; or inshō, 印章) 2465 in Japan becomes evident when considering the following historical anecdote: The famous Japanese National Treasure of the 'King of Na's Golden Seal' ('漢委奴国王 金印', kan wa na koku'o kin'in) ${ }^{2466}$, a golden seal bestowed upon the King of $\mathrm{Na}$ by the Chinese Emperor Guangwu in $57 \mathrm{AD}$, is often referred to as

2462 This was not only true for the nobility or the warrior class. Persons having important (administrative) functions, such as the headmen of villages, were literate, see Henderson and Torbert (fn 1662) 7. This may correlate with the fact that education was traditionally restricted, namely, during the Classical era, to the nobility. The warrior class began to be educated in non-military matters in the Middle Ages, while merchants would only receive education beginning in the Tokugawa era. On this, see Encyclopaedia Britannica, Education (Online Academic Edition 2017), http://academic.eb.com/levels/collegiate/article/education/105951\#47520.toc at 'Japan'.

2463 See the table showing the 'selected chronology for the 1870s', in: Jansen, 'Introduction' (fn 1693).

2464 Compare Marius B Jansen, Japan in the Early Nineteenth Century, in: ibid (fn 1693) 50, 57.

2465 To be precise with the terminology, inkan can mean both seal (as in the object) and sealing (the action), while insho only refers to the seal object, see Dictionary of Standard Japanese Legal Terms (fn 9) 33. See further Ino'ue (fn 2072), who states that the term hanko also refers to the object. Accordingly, the terms insho or hanko will be used here to refer to the object. Note that during the Tokugawa era, seals were also referred to as oku'in (奥印), see Wigmore, 'Customary Law' (fn 1675) 1 and 2. Kanji taken from the respective entries in the Japanese online dictionary Goo at http://dictionary.goo.ne.jp.

2466 http://museum.city.fukuoka.jp/gold/index.html. 
proof for the (coming into) existence of a nation in Japan. ${ }^{2467}$ Indeed, it is said to be the oldest known seal in Japan, ${ }^{2468}$ and has been described as the beginning of the history of seals in Japan. ${ }^{2469}$ Furthermore, this seal may have been one of the first objects to introduce the Chinese character-script to Japan, which would later, in the seventh century, be adopted as kanji (漢字, literally meaning 'Chinese/Sino-' and 'Character' respectively). ${ }^{2470}$ As will be seen in the subsequent section (ii.), they remain of great relevance today.

While these facts might not be surprising, it may be astonishing that seals were of great importance in England and Germany in many respects until the nineteenth century as well. ${ }^{2471}$ Moreover, several types of seals existed, fulfilling different functions (see Section aa) below), which included contracting (Section bb)). Nevertheless, due to the limited accessibility of seals (Section $\mathrm{cc}$ )), the practice of sealing did not percolate all strata of society. The development of the sealing practice was not parallel in Japan and England and Germany, but rather opposite (see Section dd)).

2467 http://museum.city.fukuoka.jp/en/exhibition.html. Na was a kingdom in Ancient Japan, then referred to as Wa, located in the area of today's prefecture of Fukuoka, see www.fukuoka-art-museum.jp/english/eb/html/eb01/2011/kin_in/ kin_in.html.

2468 Ishii K (fn 1699) 21.

2469 Masao Kume, Mono to ningen no bunka-shi 178: hanko [The Cultural History of Objects and Humans No 178: Hanko] (Hōsei Daigaku Shuppan-kyoku 2016) 49. cf the website by the Zen-Nihon Inshö Gyo-kyōkai at www.inshou.or.jp/rekishipage/japanpage/nihon1.html, where it is stated that a systematic order for seals was only established in the ritsuryo laws under the Taika reforms. Kume, ibid, 140, goes on to say that Japanese seals began to be bestowed upon public authorities by Japan itself in the Ancient era. This marks a change in two senses. First, seals had previously been bestowed on the monarchs of Japan by China, whereas now it was the Japanese monarch who conferred the right to use seals. Japan had therefore determined its own independent (political) authority in this matter. Secondly, as a consequence, it was no longer solely the Japanese Tennō who employed a seal as a sign of administrative power. For further details on this change, see Kume, ibid, 140-142.

2470 Compare Wolfgang Hadamitzky, Handbuch und Lexikon der japanischen Schrift: Kanji und Kana 1 [Handbook on the Japanese script: Kanji and Kana 1] (Langenscheidt KG 1995) 9.

2471 See Stieldorf (fn 969) 34-35. cf Seidmann (fn 2461) 153, focusing on the use in private correspondence. 
aa) Types and Functions of Seals

In all three countries, there were then - and in Japan, continue to be - both private uses of seals, as well as employment of seals in business situations or when acting in an official role. Nevertheless, the borders between private and business were sometimes blurred. This fluidity already becomes evident from the kind of seals that existed, with some being private (private Siegel; shi'in, 私印), others of institutional or official nature (institutionelle Siegel including Amtssiegel; ko'in, 公印, official seals), ${ }^{2472}$ and yet others with a kind of dual nature, such as personale Amtssiegel (personal official seals), employed by a person in the German territories by reason of their office, whereby these seals were not passed on to the person's successor in office. ${ }^{2473}$

There was also no clear borderline with some functions of seals. One example is the sealing of documents: the employment could be for private or business correspondence, contracts, and other business documents such as receipts. ${ }^{2474}$ The most prominent use was for sealing (and thus authenticating) such documents, ${ }^{2475}$ or closing the same (called 'versiegeln' in German, sealing). ${ }^{2476}$ Whether the seal impression was for official or private matters seems to have depended on the situation. Beside this, seal impressions were also used to verify different matters, such as the veracity of weights and measures used by merchants through the town's seal, ${ }^{2477}$ or the quality of particular kinds of manufactured goods, such as cloth. ${ }^{2478}$ In the Tokugawa era, seals were also employed in Japan to indicate that

2472 For Japan, see Mori'in-bō (fn 1690), who notes that the production and use of private seals was prohibited in the Ancient era (sixth-eighth century).

2473 On this, see Stieldorf (fn 969) 21-22.

2474 For further examples, see Dominique Collon, Introduction, in: ibid (fn 807) 9.

2475 von Mehren, 'Formalities' (fn 791) 45. See also Stoljar (fn 194) 6, who goes on to note that this formalisation brought legal certainty to the agreement. Similarly, Stieldorf (fn 969) 36 states that the document obtained its legal validity ('Rechtskraft') through the act of sealing.

2476 Stieldorf (fn 969) 32, 3. The seals used for this purpose were known as Sekretsiegel or Missivensiegel, ie, privy seals, ibid 22.

2477 Frances E Baldwin, Sumptuary Legislation and Personal Regulation in England (PhD thesis, Johns Hopkins University 1923) 8 in note 28.

2478 On this, see Stieldorf (fn 969) 33; John Cherry, Medieval and Post-Medieval Seals, in: Collon (fn 807) 124, 132. The seal impression (Aufdruck) on such goods is generally known as a Besiegelung (sealing), see Stieldorf, ibid 32. cf Cherry, ibid, who notes that a lead tag was normally affixed to cloth having the approved quality. 
the content of documents had been verified or approved by a person of authority, like a village headman. ${ }^{2479}$ Another example of a use that might be of private or official nature is the closing of containers or rooms, or the marking of property. ${ }^{2480}$ Again, it depended on the role of the sealing person whether the act was private.

In a manner similar to the authentication of documents, a piece of material with a seal impression called a 'messenger seal' (Botensiegel) was used to raise the level of trustworthiness (Glaubwürdigkeit) of oral messages transmitted by way of a messenger. ${ }^{2481}$ The handing over of the seal itself acted like a power of attorney, in that being in possession of the seal carried an authority to act on behalf of the seal's owner. ${ }^{2482}$ The seal itself also had the function of acting as an identity for the person using it. ${ }^{2483}$

A seal also had - and continues to have - similar functions in Japan. First, it has always been a form of identifying the author of or otherwise related party to a written document. ${ }^{2484}$ Secondly, placing one's seal impression on a document entailed the taking on of some form of responsibility. ${ }^{2485}$ This correlates with an understanding in Europe that a person sealing a document might do so from a range of contractual positions: as the creator of the document containing some obligation, whereby the bindingness of the obligation is verified by the placing of a seal on the document; as the counterparty to an agreement, whereby the placing of the seal on the document then connotes consent to the content; as a witness or arbitrator; or even as an unrelated third party, who has lent their seal to a

2479 Compare Henderson and Torbert (fn 1662) 9 and fn 28.

2480 See Stieldorf (fn 969) 32, 33. See also Cherry (fn 2478) 132. The last function was achieved by dripping melted wax onto the object to be sealed and impressing the wax with a personal mark, or even just a scratch, see Stoljar (fn 194) 6.

2481 Stieldorf (fn 969) 35.

2482 See ibid.

2483 See ibid 36.

2484 To enable the first function, local authorities kept seal books, in which a seal was registered to a person. On this, see Wigmore, 'Customary Law' (fn 1675) 7.

2485 Responsibility could be in the form of becoming a 'primary' party to a legal undertaking, ie, as obligee and obligor, or as a 'secondary' party, such as a guarantor. The latter is evidenced in the term 'sealer' (kahan-nin, 加判人) being employed to 'witnesses' contracts in the region of Iwashiro and Uzen (today's prefectures of Yamagata and (roughly) Fukushima respectively) during the Tokugawa era. It should be noted that a 'witness' was treated as being both an observer and a guarantor in that period, see Wigmore, 'Customary Law' (fn 1675) 7-8. Exceptionally, responsibility in a transaction might arise from acting as a witness, even if no sealing took place by that person, see ibid 10. 
person not owning their own seal (referred to as a Siegelkarenz, dispension of seal $\left.{ }^{2486}\right) .{ }^{2487}$ Furthermore, a person that wielded another person's seal in Japan was understood to be acting as that person's agent. ${ }^{2488}$

Due to its general importance and its function as a kind of power of attorney in particular, misuse might easily occur where the seal fell into the hands of another party. In order to avoid such scenarios, some regional rules in Tokugawa Japan required a person to keep their seal in their possession always and not to entrust it to another person, although certain exceptions were permissible. ${ }^{2489}$ In a similar manner, regulations existed in the German territories requiring the seal's owner to ensure its exclusive access. Consequently, a seal may have been required to be kept in a locked room or container, whereby, in the case of institutions or a city, different keys were to be given to several persons, so that the seal could only be used by these persons jointly. ${ }^{2490}$ While not discussed in relation to England, both misuse and forgery of seals was arguably also a problem there. ${ }^{2491}$

\section{bb) Sealing in Contracting}

Sealing thus had a range of functions, including a legal one. Indeed, as was seen in Section B.II.2.a. above, formal contracts in medieval England had to be made 'under seal', ie, a seal had to be affixed to fulfil the form requirements. ${ }^{2492}$ Where no seal was affixed, the contract would be denominated as a 'simple contract', with the word 'simple' taking on the sense of 'unadorned' or 'informal' during the fifteenth century. ${ }^{2493}$ Even before, in the fourteenth century, contracts or other legal documents not bearing

2486 The term Karenz must be understood in the sense of the Latin term carentia, meaning to not have (own) or to do without something, see the entry for 'Karenz' in Duden online at www.duden.de.

2487 See Stieldorf (fn 969) 36-37.

2488 See Wigmore, 'Customary Law' (fn 1675) 7.

2489 For example, handing over one's seal was allowed to close relatives (parents, brothers, sons), see ibid 7.

2490 See Stieldorf (fn 969) 57.

2491 Compare in this respect ibid 58, noting that forging of the English Great Seal (Königssiegel) was punishable by execution, as the act was said to be one of high treason. On this seal, see also Baker, 'English Legal History' (fn 63) 114-115.

2492 Compare Stoljar (fn 194) 6, who notes that a seal was 'imperative' for covenants, beginning in the fourteenth century.

2493 Simpson, 'History' (fn 232) 190. 
a seal impression were deemed 'suspect'. ${ }^{2494}$ Perhaps as a consequence of this, persons not owning a seal would borrow one for concluding transactions. ${ }^{2495}$ Simple agreements would bear the seal(s) of the party or parties, whereas important transactions would additionally be sealed by witnesses or arbitrators in order to afford the contract with 'greater force'. ${ }^{2496}$ For similar reasons, transactions concluded between persons from lower classes might include the seal impression of institutions or persons of higher standing. ${ }^{2497}$ Although a seal impression made the agreement more formal, it may be surprising that it 'did not confer any other superiority upon the covenant', but that it was simply an authentication method and proof of the parties' consent. ${ }^{2498}$ Indeed, a seal did not substitute consideration, so that both were necessary. ${ }^{2499}$ Nevertheless, seals formed an essential part of deeds and covenants until modern times (see subsequent section). Furthermore, debt instruments like bonds were held to be invalid where the seal was missing or had (ostensibly) been tampered with. ${ }^{2500}$ Although this seems to be covered with the dust of antiquity, the requirement of sealing formed a necessary part of the execution of deeds until the late twentieth century. In fact, it was only through the LPA 1925 that the signature was first introduced as a formal requirement for a deed, whereby the rule in $s 73$ (1) LPA 1925 required both a signature (or a mark) and sealing. ${ }^{2501}$ The part of the rule on sealing was abolished through s 4, Sch 2 LPMPA 1989, however, so that private individuals no longer 'seal' legal documents.

A similar development occurred in the German territories, where instruments were required to be sealed in practice from the second half of the

2494 Cherry (fn 2478) 128.

2495 See ibid.

2496 See ibid.

2497 See ibid.

2498 See Stoljar (fn 194) 6.

2499 Compare ibid.

2500 Simpson, 'History' (fn 232) 90. An illustrative example of documents being invalidated by removal of the seal is of a group of peasants from Norfolk, who had gained their freedom in a charter sealed by their lord. Their act of removing the seal impression from the document and destroying it led them to fall back into servitude, as the charter had lost its legal effect. Compare on this Cherry (fn 2478) 124.

2501 David C Hoath, The Sealing of Documents. Fact or Fiction (1980) 43 No 4 The Modern Law Review 415-416. He suggests that the alternative requirement of a mark was intended for illiterate people or those otherwise incapable of signing, see ibid 416. 
twelfth century. ${ }^{2502}$ The trend continued for around six centuries, until form requirements increasingly prescribed a signature instead of sealing in the eighteenth century. ${ }^{2503}$ One example is the Allgemeines Landrecht für die Preußischen Staaten ('ALR') from 1794, which already foresaw a signature and not sealing as the authentication method of written contracts (see Vol I Title $5 \$ \$ 116,119$ ALR). Similarly, it was stated in the motives to the BGB that sealing was not a requirement for written documents. ${ }^{2504}$

In Japan, contractual documents of the Tokugawa era were only enforceable if they had been attested through the seal impressions of the local authorities, or where permission to contract had been granted by them. ${ }^{2505}$ This was the general rule for the most prominent contracts of the time, like transactions of sale, or those relating to land or buildings. ${ }^{2506}$ In contrast, other, ie 'ordinary', contracts were governed by local custom only, leading to great variations in terms of what kind of documents necessitated the seal impression of which authorities, and even as to the sealing that was required. ${ }^{2507}$

\section{cc) The Accessibility of Seals}

Despite the practice of sealing being widespread in all three countries, not every person had access to them. Rather, the use of seals was historically restricted to particular strata in the social hierarchy in Japan, Germany,

2502 See Stieldorf (fn 969) 45.

2503 On this, see ibid 52, who also notes that the spread of the office of Notare was a factor for the decrease in the use of seals by private as opposed to official persons from the sixteenth century.

2504 See Mugdan (fn 883) Vol 1455 at $\$ 93$.

2505 See Wigmore, 'Customary Law' (fn 1675) 1 and 35, 39 respectively.

2506 See ibid 1. Nevertheless, local customs foresaw a range of variations of this rule. Thus, in Ugo (roughly today's Akita prefecture), the contract would often bear the seal impressions of the seller of land and of a middleman, who had facilitated the sale transaction, see ibid 27. In other parts, like Shima (in today's Mie prefecture) and Iwaki (in today's Fukushima prefecture), all that was required was for the deed of title of the land to be handed over to the buyer, see ibid 16 and 24. Sometimes, third parties had to be consulted before a transaction could be carried out. Hence, the sale of land had to be previously announced to the neighbourhood and its members consulted concerning the buyer before the transaction could be finalised in Settsu (today's Ōsaka prefecture), see ibid 14 .

2507 Ibid 1. For further details, see Section C.III.1.c.iii. above. 
and England. It seems that the practice eventually trickled down from persons in power to commoners during the Middle Ages. In Japan, seals were initially employed only by the Emperor and the Imperial Court for administration purposes, as is reflected in the four-tiered seal-system that was established through a series of legislation during the Ancient era in $701 \mathrm{AD}$; gradually, however, other institutions such as temples or villages, and, still later, in the Classical era (Heian, eighth $\sim$ twelfth century), feudal lords (daimyō) would also come to use seals as signs of authority. ${ }^{2508}$ In parallel, the Japanese nobility began to use private seals in form of 'family seals' ('家印', iejirushi,), ${ }^{2509}$ which were used to mark a family's possessions and were also sometimes used as tradenames or trademarks. ${ }^{2510}$ In a similar manner, monarchs and popes were the first men of power to use seals in the German territories for official purposes, although the practice slowly extended to institutions of the church, the nobility, as well as to cities. ${ }^{2511}$ During the twelfth century, the circle extended to include corporations (Korporationen) such as universities and merchant guilds. ${ }^{2512}$ Other institutions, namely, judges and courts, as well as commoners only began to use seals starting from the thirteenth century, whereas government offices $(B e-$ hörden, Ämter) followed one century later and peasants in another two. ${ }^{2513}$

It seems that the practice of sealing advanced more quickly in England. It has been noted that sealing was 'a widespread fashion among all classes' by the twelfth century; however, it seems that primarily elite members of the church or nobility used seals even before then. ${ }^{2514}$ Sealing only became common practice in the thirteenth century, at the same time that cities seem to have started to use seals. ${ }^{2515}$ In Japan, merchants only began to employ seals in the course of their business much later, namely, sometime in the Tokugawa era. ${ }^{2516}$ Common people did not use seals and would instead write down their names at times when a signature was required -

2508 For details on the four-tier seal-system, see Ishii K (fn 1699) 22-23. On the periodisation of Japanese history, see Steenstrup (fn 1587).

2509 Mori'in-bō (fn 1690).

2510 See the entry for '家印' in the Japanese online dictionary Goo at http://dictiona ry.goo.ne.jp. Transcription adapted from this source.

2511 For details, see Stieldorf (fn 969) 37-44.

2512 Ibid 48-49.

2513 See ibid 50-52, 46-48 for details on this development.

2514 Cherry (fn 2478) 124-125. See also ibid 126-127.

2515 Compare ibid 127-128.

2516 For example, to acknowledge the receipt of delivered goods, see Wigmore, 'Introduction' (fn 1650) 92. 
if they were literate. ${ }^{2517}$ An exception was made for commoners in official positions, like the chief of the village-groups. ${ }^{2518}$ This was not to change until the Modern era (see Section ii. below).

\section{dd) The Development of the Sealing Practice}

The foregoing exposition notwithstanding, the practice of sealing was not on a constant rise in all three countries. In Japan, the use of official seals declined in the Classical era (eighth $\sim$ twelfth century) and was replaced by a form of signing known as kao (花押; see Section c. below). ${ }^{2519}$ Later, in the Middle Ages, at least the use of private seals would become popular once again. ${ }^{2520}$ Meanwhile, commoners resorted to different methods of authorising documents (see Sections a. above and c. below). The modern system of seals in Japan was established at the beginning of the Meiji era through a decree of the Grand Council of State (daijo-kan, 太政官).2521 Beside the Japanese State and the Emperor, whose seals are referred to as the 'Great Seal of Japan' ('国䨝', Kokuji) and 'Imperial Seal' ('御霆”,

2517 See Steenstrup (fn 1587) 150, who states: 'villagers [...] who could read, should attest in writing that they had understood [the duties that had been laid upon them], and those who could not read, should attest by their thumb-marks'. This form of attesting 'in writing' is understood to mean a hand-written signature since it is contrasted with 'thumb-marks'. Note that while $80 \%$ of the population during the Tokugawa period were peasants, they were prohibited from conducting non-agricultural, ie, commercial, activities, see Encyclopaedia Britannica, 'Tokugawa Period' (fn 1653). An explanation for commoners not using seals may lie in the fact that commoners did not have surnames until the nineteenth century, see Section b. above.

2518 See Wigmore, 'Introduction' (fn 1650) 18-19.

2519 Mori'in-bō (fn 1690) at 'kan'in-sei ni kawaru kaō no hajimari' [The Beginning of the Replacement of Official Seals Through Handwritten Signatures].

2520 At least with military commanders, see Mori'in-bō (fn 1690) at 'sengoku bujō no in' [The Seals of Military Commanders]. One prominent example is the seal of Nobunaga Oda, on whose seal the words 'unification of military power' (tenka fubu, 天下布武) were inscribed: Naka, Legal Practice Lecture 2017 (fn 2047).

2521 The Zen-Nihon Inshō Gyō-kyōkai [Pan-Japan Seal Association] states the year to be 1873 , see www.inshou.or.jp/inshou/about/message.html. Contrast Pardieck (fn 2045) 183, who cites a decree from 1871 (Edict No 456/1871). 
Gyoji $)^{2522}$ respectively, all Japanese people - both natural and legal could now use seals to conduct business. ${ }^{2523}$

This development is also true for England, and, to some extent for Germany as well. While people's interest in written documents increased in the German territories during the twelfth century, the use of seals by private persons went into decline four centuries later, culminating in the requirement of a signature being accepted in legislation instead of sealing in the eighteenth century. ${ }^{2524}$ Seals were not only valued as practical objects in England, but also as jewellery and were viewed as 'indispensable items of everyday use' even in the seventeenth and eighteenth centuries. ${ }^{2525}$ The introduction of postage stamps and gummed envelopes in 1840 seems to have led to the decline in the use of seals, particularly in (private) correspondence. ${ }^{2526}$ In this sense, it has been remarked that sealing was an important practice while English society was illiterate and classes strictly divided; but that, as literacy and egalitarianism increased, the seal lost its importance as a formal requirement. ${ }^{2527}$ Indeed, this seems to be a logical development, although this raises the question of the fate of seals in modern times.

\section{ii. Today's Use of Seals in England, Germany, and Japan}

The foregoing analysis has already foreshadowed the fate of seals in current times: At least in England and Germany, seals are no longer used by private parties, although (public) institutions and companies continue to use seals today. ${ }^{2528}$ Instead, seals have been substituted by signatures, as already discussed above. In contrast, inshō have maintained their relevance in relation to private but even more so in formal matters in Japan. Indeed,

2522 Jones (fn 2045). Kanji taken from the respective entries in the Japanese online dictionary Goo at http://dictionary.goo.ne.jp.

2523 See Pardieck (fn 2045) 183.

2524 See Stieldorf (fn 969) 44, 52.

2525 Seidmann (fn 2461) 143.

2526 Compare ibid 143, 153.

2527 See von Mehren, 'Formalities' (fn 791) 45. See also Seidmann (fn 2461) 153.

2528 For Germany, see Stieldorf (fn 969) 52, 53. For England, compare Collon, 'Introduction' (fn 2474) 10. 
while sealing is currently not the only form of making legally binding declarations of intention, it predominates over handwritten signatures. ${ }^{2529}$

The lingering importance of seals in Japan is evidenced by the 1 October, which is designated as 'inshō no hi' ('印象の日', Day of the Seal).2530 It commemorates the day from which all Japanese - including commoners - were allowed to employ seals instead of signatures: 1 October 1873 (Meiji 6). ${ }^{2531}$ Today, seals that are no longer used are burned on this date at Shinto shrines or Buddhist temples during a ceremony showing gratitude and respect, $k u y \bar{o}$ (供養). ${ }^{2532}$ While being a ceremony, this tradition may also have originated from the practical need to dispose of the insho of deceased persons in a way that would ensure they could not be misused.

The widespread use of seals in Japan has occasioned the existence of a whole series of different kinds of seals. Before turning to these types (in Section bb) below), the current situation in England and Germany is analysed briefly.

\section{aa) Seals in England and Germany}

In England and Germany, no abundance in seal types exists today. In Germany, there are Dienstsiegel for selected public officials or institutions, such as notaries (see Section B.III.3.b.iv.aa) above), while ink stamps (Stem$\mathrm{pel}$ ) are often used by companies or freelancers in business practice. ${ }^{2533}$ These stamps are used in many ways, including to show the author or address of a person or company, ${ }^{2534}$ and as such sometimes even replace

2529 Westhoff (fn 2067) 190 para 8. But see the information given on, eg, the website of the Kyōto City International Foundation, www.kcif.or.jp/HP/guide/ mainichi/en/communication.html at $4-1$, where it is stated that contracting in Japan normally requires both sealing and a handwritten signature.

2530 Jones (fn 2045). Kanji taken from the website of the Zen-Nihon Inshō Gyō-kyōkai [Pan-Japan Seal Association] at www.inshou.or.jp/koryupege/ivent1.html.

2531 Mori'in-bō (fn 1690) at 'genzai no inkan seido' [The Present Seal System].

2532 See fn 2530. While this (Buddhist) ceremony is one that is usually conducted for deceased persons, variations exist for other living things, such as cows (ushi$k u y \bar{o}$, 牛供養), and inanimate objects, such as kane-kuyō (鐘供養, ceremony for newly-cast temple bells) or hashi-kuyō (橋供養, ceremony for newly-constructed bridges, conducted before the opening ceremony), see the respective entries in the Japanese online dictionary Goo at http://dictionary.goo.ne.jp.

2533 See, eg, https://das-unternehmerhandbuch.de/firmenstempel/.

2534 See ibid. 
a signature, albeit not on contracts. ${ }^{2535}$ Thus, although business practice seems to afford company stamps a legitimising effect in that a person using a stamp is deemed to be authorised by the company or institution, a signature is still required under the written form. ${ }^{2536}$

In contrast, companies in England are required to use a company seal in certain situations, namely, when executing instruments such as deeds (see s 74 LPA 1925). This is only true if the legal entity has a seal, however, since the rule that companies are obliged to have a company seal has been abolished. ${ }^{2537}$ As a consequence, the signature by two authorised persons suffices to substitute a company seal (see s 44 subss 1,2 Companies Act 2006, 'CoA 2006').2538 Similar to German notaries, sealing is still practiced in England by notary publics and normally involves red paper wafers being stuck onto a document next to the signature, ${ }^{2539}$ and a metal seal embossing both the paper of the document and the wafer. ${ }^{2540}$ Furthermore, courts seal procedural documents such as claim forms (r 2.6 Civil Procedure Rules 1998, 'CPR 1998'), in order 'to indicate that the document has been issued by the court' (Glossary of the CPR 1998).

The abolishment of the requirement of sealing in England followed legal discussions in which the declining importance of seals was asserted, with one Judge even calling the practice of sealing to be 'very much in the nature of a legal fiction. ${ }^{2541}$ The courts were thus often lenient and found ways of allowing deeds not properly sealed, ie, without a wafer, to be valid at law. ${ }^{2542}$ Where a deed was not duly executed in terms of sealing, it was not entirely without effect if consideration had been provided, since it was still valid in equity, creating 'equitable interests' ${ }^{2543}$ This is thus another

2535 See, eg, www.stempelshop4you.de/blog/firmenstempel-pflicht/.

2536 Compare BGH decision of 23 January 2013, XII ZR 35/11, NJW 2013, 1082 1083, para 14. The case concerned the issue whether it was sufficient for the conclusion of a lease contract under $₫ 550$ BGB by a company if one authorised person of the company signed the contract. The court found that this was so if the signing person's sole authority was made clear by some addition (Zusatz) to the signature, like the impression of a company stamp.

2537 On this, see Section B.II.3.b.iv. above.

2538 In contrast, s 91 subs 2 BEA 1882 allows a company seal impression to substitute a signature on instruments executed under that Act.

2539 Hoath (fn 2501) 415.

2540 See, eg, http://citycoseals.co.uk/company-and-notary-seals/c1/ for pictures of embossers and wafers.

2541 Goddard J, cited by Hoath (fn 2501) 416.

2542 For more information on these judicial approaches, see ibid 417-426.

2543 Ibid 419. 
example of how consideration was employed as a means of giving effect to contracts without the form of a deed.

bb) Seals in Japan

Several categories of seals exist in Japan that stem from the importance attached to the seal itself, or rather from the use of the particular type of seal. Similarly, the material from which the seal is made, as well as its size and the design of the seal's face vary according to the seal's function. ${ }^{2544}$ While the categories of seals for natural and legal persons are similar in their function, denominations vary. ${ }^{2545}$ The different seals used by private individuals will be discussed briefly below. ${ }^{2546}$

A natural person in Japan — including foreigners - can own the following three types of seals: First, a jitsu'in ('実印', literally 'real seal', 'registered seal'). Secondly, there is a ginko-in (銀行印, literally 'bank seal') and thirdly, a mitome'in (認印, also known as a sanmon-ban, 三文判, a 'common' or 'off-the-shelf' seal). ${ }^{2547}$ The jitsu'in is the most important category, since this kind of seal is used for legal transactions of utmost significance, such as the conclusion of contracts, sales of land, testamentary dispositions, or on documents of the land- or civil register. ${ }^{2548} \mathrm{~A}$ person can only have one of these seals, as the seal must be registered.2549 After registration of the seal, a 'proof of registration' card ('印鑑登録証', inkan töroku-shō) bearing a registration number is issued by the competent administration authority, which can later be used to obtain a certificate showing the registration of the seal (inkan shömei or inkan töroku shomeisho, 印鑑登録証明書), containing the personal data identifying the owner

2544 For an overview over the materials, sizes, and designs of the different seals, see, eg, www.hankoya.com/guidance/ at 'Hajimete no kyakusama e osusume kontentsu' [Suggested content for first-time customers]. For an overview of the rules regarding the design of the face of the seal, see Ino'ue (fn 2072) at 'Making and registering your seal at your local municipal office'.

2545 Unless otherwise stated, Japanese denominations and kanji characters for the different seal-types in the following are taken from Ishii K (fn 1699) 8-14.

2546 For details, see Section C.IV.1.b.cc) above.

2547 These types were already discussed in Section C.IV.1.b.cc) above.

2548 See Westhoff (fn 2067) 190 para 8 and Ishii K (fn 1699) 8.

2549 This registration system seems to have been established in the Meiji era, see Pardieck (fn 2045) 183. Details of the registration were already been discussed in Section C.IV.b.iii.cc) above. 
of the seal and a seal-imprint. ${ }^{2550}$ An imprint of the jitsu'in, together with the seal's certificate, are seen as a legally binding signature of the seal's owner, and is functionally equivalent to a signature authenticated by a notary. ${ }^{2551}$

While the primary use of seals in Japan today is to substitute or complement a signature on documents, they may be employed in other ways in connection with contracts. One is the sealing of text alterations after the execution of a contract (called teisei-in, 訂正印,2552 'correction seal'), 2553 which is functionally equivalent to the marking of one's initials next to an alteration in Europe. One example is in notarial authentications, in which case all the parties and the notary are required to seal the amendment (art 38 paras 2-3 Kösho-nin-hō). Another use is the application of divided seals (wari'in, 割印) on several original copies of a document. In a similar manner, the adjacent pages of a bound contractual document may be sealed at the page intersections (kei'in, 契印, 2554 literally 'contract seal') to prevent the document being altered through replacement of any of the pages. ${ }^{2555}$ An example of this being prescribed by law is in art 41 para 2 Kösho-nin-ho, according to which the notary must seal the page intersections. A seal may furthermore indicate the end of a document, so that further additions of text after the execution are inhibited. ${ }^{2556}$ Finally, in relation to stamp tax, it was mentioned above (in Section C.IV. 1.c.ii.) that the stamp must be imprinted with a seal after being affixed to a document (art 8 para 2 Inshi-zei-hō) so that it may not be re-used. Not invalidating the stamp may lead to a monetary fine of up to $¥ 300,000$ (art 23 para 1 Inshi-zei-ho ; approx. €2,500). This imprint is known as a 'stamp cancellation mark' ('消 印', keshi'in). ${ }^{2557}$

2550 For further details and pictures of the forms and the seal-certificate, see Ishii $\mathrm{K}$ (fn 1699) 8-10. Note that it is not necessary to bring the seal itself to obtain the certificate, see Chūō Kūyaku-sho (fn 2073) at 'Inkan tōroku shōmei-sho no köfu' [Issuance of Proof of Seal Registration Certificate].

2551 Ishii K (fn 1699) 11, 8. See also Westhoff (fn 2067) 190-191 para 8.

2552 Kanji taken from Götze, 'Rechtswörterbuch' (fn 10) 550, 171.

2553 Pardieck (fn 2045) 186.

2554 Kanji taken from Götze, 'Rechtswörterbuch' (fn 10) 262.

2555 See Pardieck (fn 2045) 186.

2556 Jones (fn 2045).

2557 Naka, Legal Practice Lecture 2017 (fn 2047). 


\section{c. Excursus: Other Forms of Authenticating Documents}

Signing and sealing were not the only forms of authenticating documents that were known in England, Germany, and Japan. This excursus will briefly explore these methods for completeness. As was stated above, s 1 subs 4 LPMPA 1925 defines a signature to include a mark. ${ }^{2558}$ A signature could therefore be replaced with a simple mark, which implies that the latter is a sign other than writing out one's name by hand. Indeed, it is generally understood to mean a simple cross, the mark often made by illiterate persons. ${ }^{2559}$ Something similar exists in Germany in the form of a Handzeichen, which can consist of a person's initials or an X. ${ }^{2560}$ In contrast to English law, it is not generally sufficient as a substitute for a signature in German law, unless the mark is certified by a notary. ${ }^{2561}$

While only one method seems to still exist in Germany and England, several forms of signing or otherwise authenticating documents have been known at least since the Ancient era in Japan. ${ }^{2562}$ First and foremost, there were handwritten signatures ( $k a \bar{o}$, 花押). ${ }^{2563}$ These consisted of stylised depictions of kanji, so that the shape sometimes resembled plants or flowers. ${ }^{2564}$ This form of signing was particularly popular in the Classical era (ninth $\sim$ thirteenth century) to the extent that seals were rarely used, but the increasing complexity of the designs made a signing by hand impractical, so that people reverted to using seals. ${ }^{2565}$

There were also 'fingernail-stamps' ('爪印', tsume'in), which were banished after the Meiji-reforms; and, from the Edo period, what are referred to as 'blush-imprint' ('紅印', kö'in), fingerprints not in ink but cosmetic

2558 See Section 2.a. above.

2559 Compare entry number 13.b. for 'mark' in the Oxford English Dictionary Online at www.oed.com.

2560 See Section B.III.3.b.iv. above for further details.

2561 See ibid and Section B.III.3.b.iii.bb) above.

2562 See Mori'in-bō (fn 1690) at 'inshō seido no hajimari' et seq.

2563 This is also known as 'written seal' ('書き判', kakihan) and is a form of writing one's real name (jitsumei, 実名) at the end of a document in any of various script styles. It appeared at the end of the Classical era. See the entry in the Japanese online dictionary Goo at http://dictionary.goo.ne.jp. cf Mori'in-bō (fn 1690) at 'kan'in-sei ni kawaru kao no hajimari', where it is stated that these signatures were already widely used from the middle of that era. Several example images are also shown.

2564 Examples can be seen in Ishii K (fn 1699) 23. Perhaps it is due to this reason that these signatures obtained the name 'pressed flower'.

2565 See ibid 23-24. 
blush, used by women. ${ }^{2566}$ Moreover, sometimes thumb prints (bo'in, 拇 印) or handprints (te'in, 手印) were used instead of seals. ${ }^{2567}$ A contemporary example of these being used is by prisoners. ${ }^{2568}$

\section{Contracts in the Digital Economy: Online Transactions and Beyond}

The ability to span the temporal and spatial distance between individuals by using the internet and new technologies has made a reconsideration of the traditional contract law rules necessary in all three legal systems examined in this dissertation. ${ }^{2569}$ As has been rightly pointed out, the issue is not if, but how the rules once created for traditional contracting methods are to be applied to digital contracts ${ }^{2570}$, ie, transactions concluded online, either on websites or through exchanges of e-mails or messages in chats. ${ }^{2571}$ Nevertheless, such online transactions are no longer the only instance of digital contracts. Technological advances have brought forward new contracting methods in the form of automated and autonomous systems. While the latter is characterised by the system (computer (programme) or other machine) acting independent of human intervention, based on an algorithm and independent learning through data, the former act in accordance with settings configured by humans. ${ }^{2572}$ An example of a half-

2566 Ibid 26 and 27 respectively. Fingernail-stamps were used by illiterate villagers for example, see Section C.III.1.c.iii. and fn 2517 above.

2567 See Steenstrup (fn 1587) 150, cited in fn 2517 above. For further details on the development and use of these forms of authenticating a document, see Minahiko Ogino, Inshō [Seals] (repr, Yoshikawa Kōbun-kan 1995) 346-355.

2568 Jones (fn 2045). The reason for using this substitute method is because prisoners are not allowed to have inkan, ibid.

2569 See generally Matsumoto, 'Denshi shakai' (fn 1819) 290.

2570 One definition of these kinds of contracts is that they are 'agreements entered into by two or more parties over an electronic communication line', whereby the contract is purely electronic and not in physical form. Rolf $\mathrm{H}$ Weber, Contractual Duties and Allocation of Liability in Automated Digital Contracts, in: Sebastian Lohsse and Reiner Schulze and Dirk Staudenmayer (eds), Trading Data in the Digital Economy: Legal Concepts and Tools (Nomos 2017) 163, 165.

2571 Furmston and Tolhurst (fn 440) 150-152 paras 6.03-6.05. See also Murray (fn 440) 18; Weber (fn 2570) 186.

2572 A succinct description of both of these forms can be found in, eg, Louisa Specht and Sophie Herold, Roboter als Vertragspartner? Gedanken zu Vertragsabschlüssen unter Einbeziehung automatisiert und autonom agierender Systeme [Robots as Contracting Partners? Thoughts on the Conclusion of Contracts by Way of Systems Acting Autonomously] (2018) MMR 40-41. 
automated system is Amazon's 'Dash Button', 2573 a small device that allows a specific product to be ordered by simply pressing the button. ${ }^{2574}$ Another example is automated electronic agents, such as Amazon's 'Echo', a device that allows all kinds of products to be purchased from the Amazon platform through oral communication between the user and the device. ${ }^{2575}$ Finally, there are fully automated processes, namely, smart contracts. ${ }^{2576}$ The legal situation with regard to the latter two situations is not yet settled. 2577

Several aspects of contract formation need to be considered. First, the classification of digital communication in terms of declarations of inten-

2573 Specht and Herold (fn 2572) 41, who refer to it as an 'electronic ordering assistant' (elektronische Bestellhilfe).

2574 The German courts have held the use of these devices to contravene (EU) consumer protection regulation, ie, $\$ 312 \mathrm{j}$ paras $2-3$ BGB (Besondere Pflichten im elektronischen Geschäftsverkehr gegenüber Verbrauchern; Special obligations vis-à-vis consumers in electronic commerce). See OLG München decision of 10 January 2019, 29 U 1091/18, MMR 2019, 532-535. Paragraphs 3-4 of the decision contain a succinct description of the order process using the Dash Button. On the Dash Button ordering process and for an analysis of the clash of innovation and EU consumer law, see also Christoph Busch, Case Note: Does the Amazon Dash Button Violate EU Consumer Law? (2018) 7 No 2 Journal of European Consumer and Market Law (EuCML) 78-80. Note that the Dash Button seems not to have been marketed by Amazon in Japan.

2575 It seems that the process begins with the user giving a corresponding command to the device. The device will respond by asking for confirmation of the purchase of a specific article at a named price, which the user can accept by saying 'yes' or by using a codeword. The user then has fifteen minutes within which the order can be cancelled or amended in the app or on the website. On this process, see the description provided in Amazon.co.uk Alexa and Alexa Device FAQs no 8, www.amazon.co.uk/gp/help/customer/display.html? nodeId=201602230 (retrieved 20 September 2019); Amazon.de Alexa Nutzungsbedingungen [Alexa Terms of Use] no 1.4 (17 May 2019), www.amazon.de/gp/ help/customer/display.html?nodeId $=201809740$. According to Specht and Herold (fn 2572) 41, these agents have a certain freedom to act ('Handlungsspielraum') that simpler devices like the Dash Button do not.

2576 See Weber (fn 2570) 165. There are also 'Internet of Things automated contracts', which come about when an electronic device detects an item running low and ordering the re-supply of that item. This application is used increasingly by businesses in an ongoing relationship under a framework contract. Problems do not often seem to arise in this context, but rather in relation to private parties. On this, see ibid 178-180.

2577 For an analysis of the contractual situation with automated agents, see Specht and Herold (fn 2572) 41-42. For smart contracts, see, eg, Weber (fn 2570) 165-167. See also Section 3. below. 
tion or legally irrelevant statements, as well as the coming into effect of any electronic declarations of intention (see Section 1. below). Secondly, the contractual form, in particular, the authentication method (Section 2.). A final point to deliberate is the further future development of contracting in general, namely, under what is termed 'legal tech' (Section 3.).

\section{Declarations of Intention and Formation of Contracts in Online Transactions}

Several issues arise in connection with declarations of intention made in the context of online transactions. First, it needs to be considered whether statements or acts made 'online' are legally relevant (see Section a. below). If this is so, the second question is when these declarations come into effect (Section b.). Before giving attention to this, a quick note needs to be made on the issue of consideration from English contract law. As with traditional contracts, consideration is a necessary requirement for contracts concluded electronically. Having said this, this aspect should not be problematic in most cases, seeing as the provision of the offeree's personal information can be sufficient, so that acts like monetary payments are not necessary. 2578

a. The Classification of Statements made Electronically as Legally (Ir)relevant

As far as the attribution of legal relevance to statements made online or through electronic means is concerned, English, German, and Japanese contract law generally recognise the legal effect of declarations made in such a manner; ${ }^{2579}$ however, the question is what constitutes an offer and what amounts to acceptance if made in the form of an e-mail, in an electronic document, when statements are displayed on websites or made orally to automated agents. In other words, the issue is at what point 'online interactions $[\ldots]$ becom $[\mathrm{e}]$ online transactions' ${ }^{2580}$ In relation to offers, the

2578 See Furmston and Tolhurst (fn 440) 153-154 para 6.08. On the wide scope of consideration, see Section B.II.3.a.v. above.

2579 For England, see Section B.II.3.a.i. and ii.bb) above. For Germany, see Sections B.III.3.a.ii.aa) and iii.aa). For Japan, see Section C.IV.1.a.i.

2580 Furmston and Tolhurst (fn 440) 149 para 6.01 (original emphasis). 
differentiation is mainly between offers and invitations to make an offer (invitations to treat, Aufforderung zur Abgabe eines Angebots, and möshikomi no yüin (申込みの誘引) in English, German, and Japanese respectively), whereas acceptance is mainly distinguished from confirmations.

It has already been noted in Section II.1.a.ii. above that advertisements made online are generally considered to be mere invitations to treat under all three countries' contract laws. ${ }^{2581}$ Of course, exceptions exist where a statement is more concrete than a mere advertisement, such as where delivery dates are specified. ${ }^{2582}$ Amazon's Dash Button device, a half-automated system, has also been said to be a mere invitation to treat; so that the offer is made by the user when pressing the button. ${ }^{2583}$ Applying the same logic to automated agents like Amazon's Echo, the device itself ought to be seen as an invitation to treat, meaning that the user would make the offer. ${ }^{2584}$ Nevertheless, it has been argued convincingly that websites about tangible goods and, arguably, services rendered offline, must be differentiated from websites about intangible products and online services. ${ }^{2585}$ Due in particular to the issue of goods being in stock or a service provider being available for providing the service, advertisements of tangible goods or services ought to be treated analogously to advertisements in non-digital

2581 The terms and conditions of some websites thus state that the order made by a website's user is an offer, which is accepted by the website's operator when sending out the confirmation of dispatch of the order. See, eg, Amazon.co.uk Conditions of Use \& Sale: Conditions of Sale no 1 (10 July 2019), www.amazon.co.uk/gp/help/customer/display.html?nodeId=1040616; Amazon.de Allgemeine Geschäftsbedingungen: Verkaufsbedingungen [Amazon.de General Terms: Conditions of Sale] no 2 (26 June 2019), www.amazon.de/gp/ help/customer/display.html/ref=footer_cou?ie=UTF8\&nodeId=505048. On a different issue related to advertisements, namely, how influencers make hidden advertisements for certain products - a topic outside the scope of this dissertation - see Catalina Goanta, How Technology Disrupts Private Law: An Exploratory Study of California and Switzerland as Innovative Jurisdictions (Stanford-Vienna TTLF Working Paper No 38/2018) 30-44, available online at https://ssrn.com/abstract=3256196.

2582 Weber (fn 2570) 175.

2583 See Cyril Hergenröder, Die Vereinbarkeit sogenannter "Dash Buttons" mit den zivilrechtlichen Regelungen zum E-Commerce [The Compatibility of what are known as 'Dash Buttons' and Private Law Rules of E-Commerce] (2017) Verbraucher und Recht (VuR) 174-178.

2584 Incidentally, this would match the stipulation in Amazon's standard terms, see fn 2581 above.

2585 This distinction is strongly advocated by Furmston and Tolhurst (fn 440) 157159 para 6.13. 
form, so that the advertising party is protected from having to perform when no items are left to sell or the service cannot be rendered as requested. Conversely, such protection is unnecessary for intangible goods, such as digital content (programs, music, videos, e-books, etc) which can be reproduced infinitely and therefore cannot run out. ${ }^{2586}$ Similarly, services rendered online might not require human intervention due to processes being automated or because recorded audio or video fies are being provided, so that the problem of availability of personnel does not apply. It is therefore better to deem websites for digital content or online services to contain offers, because the contract can be executed immediately without the need for mental reservations on either side, just like with vending machines. ${ }^{2587}$

In cases of websites not displaying offers but mere information about products or services, the statement made by the user of the website, eg, by placing an order for goods or services through filling out an online form, is deemed to be the offer, which then needs to be accepted by the other party. ${ }^{2588}$ Although not discussed in legal academic literature, similar considerations ought to apply to statements made in e-mails: where the product or service is for tangible goods or offline services, the e-mail's content ought to be deemed as an invitation to treat, whereas e-mails about intangible goods or online services ought to be generally deemed as offers.

Similarly, the differentiation between declarations amounting to acceptance and legally irrelevant statements is not confined to online transactions and is treated analogously to traditional communication methods. Accordingly, acceptance is distinguished from mere confirmations, as already noted in Section II.2.a. above. Nevertheless, it seems that this is not an overly serious issue; discussions in legal academic literature instead focus on the method of acceptance and its effectiveness.

\section{b. Coming into Effect of Electronic Declarations of Intention}

Declarations of intention that are offers, made in England, Germany, or Japan by electronic means will come into effect upon receipt (Zugang;

2586 Compare ibid 158 para 6.13.

2587 Compare ibid 159 para 6.13.

2588 On this, compare Sections B.II.3.a.i.bb) (in particular fn 440), B.III.3.a.ii.bb), and C.IV.1.a.ii.aa) above for England, Germany, and Japan respectively. 
tòtatsu, 到達), just as if they had been made by traditional communication methods (see Section II.1.c. above). In this respect, 'receipt' means that the e-mail has been saved on the offeree's e-mail provider's server and can be downloaded, and, consequently, read, at any time. Similarly, online offers - such as those made on websites or in chats - are received once they are accessible to the offeree. ${ }^{2589}$ Access is therefore the key requirement, whereas knowledge by the offeree is not necessary. ${ }^{2590}$ The same is true for acceptance in all three countries. Thus, under German and English law, the case is the same as with offers, ie, acceptance by electronic communication comes into effect upon being received. ${ }^{2591}$ In Japan, acceptance communicated electronically (including through e-mail and online) are not governed by the general rules for acceptance communicated by traditional means, but falls within the scope of special regulation, to the effect that it becomes effective upon its arrival or receipt (see art 4 Denshi keiyaku-hō, art 97 Minpō). ${ }^{2592}$ Receipt has the same meaning as noted above.

Special mention needs to be made of a particularity of Japanese consumer law that relates to online transactions. When conducting business with a consumer electronically in Japan, the merchant has to take a precaution: the merchant must ensure that measures are in place to verify the consumer's presumable declaration of intention to contract at the time of concluding a contract, ie, that the consumer did not make the offer unintentionally (ito shinai mōshikomi, 意図しない申込み; literally 'offer without intention').2593 A lack of such means of control can lead to the contract not having been formed due to a mistake on the consumer's part in that the consumer did not intend to conclude a contract at all or at least not in that form (art 3 Denshi keiyaku-hō). The required measure of seeking confirmation (kakunin wo mitomeru sochi, 確認を求める措置) has to consist of a substantial investigation that allows the merchant to

2589 For English law, see Section B.II.3.a.ii.ee) above. For German law, see Section B.III.3.a.ii.dd) above. For Japanese law, see Sections C.IV.1.a.ii.bb) and C.IV.1.a.iii.cc) above.

2590 See ibid.

2591 See Sections B.III.3.a.iii.dd) and ii.dd) above for Germany, and Section B.II.3.a.ii.dd) for England.

2592 See Section C.IV.1.a.iii.cc) above for further details on this. Note that this regulation but not the result changes under the Minpo reform, see Section C.V.3.a. above.

2593 See E-Commerce Interpretation Guideline (fn 1873) i.8, the example given being that the consumer has clicked on the 'order' button by mistake, either while still contemplating whether to purchase the goods in question, or due to having confused it with the 'cancel' button. 
judge whether the consumer intended to contract (as declared), eg, by the website making it clear to the consumer that clicking a specific button will mean making an offer to purchase. ${ }^{2594}$ The consumer can explicitly waive the opportunity to confirm the declaration made electronically, whereby art 3 Denshi keiyaku-hō and art 96 Minpō do not apply (art 3 Denshi keiyakuhō). 2595 While such a waiver may release the merchant from civil liability where no confirmation measures are in place, there may yet be administrative consequences pursuant to art 14 Tokutei shö-toribiki-hō,, 596 especially paras ii (inducing the consumer to enter into a contract against their will) or iii (merchant's conduct prejudicing the transaction's fairness), or in conjunction with art 11 (provision of information on the contract upon request). ${ }^{2597}$ These cases should not be confused with those of what are known as 'one-click billing' (wan kurikku seikyū, ワンクリック請求) and which border on fraud: clicking a link in an e-mail will display a message leading the consumer to believe that they have automatically registered for a service incurring fees. ${ }^{2598}$

\section{Contractual Form and Methods of Authentication in Online Transactions}

As has already become apparent from the discussion in Section III. Above, there are not many instances in which English, German, or Japanese law foresee a mandatory form for contracts. While this is true, one important question with respect to online transactions is whether electronic docu-

2594 Ibid i.6. Visual examples of both sufficient and insufficient measures are given at ibid i.7, i.8-i.9. The common practice nowadays is for a website to display a final confirmation screen after leaving the input page, see ibid i.9.

2595 See ibid i.9-i.10 for further details. Also see ibid i.7 for visual examples of void and invalid waivers.

2596 See ibid i.9, with more details at i.14-i.16. For visual examples, see ibid i.11i.13.

2597 A specification of what the phrase 'act of causing customer to make application for contract against his/her will’ (“顧客の意に反して契約の申込みをさ せようとする行為, kokyaku no i ni hanshite keiyaku no mōshikomi wo saseyō to suru kōi) encompasses is found in art 16 para 1 Tokutei shö-toribiki ni kansuru höritsu shikō kisoku: namely, inter alia, a failure to indicate clearly to the consumer that they are about to make an offer (no i).

2598 This issue will not be treated further, as it goes beyond the scope of this dissertation. Interested readers are referred to E-Commerce Interpretation Guideline (fn 1873) i.17-i.22. 
ments, e-mails, or simply displaying text on a screen, etc can satisfy existing form requirements where no electronic contract form as such exists (see Section a. below). Moreover, seeing as a signature or a seal impression is usually required in written forms, the second question is whether there are electronic equivalents for these authentication methods (Section b.).

\section{a. Electronic Contract Forms}

As statutory legislation requiring contracts to be in writing were enacted as late as the end of the nineteenth century, it is logical that electronic communication was not envisaged and therefore not included within the meaning of 'writing' of that time. ${ }^{2599}$ This has necessitated the legislators and the courts to reconsider the existing framework and to adapt it to the new technologies.

Out of the three legal systems considered in this dissertation, German law has embraced the digitalisation process the most, explicitly providing for two forms that relate to online transactions: one is the Textform, already discussed in Section III.1.a. above; the other is a formal elektronische Form (electronic form), found in $\$ 126 \mathrm{a}$ BGB (discussed in detail in Section B.III.3.b.iii. above). Since $\$ 126$ a para 1 allows the standard written form (Schriftform) to be substituted by this electronic form, this means that electronic transactions conducted under German law are facilitated by the provisions. This is not true, however, with respect to the notarial authentication. The notarisation of a contract cannot be made in electronic form and while $\$ 39$ a BeurkG does allow 'einfache Zeugnisse' (simple certifications) to be made electronically, the provision does not apply to authentications of declarations of intention or of other circumstances. ${ }^{2600}$ Simple certifications are used most often in relation to the association- or

2599 In this respect, see Minpō (Saiken-hō) Kaisei Kentō I'in-kai, Japanese Civil Code (Law of Obligations) Reform Commission Draft Proposals (2010) proposal [3.1.1.04], according to which the definition of writing ought to be amended so as to include 'electronic records'. The proposal is available online at http://wwr7.ucom.ne.jp/sh01/english/draft_en.html. Interestingly, this suggestion was not adopted in the discussions on the Minpös reform, on which see Section C.V. above.

2600 See Alexander Lutz, $\$ 39 a$ Einfache elektronische Zeugnisse [Section 39a Simple Electronic Certifications], in: Beate Gesell and others (eds), beckonline.GROSSKOMMENTAR: BeurkG [beck-online.Comprehensive Commentary: Notarial Authentication Law] (online edn, CH Beck 2017) paras 1, 9. 
the commercial register (Vereinsregister and Handelsregister respectively). ${ }^{2601}$ Having said this, it is possible - and is in fact frequent in practice - to have a copy of a contract (Abschrift) or of a notarial instrument authenticated electronically, as this is within the scope of $\$ \$ 39 a, 39$ BeurkG. ${ }^{2602}$

In contrast, there is no electronic statutory form to be found in English nor Japanese law. Nevertheless, both legal systems have made allowance for electronic contracting. Consequently, Japanese law has generally provided for special regulation of electronic notices of acceptance under the Denshi keiyaku-ho, which also applies to commercial contracts (see Section C.IV.1.a.iii.cc) above). One example found in England is electronic conveyancing: In accordance with s 91 subss 1-5 LRA 2002, electronic documents effecting a disposition of, say, an estate in land, are recognised sas deeds if the documents contain the electronic signature(s) of the party or parties - of both natural or legal persons - and the date and time of coming into effect. Similarly, the view that commercial contracts concluded through e-mail or websites ought to be deemed to satisfy the requirement of writing has been expressed both by the Law Commission and the English courts. ${ }^{2603}$ The cases in question acknowledged that e-mails were capable of constituting a memorandum of a contract of guarantee for the purposes of s 4 SOF; however, there was also the issue of whether these memoranda were signed. ${ }^{2604}$ This aspect is considered in the subsequent section.

In a similar manner, art 446 para 3 Minpō allows a guarantee (boshō keiyaku, 保障契約) to be made in Japan by way of an electromagnetic

2601 Lutz (fn 2600) para 4, who expects electronic notarial documents to gain importance in future. In this respect, see also Michael Bohrer, Notarielle Form, Beurkundung und elektronischer Rechtsverkehr [Notarial Form, Authentication and Electronic Legal Transactions] (2008) DNotZ 39, 50-59.

2602 See Lutz (fn 2600) paras 9-10, 12.

2603 See Law Commission, 'Electronic Commerce' (fn 502) para 3.9, in which it is stated further that another form of online transactions, electronic data interchange (hereinafter 'EDI') does not constitute writing. Explanations are given in paras 3.10 and 3.17 (e-mail), 3.18 (website trading), 3.19-3.20 (EDI). The reason, in summary, is that the contract('s content) will be visible with e-mails and on websites and thus satisfy the need for there to be some 'visible representation', whereas this will not be the case for EDI, as this consists of an automatic exchange of data messages (protocols) that are not (intended to be) read by a person. The court cases are discussed below.

2604 See J Pereira Fernandes SA v Mehta (fn 799) [11]-[17] (Pelling J) and Golden Ocean v Salgaocar (fn 413) [20]-[22], [28]-[30] (Tomlinson LJ). 
record (denjiteki kiroku, 電磁的記録). ${ }^{2605}$ Apart from this, there are only few Japanese statutory provisions explicitly allowing electronic forms. For example, the contract document can be transmitted to the other party by electronic means under art 19 para 3 Kensetsu-gyo-ho, and art 3 para 2 Shita'uke-ho. ${ }^{2606}$ This is comparable to the duties imposed to service providers in England under rr 9, 11 E-Commerce Regulations, in accordance with which information about the electronic contracting process and acknowledgement of the order must be sent to the other party - who can be a consumer, or, if the parties have not opted out, a merchant - in

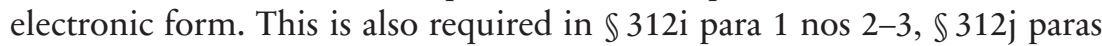
2-3 BGB.

Apart from the contract form, endeavours have also been made in all three countries to promote electronic transactions with public institutions. As has already been alluded to above, in the case of Germany, this is true for business conducted with the public registers. In particular, business with the land register (Grundbuchamt) is handled by notaries through an electronic procedure. ${ }^{2607}$ In this respect, the business e-services portal of the English Land Registry enabling electronic conveyancing is similar, although it is not notaries but other professionals, namely, solicitors, who deal with the registration of land and any changes in title, and so on. ${ }^{2608}$ A system of e-notarisation has also been introduced to the Kosh $\bar{o}-n i n-h \bar{o}$ in $2000,{ }^{2609}$ allowing a kosho-nin to perform a range of services electronically, including the authentication of electronic documents, supplying certified copies of such documents if deposited with the notary, or certifying that an electronic document in the possession of a person who is not a notary is identical with the deposited document. ${ }^{2610}$

2605 See also Section C.IV.1.b.ii.aa) above.

2606 See Section C.IV.1.b.ii.aa) above. Another example is art 4-2 Kappu hanbai-hö.

2607 Although it seems that the system is not without problems. See on this Matthias Frohn, Elektronischer Rechtsverkehr in Grundbuchsachen [Electronic Legal Transactions in Matters of Land Registration] (2016) DNotZ Special Edition 157-165, noting in particular the complications arising from deviating regulation within Germany, ie, in each Bundesland.

2608 On this system, see Section B.II.3.c.i. above. The role of solicitors in transactions concerning land will be considered in Section V.4.a. below.

2609 Pardieck (fn 2045) 189.

2610 See Japanese Notaries Guide (fn 2091) 11-12. An authentication is requested by a party online and forwarded through the website administered by the Hömu-sho to a kosho-nin. The party must then appear in person before or send an agent to the notary, who then adds the authentication certificate to the electronic document if all the requirements are satisfied. See ibid 12. 
b. Electronic Forms of Authentication: Electronic Signatures and Seals

Having established that electronic contract forms exist in English, German, and Japanese law, focus is now turned to the authentication of the contract, namely, the signature or seal imprint. The question is what can suffice as electronic equivalents to traditional signatures and seals, ie, what constitutes an electronic signature or digital seal impression.

Seeing as no statutory electronic form exists in English law, there is also no single statutorily defined electronic signature. Instead, a number of ways of signing one's name have been considered as signs of authentication in online transactions. It has been noted that electronic signatures are generally admissible and that a 'scanned manuscript signature' is a sufficient form of authentication in electronic communication. ${ }^{2611}$ This does not mean, however, that signatures need to be handwritten. In one instance, the English CA considered a contract of guarantee that was contained in a series of e-mails as being signed, with the signature consisting of the first name of the defendant. ${ }^{2612}$ In another case, the English HC had to decide a similar matter. While the court in this second case recognised that not just a (full) name, but even 'a pseudonym or a combination of letters and numbers' could constitute a signature for the purposes of $s 4$ SOF, it denied an e-mail address to be sufficient, as it had been inserted automatically by the programme and not the sender, so that it was not inserted into the document in order to give, and with the intention of giving, authenticity to it. ${ }^{2613}$

This coincides with s 7 subs 1 (a) Electronic Communications Act 2000, which requires that an electronic signature be 'incorporated into or logically associated with a particular electronic communication'. It has even been said that the clicking of a button on a website is 'the technological equivalent of a manuscript " $\mathrm{X}$ " signature' and thus a valid form of authentication of one's intention to contract. ${ }^{2614}$ It can be concluded from all of

2611 See Section B.II.3.b.v. above, where the rules regarding civil litigation are discussed. On the latter, see Law Commission, 'Electronic Commerce' (fn 502) 14 paras 3.32-3.33.

2612 See Golden Ocean v Salgaocar (fn 413), discussed in Section B.II.3.b.v. above. A similar opinion has been advanced by the Law Commission, 'Electronic Commerce' (fn 502) 14 paras 3.34-3.35, who would even recognise automatically inserted names or initials as signatures. Cf fn 2613 below.

2613 J Pereira Fernandes SA v Mehta (fn 799) [18]-[31] (Pelling J), in particular [27]. This case was discussed already in Section B.II.3.b.v. above. of fn 2612 above.

2614 Law Commission, 'Electronic Commerce' (fn 502) 15 para 3.37. 
the above that while the scope for electronic signatures is perhaps wider than for traditional, handwritten signatures, the important point is not what is used as a signature, but that it be used deliberately and with the intention of authenticating the document in question. Indeed, it seems that whether an electronic 'signature' is sufficient ultimately depends on the general common law test for signatures, namely, whether it is made with the intention of authenticating the document or transaction. ${ }^{2615}$

While this is true, the eIDAS Regulation 2014 established a systematic framework of electronic signatures (and seals) that has applied in EU Member States since 20162616 — and thus, in Germany as well. It provides for two types of signatures, 'advanced' and 'qualified' signatures, and establishes their legal effect, including as evidence in civil litigation (see art 25 eIDAS Regulation 2014). The minimum requirements for advanced electronic signatures are a unique link to the signatory by identifying that person, and that it is 'created using electronic signature creation data' under that person's 'sole control' in a way that inhibits subsequent changes (art 26 ibid). The prerequisites for qualified signatures are stricter, requiring a certificate with the signing person's name (or pseudonym), a unique code, and a set period of validity, among others (art 28 para 1 and Annex I ibid).

There have also been endeavours in Japan to create a legal framework for electronic signatures and seals. The Denshi shomei oyobi ninshö gyömu ni kansuru höritsu (hereinafter 'Denshi shomei-ho' ${ }^{2617}$ ) came into force in April $2006^{2618}$ and established a system for accrediting providers of electronic signature services (see arts 6 et seq Denshi shomei-hō). It aims to provide a 'legal basis for making electronic signatures and seals equivalent to hand-

2615 Compare Treitel/Peel (fn 65) para 5-030.

2616 On the background of this Regulation, see, eg, Dan Puterbaugh, E-signatures and the Realization of the EU Single Digital Market (Adobe Blog, 24 April 2016), https://blogs.adobe.com/documentcloud/e-signatures-and-the-realization-of-the-eu-single-digital-market/. See also the website of the European Commission on this topic at https://ec.europa.eu/digital-single-market/en/ trust-services-and-eid.

2617 電子署名及び認証業務に関する法律, Act on Electronic Signatures and Certification Business, Law No $102 / 2000$ as amended. An English translation is available online at www.japaneselawtranslation.go.jp/law/detail/? $\mathrm{id}=109 \& \mathrm{vm}=04 \& \mathrm{re}=2 \&$ new $=1$.

2618 It seems that this law originally came into force on 1 April 2000, see Hōmu-shō, Denshi shomei-hō no gaiyō to nintei seido ni tsuite [Concerning an Overview of the Electronic Signatures Act and the Certification System], www.moj.go.jp/MINJI/minji32.html. 
written signatures and seals'. ${ }^{2619}$ An electronic signature is required to indicate that it was created by the signatory and that it contains 'measure $[s]$ to confirm whether such information has been altered' (art 2 para 1 Denshi shomei-hö). ${ }^{2620}$ An electronic signature made in accordance with this law is assumed to be genuine, ie, made with the intention of the signing person to authenticate the document. ${ }^{2621}$ In this way, the law will enhance trust in using electronic signatures certified by accredited signature certification businesses. ${ }^{2622}$

3. Excursus: The Future of Contracting in Online Transactions through Legal Tech and Smart Contracts

Technological developments, in particular the internet, have changed the way contracts are concluded.2623 E-mails and online transactions (in browsers ${ }^{2624}$ ) are two methods that have already been considered above. Now, a whole new dimension to contracting is emerging from 'legal technology', usually referred to simply as 'legal tech', which seems to have three evolutionary stages. ${ }^{2625}$ The first stage is 'legal technology 1.0 ' and

2619 See Hōmu-shō, 'Denshi shomei nintei seido’ (fn 2618): ‘電子署名が手書きの 署名や押印と同等に通用する法的基盤が整備されました’ (denshi shomei ga tegaki no shomei ya ò'in to dōtō ni tsūyōsuru hōteki kiban ga seibisaremashita).

2620 The original provision reads: ‘当該情報について改変が行われていないか どうかを確認することができるもの' (tögai jōhō ni tsuite kaihen ga okonawareteinai ka dō ka wo kakuninsuru koto ga dekiru mono).

2621 See art 3 Denshi shomei-hō. See also Hōmu-shō, 'Denshi shomei nintei seido' (fn 2618).

2622 An illustration of how the system works in practice can be found in Hōmushō, Denshi Shomei-hō no gaiyō ni tsuite [Concerning an Overview of the Electronic Signatures Act], www.moj.go.jp/MINJI/minji32-1.html.

2623 On this change, see Goanta (fn 2581) 1, 17-19.

2624 Ibid 18 differentiates between two methods using browsers, 'click-wrap' and 'browse wrap': the former entails the consumer clicking a button in order to conclude a contract, whereas the latter simply requires that the consumer visits ('browses') a website for a contract to be concluded. No examples are given; however, it is conceivable that the first method is used in a web-store, while the second might be used for gratuitous services, such as social networks.

2625 The exposition following in this paragraph draws from Oliver R Goodenough, Getting to Computational Jurisprudence 3.0, in: Amedeo Santosuosso and Oliver R Goodenough and Marta Tomasi (eds), The Challenge of Innovation in Law: The Impact of Technology and Science on Legal Studies and Practice (Pavia University Press 2015) 3, 4-8. See also Ralph Baxter, Legal Tech 
consists of technology supporting lawyers in their work, eg, legal research in online databases or document drafting with the aid of word processors. The stage we are currently in, 'legal technology 2.0', has seen legal technology become 'disruptive, not just enabling' in that technology replaces lawyers in part, so that non-experts can, say, create contractual documents through use of a specific contract drafting software. ${ }^{2626}$ The third and final stage, 'legal technology 3.0', is characterised by standard legal processes being fully replaced by technology, so that '[c]ontracts, compliance systems, and dispute resolution systems [...] are able to operate within their own encoded systems. ${ }^{2627}$

It could be argued that we are entering the third stage already, albeit the second stage perhaps not yet being completed. This is because a new kind of contract is beginning to emerge: ${ }^{2628}$ This can be found in what are called 'smart contracts', self-executing arrangements of electronic functions called blockchains, which can eliminate the need for intermediaries and increase security in contracting, as the self-executing feature removes fear and distrust towards the other contracting party. ${ }^{2629}$ This is due to the

2.0: The World We Live in Now (Thomson Reuters Legal Executive Institute, 24 March 2015), www.legalexecutiveinstitute.com/legal-tech-2-0-the-world-welive-in-now-by-ralph-baxter/.

2626 For information on how the process of contracting evolves, see Kingsley Martin, Contract Maturity Model (Part 2): Technology Assembly Line - from Active to Passive Systems (Thomson Reuters Legal Executive Institute, 16 June 2016), www.legalexecutiveinstitute.com/contract-maturity-technology-assembly-line/. On technological developments being disruptive for 'challenging established legal practices', see also Goanta (fn 2581) 1.

2627 Baxter (fn 2625).

2628 Already in 2015, the prognosis was that smart contracts would be 'most likely to appear in your daily life soon' as an application of blockchains, see Bill Marino, Smart Contracts: The Next Big Blockchain Application (Cornell Tech News, 2 December 2015), https://tech.cornell.edu/news/smart-contractsthe-next-big-blockchain-application/. Approximately three years on, in 2018, several platforms have been established that facilitate smart-contracting, such as Ethereum. On this, see Goanta (fn 2581) 47.

2629 Compare the definition given by Oliver Herzfeld, Smart Contracts May Create Significant Innovative Disruption, Forbes (online, 22 February 2016), www.forbes.com/sites/oliverherzfeld/2016/02/22/smart-contracts-may-create-significant-innovative-disruption/\#56aa6cfd2702. See also Blockchains: The great chain of being sure about things, The Economist (London, 31 October 2015); Goanta (fn 2581) 47, who also gives a succinct description of how blockchains work at 44-45. For a brief technical explanation of blockchains, see Kai Brünnler, Blockchain kurz \& gut [Blockchain short and good] (dpunkt.verlag 2018). 
nature of the blockchain allowing programmed commands to be enforced automatically, so that obligations that are determined in the blockchain will be self-executed. ${ }^{2630}$ This self-enforcement without interference guarantees that the smart contract will be executed without fail, ${ }^{2631}$ if the conditions for starting the chain of commands are met. In this way, once one party has performed their duty, so will the other, as fulfilment is achieved through an action in the blockchain. A good illustration is the example of accommodation being rented out: A digital key (code) to the house and the rental fee (in cryptocurrency) may be put into the smart contract, whereby the information is to be stored until the commencement of the rental period. At that time, the rent will be sent to the lessor, and the code will be sent to the tenant, enabling the latter to access the house - but only if both conditions (input of the code and the fee) have been met; if they have not, the information provided by one party will not be released to the other. ${ }^{2632} \mathrm{~A}$ simpler application is the tracking of a package through GPS and the release of the purchase price to the seller once the package has arrived. ${ }^{2633}$

While this may sound like an utopian-like state for contract lawyers, there are in fact several legal issues that may nevertheless arise. On a very general level, there is the question of whether smart contracts fit into existing contract models so as to be given legal effect under English, Japanese, or German law. ${ }^{2634}$ This is indeed a legitimate concern, since smart contracts are entirely digital and, due to being contained in a blockchain as a series of commands, are arguably not 'in writing' as they are not recorded visibly. ${ }^{2635}$ Pending regulation on the matter, smart contracts may therefore fail to fulfil form requirements. Beside this, a smart contract may already fall short of being legally effective on other counts, namely,

2630 See Goanta (fn 2581) 48; Marino, 'Smart Contracts' (fn 2628).

2631 Brünnler (fn 2629) 77 notes that a smart contract 'can practically not be manipulated or stopped' (praktisch nicht zu manipulieren oder $z u$ stoppen), as explained at $46-56$.

2632 Example and explanation based on Marino, 'Smart Contracts' (fn 2628). Of course, such an application presupposes the necessary equipment. On such an 'infrastructure', see European Institute of Law (ELI), Preliminary Report 'Blockchains, Decentralized Autonomous Organizations (DAO) and Smart Contracts' (28 August 2019) 1, 20.

2633 Weber (fn 2570) 180.

2634 Compare Goanta (fn 2581) 48, calling this one of the challenges of this legal innovation and suggesting that any legal regulation is best done by way of transnational harmonisation. On the method of regulation, see ibid 51-58.

2635 Compare the discussion of electronic contract forms in Section IV.2. above. 
on the ground of the basic elements of offer, acceptance, and consideration not being identifiable in the code. ${ }^{2636}$ Moreover, there may be issues in or related to the performance of the contract, since the blockchain cannot be stopped once started. ${ }^{2637}$ Similarly, the contract cannot be modified after the blockchain has been programmed. ${ }^{2638}$ It has been suggested that some of these issues can be avoided by inserting clauses ('functions') into the smart contract that correspond to the basic elements of contract law theory (offer, acceptance, consideration), as well as an 'off-switch' in order to be able to halt the execution if necessary. ${ }^{2639}$ Although this sounds like a solution, the question of whether existing requirements of (written) form can be met by smart contracts remains. There is, furthermore, a potential problem for consumers, especially if they are not familiar with the blockchain technology. Thus, they might not be aware that a contract is being concluded and that it will be executed when they press a button on a website. The suggestion to extend merchants' information duties, in particular so as to make the consumer aware that the smart contract technology will be used, seems appropriate for this problem. ${ }^{2640}$

In respect to the other issues, it is submitted that inserting special functions in order to mimic the elements of a contract may not necessarily be required, especially where a contract can be concluded in any form. This is because the contract conclusion method of click-wrapping, ie, of clicking a button in a browser, can be applied by analogy: smart contracts may already have been programmed, so that concrete exchanges of cryptocurrency and other intangible things may be suggested in an application. ${ }^{2641}$ These 'suggestions' can be deemed to be offers rather than mere statements displayed on websites, since the intention of the statement maker is different. The manager of an online store wanting to reserve the ultimate decision on whether to enter into a contract with a person who reacts to

2636 Compare Goanta (fn 2581) 48, focusing on the question of the parties' intention.

2637 On this, see Marino, 'Smart Contracts' (fn 2628).

2638 See Bill Marino, Agreement Making in Ethereum - A Legal Perspective (Lecture, Ethereum Devcon 1, Gibson Hall, London, UK, 13 November 2015).

2639 See Marino, Agreement Making Lecture 2015 (fn 2638), who suggests ways in which this can be achieved.

2640 This suggestion was made in ELI (fn 2632) 36.

2641 See, eg, www.ethereum.org for examples of what kind of contracts are possible. For a list of ethereum applications, see www.stateofthedapps.com/rankings/platform/ethereum, showing that things from games to exchanges and even marketplaces exist. 
their statement, eg, in order to ensure the requested item is in stock, may be said to be making an invitation to treat only. In contrast, someone who solicits an exchange by providing a smart contract ought to be deemed to be making an offer, since the immutable nature of the blockchain technology means that the parties will be bound: Once the application's user clicks a button to start a transaction, the smart contract cannot be stopped so that there is no room for the parties to change their mind. A definite intention of the parties to be bound can therefore be presupposed under these circumstances. This must be even more true where no smart contract is pre-programmed, as the parties would arguably first communicate in some way before a smart contract fitting their needs is created. In this way, the agreement between the parties will have arisen before or at the latest once the smart contract is executed. Even this analysis does not resolve the issue of contract form, however, so that it must ultimately be seen how the legislators, the courts, legal academics, and practitioners classify smart contracts, and, moreover, whether they recognise these as legally binding agreements.

\section{The Formation of a Sales Contract Concerning Real Estate}

The differences between contract law as practiced in England, Germany, and Japan can be illustrated well by looking at transactions involving real estate, since both the requirements for a legally effective contract and the legal and business practices vary with sales of land. The differences begin with one fundamental aspect, namely, the legal classification of land and buildings (see Section 1. Below). Focus is then turned on the real estate transaction process in practice (Section 2.). The contractual requirements already mentioned in Sections B. and C. above will be briefly summarised and then contrasted in Section 3. Below. One particularly interesting aspect of the transaction process is the professionals supporting the contracting parties. Special attention is thus given to these persons, who will be identified and compared in Section 4 .

\section{The Classification of Real Estate in Terms of Property}

One fundamental aspect of the three legal systems is the classification of things. It has already been mentioned in Sections B. and C. above that subtle differences exist in this differentiation process. Of interest here is 
the definition of land or real (immovable) property. In fact, this varies in all three countries' laws. While English and Japanese law adopt the approach of considering that all things not real property (fudo-san, 不動 産, immovable property) to be personal property (dōsan, 動産, movable property), thus making the latter a residual category, German law does not give a definition at all; the BGB simply speaks of two different kinds of movable things (bewegliche Sachen) in $\$ \$ 91-92$ (vertretbare Sachen or fungible things, and verbrauchbare Sachen or consumable things respectively), and of Grundstücke (plots of land) in, eg, $\$ 94$ BGB.

There is, moreover, another difference beyond this semantic aspect. German law provides in $\$ 94$ para 1 BGB that:

$[t]$ he essential parts of a plot of land include the things firmly attached to the land, in particular buildings, and the produce of the plot of land, as long as it is connected with the land [...]. ${ }^{2642}$

Similarly, English law provides in sch 1 Interpretation Act 1978 and s 205 subs 1 (1)(ix) LPA 1925 that buildings or parts thereof form part of the definition of 'land'. ${ }^{2643}$ In contrast, Japanese law foresees in art 86 para 1 Minpō that '[1]and any fixtures thereto are regarded as real estate' ('土 地及びその定着物は、不動産とする', tochi oyobi sono teichaku-butsu ba, fudō-san to suru), whereby the connotation of the word 'and' ('及び', oyobi) between the words land and fixtures is that the connected terms are on the same level. ${ }^{2644}$ It is interesting to observe that the civil and common law traditions found in Germany and England, while always said to be very different, are in fact in agreement on the point of buildings forming part of land, whereas the hybrid system found in Japan takes a different approach. Looking at the traditional structure of houses in Japan, namely, of these being built on platforms on top of pillars protruding from the ground, the contrast could be said to be even greater. This is because it might be argued that both German and English law might deem such buildings not to be immovable property at all, due to their construction. It goes beyond the scope of this dissertation to pursue this idea further; however, it is plausible that English and German law would deem such

2642 The original provision states: ' $\mathrm{Zu}$ den wesentlichen Bestandteilen eines Grundstücks gehören die mit dem Grund und Boden fest verbundenen Sachen, insbesondere Gebäude, sowie die Erzeugnisse des Grundstücks, solange sie mit dem Boden zusammenhängen. [...]'. For further discussion, see Section B.III.3.b.i. above.

2643 For further discussion, see Section B.II.3.b.i. above.

2644 Compare the entry for '及び' in the Japanese online dictionary Kotobanku at https://kotobank.jp/. For further discussion, see Section C.IV.1.b.i. above. 
buildings as part of land, notwithstanding the platform-like construction, because the buildings will not have been erected for a temporary purpose, and as such would thus not be deemed as severable fixtures but as a part of the land on which it is built.

\section{The Course of a Real Estate Transaction in Practice}

It is natural that legal and business practices vary across the globe. The important question is by how much the practices differ. The aim of this section is to raise awareness of some important deviations found in this respect in England, Germany, and Japan. ${ }^{2645}$ Seeing as the focus of this dissertation is on Japan, that country's conveyancing process will form the basis of the following account.

The first point to note is that in Japan, the transaction process for sales of land or existing buildings is similar, while the process for newly constructed or not yet finished buildings differs in practice. This seems not to be the case in the other two countries considered in this dissertation: While there seems to be no apparent differentiation at all in Germany, there does seem to be slight variations in England, depending on whether the property in question is registered or unregistered land. ${ }^{2646}$

In the case of the object being land or an existing building, the owner in Japan, just like in England or Germany, is often a private individual. The process will begin by that person employing the services of a real estate agent (fu-dosan gyōsha, 不動産業者, see Section 4.c. below) in order to sell the land or building. A price will be set, depending on the location and size, as well as the condition and any encumbrances, among others, but this will usually be re-negotiated during the transaction process. The agent will then advertise the object and act as the contact person for interested parties. They will also conduct viewings of the object. In ensuing negotiations, the agent acts as intermediary between the seller and prospective buyers - a cultural necessity, as the parties would not otherwise negotiate to the same extent in order not to affront or displease the other party.

2645 The following account of the practices in Japan is based on a personal interview with Mika Yokoyama, Professor, Faculty of Law, University of Kyoto (Kyōto, Japan, 9 September 2016), unless indicated otherwise.

2646 This seems to concern investigations in relation to the land, in particular the Index Map and the Land Charges Department searches, see Halsbury's Laws Vol 23 (fn 729) paras 95, 97. 
Where the real estate in question is either a newly-constructed or not yet finished building, the owner will be either an individual owner or, more commonly, a construction and development company (called a takuchi tatemono toribiki gyösha, 宅地建物取引業者, real estate broker in the Takuchi-gyo- $h \bar{o})$. In either case, the sale is initiated through advertisements by the seller, who acts as the contact person for interested parties and conducts viewings of the building or, in case of an unfinished construction, a model. Where the building is an apartment block, prospective buyers will indicate their interest in a particular unit. If there are several interested parties for the same unit, these are grouped together, and one party is chosen by lottery as the buyer. It is only at this point that negotiations will begin, including alterations to the building plans of the interior, such as wall positions, floor materials, etc. It ought to be noted that the price of the object will have been set by the seller from the beginning and will not be negotiable, whereby the price will vary for different units according to certain factors, in particular the direction of the main windows, ${ }^{2647}$ and the location of the unit within the building complex. ${ }^{2648}$

Once the negotiations are underway, the buyer pays a small sum of money between $¥ 50,000$ to $¥ 100,000$ (approx. €400-€800) to show the seller that they are entering negotiations with a serious intention to buy. This is called 'mōshikomi shōko-kin' ('申込証拠金', literally 'application earnest money'), a distinct concept from tetsuke, although it can sometimes be combined at a later stage. ${ }^{2649}$ Furthermore, a provisional contract (karikeiyaku, 仮契約) may be entered into at this point, or after the negotiations have been completed. Note that where the sale does not occur, the application money will normally be returned to the buyer, ${ }^{2650}$ and another prospective buyer will be drawn from the pool of candidates, whereby the process just explained will begin anew.

After the conclusion of negotiations in Japan, the next step is (usually) the conclusion of a (final) sales contract. In case of existing buildings, this

2647 Apparently, South is most desired, followed by East, then West, and, finally, North.

2648 In particular, Japanese are concerned about which floor the unit is in. Normally, the second-most top floor is most expensive because it is light but is not heated by the sun directly and relatively quiet, whereas the disadvantage of the top floor is that it can be overly hot.

2649 For general information on this 'application money' and the distinction from tetsuke, see Muramoto (fn 2166).

2650 See Muramoto (fn 2166). 
will almost always happen through the real estate agent, ${ }^{2651}$ whereas in sales of new constructions, the seller will provide the contract documents. At this point, the buyer will pay tetsuke to the seller, which usually consists of an amount of money between 10\%-20\% of the purchase price. Depending on whether the sale is of a new or an old(er) building, its function varies slightly: Whereas tetsuke will act as a proof of the buyer's serious intention to purchase a new(ly constructed) building, it is meant to act as a kind of insurance in case of defects in the building or problems arising in the course of the transaction with old(er) buildings. ${ }^{2652}$ The seller or their agent will then engage a shibo shoshi (司法書士, Judicial scrivener, see Section 4.d. below) to effect the registration of the ownership change (see Section 3. Below), whereby this will only be done in case of a new building complex once all units of a building have been sold. Furthermore, contracting parties often make the full payment of the purchase price a condition for the transfer of property. ${ }^{2653}$ Therefore, registration of the ownership change will only be effected after the payment has been made. ${ }^{2654}$ Where a fudo-san-ya is involved in the transaction, they will be present when the payment has been made, as will the shiho shoshi. ${ }^{2655}$

The payment of the purchase price in a Japanese transaction and the symbolic delivery of the real estate by, eg, handing over of the house keys, are usually effected together in the presence of the parties, the estate agent and the shibo shoshi. ${ }^{2656}$ After this event, registration of the ownership change will be made at the Japanese land register. ${ }^{2657}$

In England and Germany, an estate agent will normally be involved in the transaction process as well, although this is apparently more often the case in Germany than in England. ${ }^{2658}$ They are hired by buyers or sellers

2651 The real estate agent has several important functions in relation to this as well as the duty to explain a series of matters to the other party (ie, the party that is not the agent's principal). See Section 4.c. below for further details.

2652 This seems to roughly correspond to the two functions of shoyaku-tetsuke and kaiyaku-tetsuke, discussed in Section C.IV.1.c.iii. above.

2653 See Kaiser (fn 1976) para 61.

2654 Compare Kaiser and Pawlita (fn 2086) 178.

2655 Ibid, who state no further details on how this is conducted. Bearing in mind the amount of money involved, it seems that the most viable procedure would be a meeting of the parties, the agent and the scrivener at the buyer's bank, where the transfer will be effected by the clerk at the buyer's direction.

2656 On this, see Kaiser (fn 1976) 706 para 71 and 705 para 64.

2657 Compare Kaiser and Pawlita (fn 2086) 178. See also Sections 3. and 4. below.

2658 According to statistical data, $83 \%$ of sellers and buyers of real estate in the UK used an estate agent in 2013-2015, while over 90\% seem to engage 
and, when acting for the former, will evaluate the property and provide information to any potential buyers. ${ }^{2659}$ Contact with the other party and viewings of the real estate in question will be facilitated by the agent, as will the negotiations of contract terms. ${ }^{2660}$ The negotiations may also be conducted through the seller's solicitor or Rechtsanwalt. ${ }^{2661}$ Similar to the application-earnest in Japan, an interested person in England may pay a pre-contract deposit to the agent or other party when making their offer as a sign of their earnest intent. ${ }^{2662}$ The offer will be made either to the seller directly, or to their estate agent or solicitor. ${ }^{2663}$ Note that these are not legally binding, ${ }^{2664}$ which seems to cause insecurity for a portion of both buyers and sellers. ${ }^{2665}$ It may happen that the price is altered by either the buyer or the seller, but this seems to be rare. ${ }^{2666}$ After acceptance of the offer, the contract document (deed) will be drawn up (see Sections 3. And 4.a. below) and a deposit of approximately $10 \%$ of the purchase price is paid by the buyer, either to the seller's estate agent or the solicitor. ${ }^{2667}$

agents in Germany. On England, see Department for Business, Energy \& Industrial Strategy, Research on Buying and Selling Homes (Research paper No BIS/283, 22 October 2017) 4-5, 18, available online at www.gov.uk/government/publications/buying-and-selling-homes-consumer-experience-study (hereinafter 'House Sales Research Paper'). On Germany, see Christoph Hamm and Peter Schwerdtner (Founder), Maklerrecht [The Law of Agency] ( $6^{\text {th }}$ rev edn, $\mathrm{CH}$ Beck 2012) 1-2 para 3, who note that it was $99 \%$ (!) in the 1990 s and is unlikely to have changed much.

2659 For statistical data on these activities, see House Sales Research Paper (fn 2658) $5-6$.

2660 The role of the estate agent will be considered in detail in Section 4. below. For a general description of their function in England, see, eg, https://targetjobs.co.uk/careers-advice/job-descriptions/279481-estate-agentjob-description and House Sales Research Paper (fn 2658) 5-6. For Germany, see generally Hamm and Schwerdtner (fn 2658) 4 para 12.

2661 Compare Halsbury's Laws Vol 23 (fn 729) para 2.

2662 Compare s 12 subss 1 and 3 Estate Agents Act 1979.

2663 See www.gov.uk/buy-sell-your-home/offers.

2664 See ibid.

2665 The House Sales Research Paper (fn 2658) 7 states 33\% of buyers and 46\% of sellers were concerned about the other party changing their mind about the transaction.

2666 Only $2 \%$ or sellers but $18 \%$ of buyers change their asking/bidding price after an offer has been made, see House Sales Research Paper (fn 2658) 7.

2667 See ss 12 subss 1-2, 13 Estate Agents Act 1979 and Halsbury's Laws Vol 23 (fn 729) para 2. 


\section{The Legal Requirements for a Contract Concerning Real Estate}

The formal requirements for contracts have already been discussed separately for each country in Sections B.II.3.b., B.III.3.b. and C.IV.1.b. above. The focus in this section will therefore be on contrasting the main form used for conveyances of real estate in England, Germany, and Japan while pointing out some aspects from legal practice. It is in this respect that we encounter the strongest divergences between the three countries' laws. This is due to the fact that while English and German law require formal documents, namely, a deed and a notarial deed (notarielle Urkunde) respectively, sale contracts of real estate in Japan are concluded only in writing. Moreover, German law requires that the change in property rights be entered into the Grundbuch (land register, $\mathbb{S} 873$ para $1 \mathrm{BGB}$ ) in order for the transfer to become legally effective (see Section 4. below).

In England, a contract to sell real estate (an executory act) must be made in writing, while a conveyance (an executed act), ie, a transfer of the legal title (property), must be made by deed. ${ }^{2668}$ Similar to this latter requirement, a notarial deed (notarielle Urkunde) is necessary in Germany, as a notarielle Beurkundung is required under $₫ 311 \mathrm{~b}$ BGB for contracts of sale of real estate. As with the English deed, the legal requirements for this document are strict. In contrast, art 176 Minpo expressly allows a sales contract for real estate to be made consensually in Japan, free of form. Nevertheless, the parties normally opt for a written contract of their own accord for various reasons. ${ }^{2669}$ While this is true, a template form will normally be used for the contract, rather than free-text documents. ${ }^{2670}$

For real estate contracts being concluded in England, the document is drawn up by the seller (or their solicitor) and must contain the contract's terms (s 2 subs 1 LPMPA 1989), particularly, details of the contracting parties and the real estate to be sold, as well as the price or other consideration to be provided. ${ }^{2671}$ The parties must be identified through the description provided so that 'their identities cannot fairly be disputed'. ${ }^{2672}$ As for the contract's content, information of the contractual object might include

2668 Contrast ss 2 LPMPA 1989 and 52 subs 1 LPA 1925. On the difference between executory and executed acts, see fn 173 above.

2669 These will not be reiterated here. See Sections C.IV.1.b. and 2.b.-c. above.

2670 Compare Kaiser (fn 1976) para 57.

2671 See www.gov.uk/buy-sell-your-home/transferring-ownership-conveyancing and Halsbury's Laws Vol 23 (fn 729) para 37. On identifying the property sufficiently, see Halsbury's, ibid, para 39.

2672 Halsbury's Laws Vol 23 (fn 729) para 38. 
a description of the property boundaries, a list of fixtures and fittings included in the sale, how the building is serviced (water, gas, drainage, etc), notice of encumbrances on the land, such as public footpaths, and planning restrictions. ${ }^{2673}$ If no statement as to the completion of the transaction is made in the document, a reasonable period may be implied by law. ${ }^{2674}$ A peculiarity of the English deed is that it needs to be intended as a deed, be signed by the parties in the presence of a witness, and be executed and delivered (s 1 subss 2 and 3 LPMPA 1989). ${ }^{2675}$

These requirements are not dissimilar to those of a German notarial deed, since the Niederschrift must identify the parties and the notary clearly so as to avoid confusion with other persons and state the date and time of the authentication ( $\$ 9$ BeurkG). Furthermore, it will describe the contract's object, the real estate. The document will be drafted and executed by the Notar and signed by the notary and the parties after the document is read out and approved by the latter (compare $₫ 13$ para 1 BeurkG). ${ }^{2676}$

\section{The Professional Parties Involved in a Real Estate Transaction}

As has been alluded to above, the contracting parties will normally be aided by a number of different (legal) professionals when concluding a contract. This is particularly true for conveyances of real estate, because these transactions are subject to the most stringent form requirements at least under English and German law. That said, at times the contracting parties themselves will also be professionals. This is particularly true where a building that is to be sold has been newly-developed. In this situation, the seller may be the developer, as is normally the case in Japan, ${ }^{2677}$ or a real estate agent, acting on behalf of either of the parties. This section will explore those professionals supporting the contracting parties and their roles in more detail. Where similar types of professionals exist in any of the three countries, these will be grouped together.

2673 www.gov.uk/buy-sell-your-home/transferring-ownership-conveyancing.

2674 See Halsbury's Laws Vol 23 (fn 729) para 37.

2675 On these requirements, see further Section B.II.3.b.iii. above.

2676 For further details of this process, see Section B.III.3.b.iii.cc) above.

2677 See Section 2. above. 
a. The Role of Solicitors, Rechtsanwälte, and Bengo-shi (弁護士)

In Germany and England, Rechtsanwälte and solicitors have active roles in real estate transactions, whereas bengo-shi (弁護士) in Japan are not regularly consulted by individuals during negotiations to or drafting of contracts. Rather than being part of these processes directly, they will work behind the scenes in most cases and only become involved directly in matters of litigation. ${ }^{2678}$ Instead, the Japanese estate agent (see Section c. below) is very active in Japanese real estate transactions. In contrast, German lawyers will negotiate and therefore shape the content of the contract of sale, while informing their client on their rights and duties at the same time. In terms of their function, the English solicitor could be said to be a blend of the German Rechtsanwalt and the Notar: Not only will they negotiate the contract, but will furthermore furnish the documents (including the deed) necessary to effect the transfer and apply for the change in ownership at the Land Register - the latter of which is something that a Notar in Germany will do (see below). The solicitor can therefore be said to be the professional of most importance in English transactions on real estate, while German and even more so Japanese lawyers only play a marginal role.

\section{b. The Role of Notaries Public, Notare, and Köshō-nin (公証人)}

It is the German Notar who plays a central role in German sales of real estate. This is not only due to the fact that German law requires a notarial authentication for the sale contract's form, but also because they will handle the registration of the ownership change at the German land register. In accordance with their function, notaries are obliged under $\mathbb{\$} 10$ para 1 BeurkG to establish the identities of the parties and must record

2678 See Gray (fn 1633) 110, 101. For some statistical data from 1983, see ibid 110: Over $50 \%$ of lawyers questioned about their participation in contract negotiations replied that they were seldom or not at all involved directly, although $80 \%$ stated that they had often been involved 'behind the scenes'. Note that the same is not true for Japanese lawyers employed in companies or banks: they seem to be involved in the drafting process regularly. See ibid 111, giving $86 \%$ as the statistical number in his survey. While this data is old, the information can nevertheless be seen as essentially being true, as the practice has not generally changed much in this respect. This will become apparent in the following discussion. 
the method of identification in the Urkunde ( $\mathbb{1 0}$ para 3 BeurkG), ie, whether the person(s) is or are known to them personally, or what kind of document is used for the identification (passport, driver's licence, etc). ${ }^{2679}$ This function of the notary lends (legal) certainty to the transaction, as the verification of the parties' identities and recording of their details (name, date of birth, place of residence $)^{2680}$ is made by a third party, who needs to take particular care in doing so. ${ }^{2681}$ They will also advise the parties on particular points of law during the authentication (compare $\$ 17$ BeurkG) and make the application to the German Grundbuch to reflect the change in ownership. ${ }^{2682}$

In contrast, Japanese and English notaries (köshö-nin, 公証人; notaries public) are not involved in the sale of real estate. This may be a consequence of the fact that no notarial form is prescribed in Japanese and English law for such (or any) contracts; however, a köshö-nin may become involved where the transaction is not a sale, but a gift of real estate. ${ }^{2683}$ In the case of English notaries public, it will also be related to their general function: Notaries public are not usually involved in drafting or authenticating documents for domestic purposes, but rather for use

2679 Contrast the requirements under the Gesetz über das Aufspüren von Gewinnen aus schweren Straftaten [Law on Tracing of Profits from Serious Criminal Offences] of 23 June 2017, also known as Geldwäschegesetz, BGBl 2017 I 1822. See on the requirements under the 2008-version Otto (fn 1342) 8, 9-10. A concise general overview over the law in German and English can further be found at http://plattform-compliance.de/uebersetzungen-g-k/gwg-englische-uebersetzung-des-geldwaeschegesetzes-2/.

2680 Note that $\$ 10$ BeurkG does not specify the details or method of identification; para 3 merely requires that 'die Person der Beteiligten so genau bezeichnet werden, daß Zweifel und Verwechslungen ausgeschlossen sind' (the parties involved be identified as precisely as possible in order to avoid doubts or mistakes as to the person; translation by this author).

2681 cf Otto (fn 1342) 8. Where identification is not possible, the notary may nevertheless proceed with the recording if this is requested by the parties. In such cases, the non-verification of a party's identy must be stated in the Urkunde ( $\mathbb{S} 10$ para 3 BeurkG); however, the verification may be made later and a corresponding note be affixed to the Urkunde by the notary. See ibid 9.

2682 Compare Kaiser (fn 1976) 701 para 48. For further details on the notarial authentication, see Section B.III.3.b.iii.cc) above.

2683 See Kaiser (fn 1976) 701 para 48. 
abroad, although this may include a sale of real estate located outside England. ${ }^{2684}$

\section{c. The Role of Real Estate Agents, Immobilienmakler, and Fudō-san-ya (不動産屋)}

Real Estate Agents (Immobilienmakler in German; fudō-san-ya (不動産屋) or fudo-san gyösha (不動産業者) in Japanese ${ }^{2685}$ ) are involved in the conveyance of real estate to a different extent in each country. It is true to say that they are central to the conveyancing process in Japan, while this is not so in England or Germany. Nevertheless, their role will always be one of an intermediary, including bringing together potential buyers and potential sellers. ${ }^{2686}$ Other tasks, as discussed, are the advertising of the object, providing information to interested persons, and organising viewings, sometimes also the negotiation of the contract terms. ${ }^{2687}$ In Japan, the agent also has other important functions. One is to act as a witness upon the conclusion of the contract by sealing the document in addition to the parties. $^{2688}$ This seems to be a task that is unique to Japan, as there is no mention of German or English agents acting in this function.

A perhaps more important function is the obligation to explain particular matters to the party who is not the agent's principal (hereinafter 'other party'), as provided in art 35 para 1 Takuchi-gy $\overline{0}-\bar{h} \overline{0}$. These encompass details of the real estate and their owner, planning restrictions, as well as the condition of service facilities such as electricity and water (ibid subparas ivi). They further comprise contractual matters, such as monetary payments other than the purchase price, including tetsuke (ibid subparas vii, $\mathrm{x}$-xii), and explaining regulations such as penalty clauses and how to cancel the

2684 Compare www.thenotariessociety.org.uk/pages/the-notarial-profession. For a range of examples of the notaries publics' tasks, see www.thenotariessociety.org.uk/pages/what-a-notary-does.

2685 See the respective entries in Götze, 'Rechtswörterbuch' (fn 10) 71.

2686 Compare personal interview with Mika Yokoyama, Professor, Faculty of Law, University of Kyōto (Kyōto, 7 September 2016) for Japan, s 1 subs (1)(a) Estate Agents Act 1979 for England, and Hamm and Schwerdtner (fn 2658) 1 para 1 and 4 para 12 for Germany.

2687 For Germany, compare Hamm and Schwerdtner (fn 2658) 1 para 1, 4 para 12. For Japan, see Kaiser and Pawlita (fn 2086) 178. For England, see https://targetjobs.co.uk/careers-advice/job-descriptions/279481-estate-agentjob-description.

2688 See Kaiser and Pawlita (fn 2086) 178. 
contract, (ibid subparas viii-ix). This information must be provided in writing, in a document sealed by the seller (ibid paras 1, 5). It seems that while an estate agent in England or Germany normally will provide information on the property and perhaps particular contractual aspects to the other party in the course of their work, they are under no legal obligation to do so. This is not to be confused with the information duties to their principal. Thus, agents must provide information about themselves and their services to potential principals prior to concluding a contract with them. ${ }^{2689}$ Further similar duties arise from the fiduciary relationship (in German: Treueverhältnis) between agent and principal. ${ }^{2690}$

Another important obligation of the fudo-san-ya is the provision of a document, after the conclusion of the contract, to the buyer that is sealed by the seller and contains the most important terms of the sales contract, such as the parties' personal data, a description of the object for sale, the purchase price, the time of delivery of the real estate, the time frame of registering the change in ownership, the possibility to cancel the contract, any liquidated damages or contractual penalties, and the regulation of liability in cases of force majeure and the payment of taxes (see art 37 paras 1 and 3 Takuchi-gyō-hö).

\section{d. The Role of Shihō shoshi (司法書士, Judicial Scriveners)}

Beside bengo-shi and koshö-nin, a third important profession had existed in Japan since the beginning of the Meiji era to support the administration of legal Justice: shiho shoshi (司法書士, judicial scriveners). ${ }^{2691}$ They have a legal qualification, as they need to pass a state examination (国家試験,

2689 See Daniel Greenberg, Estate Agents (Westlaw UK Insight, 19 November 2018) for England and $\ 2$ para 1 Dienstleistungs-Informationspflichten-Verordnung [Ordinance on the Information Duties in Services] of 12 March 2010, BGBl 2010 I 267 for Germany. Note that for the latter, $\$ 5$ TMG may apply to electronic communication and websites.

2690 For England, see Goode and McKendrick (fn 48) 190-192. For Gemany, see Hamm and Schwerdtner (fn 2658) 81-89 with details on the agent's duties to provide information (Aufklärungspflicht), give advice (Beratungspflicht), and to refrain from certain conduct (Unterlassungspflicht).

2691 For details of the historical development since their establishment in 1872 as scribes (daisho-nin, 代書人), see the website of the Japan Federation of Shiho Shoshi's Associations (日本司法書士会連合会, Nihon Shihō Shoshi-kai Rengōkai) at www.shiho-shoshi.or.jp/consulting/history.html, where it is noted that the denomination was changed to shiho shoshi in 1935. 
kokka shiken) set by the Hömu-sho that tests a candidate's knowledge in constitutional, private, and commercial law, as well as in relation to the registration of real estate or companies, amongst other things. ${ }^{2692}$ In accordance with this knowledge, their tasks are geared towards 'contributing to the proper and smooth implementation of procedures concerning registration, deposits, and litigation' (art 1 Shihō shoshi-hō, Judicial Scriveners Act, 司法書士法 2693).2694 Their work encompasses preparing documents that are to be submitted to the (District) Legal Affairs Bureau or the courts (see art 3 paras 2, 4 Shiho shoshi-hō), apply for registrations in registration offices in relation to real estate or companies (ibid para 1), give legal advice on the aforementioned (ibid para 5), ${ }^{2695}$ and, since 2002, they may represent persons in civil litigation in summary courts. ${ }^{2696}$ Their role may thus be equated to that of an English solicitor, although the tasks of the latter are wider in scope. ${ }^{2697}$

In conveyancing practice, a shibō shoshi will be involved closely in the drafting of documents for and the registration of the change in property rights over real estate in the Japanese land or building register. ${ }^{2698}$ It seems

2692 See www.shiho-shoshi.or.jp/consulting/exam.html for further information on this exam. See also Tanaka and Smith (fn 2) 563, who give a brief overview of the qualification process.

2693 Law No 197/1950 as amended.

2694 The whole provision reads: この法律は、司法書士の制度を定め、その業務の適正を図ることにより、 登記、供託及び訴訟等に関する手続の適正かつ円滑な実施に資し、もつて 国民の権利の保護に寄与することを目的とする。

Kono höritsu ha, shihō shoshi no seido wo sadame, sono gyömu no tekisei wo hakaru koto ni yori, tōki, kyōtaku oyobi soshō-tō ni kansuru tetsuzuki no tekisei katsu enkatsuna jisshi ni shishi, motte kokumin no kenri no hogo ni kiyosuru koto wo mokuteki to suru.

This Act establishes a system for judicial scriveners and contributes to the proper and smooth implementation of procedures concerning registration, deposits, and litigation etc, thereby contributing to the protection of citizens' rights.

2695 Tanaka and Smith (fn 2) 563, who go on to note that shibo shoshi practically take on the role of a lawyer in areas of Japan in which a shortage of bengo-shi, such as villages, exists.

2696 Judicial scriverners need to obtain an additional certification for this. See www.shiho-shoshi.or.jp/html/global/english/index.html and art 3 para 6 et seq Shibō shoshi-hö.

2697 Compare the succinct description by The Law Society at www.lawsociety.org.uk/law-careers/becoming-a-solicitor/.

2698 See Kaiser (fn 1976) para 46. See also Tanaka and Smith (fn 2) 563; Kaiser and Pawlita (fn 2086) 178; Rokumoto, 'Institutionen' (fn 1638) para 72. 
that they and the fudo-san-ya are even present when the balance of the purchase price is paid. ${ }^{2699}$ This further underlines the scrivener's importance in a Japanese transaction in relation to real estate.

2699 See Kaiser and Pawlita (fn 2086) 178. 


\section{E. Results of the Comparative Analysis Contrasted and Final Conclusions}

This section is dedicated to synthesising the results of the comparative analysis. It goes a step further, however, by first juxtaposing the findings from the previous section against two legal dimensions: On the international level, the provisions on the formation of contract contained in the United Nations Convention on Contracts for the International Sale of Goods ('CISG') are compared (Section I). On the supra-national level, the remarkable endeavours by various parties to create a European legal contractual framework in the form of the Common European Sales Law ('CESL'), the Draft Common Frame of Reference for European Contract Law ('DCFR'), and the Principles of European Contract Law ('PECL') will be contrasted (Section II.). These juxtapositions will allow final conclusions to be made on the points of similarity and difference existing in the three domestic laws (Section III.).

\section{Results of the Comparative Analysis Juxtaposed with the International Perspective: The CISG}

The United Nations Convention on Contracts for the International Sale of Goods ('CISG') was adopted by eleven countries in Vienna in $1980 .{ }^{2700}$ Since then, the number of parties to the treaty has increased to a total of 91 as of August 2019,2701 including Germany and Japan, but not the

2700 For details on the historical development of the CISG, see the Introduction of the CISG Explanatory Note (fn 162) paras 1-5. A succinct account of the production of the CISG's rules on contract formation is given by Mortem M Fogt, Contract Formation under the CISG: The Need for a Reform, in: Larry A DiMatteo (ed), International Sales Law: A Global Challenge (CUP 2014) 179, 197-199. See further Franco Ferrari and Clayton P Gillette, Introduction, in: ibid (eds), International Sales Law Vol 1 (Edward Elgar Publishing, 2017) xiii. See also the commentary on the CISG's drafting by Hubner (fn 109) 414-416.

2701 The status of the convention can be found online at https://treaties.un.org/ Pages/ViewDetails.aspx?src=IND\&mtdsg_no=X-10\&chapter=10\&clang=_en. 
UK. ${ }^{2702}$ This number alone indicates the CISG's potential importance in international trade of goods. ${ }^{2703}$ After a brief note on the Treaty's sphere of application (Section 1.), the rules on the formation of contract will be given attention (Section 2.). The content of these provisions will be contrasted directly with the comparative results from Section D.

\section{The Sphere of Application of the CISG: International Sale of Goods}

As its name indicates, the CISG applies to international contracts for the sale of goods. 'International' necessitates that the 'place of business' of the parties be in different countries; which must, moreover, be Contracting States of the Convention (see arts 1 para a, 100 para 2 CISG). ${ }^{2704}$ 'Sale of

2702 The (non-)accession of this convention was discussed already for earch country in Sections B.I.2.b.v., C.I.2.d., and B.I.2.a.v. above respectively.

2703 It has been remarked that the Treaty is theoretically applicable to 'up to two thirds of all such trade, see Stefan Kröll and Loukas Mistelis and Pilar Perales Viscasillas, UN Convention on Contracts for the International Sale of Goods (CISG): A Commentary ( $2^{\text {nd }}$ online edn, CH Beck 2018) foreword. cf Ingeborg Schwenzer, Introduction, in: Peter Schlechtriem and ibid (eds), Commentary on the UN Convention on the International Sale of Goods (CISG) ( $^{\text {th }}$ edn, OUP 2016) 1, giving a figure of over $80 \%$. Indeed, it seems that the CISG - in contrast to the ULFC - has been accepted in the Contracting States, compare on this Schwenzer, ibid 6. On the Convention's success, see further Peter H Schlechtriem, 25 Years of the CISG: An International Lingua Franca for Drafting Uniform Laws, Legal Principles, Domestic Legislation and Transnational Contracts, re-printed in: Ferrari and Gillette (fn 2700) 44-64, who notes that the treaty has influenced other inter- and transnational projects (see Section III. below), EU law, and even domestic law. Indeed, Schwenzer, ibid 10 notes that the CISG has influenced reforms of the German and Japanese law of obligations. For an overview of the latter, see Takashi Kubota, Sankō: Saiken-hō kaisei tei'an to CISG no sōi [Reference: The Differences Between the Proposal for the Reform of the Law of Obligations and the CISG], in: Sugiura and ibid (fn 1639) 16, 18-21.

2704 A clarification of the term 'place of business' is found in art 10 CISG. Having said that the countries need to be Contracting States, art 1 para b provides that the CISG can also be applicable if the conflict of law rules of a country - arguably not necessarily a Contracting State, compare Ingeborg Schwenzer and Pascal Hachem, Part I. Sphere of Application, in: Schlechtriem and Schwenzer (fn 2703) on art 1 at 29 para 3 - 'lead to the law of a Contracting State'. See CISG Explanatory Note (fn 162) para 7, where it is also stated that the Convention may apply, furthermore, where the parties choose to make it the law applicable to their contract. Readers interested in the issue of private international law are referred to Franco Ferrari, PIL and CISG: Friend or Foes?, 
goods' is interpreted to mean 'reciprocal contracts directed at the exchange of goods against the "price", so that the CISG governs sales by sample or by instalments but probably not barters. ${ }^{2705}$ Nevertheless, service contracts are not wholly excluded from the Treaty: In accordance with art 3 CISG, contracts for the 'supply of goods to be manufactured or produced' are deemed to be sales agreements, as long as the manufacturer supplies the necessary materials, or at least the majority part; similarly, the seller's obligations may include service or labour and the transaction will still be qualified as a sale, unless these obligations make up 'the preponderant part'. ${ }^{2706}$ Thus, a contract may involve, say, the carriage of goods and nevertheless be deemed as a sale. ${ }^{2707}$ Even where a contract is for an international sale, the treaty is not always automatically applicable, however, as its operation is restricted in a number of circumstances.

On the one hand, the CISG limits its sphere of application by excluding particular matters (see arts 2-5). Of particular interest to the discussion in this dissertation is the fact that particular kinds of transactions are excluded: sales by auction ${ }^{2708}$, purchases for 'personal use', or where the sale is of commercial instruments, company shares, ships and aircraft, among others (see art 2 CISG). ${ }^{2709}$ As a consequence, consumer contracts will usually not

re-printed in: ibid and Clayton P Gillette (eds), International Sales Law Vol 1 (Edward Elgar Publishing, 2017) 113-175.

2705 See Schwenzer and Hachem (fn 2704) on art 1 at 30 paras 8-9. On barter, compare ibid 31-32 para 11, where it is argued that barter should fall within the Convention's scope. cf Loukas Mistelis, CISG Art 1, in: Kröll and Mistelis and Viscasillas ( $\mathrm{fn} 2703$ ) para 25, speaking of 'money' being paid in exchange for goods and rejecting barter as within the CISG's scope in para 30, but allowing instalment sales in para 26.

2706 For a discussion of the meaning of these provisions, see Schwenzer and Hachem (fn 2704) on art 3 at 61-72 paras e et seq, pointing out that the term 'substantial' is interpreted by taking into account the volume, value, and importance of the materials for the end-product, whereas 'preponderant' is deemed to mean more than $50 \%$ of the economic value of the contract.

2707 See Schwenzer and Hachem (fn 2704) on art 1 at 30 para 9. For further kinds of agreements that are not covered by the treaty, see Mistelis ( $\mathrm{fn} 2705$ ) paras $32-35$.

2708 It ought to be noted that auctions conducted online are said to be within the CISG's scope, see Ulrich G Schroeter, Part II: Formation of the Contract, in: Schlechtriem and Schwenzer (fn 2703) in the introductory remarks at 223, 251 para 54. See also Schwenzer and Hachem (fn 2704) on art 2 at 55 para 21.

2709 See Henry Mather, Choice of Law for International Sales Issues not Resolved by the CISG, re-printed in: Franco Ferrari and Clayton P Gillette (eds), International Sales Law Vol 1 (Edward Elgar Publishing, 2017) 362. The simple explanation given in the CISG Explanatory Note (fn 162) para 10 for these exclusions 
be governed by this convention, but by domestic law. ${ }^{2710}$ Apart from this exclusion, the sale transactions need not necessarily be of a commercial nature; they can be 'civil', ie, private, as long as consumers are not involved and the intended purpose of the goods is for business use. ${ }^{2711}$

This leads to the question of the interpretation of the term 'goods', as no explicit definition is given in the CISG. While the Convention apparently does not define goods in terms of movable and immovable, or tangible and intangible objects, there is no dispute between commentators that tangible goods are within the treaty's scope. ${ }^{2712}$ These need to be movable, but can be new or used, alive or inanimate. ${ }^{2713}$ Thus, livestock, pharmaceuticals, and cultural items are all goods within the meaning of the CISG. ${ }^{2714}$ Conversely, the Convention does not apply to immovable or real property. ${ }^{2715}$ Furthermore, sales of incorporeal objects, including intellectual property, know-how, rights, and businesses or companies, would not be a sale of goods for the purpose of the CISG. ${ }^{2716}$

One recent issue in this regard is software. While not contemplated by the Convention, it has been suggested that contracts for digital goods, such as software, ought to fall within the scope of the CISG. ${ }^{2717}$ In summary, the arguments put forward were that the meaning of 'goods' under the CISG can encompass incorporeal things like software, although it is

is that sale contracts on these objects are often 'governed by special rules reflecting their special nature'.

2710 On the possibility of the CISG being applicable in relation to consumers, see Ferrari, 'PIL and CISG' (fn 2704) 133-134. Schwenzer (fn 2703) 5 notes the reason for this exclusion to be that consumer law is not dispositive but mandatory law.

2711 See Schwenzer and Hachem (fn 2704) on art 1 at 29 para 6, 45-46 paras 47-48, and on art 2 at 48-49 para 4. See also Mistelis (fn 2705) paras 15-16.

2712 See, eg, Mistelis (fn 2705) paras 36, 26; Schwenzer and Hachem (fn 2704) on art 1 at 33-34 para 16.

2713 On moveability, see Schwenzer and Hachem (fn 2704) on art 1 at 34 para 17. On the latter aspects, see Mistelis (fn 2705) para 37.

2714 Schwenzer and Hachem (fn 2704) on art 1 at 33-34 para 16.

2715 Mistelis (fn 2705) para 39.

2716 For further discussion, see Mistelis (fn 2705) paras 38-39, 41 and Schwenzer and Hachem (fn 2704) on art 1 at 35-36 paras 19-22.

2717 See, eg, Mirjam Eggen, Digitale Inhalte unter dem CISG: Eine Rundschau über Herausforderungen und mögliche Lösungen [Digital Contents under the CISG: An Overview of the Challenges and Possible Solutions] (2017) Internationales Handelsrecht (IHR) 229-237. Supporting: Schwenzer and Hachem (fn 2704) on art 1 at 34 para 18; Saidov and Green (fn 111). More reserved: Mistelis (fn 2705) para 40. 
uncertain whether the same is true for digital copies of music, videos, or texts. ${ }^{2718}$ Consequently, contracts concerning software ought to be governed by the CISG, provided that the contract is an exchange of money and such digital goods. ${ }^{2719}$ This result is the same under German law: While academic opinion is divided on whether software can be classified as a Sache (thing), sales law is nevertheless applied to contracts over it. ${ }^{2720}$ In contrast, it seems that a physical device (carrier) is required for software under Japanese and English law, as data or software by itself is not considered to be a thing capable of being the object of rights and thus to constitute goods. 2721

On the other hand, the CISG's function is restricted because the Convention allows the parties to exclude its application, or to stipulate provisions deviating from its rules (see art 6 CISG). While this gives the parties freedom in contracting, ${ }^{2722}$ it also means that the CISG may not be applied even where a contract is an international sale of goods. This principle of derogability is shared with Japanese, German, and English private law: Apart from mandatory rules concerning consumers or form, the basic provisions on the formation of contracts can be replaced by stipulations agreed between the parties. ${ }^{2723}$

2718 See Eggen (fn 2717) 230-231, who notes that individually-created software might also be outside the CISG's scope, as the agreement may constitute a work contract (see subsequent fn).

2719 This poses a problem with software that is created individually rather then being mass-produced, as the contract in such cases will be deemed to be a work contract (Werkvertrag), rather than one of sale of goods. See on this Eggen (fn 2717) 231-233, who goes on to considers whether cryptocurrency, like Bitcoin, can be accepted as payment under the CISG and concludes that it can, see ibid 235-236. of Schwenzer and Hachem (fn 2704) on art 3 at 62 para 3 , according to whom a 'sale of standard and customized software' are to be treated in the same way.

2720 See Section B.III.3.b.i. above.

2721 On Japanese law, see Section C.IV.1.b.i. above. On English law, see Section B.II.3.b.i. above.

2722 See CISG Explanatory Note (fn 162) para 12, indicating how the CISG's provisions may be derogated from. See also Fogt (fn 2700) 199, stating party autonomy to be one of the CISG's principles.

2723 On the dispositiveness of the domestic legal provisions, see Sections C.IV.1., B.III.2.b., and B.II.3. above respectively. 


\section{E. Results of the Comparative Analysis Contrasted and Final Conclusions}

Taken together, these exceptions mean that the CISG does not contain a comprehensive regulation of sale of goods contracts. ${ }^{2724}$ Rather, it is a Convention that regulates selected aspects of a particular kind of international contract. Nevertheless, the convention's rules on the formation of such sale contracts are of great comparative interest and important for this work.

\section{The Formation of Contract under the CISG: Offer and Acceptance, no} Form

The CISG does not contain a definition of the term 'contract'; however, the notion that is presupposed is of a bi- or multilateral agreement. ${ }^{2725}$ The Convention adopts the offer-and-acceptance model as its contract conclusion mechanism, just like the contract laws of England, Germany, and Japan. ${ }^{2726}$ Consequently, an international contract for the sale of goods under the CISG is usually formed once an offer has been accepted. In contrast to English, German, and Japanese law, this principle is explicit in art 23 CISG, which determines the exact point in time of the contract's conclusion as that of the declaration of acceptance becoming effective. ${ }^{2727}$ Nevertheless, the offer-and-acceptance model is not the only way in which contracts may be concluded. An agreement between the parties is deemed sufficient, so that the elements of offer and acceptance need not always be identifiable. ${ }^{2728}$ Accordingly, an exchange of correspondence or other

2724 See Ferrari, 'PIL and CISG' (fn 2704) 151. Fogt (fn 2700) 199, 201-202 rightly describes the rules as fragmented and advocates a reform of the scope of these rules to decrease 'uncertainty and national discrepancies'.

2725 Compare Sono (fn 1640) 2, speaking of 'contract' (keiyaku, 契約) as agreement ( $g$ oi $i$, 合意) between the parties.

2726 See Section D.II. above. On Japanese law, see also Sono (fn 1640) 10; Yasutomo Sugiura, Dai-2-bu keiyaku no seiritsu [Part II Formation of Contracts], in: ibid and Kubota (fn 1639) 60.

2727 See also CISG Explanatory Note (fn 162) para 17. Schroeter (fn 2708) on art 18 at 341 para 22 states the contract to be 'perfected only when acceptance' is made effectively. After the reform of the Japanese law of obligations has come into force, an explicit provision of this principle will also be found in Japanese law. See on this Section C.V.3.b. above.

2728 See Ferrari and Gillette (fn 2700) xvii. According to Fogt (fn 2700) 187, a consensus between the parties is required, ie, 'a common intention to contract' on the same terms. 
forms of negotiations can lead to a contract being concluded under the CISG, as long as the contract's basic terms are discernible. ${ }^{2729}$

The preceding arts 14-22 CISG set out the rules concerning the declarations of offer and acceptance and their effectiveness. These matters will be considered in the subsequent sections. First, the definition of an offer and the distinction between offers and invitations to make an offer will be explored in Section a. This is followed by a description of the element of acceptance in Section b. The third section (c.) will consider the issue of when declarations of offer and acceptance come into effect and how they may lose their effectiveness, before the question of form is addressed in Section d.

\section{a. Offers}

The regulation of the declaration of an offer is found in arts 14-17 CISG and largely corresponds to the provisions under English, German, and Japanese law. This is true for the definition of offers and the distinction with non-binding statements (see Section i. below), as well as its requirements (Section ii.).

2729 On this, see Schroeter (fn 2708) in the introductory remarks at 240-241 paras 32-34, 248 para 49. For examples of other mechanisms, see ibid 247 paras 47-48. On the basic contract terms, see the subsequent section (a.). In Hanwha Corporation $v$ Cedar Petrochemicals Inc, decision of the Southern District Court of New York on 18 January 2011, 09 Civ 10559 (available online at http:// cisgw3.law.pace.edu/cases/110118u1.html), the parties concluded contracts in a 'two-step process'. In the first step, the plaintiff submitted a 'bid' for a specific quantity of a named product at a given price. If this was acceptable to the defendant, a 'firm bid' was formed, ie, an agreement on the goods, price, and quantity. In a second step, signed contract documents 'set[ting] forth the entire agreement' would be provided by the defendant to the plaintiff, which the latter would either counter-sign and thus accept, modify and sign, or not sign. The court found no contract to have been concluded since the parties did not agree on the terms of the contract, namely, the choice of law clause, in the second step of their contracting process. Another contracting process is the ordering (Order) by the German purchaser and the order confirmation (Auftragsbestätigung) by the Danish seller, see OLG Dresden decision of 30 November 2010, 10 U 0269/10, Internationales Handelsrecht (IHR) 2011, 142-145, available online at www.cisg-online.ch/content/api/cisg/display.cfm? test $=2183$, para 1 . This case will be discussed further below. 


\section{E. Results of the Comparative Analysis Contrasted and Final Conclusions}

\section{i. 'Offer' Defined and Distinction from Invitations to Make an Offer}

Like the domestic laws investigated in this dissertation, the CISG differs between statements that lead to a contract being concluded and non-binding statements. An offer is defined in art 14 para 1 CISG as

[a] proposal for concluding a contract addressed to one or more specific persons $[\ldots]$ if it is sufficiently definite and indicates the intention of the offeror to be bound.

The term 'offer' need not be used; other denominations, including 'invoice' or 'letter of confirmation', are admissible. ${ }^{2730}$ This definition and the required elements are therefore the same as under Japanese, German, and English law. 2731

One basic point on which the CISG differs from the three domestic laws is on whether the offeree(s) must be specific. Under the Convention, a proposal that is not directed at specific persons but is addressed to the world at large will constitute an 'invitation to make an offer' by default, unless the proposal indicates the offeror's intention to be bound (compare art 14 para 2 CISG). The dividing line between specific and nonspecific persons can be a fine one: It seems that where the offeror 'has a clear idea of the persons addressed', a statement made to a group of persons as a whole may be deemed to be an offer. ${ }^{2732}$ In other words, the addressee(s) need to be ascertainable at least. ${ }^{2733}$ The offeror's intention to be bound is apparently assumed where the statement contains phrases such as 'while stocks last' or where a time frame for a response is set. ${ }^{2734}$

The situation is not necessarily the same in the three contract laws discussed earlier in this dissertation: these principally allow offers to be directed at the world at large; however, it is required that the statement

2730 Schroeter (fn 2708) on art 14 at 269 para 2. On the commercial letter of confirmation or similarly denominated letters as an offer, see further ibid in the introductory remarks at $242-243$ paras 36,39 . In this sense, the plaintiff's 'bid' in Hanwha $v$ Cedar (fn 2729) could have been an offer, as it specified the goods, the quantity, and the price; however, as the court pointed out, the plaintiff lacked the required intention to be bound, as it was customary for the parties to follow up their negotiations by documenting their contract. See fn 2729 above.

2731 For a synthesis of the definition of offers, see Section D.II.1. above.

2732 Franco Ferrari, CISG Article 14, in: Kröll and Mistelis and Viscasillas (fn 2703) para 8.

2733 Schroeter (fn 2708) on art 14 at 271 para 4.

2734 Ibid on art 14 at 287 para 32. 
be made with the intention to be bound for it to be an offer and not an invitation to treat. ${ }^{2735}$ It might be argued that the requirement is essentially the same and that it is simply phrased differently: the CISG makes invitations to treat to an indefinite number of persons the default rule, ${ }^{2736}$ and thus favours an interpretation as an invitatio, while Japanese, German, and English law proceed from the stand point that statements to the world can be offers. Having said this, the CISG's provisions do allow an offer to be addressed to one or several persons that are specified (see art 14 para 1), which is the same under the three domestic laws. Indeed, the cases that are seen as mere invitations to make an offer are the same under the three domestic laws and the Convention: Advertisements (in newspapers, per email, online, on tv or radio), including prospectuses, catalogues, and price lists all count as invitations to treat. ${ }^{2737}$ In the end, the practical difference seems to be a small one.

Beside invitations to make an offer, other non-binding statements such as those made in negotiations, enquiries, or by giving information, must be contrasted with offers under the CISG regime and English, German, and Japanese law, whereby the latter need to be differentiated based on whether the statement maker has an intention to be bound. ${ }^{2738}$ This aspect is considered below.

\section{ii. Requirements of Offers: Certainty of Terms and Intention}

In terms of the degree of certainty that is required under the CISG, an offer must contain the basic terms of the agreement, so that acceptance brings about the contract, just like under English, German, and Japanese contract law. ${ }^{2739}$ This means that at least the goods and a mechanism to

2735 See Section D.II.1. and ibid a. above.

2736 See Giulio Giannini, The Formation of the Contract in the UN Convention on the International Sale of Goods: A Comparative Analysis, in: Ferrari and Gillette (fn 2700) 16, 19, stating that a statement will be an invitation 'in case of doubt'.

2737 On the CISG, see Ferrari, 'CISG Article 14' (fn 2732) para 8. Compare Schroeter (fn 2708) on art 14 at 284-285 paras $29-30$ and 286-287 paras 32-33, who notes that such statements can amount to offers in certain circumstances. On the three domestic laws, see Section D.II.1.a.ii. above.

2738 On the three domestic laws, see Section D.II.1.a. above. On the CISG, see Fogt (fn 2700) 194.

2739 See Schroeter (fn 2708) on art 14 at 270 para 3. In the OLG Dresden decision of 30 November 2010 (fn 2729) para 37, the purchaser's e-mail called 'order' contained details on the goods, their quantity, size, the price, and a binding 


\section{E. Results of the Comparative Analysis Contrasted and Final Conclusions}

determine the price and quantity must be stipulated (art 14 para 1 CISG). Accordingly, the exact quantity need not be specified, but can be left open and be determined by either party at a later stage. ${ }^{2740}$ Similarly, the goods can be determined by their species; or generically if the nature and type is included. ${ }^{2741}$ Consequently, it is sufficient if particular details of goods that are customised for the purchaser are left to be determined later. ${ }^{2742}$ Other contract terms, even the names of the parties, are not essential and need not be included, as the CISG makes default provisions for the parties' obligations. ${ }^{2743}$

In terms of the intention to be bound by the offer, it first ought to be noted that this intention is not related to the offer's (ir)revocability (on which, see Section c. below). ${ }^{2744}$ The intention need not be stated explicitly; phrases evidencing such an intention, like, for instance, 'while stocks last' or where a deadline for accepting the offer is set, are sufficient. ${ }^{2745}$ In contrast, phrases such as 'non-binding' or 'subject to contract' can show that there is no intention to be bound. ${ }^{2746}$ It can be generally stated that the likelihood of an intention to be bound being found is higher the more definite an offer is in the sense of meeting the CISG's requirements of containing the contract's terms and specific addressee(s). ${ }^{2747}$ Having said

date for delivery and was therefore deemed to be an offer within the meaning of the CISG by the court. On the domestic laws, see Section D.II.1.b. above. The insertion of a requirement of certainty into the Minpō had been proposed under the Japanese law reform, but this has been rejected. On this, see Sugiura, 'Dai-2-bu' (fn 2726) on art 14 at 65. See also Section C.V.3.b. above.

2740 See Fogt (fn 2700) 193.

2741 Ibid 191-192.

2742 See Schroeter (fn 2708) on art 14 at 270 para 3, giving several examples.

2743 On this, see Ferrari, 'CISG Article 14' (fn 2732) paras 17, 20. For further discussion of the required indication of the price and the goods, see ibid paras 21-36. On the determinability of the minimum terms, see also Schroeter (fn 2708) on art 14 at 272 et seq. cf Fogt (fn 2700) 188, 189, who states that art 14 para 1 CISG implicitly requires the identity of the parties to 'be evident in the offer', but does not deem this an essential term. Other terms, such as the time of performance, may of course be of essence in a particular situation, in which case the offer has to contain these terms as well, see Giannini (fn 2736) 20. See also Schroeter, ibid 271 para 5.

2744 Schroeter (fn 2708) on art 14 at 282 para 25.

2745 For further discussion, see Ferrari, 'CISG Article 14' (fn 2732) para 8.

2746 See Ferrari, ibid para 14. Schroeter (fn 2708) on art 14 at 283 para 27 notes that such 'proposals' are deemed to be mere invitations to make an offer.

2747 See Ferrari, 'CISG Article 14' (fn 2732) para 12. 
this, LOI or other similar kinds of business letters are generally treated as being non-binding. ${ }^{2748}$ This is the same in the three domestic laws. ${ }^{2749}$

\section{b. Acceptance}

The declaration of acceptance is regulated in arts 18-22 CISG. More differences come to light in this respect between the Convention and the three domestic laws. While this does not apply to the definition of acceptance and its distinction from non-binding acts and statements (Section i.), nor to its method (Section ii.), it is true for the requirement of congruency between offer and acceptance (Section iii.).

\section{i. 'Acceptance' Defined; Distinction from Other Acts and Statements}

The definition of a declaration of acceptance is found in art 18 para 1 CISG. Both an express statement to the offeror, or some 'other conduct of the offeree indicating assent', such as the offeree fulfilling their obligation (shipping of goods or payment of price, etc) is sufficient. ${ }^{2750}$ Another instance of 'other conduct' might be the offeree writing their initials or signing the document containing the offer. ${ }^{2751}$

Acceptance is contrasted with statements that do not lead to the conclusion of a contract, such as mere confirmations of having received an offer, or clarification requests. ${ }^{2752}$ Responses to offers that contain 'reservations [...] regarding individual points still to be negotiated' are not deemed

2748 On this, see Ferrari, 'CISG Article 14' (fn 2732) para 14. cf Schroeter (fn 2708) on art 14 at 284 para 28 , who states that LOI may be 'a binding preliminary agreement' in some circumstances.

2749 See Section D.II.3. above.

2750 CISG Explanatory Note (fn 162) para 20. For further examples, see Franco Ferrari, CISG Article 18, in: Kröll and Mistelis and Viscasillas (fn 2703) para 8. In essence, these constitute performance of the party's obligation or are preparatory acts of the same. According to Fogt (fn 2700) 195, the act can be undertaken upon contract conclusion or subsequently.

2751 Schroeter (fn 2708) on art 16 at 333-334 para 5. Further examples are given at ibid 336-337 para 13.

2752 See Ferrari, 'CISG Article 18' (fn 2750) para 2, who notes that the distinction is a question of interpretation under art 8 CISG. 
as declarations of acceptance. ${ }^{2753}$ This differentiation corresponds to the understanding in English, German, and Japanese law. ${ }^{2754}$

\section{ii. Method of Acceptance}

Irrespective of the method of acceptance, the assent must be communicated to the offeror, just like under English, German, and Japanese law. ${ }^{2755}$ In this regard, art 18 para 3 CISG makes it clear that a separate notice of acceptance is not required where the parties have dispensed with such an announcement through usage or 'practices which the parties have established between themselves'. ${ }^{2756}$ Explicit and implicit acceptance must be contrasted with mere '[s]ilence or inactivity', both of which is not 'in itself enough (art 18 para 1 CISG). Where silence is accompanied by other circumstances, such as some practice between the parties, silence can sometimes amount to acceptance. ${ }^{2757}$ Indeed, it might be possible to agree on silence acting as a declaration of intention, as art 9 CISG binds the parties to practices or usages that were agreed or at least (ought to have been) known to them. This is uncertain, however, as it comes down to a question of fact. ${ }^{2758}$ Therefore, while an immediate notice of acceptance to the offeror may not always be necessary, there must always be some way for the offeror to have knowledge of the offeree's reaction. ${ }^{2759}$ This treatment of mere silence is the same in the three domestic laws; however, German and Japanese law contain an exception for commercial settings. Where a merchant sends a letter of confirmation (kaufmännisches Bestätigungsschreiben), inaction by the merchant-addressee may be deemed as acceptance under German law. ${ }^{2760}$ Similarly, silence to an offer from regular business part-

2753 Schroeter (fn 2708) on art 18 at 333 para 4.

2754 On the definition and distinction with other statements, see Section D.II.2.a. above.

2755 On the Convention, see CISG Explanatory Note (fn 162) 37 para 20. On the three domestic laws, see Section D.II.2.b. above.

2756 Note that one side alone, ie, the offeror, cannot make silence or inactivity amount to acceptance, although it is possible for the offeror to waive a notice of acceptance, see Ferrari, 'CISG Article 18' (fn 2750) paras 12, 18, 20.

2757 Schroeter (fn 2708) on art 18 340-341 para 19. Interestingly, a draft version of the CISG had contained a provision admitting silence as a declaration where a practice between the parties allowed this. On this, see Fogt (fn 2700) 185, 184.

2758 See on this Rothermel and Dahmen (fn 1240) 182-183. See also fn 2756 above.

2759 Compare Ferrari, 'CISG Article 18' (fn 2750) para 10.

2760 See Section B.III.3.a.iii.bb) above. 
ners can be acceptance under Japanese commercial law. ${ }^{2761}$ The CISG does not admit silence in response to a commercial letter of confirmation to constitute implicit acceptance like under German law, unless a usage or some practice between the parties foresees otherwise. ${ }^{2762}$ As a consequence, the practical difference between the Convention's approach and German and Japanese law may not be great. ${ }^{2763}$

\section{iii. Congruence Between Offer and Acceptance}

The domestic and international rules deviate more on another point: While art 19 para 1 CISG and the three legal systems discussed above generally require acceptance to be congruent with the offer, ie, not to alter its terms, ${ }^{2764}$ the Convention nevertheless allows changes that 'do not materially alter' the offer. Where such deviating terms are not objected to by the offeror 'without undue delay', they are deemed to become part of the contract and the declaration is seen as constituting acceptance (see art 19 para 2 CISG). This approach is unknown in the three domestic laws.

The objection under art 19 para 2 is a statement - not an act - that indicates disagreement with the changes, ie, shows an intention by the offeror not to be bound by the altered terms. ${ }^{2765}$ It can be made orally or by way of a notice (ibid), so that communication by telephone, in writing or by electronic means are admissible. ${ }^{2766}$ As for the time frame in which this statement must be made, it seems that an immediate reaction is not necessary as long as the delay is not due to the offeror's fault (cf

2761 See Section C.IV.1.a.iii.bb) above.

2762 This was confirmed in the OLG Dresden decision of 30 November 2010 (fn 2729) para 40. See on this generally Franco Ferrari, CISG Article 19, in: Kröll and Mistelis and Viscasillas (fn 2703) para 17. See also ibid, 'CISG Article $18^{\prime}$ (fn 2750) para 11.

2763 See Sugiura, 'Dai-2-bu' (fn 2726) on art 18 at 81.

2764 Schroeter ( $\mathrm{fn} 2708$ ) on art 19 at 351 para 3 notes that the CISG provision "corresponds to the common law "mirror rule", as well as to $[\ldots] \mathbb{S} 150(2)$ German BGB [...]'. On the correlation with Japanese law, see Sono (fn 1640) 11-12. On the domestic laws, see Section D.II.2.b. above.

2765 Compare Ferrari, 'CISG Article 19' (fn 2754) paras 21-22. In Hanwha v Cedar (fn 2729), the court held the plaintiff's alteration of the choice of law clause to be a counter-offer that was rejected by the defendants.

2766 Schroeter ( $\mathrm{fn} 2708$ ) on art 19 at 362 para 27 also mentions radio transmission and EDI. 
art 27 CISG); ${ }^{2767}$ however, the period is short, perhaps around three days, unless the transaction requires greater speed. ${ }^{2768}$ The pertinent moment for a notice that is not made orally is its time of dispatch. ${ }^{2769}$ This approach of allowing small changes unless the offeror objects is 'strikingly different' from Japanese, German, and English law, which have no such provision. ${ }^{2770}$

Modifications that are not allowed are those that relate to the contract's essential terms like the price and payment or on the goods (art 19 para 3 CISG). Of course, the parties are free to determine that a stipulation is immaterial, or to give the offeree discretion to propose a different term. ${ }^{2771}$ Moreover, the enumeration found in art 19 para 3 CISG is not exhaustive and, furthermore, constitutes a rebuttable presumption. It therefore becomes a question of interpretation in each case whether the change in a term is material within the meaning of this provision. ${ }^{2772}$

The consequence of a material alteration is that the purported declaration of acceptance is seen as 'a rejection of the offer and constitutes a counter-offer' (art 19 para 1 CISG) that must be accepted by the original offeror. ${ }^{2773}$ Here the identity with the three domestic laws reappears: English, German, and Japanese law also deem acceptance altering an offer to constitute a counter-offer. ${ }^{2774}$ This is not true where the declaration makes terms explicit that are either implicit in the offer or are default provisions by some usage, the Convention, or domestic law; neither case

2767 See Ferrari, 'CISG Article 19' (fn 2754) para 23.

2768 See Schroeter (fn 2708) on art 19 at 362 para 28.

2769 See ibid at 363 para 28 . Note that the objection, unlike other declarations of intention (see Section c.i. below), becomes effective upon its dispatch.

2770 Sugiura, 'Dai-2-bu' (fn 2726) on art 19 at 85 on Japanese law ('著しく異なる', ichijirushiku kotonaru). The proposal to amend the rule in art 528 Minpo and include the qualification of an 'essential change' (事実的変更, jijitsuteki henkō) under the Japanese law reform was not taken up. On this, see ibid 86 and Kubota, 'Sankō' (fn 2703) 16. See also Minpō Provision Comparison (fn 2240) 102 , where no changes to art 528 are listed.

2771 See Schroeter (fn 2708) on art 19 at 356-357 para 15.

2772 On this, see Ferrari, 'CISG Article 19' (fn 2754) para 10. Factors of importance might be the contract's other terms, as well as the economic circumstances or whether the change benefits the offeror, see ibid para 13. A range of examples of material and immaterial alterations is given by Schroeter ( $\mathrm{fn} 2708$ ) on art 19 at 358-359 para 17 and 361 para 25.

2773 See CISG Explanatory Note (fn 162) para 22. For further details on the ensuing process of counter-offer and its acceptance, see Schroeter (fn 2708) on art 19 at 360 paras $20-23$.

2774 See Section D.II.2.b. above. 
is viewed as 'additions' under art 19 CISG. ${ }^{2775}$ As a modification must relate to the term's content, mere variations of the wording (terminology or typography) or grammar are not problematic, ${ }^{2776}$ whereas use of a form other than the one foreseen in the offer makes a material deviation. ${ }^{2777}$ In contrast, where no form is prescribed by the offer, acceptance can be made by any means, including one that is different from that used for making the offer, provided that the declaration of acceptance can reach the offeror through the chosen means. ${ }^{2778}$

\section{c. The Effectiveness of Declarations of Intention}

Two aspects are relevant when considering the effectiveness of declarations of intention: the time of their coming into effect (see Section i. below), and the end of their effectiveness (Section ii.). While the CISG's rule on the former is straightforward, the latter issue is more complex, as it encompasses several elements that need to be considered. One further aspect to note is that declarations of intention such as offer and acceptance can be made in any manner, ie, orally, in writing, or by electronic means. ${ }^{2779}$ In this respect, direct conversations, ${ }^{2780}$ telephone calls, ${ }^{2781}$ as well as sound and communication transmitted electronically in real time, like in online chats and voice or video calls are deemed to be 'oral' means of communi-

2775 Ferrari, 'CISG Article 19' (fn 2754) para 6, who goes on to argue at para 11 that the addition of clauses in a declaration of acceptance regulating issues not contemplated in the offer but which lead to a different result than the applicable law ought to constitute material alterations.

2776 Schroeter (fn 2708) on art 19 at 353 para 6.

2777 See Ferrari, 'CISG Article 19' (fn 2754) paras 7, 11. The argument used in relation to the latter is that the freedom of form principle of the CISG (see Section d. below) implies that the form prescribed in an offer is of importance to the offeror. Consequently, use of a different form for making acceptance ought to be deemed as a material alteration of the offer. On this argument, see ibid para 12. See also Ferrari, 'CISG Article 18' (fn 2750) para 4.

2778 See Schroeter (fn 2708) on art 18 at 334-335 paras 7-8, 336 para 11.

2779 Cf art 11 CISG on the form of contracts, discussed in Section d. below. See further Christina Ramberg (Rapporteur), CISG-AC (Advisory Council) Opinion No 1: Electronic Communications under CISG (15 August 2003; hereinafter referred to as 'CISG Opinion No 1'), www.cisgac.com/cisgac-opinion-no1/, at 'CISG Art 11'.

2780 Eg, Schroeter (fn 2708) on art 24 at 396 para 5.

2781 Ibid on art 18 at 345 para 33; Franco Ferrari, CISG Article 22, in: Kröll and Mistelis and Viscasillas (fn 2703) paras 1, 3. 


\section{E. Results of the Comparative Analysis Contrasted and Final Conclusions}

cation. ${ }^{2782}$ According to art 13 CISG, the term 'writing' includes some electronic means of communication, namely, telegram and telex. By way of interpretation, 'any electronic communication retrievable in perceivable form' is generally admissible; in particular, e-mails are deemed analogous to letters and not as an instantaneous communication method. ${ }^{2783}$ Similarly, statements on non-interactive ('passive') websites are also deemed to be 'non-real time'. ${ }^{2784}$

\section{i. Coming into Effect of Declarations of Intention}

The CISG has adopted one rule to govern the coming into effect of offer and acceptance: the arrival rule. Accordingly, art 15 para 1 and art 18 para 2 CISG require that the declaration must 'reach' the other party in order to become effective. Similarly, other declarations of intention such as withdrawals (art 15 para 2 and art 22 CISG for offers and acceptance respectively) or revocations (art 16 para $1 \mathrm{ibid}$ ), discussed below, are governed by this rule. ${ }^{2785}$ Thus, even if the recipient becomes aware of the declaration's content by some means other than through the statement itself reaching them, the declaration will be deemed to be invalid. ${ }^{2786}$ The caveat is that the declaration is communicated with the declaring person's intention. ${ }^{2787}$

The CISG's rule is tweaked in two particular instances: with offers to the public (Section aa) below) and with acceptance that must be made within a set period (Section bb)). Otherwise, the CISG generally makes no distinction between declarations of intention between persons inter presentes and inter absentes, nor between declarations made by different methods, ie, written or electronic. Consequently, the receipt rule applies

2782 Compare CISG Opinion No 1 (fn 2779) at 'CISG Art 18(2)' comment 18.4 and at 'CISG Art 20(1)' comment 20.5.

2783 Ibid at 'CISG Art 13' and at 'CISG Art 20(1)' comment 20.3.

2784 Ibid at 'CISG Art 20(1)' comment 20.4.

2785 Schroeter (fn 2708) on art 24 para 3 notes that objections and approvals in relation to declarations of acceptance under arts 19 para 2 and 21 para 1 CISG are not within the scope of the provision. These statements will be considered in Section ii. below.

2786 See Franco Ferrari, CISG Article 15, in: Kröll and Mistelis and Viscasillas (fn 2703) para 1, who goes on to note at para 2 that this rule is in the best interest of both parties, as the risk is distributed evenly.

2787 On offers, see Schroeter (fn 2708) on art 15 at 313-314 para 2. On acceptance, see ibid on art 18 at 341 para 24. 
to all kinds of declarations of intention irrespective of their form and the communication method (compare art 24 CISG, discussed below; the meaning of 'reaching' will be examined in Section cc)). The position is the same under German law, but not under English and Japanese law, since the latter two regimes not only use the mailbox (arrival) rule but also apply the postal (dispatch) rule for declarations of intention, depending on their kind or their method. ${ }^{2788}$

aa) Coming into Effect of Offers to the Public

The coming into effect of offers to the public under the CISG is not as straightforward as with offers directed at particular individuals. Presupposing that such statements are offers, their coming into effect depends on the manner in which the offer is made, ie, whether the addressees are identifiable. This situation arises with statements that are communicated directly to a group of people, such as when catalogues are sent out; or more indirectly where the statement is displayed in a publicly accessible place, such as the internet or a magazine. In the former case, the offer will become effective in accordance with the normal rule under art 15 para 1 CISG, whereas the offer in the latter case will be effective from a determined moment, such as a phrase evidencing such intention, or, failing such provision, upon being published. ${ }^{2789}$ The three legal systems examined in this dissertation have no such special rule for public offers. Instead, these are treated like offers to individuals.

2788 See Sections D.II.1.c. and D.II.2.c. above for offer and acceptance respectively. For a comparison with Japanese law, see Sono (fn 1640) 16. See also Takashi Kubota, Honsho no yomikata [How to Read this Book], in: Yasutomo Sugiura and ibid (eds), Uìn baibai jōyaku no jitsumu kaisetsu [Practice Commentary on the Vienna Sales Convention] (2 ${ }^{\text {nd }}$ edn, Chūō Keizai-sha 2011) 1, 9. Sugiura, 'Dai-2-bu' (fn 2726) on art 18 at 81, notes that the Japanese law reform will make the arrival rule applicable equally to declarations of offer and acceptance. For details, see Section C.V.3.a. above.

2789 See Schroeter (fn 2708) on art 15 at 314 para 3. 
bb) Coming into Effect of Acceptance: Must be Made Within a Set or Reasonable Period; Late Acceptance

A declaration of acceptance must not simply reach the offeror but arrive within the period set for acceptance, or, otherwise, within a reasonable period (art 18 para 2 CISG). This also applies to acceptance under art 18 para 3 CISG, according to which no communication is required. Such a declaration of acceptance becomes effective 'at the moment that the act is performed' (art 18 para 3 CISG). ${ }^{2790}$ In contrast, the rule does not apply to acceptance of an oral offer, as these kind of offers must normally be accepted immediately (art 18 para 2 CISG), ie, without any delay. ${ }^{2791}$ The three domestic laws know of a similar rule in that they require acceptance to be made within a set or reasonable period as well. ${ }^{2792}$ In contrast, the exception for oral offers is only contained in German and Japanese law (compare Section ii. below).

The time frame for acceptance can be set implicitly or expressly, whereby the offeror can either choose a period by specifying the length, by referring to some determinable moment (eg, New Years Day), or by giving an exact deadline. ${ }^{2793}$ Like under English, German, and Japanese law, the appropriate length of time where no period is fixed is assessed by taking into account the particularities of the case, especially the speed of the communication method used by the offeror. ${ }^{2794}$ Moreover, the time

2790 In the case of an offer in the form of a cheque, its presentation for cashing is the moment of acceptance, see ibid on art 18 at 346 para 36.

2791 Ibid on art 18 at 345 para 31.

2792 See Section D.II.2.c.i. above. On Japanese law, see also Sugiura, 'Dai-2-bu' (fn 2726) on art 18 at 81.

2793 See Ferrari, 'CISG Article 18' (fn 2750) para 25. Schroeter (fn 2708) on art 18 at 343 para 27 notes that the date of the event can be uncertain, such as the occurrence of some meteorological event at a certain place. Where an offer including a period specified by length does not contain a starting time, art 20 para 1 CISG contains a default rule for the commencing of the period. On this, compare Schroeter ( $\mathrm{fn} 2708$ ) on art 20 at 373 para 1, who notes that the offeror can specify a starting date. See on this further ibid at 374 para 3, and CISG Opinion No 1 (fn 2779) at 'CISG Art 20', where the rule is applied by analogy to other (electronic) means of communication, such as fax and e-mail.

2794 This fact is also relevant for cases in which a time frame is set for a reply, since the period begins to run from the moment of the offer's dispatch if communicated by letter (art 20 para 1 CISG). In contrast, where instantaneous communication' like telephone or fax is used, the starting point is the time when the offer reaches the offeree (ibid). On the domestic laws, see Section D.II.2.c.i. above. 
needed to consider the offer and how long it will take for the declaration of acceptance to reach the offeror are also relevant facts. ${ }^{2795}$ In this way, the communication method may lengthen or shorten the reasonable period. In particular, where instant electronic means of communication such as online chats are used, the rule for oral offers may apply, necessitating immediate acceptance. ${ }^{2796}$ Nevertheless, it ought to be noted that the offeree does not generally have to use the same communication method as the offeror, although this may be required due to usage, the practices between the parties, or by the offer. ${ }^{2797}$ Arguably, this will only be true where the method of acceptance is reasonable in the circumstances. ${ }^{2798}$

Under the CISG, there are two exceptions to the rule that declarations of acceptance must be received by the offeror within a set or reasonable time frame that are also foreseen in Japanese and German law. ${ }^{2799}$ First, where a declaration sent by 'letter or other writing' 2800 arrives late and it appears that it ought to have arrived on time 'if its transmission had been normal', acceptance can still be effective if the offeror fails to give oral or written notice of the tardiness 'without delay' (art 21 para 2 CISG). This means that where a written declaration of acceptance arrives late due to

2795 Ferrari, 'CISG Article 18' (fn 2750) para 28, who goes on to note the factors relevant to determine the reasonable consideration period in para 30: inter alia, the nature of the goods and the stability of the price, or 'the need to obtain further information'.

2796 See Schroeter (fn 2708) on art 18 at 343 para 28.

2797 See Ferrari, 'CISG Article 18' (fn 2750) para 29.

2798 Compare art 18 para 2 CISG, which states that the 'circumstances of the transaction' are to be taken into account when assessing a reasonable period for acceptance. Moreover, it has been held in the OLG Dresden decision of 30 November 2010 (fn 2729) paras 44, 43, that an offer communicated by e-mail must be responded to 'promptly' ('zeitnab'). In that case, the reasonable period was held to be one week. The court doubted that the offer could have been accepted on time if the declaration had been communicated by letter. In the event, no response had been made by the purchaser within such a period and the court found that a contract had also not been concluded between the parties by way of an acknowledgement of the effectiveness of the seller's acceptance pursuant to art 21 para 1 CISG, as no such notice had been given. This rule is discussed subsequently.

2799 See generally Section D.II.2.c.i. above for the domestic laws. On Japanese law, see also Sugiura, 'Dai-2-bu' (fn 2726) on art 21 at 90.

2800 According to Schroeter (fn 2708) on art 21 at 385 para 18, this rule applies to declarations sent by way of electronic means of communication. 


\section{E. Results of the Comparative Analysis Contrasted and Final Conclusions}

circumstances outside the offeree's power, it will still be effective and a contract will be concluded, unless the offeror 'protests' ${ }^{2801}$

Secondly, the offeror has a discretionary power to admit a late declaration of acceptance as being effective by giving a notice to that effect to the offeree 'without delay' (art 21 para 1 CISG). In this respect, 'late' is not connected to a delay in transmission, but could simply be due to the period of acceptance being formulated vaguely (ie, being uncertain or for a reasonable period) or due to the offeree responding just before the expiry of the acceptance period. ${ }^{2802}$ The discretion can only be exercised where art 21 para 2 CISG does not apply and must be exercised within a short period, ${ }^{2803}$ such as a day or perhaps two. ${ }^{2804}$ In order to do so, the offeror must make a declaration of approval by any means other than conduct. ${ }^{2805}$ Where no approval is given by the offeror, acceptance does not become valid and no contract is formed. ${ }^{2806}$ Conversely, where a late declaration of acceptance is approved, a contract is formed retrospectively at the time when the late notice arrived or, in case of acceptance by conduct, once the act had been performed. ${ }^{2807}$ For the effectiveness of both the offeror's protest and their approval, the moment of dispatch is pertinent (compare art 21 paras 1-2 CISG), so that it is irrelevant whether the declaration actually reaches the offeree. ${ }^{2808}$

2801 On this, see Franco Ferrari, CISG Article 21, in: Kröll and Mistelis and Viscasillas (fn 2703) paras 14-16, 12, 18. Named pertinent circumstances include strikes, weather conditions, and the post being misdirected, unless this occurs due to a wrong address having being used.

2802 Schroeter (fn 2708) on art 21 at 379 para 3 and at 380 para 5.

2803 According to Ferrari, 'CISG Article 21' (fn 2801) para 5, art 21 para 2 CISG contains a special rule. On the period, see ibid para 8 , where the author states it to be shorter than the period for the offeror making an objection to added or altered terms under art 19 para 2 CISG, but long enough for the offeror to consider whether to approve.

2804 Compare Schroeter (fn 2708) on art 21 at 381-382 para 8.

2805 See Ferrari, 'CISG Article 21' (fn 2801) para 6. cf Schroeter (fn 2708) on art 21 at 384 para 15 , who notes that silence by the offeror with respect to late acceptance may constitute approval in exceptional circumstances, eg, where a usage to that effect exists between the parties.

2806 See Ferrari, 'CISG Article 21' (fn 2801) para 10.

2807 Schroeter (fn 2708) on art 21 at 383 para 10.

2808 Compare ibid at 381 para 7 and at 386 para 20. 
cc) 'Reaching' Defined

The moment in time at which a declaration 'reaches' the other party is defined in art 24 CISG as the time when the statement is either

'made orally to [that party] or [is] delivered by any other means to him personally, to his place of business or mailing address or, if he does not have a place of business or mailing address, to his habitual residence.'

There are therefore three modes of delivery under the CISG, whereby the Convention distinguishes between two transmission methods: orally, and anything else. In the latter situation, the declaration can be delivered by any means. It has been argued that this phrase makes the provision so wide as to encompass electronic means of communication without the need to state so explicitly. ${ }^{2809}$ Indeed, as discussed at the beginning of Section i. above, electronic communication has been admitted under the CISG. Accordingly, letters, fax, SMS, and e-mail among others will be deemed to be made 'by any other means' under art 24 CISG, while direct conversations, including those on the telephone or over the internet, are declarations delivered orally. ${ }^{2810}$

With respect to the mode, a non-oral declaration can either be handed over to the addressee personally, or be delivered to one of their addresses. ${ }^{2811}$ Personal delivery means that a corporeal form of the declaration, such as a letter, is handed over to the addressee directly. ${ }^{2812}$ Here, the place is irrelevant, as long as the delivery is personal. ${ }^{2813}$ In contrast, the CISG

2809 Compare Jan Peter Schmidt, Art 1:303: Notice, in: Jansen and Zimmermann (fn 38) 179, 193 in fn 133. Compare also Schroeter (fn 2708) on art 24 at 396 para 6.

2810 See on this generally Franco Ferrari, CISG Article 24, in: Kröll and Mistelis and Viscasillas (fn 2703) paras 1, 3-4, 7. See also Schroeter (fn 2708) on art 24 at 396 paras 5-6.

2811 Maria del Pilar Perales Viscasillas, Contract Conclusion under CISG, in: Franco Ferrari and Clayton P Gillette (eds), International Sales Law Vol 1 (Edward Elgar Publishing, 2017) 46, 53-54; Ferrari, 'CISG Article 24' (fn 2810) paras 10-11. Contrast Schroeter (fn 2708) on art 24 at 400 para 15, who seems to interpret the provision to mean that personal delivery must be made to one of the addressee's addresses. This is not convincing, as the provision's punctuation, namely, the comma between 'personally' and 'to his place of business' etc, and the wording indicate an enumeration of different methods of delivery.

2812 See Schroeter (fn 2708) on art 24 at 401 para 18.

2813 Ferrari, 'CISG Article 24' (fn 2810) para 10. Contrast Schroeter (fn 2708) on art 24 at 400 para 15 , as discussed in fn 2811 above. 


\section{E. Results of the Comparative Analysis Contrasted and Final Conclusions}

provision specifies places to which non-personal delivery can be made and sets an order of preference: Delivery of this kind first ought to be made to the addressee's place of business or their mailing address; only where the addressee has neither of these, declarations may be sent to the addressee's habitual residence.

The exact point in time at which a declaration is said to have reached the other party depends on the communication method. Oral communication being instantaneous, it is deemed to be 'delivered' as soon as it is made, but needs to be perceptible for the addressee, so that they can gain knowledge of it. ${ }^{2814}$ In this respect, 'reach' means that the declaration enters the addressee's sphere of influence, so as to enable the addressee to gain knowledge of the declaration. ${ }^{2815}$ This means that a letter inserted into the addressee's post-box has reached them. ${ }^{2816}$ An offer or acceptance that is made through means of electronic communication, such as e-mail, comes into effect once it has 'entered the [addressee's] server'. ${ }^{2817}$ Similarly, a declarations sent via fax is deemed to have reached the addressee when it has been saved by the addressee's fax machine; it may also have to be printed. ${ }^{2818}$ In all cases, it seems to be irrelevant whether the declaration arrives within business hours or on, say, public holidays: It will arrive at that time and not on the next usual business day, unless the device for receiving the declaration, ie, the post-box, fax machine, or e-mail server, are not 'reachable' due to being inaccessible or switched off. ${ }^{2819}$ This is different from German and English law, which take business hours into account for receipt. ${ }^{2820}$

2814 Cf Schroeter (fn 2708) on art 24 at 398 para 11, according to whom the oral declaration must be perceptible for the addressee.

2815 Actual knowledge is not required. See Ferrari, 'CISG Article 24' (fn 2810) para 8. cf Schroeter (fn 2708) on art 24 at 401-402 para 18, stating that it is unclear whether the possibility to have knowledge is required.

2816 Ferrari, 'CISG Article 24' (fn 2810) para 11; Schroeter (fn 2708) on art 24 at 402 para 19. It is unclear whether a notification of a registered letter in the addressee's post-box is sufficient. For: eg, Ferrari, ibid. Against: eg, Schroeter, ibid para 20.

2817 CISG Opinion No 1 (fn 2779) at 'CISG Art 15'. It is noted at 'CISG Art 18' that the offeror must have agreed to acceptance being made through electronic means of communication.

2818 Schroeter (fn 2708) on art 24 at 403 para 23 deems printing unnecessary. Contrast Ferrari, 'CISG Article 24' (fn 2810) para 11, according to whom printing is normally required.

2819 Schroeter (fn 2708) on art 24 at 408 para 32.

2820 On this, see Sections B.III.3.a.ii.dd) and B.II.3.a.ii.ee) above respectively. 
There are three special cases with offer and acceptance that need to be mentioned: Where an offer is made to a group of unspecified persons, the moment in time at which it comes into effect is the point at which it is possible [for each person] to gain knowledge of the offer', unless the offer foresees otherwise. ${ }^{2821}$ In case of acceptance that is made implicitly through some conduct, it comes into effect at the time when the act is fully performed and notice of the conduct has reached the offeror. ${ }^{2822}$ On the other hand, where a declaration of acceptance modifies the offer in an immaterial manner, it will become effective upon reaching the offeror, although this effect might be undone retroactively by the offeror objecting to the modifications. ${ }^{2823}$

\section{ii. Loss of Effect of Declarations of Intention}

Declarations of intentions can lose their effectiveness for several reasons. In case of an offer, it may simply expire. This can happen where an oral offer $^{2824}$ under the CISG is not accepted immediately (compare art 18 para 2 CISG). Arguably, an offer will also expire after a reasonable period passes and acceptance is not made (see ibid). As discussed above, German, Japanese, and English law concur on these points. ${ }^{2825}$ Declarations of intention can also be withdrawn or revoked under particular circumstances.

Seeing as the arrival rule governs declarations of offer and acceptance, these can be withdrawn, provided that the withdrawal reaches the addressee at least together with the offer or acceptance, as the case may be

2821 See Ferrari, 'CISG Article 15’ (fn 2786) para 4.

2822 See art 18 para 3 CISG and CISG Explanatory Note (fn 162) para 20. See also Ferrari, 'CISG Article 18' (fn 2750) para 13.

2823 Compare Ferrari, 'CISG Article 19' (fn 2754) paras 18, 20, who states that the concluded contract is subject to the condition that the new terms are not objected to by the offeror. See also ibid para 23, where it is noted that the objection 'dissolves' the concluded contract retroactively. Also see the discussion in the foregoing section (b.).

2824 Beside the parties being in each other's physical presence, telephone conversations or announcements on radio fall into this category, whereas communication by e-mail, fax, or videotext do not. The distinction is made on whether acceptance can be indicated immediately after the offer having been made. See on this Ferrari, 'CISG Article 18' (fn 2750) para 34.

2825 See Section D.II.1.c. above. Note that while English law does not foresee expressly that oral offers need to be accepted immediately, this is a logical deduction from the rules on offer and acceptance. 
(arts 15 para 2, 22 CISG). ${ }^{2826}$ This is the same position as under English, German, and Japanese law. ${ }^{2827}$ Under the CISG, even irrevocable offers can be withdrawn, whereas declarations of acceptance made by conduct cannot. ${ }^{2828}$ At least a declaration of acceptance can be withdrawn in part or as a whole, ${ }^{2829}$ although, logically, the same ought to be true for offers. ${ }^{2830}$ In contrast, notices of approval and of protest under art 21 CISG or objections under art 19 are governed by the dispatch rule and therefore cannot be withdrawn. ${ }^{2831}$ Whether a withdrawal itself can be withdrawn before becoming effective is a controversial topic in academic literature. It is submitted that it would be logical to allow withdrawals to be withdrawn before coming into effect and thus to treat it the same as other declarations of intention. ${ }^{2832}$

As a general rule, an offer may be revoked before a contract has been made (art 16 para 1 CISG). Nevertheless, the offeror's right persists on-

2826 The coming into effect of withdrawals is governed by art 24 CISG, discussed in Section i. above. An offer and its withdrawal that are both sent by letter might arrive simultaneously if both letters are delivered together, see Schroeter (fn 2708) on art 15 at 315 para 5. In case of offers sent by e-mail, these can be withdrawn if a declaration to that effect arrives on the offeree's server before or together with the offer, see CISG Opinion No 1 (fn 2779) at 'CISG Art 15'. Nevertheless, it is acknowledged in ibid comment 15.2. that this will usually not be possible, as there are no faster means than electronic communication. Schroeter, ibid at 314 para 4 uses the apt phrasing of the withdrawal having to 'overtake' the declaration in question. Irrespective of this, the addressee must have explicitly or implicitly consented to receive withdrawals through that channel, ibid. Such consent will not be deemed to exist where an incorrect e-mail-address is used and the server does not redirect the e-mail to the correct address, see CISG Opinion No 1, ibid comment 15.5.

2827 See Sections D.II.2.c. and D.II.3.c.ii. above for offer and acceptance respectively. On withdrawals under Japanese law, see also Sono (fn 1640) 17. cf Sugiura, 'Dai-2-bu' (fn 2726) on art 22 at 91, noting that acceptance cannot be withdrawn where the dispatch rule applies.

2828 On the former, see art 15 para 2 CISG. On the latter, see Schroeter (fn 2708) on art 22 at 389 para 3.

2829 Franco Ferrari, CISG Article 22, in: Kröll and Mistelis and Viscasillas (fn 2703) paras 1,3 .

2830 Compare the offer's revocability under the CISG, discussed subsequently.

2831 Compare Ferrari, 'CISG Article 21' (fn 2801) paras 7, 19, and Ferrari, 'CISG Article 19' (fn 2754) para 21 respectively.

2832 In favour of allowing withdrawals to be withdrawn are Ferrari, 'CISG Article 15' (fn 2719) para 13 (offers), ibid, 'CISG Article 22' (fn 2829) para 8, and, partially, Schroeter (fn 2708) on art 22 at 389 para 4 (allowed for withdrawals of acceptance). Against this position, see, eg, Giannini (fn 2736) 25. 
ly until the declaration of acceptance is dispatched (ibid) and not until the declaration becomes effective upon its receipt under art 18 para 2 CISG, thus bringing the possibility to an end even before the contract is formed. ${ }^{2833}$ This means that the revocation has to reach the offeree before they send out their declaration of acceptance. ${ }^{2834}$ The declaration can relate to a part or the whole of the offer. ${ }^{2835}$ If it reaches the offeree before the offer, it will be deemed as a withdrawal of the offer instead. ${ }^{2836}$ While the revocation can be withdrawn, it cannot be revoked. ${ }^{2837}$ Therefore, where the revocation takes effect, an offer must be declared anew. In contrast to offers, a declaration of acceptance cannot be revoked, as the contract comes into existence once the declaration is effective. ${ }^{2838}$

Exceptions to the revocability of offers exist in two situations. First, where the offer clearly states in some form that it is to be irrevocable, in particular by foreseeing a time frame for acceptance (see art 16 para 2(a) CISG). Nevertheless, a fixed period of acceptance only raises a rebuttable presumption. ${ }^{2839}$ Phrases such as 'fix' or 'firm offer' will generally be deemed to express the offer's irrevocability, whereby the firmness may but

2833 Schroeter ( $\mathrm{fn} 2708$ ) on art 16 at 321 para 4, who goes on to note that this rule is 'more far-reaching' than the English postal rule (while Schroeter erroneously writes 'mailbox rule' in the main text, a quote on the postal rule is given in the accompanying $\mathrm{fn}$ ), as the CISG's rule applies to all forms of communication, whereas the postal rule only applies to letters and telegrams, as discussed in Section B.II.3.iii.cc) above.

2834 On the point in time of arrival, see Section i. above. For revocations by e-mail, see also CISG Opinion No 1 (fn 2779) at 'CISG Art 16', where it is also noted that acceptance by e-mail is deemed to have been dispatched once the message 'has left the offeree's server'.

2835 Franco Ferrari, CISG Article 16, in: Kröll and Mistelis and Viscasillas (fn 2703) paras 1, 4; Schroeter (fn 2708) on art 16 at 320 para 3.

2836 Schroeter (fn 2708) on art 16 at 320 para 3; Ferrari, 'CISG Article 16' (fn 2835) para 7.

2837 Ferrari, 'CISG Article 16' (fn 2835) para 7. Contrast Schroeter (fn 2708) on art 16 at 320 para 3, stating that a revocation's revocation ought to be possible where the addressee has not had knowledge of the original revocation, or has at least not acted in reliance of it.

2838 This can be deduced from art 22 CISG, which allows withdrawals only until the point in time at which a declaration of acceptance becomes effective, while there is no other provision allowing a revocation. See also Ferrari, 'CISG Article $18^{\prime}$ (fn 2750) para 21.

2839 For further details, see Schroeter (fn 2708) on art 16 at 323-324 paras 9-10. 


\section{E. Results of the Comparative Analysis Contrasted and Final Conclusions}

does not have to be limited in time. ${ }^{2840}$ Secondly, the offer is irrevocable where the offeree reasonably assumed irrevocability and acted in reliance of this belief (ibid 2(b) CISG). Reliance is placed by the offeree where they undertake preparatory acts for the fulfilment of their obligation, such as purchasing the materials necessary to manufacture the goods under the contract. ${ }^{2841}$

This rule is basically the same under English law, but generally opposite to German law, ${ }^{2842}$ and in part both with respect to Japanese law. This is because offers are generally revocable under English law, but irrevocable according to the German regulation; and under the Japanese norms, the general principle of irrevocability is sometimes excepted. ${ }^{2843}$ Indeed, the provision apparently constitutes a compromise between English and other European laws. 2844 Where a revocation is attempted for an irrevocable offer, the declaration of revocation will be without effect and not affect the offer. $^{2845}$

An offer will also lose its effectiveness by the offeree rejecting it (art 17 CISG). In order for this to occur, the rejection must reach the offeror like any other declaration of intention governed by the receipt rule contained in art 24 CISG. Arguably, an offer will also expire where the stipulated period of acceptance passes without acceptance having been made. While not stated expressly, this follows logically from the provision in art 18 para 2 CISG, according to which acceptance is not effective unless it reaches

2840 Ferrari, 'CISG Article 16' (fn 2835) para 14. Other phrases might convey the intention of an irrevocable offer in a particular trade, such as 'option', Schroeter (fn 2708) on art 16 at 322 para 8.

2841 Ferrari, 'CISG Article 16' (fn 2835) para 21. Further examples are given by Schroeter (fn 2708) on art 16 at 325 para 11, who notes that omissions, such as no solicitation of alternative offers, may be sufficient in terms or reliance. On whether the reliance is reasonable, see Ferrari, ibid para 20.

2842 Interestingly, Busche, ' $\mathbb{S} 145 B G B$ ' (fn 893) para 3 notes that the drafters of the $\mathrm{BGB}$ had considered and rejected a regulation like the CISG's rule. One important reason was that binding offers had become standard practice in commerce so as to become indispensable ('unentbehrlich'), see Mugdan (fn 883) Vol 1 443-444.

2843 See Section D.II.1.c. above. On Japanese law, see also Sono (fn 1640) 17; Kubota, 'Yomikata' (fn 2788) 9; Sugiura, 'Dai-2-bu' (fn 2726) on art 16 at 75-76. As noted by Kubota, 'Sankö' (fn 2703) 19, the situation will change by virtue of the Japanese law reform. On this, see Sections C.V.3.c.i. and iii. Above.

2844 Schwenzer (fn 2703) 5. See further Schroeter (fn 2708) on art 16 318-319 para 1.

2845 See Schroeter (fn 2708) on art 16 at 326 para 14. 
the offeror within the stipulated time period. ${ }^{2846}$ This effect is recognised under German, English, and Japanese law as well. ${ }^{2847}$

\section{d. No Form Requirements}

As stated in art 11 CISG, the Convention does not foresee a mandatory form for international contracts of sale. In particular, writing is not required. As a consequence, all declarations of intention under the CISG, ie, an offer, acceptance, or objections, etc, can be made in any form: oral, in writing, and by electronic means. ${ }^{2848}$ This freedom of form extends to the modification or the termination of a contract (art 29 para 1 CISG); however, a stipulation by the parties in a written contract that modifications need to be made in writing is generally upheld by art 29 para 2 CISG. Where the parties make express or implicit ${ }^{2849}$ stipulations on the contract's form under art 6 CISG, or where usages or practices between the parties foresee otherwise, the form will be mandatory and, eg, a declaration of acceptance made in a different form will be deemed to be a counter-offer for altering the offer's terms in a material way. ${ }^{2850}$ Moreover, the parties are free to define the form, such as 'writing' and thus deviate from art 13 CISG. ${ }^{2851}$

The provision's scope is so broad as 'to displace special requirements of consent such as consideration or causa', as well as protective provisions such as under (EU) consumer law. ${ }^{2852}$ It ought to be noted that Contracting States may make reservations considering the contract form under art 96 CISG, in which case the provisions would not apply in relation to those countries (see art 12 CISG); however, no such reservation has been

2846 Compare Wolf and Neuner (fn 48) 421 para 16.

2847 See Section D.II.1.c. above.

2848 Compare further Franco Ferrari, CISG Article 11, in: Kröll and Mistelis and Viscasillas (fn 2703) para 9; Ferrari, 'CISG Article 18' (fn 2750) para 4.

2849 Martin Schmidt-Kessel, Article 11, in: Schlechtriem and Schwenzer (fn 2703) 203, 212 para 20.

2850 On this, see Ferrari, 'CISG Article 19' (fn 2754) para 12; ibid, 'CISG Article 18' (fn 2750) para 4; and Section b. above. Cf Ferrari, 'Article 11' (fn 2848) para 20, who states that where no clear intention as to the nature of the form requirement exists, it will be deemed to have an evidentiary function only.

2851 Schmidt-Kessel (fn 2849) 212 para 20. The meaning of writing under that provision was already discussed in Section c.i. above.

2852 Ferrari, 'Article 11' (fn 2848) paras 4, 8, 10. 
made by Germany or Japan. ${ }^{2853}$ Considering that German law foresees a range of form requirements in relation to contracts, this is perhaps surprising, while this is not so much so for Japan, which has a more liberal attitude in this respect. ${ }^{2854}$

\section{Summary of Results}

To recapitulate, English, German, and Japanese law and the CISG coincide in several respects on the formation of contracts. First, the basis of a (sale) contract is the consensual agreement of the parties; although German, English, and Japanese law sometimes foresee a mandatory form for some (other) contracts, which is not the case under the CISG. Further requirements like consideration or tetsuke are not necessary under the Convention either. The standard model for the contract conclusion is by way of offer and acceptance, whereby the declarations of intention must be congruent in order to form a contract. Otherwise, the purported declaration of acceptance will constitute a counter-offer under the domestic laws and the CISG; however, the Convention explicitly allows non-material alterations.

Both declarations of intention are distinguished from other statements or acts. Therefore, a degree of certainty and an intention to be bound by the statement is required under the CISG and the three domestic laws. Having said this, offers to the world at large, ie, unspecific persons, will normally be deemed to be an invitation to make an offer under the Convention, while English, German, and Japanese law assess this on a case-by-case basis. In the end, the situations that fall into the category of invitations to make an offer are the same under the four laws. Although acceptance can be through express or implied acts or statements, neither the CISG nor the three domestic laws allow silence on its own to constitute the offeree's assent. Otherwise, different ways of making declarations, such as orally, in writing, or in electronic form, are recognised under the CISG and the domestic laws.

Unlike English and Japanese law, but congruent with the German approach, the Convention foresees one rule for the coming into effect of declarations of intention, namely, upon its arrival. In order to 'reach' the

2853 For further discussion of this issue, see Mather (fn 2709) 373.

2854 See the discussion in Section D.III. above for a comparison of English, German, and Japanese law. Sono (fn 1640) 7 even calls the freedom of form 'a matter of course' ('当然のこと’, tözen no koto) in Japanese legal thought. 
other party, the notice of the declaration or conduct has to enter the recipient's sphere of influence, such as their post-box or e-mail server. Two deviations from the arrival rule under the CISG are offers to the public and acceptance by conduct that must be made within a set period. Here, the coming into effect of the former depends on the offeror's intention as evidenced in the offer, while the latter is effective once the act in question has been performed. Although such provisions are not found in the three domestic laws, these recognise a time frame for making acceptance, just like the CISG. Furthermore, German and Japanese law concur with the CISG in that an oral offer must be accepted immediately. These two domestic laws also recognise that declarations that are late because of an unusually long transmission time can still be effective if the offeror does not object and, otherwise, give the offeror the discretion to deem a late acceptance as a new offer.

The ways in which declarations of intention can lose their effectiveness under the CISG is through expiry, rejection (of an offer), withdrawal, and revocation. While English, German, and Japanese law also principally recognise these acts, German law does not allow the revocation of an offer, while Japanese law sometimes allows it but English law generally recognises it. The rules under the contract laws therefore coincide - for the most part - on the main issues but deviate on individual points.

\section{Results of the Comparative Analysis Juxtaposed with the European Legal- political Perspective: The DCFR, the CESL, and the PECL}

Beside EU law on contract and, in particular, consumer law, several efforts have been made by legal academics to explore principles of a supra-national European private law. Three important projects, namely, the DCFR, the CESL, and the PECL will be considered and contrasted with English, German, and Japanese contract law. 2855 While the provisions of the CESL, the DCFR, and the PECL - unlike the CISG - are all not binding but constitute 'non-legislative codifications' ${ }^{2856}$, their nature differs. This

2855 The following analysis is based on the outstanding comparative work on the three European projects by Jansen and Zimmermann (fn 38). It also draws from the work of Schmidt J (fn 25), who compares German, English, and French contract rules with the CESL.

2856 Nils Jansen, Art 1:101: Application of Principles, in: Jansen N and Zimmermann (fn 38) 27, 28. 


\section{E. Results of the Comparative Analysis Contrasted and Final Conclusions}

is due to the fact that the objectives for their drafting vary. The CESL is the most ambitious project, as it was originally envisioned as a 'secondary contract law regime' found 'within each [EU] Member State's national law'. ${ }^{2857}$ While having been abandoned as a proposal for legislation, it is nevertheless 'a source of inspiration' ${ }^{2858}$ In contrast, the DCFR and the PECL are more humble projects, as they are foreseen as optional sets of uniform rules to be used by drafters of 'legal instruments and contracts', as well as judges. ${ }^{2859}$ The provisions of the three projects on the sphere of application and the formation of contracts of these codifications are examined in Sections 1. and 2. below.

\section{The Sphere of Application of the CESL, the DCFR, and the PECL}

Each of the three European projects contains rules on their sphere of application; however, while all of them concern European private law, there are differences in their scopes. As its name suggests, the CESL's reach is limited to 'cross-border transactions for the sale of goods, for the supply of digital content and for related services' (art 1 CESL Reg). ${ }^{2860}$ In contrast, the DCFR and the PECL constitute more general legal regimes for contracts (art I-1:101 DCFR, art 1:101 para 1 PECL). Only the DCFR contains an explicit list of circumstances which are not meant to be covered, inter alia, negotiable instruments, immovable property, and employment contracts (art I-1:101 para 2 DCFR). Nevertheless, this does not mean that the PECL's scope is wider; on the contrary, the PECL seems to contain general contract rules while the DCFR encompasses both general and specific contracts, as well as non-contractual obligations. ${ }^{2861}$ Having said this, it seems that, in the end, the scope of application of the DCFR depends on the parties in that these may decide freely to apply the Rules to a priori

2857 See preamble nos 8 and 9 CESL Reg.

2858 Jansen $\mathrm{N}$ and Zimmermann, 'Introduction' (fn 38) 29. On the project having been abandoned, see fn 37 above.

2859 See the comments to art I-1:101 DCFR in von Bar and Schulte-Nölke (fn 36) 131. See also Jansen N, 'Art 1:101 PECL' (fn 2856) 28-29 para 2.

2860 Mixed contracts, even where these include sale of goods or of digital content, as well as consumer credit agreements are explicitly excluded under art 6 CESL Reg.

2861 See also Christian von Bar and others, Introduction, in: von Bar and SchulteNölke (fn 36) 20-21, who state that the DCFR has a wider coverage than the PECL. 
excluded matters. ${ }^{2862}$ In what follows, only the rules that are pertinent for to the formation of contracts will be considered. It is necessary, however, to make a brief note of the definitions found in the CESL and the DCFR in relation to the terms of their application.

The CESL has two sets of criteria for the definition of 'cross-border', which depend on whether the transaction in question is B2B or B2C. In case of the former, the habitual residence of the traders need to be in different countries (art 4 para 2 CESL Reg), whereas it is sufficient for B2C transactions if the consumer's address, that for delivery, or the one used for billing is not in the same country as the trader (ibid para 3). In either case, one country at least needs to be a EU Member State (ibid). This requirement echoes the CISG's internationality requirement, although the CESL applies to both $\mathrm{B} 2 \mathrm{~B}$ and $\mathrm{B} 2 \mathrm{C}$ transactions, whereas the CISG does not. ${ }^{2863}$ Neither the DCFR nor the PECL make such a differentiation; however, it seems that both Principles deal with consumers. ${ }^{2864}$ In this respect, the definition of 'consumer' is almost identical in the CESL and the DCFR, as both mean a natural person whose act is for private rather than for business reasons. ${ }^{2865} \mathrm{~A}$ person acting for the latter purposes is termed 'trader' in the CESL (art 2 para e CESL Reg) and 'business' in the DCFR (art I-1:105 para 2). The two definitions are similar in that legal and natural persons are included in both notions. ${ }^{2866}$ These definitions are congruent with the conceptions under EU, English, German, and Japanese law. ${ }^{2867}$

In terms of the transactions covered by the projects, the PECL states itself to be applicable 'as general rules of contract law' (art 1:101 para 1),

2862 See von Bar and Schulte-Nölke (fn 36) 131-132 on art I-1:101 DCFR.

2863 Compare art 1 CESL Reg and arts 1, 2, 100 para 2 CISG, as discussed in Section I.1. above.

2864 While the DCFR contains a definition of the term 'consumer' and mentions them explicitly in some rules, the PECL treats the matter implicitly. This will become apparent from the discussion in Section 2.g. below.

2865 cf art 2 paraf CESL Reg: “[C]onsumer' means any natural person who is acting for purposes which are outside that person's trade, business, craft, or profession'; and art I-1:105 para 1 DCFR: 'A “consumer" means any natural person who is acting primarily for purposes which are not related to his or her trade, business or profession'.

2866 Nevertheless, the DCFR contains the additional clarification that 'publicly or privately owned' legal persons can be a business to which the DCFR applies, if the work is on a self-employed basis; moreover, an intention to make a profit from the act is not required.

2867 This was discussed in Sections B.II.3., B.III.3., and C.I.2.b. above. 


\section{E. Results of the Comparative Analysis Contrasted and Final Conclusions}

which explicitly cover issues of agreement in so far as the incorporation of the PECL are concerned (art 1:104 para 1), but are displaced by practices or usages established between the parties (art 1:103 ibid), or by domestic or supranational mandatory law that is applicable irrespective of the law chosen (ibid). According to art I-1:101 DCFR, the Framework 'primarily' covers 'contracts and other juridical acts'. The meaning of these two terms is considered in Section 2.a. below.

The CESL covers 'sales of goods' as well as transactions 'for the supply of digital content and for related services' (art 1 para 1 CESL Reg). It defines 'goods' as any 'tangible movable items' except electricity, natural gas, and water under public utility services (art 2 para h ibid), while 'digital content' is data in any electronic form that can but does not need to be produced or supplied 'according to the buyer's specifications' (ibid para j). This distinction is congruent with the definition adopted in English consumer law (s 2 subs 8-9 Consumer Rights Act 2015, 'CRA 2015'). The distinction between goods and digital things is also found in English commercial law, as well as in German and Japanese law; however, neither of these, nor the CISG, deem data or software to be goods. ${ }^{2868}$

All three projects have in common that their provisions are not automatically binding on the parties, but need to be opted into, unlike dispositive domestic law and the CISG, which needs to be opted out of by providing alternative stipulations. ${ }^{2869}$ Where they apply, the parties are generally free to derogate from the provisions contained in the CESL, the DCFR, and the PECL, unless any of the rules foresee otherwise. ${ }^{2870}$ This is the same as under the CISG and the three domestic laws examined in this dissertation. ${ }^{2871}$

2868 On this, see Sections B.II.3.b.i., B.III.3.b.i., C.IV.1.b.i., and I.1. above respectively.

2869 See art 1:101 PECL, arts 3, 8 para 1 CESL Reg, and the comments to art I-1:101 DCFR in von Bar and Schulte-Nölke (fn 36) 131. On the non-bindingness of these projects, see also, eg, Schmidt-Kessel and McNamee (fn 13) 432 (DCFR and CESL). On the CISG being automatically applicable unless opted out of, see Section I.1. above.

2870 See art 1 CESL, art II-1:102 paras 1-2 DCFR, arts 1:102-1:103 PECL respectively. The caveat with the CESL is that partial derogation is not possible in B2C constellations, see art 8 para 3 CESL Reg.

2871 On the CISG's derogability, see Section I.1. above. On English, German, and Japanese law, see Section D.II. above. 
2. The Formation of Contracts under the CESL, the DCFR, and the PECL

The basis of the conclusion of a contract under the three European projects is an agreement between the parties and an intention to be legally bound by their contract (see art 30 CESL, art II-4:1:01 DCFR, art 2:101 para 1 PECL), which thus adhere to the principle of consensuality. ${ }^{2872}$ The standard analytic tool used for finding an agreement is the offer-and-acceptance model, just like in English, German, and Japanese law and the CISG. ${ }^{2873}$ Accordingly, the projects contain rules for the declarations of offer and acceptance (see Sections b. and c. below) and the effectiveness of declarations of intention (Section d.). Furthermore, there are stipulations on the sufficiency of the agreement (Section e.), and the intention to be legally bound (Section f.). On the other hand, the three European projects do not foresee further requirements for the conclusion of a contract, such as the indicia of seriousness of consideration in English law or tetsuke in Japanese law. ${ }^{2874}$ As will be seen, no form is prescribed either, not even for what are known as real contracts (Section g.). ${ }^{2875}$ Before analysing the content of the formation requirements, the definition of contract is explored subsequently.

2872 Schmidt J (fn 25) 128, who notes at 127 that the concept of real contracts is not included in the three projects. On real contracts in English, German, and Japanese law, see Section D.I. above.

2873 See art 30 para 2 CESL; comments to art II-4:201 DCFR in von Bar and Schulte-Nölke (fn 36) 316; compare arts 2:201, 2:204-2:205 PECL. On the three domestic laws, see Section D.II. above. On the CISG, see Section I.2. above. While the PECL does not foresee the model explicitly, other contract conclusion mechanisms are acknowledged in art 2:211. See Schmidt J (fn 25) $108-110$, who also notes that the three projects recognise other contract conclusion mechanisms. Christandl, 'Art 2:101 (1) PECL' (fn 2874) 239 para 6 remarks that such alternative modes of contracting are spreading in business practice.

2874 This is explicit in art 2:101 para 1 PECL, and in the comments to art II-4:101 DCFR in von Bar and Schulte-Nölke (fn 36) 290. It is implicit in art 30 CESL, as the list of requirements does not contain any other signs of serious intention. See on this further Gregor Christandl, Art 2:101 (1): Conditions for the Conclusion of a Contract (General), in: Jansen and Zimmermann (fn 38) 236, 244-245 para 18; Schmidt J (fn 25) 128. On consideration and tetsuke, see Section D.II.4. above.

2875 On real contracts in the European projects, see ibid 248 para 21. On the treatment in the three domestic laws, see Section D.I. above. 
a. 'Contract' Defined

Under the DCFR, a contract is understood as a bi- or multilateral 'agreement which is intended to give rise to a binding legal relationship or to have some other legal effect' (art II-1:101 para 1 DCFR). The latter phrase encompasses situations such as contract modification agreements and arrangements to transfer property immediately. ${ }^{2876}$ This term is contrasted with uni-, bi- or multi-lateral 'juridical acts', ie, 'any statement or agreement, whether express or implied from conduct, which is intended to have legal effect as such' (art II-1:101 para 2 DCFR). Examples include promises, grants of approval, and withdrawals. ${ }^{2877}$ This differentiation is also made in German and Japanese legal theory, according to which Verträge and keiyaku (契約) are one kind of Rechtsgeschäft or hōritsu köi (法律行為) respectively. ${ }^{2878}$

In contrast, the PECL and the CESL - just like the CISG and English law - do not make such a distinction. ${ }^{2879}$ Nevertheless, the provisions of the European projects listing the requirements for contracts (see above) all have the objective of differentiating between legally binding agreements and irrelevant arrangements or unilateral binding acts. ${ }^{2880}$ This difference notwithstanding, the notion of a contract is similar in the three European projects. The CESL - perhaps due to its more narrow scope of application - does not mention juridical acts, but gives a similar meaning to 'contract' as the DCFR, namely, as 'an agreement intended to give rise to obligations or other legal effects' (art 2 para a CESL Reg). While the PECL contains no explicit definition, a contract is also understood as a bior multilateral agreement that is intended to have legal effect. This can be deduced from art 2:101 para 1 PECL, which requires 'the parties [to] intend to be legally bound' and for them to 'reach a sufficient agreement' (emphasis added). These two requirements, which will be discussed in Sectionsf. and e. below, are found in the other two Rules as well (see art 30

2876 See von Bar and Schulte-Nölke (fn 36) 170 on art II-1:101 DCFR.

2877 See ibid.

2878 On German law, see Section B.III.3.a.i. above. On Japanese law, see Section C.IV.1.a. above.

2879 On the CISG, see Section I.2. above. On English law, see Section B.II.3.a. above.

2880 Compare Christandl, 'Art 2:101 (1) PECL' (fn 2874) 237 paras 2-3. See also the comments to art II-4:101 DCFR in von Bar and Schulte-Nölke (fn 36) 290. 
CESL and art II-4:1:01 DCFR). They also form part of the requirements under English, German, and Japanese law. ${ }^{2881}$

\section{b. Offers}

All of the three European projects contain rules on offers, in particular in relation to its definition and differentiation from non-binding statements like invitations to treat, but also with regard to its effectiveness, ie, its coming into and loss of effect, as well as its (ir)revocability. The first two aspects will be discussed here, while the effectiveness of the declaration is considered in Section d. below.

The CESL, the DCFR, and the PECL define an offer in an almost identical manner, namely, as a 'proposal' that is geared towards the conclusion of a contract. As such, it must be made with an intention to this effect and furthermore be sufficiently certain in order to form the basis of a contract (compare art 31 para 1 CESL, art II-4:201 para 1 DCFR, art 2:201 para $1 \mathrm{PECL}$ ). The intention that is required must be for the statement maker to be bound by their proposal if it is accepted by another person (see art 31 para 1 (a) CESL, art II-4:201 para 1 (a) DCFR, art 2:201 para 1 (a) PECL). ${ }^{2882}$ In terms of the certainty of the offer, its content must amount to a contract if accepted (compare art 31 para 1 (b) CESL, art II4:201 para 1 (b) DCFR, art 2:201 para 1 (b) PECL). This matter is closely connected with the agreement's sufficiency, which is discussed in Section e. below. Finally, all three European projects implicitly require that an offer be communicated. This can be deduced from art 31 para 2 CESL, art II-4:201 para 2 DCFR, and art 2:201 para 2 PECL, which state that an offer is or can be 'made' to some person(s). ${ }^{2883}$

While the Rules are the same thus far in relation to the requirements for offers under the CISG and the three domestic laws discussed in this

2881 For a discussion of the basic requirements, see Section D.II. above.

2882 Where the intention is not express, the statement maker's words will be interpreted in accordance with the rules discussed in Section $\mathrm{f}$. below. See on this generally Gregor Christandl, Art 2:201: Offer, in: Jansen and Zimmermann (fn 38) 294, 296 para 5.

2883 See also the comments to art II-4:201 DCFR in von Bar and Schulte-Nölke (fn 36) 316. On the CESL, see also Schmidt J (fn 25) 285. This is also necessary for unilateral juridical acts under art II-4:301 para c DCFR, which generally requires that 'notice of the act reaches the person to whom it is addressed'. 


\section{E. Results of the Comparative Analysis Contrasted and Final Conclusions}

dissertation, ${ }^{2884}$ there is one important difference. This concerns the offeree, namely, their number and specificity, whereby the approaches in the European projects are not uniform. On the one hand, the CESL, like the CISG, treats proposals made to the public as non-binding statements by default. $^{2885}$ Therefore, 'unless the circumstances indicate otherwise', such statements will be deemed to be invitations to treat and have no legal effect (art 31 para 3 CESL). This approach is the same in English, German, and Japanese law, according to which advertisements and display of goods in shop windows are also treated as invitationes ad offerenda. ${ }^{2886}$ In contrast, both the DCFR and the PECL foresee that proposals by 'a professional supplier' in the form of advertisements, including catalogues, and displays of goods, are deemed to be offers to supply goods or services at that price until their stock or capacity to perform the service is exhausted (art II-4:201 para 3 DCFR, art 2:201 para 3 PECL). Nevertheless, in circumstances such as the offeree's person being important to the offeror, eg, with lease or employment contracts, an advertisement for one or the other would not automatically be deemed to be an offer under the DCFR and the PECL either, but only as an invitation to make an offer. ${ }^{2887}$ The consequence is that the deviation is not as large as it may seem at first glance. Indeed, this is even more true when one bears in mind that all the rules just discussed are only default and not mandatory rules, so that statement makers can make their proposals binding by choosing the wording carefully. ${ }^{2888}$ Furthermore, the European projects, the CISG, and the three domestic laws concur in that an offer can be made to more than one specific person. ${ }^{2889}$

2884 Schmidt J (fn 25) 133-134. On the CISG, see Section I.2.a. above. On English, German, and Japanese law, see Section D.II.1.b. above. For a discussion of the differences between the details of the requirement of certainty in the CESL and English and German law, particularly regarding the price, see Schmidt J, ibid 279-282, 252-257, 262-279.

2885 See Section I.2.a. above for a discussion of the CISG's provision.

2886 On this, see Section D.II.1.a.ii. above. For a comparison with the CESL, see Schmidt J (fn 25) 201, 206-207, 210. Other cases are discussed comparatively in ibid 211 et seq.

2887 See von Bar and Schulte-Nölke (fn 36) 316 on art II-4:201 DCFR.

2888 One example given in ibid 317 is an auction sale made 'without reserve'. Another is an advertisement for a sale of land, which is to be done with the first person to pay a specified amount of money in cash.

2889 See art 31 para 2 CESL, art II-4:201 para 2 DCFR, art 2:201 para 2 PECL, as well as the discussions in Section I.2.a. above on the CISG, and in Section D.II.a. above on English, German, and Japanese law. 


\section{c. Acceptance}

The notion of acceptance is identical under the CESL, the DCFR, and the PECL, as it is defined uniformly as '[a]ny form of statement or conduct by the offeree [...] if it indicates assent to the offer' (art 34 para 1 CESL, art II-4:204 para 1 DCFR, art 2:204 para 1 PECL). This has been interpreted to mean a final and clear 'affirmative reaction' to an offer, ie, one that makes clear which offer or terms are accepted. ${ }^{2890}$ The definition of acceptance implies that the offeree must have an intention to be bound by the offer and thus to enter into a contract, so that acceptance is distinguished from acts like the mere acknowledgement of an offer. ${ }^{2891}$ As was seen above, this is true for the CISG and the three domestic laws as well. ${ }^{2892}$

The definition of acceptance makes it clear that not only verbal statements but also conduct can suffice. Beside express declarations, statements or conduct may imply acceptance, such as performance of the offeree's duty. ${ }^{2893}$ In addition, the three European codification projects regulate the converse case exactly like the CISG: 'Silence or inactivity does not in itself amount to acceptance' (art 34 para 2 CESL, art II-4:204 para 2 DCFR, art 2:204 para 2 PECL, art 18 para 1 CISG). While an express provision to the same effect cannot be found in English, German, or Japanese law, all three legal systems do not deem mere silence to constitute acceptance, although implied acceptance is generally allowed. ${ }^{2894}$ Nevertheless, both the harmonisation projects and the domestic laws admit silence or inactivity as acceptance under special circumstances, such as a framework agreement between the parties or statements by the offeror to that effect. In particular, it will be admitted where a pertinent practice or usage exists between the parties. ${ }^{2895}$

2890 Gregor Christandl, Art 2:204: Acceptance, in: Jansen and Zimmermann (fn 38) 316,317 paras 2,4 .

2891 See ibid 317 para 3. On the contractual intention to be bound, see further the discussion in Section $\mathrm{f}$. below.

2892 See Sections I.2.b. and D.II.2. above respectively. For a comparison of the CESL and English and German law, see Schmidt J (fn 25) 438, 445.

2893 On this, see Christandl, 'Art 2:204 PECL' (fn 2890) 319 para 8, who notes that implied statements under the PECL will be interpreted using an objective test. Several examples are given in the comments to art II-4:205 DCFR in von Bar and Schulte-Nölke (fn 36) 339, including the 'production of goods ordered'.

2894 See Section D.II.2.a. above.

2895 See generally Christandl, 'Art 2:204 PECL' (fn 2890) 320 paras 12-13. On the DCFR, see also the comments to art II-4:204 DCFR in von Bar and Schulte-Nölke (fn 36) 335. On English, German, and Japanese law, see Section 


\section{E. Results of the Comparative Analysis Contrasted and Final Conclusions}

This rule, together with the general requirement of a declaration of intention having to reach the other party (see Section d.i. below), indicates that acceptance, like an offer, must be communicated to the other party, unless the parties or some usage between them dispense with this formality. ${ }^{2896}$ This requirement exists likewise under the CISG, Japanese, German, and English law. ${ }^{2897}$ The parties are free to stipulate a particular manner of accepting, whereby it would have to be clear that the mode is mandatory. ${ }^{2898}$

One point on which the CESL, the PECL, and the DCFR differ from the three domestic laws is with regard to the congruence of offer and acceptance. While the latter require declarations of acceptance to correspond to the offer, ${ }^{2899}$ the former - like the CISG - give the offeree some leeway. Consequently, in accordance with art 38 para 3 CESL, art II-4:208 para 2 DCFR, and art 2:208 para 2 PECL, non-material alterations of the offer's terms do not affect the declaration as acceptance. Nevertheless, the European projects deem material changes as a rejection of the offer, so that the declaration in this case will be a new offer and not acceptance (art 38 para 1 CESL, art II-4:208 para 1 DCFR, art 2:208 para 1 PECL). Moreover, the effect is mitigated further by presumptions of a statement as a rejection, inter alia, where the offeror rejects changes without delay (art 38 para 4 (b) CESL, art II-4:208 para 3 (b) DCFR, art 2:208 para 3 (b) PECL), or where the changes relate to the contract's main terms such as the price, goods, or delivery (art 38 para 2 CESL). As a consequence, the result under the European projects, the CISG, and the domestic laws is basically the same. ${ }^{2900}$

\section{d. Effectiveness of Declarations of Intention}

Just like under the domestic laws and the CISG, declarations of intention made under the CESL, the DCFR, and the PECL will come into effect and

D.II.2.a. above. For a comparison of English and German law and the CESL, see Schmidt J (fn 25) 542-545.

2896 See art 35 para 3 CESL, art II-4:205 para 3 DCFR, art 2:205 para 3 PECL. See also Christandl, 'Art 2:204 PECL' (fn 2890) 317 para 3.

2897 See Sections I.2.b.ii. and D.II.2.b. above respectively. For a comparison of German and English law and the CESL, see Schmidt J (fn 25) 499.

2898 Christandl, 'Art 2:204 PECL' (fn 2890) 318 para 7.

2899 See Section D.II.2.b. above.

2900 See Schmidt J (fn 25) 478. 
may lose their effect at different points in time in various ways. As will be seen in Sections i. and ii. below, the regulation is almost identical in the three European harmonisation projects and the CISG, but differs in several respects from German, English, and Japanese law, in particular with regard to the last two legal orders.

\section{i. Coming into Effect of Declarations of Intention}

The coming into effect of the declarations of offer and acceptance are of significance, as the conclusion of the contract depends on these circumstances. Consequently, a contract under the CESL, the DCFR, and the PECL is formed when the declaration of acceptance comes into effect (see art 35 CESL, art II-4:205 DCFR, art 2:205 PECL). This is a codification of a general principle shared by English, German, and Japanese law and the CISG. ${ }^{2901}$ The usual point in time at which declarations of intention come into effect under the three European codification projects is the time when they arrive (art 10 para 3 CESL, art I-1:109 para 3 DCFR, art 1:303 para 2 PECL). While this rule is the same under the CISG and German law, and in part English and Japanese law, ${ }^{2902}$ the terminology and details in the regulation (on which, see below) differ. With regard to the language, the three projects use the term 'notice' instead of 'declaration of intention'; however, not only legally binding statements like offer and acceptance, but non-binding communications such as requests for and giving of information are included. The term thus encompasses different kinds of unilateral declarations as well. ${ }^{2903}$

Notice can be given 'by any means appropriate to the circumstances' (art 10 para 2 CESL, art I-1:109 para 2 DCFR, art 1:303 para 1 PECL), which has been interpreted to mean that the addressee must reasonably

2901 On the domestic laws, see Section D.II. above. On the CISG, see Section I.2. above.

2902 For the CISG, see Section I.2.c.i. above. For a comparative discussion of the three domestic laws, see Sections D.II.1.c. and D.II.2.c.i. for offers and acceptances respectively. See further Schmidt J (fn 25) 669-682, who makes a comprehensive comparison of the rules under English and German law and the CESL.

2903 A comprehensive list is given by Schmidt JP (fn 2809) 180-181 para 1. He goes on to note at $184-185$ para 8 that the term is used inconsistently, in that it sometimes means 'act of communication' and is sometimes used in the sense of a 'statement', whereby an interpretation in the latter sense seems favourable. 


\section{E. Results of the Comparative Analysis Contrasted and Final Conclusions}

anticipate receiving declarations by the means in question. ${ }^{2904}$ Similar to art 24 CISG, a notice under these three projects comes into effect at the moment when the declaration is delivered to the addressee, their place of business, or, where applicable, their residence (art 10 para 4(b) CESL, art I-1:109 para 4(a)-(b) DCFR, art 1:303 para 3 PECL). Moreover, the DCFR and the CESL contain a provision for electronic communication, under which a declaration is deemed to have arrived 'when it can be accessed by the addressee' (art I-1:109 para 4(c) and art 10 para 4(c) respectively). Finally, these two codification projects foresee that making the notice available so that the addressee can 'be expected to obtain access to it without undue delay' (ibid paras 4(d)), a 'catch all-provision' 2905 .

It ought to be stressed that actual knowledge of the notice or its content is not required by any of the provisions; the declaration entering the addressee's sphere of influence is sufficient for it to come into effect. ${ }^{2906}$ The regulation differs from German law and, to some extent, from English law in this respect, as both of these domestic laws - the former decisively more than the latter — take into account the time declarations would normally be accessed, in particular, business hours, while the three codification projects disregard this aspect. ${ }^{2907}$

In cases of declarations of acceptance, the caveat for their coming into effect is that these reach the offeror either within a specified period or at least within a reasonable time (art 36 paras 1-2 CESL, art II-4:206 paras 12 DCFR, art 2:206 paras 1-2 PECL). In accordance with art 5 para 1 CESL, art I-1:104 DCFR, and art 1:303 PECL, the appropriate period is assessed by taking into account the circumstances of the contract, including its pur-

2904 See Schmidt JP (fn 2809) 195 para 26, who notes that an explicit or implied consent for the use of electronic communication means is usually said to be required.

2905 Ibid 193 para 22.

2906 Compare ibid 193-194 paras 23-24.

2907 On the projects, see ibid 194 para 24. On German law, see Section B.III.3.a.ii.dd) above. On English law, compare Section B.II.3.a.ii.ee) above. For a comparison of the CESL, English and German law, see Schmidt J (fn 25) 346-347. She interprets the consideration of business hours in England as a requirement of actual knowledge by the addressee; however, her argument at ibid 326-329 is not convincing. While some English legal authors indeed argue that (business) hours ought to be borne in mind, the requirement for offers is only said to be communication, which is apparently necessary in order to allow the offeree to have knowledge. 
pose and any existing practices between the parties. ${ }^{2908}$ This corresponds to the regulation in art 18 para 2 CISG, as well as English, German, and Japanese law. ${ }^{2909}$ Unlike the CISG, $\mathbb{} 147$ para $1 \mathrm{BGB}$, and art 507 Shō $\bar{o}$ (Japanese Commercial Code), neither of the three harmonisation projects foresee explicitly that offers made to a present person must be accepted immediately; however, at least the PECL seems to allow such an interpretation. ${ }^{2910}$

Where acceptance is not made within the time frame, it will normally not be effective; however, the CESL, the DCFR, and the PECL provide two exceptions. On the one hand, the offeror has the discretion to deem a declaration of acceptance to be effective despite it being late; in which case they must inform the offeree without delay (art 37 para 1 CESL, art II-4:207 para 1 DCFR, art 2:207 para 1 PECL). The offeror's declaration of assent can be express or implied from conduct, such as the performance of their obligation. ${ }^{2911}$ On the other hand, where it is clear from the postal or other communication of acceptance that its late arrival is due to an unusually long transmission, the declaration will be effective unless the offeror reacts without delay, ie, gives notice of the lateness to the offeree (see ibid paras 2). These exceptions are also known in German and Japanese law and in the CISG. ${ }^{2912}$

Where no communication of acceptance is required (see Section c. above), the declaration of acceptance will consist of an act. Here, acceptance becomes effective when the act has been fully performed, even where the offeror only has notice of this after the time frame for acceptance has lapsed. ${ }^{2913}$ This scenario is similar to English unilateral contracts or

2908 On the point in time at which this period starts, namely, receipt of the offer by the offeree, see Gregor Christandl, Article 2:206: Time Limit for Acceptance, in: Jansen and Zimmermann (fn 38) 328, 329 para 3.

2909 On the domestic laws, see Section D.II.2.c.i. above. On the CISG, see Section I.2.c.i.bb) above. For a comparison of English and German law and the CESL, see Schmidt J (fn 25) 578-579.

2910 Christandl, 'Art 2:206 PECL' (fn 2908) 329 para 2.

2911 See von Bar and Schulte-Nölke (fn 36) 347 on art II-4:207 DCFR.

2912 See Sections D.II.2.c.i. and I.2.c.i.bb) above for the two domestic laws and the CISG respectively. For a comparison of the CESL and German and English law, see Schmidt J (fn 25) 598-599.

2913 See the comments to art II-4:205 DCFR in von Bar and Schulte-Nölke (fn 36) 340. Nevertheless, in such cases, starting performance 'will be at the offeree's own risk' (ibid), presumably because the offeror may assume that the offer has not been accepted and may look to contract with another party. Here, an 'express assent' will avoid such misunderstandings, ibid. It ought to be noted 
advertisements offering prizes under German and Japanese law, as the act's performance is pertinent here as well. ${ }^{2914}$

\section{ii. Loss of Effect of Declarations of Intention}

In general, declarations of intention can lose their effectiveness in different ways, depending on their kind. All types can usually be withdrawn before they have come into effect. Provisions to this effect exist in the CESL (art 10 para 5), the DCFR (art I-1:109 para 5), and the PECL (art 1:303 para 5), whereby the latter denominates this act as a 'withdrawal', while the former two use the term 'revocation'. Apart from this difference in terminology, the three provisions are identical in content. The same notion is also contained in the CISG (arts 15 para 2, 22; using the term 'withdrawal') and in the three domestic laws discussed above. ${ }^{2915}$

An offer will lose its effectiveness if it is rejected by the offeree (art 33 CESL, art II-4:203 DCFR, art 2:203 PECL) or when the set period for accepting the offer expires. ${ }^{2916}$ This can be deduced from the rule that a declaration of acceptance will not come into effect if it does not reach the offeror within the fixed time frame or, at least, within a reasonable period (compare art 36 CESL, II-4:206 DCFR, art 2:206 PECL). As was already mentioned in Section i. above, this is also true for the CISG and the three domestic laws.

Another way in which declarations of intention may lose its effect is through revocation. By virtue of art 32 CESL, art II-4:202 DCFR, and art 2:202 PECL, this is true for offers under these three regimes, unless a fixed period for acceptance or some other circumstance makes it irrevocable. ${ }^{2917}$ Accordingly, a revocable offer can be withdrawn until acceptance

that the initiation of performance is pertinent, while mere preparatory acts are irrelevant in this respect, ibid.

2914 See Section D.II.2.a. above for further details.

2915 See Sections D.II.2.c. and D.II.3.c.ii. above for offer and acceptance respectively. For further details on the CISG's provision, see Section I.2.c.ii. above.

2916 See the comments to art II-4:203 DCFR in von Bar and Schulte-Nölke (fn 36) 333 , where it is also noted that a declaration of rejection can be withdrawn under the general rules for notices (explained in the preceding paragraph above).

2917 For a discussion of these exceptions, see Gregor Christandl, Art 2:202: Revocation of an Offer, in: Jansen and Zimmermann (fn 38) 301, 309-310 paras 13-15. See further the comments to art II-4:202 DCFR in von Bar and Schulte-Nölke (fn 36) 326-327. 
is made, ie, before a statement to that effect is dispatched or the conduct in question has been concluded (ibid paras 1). ${ }^{2918}$ Where an offer is to the public, it can be revoked by the same means in which the offer was made (ibid paras 2). ${ }^{2919}$ In contrast, acceptance cannot be revoked once it has come into effect, as a contract will have been concluded. ${ }^{2920}$ Nevertheless, the declaration of acceptance can be withdrawn before it comes into effect (see above). This regulation corresponds to the norms found in the CISG, which also do not allow acceptance but do allow an offer to be revoked. ${ }^{2921}$ In terms of the result, the situation is also the same in English law, but different in German and Japanese law: the former permits the revocation of an offer but not of acceptance; Japanese law sometimes does and sometimes does not, depending on which rule is applicable to the coming into effect of the declaration in question; while German law, in contrast, allows the revocation of acceptance but not of an offer. ${ }^{2922}$

\section{e. The Sufficiency of the Agreement: Certainty or Determinability}

As has already been noted above, the three European projects not only require that an agreement be reached, but that it be 'sufficient' (see art 30 para 1(c) CESL, arts II-4:101 and II-4:103 para 1 DCFR, art 2:101 para $1 \mathrm{PECL}$ ). According to art 2:103 para $1 \mathrm{PECL}$, this means that the contract's terms must be either defined in such a way so as to make the agreement enforceable, or that they be determinable by recourse to the PECL. Although the terminology is different, this requirement is the same

2918 In the latter case, the pertinent point in time is the offeror's knowledge of the conduct, so that a revocation that reaches the offeree before the offeror learns of the acceptance-conduct is effective, see the comments to art II-4:202 DCFR in von Bar and Schulte-Nölke (fn 36) 325.

2919 The time limit is the dispatch of the offeree's acceptance. Thus, the revocation must reach the offeree if the advertisement was sent to them directly, or must be available publicly, eg, in the case of a newspaper from the newspaper agent, before acceptance is made. See on this the comments to art II-4:202 DCFR in von Bar and Schulte-Nölke (fn 36) 325.

2920 Compare the comments to art II-4:205 DCFR in von Bar and Schulte-Nölke (fn 36) 339. This is also true for acceptance by conduct, see ibid 340.

2921 On this, see Section I.2.c.ii. above.

2922 For details, see Sections D.II.1.c. and D.II.2.c.ii. on offer and acceptance respectively. For a comparison of the CESL, German, and English law, see Schmidt J (fn 25) 347 and 348 (withdrawal of offer), 420-421 and 424-425 (revocation of offer), 431-432 (rejection and expiration of offer). 


\section{E. Results of the Comparative Analysis Contrasted and Final Conclusions}

under the CESL and the DCFR (see art 30 para 1(c) CESL, art II-4:103 para 1 DCFR). ${ }^{2923}$ As a consequence, the contract's content cannot be vague, which normally means that at least the parties' obligations must be discernible. ${ }^{2924}$ While English, German, and Japanese law and the CISG do not have provisions that demand the contract to be certain, they nevertheless foresee that the content of the agreement be definite or at least determinable - by requiring an offer to be certain. ${ }^{2925}$

In accordance with the principle of freedom of form, all three Rules allow the parties to make a term essential for the contract's conclusion (see art 30 para 4 CESL, art II-4:103 para 2 DCFR, art 2:103 para 2 PECL). ${ }^{2926}$ A similar provision is found in German law ( $₫ 154$ para $1 \mathrm{BGB}),{ }^{2927}$ but neither in Japanese nor English law, nor in the CISG.

\section{f. The Requirement of an Intention to be Legally Bound}

Although the terminology varies, the CESL, the DCFR, and the PECL require the parties to have an intention to be legally bound by their contract. The phrasing of the CESL is widest, simply making it necessary for the parties to 'intend the agreement to have legal effect' (art 30 para 1(b)). The provision in the DCFR provides an alternative set of requirements: The parties may either 'intend to enter into a binding legal relationship or bring about some other legal effect' (art II-4:101 para a; emphasis added). On the other hand, the PECL requires that 'the parties intend to be legally bound' (art 2:101 para 1(a)). While essentially the same, there seems to be a subtle difference between these requirements. Both the phrasing of the DCFR and the CESL encompass cases of 'instantaneous transactions',

2923 See art 30 para 1(c) CESL and the comments to art II-4:101 DCFR in von Bar and Schulte-Nölke (fn 36) 290.

2924 Comments to arts II-4:101 and II-4:103 DCFR in von Bar and Schulte-Nölke (fn 36) 290 and 302.

2925 On the certainty of offers, see Section D.II.1.b. above for the three domestic laws, and Section I.2.a. for the CISG.

2926 It ought to be noted that the level of intention required differs between the three projects. While 'any sufficiently clear manifestation of intention' to elevate a term to an essential condition of a contract conclusion is enough under the CESL, the PECL and the DCFR require a stronger intention of one of the parties, namely, to refuse to contract unless the term in question is agreed upon. See on this Gregor Christandl, Art 2:103: Sufficient Agreement, in: Jansen and Zimmermann (fn 38) 268 para 1, 270 paras 5-6.

2927 On this, see Christandl, 'Art 2:103 PECL' (fn 2926) 270-271 para 8. 
which are executed immediately, such as purchases of daily items like newspapers or bread, and which are not meant to create long-standing contractual relations between the parties. ${ }^{2928}$

The existence of this intention to be legally bound is assessed on an objective standard, namely, the outward appearance of the parties' intention in the form of their statements and conduct (art 30 para 3 CESL, art II-4:102 DCFR, art 2:102 PECL). In this respect, the PECL and the DCFR make it clear that the objective standard is equal to what was 'reasonably understood by the other party' (ibid). A similar result is reached under the CESL when taking into account the interpretation standard for unilateral acts contained in art 12 para 1 CESL, namely, that such a statement 'is to be interpreted in the way in which the person to whom it is addressed could be expected to understand it.' This objective approach is shared by the three domestic laws, whereby only English law has the standard of the reasonable understanding of a person in the position of the other party. ${ }^{2929}$ At least under the PECL, actual knowledge of the statement giver's intention by the addressee trumps over an objective interpretation, just like in English law. ${ }^{2930}$

\section{g. Form Requirements}

As was already noted above, none of the three European projects generally require particular contract forms. This is in line with the principle of freedom of form, which is made explicit in art 6 CESL, art II-1:106 para 1 DCFR, and art 2:101 para 2 PECL. Unlike the provision found in art 11 CISG, ${ }^{2931}$ however, the application of the provisions just mentioned is not universal. Notably, the European projects foresee forms in relation to contracts involving consumers. Moreover, the DCFR contains a stipulation for gratuitous gifts (donations). We therefore see a partial difference between the international projects and English, German, and Japanese law. This is because currently, none of these three domestic laws make an explicit stip-

2928 See Christandl, 'Art 2:101 (1) PECL' (fn 2874) 339-240 para 8. For comparative remarks on situations in which no legal relations are intended at all, such as with social arrangements, see ibid 242-244 paras 12-15.

2929 On the situation in English law, see Section B.II.3.a.i. above. On German and Japanese law, see Sections B.III.3.a.i.cc) and C.IV.1.a.i. above respectively.

2930 Gregor Christandl, Art 2:102: Intention, in: Jansen and Zimmermann (fn 38) 266 paras $1-2$.

2931 For further details on this provision, see Section I.2.d. above. 


\section{E. Results of the Comparative Analysis Contrasted and Final Conclusions}

ulation recognising this principle, even though it undoubtedly forms part of their contract laws. ${ }^{2932}$ Having said this, from 1 April 2020, Japanese law introduces a norm whose wording is very similar to those of the provisions in the three European projects. ${ }^{2933}$ At least Japanese law will thus come closer to the transnational harmonisation rules. This change will not alter the fact that forms are required for particular contracts, such as in the two instances just mentioned. English and German law go further, as formal requirements are also required for transactions over real estate. ${ }^{2934}$ This latter instance is not covered by the DCFR and the PECL, as real estate is explicitly or implicitly excluded from their sphere of application. ${ }^{2935}$

Like in the domestic laws discussed in this dissertation, the European projects contain two different types of written forms: standard writing, sometimes including a signature, and a 'textual form', often to be delivered on a 'durable medium'. The meaning of these two forms will be explored briefly in Section i. before the instances of the form requirements are discussed in Section ii.

\section{i. The Standard Written Form and the Textual Form}

The requirements of form discussed in the subsequent section contain four different elements that will be analysed separately. In connection with the standard or traditional written form, the terms 'writing' and 'signature' need to be defined, whereas the meaning of 'textual form' and 'durable medium' are relevant in relation to the other kind of form.

'Writing' by itself is not defined in any of the three European projects. Rather, the traditional notion of a pen-on-paper method seems to be presupposed. This becomes clear from the CESL, which expressly states the word 'paper' in some norms (eg, arts 13 para 4 a, 18 para 1) and contrasts this with 'other durable mediums'. It is equally true for the DCFR, which makes clear that the phrase 'in writing' means 'characters

2932 On this, see Sections B.II.3.a.i., B.III.2.a., C.IV.1.a., and D.III. above.

2933 This is the new art 522 para 2 Minpō. On this provision, see Section C.V.3.d.i. above.

2934 These forms were discussed in a comparative manner in Section D.III. above.

2935 cf art I-1:101 para 2 (f) DCFR and art 1:101 PECL, the latter of which merely states to be a set of 'general rules of contract law' and does not mention real estate in any of its provisions. The CESL and the CISG - being rules on sales of goods - also do not regulate transactions on real estate, see arts 1 and 2 para h CESL Reg and Mistelis (fn 2705) para 39 respectively. 
which are directly legible from paper or another tangible durable medium' (art I-1:106 para 1), but does not refer to electronic methods. ${ }^{2936}$ Indeed, while carvings on stone or braille script fulfil the definition, recordings of sound, e-mail messages, and digital storage mediums such as DVDs in themselves do not, as they are not directly legible, ie, not legible without the use of a technical device. ${ }^{2937}$ In contrast to the CESL and the DCFR, the PECL includes electronic forms by clarifying which means of distance communication are admissible for statements made in writing, namely, anything from telegram to e-mail as long as it is 'capable of providing a readable record of the statement on both sides' (art 1:301 para 6). The standard written form admits text written in alphabetic or other characters, but not symbols. ${ }^{2938}$

Closely connected with writing is a signature. It is defined in art I-1:107 DCFR as a class denomination, encompassing two kinds: handwritten and electronic signatures. The former takes on a traditional meaning, namely, as 'the name of, or sign representing, a person written by that person's own hand for the purpose of authentication' (ibid para 2). Despite the definition, written forms under the DCFR do not automatically require a signature. ${ }^{2939}$ In contrast, the understanding of a signature as a form of authentication is presupposed in the CESL, which does not contain a definition of the term but provides in art 70 para 2 that the duty of a merchant to bring contract terms to the attention of a consumer is not fulfilled through 'a mere reference to them in a contract document, even if the consumer signs the document' (emphasis added). Here, the signature's function as a sign of consent is assumed but denied. This is also the case in art II-9:103 para 3(b) DCFR and art 2:104 para 2 PECL, the applications of which seem not to be restricted to consumers, however, as the provisions refers to 'one' or 'a' and 'the other party'. The same function is ascribed to electronic signatures, which are data that is either 'attached to or logically associated with other electronic data, and which serve[s] as a method of authentication' (art I-1:107 para 3 DCFR). Furthermore, the DCFR foresees 'advanced electronic signatures' to be electronic signatures that are created by means under the signatory's exclusive control, linked to that party, and that can identify them, whereby subsequent changes to the

2936 Compare von Bar and Schulte-Nölke (fn 36) 151 on art I-1:106 DCFR.

2937 Ibid 152.

2938 On the DCFR, compare ibid, where this is noted in relation to the textual form (discussed below).

2939 See ibid 151. 
signature are 'detectable' from the data (ibid para 4). These latter two provisions make the DCFR most technologically advanced among the three European projects, as neither the CESL nor the PECL explicitly mention the notion of electronic signatures. The former thus approximates best to the situation in English, German, and Japanese law, as their contract laws also contain provisions on (advanced) electronic signatures. ${ }^{2940}$

In a similar manner, the DCFR is closest to German and, to some extent, English law, since these legal orders know a simpler written form: The former two have a textual form or Textform, while the latter has the form of 'evidence in writing'. ${ }^{2941}$ It seems that no such form is known under Japanese law. ${ }^{2942}$ According to art I-1:106 para 2 DCFR, this form is any 'text which is expressed in alphabetical or other intelligible characters by means of any support which permits reading, recording of the information contained in the text and its reproduction in tangible form'. This means that the text need not be available permanently, so that statements displayed on a website are made in the text form under the DCFR, just like under the German Textform. ${ }^{2943}$ This is because the definition is similar to the requirement under German law for the declaration to be 'readable' ('lesbar', see $₫ 126 \mathrm{~b} \mathrm{BGB})$. In this way, this form embraces electronic statements.

Both the DCFR and German law furthermore require that the statement in textual form be stored on a 'durable medium' ('dauerhafter Datenträger'). A medium fulfils the requirement if it is durable and the sender cannot subsequently alter it, so that physical media such as CD-Roms or paper, but also the addressee's e-mail server fall within this definition, while websites are generally not sufficient. ${ }^{2944}$ The CESL, unlike the PECL, also speaks of a durable medium in relation to its form requirements. The definition is similar: According to art 2 para t CESL Reg, the durable medium must allow the addressee to store the information for future reference for an 'adequate' period of time and allow 'the unchanged reproduction of the information stored'.

2940 See the discussion in Section D.IV.2.b. above.

2941 There is no such simple written form in Japanese law. On the domestic laws, in particular the difference between the German and English simple written forms, see Section D.III.1.a. above.

2942 Compare Section C.IV.1.b.ii. above.

2943 On the DCFR, see the comments to art I-1:106 DCFR in von Bar and SchulteNölke (fn 36) 152. Compare also the comments to art II-9:103 DCFR in ibid 620. For German law, see Section B.III.3.b.ii.bb) above.

2944 See von Bar and Schulte-Nölke (fn 36) 153 on art I-1:106 DCFR. 


\section{ii. Instances of Form Requirements}

As mentioned above, the CESL, the DCFR, and the PECL require a contract form in three sets of circumstances, whereby two are linked to consumers and only one is shared by the three European Rules. This number is lower than in the three domestic contract laws, which also foresee forms in other cases, in particular with sales or leases of real estate.

The first circumstance in which the freedom of form is restricted under the European projects is in transactions involving consumers. By way of example, the CESL requires for distance contracts concluded on the telephone that the consumer has signed the offer or otherwise gives their written consent to conclude the contract in question (art 19 para 4). Moreover, the trader has to send a confirmation of the distance contract whether concluded by telephone or other means - to the consumer on a durable medium (art 19 paras 4-5 CESL; compare also art II-3:106 para 4 DCFR). Likewise, the consumer must receive a paper or digital copy (on a durable medium) of an off-premise contract from the merchant under art 18 para 1 CESL. ${ }^{2945}$ Similar regulation is also found in the domestic contract laws. ${ }^{2946}$

2945 Furthermore, there are information duties in relation to consumers under arts 13 et seq CESL, according to which the information must be 'made available to the consumer in a way that is appropriate to the means of distance communication used' with distance contracts, or, in paper or digital form with off-premise contracts, unless the price is less than $€ 50$ or the contract's object is household goods (see art 13 paras 3-5 CESL). The information duties towards other merchants are more lenient, as a 'disclos[ur]e by any appropriate means' is sufficient (see art 23 para $1 \mathrm{ibid}$ ). Finally, there are provisions for contracts concluded by electronic means other than 'exclusive exchange of electronic mail or other individual communication', which also include information duties (see arts 24-25 ibid). Information duties under the DCFR are found in arts II-3:101 et seq. In arts II-3:105 para 2 and II-3:106 para 4 DCFR, the textual form is required. It is recognised in art II-3:106 para 3 DCFR that a form may be required for the information in cases other than distance contracts; however, the provision does not constitute 'a general requirement' of form for information provided. See on this the comments to ibid in von Bar and Schulte-Nölke (fn 36) 260-261. While the PECL do not contain such detailed provisions, a general duty to provide information is inferred from art 4:107 para 3 PECL. See on this David Kästle-Lamparter, Art 2:401: Duty to Disclose Information, in: Jansen and Zimmermann (fn 38) 411, 413 para 3, 412 para 1.

2946 This was discussed briefly in Section D.III.1.a. above. For a comparison of, inter alia, English, German, and EU law, as well as various harmonisation projects, see David Kästle-Lamparter, Introduction before Art 2:401, in: Jansen and Zimmermann (fn 38) 384-410. 


\section{E. Results of the Comparative Analysis Contrasted and Final Conclusions}

Another singular circumstance which requires a contract form also relates to consumers: Under the DCFR, a personal surety involving a consumer must be made in text form on a durable medium and must furthermore be signed by the security provider (arts IV.G-4:104, IV.G-1:101 DCFR). This is one example of a signature being required in the European Rules, albeit an electronic one. ${ }^{2947}$ While English, German, and Japanese law also foresee forms for personal guarantees, the requirements range from signed written documents to merely being evidenced in writing. ${ }^{2948}$ In contrast, the CESL and the PECL do not regulate this matter.

The other situation is a contract for gratuitious gifts (donations) under arts IV.H-1:101 et seq DCFR. Accordingly, donations of, inter alia, goods, money, and some types of incorporeal property must be made in text form on a durable medium that is signed by the donor (arts IV.H-1:103 para 1, IV.H-2:101 DCFR). This does not apply where the donor is a business, or where the donation is executed immediately (art IV.H-2:102 paras $a-b$ DCFR). Again, the CESL and the PECL do not regulate this kind of transaction. Neither does the CISG. Under the domestic laws, gifts are regulated differently: Japanese law requires standard writing, while German and English law require a (notarial) deed. ${ }^{2949}$

\section{Summary of Results}

In conclusion, consensuality is a basic principle of the CESL, the DCFR, and the PECL, the same as for the CISG, as well as English, German, and Japanese law. Accordingly, a contract is formed through the concurrent intention of the parties coupled with the will to be bound by the agreement. Whether these elements exist depends on whether declarations of offer and acceptance have been made effectively, whereas it is generally irrelevant in what form the contract is concluded. Nevertheless, just as in the three domestic laws, there are single situations in which a written document or text is required under the three European harmonisation projects, namely, in relation to consumers. In particular, the DCFR has a form requirement for donations. A similar stipulation is also encountered in Japanese, German, and English law. Furthermore, the DCFR is similar to English and German law in that it has a simple written form, which is

2947 See von Bar and Schulte-Nölke (fn 36) 153 on art I-1:106 DCFR.

2948 For details, see Section D.III.1.b. above.

2949 See Sections D.III.1.b. and c. above. 
not found in the CISG, the PECL, nor in Japanese law. Nevertheless, the CESL also admits electronic modes, like storage on a durable medium.

Both offer and acceptance are distinguished from non-binding statements and acts under the CESL, the DCFR, and the PECL, and a degree of certainty and an intention to be bound are required for these declarations. While this is the same under the CISG and the three domestic laws, the distinction between offers and invitations to make an offer is not a priori the same. The DCFR and the PECL deem particular kinds of advertising materials by professionals as offers to supply as long as stocks last, while the CESL deems statements to the undefined public as invitations to make an offer. The latter approach is congruent with the CISG, while the former can lead to the same result under German, Japanese, and English law, provided that the offeror has an adequate intention to be bound. Like the CISG, the three European projects explicitly admit congruence between offer and acceptance, notwithstanding non-material alterations. Such provisions are not known in the domestic laws analysed in this dissertation.

Like the CISG and German law, and in part Japanese and English law, the CESL, the DCFR, and the PECL determine the effectiveness of declarations of intention to begin from their arrival, ie, when the recipient can access the notice and thus have knowledge. Furthermore, all laws concur that acceptance can be made by statements and conduct, but not silence. In principle, its notice must reach the offeror within the set or a reasonable period, although the two exceptions recognised under the CISG are also admitted under the European projects: unless the offeror gives notice of a delay for undue long transmissions, acceptance will be effective; otherwise, the offeror has the discretion to deem a late notice of acceptance as a new offer. In case of acceptance by conduct, however, the notice of conduct must not reach the offeror on time, which is in contrast to the CISG, but similar to German, Japanese, and English law.

Under the three European projects, loss of effect of the declarations of intention may be due to expiry, rejection (of an offer), withdrawal, or revocation. While this is in principle also true for the CISG and the three domestic laws, differences exist. These concern the revocation of offers, which is generally not possible under German law, but admitted under Japanese law in some circumstances and normally allowed under English law. The European projects seem to follow English law in this respect. 


\section{Synthesis of the Comparative Analysis and Final Conclusions}

As can be seen from the foregoing discussion, the rules on the formation of contracts in English, German, and Japanese law converge in respect of their global structure but deviate on finer points of regulation. Similarly, the transnational projects discussed in Sections I. and II. above are largely uniform in their regulatory approaches, although differences among them and, in particular, in juxtaposition with the three domestic laws, appear in several respects. There are several reasons and consequences for the differences.

One factor influencing the divergence is the legal framework in question. First, as discussed in Sections B.I. and C.I. above, the three domestic jurisdictions belong to different legal traditions with particular weighting of the instruments used to materialise the law (legal sources). Consequently, the extent to which legislated codes or statutes, court judgements, customs, and other materials of authority are encountered in legal practice varies in accordance with the type of legal system. English law as the 'mother' of common law ${ }^{2950}$ places most importance on case law, with legislation only coming second as a source of law in practice. Furthermore, customs and equity, as well as academic texts (books of authority) are secondary sources, of which, however, only the latter is relevant for the purpose of the discussion in this dissertation. ${ }^{2951}$ This is in stark contrast with Germany, which - true to its (Roman-) Germanic legal heritage traditionally places stronger emphasis on codified law, whereas court decisions are not traditionally recognised as a source of law..$^{2952}$ Nevertheless, they are taken into account in legal practice and thus form part of the applicable law. ${ }^{2953}$ Despite these differences, both jurisdictions have legislation and case law stemming from the organs of the EU in common. ${ }^{2954}$ Japan takes the intermediate position between the two. Due to the multitude of influences this legal system has experienced to date, it has been

2950 See Darbyshire (fn 28) 11 para 1-013.

2951 For details, see Sections B.I.1. and B.I.2.a. above.

2952 Indeed, apart from decisions by the German Federal Supreme Court (Bundesverfassungsgericht), which can have force of law under certain circumstances, court decisions are generally not binding on courts in other cases, see Section B.I.2.b.iii. above.

2953 See Sections B.I.1. and B.I.2.b. above for further details.

2954 On this, see Sections B.I.2.a.iii. and B.I.2.b.iv. above for England and Germany respectively. 
described as a mixed legal system. True to this nature, legislation, customs, and court judgements are all recognised as legal sources. ${ }^{2955}$

Secondly, each legal system in general and its contract law in particular has historically evolved in a different manner, as was seen in Sections B.II.2., B.III.2., and C.III. above for England, Germany, and Japan respectively. While English contract law has basically been developed from court procedures (writs) and commercial customs and needs, German contract law developed from Roman and customary law. 2956 This development was not uniform, since the law was fragmented throughout the different German territories until the BGB came into force. ${ }^{2957}$ The division was perhaps not as severe in England, due to the court procedure being more centralised and the development thus being more uniform. ${ }^{2958}$ Although the existence of a direct connection between English and Roman law is generally rejected by English academics, inspiration from Roman law concepts are nevertheless discernible in places, as with the offer-and-acceptance model. ${ }^{2959}$ In Japan, contract law first developed from customs and commercial practice and would only be unified with the coming into force of the Minpo at the end of the nineteenth century, whereby influences in contract law come down to an amalgamation of elements taken from Japanese, French, German, and English law. ${ }^{2960}$ All of these legal developments were of course based on social, economic, and political changes. In particular, the method of concluding contracts moved from barter to promises being exchanged, and from direct contracting between present persons to contracts being concluded at distance through correspondence by post in the eighteenth century, and, later, through telecommunication and now, electronic transmissions.

In terms of the ramifications of this development, all three domestic jurisdictions as well as the four transnational projects considered above require a consensual agreement between the parties in order for there to be a contract. It may be synallagmatic, ie, obliging for all parties, or binding for one side only; however, the concepts of the latter in the form

2955 See Sections C.I.1. and C.I.2. above for furher discussion.

2956 See Sections B.II.2., in particular B.II.2.a.iii.bb), and B.III.2. above for English and German law respectively.

2957 On this situation in the alte Reich (from sixteenth century), see Secions B.III.2.a.ii. and iii. above.

2958 On the historical state of the law and the English procedural system, see Sections B.II.2.a.ii. and B.II.2.b.ii. above.

2959 On this, see Section B.II.2.b.ii.bb) above.

2960 See Sections C.III.1. and 2. above for further details. 
of unilateral contracts under English law, einseitig verpflichtende Verträge under German law, and henmu keiyaku (片務契約) under Japanese law differ to some extent. ${ }^{2961}$ This is even more true for the DCFR, which does not recognise one-sided contracts, only unilateral juridical acts. ${ }^{2962}$ In contrast, the CISG, the CESL, and the PECL only admit bi- or multilateral contracts. ${ }^{2963}$ Despite this disparity, the pillars of contract formation are the same in all systems and consist of offer, acceptance, and an intention to be bound by the agreement. ${ }^{2964}$ It is remarkable that the understanding and treatment of these concepts under the domestic laws is comparable, as, for example, with the distinction between offers and invitations to treat (Aufforderung zur Abgabe eines Angebots; mōshikomi no yūin, 申込みの誘引), or the presumptive distinction between legally binding arrangements with commercial relations and non-binding arrangements in social and family relations. ${ }^{2965}$ Having said this, differences exist in respect of the classification of invitations to make an offer with the transnational projects. While the three domestic laws deem advertisements to be invitations to treat, the PECL and the DCFR have a default rule according to which they are offers to supply until stocks are depleted. ${ }^{2966}$ Moreover, the CISG and the CESL treat offers to the general public as invitations, while the three domestic laws admit these to be offers ad incertas personas under certain circumstances. ${ }^{2967}$

While these parallels also exist with respect to the general requirements for declarations of intention, ${ }^{2968}$ the regulations diverge on the point of the declarations coming into effect and losing the same. This is due, in

2961 For a comparison of these concepts, see Section D.I. above.

2962 See Section II.2.a. above.

2963 On the CISG, see Section I.2. above. On the PECL and the CESL, see Section II.2.a. above.

2964 This is analysed in Section D.II. above. On the transnational projects, see Sections I.2. and II.2. above.

2965 On this differentiation, see Sections D.II.1.a. and D.II.3. above. In like manner to offers, declarations of acceptance are also distinguished from non-binding statements, see Section D.II.2.a. above.

2966 See Sections D.II.1.a.ii. and II.2.b. above for the domestic and transnational rules respectively.

2967 On the CISG and the CESL, see Sections I.2.a.i. and II.2.b. above respectively. On the domestic laws, see Section D.II.1.a.ii. above.

2968 See Sections D.II.1.b. and D.II.2.b. above for a comparative overview of the requirements for offer and acceptance under the three domestic laws, and Sections I.2.a.-b. and II.2.b.-c. for the rules under the transnational projects. One exception is the congruence of offer and acceptance, which is treated more leniently under the transnational projects than under the domestic laws 
part, to the existence of two different sets of rules regulating the coming into effect of declarations of intention. These are the postal rule or hasshin shugi (発信主義, dispatch rule) found in English and Japanese law on the one hand, and the mailbox rule, tōtatsu shugi (到達主義, arrival rule), or Empfangstheorie (literally 'receipt theory') found in English, Japanese, and German law on the other. ${ }^{2969}$ The latter is also found in the CISG, the CESL, the DCFR, and the PECL. ${ }^{2970}$ Consequently, this issue is straightforward in German law and the transnational projects, since all declarations will normally be required to have been received. In contrast, this point is more complex in English law and even more so in Japanese law, since the rules of posting and receipt apply sometimes to offers and sometimes to acceptance, depending on the nature of the declaration and its communication method. In summary, offers made under English law are governed by the mailbox rule, whereas acceptance may fall under either the mailbox or the postal rule. Similarly, the arrival rule applies to offers while acceptance may be governed by either the arrival or the dispatch rule found in Japanese law. ${ }^{2971}$ While this is true, the dispatch rule has been abolished under the reform of the Japanese law of obligations, so that only the arrival rule will be applicable from April 2020, unless the parties foresee otherwise. ${ }^{2972}$

On the other hand, there is also discord on the question of whether declarations of intention are revocable and so may lose their effect before expiring. While English law allows declaration of offer and acceptance not governed by the postal rule to be revoked, German law does not generally allow it, unless special circumstances apply. Under Japanese law, it depends on whether the declaration is made to persons who are physically present or at distance, and what communication method is used. ${ }^{2973}$ The

in that non-material alterations are admitted explicitly under the former Rules. On this, see Sections I.2.b.iii. and II.2.c. above.

2969 In general, see Sections D.II.1.c. and D.II.2.c. above for offer and acceptance respectively.

2970 See Section I.2.c.i. for the CISG and Section II.2.d.i. above for the European projects.

2971 Details of the rules' application can be found in Sections B.III.3.a.ii.dd) and iii.cc) above for German law, in Sections B.II.3.a.i.ee) and ii.cc) for English law, and in Section C.IV.1.a., in particular in iv., for Japanese law.

2972 On this change, see Section C.V.3.a. above.

2973 For a comparative summary, see Sections D.II.1.c. and 2.c. above. For details on English law, see Sections B.II.3.a.i.ee) and ii.cc). For German law, see Sections B.III.3.a.ii.ee) and iii.cc). For Japanese law, see Sections C.IV.1.a.ii.bb) and iii.bb). 
transnational projects adopt a similar approach to English law in that revocations of offers are normally allowed, unless the offer is irrevocable. ${ }^{2974}$

The greatest points of disparity may be found in a range of requirements beyond a mere exchange of offer and acceptance in order for there to be a legally binding contract. These prerequisites are of two kinds and can be loosely grouped together as 'indicia of seriousness' and as form requirements. With regard to the signs of earnestness, differences come to light once again between German law and the transnational Rules on the one side and Japanese and English law on the other. This is because only the latter two know of such external signs in the form of tetsuke (手 付) and consideration. ${ }^{2975}$ Although both are used as indications of the party's serious intention, the concepts are radically different. The simple reason is that consideration is a constitutive element of a contract under English law, while tetsuke is an act that is only partially implemented in legal practice. ${ }^{2976}$

The other external sign that is required to varying degrees in the three domestic contract laws and only in singular cases under the transnational projects is a particular form. ${ }^{2977}$ German law is most strict, requiring highly formal acts that are performed before a public officer, a Notar (notary), for transactions of great consequence, such as transfers of titles to real estate. ${ }^{2978}$ The opposite is true for Japanese law, which allows such transactions to be concluded orally. ${ }^{2979}$ Similarly, the CISG does not require any form for sale contracts within its sphere of application. ${ }^{2980}$ The middle position is adopted by English contract law, whose strictest form is required for transfers of title to real estate, namely, a deed, an instrument

2974 On this, see Sections I.2.c.ii. and II.2.d.ii. above for the CISG and the European projects respectively.

2975 In theory, German law has a concept that is similar to tetsuke, called Draufgabe; however, as it is no longer used in practice, it has become legally irrelevant. See on this Section B.III. 3.b.vi.bb) above. For a comparison of Japanese and English law, see Section D.II.4. above.

2976 For further differences, see the juxtaposition in Section D.II.4. above. See also Section B.II.3.a.iv. above on consideration and Section C.IV.1.b.vi. on tetsuke.

2977 In general, see Section D.III. above on the domestic laws. On the transnational projects, see Sections I.2.d. and II.2.g. above.

2978 For details, see Section B.III.3.b.iii. above.

2979 See Section C.IV.1.b. above for details.

2980 See Section I.2.d. above. 
executed by private parties, albeit with professionals (solicitors) normally being involved in the drafting process. ${ }^{2981}$

Beside these traditional forms, German law and the DCFR have a textual form (Textform) that facilitates e-commerce. ${ }^{2982}$ English and Japanese law also have more lenient requirements: The former has the form of evidence in writing, which is applied to, inter alia, guarantees, while the latter requires standard writing or an electromagnetic record. ${ }^{2983}$

These differences in the legal framework are reflected in legal and business practice in the legal cultures of the three domestic laws. ${ }^{2984}$ One point in common is that agreements regarding real estate are - regardless of the legal formalities - concluded in some kind of written form in Japan, Germany, and England. Furthermore, several professions support the contracting parties during the transaction to varying degrees. The differences arise from the different course that a real transaction takes in the three countries, which in turn explains why different professionals are involved, in some cases from outside the legal profession.

Seen from a regulatory point of view, the differences described above are not as severe as they may at first appear to be, seeing as lack of one feature in one legal system is compensated by different features in another system. This can be illustrated by the doctrine of consideration in English law and tetsuke in Japan: Under both English and Japanese law, statutory form requirements are few in number. Despite this, laypersons generally desire some formality to express their earnestness, while at the same time perhaps for economic reasons - shy away from voluntarily using a formal mode. Consideration and tetsuke may have provided an uncomplicated compromise in satisfying this practical need. In contrast, the need, and therefore the practice of Draufgabe may not have endured in Germany due to the high level of statutory mandatory forms, in particular the intervention of a public officer, a Notar, being required in some circumstances.

2981 These executed contracts must be differentiated from executory agreements to sell land, which need only be in writing. See on this difference fn 759 above. On the two form requirements, see Sections B.II.3.b.iii. and ii. for deeds and for other written forms respectively. The involvement of professionals in real estate transactions was discussed in Section D.V.4. above.

2982 A comparison was already made in Section II.2.g. above.

2983 On these forms, see Sections B.II.3.b.ii.bb)-cc) and C.IV.1.b.ii. above respectively.

2984 The practical aspects of the sale of real estate were compared in Section D.V. above. 
Finally, it must be noted that the picture sketched in this dissertation is not a static one. As contract law has evolved in history, it will continue to do so in future. In this respect, both globalisation and modern technologies may be driving forces, changing current concepts or even replacing existing practices. ${ }^{2985}$ One - from both a legal and a cultural perspective regrettable - example might be Japanese seals, inshō (印章), which are sadly faced with declining importance, as requirements of written (paper) forms are apparently gradually being replaced by electronic forms. ${ }^{2986}$ It remains to be seen how the laws continue to develop; however, from a comparative lawyer's perspective, it would be preferable if legal culture were not cast aside completely for the sake of global commercial convenience.

2985 The possible impact of legal tech and smart contracts was considered in Section D.IV.3. above.

2986 This prediction is made in Personal seals in Japan: For the chop, The Economist (Tōkyō, 23 March 2019). 


\section{Bibliography}

\section{Literature in Print}

Aihara T, Tetsuke to uchikin [Tetsuke and Deposits], in: Keiyaku-hō Taikei Kankō I'in-kai [Publication Committee of the Contract Law Compendium], Keiyaku-hō Taikei 2: zōyō, baibai [Contract Law Compendium Vol 2: Gifts, Sales] (Yühikaku 1962) 58-69

Alpa G, Conceptions and Definitions of Contract: Some Thoughts on the Differences in English and German Law (2019) 2 Zeitschrift für Internationales Wirtschaftsrecht 51-56

Andersen U and Woyke W (eds), Handwörterbuch des politischen Systems der Bundesrepublik Deutschland [Handbook on the Political System of the Federal Republic of Germany] ( $7^{\text {th }}$ edn, Springer VS 2013)

Anderson S, Part One: Property, in: William Cornish and others (eds), The Oxford History of the Laws of England Vol XII: 1820-1914 Private Law (OUP 2010) 1-293

Andrews G and Millett R, Law of Guarantees ( $7^{\text {th }}$ edn, Sweet \& Maxwell 2015)

Andrews N, Contract Law (2 ${ }^{\text {nd }}$ edn, CUP 2015)

Anson WR, Principles of the English Law of Contract and of Agency in its Relation to Contract $\left(1^{\text {st }}\right.$ edn $1879 ; 3^{\text {rd }}$ edn, Clarendon Press 1884)

Armbrüster C, Vorbemerkung (Vor $\$ 116$ ) [Foreword (to S 116)], in: Franz J Säcker and others, Münchener Kommentar zum BGB [Munich Commentary on the Civil Code] Vol 1 ( $7^{\text {th }}$ online edn, CH Beck 2015) paras 1-30

Arnold MS, Fourteenth-Century Promises (1976) 35 No 2 CLJ 321-334

Atiyah PS, Essays on Contract (repr, Clarendon Press 1990)

- - Atiyah's Introduction to the Law of Contract ( $5^{\text {th }}$ edn, Clarendon Press 1995)

Bahr RR, Das rechtliche Verhältnis von Grundstück und Gebäude als Beispiel [The Relationship Between Land and Buildings as an Example], in: Heinrich Menkhaus (ed), Das Japanische im japanischen Recht [The Japanese in Japanese Law] (Iudicum 1994) 103-121

Baker JH, New Light on Slade's Case (1971) 29 No 1 CLJ 51-67

- - New Light on Slade's Case (1971) 29 No 2 CLJ 213-236

- - Origins of the "Doctrine" of Consideration, 1535-1585, in: Morris S Arnold and others (eds), On the Laws and Customs of England: Essays in Honor of Samuel E Thorne (University of North Carolina Press 1981) 336-358

- - An Introduction to English Legal History ( $3^{\text {rd }}$ edn, Butterworth 1990)

- - Why the History of English Law has not Been Finished (2000) 59 No 1 CLJ

Baldwin FE, Sumptuary Legislation and Personal Regulation in England (PhD Thesis, Johns Hopkins University 1923) 
Basedow J, Internationales Privatrecht [English title: Private International Law], in: ibid and Klaus J Hopt and Reinhard Zimmermann (eds), Handwörterbuch des europäischen Privatrechts [English title: The Max Planck Encyclopedia of European Private Law] (Mohr Siebeck 2009) Vol I 902-906

Baum $\mathrm{H}$ and Takahashi E, Commercial and Corporate Law in Japan: Legal and Economic Developments after 1868, in: Wilhelm Röhl (ed), History of Law in Japan Since 1868 (Brill 2005) 330-401

- - and Bälz M, $\mathbb{1} 1$ Rechtsentwicklung, Rechtsmentalität, Rechtsumsetzung [Chapter 1 Legal Development, Legal Mentality, Legal Implementation], in: Harald Baum and Moritz Bälz (eds), Handbuch Japanisches Handels- und Wirtschaftsrecht [Handbook Japanese Commercial- and Business Law] (Heymann 2011) 1-29

Baumbach A (founder) and Hopt KJ and others, Beck'sche Kurz-Kommentare Band 9 Handelsgesetzbuch [Beck's Concise Commentary Vol 9 Commercial Code] $\left(38^{\text {th }}\right.$ online edn, CH Beck 2018)

Behn M, Das Wirksamwerden von schriftlichen Willenserklärungen mittels Einschreiben: Zur Bedeutung der Zurücklassung des Benachrichtigungszettels [The Coming into Effect of Written Declarations of Intention: On the Importance of the Notification] (1978) 178 No 6 AcP 505-532

Bettendorf J, Elektronische Dokumente und Formqualität [Electronic Documents and Quality of Form] (2005) Rheinische Notar-Zeitschrift 227-294

Blümmel M-V, Die Dominanz des Kaiserhofs vom Ende des 7. bis zum 12. Jahrhundert [The Dominance of the Imperial Court from the end of the $7^{\text {th }}$ to the $12^{\text {th }}$ Century], in: Josef Kreiner (ed), Geschichte Japans [Japan's History] (4 ${ }^{\text {th }}$ edn, Reclam 2016) 52-93

Böckenförde E-W, Der Rechtsbegriff in seiner geschichtlichen Entwicklung: Aufriß eines Problems [The Concept of Law seen in its Historical Development: Outline of the Matter] (1968) 12 Archiv für Begriffsgeschichte 145-165

Bohrer M, Notarielle Form, Beurkundung und elektronischer Rechtsverkehr [Notarial Form, Authentication and Electronic Legal Transactions] (2008) DNotZ 39-60

Bork R, Vorbemerkungen zu SS 145-156 [Preliminary Notes on Ss 145-156], in: Julius von Staudinger and others, Kommentar zum Bürgerlichen Gesetzbuch mit Einführungsgesetz und Nebengesetzen [Commentary on the Civil Code with Introductory Act and Ancillary Laws] (rev online edn, Sellier de Gruyter 2015) paras 1-99

- - $\$ 145$ Bindung an den Antrag [Section 145 Binding Effect of an Offer], in: Julius von Staudinger and others, Kommentar zum Bürgerlichen Gesetzbuch mit Einführungsgesetz und Nebengesetzen [Commentary on the Civil Code with Introductory Act and Ancillary Laws] (rev online edn, Sellier de Gruyter 2015) paras $1-38$

- - Allgemeiner Teil des Bürgerlichen Gesetzbuchs [General Part of the Civil Code] (4 $^{\text {th }}$ edn, Mohr Siebeck 2016)

Breidenbach S and Glatz F, Einführung [Introduction], in: ibid (eds), Rechtshandbuch Legal Tech [Handbook on Legal Tech] (CH Beck 2018) 1-36 
- - Vorwort der Herausgeber [Foreword by the Editors], in: ibid (eds), Rechtshandbuch Legal Tech [Handbook on Legal Tech] (CH Beck 2018) V-VI

Bridge M, Personal Property Law (4 $4^{\text {th }}$ edn, OUP 2015)

- - Certainty, Intention and Identification in Personal Property Law, in: Paul S Davies and James Penner (eds), Equity, Trust, and Commerce (Hart Publishing 2017) 87-111

Brockhaus' Konversations-Lexikon (14 ${ }^{\text {th }}$ edn, FA Brockhaus Verlag 1898) Vol 1

Brünnler K, Blockchain kurz \& gut [Blockchain short and good] (dpunkt.verlag (sic) 2018)

Bundesgerichtshof, Der Bundesgerichtshof / The Federal Court of Justice (brochure, 2014)

Bundesrat, Gesetzentwurf der Bundesregierung: Entwurf eines Gesetzes zum Abbau verzichtbarer Anordnungen der Schriftform im Verwaltungsrecht des Bundes [Draft Law of the Government: Draft of a Law to Reduce Dispensable Requirements of the Written Form in Federal Administrative Law] (Drucksache [printed matter] 491/16, 02 September 2016)

Burrows A, The Relationship Between Common Law and Statute in the Law of Obligations (2012) 128 LQR 232-259

Busch C, Case Note: Does the Amazon Dash Button Violate EU Consumer Law? (2018) 7 No 2 Journal of European Consumer and Market Law (EuCML) 78-80

Busche J, $\mathbb{1 3 3}$ Auslegung einer Willenserklärung [Section 133 Interpretation of a Declaration of Intention], in: Franz J Säcker and others, Münchener Kommentar zum BGB [Munich Commentary on the Civil Code] Vol 1 ( $7^{\text {th }}$ online edn, CH Beck 2015) paras 1-74

- - Vorbemerkung (Vor $\mathbb{S} 145$ ) [Foreword (to S 145)], in: Franz J Säcker and others, Münchener Kommentar zum BGB [Munich Commentary on the Civil Code] Vol 1 ( $7^{\text {th }}$ online edn, $\mathrm{CH}$ Beck 2015) paras 1-77

- - $\$ 145$ Bindung an den Antrag [Section 145 Binding effect of an offer], in: Franz J Säcker and others, Münchener Kommentar zum BGB [Munich Commentary on the Civil Code] Vol 1 ( $7^{\text {th }}$ online edn, CH Beck 2015) paras 1-24

- - $\int 147$ Annahmefrist [Section 147 Period for Acceptance], in: Franz J Säcker and others, Münchener Kommentar zum BGB [Munich Commentary on the Civil Code] Vol 1 ( $7^{\text {th }}$ online edn, CH Beck 2015) paras 1-36

- - 151 Annahme ohne Erklärung gegenüber dem Antragenden [Section 151 Acceptance without declaration to the offeror], in: Franz J Säcker and others, Münchener Kommentar zum BGB [Munich Commentary on the Civil Code] Vol 1 ( $^{\text {th }}$ online edn, CH Beck 2015) paras 1-12

Byrd BS and Lehmann M, Zitierfibel für Juristen [Citationguide for Lawyers] ( $^{\text {nd }}$ edn CH Beck/Nomos/Manz/Vahlen 2016)

Canaris C-W, Handelsrecht [Commercial Law] (24 ${ }^{\text {th }}$ edn, Beck 2006)

Cartwright J, Formation and Variation of Contracts: The Agreement, Formalities, Consideration and Promissory Estoppel (Sweet \& Maxwell 2014) 
Ch'en PH-C, The Formation of the Early Meiji Legal Order: The Japanese Code of 1871 and its Chinese Foundation (OUP 1981)

Chambers R, The Importance of Specific Performance, in: Simone Degeling and James Edelman (eds), Equity in Commercial Law (Lawbook 2005) 431-462

Cherry J, Medieval and Post-Medieval Seals, in: Dominique Collon, 7000 Years of Seals (British Museum Press 1997) 124-142

Chitty Jr J, A Practical Treatise on the Law of Contracts not Under Seal; and Upon the Usual Defences to Actions Thereon ( $1^{\text {st }}$ edn $1826 ; 2^{\text {nd }}$ edn, $S$ Sweet 1834 )

Chiusi TJ, $\mathbb{S} 516$ Begriff der Schenkung [Section 516 Concept of Donation], in: Julius von Staudinger and others, Kommentar zum Bürgerlichen Gesetzbuch mit Einführungsgesetz und Nebengesetzen [Commentary on the Civil Code with Introductory Act and Ancillary Laws] (rev online edn, Sellier de Gruyter 2013, updated 20 June 2018) paras 1-359

Christandl G, Introduction before Art 2:101, in: Nils Jansen and Reinhard Zimmermann (eds), Commentaries on European Contract Laws (OUP 2018) 231-235

- - Art 2:101 (1): Conditions for the Conclusion of a Contract (General), in: Nils Jansen and Reinhard Zimmermann (eds), Commentaries on European Contract Laws (OUP 2018) 236-248

- - Art 2:102: Intention, in: Nils Jansen and Reinhard Zimmermann (eds), Commentaries on European Contract Laws (OUP 2018) 266-267

- - Art 2:103: Sufficient Agreement, in: Nils Jansen and Reinhard Zimmermann (eds), Commentaries on European Contract Laws (OUP 2018) 268-271

- - Art 2:201: Offer, in: Nils Jansen and Reinhard Zimmermann (eds), Commentaries on European Contract Laws (OUP 2018) 294-300

- - Art 2:202: Revocation of an Offer, in: Nils Jansen and Reinhard Zimmermann (eds), Commentaries on European Contract Laws (OUP 2018) 301-312

- - Art 2:204: Acceptance, in: Nils Jansen and Reinhard Zimmermann (eds), Commentaries on European Contract Laws (OUP 2018) 316-322

- - Art 2:206: Time Limit for Acceptance, in: Nils Jansen and Reinhard Zimmermann (eds), Commentaries on European Contract Laws (OUP 2018) 328-330

Clarke $\mathrm{M}$ and others, Commercial Law: Text, Cases, and Materials $\left(5^{\text {th }}\right.$ edn, OUP 2017)

Collins L (gen ed) and others, Dicey, Morris and Collins on the Conflict of Laws $\left(15^{\text {th }}\right.$ edn, Sweet \& Maxwell 2012) 2 Vols

Collon D, Introduction, in: ibid, 7000 Years of Seals (British Museum Press 1997) 9-10

- - Glossary, in: ibid, 7000 Years of Seals (British Museum Press 1997) 223-224

Comyns, A Digest of the Laws of England Vol I ( $5^{\text {th }}$ edn, Collins \& Hannay 1824)

Cooke C and Oughton DW, The Common Law of Obligations ( $3^{\text {rd }}$ edn, Butterworth 2000)

Cornish WR and Clark G de N, Law and Society in England: 1750/1950 (Sweet \& Maxwell 1989) 
Craig P and de Búrca G, EU Law ( $6^{\text {th }}$ edn, OUP 2015)

Darbyshire P, Darbyshire on the English Legal System (11 ${ }^{\text {th }}$ edn, Sweet \& Maxwell 2014)

Department for Business, Energy \& Industrial Strategy, Electronic Signatures and Trust Services (Guide, August 2016)

- - Research on Buying and Selling Homes (Research Paper No BIS/283, 22 October 2017)

Department for Exiting the European Union, Legislating for the United Kingdom's withdrawal from the European Union (White Paper, Cm 9446)

- - European Union (Withdrawal) Act 2018 Explanatory Notes (c 16-EN, 2018)

Department of Business, Innovation and Skills, Consumer Rights Act 2015: Explanatory Notes (2015)

Dernauer M, Verbraucherschutz und Vertragsfreibeit im japanischen Recht [Consumer Protection and Freedom of Contract in Japanese Law] (Mohr Siebeck 2006)

- - $\int 13$ Verbraucherschutz [Chapter 13 Consumer Protection], in: Harald Baum and Moritz Bälz (eds), Handbuch Japanisches Handels- und Wirtschaftsrecht [Handbook Japanese Commercial- and Business Law] (Heymann 2011) 567-603

Deutscher Bundestag, Beschlussempfehlung und Bericht des Ausschusses für Recht und Verbraucherschutz (6. Ausschuss) zu dem Gesetzentwurf der Bundesregierung - Drucksache 18/8486. Entwurf eines Gesetzes zur Reform des Bauvertragsrechts und zur Änderung der kaufrechtlichen Mängelhaftung [Final Recommendation and Report by the Commission on Law and Consumer Protection ( $6^{\text {th }}$ Committee) on the Government's Draft Law - Printed Matter 18/8486. Draft of a Law to Reform Construction Contract Law and to Amend Commercial Warranties] (8 March 2017)

- - Gesetzentwurf der Bundesregierung: Entwurf eines Gesetzes zur Anpassung der Formvorschriften des Privatrechts und anderer Vorschriften an den modernen Rechtsgeschäfsverkehr [Draft Law of the Government: Draft of a Law to Adapt the Form Requirements in Private Law and other Provisions to Modern Legal Transactions] (Drucksache [printed matter] 14/4987, 14 December 2000)

Dickinson A, Back to the Future - The UK's EU Exit and the Conflict of Laws (2016) Oxford Legal Studies Research Paper No 35 (draft as of 31 May 2016)

DiMatteo L A (ed), International Sales Law: A Global Challenge (CUP 2014)

Distelrath G, Die Vorindustrielle Dynamik der Frühen Neuzeit [The Pre-industrial Dynamics During Early Modern Times], in: Josef Kreiner (ed), Geschichte Japans [Japan's History] (4 ${ }^{\text {th }}$ edn, Reclam 2016) 204-260

Duus P (ed), The Cambridge History of Japan Volume 6: The Twentieth Century ( $8^{\text {th }}$ edn, CUP 2005)

Eckey-Rieger A, Der Kodifikationsstreit zum japanischen Bürgerlichen Gesetzbuch [The Codification Dispute Concerning the Japanese Civil Code] (Master thesis, University of Bonn 1993, Bonn 1994) 
Eggen M, Digitale Inhalte unter dem CISG: Eine Rundschau über Herausforderungen und mögliche Lösungen [Digital Contents under the CISG: An Overview of the Challenges and Possible Solutions] (2017) Internationales Handelsrecht (IHR) 229-237

Einsele D, $\mathbb{S} 126$ a Elektronische Form [Section 126a Electronic Form], in: Franz J Säcker and others, Münchener Kommentar zum BGB [Munich Commentary on the Civil Code] Vol 1 ( $7^{\text {th }}$ online edn, CH Beck 2015) paras 1-26

- - \$126b Textform [Section 126b Text Form], in: Franz J Säcker and others, Münchener Kommentar zum BGB [Munich Commentary on the Civil Code] Vol 1 ( $7^{\text {th }}$ online edn, CH Beck 2015) paras $1-13$

- - $\$ 130$ Wirksamwerden der Willenserklärung gegenüber Abwesenden [Section 130 Coming into Effect of the Declarations of Intention Between Absent Persons], in: Franz J Säcker and others, Münchener Kommentar zum BGB [Munich Commentary on the Civil Code] Vol 1 ( $7^{\text {th }}$ online edn, CH Beck 2015) paras 1-46

Egashira K, Shö-toribiki-hō [The Law of Commercial Transactions] ( $7^{\text {th }}$ edn, Kōbundō 2013)

Elliott C and Quinn F, English Legal System (15 ${ }^{\text {th }}$ edn, Pearson 2014)

Emmerich V, Vorbemerkung zu $₫ 535$ [Preliminary Notes on S 535], in: Julius von Staudinger and others, Kommentar zum Bürgerlichen Gesetzbuch mit Einführungsgesetz und Nebengesetzen [Commentary on the Civil Code with Introductory Act and Ancillary Laws] (rev online edn, Sellier de Gruyter 2018) paras 1-124

- - $\$ 535$ [Section 535], in: Julius von Staudinger and others, Kommentar zum Bürgerlichen Gesetzbuch mit Einführungsgesetz und Nebengesetzen [Commentary on the Civil Code with Introductory Act and Ancillary Laws] (rev online edn, Sellier de Gruyter 2018) paras 1-156

- - $\$ 550$ [Section 550], in: Julius von Staudinger and others, Kommentar zum Bürgerlichen Gesetzbuch mit Einführungsgesetz und Nebengesetzen [Commentary on the Civil Code with Introductory Act and Ancillary Laws] (rev online edn, Sellier de Gruyter 2018) paras 1-50

- - Vorbemerkungen zu $\$ 581$ [Preliminary Notes on S 581], in: Julius von Staudinger and others, Kommentar zum Bürgerlichen Gesetzbuch mit Einführungsgesetz und Nebengesetzen [Commentary on the Civil Code with Introductory Act and Ancillary Laws] (rev online edn, Sellier de Gruyter 2018) paras 1-135

- - 5581 [Section 581], in: Julius von Staudinger and others, Kommentar zum Bürgerlichen Gesetzbuch mit Einführungsgesetz und Nebengesetzen [Commentary on the Civil Code with Introductory Act and Ancillary Laws] (rev online edn, Sellier de Gruyter 2018) paras 1-483

Endō K and Matsuda K, Puchi konmentāru: shōhō sōsoku, shōkōì-hō [Small Commentary: Commercial Law, General Provisions and Commercial Transactions] (revised edn, Zeimu Keiri Kyōkai 2015)

Ernst W, Einleitung [zum Schuldrecht] [Introduction [to the Law of Obligations]], in: Franz J Säcker and others, Münchener Kommentar zum BGB [Munich Commentary on the Civil Code] Vol 2 ( $7^{\text {th }}$ online edn, CH Beck 2015) paras 1-81 
European Commission, Proposal for a Regulation of the European Parliament and of the Council on a Common European Sales Law COM (2011) 635 final

European Institute of Law (ELI), Preliminary Report 'Blockchains, Decentralized Autonomous Organizations (DAO) and Smart Contracts' (28 August 2019)

Ferrari F, PIL and CISG: Friend or Foes?, re-printed in: ibid and Clayton P Gillette (eds), International Sales Law Vol 1 (Edward Elgar Publishing, 2017) 113-175

- - CISG Article 11, in: Stefan Kröll and Loukas Mistelis and Pilar Perales Viscasillas, UN Convention on Contracts for the International Sale of Goods (CISG): A Commentary ( $2^{\text {nd }}$ online edn, CH Beck 2018) paras 1-27

- - CISG Article 14, in: Stefan Kröll and Loukas Mistelis and Pilar Perales Viscasillas, UN Convention on Contracts for the International Sale of Goods (CISG): A Commentary ( $2^{\text {nd }}$ online edn, CH Beck 2018) paras 1-47

- - CISG Article 15, in: Stefan Kröll and Loukas Mistelis and Pilar Perales Viscasillas, UN Convention on Contracts for the International Sale of Goods (CISG): A Commentary ( $2^{\text {nd }}$ online edn, CH Beck 2018) paras 1-18

- - CISG Article 16, in: Stefan Kröll and Loukas Mistelis and Pilar Perales Viscasillas, UN Convention on Contracts for the International Sale of Goods (CISG): A Commentary ( $2^{\text {nd }}$ online edn, CH Beck 2018) paras 1-27

- - CISG Article 18, in: Stefan Kröll and Loukas Mistelis and Pilar Perales Viscasillas, UN Convention on Contracts for the International Sale of Goods (CISG): A Commentary ( $2^{\text {nd }}$ online edn, CH Beck 2018) paras 1-37

- - CISG Article 19, in: Stefan Kröll and Loukas Mistelis and Pilar Perales Viscasillas, UN Convention on Contracts for the International Sale of Goods (CISG): A Commentary (2 $2^{\text {nd }}$ online edn, CH Beck 2018) paras 1- 29

- - CISG Article 21, in: Stefan Kröll and Loukas Mistelis and Pilar Perales Viscasillas, UN Convention on Contracts for the International Sale of Goods (CISG): A Commentary (2 ${ }^{\text {nd }}$ online edn, CH Beck 2018) paras 1-25

- - CISG Article 22, in: Stefan Kröll and Loukas Mistelis and Pilar Perales Viscasillas, UN Convention on Contracts for the International Sale of Goods (CISG): A Commentary ( $2^{\text {nd }}$ online edn, CH Beck 2018) paras 1-11

- - CISG Article 24, in: Stefan Kröll and Loukas Mistelis and Pilar Perales Viscasillas, UN Convention on Contracts for the International Sale of Goods (CISG): A Commentary (2 ${ }^{\text {nd }}$ online edn, CH Beck 2018) paras 1-19

- - and Gillette CP, International Sales Law Vol 1 (Edward Elgar Publishing, 2017)

- - and Gillette CP, Introduction, in: ibid (eds), International Sales Law Vol 1 (Edward Elgar Publishing, 2017) xiii-xx

Fleckner AM, Allgemeines Deutsches Handelsgesetzbuch [Common German Commercial Code], in: Jürgen Basedow and Klaus J Hopt and Reinhard Zimmermann (eds), Handwörterbuch des europäischen Privatrechts [English title: The Max Planck Encyclopedia of European Private Law] (Mohr Siebeck 2009) Vol I 45-50

Flume W, Allgemeiner Teil des Bürgerlichen Rechts [General Part of the German Civil Code] Vol 2 Das Rechtsgeschäft [The Legal Transaction] (4 ${ }^{\text {th }}$ edn, Springer Verlag 1992) 
Fogt MM, Contract Formation under the CISG: The Need for a Reform, in: Larry A DiMatteo (ed), International Sales Law: A Global Challenge (CUP 2014) 179-202

Frank R, Civil Code: General Provisions, in: Wilhelm Röhl (ed), History of Law in Japan Since 1868 (Brill 2005) 166-204

- - Law of Obligations, in: Wilhelm Röhl (ed), History of Law in Japan Since 1868 (Brill 2005) 227-261

Franzen M, Vorbemerkung (Vor $\$ 481$ ) [Foreword (to S 116)], in: Franz J Säcker and others, Münchener Kommentar zum BGB [Munich Commentary on the Civil Code] Vol 3 ( $7^{\text {th }}$ online edn, CH Beck 2016) paras 1-30

- - 4482 [Section 482], in: Franz J Säcker and others, Münchener Kommentar zum $B G B$ [Munich Commentary on the Civil Code] Vol 3 ( $7^{\text {th }}$ online edn, CH Beck 2016) paras 1-16

Freitag R, $\mathbb{} 488$ Vertragstypische Pflichten beim Darlehensvertrag [Section 488 Typical Contractual Typical Contractual Duties in a Loan Contract], in: Julius von Staudinger and others, Kommentar zum Bürgerlichen Gesetzbuch mit Einführungsgesetz und Nebengesetzen [Commentary on the Civil Code with Introductory Act and Ancillary Laws] (rev online edn, Sellier de Gruyter 2015) paras 1-486

Frere SS, Britannia: A History of Roman Britain ( $3^{\text {rd }}$ edn, Routledge $\&$ Kegan Paul 1987)

Fritzsche J, $\mathbb{1 3}$ Verbraucher [Section 13 Consumer], in: Julius von Staudinger and others, Kommentar zum Bürgerlichen Gesetzbuch mit Einführungsgesetz und Nebengesetzen [Commentary on the Civil Code with Introductory Act and Ancillary Laws] (rev online edn, Sellier de Gruyter 2018) paras 1-72

- - 14 Unternehmer [Section 14 Enterpreneur], in: Julius von Staudinger and others, Kommentar zum Bürgerlichen Gesetzbuch mit Einführungsgesetz und Nebengesetzen [Commentary on the Civil Code with Introductory Act and Ancillary Laws] (rev online edn, Sellier de Gruyter 2018) paras 1-91

Frohn M, Elektronischer Rechtsverkehr in Grundbuchsachen [Electronic Legal Transactions in Matters of Land Registration] (2016) DNotZ Special Edition 157-165

- - and Primaczenko V, $\mathbb{S} 126$ a Elektronische Form [Section 126a Electronic Form], in: Johannes Hager and others, beck-online.GROSSKOMMENTAR: BGB [beckonline.Comprehensive Commentary: German Civil Code] (online edn, $\mathrm{CH}$ Beck 2018) paras 0-36

Furmston $\mathrm{M}$ and Tolhurst GJ, Contract Formation: Law and Practice ( $2^{\text {nd }}$ edn, OUP 2016)

Gaier R, Einleitung zum Sachenrecht [Introduction to Property Law], in: Franz J Säcker and others, Münchener Kommentar zum BGB [Munich Commentary on the Civil Code] Vol 7 ( $7^{\text {th }}$ online edn, CH Beck 2017) paras 1-29

Gardner S, Trashing with Trollope: A deconstruction of the Postal Rules in Contract (1992) 12 OJLS 170 
Gastreich F, Die Draufgabe und ibre historische Entwicklung: Eine Darstellung arrhalischer Rechtsformen in ibrer essentiellen und funktionellen Bedeutung nach altem und neuem Rechte [Earnest and its Historical Development: An Account on the Legal Forms of Arrha in their Essential and Functional Meaning in Old and New Law] (Regensbergschen Buchdruckerei Münster i.W. 1933)

Giannini G, The Formation of the Contract in the UN Convention on the International Sale of Goods: A Comparative Analysis, in: Franco Ferrari and Clayton P Gillette (eds), International Sales Law Vol 1 (Edward Elgar Publishing, 2017) 16-45

Glenn HP, Legal Traditions of the World: Sustainable Diversity in Law (5 $5^{\text {th }} \mathrm{edn}$, OUP 2014)

Goanta C, How Technology Disrupts Private Law: An Exploratory Study of California and Switzerland as Innovative Jurisdictions (Stanford-Vienna TTLF Working Paper No 38/2018)

Goode R, Reflections on the Harmonisation of Commercial Law (1991) 19 No 1 Uniform Law Review 54-74

- - (founder) and McKendrick E, Goode on Commercial Law (5 th $^{\text {edn, Penguin }}$ Books 2016)

Goodenough OR, Getting to Computational Jurisprudence 3.0, in: Amedeo Santosuosso and Oliver R Goodenough and Marta Tomasi (eds), The Challenge of Innovation in Law: The Impact of Technology and Science on Legal Studies and Practice (Pavia University Press 2015) 3-17

Goodhart AL, Unilateral Contracts (1951) 67 LQR 456-460

- - A Short Replication (1953) 69 LQR 106-110

Gotthard A, Das Alte Reich 1495-1806 [The Old Reich 1495-1806] (Wissenschaftliche Buchgesellschaft 2003)

Gottwald P, $\$ 336$ Auslegung der Draufgabe [Section 336 Interpretation of earnest], in: Franz J Säcker and others, Münchener Kommentar zum BGB [Munich Commentary on the Civil Code] Vol 2 ( $7^{\text {th }}$ online edn, CH Beck 2016) paras 1-10

Götze BJ, Wortsegmentierungsregeln (nicht nur) für japanische Rechtsbegriffe [Word Segmentation Rules (Not Just) for Japanese Legal Terms] (2005) 19 ZJapanR / JJapanL 207-213

- -Japanisch-Deutsches Rechtswörterbuch [Japanese-German Legal Dictionary] $\left(2^{\text {nd }}\right.$ edn, Seibun-dō 2011)

- - and Baum H, Merkblatt für eine einheitliche Transkription, Übersetzungen und Zitierweise für Veröffentlichungen in der Zeitschrift für Japanisches Recht [Explanatory Notes for a Uniform Approach Regarding Transcriptions, Translations and Citations in Publications for the Journal of Japanese Law] (1998) 5 ZJapanR / JJapanL 207-216

Gray W, Use and Non-Use of Contract Law in Japan: A Preliminary Study (1984) 17 Law in Japan 97-119

Green K and Cursley J, Land Law (5 $5^{\text {th }}$ edn, Palgrave Macmillan 2004)

Griffith DH and Harrison J, United Kingdom, in: Dennis Campbell (ed), E-commerce and the Law of Digital Signatures (Oceana Publishing 2005) 637-693 
Grupp TM, Vertragsgestaltung in Zeiten von Brexit [Contract Drafting in Times of Brexit] (2017) NJW 2065-2070

Grundmann B, Gründe, Ziele, Konzeption und Probleme der Schuldrechtsreform [Reasons, Objectives and Problems of the Reform of the Law of Obligations], in: Makoto Tadaki and Harald Baum (eds), Saiken-hō kaisei ni kansuru hikaku-hōteki kentō: nichidoku-hō no shiten kara [A Comparative Analysis of the Modernisation of the Law of Obligations in Japan: From the Perspective of Japanese and German Law] (Chūō Daigaku Shuppan-bu 2014) 15-22

Grundmann S, Series Preface, in: Karl Riesenhuber (ed), European Legal Methodology (Intersentia 2017) v-vii

- - and Thiessen J, Vorwort [Preface], in: ibid (eds), Recht und Sozialtheorie im Rechtsvergleich / Law in the Context of Disciplines: Interdisziplinaeres Denken in Rechtswissenschaft und -praxis / Interdisciplinary Approaches in Legal Academia and Practice (Mohr Siebeck 2015) V-VI

Grzeszick B, Artikel 20 GG, in: Theodor Maunz and others (eds), Grundgesetz Kommentar [Basic Law Commentary] (CH Beck, 2017 issue)

Hadamitzky W, Handbuch und Lexikon der japanischen Schrift: Kanji und Kana 1 [Handbook on the Japanese Script: Kanji and Kana 1] (Langenscheidt KG 1995)

- - and others (eds), Langenscheidt Großwörterbuch Japanisch-Deutsch Zeichenwörterbuch [Langenscheidt's Japanese-German Character Dictionary] (Langenscheidt KG 1997)

Haferkamp H-P, Bürgerliches Gesetzbuch [Civil Code], in: Jürgen Basedow and Klaus J Hopt and Reinhard Zimmermann (eds), Handwörterbuch des europäischen Privatrechts [English title: The Max Planck Encyclopedia of European Private Law] (Mohr Siebeck 2009) Vol I 229-233

Haley JO, Rethinking Contract Practice and Law in Japan (2008) 1 Journal of East Asia \& International Law 47-69

- - Rivers and Rice: What Lawyers and Legal Historians Should know about Medieval Japan (2010) 36 Journal of Japanese Studies 313-349

Halsbury's Laws of England

- - Vol 9 (4 $4^{\text {th }}$ edn, LexisNexis 1974) paras 201-750

- - Vol $22\left(5^{\text {th }}\right.$ edn, LexisNexis 2012) paras 202-652

- - Vol 23 ( $5^{\text {th }}$ edn, LexisNexis 2016) paras 1-500

-- Vol $32\left(5^{\text {th }}\right.$ edn, LexisNexis 2012) paras 1-200

- - Vol 96 ( $5^{\text {th }}$ edn, LexisNexis 2012) paras 301-600

Hamm C and Schwerdtner P (Founder), Maklerrecht [The Law of Agency] ( $^{\text {th }}$ rev edn, CH Beck 2012)

Hanbury HG (Founder) and Martin JE, Modern Equity (18 $8^{\text {th }}$ edn, Sweet \& Maxwell 2009)

Hanseatische Rechtsanwaltskammer Hamburg, Aktuelles zum elektronischen Rechtsverkehr beim Finanzgericht [Latest News on Electronic Legal Transactions with the Finance Court] (Kammerreport No 4 2014) 12-14 
Härting $\mathrm{N}$, Internetrecht [Internet Law] $\left(6^{\text {th }}\right.$ online edn, Verlag Dr Otto Schmidt 2017)

Hedley S, Keeping Contract in its Place: Balfour $v$ Balfour and the Enforceability of Informal Agreements (1985) 5 OJLS 391-415

Henderson DF, Village "Contracts" in Tokugawa Japan: 50 Specimens with English Translation and Comments (University of Washington Press, 1975)

- - and Torbert PM, Traditional Contract Law in Japan and China, in: René David and others (eds), International Encyclopedia of Comparative Law (Mohr Siebeck/ Nijhoff 2008) Vol VII/1 3-34

Henig M, Roman Sealstones, in: Dominique Collon, 7000 Years of Seals (British Museum Press 1997) 88-106

Henne T, Handelsgesetzbuch [Commercial Code], in: Albrecht Cordes and others (eds), Handwörterbuch zur deutschen Rechtsgeschichte [Handbook on German Legal History] (online edn, Erich Schmidt Verlag 2018) Vol II paras 712-714

Hergenröder C, Die Vereinbarkeit sogenannter "Dash Buttons" mit den zivilrechtlichen Regelungen zum E-Commerce [The Compatibility of what are known as "Dash Buttons" and Private Law Rules of E-Commerce] (2017) Verbraucher und Recht (VuR) 174-178

Hertel C, $\mathbb{S} 125$ [Section 125], in: Julius von Staudinger and others, Kommentar zum Bürgerlichen Gesetzbuch mit Einführungsgesetz und Nebengesetzen [Commentary on the Civil Code with Introductory Act and Ancillary Laws] (rev online edn, Sellier de Gruyter 2017) paras 1-127

- - $\$ 126$ [Section 126], in: Julius von Staudinger and others, Kommentar zum Bürgerlichen Gesetzbuch mit Einführungsgesetz und Nebengesetzen [Commentary on the Civil Code with Introductory Act and Ancillary Laws] (rev online edn, Sellier de Gruyter 2017) paras 1-188

- - $\$ 129$ [Section 129], in: Julius von Staudinger and others, Kommentar zum Bürgerlichen Gesetzbuch mit Einführungsgesetz und Nebengesetzen [Commentary on the Civil Code with Introductory Act and Ancillary Laws] (rev online edn, Sellier de Gruyter 2017) paras 1-159

- - Beurkundungsgesetz [Notarial Authentication Law], in: Julius von Staudinger and others, Kommentar zum Bürgerlichen Gesetzbuch mit Einführungsgesetz und Nebengesetzen [Commentary on the Civil Code with Introductory Act and Ancillary Laws] (rev online edn, Sellier de Gruyter 2017) paras 1-933

Heydn TJ, Germany, in: Dennis Campbell (ed), E-commerce and the Law of Digital Signatures (Oceana Publications 2005) 221-268

Hirai Y, Zenchū (SS 90-98 [hōritsu kōi]) [Preliminary Note (Arts 90-98 [Juridical Acts])], in: Takeyoshi Kawashima and ibid (eds), Shinhan chüshaku minpō (3) sōsoku (3) [Japanese Civil Law Annotated Vol 3 General Provisions Part 3] (2 edn, Yūhikaku 2003) 1-93

HM Land Registry, Registration Services Fees (Guide, March 2017)

Hoath DC, The Sealing of Documents. Fact or Fiction (1980) 43 No 4 The Modern Law Review 415-428 
Hoffmann J and Höpfner U, Kündigung per E-Mail im elektronischen Geschäftsverkehr [Cancellation by E-mail in Electronic Commerce] (2016) 49 Betriebsberater (BB) 2952-2955

Hōmu-shō, Minpō (saiken kankei) no kaisei ni kansuru chūkan shi an seigō-byō [Correction of the Interim Tentative Plan for the Reform of the Civil Code (Law of Obligations)] dated 4 July 2013, document no 000112240

Hōmu-shō Minji-kyoku, Tōki inshi no tori'atsukai ni tsuite [Regarding the Handling of Registration Stamps] (1 April 2011)

Honsell H, Einleitung zum Bürgerlichen Gesetzbuch [Introduction to the Civil Code], in: Staudinger and others, Kommentar zum Bürgerlichen Gesetzbuch mit Einführungsgesetz und Nebengesetzen [Commentary on the Civil Code with Introductory Act and Ancillary Laws] (rev online edn, Sellier de Gruyter 2018) paras $1-237$

Hōsei Shingi-kai Minpō (Saiken Kankei) Bukai, Minpō saiken kankei no minaoshi ni tsuite [Concerning the Revision of the Civil Code's Law of Obligations] (date unknown)

- - Minpō (saiken kankei) no kaisei ni kansuru chükan shi'an [Interim Tentative Plan for the Reform of the Civil Code (Law of Obligations)] (March 2013)

- Minpō (saiken kankei) no kaisei in kansuru chükan shi'an no hosoku setsumei [Supplementary Explanations with Regard to the Interim Tentative Plan for the Reform of the Civil Code (Law of Obligations)] (last amended July 2013)

- - Minpō (saiken kankei) no kaisei ni kansuru yōkō-an no tatakidai (1) [Draft Proposal for the Motion Outline in Relation to the Reform of the Civil Code (Law of Obligations) (1)] (September 2013)

- - Minpō (saiken kankei) no kaisei ni kansuru yōkō-an no tatakidai (2) [Draft Proposal for the Motion Outline in Relation to the Reform of the Civil Code (Law of Obligations) (2)] (September 2013)

- - Minpō ichibu wo kaisei suru höritsu [Law to amend one part of the Civil Code] (submitted for consideration by the Japanese Parliament on 31 March 2015)

- - Minpō ichibu wo kaisei suru hōritsu-an ni taisuru shūsei-an shinkyū taishō jōbun [Amendment Proposal to the Law to Amend one Part of the Civil Code, Old and New Text Contrasted]

- - Minpō ichibu wo kaisei suru höritsu-an ni taisuru shüsei-an yōkō [Amendment Proposal to the Outline of the Law to Amend one Part of the Civil Code], document no 001226882

- - Minpō ichibu wo kaisei suru höritsu-an ni taisuru shüsei-an-an [Amendment Proposal to the Draft Law to Amend one Part of the Civil Code], document no 001226883

- - Minpō ichibu wo kaisei suru hōritsu-an shinkyū taishō jōbun [Comparison of New and Old Provisions of the Draft Law to Amend one Part of the Civil Code], document no 001142671

- - Riyü [Motives], document no 001142183

House of Commons, European Union (Withdrawal) Bill Explanatory Notes (Bill 5EN, 2017) 
House of Lords, Practice Statement (Judicial Precedent) [1966] 1 WLR 1234

Hozumi N, Lectures on the New Japanese Civil Code as Material for the Study of Comparative Jurisprudence (Maruzen Kabushiki-kaisha 1912)

Hubner U, Der UNCITRAL-Entwurf eines Übereinkommens über internationale Warenkaufverträge [The UNCITRAL-Draft of a Convention on International Sale Contracts] (1979) 43 RabelsZ 413-526

Ibbetson D, Assumpsit and Debt in the Early Sixteenth Century: The Origins of the Indebitatus Count (1982) 43 No 3 CLJ 142-161

- - A Historical Introduction to the Law of Obligations (OUP, repr 2006)

Industrie- und Handelskammer Bonn/Rhein-Sieg, Kostenvoranschlag [Cost Estimate] (leaflet, May 2018)

International Court of Justice, Acts and Documents Concerning the Organization of the Court No 6 (February 2007)

International Institute for the Unification of Private Law (UNIDROIT), UNIDROIT Principles of International Commercial Contracts (2016)

Ishii K, Japanische Unterschriftsstempel: Gegenwart und Geschichte [Japanese Nameseals: Present and History] (Expert Opinion, Technische Universität Berlin 2000)

Ishii R (ed) and Chambliss WJ (tr), Japanese Culture in the Meiji Era, Vol IX: Japanese Legislation in the Meiji Era (repr edn, The Toyo Bunko 1969)

Jachmann M, Artikel 96 GG, in: Theodor Maunz and others (eds), Grundgesetz Kommentar [Basic Law Commentary] (CH Beck, 2017 issue) paras 10-16

Jansen MB, The Making of Modern Japan (Harvard University Press 2000)

- - Introduction, in: ibid (ed), The Cambridge History of Japan Volume 5: The Nineteenth Century (repr, CUP 2007) 1-49

- - Japan in the Early Nineteenth Century, in: ibid (ed), The Cambridge History of Japan Volume 5: The Nineteenth Century (repr, CUP 2007) 50-115

Jansen N, Art 1:101: Application of Principles, in: ibid and Reinhard Zimmermann (eds), Commentaries on European Contract Laws (OUP 2018) 27-29

- - and Zimmermann R, General Introduction: European Contract Laws, in: ibid (eds), Commentaries on European Contract Laws (OUP 2018) 1-18

Japanese Law Translation Council, Hōrei yōgo nichi'ei byöjun taiyaku jisho [English title: Standard Legal Terms Dictionary] (Version 14, 2019)

Kadner Graziano T, Comparative Contract Law: Cases, Materials and Exercises (Eleanor Grant tr, Palgrave Macmillan 2009)

Kaiser A, $\mathbb{S} 16$ Immobilienrecht [Chapter 16 Real Estate Law], in: Harald Baum and Moritz Bälz (eds), Handbuch Japanisches Handels- und Wirtschaftsrecht [Handbook Japanese Commercial- and Business Law] (Heymann 2011) 687-744

- - and Pawlita S, Das Notariat in Japan [The Notary's Office in Japan] (2005) 20 ZJapanR / JJapanL 163-192

Kano N, Dai-3-hen dai-2-chō dai-3-setsu dai-1-kan sōsoku [Part 3 Chapter 2 Section 3 Subsection 1 General Provisions], in: Hisakazu Matsuoka and Kunihiro Nakata (eds), Shin konmentāru minpō (zaisan-hō) [New Commentary on the Civil Code (Property Law)] (Nihon Hyōron-sha 2012) 806-812 
Kansaku H and Bälz M, $\mathbb{3}$ Gesellschaftsrecht [Chapter 3 Corporate Law], in: Harald Baum and Moritz Bälz (eds), Handbuch Japanisches Handels- und Wirtschaftsrecht [Handbook Japanese Commercial- and Business Law] (Heymann 2011) 67-140

- - and others, Übersetzung des novellierten Zivilgesetzes 2020 [Translation of the Amended Civil Code 2020] (2018) 45 ZJapanR / JJapanL 183-305

Kanzleiter R, OLG Rostock: Vor dem Notar erklärte Auflassung obne Unterschrift [OLG Rostock: Disposition Declared Before a Notary not Signed] (2007) DNotZ 220225

Kashiwagi N, Translation of Japanese Statutes into English (2007) 12 ZJapanR / JJapanL 221-226

- - Translation of Japanese Statutes (2014) 11 Univeristy of Tōkyō Journal of Law and Politics 1-7

Kassan J and Orsi J, The Legal Landscape of the Sharing Economy (2012) 27 No 1 Journal of Environmental Law \& Litigation 1-20

Kästle-Lamparter D, Art 2:401: Duty to Disclose Information, in: Nils Jansen and Reinhard Zimmermann (eds), Commentaries on European Contract Laws (OUP 2018) 411-419

- - Introduction before Art 2:401, in: Nils Jansen and Reinhard Zimmermann (eds), Commentaries on European Contract Laws (OUP 2018) 384-410

Kaufmann A, Rechtsbegriff und Rechtsdenken [The Concept of Law and Legal Thought] (1994) 37 Archiv für Begriffsgeschichte 21-100

Kaufmann E and Köbler G, Pactus, pactum, in: Albrecht Cordes and others (eds), Handwörterbuch zur deutschen Rechtsgeschichte [Handbook on German Legal History] (online edn, Erich Schmidt Verlag 2018) Vol IV paras 303-305

Kawakami S, "Keiyaku no seiritsu" wo megutte (1) [Concerning the "Formation of Contracts" (1)] (1988) 665 Hanrei Taimuzu 11-21

Keizai Sangyō-shō (METI), Denshi shō-torihiki oyobi jōhō zai-torihiki tō ni kansuru junsoku [Interpretative Guidelines on Electronic Commerce and Information Property Trading] (Guideline, April 2015)

Kenny CS, A Selection of Cases Illustrative of the Law of Contract (CUP 2014)

Kinoshita T, Eibei keiyaku-hō ni okeru ishi byöji no fu-icchi [Dissonance of Declarations of Intention in Anglo-American Contract Law] (1972) 11 Shakai Gaku Jānaru $99-120$

Kitagawa Z, Rezeption und Fortbildung des europäischen Zivilrechts in Japan [Reception and Subsequent Development of European Civil Law in Japan] (Alfred Metzner Verlag 1970)

- - Contracts and Business Activities, in: ibid (ed), Doing Business in Japan Vol 2 (Bender 1980, 2017 release of loose-leaf work)

- - Business Law in New Fields, in: ibid (ed), Doing Business in Japan (Bender 1980, 2018 release of loose-leaf work) Vol 5

Kobashi I, Wagakuni ni okeru kaisha-hō-sei no keisei [The Formation of Corporate Legislation in our Country] (Kokusai Rengō Daigaku 1981) 
Köbl H, Die Bedeutung der Form im heutigen Recht [The Importance of Form in Current Law] (1983) DNotZ 207-226

Koch CF, Lehrbuch des preußischen gemeinen Privatsrechts Band 2 [Textbook on Prussian Common Private Law Vol 2] (Verlag der Trautwein'schen Buch- und Musik-Handlung 1846)

Koku-Zeichō, Inshi-zei no tebiki [A Guide to Stamp Tax] (September 2015)

Kötz H, Seriositätsindizien [Indicia of Seriousness; in English version 'Tests of Earnestness'], in: Jürgen Basedow and Klaus J Hopt and Reinhard Zimmermann (eds), Handwörterbuch des europäischen Privatrechts [English title: The Max Planck Encyclopedia of European Private Law] (Mohr Siebeck 2009) Vol II 1397-1400

- - Vertragsrecht [Contract Law] (Mohr Siebeck 2009)

- - Europäisches Vertragsrecht [European Contract Law] (Mohr Siebeck 2015)

- - and Flessner A, European Contract Law Vol 1 Formation, Validity, and Content of Contracts; Contract and Third Parties (Clarendon Press 1997)

Krafka A, $\int 8 b$ Unternehmensregister [Section 8b Business Register], in: Karsten Schmidt (ed), Münchener Kommentar zum HGB [Munich Commentary on the Commercial Code] (4 ${ }^{\text {th }}$ online edn, CH Beck 2016) Vol 1 paras 1-22

Kramer EA and Probst T, Defects in the Contracting Process, in: René David and others (eds), International Encyclopedia of Comparative Law (Mohr Siebeck/Nijhoff 2008) Vol VII/2 3-254

Krebs and Becker M, Entstehung und Abänderbarkeit von Gewohnheitsrecht [Creation and Modifiability of Customary Law] (2013) JuS 97

Kreiner J, Japan und die Ostasiatische Staatenwelt an der Wende vom Mittelalter zur Frühen Neuzeit [Japan and East Asian States at the Turn of Medieval to Early Modern Times], in: ibid (ed), Geschichte Japans [Japan's History] (4 ${ }^{\text {th }}$ edn, Reclam 2016) 149-203

- - Vorwort [Foreword], in: ibid (ed), Geschichte Japans [Japan's History] (4 $4^{\text {th }}$ edn, Reclam 2016) 11-22

Kroeschell K, Deutsche Rechtsgeschichte Band 3: Seit 1650 [German Legal History Vol 3: From 1650] (4 ${ }^{\text {th }}$ edn, Böhlau Verlag 2005)

Kröll S and Mistelis L and Viscasillas PP, UN Convention on Contracts for the International Sale of Goods (CISG): A Commentary ( $2^{\text {nd }}$ online edn, CH Beck 2018)

Kubota T, Honsho no yomikata [How to Read this Book], in: Yasutomo Sugiura and ibid (eds), Uin baibai joyaku no jitsumu kaisetsu [Practice Commentary on the Vienna Sales Convention] (2 ${ }^{\text {nd }}$ edn, Chūō Keizai-sha 2011) 1-15

- - Sankō: Saiken-hō kaisei tei'an to CISG no söi [Reference: The Differences Between the Proposal for the Reform of the Law of Obligations and the CISG], in: Yasutomo Sugiura and ibid (eds), Uin baibai jöyaku no jitsumu kaisetsu [Practice Commentary on the Vienna Sales Convention] ( $2^{\text {nd }}$ edn, Chūō Keizai-sha 2011) $16-21$

Kume M, Mono to ningen no bunka-shi 178: hanko [The Cultural History of Objects and Humans No 178: Hanko] (Hōsei Daigaku Shuppan-kyoku 2016)

Laborde CM, Electronic Signatures in International Contracts (Peter Lang 2010) 
Lando O (ed), Principles of European Contract Law (Kluwer Law International)

- - Parts 1-2 (rev edn, 2000)

- - Part 3 (2003)

Langenfeld G, Vorwort [Preface], in: Sebastian Herrler (ed), Münchener Vertragshandbuch Band 5: Bürgerliches Recht 1 [Munich Handbook on Contracts Vol 5: Civil Law 1] (Beck 2013) VI-VII

Lapuente CS and Terryn E, Consumer Contract Law, in: Hans-Wolfgang Micklitz and Jules Stuyck and Evelyne Terryn (gen eds), Cases, Materials and Text on Consumer Law (Hart Publishing 2010) 157-238

Larenz K, Methodenlehre der Rechtswissenschaft [Methodology of Jurisprudence] $6^{\text {th }}$ edn, Springer 1993)

Law Commission, Transfer of Land: Formalities for Deeds and Escrows (Working Paper No 93, 1985)

- - Transfer of Land: Formalities for Deeds and Escrows (Law Com No 164, 1987)

- Electronic Commerce: Formal Requirements in Commercial Transactions (advice paper, 2001)

- - and The Scottish Law Commission, Unfair Terms in Contracts: A Joint Consultation Paper (Consultation Paper 166, 2002)

- - and The Scottish Law Commission, Unfair Terms in Contracts Summary [of Report] (Law Commission No 298; Scottish Law Commission No 199; 2005)

Lawson C, Found in Translation: The "Transparency of Japanese Law Project" in Context (2007) 12 ZJapanR / JJapanL 187-199

Lenz K-F, Das Japanische im japanischen Handelsrecht [The Japanese in Japanese Commercial Law], in: Heinrich Menkhaus (ed), Das Japanische im japanischen Recht [The Japanese in Japanese Law] (Iudicum 1994) 219-236

Lieder J and Berneith D, Echte und unechte Ausnahmen vom Abstraktionsprinzip [Genuine and Artificial Exceptions to the Abstraction Principle] (2016) JuS 673678

Lobban M, Part Two: Contract, in: William Cornish and others (eds), The Oxford History of the Laws of England Vol XII: 1820-1914 Private Law (OUP 2010) 295609

Long G, Arra, in: William Smith, A Dictionary of Greek and Roman Antiquities (John Murray, London 1873) 137

Löwisch M, $\int 336$ Auslegung der Draufgabe [Section 336 Interpretation of Earnest], in: Julius von Staudinger and others, Kommentar zum Bürgerlichen Gesetzbuch mit Einführungsgesetz und Nebengesetzen [Commentary on the Civil Code with Introductory Act and Ancillary Laws] (rev online edn, Sellier de Gruyter 2015) paras 1-15

- - Vorbemerkungen zu $\int \mathbb{S} 339 f f$ [Preliminary Remarks on $\$ \mathbb{S} 339$ et seq], in: Julius von Staudinger and others, Kommentar zum Bürgerlichen Gesetzbuch mit Einführungsgesetz und Nebengesetzen [Commentary on the Civil Code with Introductory Act and Ancillary Laws] (rev online edn, Sellier de Gruyter 2015) 
Luig K, Gemeines Recht [Common Law], in: Albrecht Cordes and others (eds), Handwörterbuch zur deutschen Rechtsgeschichte [Handbook on German Legal History] (online edn, Erich Schmidt Verlag 2018) Vol II paras 60-77

Lutz A, $\mathbb{3} 39$ a Einfache elektronische Zeugnisse [Section 39a Simple Electronic Certifications], in: Beate Gesell and others (eds), beck-online.GROSSKOMMENTAR: BeurkG [beck-online.Comprehensive Commentary: Notarial Authentication Law] (online edn, CH Beck 2017) paras 1-26

Maier-Reimer G, Die Form verbundener Verträge [The Form of Connected Contracts] (2004) NJW 3741-3745

Mankowski P, Formzwecke [Functions of Forms] (2010) 65 No 13 JZ 662-668

Mann M, Commercial Contracts in Germany (CH Beck 2015)

Martin EA (ed), A Dictionary of Law ( $5^{\text {th }}$ edn, OUP 2002)

Marutschke H-P, Übertragung dinglicher Rechte und gutgläubiger Erwerb im japansichen Immobiliarsachenrecht [The Transfer of Rights in Rem and Bona Fide Acquisition in Japanese Land Law] (Mohr Siebeck 1997)

- - Einführung in das japanische Recht [Introduction to Japanese Law] ( $2^{\text {nd }}$ edn, Beck 2010)

Mather H, Choice of Law for International Sales Issues not Resolved by the CISG, re-printed in: Franco Ferrari and Clayton P Gillette (eds), International Sales Law Vol 1 (Edward Elgar Publishing, 2017) 362-415

Mathias R, Das Entstehen einer modernen städtischen Gesellschaft und Kultur, 1900/1905-1932 [The Creation of a Modern Urban Society and Culture, 1900/1905-1932], in: Josef Kreiner (ed), Geschichte Japans [Japan's History] (4 ${ }^{\text {th }}$ edn, Reclam 2016) 332-380

Matsumoto T, Denshi shakai no keiyaku-hō [Contract Law in the Digital Society], in: Tomohei Taniguchi and Kiyoshi Igarashi (eds), Shinhan chüshaku minpō (13) saiken (4) [Japanese Civil Law Annotated Vol 13 Obligations Part 4] (2 ${ }^{\text {nd }}$ revised edn, Yūhikaku 2006) 288-356

- - Keiyaku no Seiritsu [The Formation of Contracts], in: Tsuneo Matsumoto and Masahiro Saitō and Yasutaka Machimura (eds), Denshi shō-torihiki-hō [The Law on Electronic Commercial Transactions] (Keisō Shobō 2013) 3-42

Matsuoka H, Dai-2-hen bukken [Part 2 Real Rights], in: ibid and Kunihiro Nakata (eds), Shin konmentāru minpō (zaisan-hō) [New Commentary on the Civil Code (Property Law)] (Nihon Hyōron-sha 2012) 281-284

- - Dai-2-hen dai-1-chō sōsoku [Part 2 Chapter 1 General Rules], in: ibid and Kunihiro Nakata (eds), Shin konmentāru minpō (zaisan-hō) [New Commentary on the Civil Code (Property Law)] (Nihon Hyōron-sha 2012) 285-317

McGrath CP and Koziol H, Is Style of Reasoning a Fundamental Difference Between the Common Law and the Civil Law? (2014) 78 RabelsZ 709-749

McKendrick E, Contract Law: Text, Cases and Materials ( $7^{\text {th }}$ edn, OUP 2016)

Mertens B, Die Reichweite gesetzlicher Formvorschriften im BGB [The Scope of Statutory Form Requirements of the BGB] (2004) 59 No 9 JZ 431-439 
Millet PJ, Equity's Place in the Law of Commerce (1998) 114 LQR 214-227

Ministry of Justice, Practice Direction 6A - Service within the United Kingdom (updated on 30 January 2017)

Minpō (Saiken-hō) Kaisei Kentō I'in-kai, Japanese Civil Code (Law of Obligations) Reform Commission Draft Proposals (2010)

Mistelis L, CISG Art 1, in: Stefan Kröll and Loukas Mistelis and Pilar Perales Viscasillas, UN Convention on Contracts for the International Sale of Goods (CISG): A Commentary ( $2^{\text {nd }}$ online edn, CH Beck 2018) paras 1-55

Miyashita S, Tetsuke to rikō no chakushu [Tetsuke and Commencement of Performance] (2008) 192 Juristo bessatsu: Fudō-san torihiki hanrei hyakusen 40-41

Moriyama H, Zōyo to shomen [Gifts and Documents] (2015) 224 Juristo bessatsu: Minpō hanrei hyakusen II saiken 98-99

Moss S, Why the United Kingdom has not Ratified the CISG (2005) 25 Journal of Law and Commerce 483-485

Mugdan B (ed), Die gesammten Materialien zum Bürgerlichen Gesetzbuch für das Deutsche Reich [The Complete Materials to the Civil Code of the German Empire] (R v Decker's Verlag 1899) 2 Vols

Murray AD, Entering into Contracts Electronically: The Real W.W.W., in: Lilian Edwards and Charlotte Waelde (eds), Law \& the Internet: A Framework for Electronic Commerce ( $2^{\text {nd }}$ edn, Hart Publishing 2000)

Musielak H-J, Zum Verhältnis von Wille und Erklärung: Eine Auseinandersetzung mit dem Tatbestand der Willenserklärung [Concerning the Relationship Between Volition and Declaration: A Discussion of the Requirements of a Declaration of Intention] (2011) 211 No 6 AcP 769-802

Nagata M, Das Japanische im japanischen Sachenrecht [The Japanese in Japanese Property Law], in: Heinrich Menkhaus (ed), Das Japanische im japanischen Recht [The Japanese in Japanese Law] (Iudicum 1994) 123-128

Nakata K, Dai-1-hen dai-4-chō mono, in: Hisakazu Matsuoka and ibid (eds), Shin konmentāru minpō (zaisan-hō) [New Commentary on the Civil Code (Property Law)] (Nihon Hyōron-sha 2012) 49-60

- - Dai-1-hen dai-5-chō hōritsu kōi [zenchū]-[dai-98-jö no 2] [Part 1 Chapter 5 Juridical Acts (Preliminary Note) - (Article 98-2)], in: Hisakazu Matsuoka and ibid (eds), Shin konmentāru minpō (zaisan-hō) [New Commentary on the Civil Code (Property Law)] (Nihon Hyōron-sha 2012) 61-134

- - Shōhi-sha-hō to ha nani ka [What is Consumer Law?], in: ibid and Naoko Kano (eds), Kihon kōgi shōhi-sha-hō [Basic Lecture of Consumer Law] (2 ${ }^{\text {nd }}$ edn, Nihon Hyōron-sha 2016) 2-18

- Shōhi-sha-hō kōgi kyōzai 2 [Consumer Law Teaching Materials 2] (document date 15 April 2016)

- - Die Modernisierung des Willenserklärungsrechts in Japan [The Modernisation of the Law of Declarations of Intention in Japan] (2019) 47 ZJapanR / JJapanL $247-268$ 
National Rail, National Rail Conditions of Travel (11 March 2018)

Nihon Kōshō-nin Rengō-kai [Japanese Association of Notaries], 'How to make good use of Japanese Notaries' (Guide, 2015)

Nishitani Y, $\mathbb{S} 26$ Internationales Privat- und Zivilverfahrensrecht [Chapter 26 Private International and International Procedural Law], in: Harald Baum and Moritz Bälz (eds), Handbuch Japanisches Handels- und Wirtschaftsrecht [Handbook Japanese Commercial- and Business Law] (Heymann 2011) 1211-1285

Nissel R, Rechtsgeschäftsmodernisierungsgesetz [Legal Transaction Modernising Law] ( $1^{\text {st }}$ edn, online, Nomos 2001)

Noriaki D, Sugu ni yakutatsu: keiyaku-sho, inkan, ryōshü-sho, tegata, kogitte no höritsu chishiki [Immediately Useful: Legal Knowledge on Contract Documents, Seals, Receipts, Promissory Notes, Cheques] (new revised edn, Sanshū-sha 2011)

Oestmann P, SS 130-132 Wirksamwerden von Willenserklärungen [Sections 130-132 Coming into Effect of Declarations of Intention], in: Mathias Schmoeckel and Joachim Rückert and Reinhard Zimmermann (eds), Historisch-kritischer Kommentar zum BGB Band 1 Allgemeiner Teil [Historical, critical Commentary on the Civil Code Vol 1 General Part] (Mohr Siebeck 2003) 532-561

Ogino M, Inshō [Seals] (repr, Yoshikawa Kōbun-kan 1995)

Olzen D, Einleitung zum Schuldrecht [Introduction to the Law of Obligations], in: Julius von Staudinger and others, Kommentar zum Bürgerlichen Gesetzbuch mit Einführungsgesetz und Nebengesetzen [Commentary on the Civil Code with Introductory Act and Ancillary Laws] (rev online edn, Sellier de Gruyter 2015) paras $1-342$

- - $\$ 241$ Pflichten aus dem Schuldverbältnis [Section 241 Duties Arising from an Obligation], in: Julius von Staudinger and others, Kommentar zum Bürgerlichen Gesetzbuch mit Einführungsgesetz und Nebengesetzen [Commentary on the Civil Code with Introductory Act and Ancillary Laws] (rev online edn, Sellier de Gruyter 2015, updated 21.12.2017) paras 1-387

- - \$241a Unbestellte Leistungen [Section 241a Unsolicited Performance], in: Julius von Staudinger and others, Kommentar zum Bürgerlichen Gesetzbuch mit Einführungsgesetz und Nebengesetzen [Commentary on the Civil Code with Introductory Act and Ancillary Laws] (rev online edn, Sellier de Gruyter 2015) paras $1-77$

Omlor S, Der neue Verbraucherbauvertrag [The New Consumer Construction Contract] (2018) NJW 817-822

Ōnaka A, Naishin no ishi no fu-icchi ['Dissonance of the Real Intention'], in: Yoshio Shiomi and Hiroto Dōgauchi (eds), Minpō Hanrei Hyakusen I: Sōsoku, bukken [One Hundred Selected Cases on the Civil Code I: General Part, Property Law] (Yūhikaku 2015) 38-39

OSCOLA 2006: Citing International Law Sources Section (excerpt from the 2006edn)

Ōtsuki T, Ippō teki shō-kōi ni okeru shōhō no tekiyō ni kansuru ichi-kōsatsu [Regarding the Application of the Shōhō to One-sided Commercial Acts] 1984 Chūō Gakuin Daigaku Ronsō 87-102 
Otto D-U, Grundstückskaufverträge [Contracts for the Sale of Land], in: Sebastian Herrler (ed), Münchener Vertragshandbuch Band 5: Bürgerliches Recht 1 [Munich Handbook on Contracts Vol 5: Civil Law 1] (Beck 2013) 1-132

Oxford University Standard for the Citation of Legal Authorities ( $4^{\text {th }}$ edn, 2012)

Pardieck AM, Executing Contracts in Japan (2015) 40 ZJapanR / JJapanL 183-191

Perales Viscasillas M del P, Contract Conclusion under CISG, in: Franco Ferrari and Clayton P Gillette (eds), International Sales Law Vol 1 (Edward Elgar Publishing, 2017) 46-75

Plewe L-I, Die gesetzlichen Formen des Rechtsgeschäfts: Eine Bestandsaufnahme zu Beginn des 21. Jahrhunderts [The Statutory Forms of Legal Transactions: A Review from the Beginning of the $21^{\text {st }}$ Century] (Shaker 2003)

Powell JJ, Essay upon the Law of Contracts and Agreements ( $1^{\text {st }}$ edn 1790; P Byrne et al 1796)

Prabhat D, "BorrowMyDoggy.Com": Rethinking Peer-to-peer Exchange for Genuine Sharing (2018) 45 No 1 Journal of Law and Society 84-98

Rabel E, The Statute of Frauds and Comparative Legal History (1947) 63 LQR 174-187

Rahn G, Recht und Rechtsmentalität in Japan [Law and Legal Mentality in Japan] (Gebrüder Tönnes 1981)

- - Rechtsdenken und Rechtsauffassung in Japan [Legal Thinking and Legal Opinion in Japan] (Beck 1990)

Ramberg C, CISG-AC (Advisory Council) Opinion No 1: Electronic Communications under CISG (15 August 2003)

Ramsay I, Consumer Law and Policy: Text and Materials on Regulating Consumer Markets ( $3^{\text {rd }}$ edn, Hart Publishing 2012)

Reymann C, Das Sonderprivatrecht der Handels- und Verbraucherverträge: Einheit, Freiheit und Gleichheit im Privatrecht [Special Private Laws for Commercial and Consumer Contracts: Union, Freedom, and Equality in Private Law] (Mohr Siebeck 2009)

Riesenhuber K, Verbraucherschutz und Schuldrechtsmodernisierung [Consumer Protection and the Modernisation of the Law of Obligations], in: Makoto Tadaki and Harald Baum (eds), Saiken-hō kaisei ni kansuru hikaku-hōteki kentō: nichidoku-hö no shiten kara [A Comparative Analysis of the Modernisation of the Law of Obligations in Japan: From the Perspective of Japanese and German Law] (Chūō Daigaku Shuppan-bu 2014) 147-177

- - Privatautonomie - ohne irrationale Schwärmerei [Private Autonomy - without Irrational Passion] (2019) Special Issue 14 ZJapanR / JJapanL 3-25

Ritter RM, New Hart's Rules: The Oxford Guide to Style (OUP 2005)

Rittler T (trans), HGB - German Commercial Code: Deutsch-englische Text-Synopse / German-English Synopsis ( $3^{\text {rd }}$ revised edn, Plattform-compliance 2015)

Rokumoto K, Japanese Law Symposium: Law and Culture in Transition (2001) 49 The American Journal of Comparative Law 545-560 
- - 2 Institutionen: Recht und Juristen in der Transformation [Chapter 2 Institutions: Law and Jurists in Transformation], in: Harald Baum and Moritz Bälz (eds), Handbuch Japanisches Handels- und Wirtschaftsrecht [Handbook Japanese Commercial- and Business Law] (Heymann 2011) 31-61

Roth H, $\$ 139$ [Section 139], in: Julius von Staudinger and others, Kommentar zum Bürgerlichen Gesetzbuch mit Einführungsgesetz und Nebengesetzen [Commentary on the Civil Code with Introductory Act and Ancillary Laws] (rev online edn, Sellier de Gruyter 2015) paras 1-91

Rothermel M and Dahmen J, Schweigen ist Silber [Silence is Silver] (2018) 4 Recht der internationalen Wirtschaft (RIW) 179-186

Röhl W, Rechtsgeschichtliches zu Jöri [The Legal History of Jori], in: ibid (ed), History of Law in Japan Since 1868 (Brill 2005) 39-49

- - Generalities, in: ibid (ed), History of Law in Japan Since 1868 (Brill 2005) 1-28

- - The Courts of Law, Appendix: Execution of Penalty, in: ibid (ed), History of Law in Japan Since 1868 (Brill 2005) 711-769

Rühl G, Rechtswahl [English title: Choice of Law by the Parties], in: Jürgen Basedow and Klaus J Hopt and Reinhard Zimmermann (eds), Handwörterbuch des europäischen Privatrechts [English title: The Max Planck Encyclopedia of European Private Law] (Mohr Siebeck 2009) Vol II 1270-1274

Ryoken-hō Kenkyū-kai [Passport Act Research Society], Ryoken-hō chikujō kaisetsu [Commentary on the Passport Act] (Nihon Hyōron-sha 2016)

Säcker FJ, Einleitung (Einl. BGB) [Introduction (Intro. Civil Code)], in: ibid and others, Münchener Kommentar zum BGB [Munich Commentary on the Civil Code] Vol 1 ( $8^{\text {th }}$ online edn, CH Beck 2018) paras 1-317

Saidov D and Green S, Software as Goods (2007) Journal of Business Law

(JBL) 161-181

Schennach M, Partikularrecht [Particular Law], in: Albrecht Cordes and others (eds), Handwörterbuch zur deutschen Rechtsgeschichte [Handbook on German Legal History] (online edn, Erich Schmidt Verlag 2018) Vol IV paras 408-410

Schlesinger RB (ed), Formation of Contracts: A Study of the Common Core of Legal Systems (Oceana 1968)

Schmidt J, Der Vertragsschluss: ein Vergleich zwischen dem deutschen, französischen, englischen Recht und dem CESL [The Formation of Contracts: A Comparison of German, French, English Law and the CESL] (Mohr Siebeck 2013)

Schmidt JP, Art 1:303: Notice, in: Nils Jansen and Reinhard Zimmermann (eds), Commentaries on European Contract Laws (OUP 2018) 179-199

Schmidt K, Vorbemerkung zu $\mathbb{1} 1$ [Foreword to S 1], in: ibid (ed), Münchener Kommentar zum HGB [Munich Commentary on the Commercial Code] (4 ${ }^{\text {th }}$ online edn, CH Beck 2016) Vol 1 paras 1-62

Schmidt-Kessel M, Article 11, in: Peter Schlechtriem and Ingeborg Schwenzer (eds), Commentary on the UN Convention on the International Sale of Goods (CISG) $\left(4^{\text {th }}\right.$ edn, OUP 2016) 203-213 
- - and McNamee S, Methodological Issues in Selected Branches: European Contract Law, in: Karl Riesenhuber (ed), European Legal Methodology (Intersentia 2017) 405-434

Schmidt-Räntsch J, $\mathbb{S} 23$. Germany, in: Karl Riesenhuber (ed), European Legal Methodology (Intersentia 2017) 591-618

Schreiber K, $\mathbb{S} 415$ Beweiskraft öffentlicher Urkunden über Erklärungen [Section 415 Evidentiary value of public records and documents regarding declarations], in: Wolfgang Krüger and Thomas Rauscher (eds), Münchener Kommentar zur ZPO [Munich Commentary on the Code of Civil Procedure] Vol 2 ( $5^{\text {th }}$ online edn, CH Beck 2016) paras 1-30

- - 4416 Beweiskraft von Privaturkunden [Section 416 Evidentiary Value of Private Records and Documents], in: Wolfgang Krüger and Thomas Rauscher (eds), Münchener Kommentar zur ZPO [Munich Commentary on the Code of Civil Procedure] Vol 2 (5 $5^{\text {th }}$ online edn, CH Beck 2016) paras 1-11

- - $\$ 440$ Beweis der Echtheit von Privaturkunden [Section 440 Evidence of the Authenticity of Private Records and Documents], in: Wolfgang Krüger and Thomas Rauscher (eds), Münchener Kommentar zur ZPO [Munich Commentary on the Code of Civil Procedure] Vol 2 ( $5^{\text {th }}$ online edn, CH Beck 2016) paras 1-6

Schroeter UG, Part II: Formation of the Contract, in: Peter Schlechtriem and Ingeborg Schwenzer (eds), Commentary on the UN Convention on the International Sale of Goods (CISG) (4 ${ }^{\text {th }}$ edn, OUP 2016) 223-267

Schwarz A, Vom Wert des Lebens und der Normen [On the Value of Life and of Norms], in: Heinrich Menkhaus (ed), Das Japanische im japanischen Recht [The Japanese in Japanese Law] (Iudicum 1994) 63-87

Schwenzer I, Introduction, in: Peter Schlechtriem and ibid (eds), Commentary on the UN Convention on the International Sale of Goods (CISG) (4 ${ }^{\text {th }}$ edn, OUP 2016) $1-12$

- - and Pascal Hachem, Part I. Sphere of Application, in: Schlechtriem and Schwenzer (fn 2703) 17-118

Sealy LS and Worthington S, Sealy and Worthington's Cases and Materials in Company Law (10 ${ }^{\text {th }}$ edn, OUP 2013)

Segawa N, Köi to keiyaku [Acts of Kindness and Contracts], in: Tomohei Taniguchi and Kiyoshi Igarashi (eds), Shinhan chüshaku minpō (13) saiken (4) [Japanese Civil Law Annotated Vol 13 Obligations Part 4] (2 ${ }^{\text {nd }}$ revised edn, Yūhikaku 2006) 51-60

- - and Uchida T, Minpō hanrei-shü saiken kakuron [Cases and Materials Civil Code: Specific Provisions of the Law of Obligations] ( $3^{\text {rd }}$ edn, Yūhikaku 2008)

Seidmann G, Personal Seals in Eighteenth- and Nineteenth-Century England and their Antecedents, in: Dominique Collon, 7000 Years of Seals (British Museum Press 1997) 143-160

Seki H, Das Japanische im japanischen Handelsrecht [The Japanese in Japanese Commercial Law], in: Heinrich Menkhaus (ed), Das Japanische im japanischen Recht [The Japanese in Japanese Law] (Iudicum 1994) 237-241 
Shibutani H, Kenpō [English title: Japanese Constitutional Law] (3 $3^{\text {rd }}$ edn, Yūhikaku 2017)

Shimizu H, $\int 177$ I [Article 177 I], in: Jun'ichi Funahashi and Mamoru Tokumoto (eds), Shinhan chüshaku minpō (6) bukken (1) [Japanese Civil Law Annotated Vol 6 Real Rights Part 1] (2 ${ }^{\text {nd }}$ revised ed, Yūhikaku 2009) 264-456

Shinomiya K and Nōmi Y, Minpō Sōsoku [Civil Code General Provisions] (9 $9^{\text {th }}$ edn, Kōbundō 2018)

Shiomi Y, Minpō (saiken kankei) kaisei höan no gaiyō [Overview of the Legislative Bill to Reform the Minpō (Law of Obligations)] (Kin'yū Zaisei Jijō Kenkyū-kai 2015)

- - Shin-saiken sōron I [New General Principles of Obligations I] (Shinzan-sha 2017)

Simpson AWB, Innovation in Nineteenth Century Contract Law (1975) 91 LQR 247278

- - A History of the Common Law of Contract: The Rise of the Action of Assumpsit (repr, Clarendon Press 1996)

Singer R, Vorbemerkungen zu SS 116-144 [Preliminary Notes on Ss 116-144], in: Julius von Staudinger and others, Kommentar zum Bürgerlichen Gesetzbuch mit Einfübrungsgesetz und Nebengesetzen [Commentary on the Civil Code with Introductory Act and Ancillary Laws] (rev online edn, Sellier de Gruyter 2017) paras $1-80$

Smith JC, Unilateral Contracts and Consideration (1953) 69 LQR 99-106

- - The Law of Contract - Alive or Dead? (1979) 13 The Law Teacher 73-82

Smits JM, Contract Law: A Comparative Introduction (2 ${ }^{\text {nd }}$ edn, Edward Elgar Publishing 2017)

Sokolowski C, Der so genannte Kodifikationenstreit in Japan [What is Known as the Codification Dispute in Japan] (Iudicium 2010)

Sono H, CISG ni okeru keiyaku no seiritsu to kaishaku ni kansuru kiritsu [The Rules of the Formation and Interpretation of Contracts under the CISG] (2008) Minshōhō zasshi 138 No 1 1-37

- - and others, Contract Law in Japan (Kluwer Law International BV 2019)

Specht L and Herold S, Roboter als Vertragspartner? Gedanken zu Vertragsabschlüssen unter Einbeziehung automatisiert und autonom agierender Systeme [Robots as Contracting Partners? Thoughts on the Conclusion of Contracts by Way of Systems Acting Autonomously] (2018) MMR 40-44

Steenstrup C, A History of Law in Japan until 1868 ( $2^{\text {nd }}$ edn, Brill 1996)

Stieldorf A, Siegelkunde [The Study of Seals] (Hahn 2004)

Stieper M, Vorbemerkungen zu SS 90-103 [Preliminary Notes on Ss 90-103], in: Julius von Staudinger and others, Kommentar zum Bürgerlichen Gesetzbuch mit Einfübrungsgesetz und Nebengesetzen [Commentary on the Civil Code with Introductory Act and Ancillary Laws] (rev online edn, Sellier de Gruyter 2017) paras $1-30$ 
- - 994 [Section 94], in: Julius von Staudinger and others, Kommentar zum Bürgerlichen Gesetzbuch mit Einführungsgesetz und Nebengesetzen [Commentary on the Civil Code with Introductory Act and Ancillary Laws] (rev online edn, Sellier de Gruyter 2017) paras 1-40

Stoljar SJ, A History of Contract at Common Law (Australian National University Press 1975)

Stone R, The Modern Law of Contract (11 ${ }^{\text {th }}$ edn, Routledge 2015)

Stuyck J, Setting the Scene, in: Hans-Wolfgang Micklitz and Jules Stuyck and Evelyne Terryn (gen eds), Cases, Materials and Text on Consumer Law (Hart Publishing 2010) 1-69

Sugiura Y, Column: CISG no moto de no kihon göi-sho [Column: Letter of Intent under the CISG], in: ibid and Takashi Kubota (eds), Uin baibai joyaku no jitsumu kaisetsu [Practice Commentary on the Vienna Sales Convention] ( $2^{\text {nd }}$ edn, Chūō Keizai-sha 2011) 71-72

- - Dai-2-bu keiyaku no seiritsu [Part II Formation of Contracts], in: ibid and Takashi Kubota (eds), Uin baibai jōyaku no jitsumu kaisetsu [Practice Commentary on the Vienna Sales Convention] ( $2^{\text {nd }}$ edn, Chūō Keizai-sha 2011) 60-97

- - and Kubota T (eds), Uìn baibai jōyaku no jitsumu kaisetsu [Practice Commentary on the Vienna Sales Convention] ( $2^{\text {nd }}$ edn, Chūō Keizai-sha 2011)

Swain W, Contract as Promise: The Role of Promising in the Law of Contract. An Historical Account (2013) 17 No 1 Edinburgh Law Review 1-21

Takimoto S, Nihon shöji kanrei ruishü [Classified Collection of Japanese Commercial Practices] (Hakutō-sha 1932)

Tanaka H and Smith MDH (eds), The Japanese Legal System: Introductory Cases and Materials (10 ${ }^{\text {th }}$ edn, UTP 2000)

Tanaka S, Dai-1-hen dai-3-chō mono [Part 1 Chapter 3 Things], in: Ryōhei Hayashi and Tatsuaki Maeda (eds), Shinhan chüshaku minpō (2) sosoku (2) [Japanese Civil Law Annotated Vol 2 General Provisions Part 2] (Yūhikaku 1997) 574-652

- - and others, Konmentāru Shö-köi-hō [Commentary on the Law of Comemercial Acts] (Keisō Shobō 1973)

Taniguchi T and Ono S, Zenchü (SS 521-532) II: keiyaku no höshiki [Preliminary Note (Articles 521-532) II: Contract Form], in: Tomohei Taniguchi and Kiyoshi Igarashi (eds), Shinhan chüshaku minpō (13) saiken (4) [Japanese Civil Law Annotated Vol 13 Obligations Part 4] (2 ${ }^{\text {nd }}$ revised edn, Yūhikaku 2006) 392-410

Taranczewski D, Der frühe Feudalismus [Early Feudalism], in: Josef Kreiner (ed), Geschichte Japans [Japan's History] (4 ${ }^{\text {th }}$ edn, Reclam 2016) 94-148

Tōda S, Keiyaku no seiritsu: dai-521-jō-dai-528-jō [Formation of Contracts: Articles 521-528], in: Tomohei Taniguchi and Kiyoshi Igarashi (eds), Shinhan chüshaku minpō (13) saiken (4) [Japanese Civil Law Annotated Vol 13 Obligations Part 4] ( $2^{\text {nd }}$ revised edn, Yūhikaku 2006) 424-507

Toyoda T, Japanese Guilds [1954] 5 No 1 The Annals of the Hitotsubashi Academy $72-85$

Transport for London, Transport for London Conditions of Carriage - Bus and Underground Services (2 September 2018) 
Treitel GH (founder) and Peel E, The Law of Contract (15 $5^{\text {th }}$ edn, Sweet \& Maxwell 2020)

Trevelyan GM, Illustrated English Social History 1: Chaucer's England and the Early Tudors (repr, Penguin Books Ltd 1973)

Tsubaki T, Minpō ni okeru kyōkō-hō, nin'i-hō [Mandatory and Dispositive Law in the Minpō] (Nihon Hyōron-sha 2015)

Uebayashi $\mathrm{H}$ and Igarashi K, Keiyaku no seiritsu: dai-529-jo-dai-532-jö [Formation of Contracts: Articles 529-532], in: Tomohei Taniguchi and Kiyoshi Igarashi (eds), Shinhan chüshaku minpō (13) saiken (4) [Japanese Civil Law Annotated Vol 13 Obligations Part 4] (2 ${ }^{\text {nd }}$ revised edn, Yūhikaku 2006) 507-532

Ueda S, Dai-3-hen dai-2-chō keiyaku [zenchū] [Part 3 Chapter 2 Contracts [Preliminary Note]], in: Hisakazu Matsuoka and Kunihiro Nakata (eds), Shin konmentāru minpō (zaisan-hō) [New Commentary on the Civil Code (Property Law)] (Nihon Hyōron-sha 2012) 753-759

- - Dai-3-hen dai-2-chō dai-1-setsu dai-1-kan keiyaku no seiritsu [Part 3 Chapter 2 Section 1 Subsection 1 Formation of Contracts], in: Hisakazu Matsuoka and Kunihiro Nakata (eds), Shin konmentāru minpō (zaisan-hō) [New Commentary on the Civil Code (Property Law)] (Nihon Hyōron-sha 2012) 760-771

Uhle A, Artikel 70 GG, in: Theodor Maunz and others (eds), Grundgesetz Kommentar [Basic Law Commentary] (CH Beck, 2017 issue)

United Nations Commission on International Trade Law (UNCITRAL) Secretariat, Explanatory Note on the United Nations Convention on Contracts for the International Sale of Goods (UN Publication, November 2010)

Unnamed author, Blockchains: The great chain of being sure about things, The Economist (London, 31 October 2015)

- - Personal seals in Japan: For the chop, The Economist (Tōkyō, 23 March 2019)

von Bar C and Clive E and Schulte-Nölke H (eds), Principles, Definitions and Model Rules of European Private Law: Draft Common Frame of Reference (DCFR) (full edn, Sellier European Law Publishers 2009) 6 Vols

- - and others, Introduction, in: ibid and Clive E and Schulte-Nölke H (eds), Principles, Definitions and Model Rules of European Private Law: Draft Common Frame of Reference (DCFR) (full edn, Sellier European Law Publishers 2009) 3-38

von Mehren AT, Chapter 1: Introduction, in: René David and others (eds), International Encyclopedia of Comparative Law (Mohr Siebeck/Nijhoff 2008) Vol VII/1 3-109

- - Chapter 10: Formal Requirements, in: René David and others (eds), International Encyclopedia of Comparative Law (Mohr Siebeck/Nijhoff 2008) Vol VII/1 31-40

Wacke A, Eigentumserwerb des Käufers durch schlichten Konsens oder erst mit Übergabe? Unterschiede im Rezeptionsprozeß und ibre mögliche Überwindung [Acquisition of Property of the Buyer by Consensuality or upon Delivery? Differences in the Receptionprocess and Possibilieties to Overcome these] (2000) ZEuP 254-262

Watson A, Legal Transplants: An Approach to Comparative Law ( $2^{\text {nd }}$ edn, University of Georgia Press 1993) 
Weber RH, Contractual Duties and Allocation of Liability in Automated Digital Contracts, in: Sebastian Lohsse and Reiner Schulze and Dirk Staudenmayer (eds), Trading Data in the Digital Economy: Legal Concepts and Tools (Nomos 2017) 163187

Wedderburn KW, Contract. Consideration. Retail Price. Copyright (1959) 17 No 2 CLJ 160-163

Wendehorst CC, Rezeption deutschen Zivilrechts - Was bleibt übrig im 21. Jahrhundert? [Reception of German Civil Law - What Remains in the 21st Century?], in: Jörg-Martin Jehle and others (eds), Rezeption und Reform im japanischen und deutschen Recht [Reception and Reform in Japanese and German Law] (Universitätsverlag Göttingen 2008) 19-30

- - \$312i [Section 312i], in: Franz J Säcker and others, Münchener Kommentar zum $B G B$ [Munich Commentary on the Civil Code] Vol 2 ( $7^{\text {th }}$ online edn, $\mathrm{CH}$ Beck 2016) paras 1-113

Wesel U, Geschichte des Rechts: Von den Frühformen bis zur Gegenwart [History of Law: From Ancient Forms to the Present] ( $3^{\text {rd }}$ edn, CH Beck 2006)

Westhoff J, Das Echo des Ie: Nachwirkungen des Haussystems im modernen japanischen Familienrecht [The Echo of the Ie: Repercussions of the House System in Modern Japanese Family Law] (Munich 1999)

- - 5 Formen und Bedingungen unternehmerischer Tätigkeit [Chapter 5 Forms and Requirements for Doing Business], in: Harald Baum and Moritz Bälz (eds), Handbuch Japanisches Handels- und Wirtschaftsrecht [Handbook Japanese Commercial- and Business Law] (Heymann 2011) 183-278

Whincup MH, Contract Law and Practice: The English System, with Scottish, Commonwealth, and Continental Comparisons ( $5^{\text {th }}$ edn, Kluwer Law International 2006)

Wigmore JH, Law and Justice in Tokugawa Japan: Materials for the History of Japanese Law and Justice Under the Tokugawa Shogunate 1603-1857

- - Part I: Introduction (UTP 1969)

- - Part II: Contract, Civil Customary Law (UTP 1967)

Winfield PH, Some Aspects of Offer and Acceptance (1939) 55 LQR 499-519

Wolf $\mathrm{M}$ and Neuner J, Allgemeiner Teil des Bürgerlichen Rechts [General Part of the Civil Code] (Karl Larenz founder, $10^{\text {th }}$ edn, Beck 2012)

Wood JC (founder) and Smith IT and Thomas G, Smith \& Wood's Employment Law ( $9^{\text {th }}$ edn, OUP 2008)

Yamada S, Tetsuke keiyaku no kaishaku [Interpretation of the Tetsuke-Contract] (2008) 192 Juristo bessatsu: Fudō-san torihiki hanrei hyakusen 38-39

Yamamoto K, $\mathbb{S} 10$ Vertragsrecht [Chapter 10 Contract Law], in: Harald Baum and Moritz Bälz (eds), Handbuch Japanisches Handels- und Wirtschaftsrecht [Handbook Japanese Commercial- and Business Law] (Heymann 2011) 461-520- - Minpō kōgi I: sōsoku [Lectures in Civil Law I: General Provisions] (3 ${ }^{\text {rd }}$ edn, $2^{\text {nd }}$ print, Yühikaku 2012)

- Minpō kōgi IV-1: keiyaku [Lectures in Civil Law IV-1: Contracts] ( $1^{\text {st }}$ edn, $6^{\text {th }}$ print, Yūhikaku 2012) 
- - Rechtsverständnis und Rechtsentwicklung: Die Erfahrungen der Rechtswissenschaft und Rechtspraxis in Japan [Understanding of Law and Legal Development: The Experiences of Legal Academia and Legal Practice in Japan], in: Stefan Grundmann and Jan Thiessen (eds), Recht und Sozialtheorie im Rechtsvergleich / Law in the Context of Disciplines: Interdisziplinaeres Denken in Rechtswissenschaft und -praxis / Interdisciplinary Approaches in Legal Academia and Practice (Mohr Siebeck 2015) 85-104

Yamamoto N, Dai-3-hen dai-1-chō dai-3-setsu dai-4-kan hoshō saimu [Part 3 Chapter 1 Section 3 Subsection 4 Guarantee Obligations], in: Hisakazu Matsuoka and Kunihiro Nakata (eds), Shin konmentāru minpō (zaisan-hō) [New Commentary on the Civil Code (Property Law)] (Nihon Hyōron-sha 2012) 641-666

Yamamoto S, Dai-2-hen dai-1-chō sōsoku: $\mathbb{S} 176$ [Part 2 Chapter 1 General Provisions: $\$ 176]$, in: Jun'ichi Funahashi and Mamoru Tokumoto (eds), Shinhan chüshaku minpō (6) Bukken (1) [Japanese Civil Law Annotated Vol 6 Real Rights Part 1]] ( $2^{\text {nd }}$ revised ed, Yūhikaku 2009) 224-263

Yamanushi M, Keiyaku to hōshiki: dakusei keiyaku ni okeru shōsho no kinō [Contract and Form: The Function of Formal Docments with Regard to Consensual Contracts], in: Keiyaku-hō Taikei Kankō I'in-kai [Publication Committee of the Contract Law Compendium], Keiyaku-hō Taikei 1: keiyaku sōron [Contract Law Compendium Vol 1: General Principles] (Yūhikaku 1962) 139-154

Yanaga M, A Bill Regarding the Electronic Declaration of Intention in Japan (2001) 11 ZJapanR / JJapanL 255-258

Yokoyama M, Fudō-san baibai keiyaku no seiritsu katei to seiritsu-mae no gōi no höteki köryoku [The Formation Process of Contracts for the Sale of Immovable Property and the Legal Effect of Agreements Prior to Formation] (1992) 54 Shihō 193-198

- - Fudōsan baibai no purosesu [The Sale Process for Immovable Property] (2007) Juristo zōkan: Minpō no sōten 91-94

- - Tetsuke no seiritsu: shōgaku no kinsen no juju [The Coming into Existence of Earnest Money: The Giving and Receiving of Small Sums of Money] (2008) 192 Juristo bessatsu: Fudō-san torihiki hanrei hyakusen 42-43

Yoshida Y, Tetsuke no kenkyū [A Study on Tetsuke] (Chūō University Publishing 2005)

Youngs R, English, French \& German Comparative Law ( $3^{\text {rd }}$ edn, Routledge 2014)

Yunoki K and Takagi T, Tetsuke: dai-557-jō [Tetsuke: Art 577], in: ibid (eds), Shinhan chüshaku minpō (14) saiken (5) [Japanese Civil Law Annotated Vol 14 Obligations Part 5] (1 $1^{\text {st }}$ edn, Yūhikaku 1993) 168-185

Zufall F, Das Abstraktionsprinzip im japanischen Zivilrecht [The Abstraction Principle in Japanese Civil Law] (2010) 29 ZJapanR / JJapanL 201-222

Zweigert K and Kötz H, Einführung in die Rechtsvergleichung [Introduction to Comparative Law] ( $3^{\text {rd }}$ edn, Mohr 1996) 
Online Resources: Blog Entries and Websites

Amazon (UK, Germany)

- - www.amazon.co.uk/gp/help/customer/display.html?nodeId=201602230

- - www.amazon.co.uk/gp/help/customer/display.html?nodeId=1040616

- - www.amazon.de/gp/help/customer/display.html?nodeId=201809740

- $\quad$ - www.amazon.de/gp/help/customer/display.html/ref=footer_cou?ie=UTF8\&nodeId $=505048$

Anytimes

- - www.any-times.com

Baraniuk C, 'Why the Fax Machine Isn't Quite Dead Yet' BBC (25 February 2015), www.bbc.com/future/story/20150224-why-the-fax-machine-wont-die

Baxter R, 'Legal Tech 2.0: The World We Live in Now' (Thomson Reuters Legal Executive Institute, 24 March 2015), www.legalexecutiveinstitute.com/legaltech-2-0-the-world-we-live-in-now-by-ralph-baxter/

Bayerische Staatsbiliothek digital

- - http://reader.digitale-sammlungen.de/de/fs1/object/display/bsb11201503_000

09.html

BBC News

- - www.bbc.com/news/politics/eu_referendum/results

- - www.bbc.com/news/uk-politics-38641208

- - www.bbc.com/timelines/zxnbr82\#z39q2hv

BBC UK History

- - www.bbc.co.uk/history/ancient/anglo_saxons/saxons.shtml

- - www.bbc.co.uk/history/british/normans/overview_normans_01.shtml

Black J, Overview: Britain from 1945 Onwards (BBC History, 3 March 2011), www.bbc.co.uk/history/british/modern/overview_1945_present_01.shtml

Bundesgerichtshof

- - www.bundesgerichtshof.de/EN/Home/home_node.html- - www.bundesger ichtshof.de/DE/Bibliothek/GesMat/WP18/B/Bauvertragsrecht.html

- - www.bundesgerichtshof.de/DE/DasGericht/StellungGerichtssystem/stellung Gerichtssystem_node

- - www.bundesgerichtshof.de/SharedDocs/Downloads/EN/BGH/brochure.pdf? _blob=publicationFile

Bundesgesetzblatt

- - www.bgbl.de

Bundesministerium der Justiz und für Verbraucherschutz

- - www.gesetze-im-internet.de/bgb/BJNR001950896.html

- - www.gesetze-im-internet.de/englisch_bgbeg/index.html

- - www.gesetze-im-internet.de/englisch_bverfgg/englisch_bverfgg.html

- - www.gesetze-im-internet.de/englisch_hgb/index.html

- - www.gesetze-im-internet.de/englisch_gvg/index.html

- - www.gesetze-im-internet.de/englisch_zpo/index.html 
- - www.gesetze-im-internet.de/hgb/index.html

- - www.gesetze-im-internet.de/Teilliste_translations.html

Bundespatentgericht

- - www.bundespatentgericht.de/cms/index.php?lang=en

Bundesverfassungsgericht

- - www.bundesgerichtshof.de/DE/DasGericht/Aufgaben/aufgaben_node.html

- - www.bundesverfassungsgericht.de/SharedDocs/Entscheidungen/EN/2005/04 /rk20050405_1bvr166404en.html

- - www.bundesverfassungsgericht.de/SharedDocs/Entscheidungen/EN/2011/05

/rs20110504_2bvr236509en.html

Bundesverwaltungsgericht

- - www.bverwg.de/gebaeude

Bundeszentrale für politische Bildung

- - www.bpb.de/nachschlagen/lexika/handwoerterbuch-politisches-system/

Chūō Kūyaku-sho

- - www.city.chuo.lg.jp/kurasi/toroku/zyuminhyo/inkan.html

City of Seals

- - http://citycoseals.co.uk/company-and-notary-seals/c1/

Council of Europe (ECHR)

- - www.coe.int/en/web/human-rights-convention/home

Curry G, 'Why the missing owners are missing out' (HM Land Registry Land and Proprty blog, 9 October 2014), http://blog.landregistry.gov.uk/giving-85per-cent/

Darwin J, Britain, the Commonwealth and the End of Empire (BCC History, 2011), www.bbc.co.uk/history/british/modern/endofempire_overview_01.shtml

Das Unternehmerhandbuch

- - https://das-unternehmerhandbuch.de/firmenstempel/

Deutsche Post

- - www.deutschepost.de/de/e/einschreiben.html

Dokumentations- und Informationssystem für Parlamentarische Vorgänge

- - http://dip21.bundestag.de/dip21/btd/18/114/1811437.pdf

Duden

- - www.duden.de

EasyBus

- - www.easybus.com/en/terms-and-conditions

Edgington T, Brexit: What is the transition period?, BBC (1 July 2020), https:// www.bbc.com/news/uk-politics-50838994

Eki.net (Japan Rail Online Reservation Service)

- - www.eki-net.com

- - www.eki-net.com/top/jrticket/guide/?src=reservetop_main 
Encyclopaedia Britannica Online Academic Edition (Encyclopaedia Britannica)

- - https://academic.eb.com/levels/collegiate/additionalcontent/10389182

- - http://academic.eb.com/levels/collegiate/article/Act-of-Union/74264

- - https://academic.eb.com/levels/collegiate/article/Bavaria/13830

- - http://academic.eb.com/levels/collegiate/article/coin/105949

- - http://academic.eb.com/levels/collegiate/article/education/105951\#47520.toc

- - https://academic.eb.com/levels/collegiate/article/Germany/106260

- - https://academic.eb.com/levels/collegiate/article/Hanseatic-League/39167

- - http://academic.eb.com/levels/collegiate/article/Japan/106451\#23137.toc

- - https://academic.eb.com/levels/collegiate/article/Prussia/61665

- - http://academic.eb.com/levels/collegiate/article/Tokugawa-period/72774

- - http://academic.eb.com/EBchecked/topic/601677/trade-association

- - http://academic.eb.com/EBchecked/topic/615557/United-Kingdom

Ethereum

- - www.ethereum.org

European Commission

- - https://ec.europa.eu/digital-single-market/en/trust-services-and-eid

European Court of Human Rights, European Convention on Human Rights

- - http://www.echr.coe.int/pages/home.aspx?p=basictexts

European Union, Institutions and Bodies

- - https://europa.eu/european-union/about-eu/institutions-bodies_en\#law-making

- $\quad$ - https://europa.eu/european-union/about-eu/institutions-bodies/court-justice_en

Fackler M, 'In High-Tech Japan, the Fax Machines Roll On' The New York Times (13 February 2013), www.nytimes.com/2013/02/14/world/asia/in-japan-the-faxmachine-is-anything-but-a-relic.html?_r=0

Flixbus

- - www.flixbus.co.uk/terms-and-conditions-of-carriage

Fukuoka Art Museum

- _ _ _ www.fukuoka-art-museum.jp/english/eb/html/eb01/2011/kin_in/ kin_in.html

Fukuoka City Museum

- - http://museum.city.fukuoka.jp/en/exhibition.html

- - http://museum.city.fukuoka.jp/gold/index.html

Gaimu-shō

- - www.mofa.go.jp/mofaj/gaiko/treaty/treaty169_5.html

Gett

- - https:/gett.com/uk/legal/terms/

Goo (Japanese online dictionary)

- - http://dictionary.goo.ne.jp 
Greenberg D, 'Estate Agents' (Westlaw UK Insight, 19 November 2018)

Hankoya Customer Guide

- - www.hankoya.com/guidance/

- - www.hankoya.com/shop/p_jituin.html

Herzfeld O, 'Smart Contracts May Create Significant Innovative Disruption' Forbes (online, 22 February 2016), www.forbes.com/sites/oliverherzfeld/2016/02/22/smart-contracts-may-create-significant-innovative-disruption/\#56aa6cfd2702

Hōmu-shō

- - 'Denshi shomei-hō no gaiyō to nintei seido ni tsuite' [Concerning an Overview of the Electronic Signatures Act and the Certification System], www.moj.go.jp/ MINJI/minji32.html

- - 'Denshi Shomei-hō no gaiyō ni tsuite' [Concerning an Overview of the Electronic Signatures Act], www.moj.go.jp/MINJI/minji32-1.html

- - www.moj.go.jp/content/000072037.pdf

- - www.moj.go.jp/content/000112240.pdf

- - www.moj.go.jp/MINJI/minji06_001070000.html

- - www.moj.go.jp/MINJI/minji07_00175.html

- - www.moj.go.jp/MINJI/minji07_00176.html

Hōsei Shingi-kai Minpō (Saiken Kankei) Bukai

- - www.moj.go.jp/content/001127663.pdf

- - www.moj.go.jp/shingi1/shingi04900184.html

- - www.moj.go.jp/shingi1/shingikai_saiken.html

Inkan tōroku no arekore

- - www.jitsuin.jp/

Ino'ue E, 'All about Japanese inkan/hanko/chops/seals' (28 August 2013), www.turning-japanese.info/2013/08/all-about-japanese-inkanhankochopsseals.html

International Court of Justice

- - www.icj-cij.org/en/publications

Internet Archive

- - https://archive.org/details/dejurenaturaeetg01 pufe- - https://archive.org/deta ils/oflawofnaturenat00pufe

Invest Northern Ireland

- $\quad$ www.nibusinessinfo.co.uk/content/difference-between-quotation-and-estimate

Japanese Law Translation

- - www.japaneselawtranslation.go.jp/

- - www.japaneselawtranslation.go.jp/common/data/outline/s49Aa000920201je3.0_h17A89.htm

- - www.japaneselawtranslation.go.jp/dict/download?re $=02$

Jones CPA, 'Making an Impression in Japan: A Hanko Primer' The Japan Times Online (Tōkyō, 13 March 2016)

Jurion 
- - www.jurion.de/gesetze/zgb_ddr/

Justice (Ministry of Justice, UK)

- - www.justice.gov.uk/courts/procedure-rules/civil/rules/part06/pd_part06a

Kanpō (Japanese official gazette, online edition)

- - https://kanpou.npb.go.jp/index.html

Kavanagh D, Thatcherism and the End of the Post-War Consensus (BBC History, 2011), www.bbc.co.uk/history/british/modern/thatcherism_01.shtml

Keizai Sangyō-shō (Japanese Ministry of Economy, Trade and Industry, METI) - - www.meti.go.jp/press/2015/04/20150427001/20150427001-3.pdf

Kokuritsu Kokkai Tosho-kan (Japanese National Diet Library) - $\quad$ - $\quad$ http://hourei.ndl.go.jp/SearchSys/viewKaisei.do?i=spINCIstKBNdEDPEOogErw\%3d\%3d

Koku-Zeichō (Japanese National Tax Agency)

- _ _ www.nta.go.jp/fukuoka/shiraberu/bunshokaito/inshi_sonota/081024/ 02.htm\#a01

Kotobanku (Japanese online dictionary)

- - https://kotobank.jp/

Kuline (Kyōto University Library Catalogue)

- - https://m.kulib.kyoto-u.ac.jp/webopac/EB03895329

Kyōto City International Foundation

- - www.kcif.or.jp/HP/guide/mainichi/en/communication.html

Kyōto Shiyaku-sho

- - www.city.kyoto.lg.jp/bunshi/page/0000145223.html

- - www.city.kyoto.lg.jp/bunshi/page/0000147302.html

Law Dictionary

- - https:/dictionary.thelaw.com/

Law Society, Execution of documents by virtual means (Practice Note, 16 February 2010), www.lawsociety.org.uk/support-services/advice/practice-notes/execution-of-documents-by-virtual-means/

- Execution of a document using an electronic signature (Practice Note, 21 July 2016), www.lawsociety.org.uk/support-services/advice/practice-notes/execution-of-a-document-using-an-electronic-signature/

Library of Things

- - www.libraryofthings.co.uk

Marino B, 'Smart Contracts: The Next Big Blockchain Application' (Cornell Tech News 2 December 2015), https://tech.cornell.edu/news/smart-contracts-the-next -big-blockchain-application/

Martin K, 'Contract Maturity Model (Part 2): Technology Assembly Line - from Active to Passive Systems' (Thomson Reuters Legal Executive Institute, 16 June 2016), www.legalexecutiveinstitute.com/contract-maturity-technology-assemblyline/

Measuring Worth

- - www.measuringworth.com/calculators/ppoweruk/ 
Megabus

- - https://uk.megabus.com/conditions/conditions-of-carriage-megabus.com

Meiji Jingū

- - www.meijijingu.or.jp/about/3-3.html

Ministry of Justice, UK

- - www.justice.gov.uk/courts/procedure-rules/civil/rules/part06/pd_part06a

Muramoto M, 'Mōshikomi shöko-kin to tetsuke no chigai ha?' [What is the Difference Between Application Earnest Money and Earnest Money?] (1 August 2007), http://allabout.co.jp/gm/gc/10297/

National Express

- - www.nationalexpress.com/en/help/conditions-of-carriage

National Rail

- - www.nationalrail.co.uk/times_fares/ticket_types.aspx\#National\%20Rail\%20Conditions

Nebenan.de

- - www.nebenan.de

Nihon Hōrei Saku'in (National Library of Japan)

- $\quad$ - $\quad$ http://hourei.ndl.go.jp/SearchSys/viewKaisei.do?i=spINCIstKBNdEDPEOogErw\%3d\%3d

Nihon Kōshō-nin Rengō-kai [Japanese Association of Notaries]

- - 'Shisho shösho no ninshö' [Authentication of Privately-signed Documents], www.koshonin.gr.jp/sini.html

- - 'Gaikoku-bun ninshö' [Authentication of Foreign Documents], www.koshonin.gr.jp/sini.html\#11

- - www.koshonin.gr.jp/index2.html

Nihon Shihō Shoshi-kai Rengō-kai (Japan Federation of Shihō Shoshi's Associations)

- - www.shiho-shoshi.or.jp/consulting/exam.html

- - www.shiho-shoshi.or.jp/consulting/history.html

- - www.shiho-shoshi.or.jp/html/global/english/index.html

On'yaku no Heya: Yomikata Jiten [Transcription Room: Way of Reading Dictionary]

- - https://hiramatu-hifuka.com/onyak/onyindx.html

- - https://hiramatu-hifuka.com/onyak/sup-ha.html

- - https://hiramatu-hifuka.com/onyak/kotoba-1/horitu/index.html

Opinioluris: Die freie juristische Bibliothek

- - https://opinioiuris.de/quelle/1621

Oxford English Dictionary Online

- -www.oed.com

Plattform Compliance

- - http://plattform-compliance.de/uebersetzungen-g-k/gwg-englische-uebersetzung-des-geldwaeschegesetzes-2/ 
Puterbaugh D, 'E-signatures and the Realization of the EU Single Digital Market' (Adobe Blog, 24 April 2016), https://blogs.adobe.com/documentcloud/e-signatures-and-the-realization-of-the-eu-single-digital-market/

Royal Mail

- - www.royalmailgroup.com/en/about-us/our-story/

- - www.royalmail.com/personal/uk-delivery/signed-2nd-class

- - www.royalmail.com/personal/uk-delivery/signed-for-1st-class

Shügi-in

- - www.shugiin.go.jp/internet/itdb_gian.nsf/html/gian/keika/1DA3FDA.htm

Simple Online Shop by Small Firms Services Limited (SFS), Wafers:

- - www.simpleonlineshop.co.uk/pid-7-Red-or-Gold-Wafers.htm

Spiegel Online

- - www.spiegel.de/einestages/die-geschichte-des-bgb-a-951164.html

SSRN

- - https://ssrn.com/abstract=2786888

Staatsbibliothek zu Berlin, Digitalisierten Sammlungen

- - http://digital.staatsbibliothek-berlin.de/suche?queryString=PPN646281224

State of the DApps

- - www.stateofthedapps.com/rankings/platform/ethereum

Stempelshop 4 you (Stempel- und Schilderfabrik Albert Walther GmbH)

- - www.stempelshop4you.de/blog/firmenstempel-pflicht/

Stollberg-Rilinger B and others, Einführung in die Frühe Neuzeit [Introduction to the Early Modern Period] (2003), www.uni-muenster.de/FNZ-Online/Welcome. html

- - and Pfister U, Einführung in die Frühe Neuzeit: Wirtschaftliche Grundstrukturen und Entwicklungen [Introduction to the Early Modern Period: Economic Basic Structures and Developments] (2003), www.uni-muenster.de/FNZ-Online/Welc ome.html

Targetjobs

- - https://targetjobs.co.uk/careers-advice/job-descriptions/279481-estate-agent-jobdescription

The Law Society

- - www.lawsociety.org.uk/law-careers/becoming-a-solicitor/

The National Archives

- - www.legislation.gov.uk/ukpga/2015/15/notes/contents

The Notaries Society

- - www.thenotariessociety.org.uk/pages/the-notarial-profession

- - www.thenotariessociety.org.uk/pages/what-a-notary-does

Timmins G, Working Life and the First Modern Census (BBC History, 18 September 2014), www.bbc.co.uk/history/trail/victorian_britain/earning_a_living/working_life_census_05.shtml 
Transport for London

- $\quad$ - https://tfl.gov.uk/corporate/terms-and-conditions/ticketing-and-travel-conditions-of-carriage?intcmp $=3774$

- - https://tfl.gov.uk/modes/taxis-and-minicabs/taxi-fares

UK Government

- - www.gov.uk/buy-sell-your-home/offers

- - www.gov.uk/buy-sell-your-home/transferring-ownership-conveyancing

- - www.gov.uk/government/publications/the-repeal-bill-white-paper

- - www.gov.uk/guidance/hm-land-registry-business-e-services

- - www.gov.uk/guidance/hm-land-registry-electronic-document-registration-service

- - www.gov.uk/guidance/hm-land-registry-registration-services-fees

- - www.gov.uk/guidance/uk-treaties

UK Parliament

- $\quad$ - www.parliament.uk/about/living-heritage/transformingsociety/livinglearning/19thcentury/keydates/

- $\quad$ - www.parliament.uk/about/living-heritage/transformingsociety/towncountry/towns/keydates/

- $\quad$ - www.parliament.uk/about/living-heritage/transformingsociety/towncountry/towns/overview/georgianimprovement/

- $\quad$ - www.parliament.uk/about/living-heritage/transformingsociety/tradeindustry/industrycommunity/keydates/

\section{UNCITRAL}

- - www.uncitral.org/pdf/english/texts/sales/cisg/V1056997-CISG-e-book.pdf

\section{UNIDROIT}

- - www.unidroit.org/instruments/commercial-contracts/unidroit-principles-2016

- - www.unidroit.org/status-ulfc-1964

United Nations Treaty Collection

- - https://treaties.un.org/Pages/ViewDetails.aspx?src=IND\&mtdsg_no=X-10\&chapter $=10 \&$ clang=_en

Universität Münster

- - www.uni-muenster.de/FNZ-Online/recht/reich/quellen/kreise.htm

University of Texas

- - https://legacy.lib.utexas.edu/maps/historical/shepherd_1911/shepherd-c-113.jpg

US Legal

- - http://definitions.uslegal.com/p/praecipe-quod-reddat/

White M, The Industrial Revolution (British Library, 14 October 2009), www.bl.uk/ georgian-britain/articles/the-industrial-revolution

- - The Rise of Cities in the $18^{\text {th }}$ Century (British Library, 14 October 2009), www.bl.uk/georgian-britain/articles/the-rise-of-cities-in-the-18th-century 
- - The Rise of Consumerism (British Library, 14 October 2009), www.bl.uk/georgian-britain/articles/the-rise-of-consumerism

Unnamed author, 'Email, e-signatures and e-commerce' (Reed Smith Client Alert, 2 February 2002), www.reedsmith.com/en/perspectives/2002/02/email-esignatures-and-ecommerce

- - 'The UK's E-Commerce Regulations' (Pinsent Masons LLP, guide 2013), www. out-law.com/page-431

- - 'Kaisei minpō sekō-bi kakugi kettei heisei 32-nen 4-gatsu tsuitachi mi-harai-kin no shōmetsu jikkō tōitsu nado 200 kömoku' [Civil Code Reform Coming into Force on 1 April 2020: 200 Provisions on the Consolidation of the Limitation Period of Debts etc] Sankei News (15 December 2017), www.sankei.com/politics/news/ 171215/plt1712150011-n1.html

- - 'Minpō kaisei-an ga Shü'in tsūka keiyaku rüru bappon minaoshi' [Civil Code Refom Bill Passed by Lower House Drastic Review of Contract Rules] Nippon Keizai Shinbun (Nikkei) (14 April 2017), www.nikkei.com/article/DGXLASFS13H70_U7A410C1MM0000/

- - 'Nihon ni okeru hanko no rekishi: hanko mame-jiten' [Japan's Seal History: Dictionary of Seal Trivia] (Mori'in-bō Hanko Mame Jiten), www.moriinbo.com/mame/rekisi.html

Yūgen Kaisha Atago Sangyō

- - http://www.025-377-6150.com/1fudousantorihiki/23

Zen-Nihon Inshō Gyō-kyōkai

- -www.inshou.or.jp/inshou/about/message.html

- - www.inshou.or.jp/koryupege/ivent1.html

- - www.inshou.or.jp/koryupege/catchphrase_h2.html

- - www.inshou.or.jp/rekishipage/japanpage/nihon1.html

\section{Personal Interviews, Lectures, and Seminars}

Kawakami Dr. S, Professor emeritus, Faculty of Law, University of Tōkyō (Tōkyō, 19 December 2015)

Lord Reed, 'Comparative Law in the UK Supreme Court' (Lecture, Max Planck Institute for Comparative and International Private Law, Hamburg, Germany, 10 July 2017)

Marino B, 'Agreement Making in Ethereum - A Legal Perspective' (Lecture, Ethereum Devcon 1, Gibson Hall, London, UK, 13 November 2015)

Naka R, 'Legal Practice of the Seal and Stamp Duty in Japan' (Lecture, Heuking Kühn Lüer Wojtek, Düsseldorf, Germany, 14 November 2017)

- - Attorney at law, Associate, Kitahama Hōritsu Jimu-sho (Kitahama Partners) (Düsseldorf, 17 November 2017) 
Nakata K, Professor, Faculty of Law, Ryūkoku University (Kyōto, 12 May 2017)

Twigg-Flesner C, 'Lessons for Consumer Law Reform from the UK's Consumer Rights Act 2015' (Lecture, Ryūkoku University, Kyōto, Japan, 8 November 2015)

Yokoyama M, Professor, Faculty of Law, University of Kyōto (Kyōto, 7 September 2016) 


\section{Table of Legislation}

The pieces of legislation in this table are listed in alphabetical order of their title in the original language, followed by the English translations used in the dissertation. In case of the EU, legislation is listed by its English title.

\section{International Conventions}

Convention for the Protection of Human Rights and Fundamental Freedoms opened for signature in Rome on 4 November 1950

Convention for the Unification of Certain Rules Relating to International Carriage by Air Signed at Warsaw on 12 October 1929 as amended by the Protocol Modifying the said Convention Signed at the Hague on 28 September 1955

Statute of the International Court of Justice, signed 26 June 1945 at San Francisco

United Nations Convention on Contracts for the International Sale of Goods, adopted 11 April 1980, 1489 UNTS 58

UNIDROIT Convention relating to a Uniform Law on the Formation of Contracts for the International Sale of Goods, adopted 1 July 1964

\section{European Union}

Consolidated Version of the Treaty on the Functioning of the European Union [2012] OJ C326/01

Council Directive 97/7/EC of 20 May 1997 on the Protection of Consumers in Respect of Distance Contracts [1997] OJ L 144/19

Council Directive 93/13/EEC of 5 April 1993 on Unfair Terms in Consumer Contracts [1993] OJ L95/29

Council Directive 2011/83/EU of 25 October 2011 on Consumer Rights [2011] OJ L304/64

Council Regulation (EC) No 44/2001 of 22 December 2000 on Jurisdiction and the Recognition and Enforcement of Judgments in Civil and Commercial Matters [2001] OJ L 12/1

Regulation (EC) No 593/2008 of the European Parliament and of the Council of 17 June 2008 on the Law Applicable to Contractual Obligations (Rome I) 
Regulation (EU) No 1215/2012 of the European Parliament and of the Council of 12 December 2012 on Jurisdiction and the Recognition and Enforcement of Judgments in Civil and Commercial Matters [2012] OJ L 351/1

Regulation (EU) 910/2014 of the European Parliament and of the Council of 23 July 2014 on Electronic Identification and Trust Services for Electronic Transactions in the Internal Market and Repealing Directive 1999/93/EC [2014] OJ L $257 / 73$

Treaty of Lisbon [2007] OJ C 306/01

\section{England}

Bills of Exchange Act 1882

Civil Procedure Rules 1998, SI 1998/3132

Commercial Agents (Council Directive) Regulations 1993, SI 1993/3053

Companies Act 2006

Consumer Credit Act 1974

Consumer Protection (Distance Selling) Regulations 2000, SI 2000/2334

Consumer Rights Act 2015

Electronic Commerce (EC Directive) Regulations 2002, SI 2002/2013

Electronic Communications Act 2000

Estate Agents Act 1979

European Communities Act 1972

European Union (Amendment) Act 2008

European Union (Withdrawal) Act 2018

Finance Act 2003

Financial Collateral Arrangements (No 2) Regulations 2003, SI 2003/3226

Insolvency Rules 1986, SI 1986/1925

Interpretation Act 1978

Landlord and Tenant Act 1954

Land Registration Act 2002

Law of Property Act 1925

Law of Property (Miscellaneous Provisions) Act 1989

Limitation Act 1980

Local Government Act 1972

Mercantile Law Amendment Act 1856

Powers of Attorney Act 1971

Rules of the Supreme Court Ord 65

Restrictive Trade Practices Act 1956

Sale of Goods Act 1979 
Table of Legislation

Stamp Act 1891

Statute of Frauds Act 1677

Supply of Goods and Services Act 1982

The Unfair Terms in Consumer Contracts Regulations 1999, SI 1999/2083

Town Police Clauses Act 1847

Trade Union and Labour Relations (Consolidation) Act 1992

Transfer of Land Act 1862

Unfair Contract Terms Act 1977

\section{Germany}

Aktiengesetz, Stock Corporation Act, of 6 September 1965, BGBl 1965 I 1089

Allgemeines Bürgerliches Gesetzbuch, General Civil Code of Austria, enacted 1811

Allgemeines Deutsches Handelsgesetzbuch, Common German Commercial Code, of 1861

Allgemeines Landrecht für die Preußischen Staaten, General State Laws of the Prussian States, 1794

Bekanntmachung über das Inkrafttreten der Konvention zum Schutze der Menschenrechte und Grundfreiheiten, Announcement of the Coming into Force of the Convention of the Protection of Human Rights and Fundamental Freedoms, 15 December 1953, BGBl 1954 II 14

Beurkundungsgesetz, Notarial Authentication Law, of 28 August 1969, BGB1 1969 I 1513

Bundesnotarordnung, Federal Ordinance on Notaries, of 13 February 1937, BGBl 1937 III No 303-1

Bürgerliches Gesetzbuch, German Civil Code, BGBl 2002 I 42, 2909 and 2003 I 738

Codex Maximilianeus Bavaricus Civilis, Maximilian Civil Code of Bavaria, enacted 1756

Der Stadt Hamburg Statuten und Gerichts-Ordnung, Statutes and Court Rules of the City of Hamburg, new unchanged edn 1771

Dienstleistungs-Informationspflichten-Verordnung, Ordinance on the Information Duties in Services, of 12 March 2010, BGBl 2010 I 267

Einführungsgesetz zum Bürgerlichen Gesetzbuche, Introductory Act to the Civil Code, BGBl 1994 I 2494 and 1997 I 1061

Gesetz über das Aufspüren von Gewinnen aus schweren Straftaten, Law on Tracing of Profits from Serious Criminal Offences of 23 June 2017, Geldwäschegesetz, BGBl 2017 I 1822

Gesetz über das Bundesverfassungsgericht, Act on the Federal Constitutional Court, BGBl 1993 I 1473 
Gesetz zu dem Übereinkommen der Vereinten Nationen vom 11 April 1980 über Verträge über den internationalen Warenkauf [...], Law on the United Nations Convention on Contracts for the International Sale of Goods of 11 April 1980 [...], of 5 July 1989, BGBl 1989 II 586 and BGBl 1990 II 1699

Gesetz zum Abbau verzichtbarer Anordnungen der Schriftform im Verwaltungsrecht des Bundes, Law to Reduce Dispensable Requirements of the Written Form in Federal Adminis-trative Law, of 29 March 2017, BGBl 2017 I 626

Gesetz zur Anpassung der Formvorschriften des Privatrechts und anderer Vorschriften an den modernen Rechtsgeschäftsverkehr, Act on the Amendment of Provisions of Form in Private Law and Other Provisions in Accordance with Modern Legal Transaction Methods, of 13 July 2001, BGBl 2001 I 1542

Gesetz zur Durchführung der Verordnung (EU) Nr.910/2014 des Europäischen Parlaments und des Rates vom 23. Juli 2014 über elektronische Identifizierung und Vertrauensdienste für elektronische Transaktionen im Binnenmarkt und zur Aufhebung der Richtlinie 1999/93/EG (eIDAS-Durchführungsgesetz), Law to Implement Regulation No 910/2014 of the European Parliament and of the Council (EU) of 23 July 2014 on electronic identification and trust services for electronic transactions in the internal market and repealing Directive 1999/93/EC (eIDAS-Implementation Law), of 18 July 2017, BGBl 2017 I 2745

Gesetz zur Einführung des elektronischen Rechtsverkehrs und der elektronischen Akte im Grundbuchverfahren sowie zur Änderung weiterer grundbuch-, register- und kostenrechtlicher Vorschriften, Act to Introduce Electronic Legal Transactions and Electronic Records in Land Register Procedures as well as to Change Other [Related] Rules, of 11 August 2009, BGBl 2009 I 2713

Gesetz zur Förderung des elektronischen Rechtsverkehrs mit den Gerichten, Act to Facilitate Legal Transactions with Courts, of 10 October 2013, BGBl 2013 I 3786

Gesetz zur Reform des Bauvertragsrechts, zur Änderung der kaufrechtlichen Mängelhaftung, zur Stärkung des zivilprozessualen Rechtsschutzes und zum maschinellen Siegel im Grundbuch- und Schiffsregisterverfahren, Law to Reform the Law on Construction Contracts, to Change the Liability for Defects under Sales Law, to Strengthen the Legal Protection in Civil Procedure, and [the Use] of Mechanical Seals in Procedures of the Land and of the Ship Register, of 28 April 2017, BGBl 2017 I 969

Gesetz zur Umsetzung der Verbraucherrichtlinie und zur Änderung des Gesetzes zur Regelung der Wohnungsvermittlung, Law to Transpose the Consumer Regulation and to Regulate Accommodation Services, of 20 September 2013, BGBl 2013 I 3642

Gerichtsverfassungsgesetz, Court Constitution Act, BGBl 1975 I 1077

Gesetz über die Konvention zum Schutze der Menschenrechte und Grundfreiheiten, Law on the Convention of the Protection of Human Rights and Fundamental Freedoms of 7 August 1952, BGBl 1952 II 685

Grundbuchordnung, Land Registration Law, Law of 26 May 1994, BGBl 1994 I 1114

Grundgesetz, Basic Law for the Federal Republic of Germany of 1949, BGBl III, Gliederungsnummer 100-1 
Handelsgesetzbuch, German Commercial Code, BGBl III Gliederungsnummer 4100-1

Signaturgesetz, Signature Law, of 16 May 2001, BGBl 2001 I 876

Telemediengesetz, Tele-media Law, of 26 February 2007, BGBl 2007 I 179

Verordnung über die technischen Rahmenbedingungen des elektronischen Rechtsverkehrs und über das besondere elektronische Behördenpostfach, Ordinance on the Technical Conditions of Electronic Legal Tranasctions and the Special Electronic Mailbox of Authorities, of 24 November 2017, BGBl 2017 I 3803

Verordnung über die Übertragung der Führung des Unternehmensregisters und die Einreichung von Dokumenten beim Betreiber des elektronischen Bundesanzeigers, Ordinance on the Transfer of the Management of the Business Register and the Submission of Documents to the Operator of the Electronic Federal Gazette, of 15 December 2006, BGB1 2006 I 3202

Zivilgesetzbuch der Deutschen Demokratischen Republik, Civil Code of the German Democratic Republic of 19 June 1975

Zivilprozessordnung, German Code of Civil Procedure, BGBl 2005 I 3202 and 2006 I 431 and 2007 I 1781

\section{Japan}

Chokurei, Imperial Edict, 勅令, No 12/1932

Denshi shōhi-sha keiyaku oyobi denshi shōdaku tsūchi ni kansuru minpō no tokurei ni kansuru hōritsu, 電子消費者契約及び電子承諾通知に関する民法の 特例に関する法律, Act on Special Provisions to the Civil Code Concerning Electronic Consumer Contracts and Electronic Acceptance Notice, Law No 95/2001

Denshi shomei oyobi ninshō gyōmu ni kansuru hōritsu, 電子署名及び認証業務に 関する法律, Act on Electronic Signatures and Certification Business, Law No $102 / 2000$ as amended

Fudō-san tōki-hō, 不動産登記法, Real Property Registration Act, Law No 123/2004 as amended

Hō no tekiyō ni kansuru tsūsoku-hō, 法の適用に関する通則法, General Rules for Application of Laws, Law No 78/2006

Inshi-zei-hō, 印紙税法, Stamp Tax Act, Law No 23/1967 as amended

Kaisha-hō, 会社法, Companies Act, Law No 86/2005 as amended

Kappu hanbai-hō, 割賦販売法, Installment Sales Act, Law No 159/1961, as amended

Keihō, 刑法, Japanese Criminal Code, Law No 45/1907, as amended

Kensetsu-gyō-hō, 建設業法, Construction Business Act, Law No 100/1949 as amended

Kōshō-nin-hō, 公証人法, Japanese Notary Act, Law No 53/1908 as amended 
Kyū-shōhō, 旧商法, former Commercial Code, Law No 32/1890

Minji shikkō-hō, 民事執行法, Japanese Civil Execution Act, Law No 4/1979 as amended

Minji soshō-hō, 民事訴訟法, Japanese Code of Civil Procedures, Law No 109/1996 as amended

Minpō, 民法, Japanese Civil Code, Law No 89/1896 and No 91/1889 as amended

Minpō ichibu wo kaisei suru hōritsu，民法の一部を改正する法律，Law No 44/2017

Minpō ichibu wo kaisei suru hōritsu no shikō ni tomonau kankei hōritsu no seibi-tō ni kansuru hōritsu, 民法の一部を改正する法律の施行に伴う関係法律 の整備等に関する法律, Law to Maintain Laws Affected by the Enforcement of the Law to Amend one Part of the Civil Code, Law No 45/2017

Nihon-koku Kenpō, 日本国憲法, Japanese Constitution, Constitution of 3 November 1946

Rōdō kumi‘ai-hō, 労働組合法, Labor Union Act, Law No 174/1949 as amended

Ryoken-hō, 旅券法, Law No 267/1951

Ryoken-hō shikō kisoku, 旅券法施行規則, Enforcement Regulations for the Passport Act, Regulation No 11/1989

Ryūboku ni kansuru hōritsu, 立木ニ関スル法律, Act on Standing Timber, Law No 22/1909 as amended

Ryūboku tōki kisoku，立木登記規則, Regulation for the Registration of Timber, Order (Hōmu-sho) No 206/2005 (Heisei 17) as amended

Saiban jimu kokoro'e, 裁判事務心得, Rules for the Conduct of Court Affairs, Government Decree No 103/1875

Saiban-sho-hō, 裁判所法, Japanese Court Act, Law No 59/1947 as amended

Shakuchi shakuya-hō, 借地借家法, Act on Land and Building Leases, Law No 90/1991 as amended

Shihō shoshi-hō, 司法書士法, Judicial Scriveners Act, Law No 197/1950 as amended

Shita'uke daikin shiharai chi'en-tō bōshi-hō, 下請代金支払遅延等防止法, Act against Delay in Payment of Subcontract Proceeds, etc to Subcontractors, Law No $120 / 1956$ as amended

Shōhi-sha keiyaku-hō, 消費者契約法, Consumer Contract Act, Law No 61/2000 as amended

Shōhi-sha kihon-hō, 消費者基本法, Basic Consumer Act, Law No 78/1968 as amended

Shōhō, 商法, Japanese Commercial Code, Law No 48/1899 as amended

Shomen no kōfu-tō ni kansuru jōhō tsūshin no gijutsu no riyō no tame no kankei hōritsu no seibi ni kansuru hōritsu, 書面の交付等に関する情報通信の技術の 利用のための関係法律の整備に関する法律, Law for Making Provisions on the Exchange of Documents etc by the use of Electronic Telecommunication Technology in Connected Laws, Law No 126/2000 
Shutsu'nyū-koku kanri oyobi nanmin nintei-hō, 出入国管理及び難民認定法, Immigration Control and Refugee Recognition Act, Cabinet Order No 319/1951

Takuchi tatemono torihiki-gyō-hō, 宅地建物取引業法, Real Estate Brokerage Act, Law No 10/1952 as amended

Tegata-hō, 手形法, Negotiable Instrument Act, Law No 20/1932 as amended

Tokutei shō-torihiki ni kansuru hōritsu, 特定商取引に関する法律, Act on Specified Commercial Transactions, Law No 57/1976 as amended

Tokutei shō-torihiki ni kansuru hōritsu shikō kisoku, 特定商取引に関する法律 施行規則, Regulations for Enforcement of the Act on Specified Commercial Transactions, Ordinance of the Ministry of International Trade and Industry No 89/1976 as amended 


\section{Table of Cases}

European Union (Court of Justice of the European Union; in chronological order)

ECJ Case C-6/64 Costa v ENEL [1964] ECR 585

ECJ Case C-9/70 Grad v Finanzamt Traunstein [1970] ECR-I 826

ECJ Case C-41/74 van Duyn v Home Office [1974] ECR-I 1338

ECJ Case C-541/99 Cape v Ideal Service [2001] ECR I-9049

ECJ Case C-464/01 Gruber v Bay Wa AG [2005] ECR I-439

\section{England (alphabetical order)}

Adams v Lindsell (1818) 1 Barnewall and Alderson 681, 106 ER 250 (KB) Anson v Trump [1998] 1 WLR 1404 (CA)

Apple Corps Ltd v Apple Computer Inc [2004] EWHC 768 (Ch), [2004] 2 CLC 720

Air Transworld Ltd v Bombardier Inc [2012] EWHC 243 (Comm), [2012] 1 CLC 145 (QB)

Balfour v Balfour [1919] 2 KB 571 (CA) [Balfour v Balfour

Barry v Heathcote Ball \& Co (Commercial Auctions) Ltd [2000] 1 WLR 1962

Beckham v Drake (1841) 9 Meeson and Welsby 79 (Exchequer), 152 ER 35

Berkley v Poulett [1977] 1 Estates Gazette Law Reports (EGLR) 86 (CA); (1977) 241

Estates Gazette (EG) 911; [1976] EWCA Civ 1

Blue $v$ Ashley [2017] EWHC 1928 (Comm), 2017 WL 03129053 (official transcript)

Brinkibon Ltd $v$ Stahag-Stabl und Stablwarenhandelsgesellschaft mbH [1983] 2 AC 34

(HoL)

Brogden v Metropolitan Railway (1877) 2 App Cas $666(\mathrm{HoL})$

Byrne \& Co $v$ Van Tienhoven \& Co (1880) 5 CPD 344 (HC)

Carlill v Carbolic Smoke Ball Co [1893] 1 QB 256 (CA)

Central London Property Trust Ltd v High Trees House Ltd [1947] 1 KB 130

Chappell \& Co Ltd v Nestlé Co Ltd [1960] AC 87 (HoL)

Cook $v$ Wright (1861) 1 Best and Smith 559, 121 ER 822 (QB)

Cooke v Oxley (1790) 3 Term Reports 653 (KB); 100 ER 785

Currie v Misa (1875) LR 10 Exchequer 153 
Daly v General Steam Navigation Co (The Dragon) [1979] 1 Lloyd's Rep 257 (QB)

Dayman v Anfield Services Ltd [2006] EWHC 2937 (QB), 2006 WL 3485359 (official transcript)

Denton v Great Northern Railway Co (1856) 5 Ellis and Blackburn 860 (QB), 119 ER 701

Dickinson v Dodds (1876) 2 Chancery Division 463 (CA)

Dunlop v Higgins (1848) 1 House of Lords Cases 381, 9 ER 805 (HoL)

Eastwood v Kenyon (1840) 11 Adolphus and Ellis 438 (QB), 113 ER 482

Eccles $v$ Bryant and Pollock [1948] Ch 93 (CA)

Edwards v Skyways Ltd [1964] 1 WLR 349 (QB)

Elitestone Ltd v Morris [1997] 1 WLR 687 (HoL)

Entores Ltd $v$ Miles Far East Corporation [1955] 2 QB 327 (CA)

Esso Petroleum Ltd $v$ Commissioners of Customs and Excise [1976] 1 WLR 1 (HoL)

Everwine Ltd and Ors $v$ The Commissioners of Customs and Excise [2003] EWCA Civ 953, 2003 WL 21353475 (official transcript)

Felthouse v Bindley (1862) 11 Common Bench Reports (New Series) 869, 142 ER 1037 (HC)

First National Securities Ltd v Jones [1978] 2 WLR 475 (CA), [1987] Ch 109

Firstpost Homes Ltd v Johnson [1995] 1 WLR 1567 (CA)

Fisher v Bell [1960] 3 WLR 919, [1961] 1 QB 394

Foakes $v$ Beer (1884) 9 App Cas 605 (HoL)

Golden Ocean Group Ltd v Salgaocar Mining Industries Pvt Ltd [2012] EWCA Civ 265, [2012] 1 WLR 3674

Golding's Case (1586) 2 Leonard 71, 74 ER 367 (KB)

Hadley $v$ Baxendale (1854) 9 Exchequer 341

Harvey $v$ Facey [1893] AC 552 (Privy Council)

Harvey $v$ Pratt [1965] 1 WLR 1025 (CA)

Heilbut, Symons \& Co v Buckleton [1913] AC 30 (HoL)

Henthorn v Fraser [1892] 2 Ch 27 (CA)

Hillas \& Co Ltd $v$ Arcos Ltd (1932) 147 LT 503 (HoL)

HSBC Trust Co (UK) Ltd v Quinn [2007] EWHC 1543 (Ch), 2007 WL 1942791 (official transcript)

Hughes $v$ Metropolitan Ry (1877) 2 App Cas 439 (HoL)

J Pereira Fernandes SA v Mehta [2006] EWHC 813 (Ch), [2006] 1 WLR 1543

Kingspan Environmental Ltd and Others v Borealis AS, Borealis UK Ltd [2012] EWHC 1147 (Comm), WL 1469127 (official transcript)

L'Estrange v F Graucob Ltd [1934] 2 KB 394

Lefkowitz v Great Minneapolis Surplus Stores (1957) 86 NW 2d 689 (SC Minnesota)

Mackenzie v Coulson (1869) LR 8 Eq 368 (Ch)

Marshall $v$ N M Financial Management Ltd [1997] 1 WLR 1527 (CA) 
May and Butcher Ltd $v$ The King [1934] $2 \mathrm{~KB}$ 17n (HoL)

Merritt v Merritt [1970] 1 WLR 1211 (CA)

Morley $v$ Boothby (1825) 3 Bingham 107 (Court of Common Pleas), [1825] 130 ER 455

Newell $v$ Tarrant [2004] EWHC 772

OTV Birwelco Ltd $v$ Technical \& General Guarantee Co Ltd [2002] EWHC 2240

(TCC) (QB), 2002 WL 31050475 (official transcript)

Pao On v Lau Yiu Long [1980] AC 614 (PC)

Patridge v Crittenden [1968] 1 WLR 1204 (QB)

Payne $v$ Cave (1789) 3 Term Reports 148 (KB); 100 ER 502

Percy Trentham Ltd v Archital Luxfer Ltd 1993 WL 963649 (official transcript, CA)

Pham v Secretary of State for the Home Department [2015] UKSC 19

Pharmaceutical Society of Great Britain v Boots Cash Chemists (Southern) Ltd [1953] 1 QB 401 (CA)

Practice Statement (Judicial Precedent) [1966] 1 WLR 1234

Quenerduaine v Cole (1883) 32 Weekly Reporter (WR) 185

$R$ (on the application of Miller) (Respondents) $v$ Secretary of State for Exiting the European Union (Appellant) [2017] UKSC 5

Re a Debtor [1996] British Company Cases (BCC) 189 (CA)

Re Doran's Application for Judicial Review $v$ re Decision of the Department for the Economy and the Minister for the Economy in Connection with the Renewable Heat Incentive Scheme (No. 2) [2017] Northern Ireland QB (NIQB) 24, 2017 WL 00956529 (official transcript)

Reg $v$ Morton (1872-75) LR 2 Court for Crown Cases Reserved (CCR) 22 Criminal Appeal Court)

Reg $v$ Secretary of State for Transport, Ex p Factortame Ltd. (No 2) [1990] 3 WLR 818 (HoL), [1991] 1 AC 603

Rollerteam Ltd v Riley [2016] EWCA Civ 1291, [2017] Ch 109

Rose and Frank Co $v$ Crompton and Brothers, Ltd [1923] 2 KB 261 (CA)

Rose and Frank Co $v$ Crompton and Brothers, Ltd [1925] AC 445 (HoL)

RTS Flexible Systems Ltd v Molkerei Alois Müller GmbH \& Co KG (UK Production) [2010] UKSC 14, [2010] 1 WLR 753

Sadler $v$ Reynolds [2005] EWHC 309 (QB)

Seward $v$ Seward (2014) WL 3535431 (HC; official transcript)

Shadwell v Shadwell (1860) 9 Common Bench Reports (New Series) 159, 142 ER 62

Sharington $v$ Strotton (1564) 1 Plowden 298, 75 ER 454 (KB)

Shipton v Dogge (1442) B\&M 391

Sidhu and Others $v$ British Airways Plc [1997] AC 430 (HoL)

Slade's case (1595) 4 Coke 91a, 76 ER 1072 (KB) 
Table of Cases

Smith $v$ Hughes (1870-71) LR 6 QB 597

St Albans City and DC v International Computers Ltd [1996] 4 All ER 481, [1997] Fleet Street Reports (FSR) 251 (CA)

Starline and Wessex Taxis Ltd $v$ The Commissioners for Her Majesty's Revenue \& Customs (London Tribunal), 2007 WL 2187088 (official transacript)

Stevenson, Jaques \& Co v McLean (1880) 5 QBD 346

Stidolph v American School in London Educational Trust Ltd (1969) 20 P\&CR 802 (CA)

Stilk v Myrick (1809) 2 Campbell 317 (Assizes), 170 ER 1168, (1809) 6 Espinasse's

Nisi Prius Reports (Esp) 129

Storer v Manchester City Council [1974] 1 WLR 1403 (CA)

Stratton v Swanlond (1374) B\&M 360

Suleman v Shahsavari (1989) 57 P\&CR 465 (HC Chancery Division)

Summit Invest Incorporated v British Steel Corporation [1987] 1 Lloyd's Report 230

(CA), 1987 WL 492632 (official transcript)

Tanistry Case (1607) Davis 28; 80 ER 516

Thornton v Shoe Lane Parking Ltd [1971] 2 QB 163 (CA)

Wade v Simeon (1846) 2 Common Bench Reports 548 (Court of Common Pleas), 135 ER 1061

Warlow v Harrison (1858) 1 Ellis and Ellis 295, 120 ER 920

Williams v Roffey Bros \& Nicholls (Contractors) Ltd [1991] QB 1

Young v Bristol Aeroplane Co, Ltd [1944] KB 718 (CA)

Germany (by court in chronological order)

Federal Consitutional Court (Bundesverfassungsgericht, 1951-)

BVerfG order of 5 April 2005, 1 BVR 1664/04

BVerfG order of 8 May 2007, 2 BvM 1/03, BVerfGE 118, 124-167

BVerfG decision of 4 May 2011, 2 BvR 2365/09, BVerfGE 128, 326-409

Federal Court of Justice (Bundesgerichtshof, 1950-)

BGH decision of 24 September 1952, II ZR 305/51, BGHZ 7, 187

BGH decision of 22 June 1956, I ZR 198/54, BGHZ 21, 102-112

BGH decision of 27 May 1957, VII ZR 223/56, WM 1957, 883-886

BGH decision of 27 June 1973, VIII ZR 201/72, BGHZ 61, 80-84

BGH decision of 13 November 1973, VI ZR 152/72, NJW 1974, 234

BGH decision of 4 June 1975, I ZR 114/74, NJW 1975, 1705-1706 
BGH decision of 2 June 1976, VIII ZR 97/74, BGHZ 66, 378-384

BGH decision of 3 November 1976, VIII ZR 140/75, BGHZ 67, 271-279

BGH decision of 6 December 1979, VII ZR 313/78, BGHZ 76, 43-50

BGH decision of 27 October 1982, V ZR 24/82, NJW 1983, 929-931

BGH decision of 1 February 1990, IX ZR 110/89, WM 1990, 603-606

BGH decision of 28 March 1990, VIII ZR 258/89, BGHZ 111, 97-103

BGH decision of 22 May 1991, IV ZR 107/90, NJW-RR 1991, 1177-1178

BGH decision of 7 June 1995, VIII ZR 125/94, BGHZ 130, 71-76

BGH decision of 29 February 1996, IX ZR 153/95, BGHZ 132, 119-132

BGH decision of 10 July 1997, IX ZR 24-97, NJW 1997, 3380-3381

BGH decision of 26 November 1997, VIII ZR 22/97, BGHZ 137, 205-211

BGH decision of 24 April 1998, V ZR 197/97, BGHZ 138, 339-348

BGH decision of 25 November 1998, VIII ZR 259/97, NJW 1999, 1259-1261

BGH decision of 29 September 1999, XII ZR 313/98, NJW 2000, 354-359

BGH decision of 20 June 2000, IX ZR 434/98, WM 2000, 1600-1605

BGH decision of 18 October 2001, XII ZR 179/98, NJW 2001, 221-223

BGH decision of 18 December 2002, XII ZR 253/01, NJW 2003, 1248-1249

BGH decision of 21 January 2004, XII ZR 214/00, NJW 2004, 1320-1321

BGH decision of 21 September 2005, VIII ZR 284/04, NJW 2005, 3567-3569

BGH decision of 16 March 2006, III ZR 152/05, BGHZ 166, 369-383

BGH decision of 4 February 2009, VIII ZR 32/08, BGHZ 179, 319-329

BGH decision of 30 September 2009, VIII ZR 7/09, NJW 2009, 3780-3781

BGH decision of 11 June 2010, V ZR 85/09, NJW 2010, 2873-2876

BGH order of 12 September 2011, IV ZR 38/09, NJW 2012, 296-301

BGH decision of 16 October 2012, X ZR 37/12, BGHZ 195, 126-134, NJW 2013, 598

BGH decision of 5 December 2012, I ZR 92/11, BGHZ 196, 254-270

BGH decision of 23 January 2013, XII ZR 35/11, NJW 2013, 1082-1083

BGH default judgement of 7 June 2013, V ZR 10/12, NJW 2013, 3434-3436

BGH decision of 10 July 2013, IV ZR 224/12, BGHZ 198, 32

BGH decision of 27 September 2017, XII ZR 114/16, BGHZ 216, 68-83, JZ 2018, 789-792

BGH decision of 17 October 2017, KZR 24/15

BGH decision of 23 November 2017, IX ZR 204/16

BGH decision of 7 March 2018, XII ZR 129/16, NJW 2018, 1540-1542 
Federal Labour Court (Bundesarbeitsgericht, 1954-)

BAG decision of 24 June 2003, 9 AZR 302/02, BAGE 106, 345-352

BAG decision of 19 April 2005, 9 AZR 233/04, BAGE 114, 206-218, NJW 2006, 1832-1836

BAG decision of 17 December 2009, NJW 2010, 1100-1103

Higher Regional Courts (Oberlandesgerichte)

OLG Köln decision of 27 April 1971, 15 U 126/70, NJW 1971, 1367-1369

OLG Düsseldorf decision of 28 December 28 December 2004, 21 U 68/04, NJW 2005, 1515-1516

OLG Rostock order of 28 April 2006, 7 U 48/06, OLG-Report (OLGR) Rostock 2006, 601-602

OLG Dresden decision of 30 November 2010, 10 U 0269/10, Internationales Handelsrecht (IHR) 2011, 142-145

OLG München order of 15 March 2012, Verg 2/12, Neue Zeitschrift für Baurecht und Vergaberecht (NZBau) 2012, 460-464

OLG München decision of 10 January 2019, 29 U 1091/18, MMR 2019, 532-535

\section{Regional Courts (Landgerichte)}

LG Berlin decision of 20 July 2004, 4 O 293/04, NJW 2004, 2831-2833

LG Hamburg decision of 7 July 2009, 312 O 142/09, Kommunikation \& Recht (K\&R) 2010, 207-208

LG Dortmund decision of 21 April 2017, 10 O 12/17

Local Courts (Amtsgerichte)

AG Meldorf decision of 29 March 2011, 81 C 1601/10, NJW 2011, 2890-2892

Imperial Court (Reichsgericht, 1879-1945)

RG decision of 15 February 1910, IV 241/09, Deutsche Juristen-Zeitung (DJZ) 1910, 594

RG decision of 21 June 1918, II 121/18, RGZ 93 175-176

RG decision of 25 March 1930, VII 440/29, RGZ 128, 187-191 


\section{Other German Courts}

Bavarian Administrative Court (Bayerischer Verwaltungsgerichtshof) order of $16 \mathrm{Au}$ gust 1976, 118 VIII/75, NJW 1978, 510-511]

Japan (by court in chronological order)

Great Court of Judicature (Dai-shin'i, 大審院, 1875-1947)

Dai-shin'i decision of 8 May 1901 (Meiji 34), Minroku 7 Vol 552

Dai-shin'i decision of 11 March 1920 (Taishō 10), Minroku Vol 27514

Dai-shin'i decision of 14 January 1933 (Shōwa 8), Dai-shin'i Saiban-rei Vol 7 min 4

Dai-shin'i decision of 25 April 1935 (Shōwa 10), (Hōritsu) Shinbun No 3835 5, 'カ フェ一丸玉女給事件 '

Dai-shin'i decision of 28 June 1944 (Shōwa 19), Takahashi v Matsuba, Minshū Vol 23387

Japanese Supreme Court (Saikō Saiban-sho, 最高裁判所, 1947-)

Saikō Saiban-sho decision of 4 October 1955 (Shōwa 30), Minshū Vol 9 No 111521

Saikō Saiban-sho decision of 20 April 1961 (Shōwa 36), Minshū Vol 15 No 4744

Saikō Saiban-sho decision of 26 March 1965 (Shōwa 40), Minshū Vol 19 No 2526

Saikō Saiban-sho decision of 4 October 1965 (Shōwa 40), Minshū Vol 19 No 82019

Saikō Saiban-sho decision of 17 December 1968 (Shōwa 43), Minshū Vol 22 No 13 2998

Saikō Saiban-sho decision of 20 December 1976 (Shōwa 51), Hanji No 84346

Saikō Saiban-sho decision of 29 November 1985 (Shōwa 60), Minshū Vol 39 No 7 1719

Japanese District Court (Chihō Saiban-sho, 地方裁判所)

Tōkyō Chihō Saiban-sho decision of 25 December 1989 (Heisei 1), Hanrei Jihō Vol 136263

Tōkyō Chihō Saiban-sho decision of 13 April 2019 (Heisei 29) 
Table of Cases

\section{Other Courts}

Chwee Kin Keong v Digilandmall.com Pte Ltd [2004] SGHC 71 (Singaporean High Court)

Hanwha Corporation v Cedar Petrochemicals Inc, decision of the Southern District Court of New York on 18 January 2011, 09 Civ 10559 


\section{Index}

Abstraktionsprinzip (abstraction principle) 219-220, 260, 439-439

Acceptance (Annabme, shödaku)

- acknowledgement of offer, and 64 in fn $469,72-72,78-78,162-162,248$, $308-308,342$ and in fn $2576,343,367$ in fn 2724, 370, 388

- certainty, see Certainty, acceptance

- coming into effect, see Mailbox rule, Postal rule

- communication, see Communication of acceptance

- confirmation and, see acknowledgement of offer

- congruence with offer 72-73, 161, 247, 309, 371-372, 389-389

- counter-offer, see Offer, counter-offer

- definition 72-73, 161-162, 247-248, 308, 369-369, 388-388

- doctrine of offer and, see Offer, acceptance-model

- express 74, 146, 162, 249, 310,369, 388

- generally 71-71, 161-161, 247-247, 308308, 369-369, 388-389

- implied 74, 146, 162-163, 249-249, 309309, 369-369, 388

- late 79, 166-166, 244, 248-248, 253, 295-295, 311-312, 375, 391-392

- loss of effect through revocation or withdrawal 79-79, 165, 253, 312, 378-379, 379, 392, 393-393

- method, see Method of acceptance

- period 79, 159-161, 166, 245-245, 252$253,296,311,374-375,391-391$

- silence as, see Method of acceptance, silence

- time frame, see period

- unilateral contracts, in, see Method of acceptance, unilateral contracts

Advertisements, see Invitations to treat, advertisements

Agents (Vertreter, dairi-nin)

- authentication of contract by 191-191, 271, 326-327

- authorisation of, see Seals, sign of authorisation

- automated electronic (Smart Speakers) $340,342,343$
- declaration of intention made by 50

- real estate, see Professionals, real estate agent

- receipt of declarations of intention by 75,156

Agreement, see Contracts, agreements and

Allgemeine Geschäftsbedingungen $(A G B)$, see Standard Terms

Annabme, see Acceptance

Arrival rule, see Mailbox rule

Auctions, see Invitations to treat, auctions

Bürgschaft, see Form and formalities, guarantees

Brexit 52-53, 308-308

Business (person), see Merchant

Certainty

- acceptance, of 72-72, 140, 165, 310

- agreement, of 29,60, 394-395

- offer, of 65-67, 140, 149, 152, 307, 369370,388

Communication of acceptance

- disruptions or technical problems during $76-77,78$ in fn 577,155

- generally 73, 145, 161, 309, 370, 374, 389

- method, see Method of acceptance

- unilateral contracts, in 73

Communication of offer

- disruptions or technical problems during 155,243

- generally $67,145,149,306-307,387$

- method, see Method of offer

- unilateral contracts, in 67

Conclusion of contracts, see Formation of contracts

Consideration, see also Indicia of seriousness; Tetsuke

- adequacy of 87-88, 92-92

- bargain theory, and 35, 42, 83, 87, 92

- deeds, and 42, 83 and in fn 615

- definition 83, 85-87

- function 83

- generally 82-85, 301, 316-318

- insufficient 90-91

- move from promisee 93-93

- nominal 89-90

- past $92-92$ 
- reciprocity and $35-37,42,83$

- sufficiency of 87-89, 92-92

- thing of value 85,87

- unilateral contracts, in 86

Consumer

- definition 55-56, 138-139, 214-214, 384

- contracts and information duties 320320

- contracts and formalities 101, 165, 183, 183-184, 194, 206, 262-262, 343-344, 346-346, 396-397, 398, 398

- regulation generally $79,94,118,137$, 138, 212, 215-215, 246-247

Contracts (Verträge, keiyaku)

- agreements, and 28-29, 35, 57-58, 116, 217, 221, 236, 300, 365, 386

- bargains as, see Contract law, bargain theory

- conclusion of, see Formation of contracts

- consideration, see Consideration

- definition 28-30, 35-37, 48-49, 115119, 124-125, 217-218, 221-221, 300$301,365,386-386$

- electronic 107-110, 192-197, 259-260, 297-298, 339-351, 396-397

- essential terms (essentialia negotii) 66$67,149,152-153,180$ in fn 1367,238 , 306, 368-368, 371, 394

- form, see Form and formalities

- formation, see Formation of contracts

- freedom of, see Freedom of, contract

- freedom of form, and, see Freedom of, form

- generally 4

- intention, see Intention to be legally bound

- negotiations, and 57, 116, 163, 237-238, 353-354, 355, 357-358, 366

- promises and 28-29, 49, 55, 83-85, 125$126,221,300,386$

- smart 339-340, 348-351

- types of, see Types of Contract

Contract law (Vertragsrecht, keiyaku-hō)

- bargain theory and 35, 300, see also Consideration, bargain theory

- dispositive and mandatory rules of 5, 12 in fn 49, 15, 55, 94, 140, 142-143, 158, 172, 199, 236, 247, 262, 276, 292, 301, $318,365,388$

- equity and 14 and in fn 63, 87 in fn 651, 92, 336, see also Estoppel

- historical development of, see Historical development of contract law
- legal practice and 113-114, 205-207, 280-285, 351-361

- reform of Japanese contract law (law of obligations), see Modernisation of Japanese law of obligations

- sources of, see Sources of (contract) law

- standard terms, see Standard terms

Conveyance, see Form and formalities, sale of land

Customs, see Sources of (contract) law, customs and customary law

Dairi-nin, see Agents

Declarations of intention (Willenserklärungen, ishi byojii)

- acceptance as 143-144, 145, 154, 161, 236, 308

- definition 144-145, 237-237

- empfangsbedürftige and nicht empfangsbedürftige declarations, see types

- generally 115,236

- interpretation 58-59, 147-148, 238

- method, see Method of acceptance; Method of offer

- offer as 143-144, 145, 149, 154, 236, 303

- Rechtsgeschäfte, and 143-144

- types 145-146

Deeds

- consideration, and, see Consideration, deeds

- definition 43 and in fn 298

- effect 83, 84, 111

- generally 93-94, 101-103, 106, 318, 322322, 357-358

- requirements 101-102, 106, 323-324, 357-358

- signature and seal impression 101, 102, 104, 106, 324, 326, 327-327, 337-338

- witness 102, 324

Dispatch rule, see Postal rule

Donation, see Gifts

Draufgabe, see Indicia of seriousness, Draufgabe

English law 36, 42-182, see also Contracts; Contract law; Formation of contracts

Entrepreneur, see Merchant

Estate agents, see Professionals, real estate agents

Estoppel 141-142

European Union law

- Brexit, see Brexit

- English law and 12, 12, 17-19

- generally 12

- German law and 12, 21, 26-26 
Freedom of

- contract (Vertragsfreiheit, keiyaku no jiyū) 12, 140, 236, 253, 289, 300

- form (Formfreiheit, hōshiki jiyū) 58, 140, 170, 236, 297, 381, 394, 395

Form and formalities

- consequence of non-fulfilment 94, 103, 197-203, 255-256,

- consumer contracts, see Consumer, contracts and formalities

- dauerhafter Datenträger (durable medium) 181-182, 320, 397

- deeds and, see Deeds, requirements

- document (shomen) 99, 259-260, 321, see also Urkunde

- electro-magnetic record (denjiteki jiroku) 260, 345

- electronic documents and 107-108, 192197, 260, 345-346

- electronic form (Elektronische Form) 194-197, 344-345

- evidence in writing 99-101, 319-320

- functions of 93, 94, 172-173, 254, 319

- generally 6, 30, 93-113, 253-255, 318318, 381-381, 395-395

- gifts, see Gifts, formalities

- guarantees (Bürgschaftserklärung, hoshō keiyaku) 43, 93 in fn 697, 100, 100, 103, 106, 108, 109, 152, 178, 183, 194-195, 201, 260-261, 320, 321-321, 326-326, $345,347,398$

- history, in 43-44, 54, 128-130, 222-224

- legal practice and, see Contract law, legal practice

- memorandum 99, 319

- notarial authentication (notarielle Beurkundung, shōsho no sakusei) and notarial deed (notarielle Urkunde, kōsei shōsho) 184-187, 269-272, 322-325

- registration of property title 110-112, 203-204, 254, 272-273

- sale of land or real estate 54-54, 100, 102, 111-112, 113, 187, 200, 203-204, $254,272-273$

- signing and sealing, see Signatures; Seals

- stamp tax, see Stamp Tax

- text form (Textform) 176-184, 319-320, 397-397

- types 93-94, 171, 318, 395

- Urkunde (instrument) 178-180, 321,

- writing 99-100, 176-184, 258-263, 319, 321-322, 396-396

Formation of contracts

- acceptance, see Acceptance

- agreement, see Contracts, agreements
- certainty, see Certainty

- consideration, see Consideration

- form and, see Form and formalities

- generally 7-9, 28-29, 57, 139-141, 236239, 293-294, 303, 365-366, 385-386, 390

- indicia of seriousness, see Indicia of seriousness

- intention to create legal relations, see Intention to be legally bound

- invitations to treat or invitatio ad offerendum or, see Invitations to treat

- offer, see Offer

German law 42-45, 55-65, 182-309, see also Contracts; Contract law; Formation of contracts

Gifts (Schenkung, zōyo)

- contracts, and 30 and in fn 181, 117, $168,217,301$

- formalities 103, 187, 237, 256, 260-260, 261, 270, 322, 324, 399

- performance of 201, 325, 399

Goods (Waren, shōhin)

- definition 66 in fn 482, 97-98, 364-365, 384-385

- display of, see Invitations to treat, display of goods

- software as 98, 173, 364-365, 384

Guarantees, see Form and formalities, guarantees

Hasshin shugi, see Postal rule

Historical development of contract law

- Allgemeines Landrecht für die Preußischen Staaten (ALR) 123-132

- contract forms, and 43-44, 54, 128-130, 222-224

- codifications of German and Japanese civil codes (BGB, Minpō) 133-136, 228233

- definition of contract 35-37, 124-125, 221-221

- English law generally, in 28, 31-55

- formation of contract 41-43, 49-52, 5454, 125-128

- forms of actions and the writ system 31, 34-35, 37-40

- German law generally, in 119-138

- Gemeines Recht (German common law) 123-132

- intention to be legally bound 51-52

- Japanese law generally, in 218-235

- postal rule 49-51, 127-127 
Hoshō keiyaku, see Form and formalities, guarantees

Indicia of seriousness, see also Intention to be legally bound; Form and formalities

- consideration, see Consideration

- Draufgabe 130-132, 135, 204-205, 302 302

- generally 6, 315-317

- historically 41-43, 130-132, 135, 224225, 302-302

- tetsuke, see Tetsuke

Inshō, see Seals

Intention to be legally bound (intention to create legal relations)

- commercial relations, in 80, 314

- courtesy or kindness (Gefälligkeiten, kōi), acts of $80,314-315$

- definition 80, 314, 394

- family relations, in $80,81-82,314$

- generally 80-82, 166-169, 314-315, 394395

- interpretation 58-59, 80, 167-169, 394395

- letters of intent (LOI) 80 in fn 595, 169, $171,314,369$

- mere puffs and sales talk 62, 304

- social relations, in 80,314

International law, see also Model contract laws

- English law, and 19-20

- European Convention on Human

Rights (ECHR) 13, 13, 21

- German law, and 27-27

- Japanese law, and 216-216

- United Nations Convention on Contracts for the International Sale of Goods (CISG) 4, 362-382

Invitations to treat (invitatio ad offerendum, möshikomi no yüin)

- advertisements 61, 152, 240, 305, 368, 388

- auctions 63, 150

- display of goods 62-63, 152, 241, 304, 305-306, 388

- generally 60-65, 150-152, 240-241, 303$304,367-368,387-388$

- mere puffs and sales talk, see Intention to be legally bound, mere puffs

- petrol station 63,151, 304

- public transport 64-64, 151, 240-241, 306

- rewards, offer of 62

- taxi 65-65, 241, 304-305

- transfer of information 62,368
- vending machines 61, 151

Ishi hyoji, see Declaration of intention

Japanese law 310-435, see also Contracts; Contract law; Formation of contracts

Kaufmann, see Merchant

Keiyaku, see Contracts

Keiyaku-hō, see Contract law

Legal thinking (Japan, generally) 410-415

Legal tradition

- civil law 11

- classification of 11-12, 208-210

- common law 11

- hybrid or mixed 208-209

Letters of Intent (LOI), see Intention to be legally bound, letters of intent

Mailbox rule (Zugangstheorie, tōtatsu shugi)

- application of 67, 76,

- business hours 68,78,

- electronic communications, and 68-69, 76 ,

- generally $67-69,75-79,154-158$,

- instantaneous communications, and 69, 76

- meaning 67-69, 76-78,

- postal communications, see Postal rule

Merchant (Kaufmann, shönin), definition 102-103, 215-216, 318, 547

Method of acceptance

- conduct 73, 163, 249, 309, 388

- electronic means 74, 250,341

- generally 73-74, 162-165, 249-249, 309$309,370-370,372-373,388-389,391$

- inactivity $73,163,164,249,370,389$

- instantaneous means, see electronic means

- orally $74,162,388$

- post and writing 74,162

- silence 73, 164, 309, 370, 389

- unilateral contracts, in, see conduct

Method of offer

- conduct 60, 149

- electronic means 60, 150, 243, 341, 372,

- generally $60-60,149-150,242-243,372-$ 373, 391

- inactivity 60

- orally 60,372

- post and written $60,242,372$

Model contract laws: Common European Sales Law (CESL), Draft Common Frame of Reference for European Con- 
tract Law (DCFR), Principles of European Contract Law (PECL) 38, 545-567

Modernisation of Japanese law of obligations

- background 286

- coming into effect of declarations of intention 289-293

- content 288-298

- form and formalities 296-298

- formation of contract 293-294

- generally $285-298$

- process 286-288

- validity of declarations of intention 295296

Mono, see Property

Mōshikomi, see Offers

Möshikomi no yüin, see Invitations to treat

Offer, see also Invitations to treat

- acceptance model, and 49, 57, 116, 236, 293, 303, 365, 385

- ad incertas personas (to unspecified persons) or to the public $60,150,240,303$, 367, 387-388

- certainty, see Certainty, offer

- coming into effect, see Mailbox rule; Postal rule

- counter-offer 69, 72, 161, 166, 248-248, 295, 309, 311, 372, 389,

- communication, see Communication of offer

- definition 59-60, 149-150, 239-240, 303-303, 367, 387

- display of goods, see Invitations to treat, display of goods

- express and implied 60, 146, 149

- generally, see definition

- loss of effect through expiry 70-70, 159160, 243-244, 307-308, 378, 380, 392

- loss of effect through rejection 71, 161, 247, 380, 392

- loss of effect through revocation or withdrawal 70-71, 158-159, 245-247, 295295, 295-296, 307-307, 378-380, 392, 393-393

- method, see Method of Offer

- new offer, see counter-offer

Postal rule (hasshin shugi)

- application of 78, 249-252

- electronic communications, and 78, 250, 251-252

- generally 78-79, 249-252

- historical development, see Historical development of contract law, postal rule
- instantaneous communications, and 78

- meaning 78-79, 249-250

Professionals

- generally 357-361, 328

- notaries public (Notare, kōshō-nin) 358359

- real estate agents (Immobilienmakler, fudō-san-ya) 354-357, 360-361

- solicitors (Rechtsanwälte, bengo-shi) 357-358

- shihō shoshi (judicial scriveners) 261, 354-355, 360-361

Property (things, Sachen, mono)

- buildings (Gebäude, tatemono) 96, 174, 257-258

- chattels and choses (things) 97-98

- corporeal (körperlich) and incorporeal (unkörperlich) 173-174

- fixtures (teichaku-butsu) and accessories (Zubehör) 96-97, 175-175, 257-258

- general classification of 96-98, 173-175, 256-258

- Herrschafts- (objects under control) and Verfügungsobjekte (objects of disposition) 173

- immovable (unbeweglich, fudō-san) and movable (beweglich, dōsan) 174, 257

- land (Grundstücke, tochi) 96-96, 174,

- personal and real 96

- software and data 97-98, 173, 257, 365

- tangible (yūtai-butsu) and intangible (mutai-butsu) 256-257

- timber and crops 97,257

Rechtsgeschäfte (hōritsu kōi, juridical act)

- contracts as 143, 236

- definition 143

- declarations of intention (Willenserklärungen, ishi hyōji) and 143, 236

- generally 143-144, 148-148, 236-236

- types 148-148

Registration of real property, see Form and formalities, registration of property title

Sachen, see Property

Sale of land or real estate, see Form and formalities, sale of land or real property

Schenkung, see Gifts

Seals (Siegel, inshō)

- definition 105, 265-265

- electronic 108, 349-349

- employment today $105,106-107,184-$ $185,188,266-266,323,336-339$

- forms, and, see employment today

- generally 103, 263-264, 328-329 
- ginkō-in 268

- jitsu'in 267-268

- historical meaning of 36, 43-44, 128129, 222-223, 329-336

- mitome'in 269

- sign of authentication, as 128, 263

- sign of authorisation, as 331, 332

- types 223, 266-268, 330-332, 338-339

Shomei, see Signatures

Shödaku, see Acceptance

Shōhin, see Goods

Shönin, see Merchant

Siegel, see Seals

Signatures (Signatur, shomei)

- definition 104, 188-190, 265-265, 326, 396-397

- electronic 108-110, 194-197, 346-348, 397

- forms, and 100, 106, 176, 266-266, 325326, 398-398

- generally 103-104, 188, 263-264, 325

- historical meaning 128-129, 222

- marks (Handzeichen) and 104, 189-190, 327

- method 104, 190-192, 326-327

- other forms of signing 222, 338-339

- sign of authentication, as 104, 188, 263

Silence, see Method of acceptance, silence

Sources of (contract) law

- case law (Rechtsprechung, hanrei) 1717, 24-26, 215-216

- customs and customary law 14, 21, 210

- English law generally, in 13

- equity 14

- EU law, see European Union law

- German law generally, in 20-21

- inter-relationship 13-15, 21-22, 211-212

- international law, see International law

- Japanese law generally, in 210-211

- legislation (Gesetze, hōrei) 15-16, 2224, 212-215

Stamp tax (inshi-zei)

- English law, in 112-113

- Japanese law, in 256, 273-275

Standard terms (Allgemeine Geschäftsbedingungen, AGB, yakkan) 181, 217, 307, 416

Sureties, see Form and formalities, guarantees

Tetsuke, see also Indicia of seriousness - definition 277-278
- functions 275, 279-281, 315-317

- generally224-225, 275-281, 316-318

- iyaku 279,317

- kaiyaku 275, 317

- method of effecting 278-279

- shōyaku 279, 317

- types 279-281, 317-317

Trader, see Merchant

Trennungsprinzip (separation principle) 218-219

Tötatsu shugi, see Mailbox rule

Types of contract

- B2B, B2C, C2C 8

- bilateral (gegenseitig or zweiseitig verpflichtend, sōmu) 29, 29-30, 115, $117,217,301,467$

- consensual (konsensual, dakusei) 116, 217, 239, 300

- dinglich (disposition) and schuldrechtlich (obligationary) 141

- executed and executory 29, 302

- formal (yōshiki) 217

- gratuitous (unentgeltlich, mushō) and onerous (entgeltlich, yūshō) 117, 217, 218

- multilateral, see bilateral

- parol 93

- real (Realvertrag, yōbutsu) 124, 126, 217

- simple and under seal or by speciality $30,93,94$

- unilateral 29-30, 62, 71, 301, 309

- unilaterally obliging (einseitig verpflichtend, henmu) $117,217,301$

Unilateral contracts see Types of contract, unilateral

Unternehmer, see Merchant

Vertrag, see Contracts

Vertragsrecht, see Contract law

Vertreter, see Agents

Waren, see Goods

Willenserklärung, see Declaration of intention

Yakkan, see Standard terms

Zōyo, see Gifts

Zugangstheorie, see Mailbox rule 